UNIVERSIDADE DE SÃO PAULO

INSTITUTO DE GEOCIENNCIAS

\title{
PETROGRAFIA E QUÍMICA MINERAL DE OCORRÊNCIAS ALCALINAS DA PROVÍNCIA ALTO PARAGUAI, BRASIL-PARAGUAI
}

João Batista de Matos

Orientador: Prof. Dr. Excelso Ruberti

TESE DE DOUTORAMENTO

Programa de Pós-Graduação em Mineralogia e Petrologia 
UNIVERSIDADE DE SÃO PAULO

INSTITUTO DE GEOCIÊNCIAS

\title{
PETROGRAFIA E QUÍMICA MINERAL DE OCORRÊNCIAS ALCALINAS DA PROVÍNCIA ALTO PARAGUAI, BRASIL-PARAGUAI
}

\author{
JOÃO BATISTA DE MATOS
}

Orientador: Prof. Dr. Excelso Ruberti

TESE DE DOUTORAMENTO

COMISSÃO JULGADORA

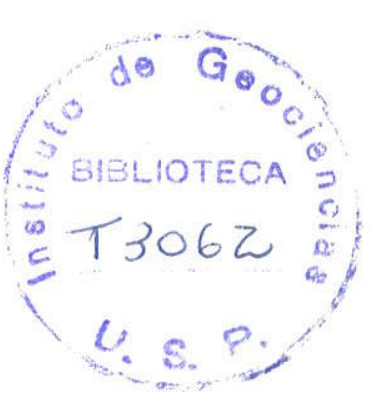

Nome

Presidente: Prof. Dr. Excelso Ruberti

Examinadores: Prof. Dr. Celso de Barros Gomes

Prof. Dr. Herbet Conceição

Prof. Dr. Joel Gomes Valença

Dr. Victor Velázquez Fernandez

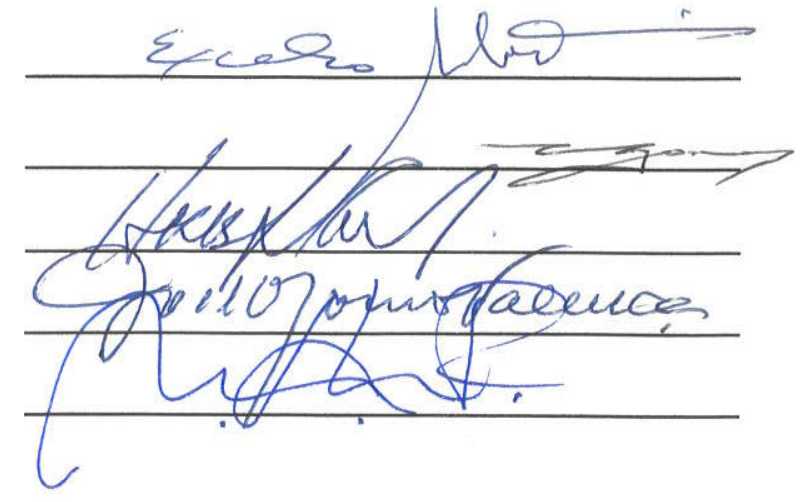




\title{
UNIVERSIDADE DE SÃO PAULO INSTITUTO DE GEOCIÊNCIAS
}

PETROGRAFIA E QUÍMICA MINERAL DE OCORRÊNCIAS ALCALINAS DA PROVÍNCIA ALTO PARAGUAI, BRASIL PARAGUAI

\author{
João Batista de Matos
}

Orientador: Prof. Dr. Excelso Ruberti

\section{TESE DE DOUTORAMENTO}

Programa de Pós-Graduação em Mineralogia e Petrologia

SÃO PAULO

2000

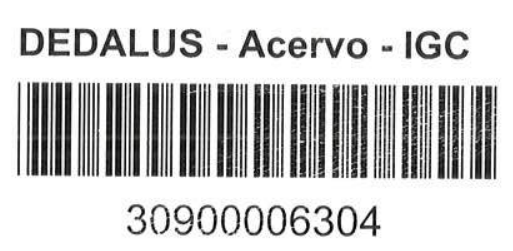


À minha mãe Antonia P. Matos (In memorian) e aos meus filhos Julianna A. Matos e Daniel D. Matos. 


\section{AGRADECIMENTOS}

Gostaria de expressar os meus sinceros agradecimentos àqueles que, direta ou indiretamente contribuíram para a realização deste trabalho. Desta forma, não poderia omitir algumas pessoas e/ou instituições às quais sinto-me especialmente grato:

Ao Projeto Temático, Petrologia e Geoquímica de Rochas Alcalinas (FAPESP 97/1210-4) na pessoa do Prof. Dr Celso de Barros Gomes da USP, financiador de todas as etapas deste trabalho, gostaria de externar os meus sinceros agradecimentos.

Á CAPES/PICDT pela concessão de bolsa de doutorado durante o período de afastamento.

Ao Dr. Victor Velázquez Fernandez da USP, pelo auxílio nos trabalhos de mapeamento, discussões a respeito de temas alcalinos e ajuda nos problemas relativos à informática. Sem os incentivos, amizade e a valiosa ajuda do Dr Victor Velázquez, este trabalho não teria sido possivel realizar.

Ao Prof Dr Excelso Ruberti, orientador deste trabalho, pelo apoio incondicional durante as inúmeras e intermináveis etapas de trabalho na microssonda eletrônica. $O$ Professor Excelso, em nenhum momento, mediu esforços no sentido de proporcionar apoio a mim, na resolução dos incontáveis "paus" que ocorreram na microssonda, assim como, durante o desenvolvimento da tese.

Aos meus filhos Julianna e Daniel, agradeço a compreensão do longo tempo de ausência, momentos dificeis para ambas as partes.

Ao colega Gaston Enrich (meu consultor nos problemas relacionados à informática) que ouvia pacientemente as minhas queixas sobre o "soft" Minpet e, na medida do possivel, solucionava os meus (inúmeros) problemas. A ajuda do amigo Gaston durante toda a etapa de trabalho e, principalmente na fase de organização e montagem da tese foi importantíssima. Agradeço sobretudo o seu despreendimento no apoio a esses trabalhos, em que pese o sacrifício pessoal de sábados, domingos e feriados e longas jornadas noturnas.

Aos colegas William Salun Filho, pós-graduando da USP e Agnelo Leite da Silva, aluno da UFMT pela excelente qualidade dos desenhos, inestimável ajuda e grande amizade. 
Ao Prof. Dr. José Moacir V. Coutinho da USP, pela inestimável ajuda durante os trabalhos de petrografia microscópica e reconhecimento de algumas fases minerais especiais.

À Profa. Dra Maria Zélia Aguiar da UFMT, pela ajuda nos trabalhos de interpretação dos dados de química mineral, leitura atenta e correções deste trabalho. A Dra Zélia, a despeito de inúmeros problemas de saúde que a sua família enfrenta, ainda conseguiu tempo para efetuar as correções da parte de Química Mineral, demonstrando seu elevado espírito de colaboração e amizade. Por enquanto, só posso dizer: muito obrigado e que Deus a abençoe.

Ao Prof. MsC. Amarildo Salina Ruiz da UFMT, pela leitura atenta de partes deste trabalho, correções e sugestões.

Aos técnicos Marcos Mansueto e Angélica D. Morente dos Laboratórios de Microssonda Eletrônica e de Óptica da USP, respectivamente, pela valiosa ajuda, espírito de cooperação e sincera amizade.

Aos colegas da Pós-Graduação, especialmente Afonso Nogueira, André Ferrari, Carmem (Xitah), Gustavo (Troglô), lede Zollinger, Paulo César C. Costa, Peter Davies, Raquel Venâncio, Rolando Campos e Rosana, dentre outros, pela ajuda nos momentos decisivos, amizade e incentivos.

Ao colega Salatiel A. Araújo pelas sugestões apresentadas, espírito de colaboração e amizade.

Aos Professores Doutores Gerson S. Saes e Ricardo K. Weska, agradeço muitíssimo por ter assumido parte de meus encargos didáticos para que eu tivesse condições de concluir este trabalho.

Aos demais colegas do Departamento de Recursos Minerais e Geologia Geral da UFMT: Alteredo O. Cutrim, Álvaro P. Quadros, Antonio B. Vecchiato, Aquiles Lazzaroto, Carlos J. Fernandes, Cléverson Cabral, Joaquim Goulart Jr., José Domingues de G. Filho, Serafim C. Melo e Zacarias Mayal Filho pelo incentivo a mim dispensado. 


\section{ÍNDICE}

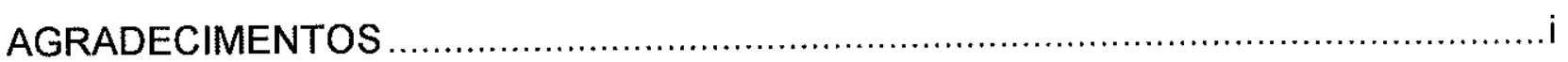

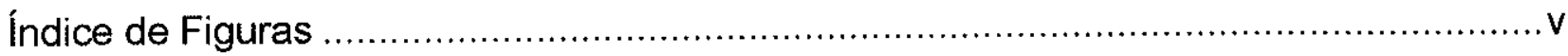

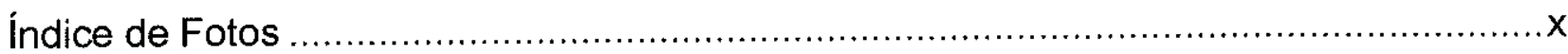

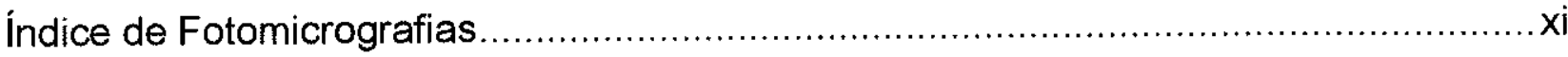

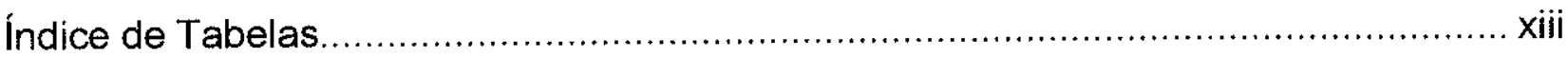

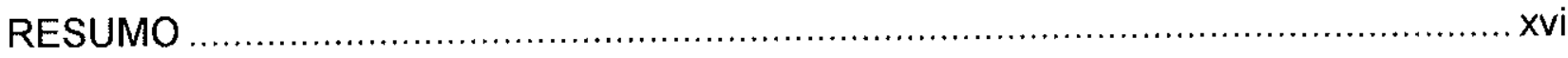

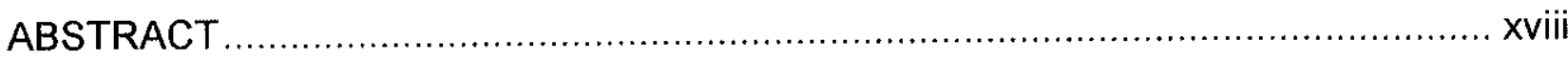

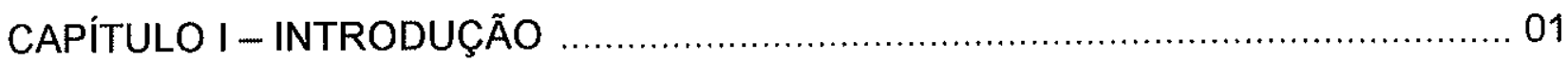

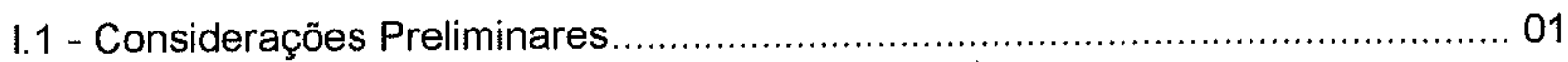

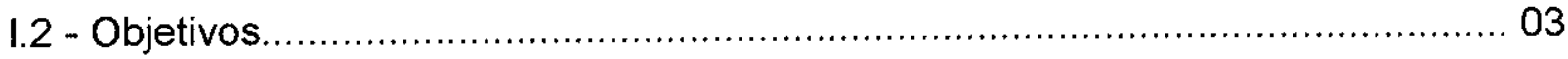

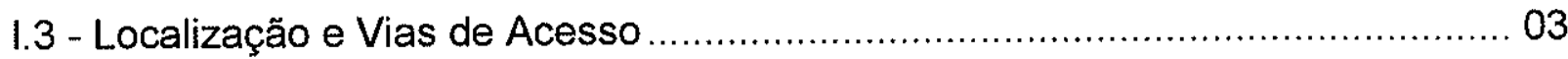

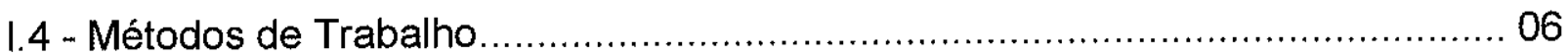

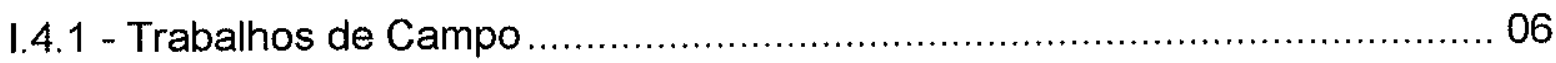

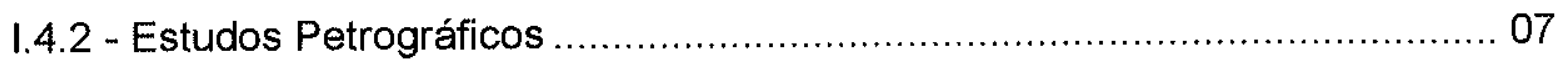

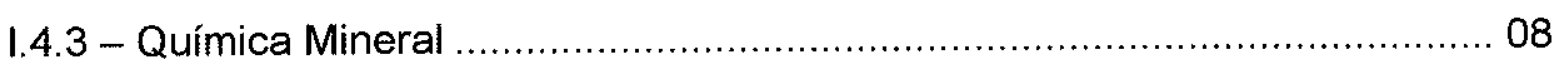

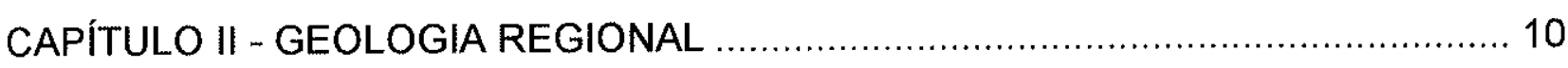

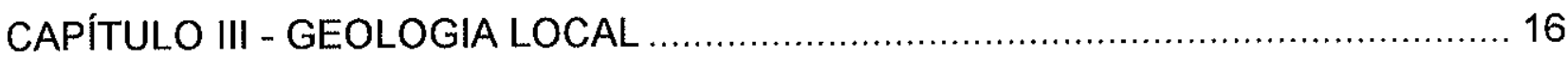

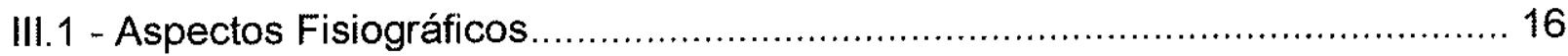

III. 2 - Província Alcalina Alto Paraguai................................................................. 20

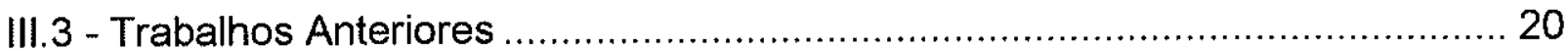

III. 4 - Formas de Ocorrência do Magmatismo Alcalino do Alto Paraguai................. 22

III. 5 - Aspectos Tectônicos Vigentes Durante o Permo-Triássico ........................... 23

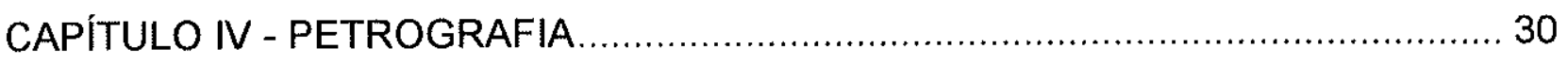

IV.1 - Cerro Boggiani e Satélites ................................................................... 30

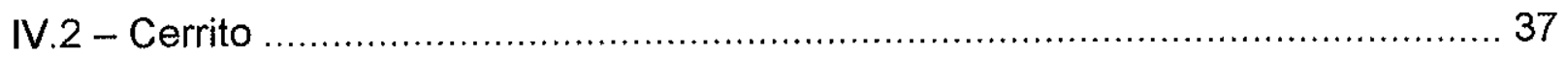

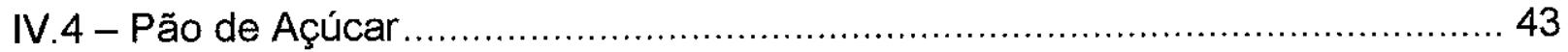

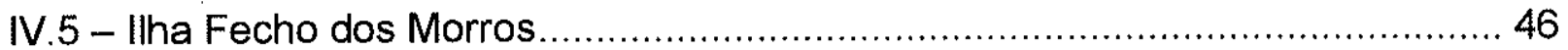

IV.6 - São Pedro, Cerro Pedreira, Porto Conceição, Morro Conceição e Morro

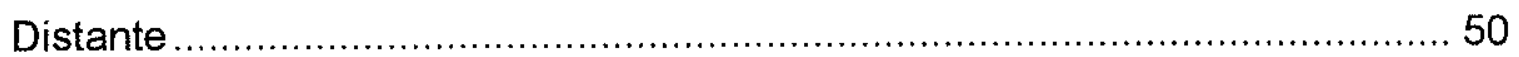

IV.7 - Cerro Siete Cabezas e Satélites ........................................................ 60 


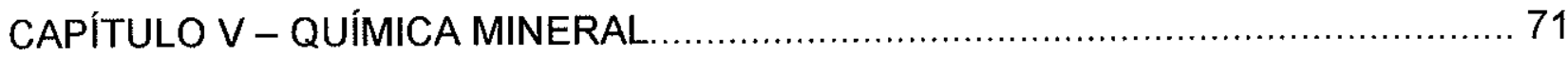

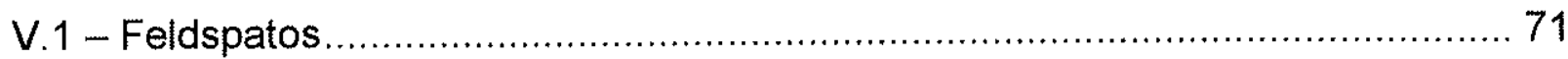

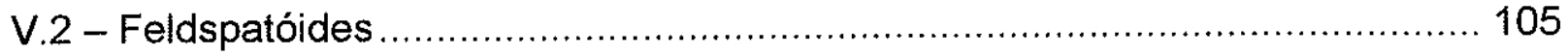

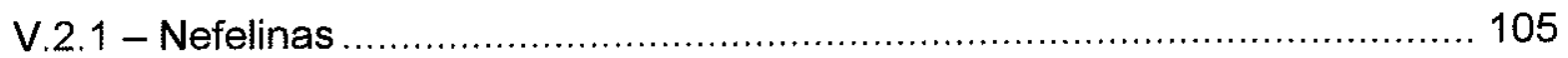

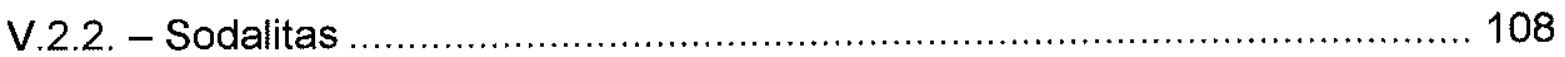

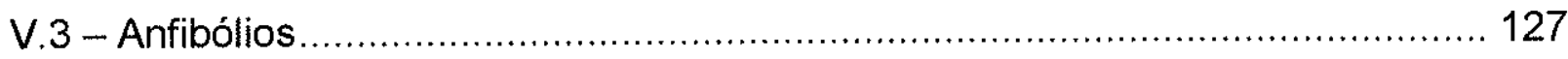

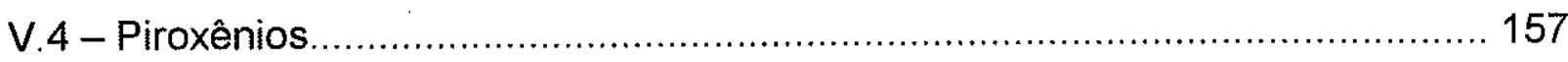

V.4.1 - Cerro Boggiani .............................................................. 159

V.4.2 - Cerro Siete Cabezas e Corpos Satélites I e II............................... 171

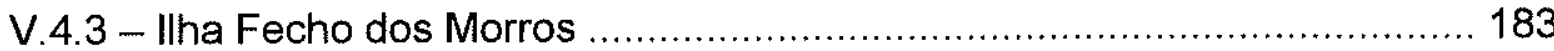

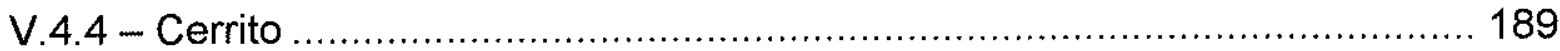

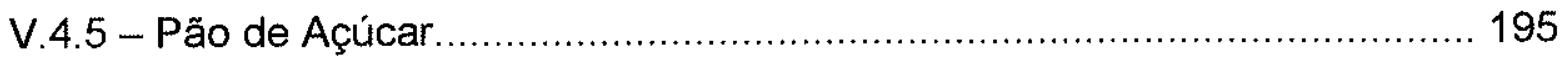

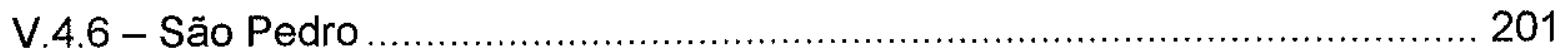

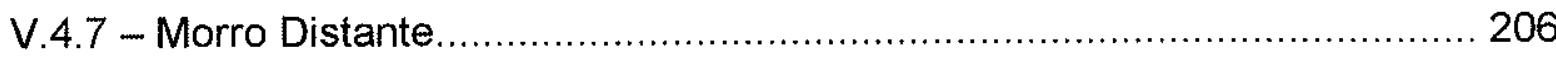

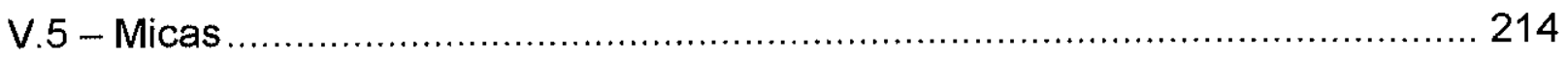

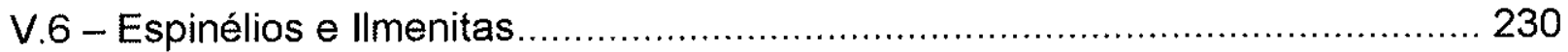

CAPÍTULO 6 - CONSIDERAÇÕES FINAIS E CONCLUSÕES ......................... 242

CAPÍTULO 7 - REFERÊNCIAS BIBLIOGRÁFICAS ....................................... 250 


\section{ÍNDICE DAS FIGURAS}

Figura 01 - Mapa de localização e vias de acesso.

5

Figura 02 - Esbôço geológico simplificado da região de Porto Murtinho (MS), segundo Araújo et al. (1982).

Figura 03 - Esboço geológico do Paraguai Oriental, enfatizando as localizações das principais províncias alcalinas conhecidas. Adaptado de Velázquez et al. (1998).

Figura 04 - Contexto Geomorfológico Regional simplificado de extremo sudoeste do Meto Grosso do Sul, de acordo com Alvarenga et al. (1982)

Figura 05 - Esquema ilustrativo de regiões representativas de alta sismicidade (intra-placa), reativação de zonas de fraqueza e colocação de magmas alcalinos na crosta terrestre (Sykes, 1978)

Figura 06 (A) - Representação esquemática mostrando as séries magmáticas relacionadas à espessura da litosfera em rifteamentos continentais e oceânicos e ainda o desenvolvimento de alinhamentos tectônicos por reativação de falhamentos pretéritos, e (B) Propagação de fraturas através da litosfera continental

Figura 07 - Mapa de localização de amostras da região do Morro Pão de

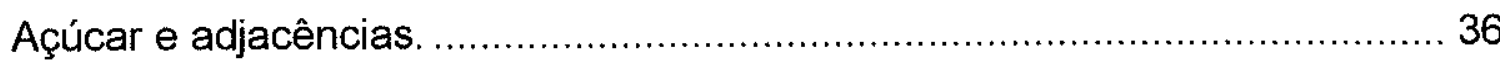

Figura 08 - Mapa de localização de amostras da região de Porto Murtinho (MS)....... 59

Figura 09 - Mapa de localização de amostras da região do Cerro Siete Cabezas (PY).

Figura 10 - Distribuição das rochas da Província Alcalina do Alto Paraguai nos diagramas superior e inferior de Streckeisen (1976).

Figura 11 e 12 - Variação composicional dos feldspatos de sienitos nefelínicos e fonólitos peralcalinos de Cerro Boggiani expressa em proporção molecular de Or-Ab-An. 98

Figura 13 - Variação composicional dos feldspatos de sienitos alcalinos do corpo Satélite II expressa em proporção molecular de Or-Ab-An 99

Figura 14 - Variação composicional dos feldspatos de sienitos alcalinos de Satélite I expressa em proporção molecular de Or-Ab-An 
Figura 15 - Variação composicional dos feldspatos dos nefelina sienitos de Cerro Siete Cabezas expressa em proporção molecular de Or-Ab-An

Figura 16 - Variação composicional dos feldspatos de quartzo sienitos de Morro Pão de Açucar, expressa em proporção molecular de Or-Ab-An.

Figura 17 - Variação composicional dos feldspatos de rochas de Pão de Açucar expressa em proporção molecular de Or-Ab-An

Figura 18 - Variação composicional dos feldspatos de rochas de Cerrito expressa em proporção molecular de Or-Ab-An

Figura 19 - Variação composicional dos feldspatos de quartzo sienitos de Cerro Pedreira expressa em proporção molecular de Or-Ab-An

Figura 20 - Variação composicional dos feldspatos de sienitos alcalinos de São

Pedro expressa em proporção molecular de Or-Ab-An.

Figura 21 - Variação composicional dos feldspatos de sienitos alcalinos de Morro

Conceição expressa em proporção molecular de Or-Ab-An

Figura 22 - Variação composicional dos feldspatos de sienitos alcalinos de Morro

Distante expressa em proporção molecular de Or-Ab-An

Figura 23a - Variação composicional dos feldspatos de sienitos alcalinos de Porto Conceição expressa em proporção molecular de Or-Ab-An

Figura 23b - Variação composicional dos feldspatos de pegmatitos de llha Fecho dos Morros expressa em proporção molecular de Or-Ab-An

Figura 24 - Diagrama Ne-Ks-Qz apresentando a evolução composicional das nefelinas das rochas de Cerro Boggiani

Figura 25 - Diagrama Ne-Ks-Qz apresentando a evolução composicional das nefelinas das rochas de Cerro Siete Cabezas

Figura 26 - Diagrama Ne-Ks-Qz apresentando a evolução composicional das nefelinas dos sienitos nefelínicos de Cerrito

Figura 27 - Diagrama Ne-Ks-Qz apresentando a evolução composicional das nefelinas dos sienitos nefelínicos da llha Fecho dos Morros

Figura 28 - Diagrama Ne-Ks-Qz apresentando a evolução composicional das nefelinas das rochas de Morro Pão de Açucar.

Figura 29a - Diagrama Ne-Ks-Qz apresentando a evolução composicional das nefelinas das rochas de São Pedro e Porto Conceição

Figura 29b - Diagrama Ne-Ks-Qz apresentando a evolução composicional das nefelinas das rochas sieníticas da Província Alcalina Alto Paraguai. 
Figura 30 - Distribuição dos anfibólios das rochas de Cerro Boggiani nos diagramas de classificação da IMA.

Figura 31 - Distribuição dos anfibólios das rochas de Cerro Siete Cabezas e Satélite I e II nos diagramas de classificação da IMA

Figura 32 - Distribuição dos anfibólios das rochas do Morro Pão de Açucar nos diagramas de classificação da IMA

Figura 33 - Distribuição dos anfibólios das rochas da llha Fecho dos Morros nos diagramas de classificação da IMA.

Figura 34 - Distribuição dos anfibólios das rochas de Cerrito nos diagramas de classificação da IMA.

Figura 35 - Distribuição dos anfibólios das rochas de São Pedro nos diagramas de classificação da IMA...

Figura 36 - Distribuição dos anfibólios das rochas de Cerro Pedreira nos diagramas de classificação da IMA

Figura 37 - Distribuição dos anfibólios das rochas de Morro Conceição nos diagramas de classificação da IMA.

Figura 38 - Distribuição dos anfibólios das rochas de Porto Conceição nos diagramas de classificação da IMA

Figura 39 - Distribuição dos anfibólios das rochas de Morro Distante nos diagramas de classificação da IMA

Figura 40 - Representação dos anfibólios da Província Alcalina Alto Paraguai nos diagramas $\mathrm{Mg}-\mathrm{Ca}-\mathrm{Fe}^{*}\left(\mathrm{Fe}^{*}=\mathrm{Fe}^{2+}+\mathrm{Fe}^{3+}+\mathrm{Mn}\right)$ e $\mathrm{Ca}-\mathrm{K}-\mathrm{Na}$.....

Figura 41 - Evolução composicional dos anfibólios das rochas da Província Alcalina Alto Paraguai no diagrama $\mathrm{TAl}+\mathrm{CCa}+\mathrm{BCa}$ versus TSi+BNa+ANa

Figura 42 - Composição dos piroxênios das rochas de Cerro Boggiani no diagrama Q-J de classificação do IMA

Figura 43 - Locação dos piroxênios das rochas de Cerro Boggiani no diagrama WEF-Jd-Ae. 168

Figura 44 - Diagramas de variação composicional de piroxênios das rochas de

Cerro Boggiani

Figura 45 - Diagramas de variação composicional de piroxênios das rochas de Cerro Boggiani 
Figura 46 - Distribuição dos piroxênios das rochas de Cerro Siete Cabezas e

Satélites I e II nos diagramas de classificação da IMA.

Figura 47 - Diagramas de variação composicional de piroxênios das rochas de

Cerro Siete Cabezas e Satélites I e II

Figura 48 - Diagramas de variação composicional de piroxênios das rochas de

Cerro Siete Cabezas e Satélites I e II

Figura 49 - Distribuição dos piroxênios das rochas da liha Fecho dos Morros nos

diagramas de classificação da IMA

Figura 50 - Diagramas de variação composicional de piroxênios das rochas de

Ilha Fecho dos Morros.

Figura 51 - Diagramas de variação composicional de piroxênios das rochas de Ilha Fecho dos Morros.

Figura 52 - Distribuição dos piroxênios das rochas do corpo Cerrito nos diagramas de classificação da IMA

Figura 53 - Diagramas de variação composicional de piroxênios das rochas de

Cerrito

Figura 54 - Diagramas de variação composicional de piroxênios das rochas de

Cerrito

Figura 55 - Distribuição dos piroxênios das rochas do Morro Pão de Açucar nos

diagramas de classificação da IMA

Figura 56 - Diagramas de variação composicional de piroxênios das rochas do

Morro Pão de Açucar

Figura 57 - Diagramas de variação composicional de piroxênios das rochas do

Morro Pão de Açucar

Figura 58 - Distribuição dos piroxênios das rochas do Morro São Pedro nos diagramas de classificação da IMA 203

Figura 59 - Diagramas de variação composicional de piroxênios das rochas do

Morro São Pedro 204

Figura 60 - Diagramas de variação composicional de piroxênios das rochas do

Morro São Pedro. 205

Figura 61 - Distribuição dos piroxênios das rochas do Morro Distante nos diagramas de classificação da IMA 208

Figura 62 - Diagramas de variação composicional de piroxênios das rochas do Morro Distante 
Figura 63 - Diagramas de variação composicional de piroxênios das rochas do Morro Distante

Figura 64 - Locação dos piroxênios das rochas da Província Alcalina Alto Paraguai no diagrama $\mathrm{Na}-\mathrm{Mg}-\mathrm{Fe}^{*}\left(\mathrm{Fe}^{2+}+\mathrm{Mn}+\left(\mathrm{Fe}^{3+}-\mathrm{Na}\right)\right)$

Figura 65 - Tendências composicionais para os piroxênios das rochas da Província Alcalina Alto Paraguai

Figura 66 - Tendência de evolução composicional de piroxênios em alguns complexos alcalinos do Brasil.

Figura 67 - Classificação das micas das rochas da Província Alcalina Alto Paraguai.

Figura 68 - Variações composicionais de biotitas das rochas da Província Alcalina Alto Paraguai 228

Figura 69 - Distribuição das biotitas das rochas da Província Alcalina Alto Paraguai nos diagramas $\mathrm{Mg}-\left(\mathrm{Al}^{\mathrm{IV}}+\mathrm{Ti}\right)-\left(\mathrm{Fe}^{2+}+\mathrm{Mn}\right)$ e $\mathrm{K}-\mathrm{Mg}-\mathrm{Fe}^{2+}$

Figura 70 - Distribuição das ilmenitas e magnetitas das rochas da Província Alcalina Alto Paraguai no diagrama $\mathrm{FeO}-\mathrm{TiO}_{2}-\mathrm{Fe}_{2} \mathrm{O}_{3}$

Figura 71 - Representação esquemática de rochas félsicas no Sistema NefelinaKalsilita-Sílica (Sistema Petrogenético Residual).

Figura 72 - (A) Diagrama Na2O + K2O versus SiO2 de Irvine \& Baragar (1971) aplicado às rochas da Província Alcalina Alto Paraguai. (B) Diagrama $\mathrm{Na} 2 \mathrm{O}+\mathrm{K} 2 \mathrm{O}$ versus $\mathrm{SiO} 2$ separando o campo das rochas alcalinas das sub-alcalinas. (C) Diagrama ANK versus ACNK, define os campos de composição preferenciais para as rochas da Província Alcalina Alto Paraguai. (D) Diagrama de variação $\mathrm{Rb}$ versus $\mathrm{Y}+\mathrm{Nb}$ (Pearce et al. 1984), para a discriminação tectônica de rochas graníticas. 


\section{ÍNDICE DE FOTOS}

Foto 01 - Aspecto geral da intrincada vegetação de cerrado encobrindo área alagada nas proximidades do Morro Pão de Açúcar

Foto 02 - Equipe de mapeamento transpondo pântano (encoberto pela vegetação) em direção aos "plugs" à Se da llha Fecho dos Morros 18

Foto 03 - Alternância de bandas de cores diferentes (bandamento primário) na intrusão de Cerrito 39

Foto 04 - Outro aspecto do bandamento primário de Cerrito 39

Foto 05 - Dique fonolítico subvertical, com falha de rejeitos centimétricos 40

Foto 06 - Vista parcial (S para N) do Morro Pão de Açúcar e "plugs" adjacentes 44

Foto 07 - llustração das rochas pegmatóides de Fecho dos Morros, onde se sobressaem grãos decimétricos de feldspato potássico, nefelina e egirina-augita 48

Foto 08 - Complexo Intrusivo Cerro Siete Cabezas e Satélite I. Vista de NE-SW 61

Foto 09 - Situação mais proximal do Complexo Siete Cabezas e Satélite I 62

Foto 10 - Aspecto geral de um afloramento de nefelina sienitos de Cerro Siete Cabezas 62 


\section{ÍNDICE DAS FOTOMICROGRAFIAS}

Fotomicrografia 01 - RP 27 - sodalita-nefelina sienito apresentando textura alotriomórfica.

Fotomicrografia 02 - RP-31A - nefelina sienito porfirítico com fenocristais centimétricos de feldspato potássico, egirina-augita, nefelina subidiomórfica e sodalita intersticial

Fotomicrografia 03 - RP-29 - nefelina sienito com grãos idiomórficos de nefelina

Fotomicrografia 04 - RP-31B - rocha piroclástica com enclaves de rochas

alcalinas, gnaisses e graníticas diversas

Fotomicrografia 05 - RP-85 - traquifonolito com textura porfirítica onde os

fenocristais de nefelina ocorrem com zoneamento químico. 40

Fotomicrografia 06 - RP-88 - Traquito com microfenocristais de feldspato potássico, com hábito tabular, orientados

Fotomicrografia 07 - RP - Textura com aspecto ignimbrítico onde são observados microfenocristais de feldspato potássico, associados a fragmentos líticos envolvidos por bandas félsicas em alternância com banda máficas

Fotomicrografia 08 - RP-78 - quartzo sienito com anfibólios com bordas de reação para biotita.

Fotomicrografia 09 - RP-91 - nefelina sienito com textura pegmatítica da liha

Fecho dos Morros

Fotomicrografia 10 - RP-255 - nefelina sienito do Morro São Pedro, com textura

intergranular e domínios poiquilíticos.

Fotomicrografia 11 - RP-258 - nefelina sienito do Morro São Pedro na trama

minerais como egirina-augita, anfibólio sódico, biotita e nefelina.

Fotomicrografia 12 - RP-264 - sienito alcalino com textura porfirítica de Morro

Distante

Fotomicrografia 13 - RP-265 - sienito alcalino porfirítico de Morro Distante onde

são destacadas as texturas microporfiríticas de matriz afanítica

Fotomicrografia 14 - RP-267 - microfenocristal de feldspato potássico apresentando texturas de sobrecrescimento de Morro Conceição 
Fotomicrografia 15 - RP-259 - textura porfirítica com os fenocristais de nefelina imersa em matriz afanítica

Fotomicrografia 16 - RP-236 - quartzo sienito de CSC apresentando feldspatos com intercrescimento pertítico e lamelas de exsolução regulares 63

Fotomicrografia 17 - RP-234 - Fenocristal arredondado de feldspato potássico, com cristalização marginal de biotita, em traquito de CSC

Fotomicrografia 18 - RP-242 - Bordas de reação piroxênio/anfibólio em sienitos alcalinos de CSC.

Fotomicrografia 19 - RP-236 - Fenocristal com textura poiquilítica de nefelina, em nefelina-sienitos de CSC 
Tabela 01 - Quadro comparativo das colunas estratigráficas do Pré-Cambriano

ao Cretáceo da parte mais Meridional do Cráton Amazonico

Tabela 02 - Características litológicas da Província Alcalina Alto Paraguai: Cerro

Boggiani

Tabela 03 - Características litológicas da Província Alcalina Alto Paraguai:

Cerrito

Tabela 04 - Características litológicas da Província Alcalina Alto Paraguai: Pão

de Açúcar

Tabela 05 - Características litológicas da Província Alcalina Alto Paraguai: Ilha

Fecho dos Morros

Tabela 06 - Características litológicas da Província Alcalina Alto Paraguai: Morro

de São Pedro 56

Tabela 07 - Características litológicas da Província Alcalina Alto Paraguai: Cerro

Pedreira e Porto Conceição 57

Tabela 08 - Características litológicas da Província Alcalina Alto Paraguai: Morro

Conceição e Morro Distante 58

Tabela 09 - Características litológicas da Província Alcalina Alto Paraguai: Cerro

Siete Cabezas e corpos satélites

Tabela 10 - Análises modais de rochas da Província Alcalina do Alto Paraguai (amostras 7 a 56) .

Tabela 11 - Análises modais de rochas da Província Alcalina do Alto Paraguai

(amostras 58 a 267)

Tabela 12.0 a 12.5 - Composição química de feldspatos de Cerro Boggiani. 74

Tabela 12.6 a 12.9 - Composição química de feldspatos de Satélite II. 80

Tabela 12.10 a 12.12 - Composição química de feldspatos de Satélite I

Tabela 12.13 a 12.15 - Composição química de feldspatos de Cerro Siete

Cabezas

Tabela 12.16 a 12.17 - Composição química de feldspatos de Pão de Açúcar.. 90

Tabela 12.18 - Composição química de feldspatos de liha Fecho dos Morros... 92

Tabela 12.19 - Composição química de feldspatos de Cerro Pedreira 93

Tabela 12.20 - Composição química de feldspatos de Morro de São Pedro 94 
Tabela 12.21 - Composição química de feldspatos de Morro Conceição .................. 95

Tabela 12.22 - Composição química de feldspatos de Porto Conceição .................... 96

Tabela 12.23 - Composição química de feldspatos de Cerrito................................. 97

Tabela 13.0 a 13.2 - Composição química de nefelinas de Cerro Boggiani............. 109

Tabela 13.3 - Composição química de nefelinas em nefelina sienitos de Cerro Siete Cabezas.

Tabela 13.4 - Composição química de nefelinas de sienitos nefelínicos de Cerrito

Tabela 13.5 - Composição química de nefelinas de sienitos nefelínicos da llha

Fecho dos Morros

Tabela 13.6 - Composição química de nefelinas de traquifonólitos de Pão de

Açúcar

Tabela 13.7 - Composição química de nefelinas de nefelina sienitos de São

Pedro e Porto Conceição

Tabela 13.8 e 13.9 - Composição química de sodalita de rochas de Cerro

Boggiani

Tabela 13.10 - Composição química de sodalita na Província Alcalina Alto

Paraguai.

Tabela 14.0 - Composição química dos anfibólios de Cerro Boggiani 130

Tabela 14.1 a 14.3 - Composição química dos anfibólios de Satélite II 131

Tabela 14.4 a 14.6 - Composição química dos anfibólios de Satélite I

Tabela 14.7 a 14.10 - Composição química dos anfibólios de Pão de Açúcar

Tabela 14.11 - Composição química dos anfibólios de Cerro Siete Cabezas....... 141

Tabela 14.12 - Composição química dos anfibólios de Cerrito 142

Tabela 14.13 - Composição química dos anfibólios de Cerro Pedreira 143

Tabela 14.14 - Composição química dos anfibólios de Morro de São Pedro. 144

Tabela 14.15 - Composição química dos anfibólios de Morro Conceição. 145

Tabela 14.16 - Composição química dos anfibólios de Porto Conceição 146

Tabela 15.0 a 15.7 - Composição química de piroxênios de Cerro Boggiani. 160

Tabela 15.8 a 15.11 - Composição química de piroxênios de Satélite II. 173

Tabela 15.12 - Composição química de piroxênios de Satélite I. 177

Tabela 15.13 a 15.14 - Composição química de piroxênios de Cerro Siete Cabezas 
Tabela 15.15 a 15.16 - Composição química de piroxênios da llha Fecho dos

Morros 184

Tabela 15.17 a 15.18 - Composição química de piroxênios de Cerrito. 190

Tabela 15.19 a 15.20 - Composição química de piroxênios de Pão de Açúcar. 196

Tabela 15.21 - Composição química de piroxênios do Morro de São Pedro 202

Tabela 15.22 - Composição química de piroxênios de Morro Distante. 207

Tabela 16.0 - Composição química de biotitas de Cerro Boggiani.. 217

Tabela 16.1 - Composição química de biotitas de Satélite II 218

Tabela 16.2 - Composição química de biotitas de Satélite I 219

Tabela 16.3 - Composição química de biotitas de Cerro Siete Cabezas 220

Tabela 16.4 - Composição química de biotitas de Morro Pão de Açúcar. 221

Tabela 16.5 - Composição química de biotitas de Cerrito 222

Tabela 16.6 - Composição química de biotitas da llha Fecho dos Morros. 223

Tabela 16.7 - Composição química de biotitas de Cerro Pedreira 224

Tabela 16.8 - Composição química de biotitas do Morro de São Pedro 225

Tabela 16.9 - Composição química de biotitas de Porto Conceição. 226

Tabela 17.0 - Composição química de magnetitas de Satélite II 233

Tabela 17.1 - Composição química de magnetitas de Cerro Siete Cabezas. 234

Tabela 17.2 - Composição química de magnetitas de Pão de Açúcar..... 235

Tabela 17.3 - Composição química de magnetitas de Cerrito 236

Tabela 17.4 - Composição química de magnetitas da llha Fecho dos Morros. 237

Tabela 17.5 - Composição química de magnetitas de São Pedro, Morro Conceição e Morro Distante 238

Tabela 18.0 a 18.1 - Composição química de ilmenitas da Província Alcalina Alto Paraguai 239 


\section{Resumo}

O presente trabalho é o resultado de investigação efetuada nas rochas da Província Alcalina Alto Paraguai, situada na região limítrofe entre o Estado de Mato

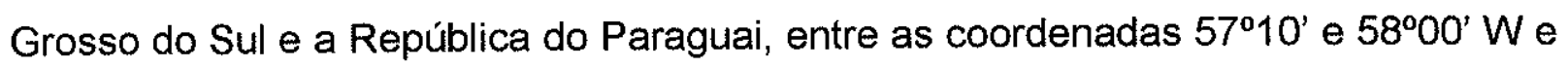
$21^{\circ} 10^{\prime \prime}$ e $23^{\circ} 25^{\prime} \mathrm{S}$.

Regionalmente, observam-se associações de litotipos variados, ocorrendo desde gnaisses graníticos e TTG (tonalítico-trondhjemítico-granodiorítico) de idade Arqueana e/ou Paleoproterozóica, representada pelo Complexo Rio Apa, rochas máfico-ultramáficas de idade desconhecida e ainda intrusivas graníticogranodioríticas do Mesoproterozóico. Localmente, destacam-se os corpos intrusivos em forma de plugs, stocks, complexos anelares e diques, representativos da Província Alcalina Alto Paraguai, com idade atribuída ao Permo-triássico.

Os tipos petrográficos estudados são representados por nefelina sienitos, nefelina-sodalita sienitos, álcali-feldspato sienitos e quartzo sienitos e seus equivalentes vulcânicos, sendo Cerro Boggiani o corpo a apresentar rochas contendo - maior índice de agpaicidade. Contudo, ocorrem rochas insaturadas em sílica também nos demais corpos como os de Cerrito, Pão de Açúcar, Ilha Fecho dos Morros e São Pedro, associados intrinsecamente a litotipos contendo quartzo modal, caracterizando, dessa forma, uma transposição da Barreira Termal do plano Ab-Or do Sistema Petrogenético Residual. Acredita-se que essas rochas sejam derivadas de um mesmo magma parental, produzindo rochas que sofreram diferenciação magmática, com importante participação de processos representativos de contaminação crustal.

Os maciços de Pão de Açúcar e Cerro Siete Cabezas evidenciam colocação em forma de complexos anelares, como sugerem as imagens orbitais e de aeronave daquela região.

Nas rochas estudadas, os minerais félsicos mais importantes do ponto de vista quantitativo são os feldspatos alcalinos, seguidos por nefelina e sodalita. Plagioclásios ocorrem apenas em Morro Conceição e Morro Distante, enquanto que o quartzo aparece em rochas de Pão de Açúcar, Morro Conceição, Satélite I e 
Satélite II. São observadas texturas de reequilibrio sólido-líquido, transformações mineralógicas sugestivas de processos pós-magmáticos tais como: sericitização de feldspatos, saussuritização de plagioclásios, uralitização de piroxênios e substituição de minerais.

Os minerais máficos ocorrem na seguinte ordem de importância: piroxênios cálcico-sódicos, piroxênios sódicos, anfibólios cálcico-sódicos, anfibólios sódicos e biotitas. Eles mostram, de uma maneira geral, tendências químicas compatíveis com processos diferenciação magmática, com diminuição de $\mathrm{Mg}$ e aumento de $\mathrm{Fe}$ e $\mathrm{Na}$. Nos anfibólios, são observados ainda importantes processos de substituição do tipo $\mathrm{Ca}+\mathrm{Al} \mathrm{I}^{\mathrm{V}}$ por $\mathrm{Si}+\mathrm{Na}$.

O estudo dos componentes moleculares Ne-Ks-Qz das nefelinas da Província Alcalina Alto Paraguai, não revela tendências de enriquecimento em $Q z$, como indicam outras ocorrências alcalinas brasileiras descritas na literatura. Esses minerais cristalizaram-se em um intervalo de temperatura que tem como limites inferior e superior, valores de $500^{\circ} \mathrm{C}$ e $1068^{\circ} \mathrm{C}$, respectivamente.

Os espinélios dos corpos alcalinos da Província Alto Paraguai possuem composição representativa de espinélios de $\mathrm{Fe}$ e $\mathrm{Ti}$ (Série da magnetitaulvöespinélio), correspondendo a temperaturas de formação de aproximadamente $600^{\circ} \mathrm{C}$ e baixas $f \mathrm{O}_{2}$, enquanto que as ilmenitas (Série ilmenita-hematita) indicam temperaturas de cristalização de até $800^{\circ} \mathrm{C}$ e $f \mathrm{O}_{2}$ maiores do que as prevalescentes durante a cristalização dos espinélios. 
Abstract

The present work is the result of the investigation carried out on rocks of the Alto Paraguay Alkaline Province, located at the border between the State of Mato Grosso do Sul and Paraguay Republic, coordinates 57 $7^{\circ} 10^{\prime}$ and $58^{\circ} 00^{\prime} \mathrm{W}$ and $21^{\circ} 10^{\prime \prime}$ and $23^{\circ} 25^{\prime} \mathrm{S}$

Regional associations of varied litotypes are present: Archean and/or Paleoproterozoic granitic and TTG (tonalitic-trondhjemitic-granodioritic) gnaisses of Apa River Complex, mafic-ultramafic rocks of unknown age and Mesoproterozoic granitic-granodioritic intrusive rocks. Likely Permotriassic plugs and stocks, ring complexes and dykes, belonging to the Alto Paraguay Alkaline Province, show up locally

The petrographic types comprised in the study include nepheline syenites, nepheline-sodalite syenites, alkali-feldspar syenites, quartz syenites and their volcanic equivalents. The Cerro Boggiani body presents the highest agpaitic index (nepheline syenites and phonolites), though silic insaturated rocks also occur in other bodies such as Cerrito, Pão de Açúcar, liha Fecho dos Morros and São Pedro, and Cerro Siete Cabezas, intrinsically associated to modal-quartz-bearing litotypes, thus characterizing a transposition of the Residual Petrogenetic System's Ab-Or plain thermal barrier. These rocks are believed to derive from a single parental magma, with determinant crust contamination along their evolution.

Orbital and aerial images show forms that evidence emplacement of Pão de Açúcar and Cerro Siete Cabezas massifs as ring complexes. This feature occurs associated to volcanic rocks such as piroclastites and ignimbrites, mainly found in Pão de Açucar body.

The most important felsic minerals in the rocks, from a quantitative point of view are alkali feldspars, followed by nepheline and sodalite. Plagioclases only occur in Morro Conceição and Morro Distante, while quartz show up in Pão de Açúcar, Morro Conceição, Satélite | and Satélite II rocks. Textures from solid-liquid reequilibrium and mineral transformations suggestive of post-magmatic processes 
like feldspar sericitization, plagioclase saussuritization, pyroxene uralitization and mineral substitution are observed.

Mafic minerals occur in the following order of importance: Quad pyroxenes, while Ca-Na pyroxenes, Na-pyroxenes, Ca-Na amphiboles, Na-amphiboles and biotites. They show a chemical trend compatible with magmatic differentiation processes, with decreasing $\mathrm{Mg}$ and increasing $\mathrm{Fe}$ and $\mathrm{Na}$. In amphiboles, important $\mathrm{Ca}+\mathrm{Al}^{\mathrm{IV}} \leftrightarrow \mathrm{Si}+\mathrm{Na}$ substitution processes are seen.

Nepheline molecular components Ne-Ks-Qz of Alto Paraguay Alkaline Province do not show any $Q z$ enrichment trend, contrarily to other Brazilian alkaline provinces described in literature. These minerals crystallized in temperatures within $500^{\circ} \mathrm{C}$ and $1068^{\circ} \mathrm{C}$.

Spinels of Alto Paraguay Alkaline Province show compositions of Fe-Ti spinels (Magnetite-Ulvöspinel Series), corresponding to crystallization temperatures of approximately $600^{\circ} \mathrm{C}$ and low $f \mathrm{O}_{2}$, while ilmenites (IImenite-Hematite Series) are indicative of formation at up to $800^{\circ} \mathrm{C}$ and $\mathrm{fO}_{2}$ higher than those of the spinels. 
CAPITULO I - INTRODUÇÃO

1.1 - Considerações Preliminares

$\mathrm{Na}$ área compreendida pelos paralelos $20^{\circ} 00^{\prime}$ e $23^{\circ} 00^{\prime} \mathrm{S}$ e meridianos $54^{\circ} 00^{\prime}$ e $58^{\circ} 30^{\prime} \mathrm{W}$, situa-se a região mais meridional do Pantanal matogrossense em território brasileiro, cuja ocorrência de rochas alcalinas é conhecida desde fins do século XIX a partir dos trabalhos pioneiros de Evans (1894). Essas ocorrências caracterizam-se pela existência de formas de relêvo colinoso, destacando-se na imensidão da planície do Pantanal, resultado da ação de longos processos erosivos que exumaram os corpos atualmente conhecidos como Província Alcalina do Alto Paraguai.

A localização genérica desses corpos distribui-se ao longo do rio Paraguai, em área limitrofe entre o Brasil e a República do Paraguai (Figura 01).

Conforme Alvarenga et al. (1982), toda essa região, é submetida a sucessivos regimes de cheias do rio Paraguai, durante os meses de novembro a março que inunda, via de regra, quase toda a área compreendida pela unidade geomórfica conhecida como "Planícies e Pantanais Mato-Grossenses".

A porção sudoeste do Estado de Mato Grosso do Sul, região onde está inserida a área supra delimitada, não foi favorecida no que diz respeito ao desenvolvimento da pesquisa de recursos minerais e do conhecimento geológico durante a primeira metade deste século, uma vez que as áreas alagadas dificultam sobremaneira os estudos geológicos potenciais. A exceção à essa regra ocorre em área adjacente à cidade de Corumbá, Morro de Jacadigo, onde Fonseca (1880, apud Araújo et al, 1982) relata ocorrências de itabirito e rochas associadas, detalhadas principalmente nos trabalhos desenvolvidos por Dorr II (1945). Posteriormente, essas ocorrências revelaram imensos jazimentos de ferro e manganês ainda hoje explotados. 
As grandes distâncias dos principais centros comércio-industriais do país também serviram como entrave à evolução dos estudos geológicos daquela área. Contudo, dentro desse quadro de dificuldades generalizadas, sobressaíram-se os trabalhos desenvolvidos por Lisboa (1909), Almeida (1943 e 1945 ), entre outros.

Os principais aspectos que se relacionaram com o povoamento e colonização de Porto Murtinho e regiões adjacentes estiveram ligados à implantação da cultura de erva mate em fins do século XIX na parte mais meridional da então "Província de Mato Grosso".

Em meados da década de 50, muitos núcleos populacionais já se haviam constituídos, resultantes da fixação do homem ao meio, efetuada durante a implantação da cultura da erva-mate (Ilex Matogrossensis), proveniente da República do Paraguai e extensamente desenvolvida na região, associado ao fato de ocorrer uma colonização mais densamente distribuida, povoada por contingentes de migrantes oriundos do sul do país, atraídos pelos solos férteis de terra roxa do Planalto de Maracajú. Sobrevieram desse período, os trabalhos mais relevantes do ponto de vista de uma tentativa de caracterização geológica preliminar, tendo sido desenvolvidos principalmente por Almeida (1964, 1965 e 1971).

$\mathrm{Da}$ necessidade de um melhor conhecimento de suas potencialidades minerais, surgiram então os Projetos Bodoquena (Corrêa et al. 1976) e BonitoAquidauana (Nogueira et al. 1978), da Companhia de Pesquisa de Recursos Minerais-CPRM, cujos trabalhos caracterizaram-se por apresentar uma revisão das proposições de Almeida, acerca do arcabouço geológico/estratigráfico da região enfocada.

Os dados levantados nesses dois projetos foram complementados $e$ ampliados pelo Projeto Radambrasil (Araújo et al. 1982), o que resultou na elaboração de mapas geológicos do sudoeste do Estado de Mato Grosso do Sul, escala ao milionésimo, utilizados até o presente momento, como ferramenta indispensável para expedições geológicas no âmbito regional e também como base para maiores detalhamentos. 
I.2 - Objetivos

A decisão de se efetuar trabalhos em corpos alcalinos da Província do Alto Paraguai, deveu-se principalmente à sua importância no contexto geológico/geotectônico, já que ela se constitui na atividade alcalina mais ocidental e mais antiga até então conhecida, da borda da Bacia do Paraná. Devido à natureza agpaítica de algumas de suas manifestações, devem ocorrer, associadas, possibilidades de mineralização em U, Th, Ta, Nb, Zr, Hf e REE (Gomes et al., 1996) e ainda, pela carência de estudos geológicos que caracteriza todo o Estado de Mato Grosso do Sul e parte oriental da República do Paraguai, notadamente os corpos alcalinos da Província Alto Paraguai, onde os trabalhos mais simples, tornam-se contribuições significativas, dado o seu caráter pioneiro e fundamental.

Foram estabelecidas também como prioridades fundamentais para este trabalho, uma melhor definição petrográfica dos litotipos alcalinos ora em estudo, assim como o seu comportamento petrográfico e a caracterização das atividades pós-magmáticas que afetaram essa província.

Pretendeu-se ainda efetuar prioritáriamente o estudo sistemático do quimismo dos principais minerais formadores de rochas dessa província e adicionalmente apresentar uma contribuição ao conhecimento petrográfico e do quimismo mineral dos seguintes corpos: São Pedro, Porto Conceição, Morro Conceição e Morro Distante, descritos pela primeira vez neste trabalho.

1.3 - Localização e Vias de Acesso

A província alcalina do Alto Paraguai está inserida no extremo sudoeste do Brasil (Estado de Mato Grosso do Sul), fronteira com a República do Paraguai, mais precisamente, entre as seguintes coordenadas: $21^{\circ} 10^{\prime}$ e $23^{\circ} 25^{\prime} \underline{\mathrm{S}}$ e $57^{\circ} 10^{\prime}$ e $58^{\circ} 00^{\prime} \underline{\mathrm{W}}$. 
Específicamente situamse dentro dos limites da Folha SF-21-Campo Grande do encarte cartográfico internacional (Figura 01).

A distância aproximada de Campo Grande, capital do Estado de Mato Grosso do Sul é de aproximadamente $400 \mathrm{~km}$ no sentido sudoeste. As principais conexões que permitem acesso à essa área (BR-267 e 163), com proveniências de São Paulo e Campo Grande, respectivamente, e BR-419, com traçado atingindo a cidade de Aquidauana afluem diretamente para a BR-267, especialmente no trecho comprendido entre as localidades de Jardim e o ponto final da rodovia, na cidade de Porto Murtinho, à margem esquerda do rio Paraguai.

O acesso aos corpos alcalinos ocorre sempre através do rio Paraguai e por áreas alagadas, baías (lagos) e "corixos" (canais que interligam drenagens e/ou baías). A distância estimada da área de maior concentração de corpos alcalinos é de cerca de $40 \mathrm{~km}$ a norte da cidade de Porto Murtinho, enquanto os outros corpos aflorantes nas áreas central e sul distam cerca de 6 e $12 \mathrm{~km}$ respectivamente, dessa localidade (Figura 01). 


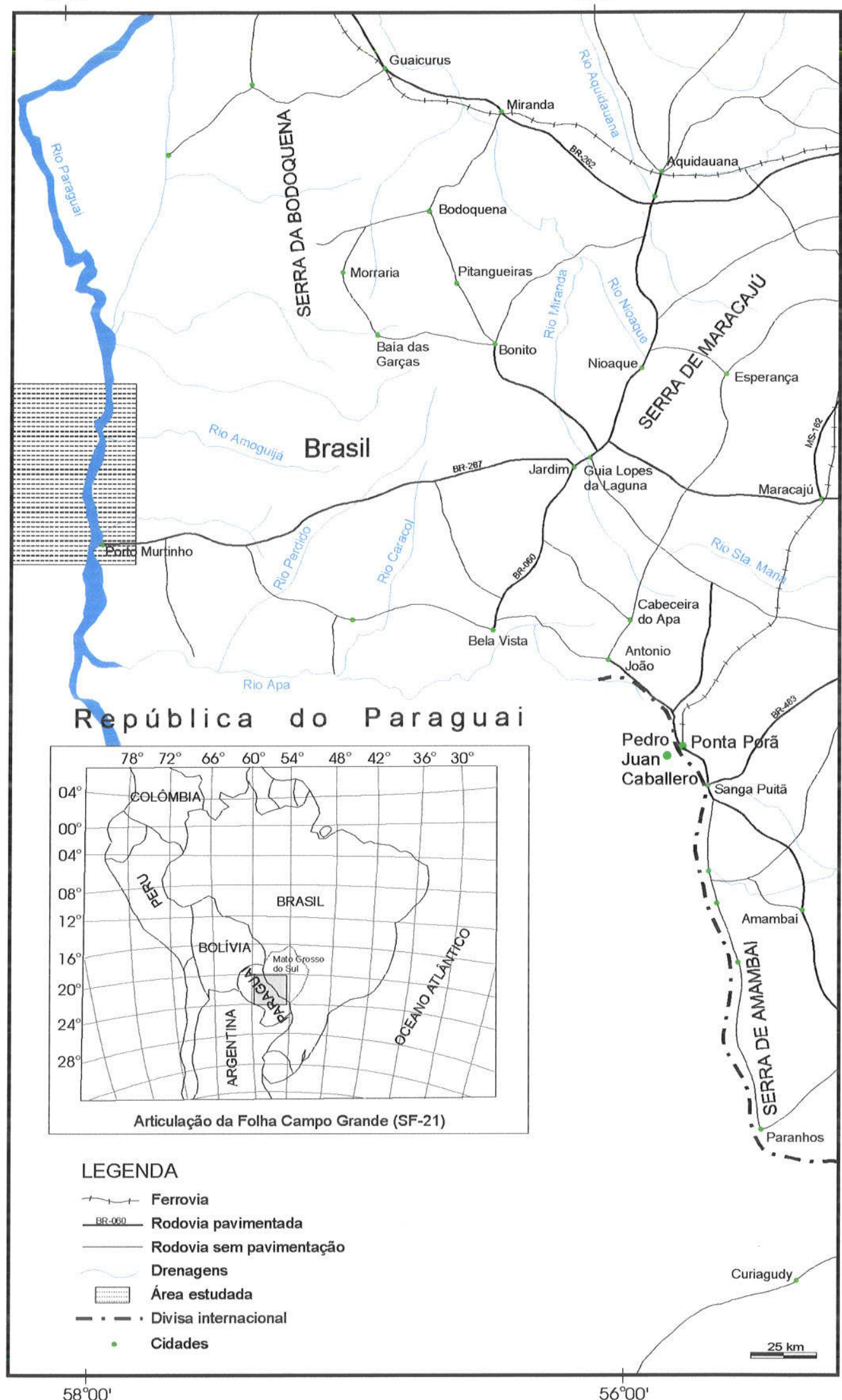

Figura 01: Mapa de localização e vias de acesso. Fonte: Guia de estradas Quatro Rodas, Ed. Abril, 1999. 
1.4 - Métodos de Trabalho

Os métodos de trabalho empregados nesta pesquisa foram os seguintes:

1) estudos bibliográficos regionais e temáticos sobre as rochas alcalinas sódicas da regiäo de Porto Murtinho (MS).

2) trabalhos laboratoriais compreendendo o estudo preliminar das ocorrências alcalinas contidas nas folhas topográficas distribuidas da seguinte forma: no lado brasileiro, a base topográfica disponível são as folhas elaboradas pela Diretoria de Serviço Geográfico, na escala 1:100.000, mais específicamente refere-se às folhas topográficas SF-21-V-D-II - Barranco Branco e SF-21-V-D-Y - Porto Murtinho, enquanto que no território paraguaio, as cartas topográficas são de procedência do DSGM daquele país, escala 1: 50.000 , e englobam principalmente as articulações (Hoja 5378 III -Puerto Guarani, Hoja 5377 IV Puerto Maria Auxiliadora e Hoja 5377 III - Puerto Tres Palmas).

3) Interpretação de mosaicos semi-controlados SLAR-Radambrasil, Folha SF-21-VD.

4) análises petrográficas, análises químicas via microssonda eletrônica, confecção de fotomicrografias, análise modal e elaboração final deste trabalho. Descrições metodológicas específicas são efetuadas no decorrer do capítulo 4.

5) determinação do quimismo mineral por microssonda eletrônica e estimativas de temperatura de cristalização para nefelinas, espinélios e ilmenitas.

\subsection{1 - Trabalhos de Campo}

Os trabalhos de campo iniciaram-se em setembro de 1997 e tiveram continuidade em julho de 1998, perfazendo um total de 24 dias. Foram descritos 77 afloramentos, com coleta de amostras para petrografia, e geoquímica, os quais, somados aos 109, estudados por Velázquez (1996), totalizam 186 afloramentos. 
Portanto, fica evidenciado que as amostras coletadas por aquele autor para fins de química de rochas e geocronologia, foram inteiramente aproveitadas neste trabalho, que pode ser perfeitamente entendido como uma continuidade e/ou extensão dos trabalhos levados a efeito por aquele autor.

A primeira etapa constou de reconhecimento geológico regional preliminar dos principais afloramentos que compõem os corpos alcalinos da Província do Alto Paraguai, com coleta de amostras. $\mathrm{Na}$ etapa subseqüente, priorizou-se o mapeamento dos corpos ainda não atingidos nos trabalhos efetuados por Velázquez (1996), com amostragem sistemática.

Destaca-se a grande dificuldade de deslocamento encontrada na área, em função dos pântanos, campos alagados e "corixos" os quais, associados a uma vegetação constituída quase que únicamente por espinhais (caraguás e urtigas entre outras), muitas vêzes tornam os caminhamentos extremamente difíceis, não se permitindo atingir os corpos alcalinos da parte oriental da área.

\subsection{2 - Estudos Petrográficos}

Do universo de amostras utilizadas, cento e cinquenta foram selecionadas macroscópicamente e remetidas ao laboratório de laminação do Instituto de Geociências da Universidade de São Paulo para fins de petrografia convencional. Destas, trinta e uma delas foram escolhidas por sua representatividade em relação aos diversos corpos investigados, com a finalidade específica de estudos do quimismo dos minerais.

$\mathrm{Na}$ realização dos trabalhos petrográficos de rotina e execução de fotomicrografias foram utilizados os microscópios tipo OLYMPUS e AXIOPLAN, do laboratório de óptica do Instituto de Geociências da Universidade de São Paulo.

Para uma melhor caracterização das descrições petrográficas efetuadas, a bibliografia consultada incidiu sobre as obras clássicas do gênero, que possuem material descritivo fartamente ilustrado para texturas, estruturas e paragêneses 
minerais tais como: Williams et al. (1954), Turner \& Verhoogen (1960), Hyndman (1972), Trögger (1979), Bard (1980), MacKenzie et al. (1982), da mesma forma que a nomenclatura adotada obedeceu aos princípios de classificação de rochas ígneas, com base em critérios mineralógicos (modais e/ou normativos) e texturais internacionalmente aceitos, principalmente àqueles descritos em: Streckeisen (1976), Le Maitre (1989), Sörensen (1979, 1986) e De La Roche (1986).

Neste trabalho, em todas as referências texturais/estruturais com respeito à granulação das rochas aqui consideradas, foram utilizados os critérios recomendados por Williams et al. (1954), abaixo transcritos:

maior que $30 \mathrm{~mm}=$ muito grossa

entre 5 e $30 \mathrm{~mm}=$ grossa

entre 1 e $5 \mathrm{~mm}=$ média

menor que $1 \mathrm{~mm}=$ fina

Os trabalhos de análise modal foram executados conforme procedimentos descritos em Chayes (1949), sendo, em média, quantificados cerca de 2000 pontos por seção delgada. A composição modal obtida foi então representada em diagramas QAP convencionais, fundamentados em normatização recomendada pela subcomissão de sistemática de rochas igneas da IUGS.

\subsection{3 - Química Mineral}

As trinta e uma amostras triadas foram preparadas para estudos de química mineral no Laboratório de Tratamento de Amostras do Departamento de Mineralogia e Geotectônica da Universidade de São Paulo, onde são efetuadas seções delgadas polidas e são nelas acrescentadas, um recobrimento de fina película de carbono por metalizador automático.

As análises foram realizadas no Laboratório de Microssonda Eletrônica do Instituto de Geociências da Universidade de São Paulo, tendo sido efetuado em equipamento JEOL-JXA-8600S contendo cinco espectrômetros, automatizado com 
um sistema TRACOR e com um programa que corrige automáticamente os dados para radiação de fundo (drift) e efeitos de matriz (fluorescência secundária, número atômico e absorção de massa). As condições de trabalho desse equipamento foram as de rotina do laboratório e são sumarizadas a seguir: potencial de aceleração de $15 \mathrm{kV}$ e $20 \mathrm{nA}$ para a corrente do feixe eletrônico, com diâmetro do feixe incidente de $5 \mu$.

As análises efetuadas em minerais silicáticos resultaram nos seguintes óxidos: $\mathrm{SiO}_{2}, \mathrm{TiO}_{2}, \mathrm{Al}_{2} \mathrm{O}_{3}, \mathrm{Cr}_{2} \mathrm{O}_{3}, \mathrm{FeO}_{\text {total, }} \mathrm{NiO}, \mathrm{MnO}, \mathrm{MgO}, \mathrm{CaO}, \mathrm{Na}_{2} \mathrm{O}, \mathrm{K} 2 \mathrm{O}$ e Cl, enquanto que àquelas realizadas em minerais opacos permitiu a obtenção dos seguintes óxidos: $\mathrm{SiO}_{2}, \mathrm{TiO}_{2}, \mathrm{Al}_{2} \mathrm{O}_{3}, \mathrm{Cr}_{2} \mathrm{O}_{3}, \mathrm{FeO}_{\text {total, }} \mathrm{NiO}, \mathrm{MnO}, \mathrm{MgO}, \mathrm{CaO}, \mathrm{Nb}_{2} \mathrm{O}_{5}$ e $\mathrm{ZnO}$.

Como metodologia intrínseca ao estudo das variações químicas dos cristais, foram efetuadas leituras obedecendo aos critérios práticos, relativamente às posições de centro e borda dos grãos, sempre levando-se em conta as suas dimensões.

As fórmulas estruturais e demais transformações catiônicas e moleculares dos minerais analizados por WDS e alguns por EDS foram executadas pelo programa MINPET (Richard, 1995).

Os dados analíticos brutos encontram-se listados nas tabelas 12.0 a 12.23 para feldspatos, 13.0 a 13.10 para feldspatóides, 14.0 a 14.16 para anfibólios, 15.0 a 15.16 para piroxênios, 16.0 a 16.10 para biotitas, 17.0 a 17.5 para magnetitas e 18.0 a 18.1 para ilmenitas. 


\section{CAPÍTULO II - GEOLOGIA REGIONAL}

A região sudoeste do Estado de Mato Grosso do Sul é definida na literatura geológica como uma associação de litotipos variados, ocorrendo desde gnaisses graníticos e TTG (tonalítico-trondhjemitico-granodiorítico) de idade atribuída ao Arqueano e/ou Paleoproterozóico, representadas pelo Complexo Rio Apa (Araújo et al. 1982), rochas máfico-ultramáficas de idade desconhecida e intrusivas graníticogranodioríticas do Mesoproterozóico.

Diversas contribuições foram importantes para a evolução do conhecimento geológico na parte brasileira desse segmento crustal, dentre os quais, podem ser destacados relevantes trabalhos como os de: Evans (1894), Derby (1895), Lisboa (1909), Oliveira (1915), Oliveira e Leonardos (1943), Almeida (1945, 1965), Dorr II (1945), Guimarães (1958), Moraes (1958) e Putzer (1958), enquanto que no lado paraguaio, somam-se em importância os trabalhos pioneiros de Eckel (1959), Hutchinson (1979-1980) e Wiens (1986), sendo que todos eles procuraram, em primeira instância, caracterizar as principais ocorrências geológicas das porções sudoeste brasileira e nordeste paraguaia.

Nesse âmbito, Almeida et al.(1967) efetuaram mapeamento geológico da parte sudoeste do Estado de Mato Grosso, incluindo no "Complexo Cristalino Brasileiro", litologias tais como: gnaisses, granitos intrusivos, anfibolitos, quartzitos e mica xistos, com idade atribuida ao Pré-cambriano Inferior. As rochas de natureza vulcanoclástica, os quartzo-pórfiros e piroclásticas associadas existentes nesse segmento crustal, foram estimadas como pertencentes ao Pré-cambriano Superior.

Corrêa et al. (1976) refere-se às rochas gnáissicas e graníticas associadas que compõem o embasamento metamórfico daquela região, como fazendo parte do Complexo Basal, inserido na unidade geotectônica denominada "Cráton do Guaporé", denominação esta, utilizada em trabalhos de mapeamento geológico da Companhia de Pesquisa de Recursos Minerais-CPRM, nas décadas de 60/70. Definem ainda um conjunto de rochas designados "Associação Metamórfica do Alto Tererê, composta por rochas de natureza parametamórfica, de idade Pré-cambriana 
Superior. Esse conjunto compreende associações petrográficas diversas, descritas a seguir: I) biotita gnaisses finos de fácies anfibolito, II) quartzitos e mica xistos de fácies anfibolito, rochas metabásicas de fácies xistos verdes e III) granada gnaisses, mica xistos e quartzitos de fácies epidoto-anfibolito. Os autores correlacionaram este conjunto de rochas ao Grupo Araxá, alegando semelhanças em termos petrográficos, de posicionamento estratigráfico/ estrutural e de metamorfismo.

Nogueira et al. (1978), Olivatti \& Correia Filho (1981), Santos \& Loguércio (1984), dentre outros, em trabalhos de mapeamento geológico naquela região, admitem a existência da "Associação Metamórfica do Alto Tererê" com ressalvas específicas a respeito de sua idade e constituição.

Araújo et al. (1982) efetuaram estudos geocronológicos em meta-vulcanitos ácidos a intermediários e piroclásticas associadas, pertencentes ao Grupo Amoguijá de Almeida, (1965), tendo encontrado valores de $1.650 \pm 63 \mathrm{Ma}$ com razão inicial ${ }^{87} \mathrm{Sr} /{ }^{86} \mathrm{Sr}$ de $0,702 \pm 0,004$ e $1.600 \pm 40 \mathrm{Ma}$ e razão inicial ${ }^{87} \mathrm{Sr} /{ }^{86} \mathrm{Sr}$ de $0,707 \pm 0,004$ para as rochas ácidas plutônicas e subvulcânicas, sendo estas últimas separadas por aquele autor em um conjunto de rochas denominadas "Suite Intrusiva Alumiador".

Silva (1998) em mapeamento geológico (esc. 1:100.000) de parte da região da Serra da Alegria, nordeste da cidade de Porto Murtinho (MS), descreve litologias pertencentes ao Complexo Rio Apa, compostas por gnaisses polimetamórficos, metagranitóides intrusivos do tipo TTG (gnaisses e granitóides tonalíticos, trondhjemíticos e granodioríticos), provavelmente formados por anatexia crustal arqueana. Ocorrem também segundo aquele autor, rochas supracrustais com características de greenstone belts, metabasíticas/ anfibolíticas, com estrutura de pillow-lava e tendências toleiíticas de fundo oceânico, associadas com xistos e metatufos básicos. Essa sequência representaria um estágio de formação e colapso tectono-metamórfico da bacia oceânica (retro-arco) de idade arqueana ou paleoproterozóica. Este autor identifica na área uma intrusão diferenciada gabroanortosítica-granofírica denominada de Serra da Alegria em função da expressão topográfica homônima, de idade paleo a mesoproterozóica, colocada em regime de estabilidade crustal, que produziria como fase final de cristalização, as rochas metavulcânicas ácidas apresentando indícios de dois processos de mistura e 
contaminação distintos: o primeiro predominantemente constituído de gabros e anortositos com características toleíticas e processos de fracionamento/diferenciação magmáticos; o segundo, constituído de granófiros diversos, com tendências alcalinas, sendo inferido como de derivação crustal. São citados ainda ocorrências de metavulcanitos e subvulcanitos ácidos e básicos. Silva (1998) inclui um último evento regional na área que seria o responsável pelo desenvolvimento da faixa móvel de idade mesoproterozóica "Associação Metamórfica do Alto Tererê". São indicadas ocorrências isoladas de $\mathrm{Cu}, \mathrm{Au}$, metais base em metabasitos, platinóides em gabros ricos em $\mathrm{Cr}$ e ainda cromititos estratiformes e sulfetos do tipo Ni-Cu-Fe.

São descritos regionalmente, tufos calcários, travertinos com gasterópodos e conglomerados com cimento calcítico e calcários concrecionários, definidos por Almeida (1943) como Formação Xaraiés, tendo sido reconhecida nos trabalhos de Correa et al. (1976) e Nogueira et al. (1978), assim como os depósitos de vasas, areias e argilas definidos por Oliveira \& Leonardos (1943) como Formação Pantanal. $A$ idade estimada para essas duas unidades é pleistocênica.

A área sob estudo inclui-se no contexto geotectônico denominado Cráton Amazônico em sua porção mais meridional, mais precisamente, dentro dos limites da Província Tapajós, Sub-Província Madeira (Amaral, 1984). Trata-se de um segmento crustal circundado a norte e a oeste pela sedimentação terciário-quaternária da Bacia Pantanal/Chaco, a leste pela Faixa de Dobramentos neo-Proterozóica "Paraguai" e a sul pelo graben denominado "Bajo de San Pedro" (Fulfaro, 1996). A situação da área e sua geologia estão sintetizados no mapa geológico proposto por Araújo et al. (1982), (Figura 02). Nesse mapa, as rochas alcalinas da Província do Alto Paraguai destacam-se ao longo do rio homônimo com a designação Alcalinas Fecho dos Morros (porção oeste do mapa). No lado paraguaio optou-se por um esbôço geológico mais atualizado em relação aos trabalhos de Hutchinson (1979) e Wiens (1986) entre outros, representado pelo esquema proposto por Velázquez et al. (1998), reproduzido na figura 03. 

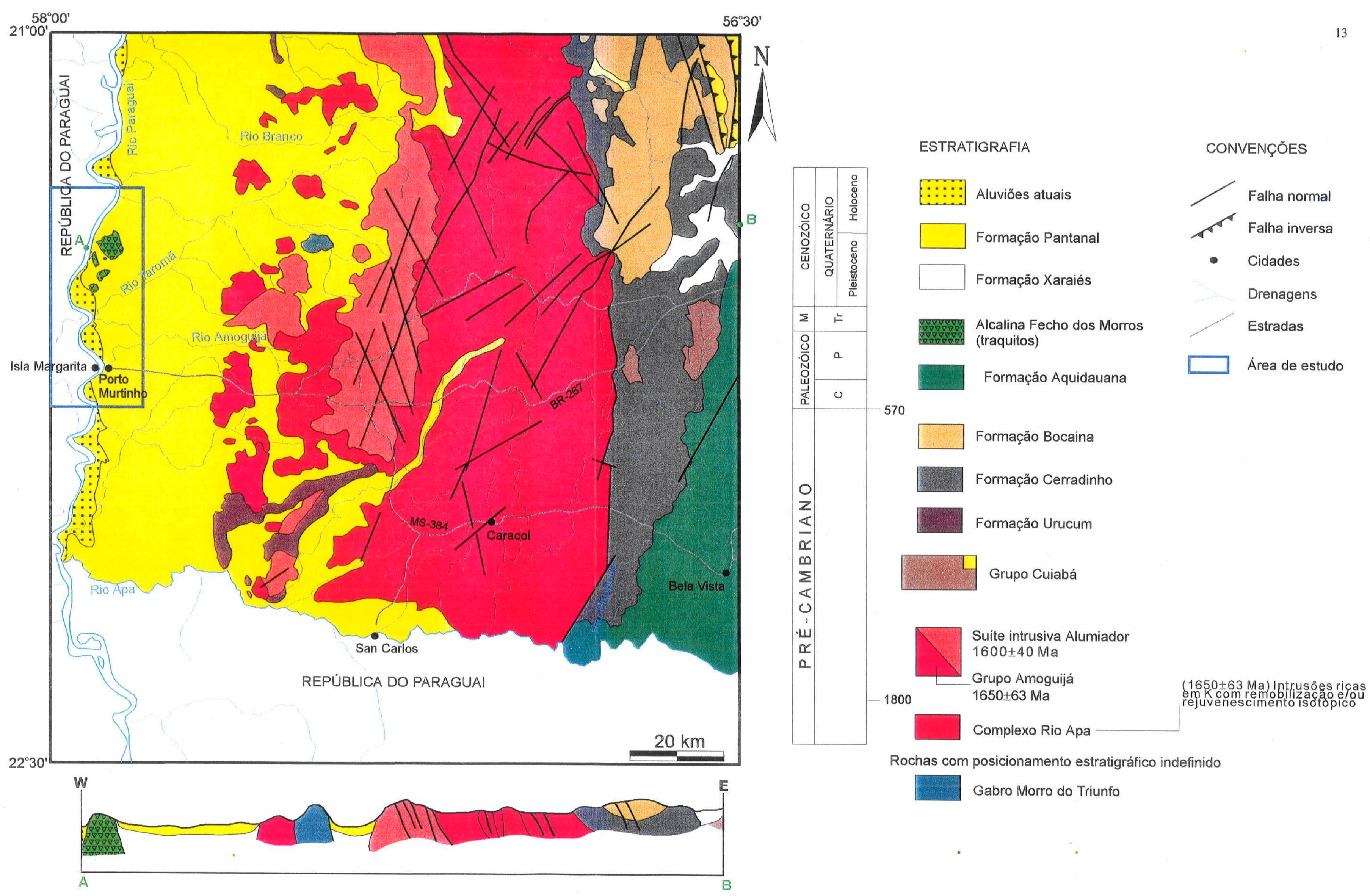

Figura 2: Esboço geológico simplificado da região de Porto Murtinho (MS) segundo Araújo et al. (1982)

Rochas com posicionamento estratigráfico indefinido

Gabro Morro do Triunfo 


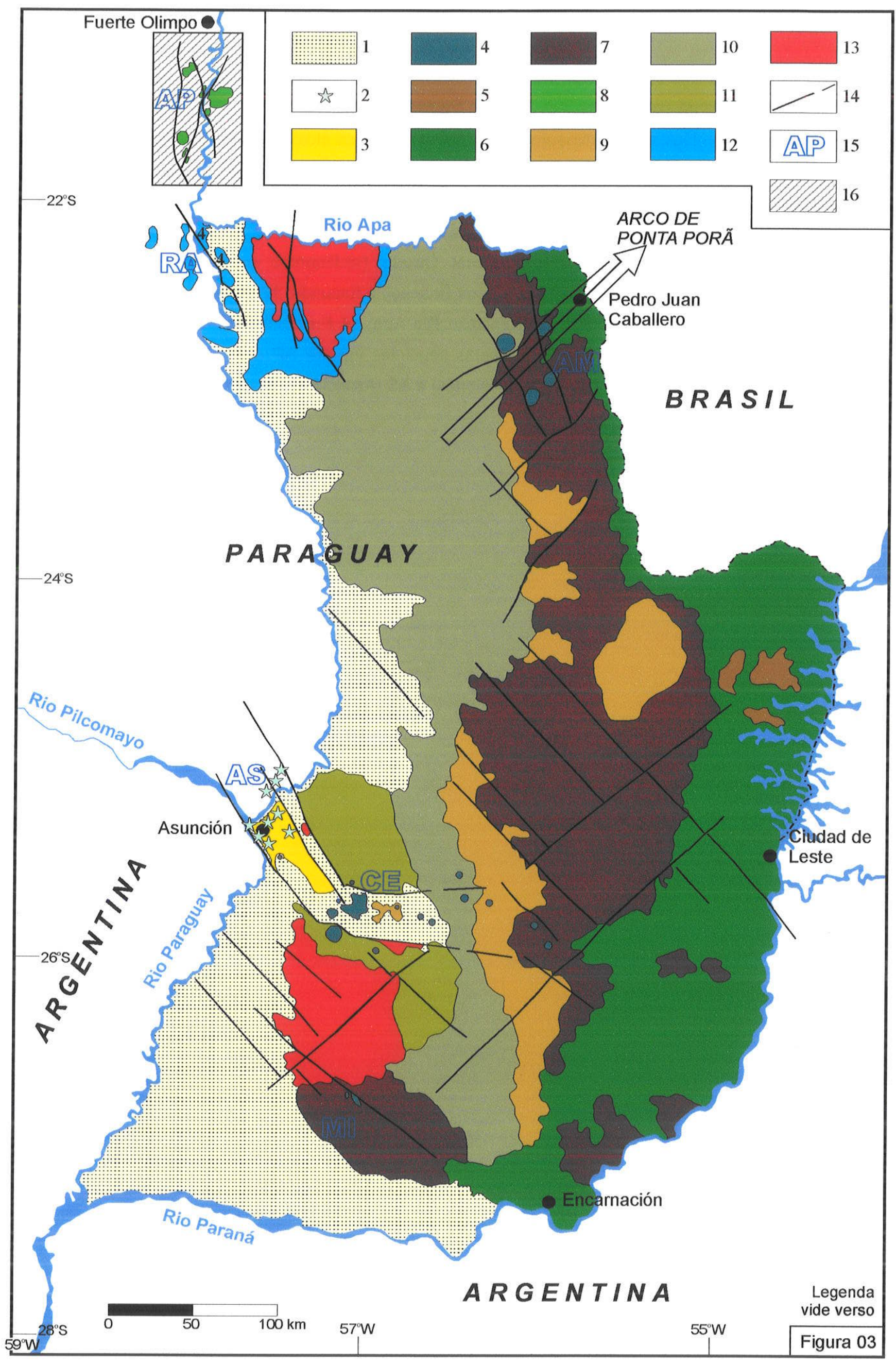


Tabela 01 - Quadro comparativo das colunas estrátigráficas do Pré-Cambriano ao Cretáceo da Parte mais Meridional do Cráton Amozônico - Região do Rio Apa.

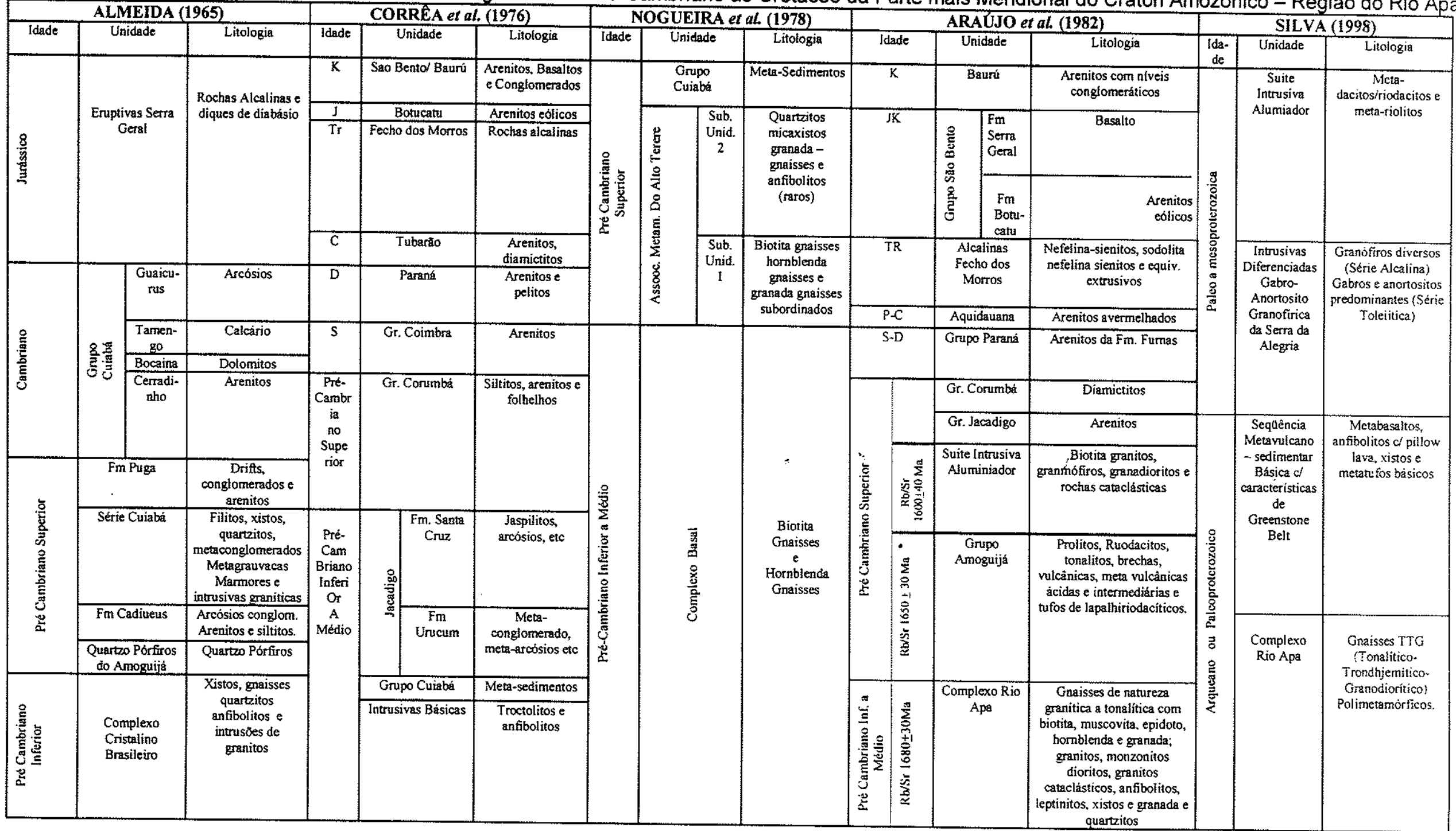


CAPÍTULO III - GEOLOGIA LOCAL

III.1 - Aspectos Fisiográficos

Estudos geomorfológicos pioneiros foram efetuados por diversos autores em meados do século XX no qual Almeida (1959) definiu uma unidade geomórfica constituída por extensa planície, com cotas altimétricas inferiores a $400 \mathrm{~m}$, entrecortada pelo rio Paraguai e seus afluentes, denominando-a de "Depressão Paraguaia".

Alvarenga et al. (1982) separaram os seguintes conjuntos geomorfológicos na região limítrofe entre o Estado de Mato Grosso do Sul e a República do Paraguai: a) Planalto da Bodoquena, constituído em termos de relêvo pela serra homônima e inselbergs adjacentes, com predominio de cotas altimétricas entre 400 e $650 \mathrm{~m}$. Litológicamente esse conjunto está representado por metassedimentos dobrados e metamorfizados na fácies dos xistos verdes; b) Depressão do Rio Paraguai, composto por superfície rebaixada, com cotas altimétricas entre 100 e $350 \mathrm{~m}$. Sob esta denominação estão reunidos os seguintes conjuntos geomórficos: Zona Cristalina Ocidental, Zona Serrana Oriental, Depressão Periférica do Miranda e Vale do Rio Apa, definidos por Almeida (1965). Em toda essa compartimentação, predominam o relêvos dissecados resultantes do recuo das escarpas da Bacia do Paraná; enquanto que as áreas sujeitas a inundações, com similitude de pântanos, foram denominadas de Planícies e Pantanais Mato-Grossenses, tal como anteriormente definida por Franco \& Pinheiro (1982), onde altitudes situam-se entre 80 e $140 \mathrm{~m}$. Seus limites a oeste se dispôem adjacentemente à região chaquenha pertencente à República do Paraguai. Como se pode observar na (Figura 04), a área estudada está integralmente inserida na última província geomorfológica (Planícies e Pantanais Mato-Grossenses), cujas cotas altimétricas somente excedem 140m quando constituem o relevo residual exumando os conjuntos alcalinos da Província Alto Paraguai. 
Almeida (1949) sustenta que os conjuntos geomórficos denominados Depressão Paraguaia, mapeados posteriormente por Alvarenga et al. (1982), como "Depressão do Rio Paraguai" e "Planícies e Pantanais Mato-Grossenses", tiveram origem fundamentada principalmente em movimentos epirogenéticos, associadas à fraturamentos de blocos sub-meridianos, à partir do Cretáceo, com importante transgressão marinha no Mioceno, incluindo a formação de um destacado delta do rio Paraguai, na região compreendida atualmente pelo país homônimo.

Alvarenga et al (1982) salienta importantes reequilibrios isostáticos que atingiram àquela região, em periodos pós-Cretácicos, soerguendo o cinturão andino e a borda ocidental da Bacia do Paraná, com consequente abatimento de toda a bacia hidrográfica do Rio Paraguai. O relevo residual (morros testemunhos) de rochas da Bacia do Paraná presente em áreas da Depressão do Rio Paraguai e Planicies e Pantanais Mato-Grossenses, atestam que a abertura daquela depressão ocorreu principalmente devido à erosão e recuo das escarpas da Bacia do Paraná.

O clima na região, classifica-se como o do tipo tropical úmido, comum a toda a região dos pantanais matogrossenses, cujo período de chuvas têm início mês de Setembro até maio, sendo mais intenso nos meses de Janeiro e Fevereiro (Nimer, 1989).

As fotos 01 e 02 ilustram, respectivamente, o aspecto geral da vegetação predominante na região do Morro Pão de Açúcar e o rio Paraguai, principal via de acesso aos corpos alcalinos da Província Alto Paraguai. 


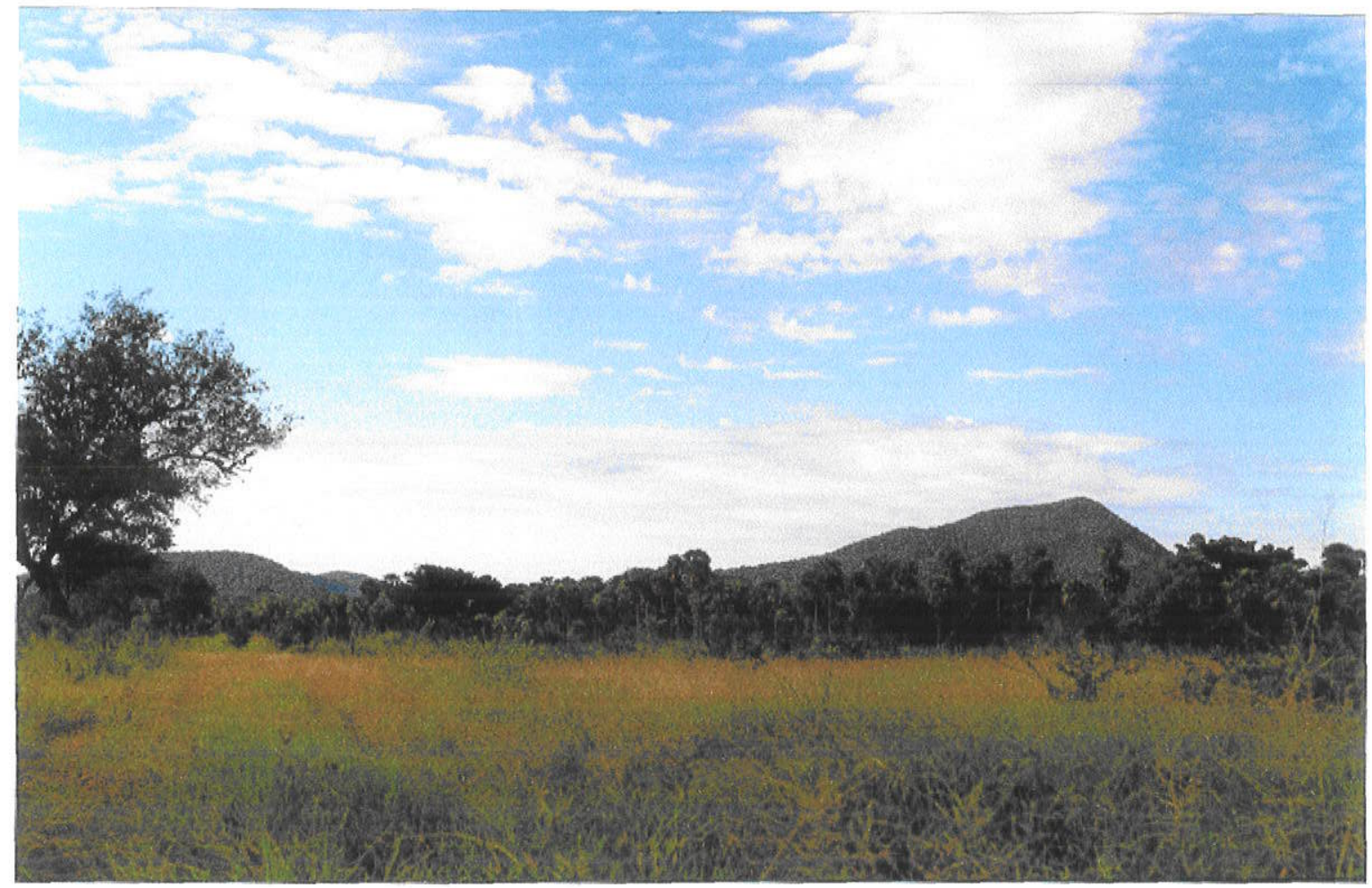

Foto 01 - Aspecto geral da intrincada vegetação de cerrado encobrindo área alagada nas proxiimidades do Morro Pão de Açúcar. Ao fundo, pode-se observar elevação homônima.

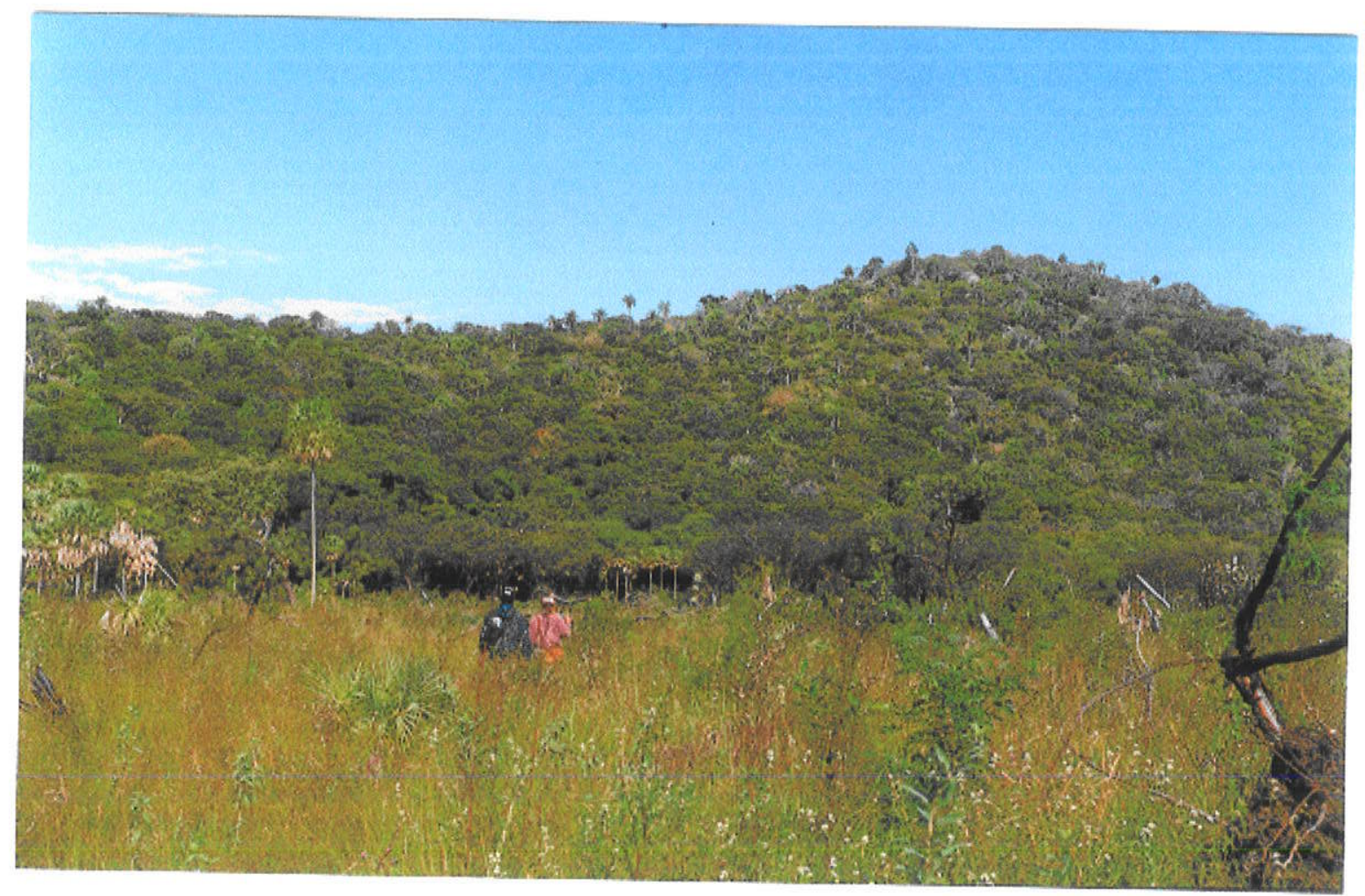

Foto 02 - Equipe de mapeamento transpondo pântano (encoberto pela vegetação) em direção aos "plugs" à SE da llha Fecho dos Morros (São Pedro, Morro Conceição e Morro Distante). 


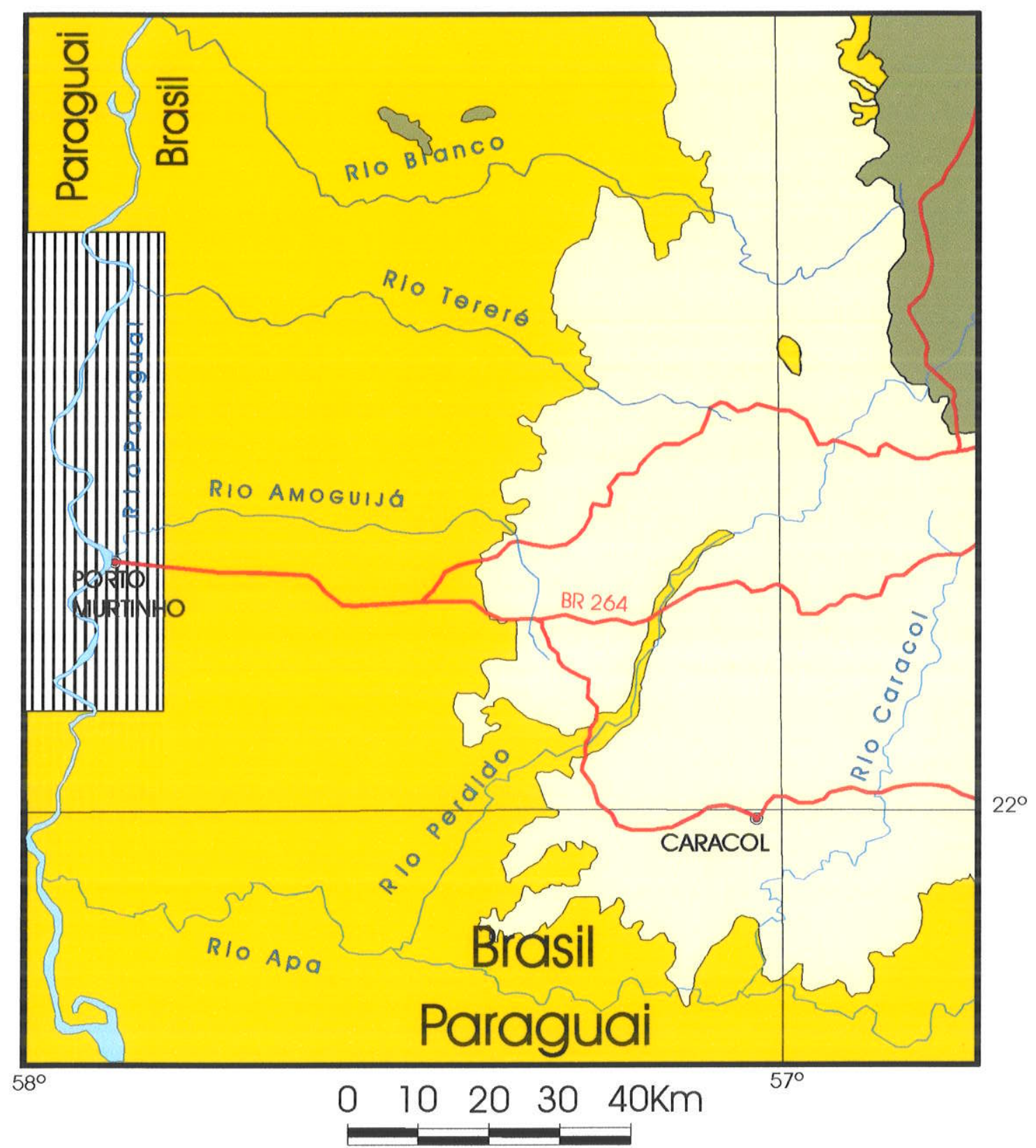

Legenda:

Planalto da Bodoquena

$\square$ Depressão do Rio Paraguai

Planícies e Pantanais Matogrossenses

||||||| Área Estudada

Figura . 04 - Contexto Geomorfológico Regional simplificado do extremo sudoeste do Mato Grosso do Sul, de acordo com Alvarenga et. al. (1982). 
III.2 - Provincia Alcalina Alto Paraguai

A área enfocada caracteriza uma província magmática de natureza alcalina sódica, inserida no contexto geotectônico denominado Cráton Amazônico, Província Tapajós, Sub Província Madeira, no sentido de Amaral et al.(1966) e, Amaral (1984) em sua porção mais meridional, como reportado no capitulo anterior.

Petrográficamente as rochas desta província situam-se como sienitos nefelínicos, nefelina sienitos, sienitos, granito alcalino e seus equivalentes extrusivos. Suas características geoquímicas são marcadas por altos teores em $\mathrm{Na}$ e K, baixos em $\mathrm{Cr}, \mathrm{Ni}, \mathrm{MgO}$ e $\mathrm{CaO}$ e concentrações variáveis em $\mathrm{TiO}_{2}, \mathrm{P}_{2} \mathrm{O}_{5}, \mathrm{Rb}, \mathrm{Ba}, \mathrm{Zr}, \mathrm{Hf}$ e U. Maiores detalhes sobre a geoquímica global incluindo cálculos normativos e indice de alcalinidade podem ser encontrados em Velázquez (1996).

III.3 - Trabalhos Anteriores

A denominação "Província Alcalina do Alto Paraguai" é relativamente recente em termos de nomenclatura geológica das rochas ocorrentes na fronteira BrasilParaguai e foi inicialmente atribuída por Livieres \& Quade (1987). Trata-se de designação utilizada para nomear corpos intrusivos e extrusivos anteriormente reconhecidos por Almeida (1983) como "Província Norte", os quais já haviam sido sucintamente descritos em trabalhos prévios por Evans (1894), Derby (1895), Lisboa (1909), Moraes (1958), Guimarães (1958) e Milton \& Eckel (1959).

Guimarães \& Dutra (1962) efetuaram investigação geoquímica em rochas alcalinas de diversas partes do Brasil, incluindo duas amostras de rochas alcalinas da localidade de Fecho dos Morros, tendo analisado os seguintes elementos: $\mathrm{Nb}, \mathrm{Zr}$, $\mathrm{Y}, \mathrm{Co}, \mathrm{Ni}, \mathrm{Ga}, \mathrm{Be}, \mathrm{V}, \mathrm{Sc}, \mathrm{Cr}, \mathrm{La}, \mathrm{Ba}$ e Sr. Essas rochas foram classificadas petrograficamente como pulaskito (com relativamente elevada concentração de $\mathrm{Zr}$ ) $\mathrm{e}$ foiaíto. Ressalta-se que o objetivo pincipal dos autores era conhecer a distribuição 
dos elementos menores em rochas alcalinas brasileiras portadoras de feldspatóides e suas concentrações relativas (abundância).

Dados radiométricos K/Ar executados por Amaral et al. (1966) referem-se ao valor de 226 Ma para um nefelina sienito do Morro Pão de Açúcar, enquanto que Comte \& Hasui (1971) registraram a idade de 209 Ma para uma rocha similar, da mesma localidade, também pelo método KJAr.

Araújo et al. (1982) efetuaram estudos petrográficos em litotipos da Província Alcalina do Alto Paraguai, região do Morro Pão-de-Açúcar e llha Fecho dos Morros, tendo encontrado variedades tais como: nefelina sienitos, traquitos, biotita-egirina sienitos, egirina-arfvdsonita sienitos, latito-andesitos e traquitos pórfiros. Ressalta-se aquí a concordância "in totum" dos autores supra-citados com as datações realizadas por Amaral et al. (1966) e Comte \& Hasui (1971), estabelecendo uma época próxima a 220 Ma para a colocação do conjunto de corpos alcalinos por eles denominado "Alcalinas Fecho dos Morros". Araújo et al. (1982) interpretaram as idades determinadas por Amaral (1966) e Comte e Hasui (1971) como representantes do mais antigo fenômeno de reativação da Plataforma Sul Americana, com intrusões alcalinas associados à movimentações da borda ocidental da Bacia do Paraná.

Velázquez et al. (1993), estabeleceram os seguintes valores para os diversos corpos datados: Cerro Boggiani (PY) - $234 \mathrm{Ma}$ (KJAr em Anfibólio) e $223 \mathrm{Ma}$ (Isócrona Interna); Pão de Açúcar - $248 \mathrm{Ma}$ (K/Ar em Biotita); Ilha Fecho dos Morros - $225 \mathrm{Ma}$ (Isócrona Interna); Cerrito - $253 \mathrm{Ma}$ (K/Ar em Biotita); Cerro Siete Cabezas $-253 \mathrm{Ma}$ (K/Ar em Biotita).

Velázquez (1996) descreve associações petrográficas tais como: nefelina sienitos, nefelina-sodalita sienitos, sienitos alcalinos, sienitos com quartzo, quartzo sienitos e eventualmente sienogranitos que envolvem desde assembléias mineralógicas fortemente insaturadas a supersaturadas em sílica. Refere-se ainda ao quimismo dos corpos da Província do Alto Paraguai como possuidor de clara tendência ligada a duas distintas séries de evolução: a primeira teria como termos menos diferenciados os sienitos alcalinos e como membros mais diferenciados os quartzo sienitos e sienogranitos, enquanto que a segunda evoluiria de nefelina sienitos para nefelina-sodalita sienitos. Este autor destaca ainda que os litotipos 
menos diferenciados possuem baixa razão inicial ${ }^{87} \mathrm{Sr} /{ }^{86} \mathrm{Sr}$, o que indica ausência de contaminação do magma, ao passo que os termos mais diferenciados demonstram elevada razão inicial ${ }^{87} \mathrm{Sr} /{ }^{86} \mathrm{Sr}$, evidenciando processos de contaminação e/ou assimilação magmática.

As relações de contato dos corpos supra mencionados e suas encaixantes regionais, não podem ser visualizadas uma vez que os seus contatos litológicos encontram-se em áreas submersas (regiões alagadas) e/ou estão encobertos pela sedimentação terciário-quaternária da Formação Pantanal.

III.4 - Formas de Ocorrência do Magmatismo Alcalino do Alto Paraguai

Inúmeras ocorrências do magmatismo alcalino de idade Permo-Triássica associam-se à Província do Alto Paraguai e distribuem-se ao longo do Rio Paraguai, região limitrofe entre a República do Paraguai e o Estado de Mato Grosso do Sul, no Brasil. Elas constituem-se de corpos que variam em suas dimensões, compreendendo desde pequenos "plugs" e "stocks" (ex. Cerro Siete Cabezas) a maciços de dimensões batolíticas como o Morro Pão de Açúcar (Fotos 01 e 02, respectivamente).

Topograficamente, essas massas intrusivas estão representadas por pequenos "cerros" cujas cotas podem atingir até $300 \mathrm{~m}$, com excessão do Morro Pão de Açúcar (a maior expressão topográfica da região), com aproximadamente $500 \mathrm{~m}$ de altitude. Essas manifestações alcalinas constituem-se nas únicas formas de relevo presentes nas imensas planícies do Pantanal matogrossense e Chaco paraguaio, provavelmente exumadas pela ação de longos processos erosivos.

Velázquez (1996) descreve o modo de ocorrência diversificada das rochas dessa província, ressaltando as características anelares dos "cerros" Siete Cabezas e Pão de Açúcar, associados a outros corpos em formas de diques e lavas, entre outros. Esse autor ainda estabelece a localidade de Puerto Coeyú como a área de maior concentração dos corpos alcalinos, onde se destacam ocorrências tais como 
Pão de Açúcar, llha Fecho dos Morros, Morro de São Pedro e Morros da Fazenda Conceição no lado brasileiro e Cerrito em território Paraguaio.

III.5 - Aspectos Tectônicos Vigentes Durante o Permo-Triássico

Tecer considerações a respeito da tectônica que prevalesceu no período compreendido entre o neo-Permiano e o eo-Triássico é tarefa das mais difíceis, especialmente quando não se possui evidências concretas dos eventos tectonomagmáticos e/ou metamórficos (amparadas em dados geofísicos, geoquímicos e geocronológicos) que dominaram a Plataforma Sulamericana nesse período. A despeito dessas dificuldades, pode-se, tentativamente, configurar o quadro tectônico estabelecido na passagem Paleozóico-Mesozóico.

O tema é complexo e polêmico, suscitando mais incertezas do que comprovações, porém, certas dúvidas podem ser exemplificadas por algumas questões anteriormente formuladas por pesquisadores que estudaram o Paleozóico na parte sudoeste do continente sul-americano, centradas principalmente na sua complexidade geológica-geotectônica, marcada por sucessivos episódios de plutonismo, vulcanismo, abertura e fechamento de oceanos, colagens de terrenos alóctones, metamorfismo e deriva de blocos crustais. Para uma revisão mais aprofundada, são aconselhados os trabalhos levados a efeito por Ramos et al (1986), Ramos (1988), Unternehr et al. (1988), Dalla Salda et al (1992a), Dalla Salda et al (1992b) Rapela et al (1992), Dalla Salda \& Dalziel (1993), Dalziel et al. (1993), e Pankhurst (1999).

Dalla Salda \& Dalziel (1993) relatam sucessivos episódios de colisão Laurentia-Gondwana durante o Paleozóico Inferior a Médio na região sudoeste da América do Sul, representados por magmatismo de arcos de itha tais como: gabros, 
quartzo dioritos, monzogranitos e granitos cálcio-alcalinos, ocorrendo ainda terrenos acrescionais associados às margens ativas.

Esses episódios de colisão teriam produzido as orogenias Tacônica e Acádica, responsáveis pelos orógenos Apalachiano (borda oriental do continente norte americano atual) e Famatiniano, tendo este último se desenvolvido no oeste argentino-leste chileno, prolongando-se desde Arequipa até os limites da Patagônia. Maiores detalhes podem ser encontrados nos trabalhos de Aceñola \& Tosseli (1976) in Dalla Salda \& Dalziel (1993), Ramos et al. (1986), Ramos (1988), Dalla Salda et al. (1992b), e Rapela et al. (1992), Dalla Salda \& Dalziel (1993).

Mpodozis \& Forsythe 1983, apud Ramos (1988) advogam uma colagem de terrenos metamórficos de Somuncura e do Maciço Deseado da Patagônia à margem do Gondwana durante o neo-Permiano, assim como outros terrenos de menor envergadura como os de Madre de Dios no sul do Chile, sofreram acresção ao supercontinente durante o neo-Paleozóico/eo-Mesozóico.

Hervé \& Thiele (1997) in Dalla Salda \& Dalziel (1993) reportam ainda eventos de deslocamento de terrenos ao longo de falhamentos transcorrentes durante 0 período Triássico.

Rapela \& Kay (1988) enfatizam a extensa ocorrência de vulcanitos ácidos da Formação Choiyoi, ocorrentes na região compreendida pelo sul do Chile e sudoeste argentino, sustentando uma forte correlação desse magmatismo marcadamente extensional aos batólitos de Somuncura e da Patagônia Central.

Almeida (1967, 1969 e 1983) define um episódio de reativação crustal na Plataforma Sul Americana denominada "Reativação Wealdeniana", tendo lugar a partir do Carbonífero Superior cujos efeitos estenderam-se até o Eoceno, sendo caracterizada fundamentalmente pela reativação de antigos falhamentos, soerguimentos de arcos estruturais, abatimentos de bacias costeiras, acentuada subsidência da Bacia do Paraná, e, consequentemente, estreita relação com a quebra do Gondwana, deriva continental e magmatismo cretácico.

Zalán et al. (1987) e Milani (1997), postulam o final do último ciclo transgressivo-regressivo a afetar as bacias intracratônicas brasileiras e em particular a Bacia do Paraná no período compreendido entre o neo-Permiano a eo-Triássico, o 
qual teria sido marcado pela sedimentação de "red beds" e pelo recuo do mar, descobrindo em definitivo, as áreas cratônicas da América do Sul.

Zalán (1990) admite como mecanismo deformacional da Bacia do Paraná, uma reativação condicionada pela estruturação brasiliana, caracterizada por zonas de fraqueza crustal com direção NE/SW ou ocorrências de flexuras regionais ocasionando subsidências.

Livieres \& Quade (1987) condicionam a ocorrência dos corpos alcalinos da Província Alto Paraguai ao Arco do Rio Apa que teria se formado desde o Proterozóico Superior.

Na concepção de Velázquez et al (1996) e Gomes et al. (1996a ), a ocorrência desses corpos estaria relacionada a uma margem cratônica, controlada por falhamentos de direção geral N-S, em razão do alinhamento dos corpos alcalinos ao longo do rio Paraguai. Nesse sentido, Ulbrich (1984) salienta o caráter marginal das ocorrências alcalinas ligadas à Bacia do Paraná, associando-as aos mecanismos que controlam a subsidência e soerguimento de suas bordas.

Velázquez (1996) com base em estudos isotópicos de ${ }^{87} \mathrm{Sr} /{ }^{86} \mathrm{Sr}$ e padrões de elementos terras raras sugere que as séries magmáticas definidas na Província Alto Paraguai, seriam oriundas de um único magma parental mantélico (basanítico), gerado à baixa $\mathrm{P}_{\mathrm{H}_{2} \mathrm{O}}$, com alto grau de saturação em água (ocorrência de anfibólios e micas), com aportes corticais e raros processos de ação deutérica.

Veevers (1994) e Veevers et al. (1994) determinaram na margem Panthalassana da Província Gondwânica, a ocorrência de extenso magmatismo, representado no continente australiano pela unidade denominada Dundee/Emmaville correlacionando-o ao magmatismo ácido de Choiyoi, no continente sul-americano, sendo ambos com idade de aproximadamente $250 \mathrm{Ma}$. Mudanças paleoclimáticas, substituições da flora (Glossopteris por Dicroidium), modificações isotópicas ${ }^{87} \mathrm{Sr} /{ }^{86} \mathrm{Sr}$ e $\delta^{13} \mathrm{C}$ e $\delta^{34} \mathrm{~S}$ e mudanças de polaridade magnética são indicadas por Veevers et al. (1994) como elementos de definição do limite entre o Permiano e o Triássico para valores em torno de $250 \mathrm{Ma}$.

Milani \& Ramos (1998) correlacionam as modificações impressas na morfologia da Bacia do Paraná, ao clímax da Orogenia Sanrafaélica (Neopermiana), 
enfatizando que o material vulcanogênico ocorrente na Formação Rio Bonito mapeado por Coutinho et al. (1991), pode ser perfeitamente correlacionável ao magmatismo Choiyoi do oeste argentino.

Correia \& Bastos (1993) relacionaram as rochas alcalinas de Porto Murtinho (Província Alto Paraguai) ao Lineamento Transbrasiliano, cuja extensão em território brasileiro é distinguida pela zona de fraqueza crustal, com direção aproximada entre $40-45^{\circ}$, representado pelos campos diamantíferos de Aquidauana, de Coxim, do Taquari, do rio Araguaia, do Sono, do Tocantins, da Parnaíba e de Gurgueia; pelas províncias kimberlíticas de Redondão, do Uruçuí Preto, de Picos e alcalinas do sudoeste goiano, alcalina de Araguainha, basaltos e rochas ultrabásicas do Graben Jaibaras (Alto Parnaiba). Os lamprófiros e basanitos de Asunción são citados como exemplos do prolongamento do Lineamento Transbrasiliano em território paraguaio.

Sörensen (1986) reconhece que o grande número de ocorrências alcalinas continentais, estariam relacionadas à ambientes cratogênicos tensionais ou em regiões de domeamento, isentas de rifteamento. Em ambos os casos, os corpos alcalinos se estendem por faixas lineares, associados a bordas cratônicas o que parece ser o caso do magmatismo Alto Paraguai. Entretanto, alguns problemas permanecem insolúveis e podem ser exemplificados pelas seguintes questões:

a) qual seria a relação petrogenética entre o vulcanismo ácido também do período Permo-Triássico de Choiyoi ocorrente no oeste do continente sul-americano e o magmatismo do Alto Paraguai? Da mesma forma, pode-se indagar se existe interrelacionamento destes (Alto Paraguai e Choiyoi), com o magmatismo de Karroo de idade Jurássica do continente Africano.

b) o periodo Permo-Triássico representaria uma época na qual teria prevalecido alta atividade relacionada à fusão crustal, geração de magmas intra-placas, associados à um princípio de quebra do Gondwana?

Essas questões ainda não podem ser respondidas com exatidão, sendo que qualquer correlação formulada no atual estágio de conhecimento, face às informações disponiveis, são ainda consideradas hipóteses de trabalho e carecem de maior rigor científico para serem consideradas corolário. Portanto, neste trabalho, adota-se preferencialmente as interpretações geotectônicas efetuadas por Velázquez 
(1996) e Gomes et al. (1996a) para o magmatismo da Província Alcalina Alto Paraguai, como controlado por falhamentos N-S, relacionado à borda do supercontinete gondwânico. Pode-se ainda acrescentar que as ocorrências de corpos alcalinos que constituem a Província Alto Paraguai, estão sempre associadas à lineamentos que controlam o rio Paraguai em alguns trechos de seu curso. Para melhor visualização desses aspectos, são mostrados nas figuras $05,06-A$ e B os esquemas representativos desse modelo. Neles, ressalta-se respectivamente uma configuração esquemática de regiões intra-placa com alta sismicidade, reativação de antigas zonas de fraqueza e ocorrências alcalinas (Sykes, 1978) e as séries magmáticas relacionadas à espessura da litosfera em rifteamentos continentais e oceânicos e o desenvolvimento de alinhamentos tectônicos por reativação de falhamentos pretéritos e ainda a propagação de fraturas através da litosfera continental (Giret \& Lameyre, 1985). 


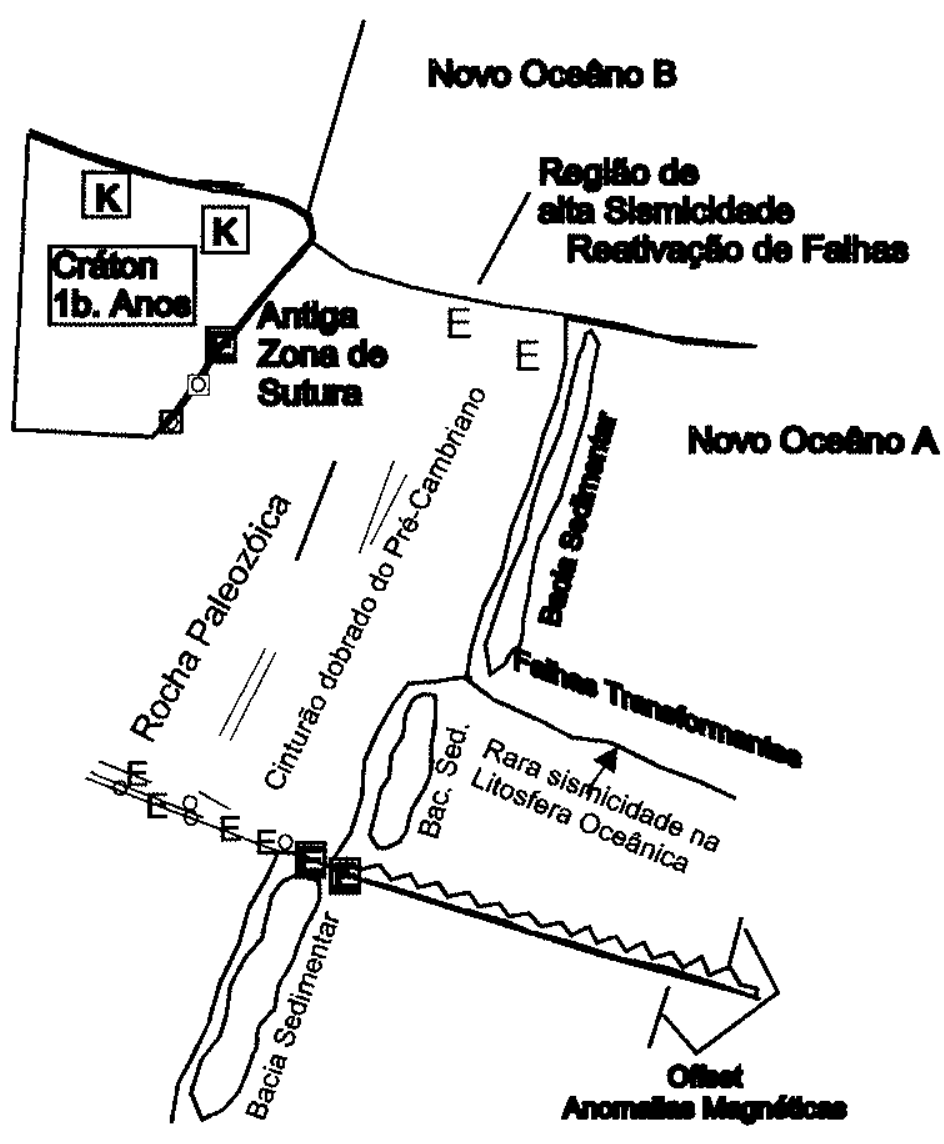

$E=$ região de alta sismicidade, rochas alcalinas e diques anelares, $k=$ Kimberlitos

Figura 05 - Esquema ilustrativo de regiỏes representativas de alta sismicidade (intra-placa), reativaçăo de zonas de fraqueza e colocação de magmas alcalinos na crosta terrestre (Sykes, 1978). 

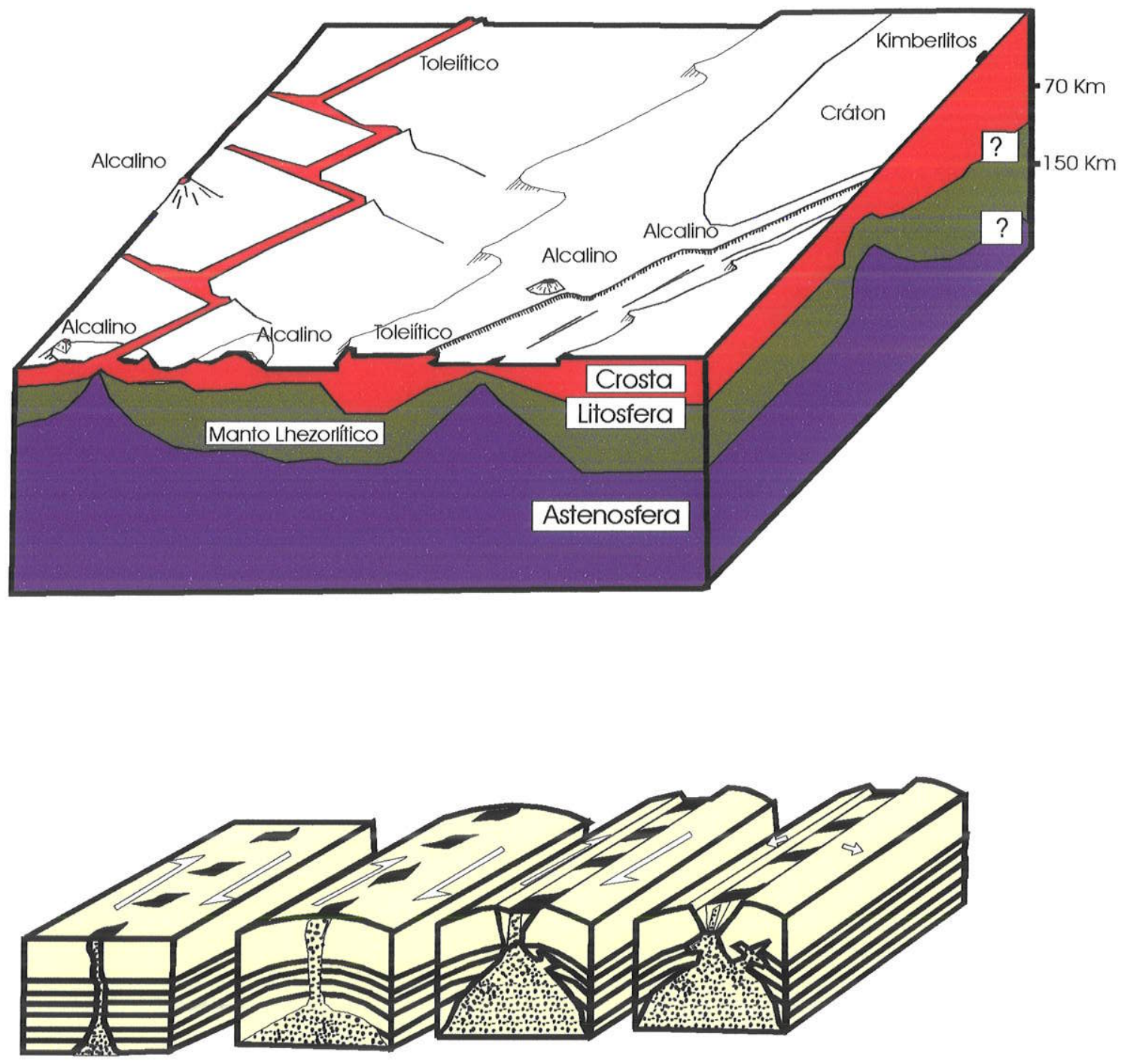

Figura 06 (A)- Representação esquemática mostrando as séries magmáticas relacionadas à espessura da litosfera em riffeamentos continentais e oceânicos e ainda o desenvolvimento de alinhamentos tectônicos por reativação de falhamentos pretéritos, segundo concepção de Giret \& Lameyre,, 1985, e . (B) Propagação de fraturas através da litosfera continental (Lameyre, in: Giret \& Lameyre, 1985) 


\section{CAPITULO IV - PETROGRAFIA}

Os estudos petrográficos aqui apresentados, compreendem a descrição sistemática das características estruturais, texturais e mineralógicas dos diversos tipos litológicos existentes nas áreas de ocorrências de Pão de Açúcar, São Pedro, Porto Conceição, Morro Conceição, Morro Distante e Cerro Pedreira no lado brasileiro e Cerro Boggiani, Cerrito e Cerro Siete Cabezas em território paraguaio. Contudo, ressalta-se que esses litotipos, em primeira instância, foram objeto de estudos macroscópicos prévios, relativamente à etapa de microscopia petrográfica, com aproximadamente 150 (cento e cinquenta) amostras coletadas, sendo que 32 (trinta e duas) delas foram selecionadas por sua representatividade textural e mineralógica, para determinação de sua composição modal, cujos resultados são apresentados nas tabelas 10 e 11 e também no diagrama QAP ilustrado na figura 10. Nas figuras 07, 08 e 09 estão representadas as localizações das amostras coletadas na Província Alcalina do Alto Paraguai.

\section{IV.1 - Cerro Boggiani e Corpos Satélites}

As rochas que compozem os corpos Cerro Boggiani e Satélites localizam-se à cerca de $10 \mathrm{~km}$ a noroeste da localidade de Puerto Coeyú (Figura 07) e constituemse de 3 pequenos morros, separados pela sedimentação Terciário-Quaternária da Formação Pantanal (Velázquez, 1996). O corpo de maior envergadura possui diâmetro aproximado de $5 \mathrm{~km}^{2}$ e altitude em torno de $140 \mathrm{~m}$, apresentando caráter eminentemente intrusivo, representado por litotipos insaturados em sílica tais como: nefelina e nefelina-sodalita sienitos. As composiçōes modais desta ocorrência, tanto os litotipos intrusivos quanto os subvulcânicos/ efusivos, plotam-se no campo 11 (feldspatóide sienitos e fonolitos) do diagrama QAP (Figura 10) Os corpos satélites que circundam a ocorrência de Cerro Boggiani, evidenciam natureza subvulcânica à 
extrusiva, sendo constituidos predominantemente por rochas fonoliticas. Salienta-se aqui que essas ocorrências, são as mais setentrionais da Província Alcalina Alto Paraguai, não se conhecendo na atualidade, corpos com menor latitude. Ressalta-se que nas duas etapas de campo realizadas, não foi possível atingir os dominios destes corpos alcalinos, em razão da logística da geografia regional. Portanto, fica subentendido que as amostras destes corpos, utilizadas para a presente pesquisa, foram todas elas coletadas por Velázquez em 1996.

Os nefelina sienitos são predominantemente leucocráticos, de coloração cinzenta (cinza clara com variações à cinza escura) e granulação geralmente média a grossa. As variedades petrográficas contendo textura porfiritica, exibem fenocristais de nefelina, sodalita e egirina-augita e egirina, com dimensóes de até $1 \mathrm{~cm}$.

As texturas, via de regra, são alotriomórficas (Fotomicrografia 01) e às vezes, porfiriticas (Fotomicrografia 02), onde os piroxênios da série egirina-augita ocasionalmente apresentam bordas de reação com desenvolvimento de anfibólio sódico.

A constituição mineralógica fundamental é essencialmente representada por feldspato potássico e secundáriamente em termos quantitativos, por núcleos e bordas de egirina-augita e subordinadamente por cristais de egirina com alguns deles indicando processo parcial de uralitização, pela formação de anfibólio cálcicosódico e ainda biotita. Grãos mais finos de egirina-augita ocorrem freqüentemente compondo a matriz.

O feldspato potássico presente é a sanidina, freqüentemente anédrica a subédrica, podendo exibir hábito tabular alongado. Secundariamente ocorre albita como cristais isolads ou como agregados da matriz. Aparecem como grãos incolores, micropertíticos, pertíticos ou mesopertíticos (intercrescimento em forma irregular, em finas lamelas e/ou anastomosados), com presença de geminação segundo a lei Carlsbad, raramente ocorrendo geminaçăo combinada Periclinio com Albita. Nestes minerais, ocorrem inclusões representadas por fases tais como: apatita, titanita e minerais máficos. 
Os feldspatóides são nefelina associada ou nāo com sodalita. A nefelina, via de regra, ocorre como representada por grãos subédricos a anédricos, nos interstícios da rocha. É incolor, de hábito prismático curto, possuindo inclusões de egirina-augita, sodalita, apatita, titanita e zircão. A sodalita distribui-se como cristais isolados, sendo o isotropismo a sua mais marcante característica. São freqüentes as inclusões de augita, egirina, nefelina e os minerais acessórios. A fotomocrografia 03 mostra a interrelação nefelina/sodalita/feldspato potássico em nefelina sienitos de Cerro Boggiani.

A egirina-augita constitui cristais euhédricos a subédricos, biaxiais positivos, com relevo e birrefringência elevados. Apresenta zoneamento setorial e as inclusões mais comuns neste mineral são, pela ordem de ocorrência: feldspato alcalino, nefelina, sodalita e opacos. O desenvolvimento poiquilitico ocorre ocasionalmente, contudo, sendo raro com a egirina.

Anfibólios cálcico-sódicos e sódicos, identificados por microssonda como ferro -richterita e ferro-eckermanita ocorrem em apenas duas amostras do universo de nefelina sienitos de Cerro Boggiani estudado. Ocorrem na forma de cristais prismáticos alongados e nas bordas de reação de egirina-augita. Apresentam pleocroísmo predominante nas cores verde-escuro, com variaçðes ao azul claro.

A biotita possui cor castanha-escura, hábito placóide, ocorrendo sempre como agregados xenomórficos, freqüentemente associadas à minerais opacos.

Os minerais acessórios mais comuns são: titanita (às vezes com geminação paralela ao elongamento do cristal), apatita, zircão e opacos. Já, os minerais secundários são representados por cancrinita, carbonatos (raros) e sericita.

Os minerais opacos são, por vezes, idiomórficos, com hábito prismático. Nas rochas de Cerro Boggiani, foram identificados por EDS, sulfetos de ferro (pirita) e de zinco (esfalerita). Ocorre ainda alguns minerais raros identificados ao microscópio como pectolita e lavenita e outros por EDS como: eudialita/eucolita. Este últime mineral também pode ser fácilmente identificado ao microscópio em virtude de seu alto relevo e por uma peculiaridade singular: em algumas amostras, o mineral apresenta uma variedade incolor, enquanto que em outras seções, a variedade presente é de cor avermelhada. 
Os fonolitos são rochas de cor escura, frequentemente porfiríticas com matriz afanítica. Apresentam fenocristais de feldspato alcalino, piroxênio augítico e nefelina. Ocasionalmente o piroxênio augítico apresenta hábito fibroso e acicular, agregandose em glomero-cristais fibrorradiados (esferulitos?), As seções basais desse mineral mostram zoneamento setorial.

Rochas piroclásticas com enclaves de rochas alcalinas, gnaisses e litotipos graníticos diversos associam-se a essas ocorrências, sendo representadas pela amostra RP-31B e ilustrada na fotomicrografia 05.

Um resumo dos aspectos litológicos e petrográficos descritos neste tópico pode ser observada na tabela 02 .

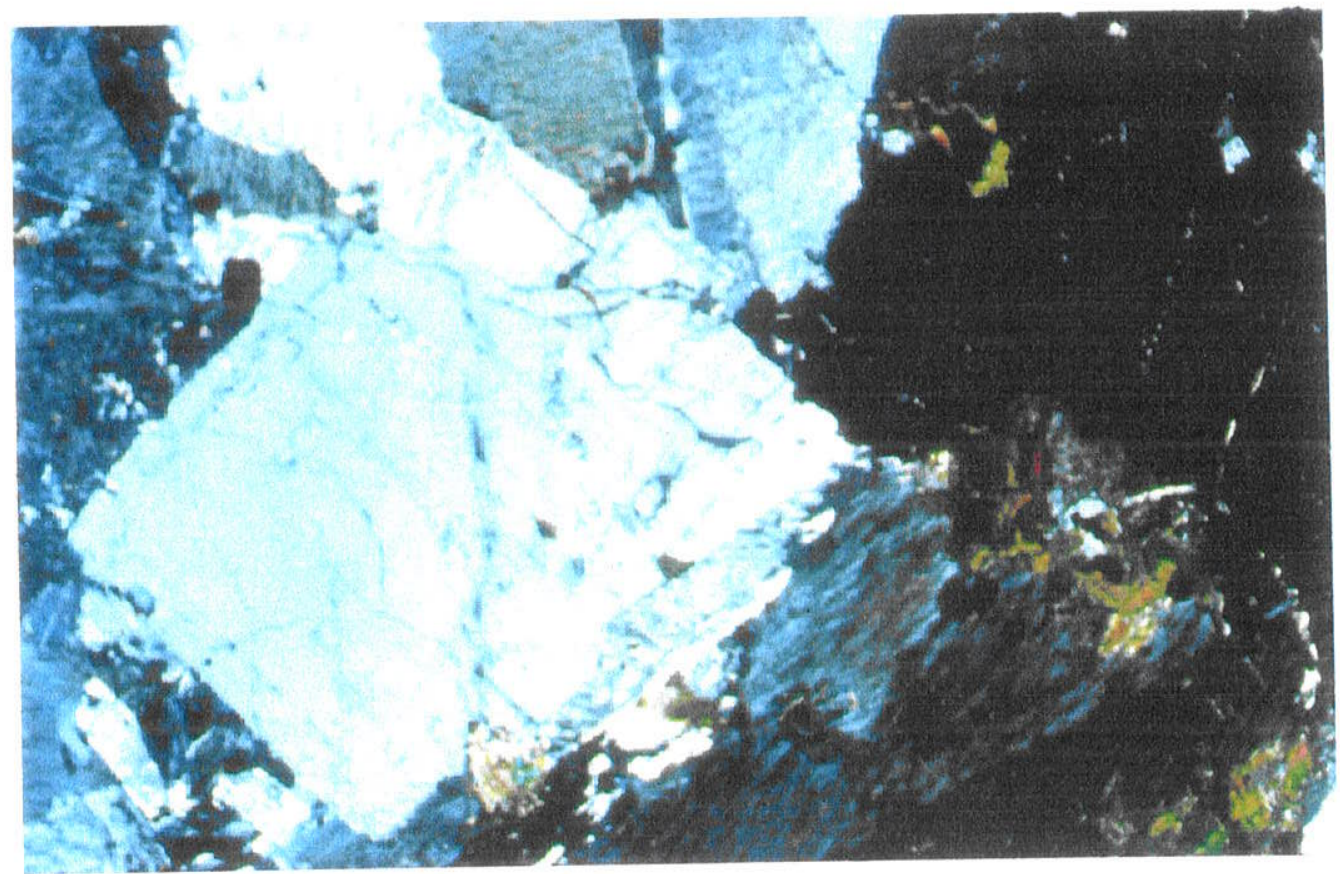

Fotomicrografia 01- RP-27, sodalita-nefelina-sienito apresentando textura alotriomórfica, com grãos idiomórficos de nefelina ao centro, sodalita à direita ao alto e feldspato potássico abaixo.Aumento 25X, polarizadores cruzados, filtro azul. 


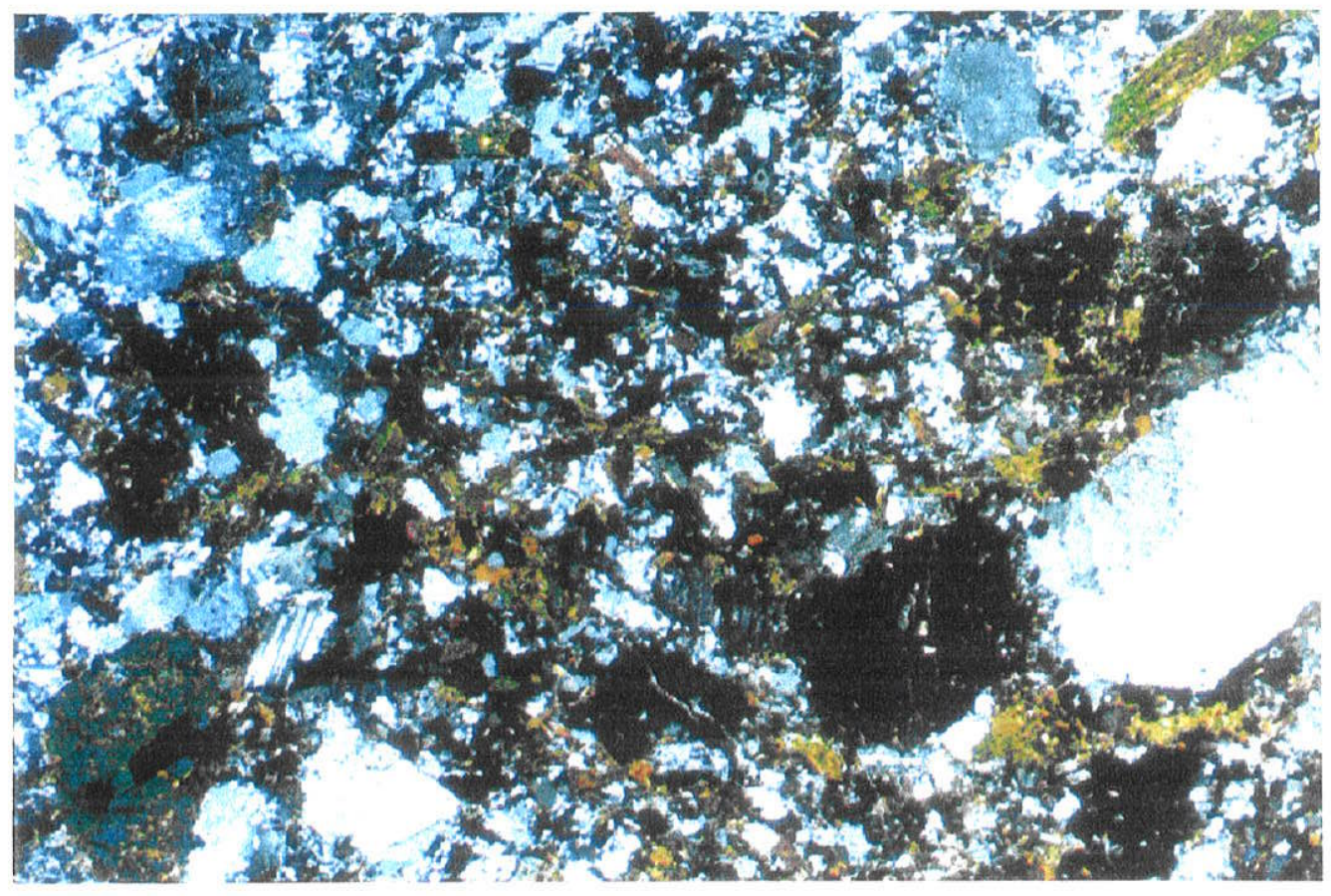

Fotomicrografia 02 - RP-31A - nefelina sienito porfirítico com fenocristais centimétricos de feldspato potássico (à direita), egirina-augita (verde), nefelina subdiomórfica e sodalita intersticial. Aumento 25X, polarizadores cruzados, filtro azul.

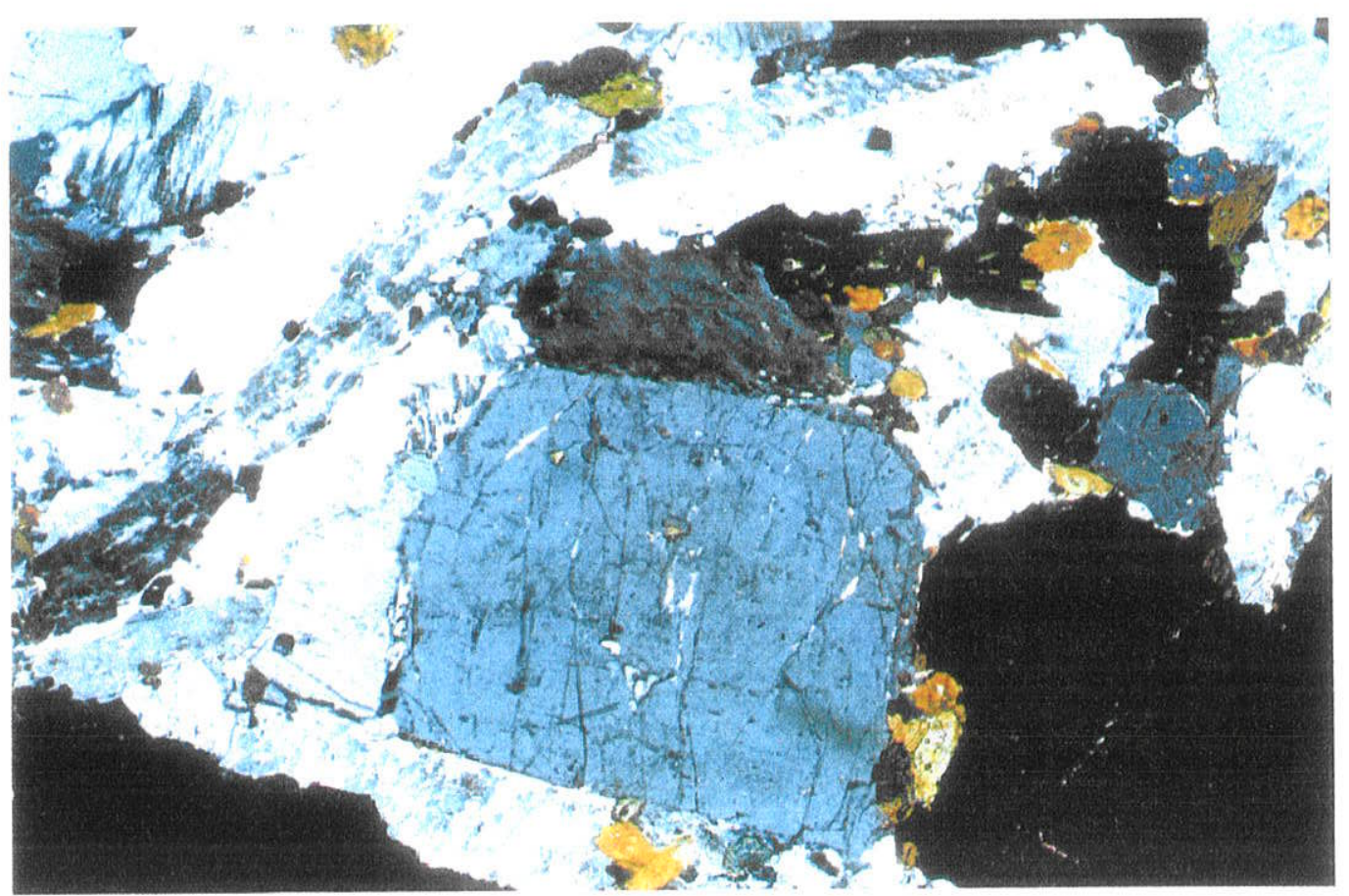

Fotomicrografia 03 - RP-29, nefelina-sienito com ocorrência de grãos idiomórficos de nefelina circundados por sodalita subédrica e feldspato potássico tabular, com geminação Carlsbad. Cancrinita constitui o mineral de alteração. Aumento 25X, polarizadores cruzados, filtro azul. 
Tabela 02 - Características litológicas da Província Alcalina Alto Paraguai: Cerro Boggiani

\begin{tabular}{|c|c|c|c|c|c|c|}
\hline \multirow{2}{*}{ 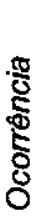 } & \multirow{2}{*}{ Feiçסes geológicas } & \multirow{2}{*}{ Litotipos } & \multirow{2}{*}{ Estrutura/Textura } & \multicolumn{3}{|c|}{ Mineralogia* } \\
\hline & & & & félsicos & máficos & acessorios \\
\hline \multirow{4}{*}{ 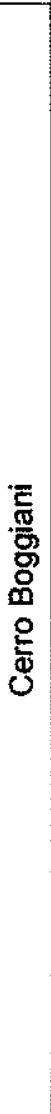 } & \multirow{4}{*}{$\begin{array}{l}\text { stock circular, area } \\
\text { de } 0,5 \mathrm{~km}^{2}\end{array}$} & $\begin{array}{l}\text { nefelina } \\
\text { sienitos } \\
\text { agpalticos }\end{array}$ & $\begin{array}{l}\text { maciça, } \\
\text { inequigranular } \\
\text { média a grossa, às } \\
\text { vezes, coronitica. }\end{array}$ & $\begin{array}{l}\left.\text { feldspato alcalino (Or }{ }_{73-96}\right) \\
\text { - micropertita geminaçăo } \\
\text { Carlsbad, zoneamento } \\
\text { normal, nefelina, sodalita. }\end{array}$ & $\begin{array}{l}\text { egirina-augita } \\
\text { zonaeamento setorial, com } \\
\text { bordas de } \mathrm{Fe} \text {-edenita rica } \\
\text { em } \mathrm{Si} \text {, biotita. }\end{array}$ & $\begin{array}{l}\text { apatita, titanita, zircăo e } \\
\text { opacos. }\end{array}$ \\
\hline & & $\begin{array}{l}\text { fonolitos } \\
\text { peralcalinos } \\
\text { agpaiticos }\end{array}$ & $\begin{array}{l}\text { maciça, } \\
\text { equigranular média } \\
\text { a fina, porfirítico } \\
\text { com aspecto } \\
\text { "ovóide" (rapakivi?), } \\
\text { coronitica. }\end{array}$ & $\begin{array}{l}\left.\text { feldspato alcalino (Or }{ }_{56-94}\right) \text {, } \\
\text { micropertítico geminaçå } \\
\text { Carlsbad; nefelina, sodalita }\end{array}$ & $\begin{array}{l}\text { egirina-augita com bordas } \\
\text { de Fe-richterita. biotita; } \\
\text { eudialita, pectolita }\end{array}$ & $\begin{array}{l}\text { apatita; titanita; zircåo e } \\
\text { opacos }\end{array}$ \\
\hline & & $\begin{array}{l}\text { diques } \\
\text { traquítico }\end{array}$ & $\begin{array}{l}\text { orientada, porfirítica } \\
\text { (porfirotraquítica) } \\
\text { com matriz } \\
\text { afanítica, } \\
\text { amigdaloidal }\end{array}$ & $\begin{array}{l}\text { fenocristais: feldspato } \\
\text { alcalino } \\
\text { criptopertitico geminação. } \\
\text { Carlsbad; } \\
\text { matriz: feldspato alcalino } \\
\text { criptocristalino. }\end{array}$ & 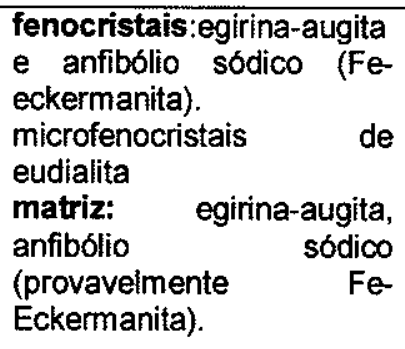 & $\begin{array}{llr}\text { apatita, } & \text { titanita, } & \text { zircão, } \\
\text { zeólita } & \text { (natrolita) } & \text { e } \\
\text { opacos. } & & \\
& & \end{array}$ \\
\hline & & $\begin{array}{l}\text { rochas } \\
\text { piroclásticas }\end{array}$ & $\begin{array}{l}\text { orientada, } r \text { com } \\
\text { fragmentos IIticos } \\
\text { diversos (enclaves } \\
\text { de } \quad \text { gnaisses, } \\
\text { granitos e rochas } \\
\text { alcalinas) afanítica. }\end{array}$ & & & \\
\hline
\end{tabular}




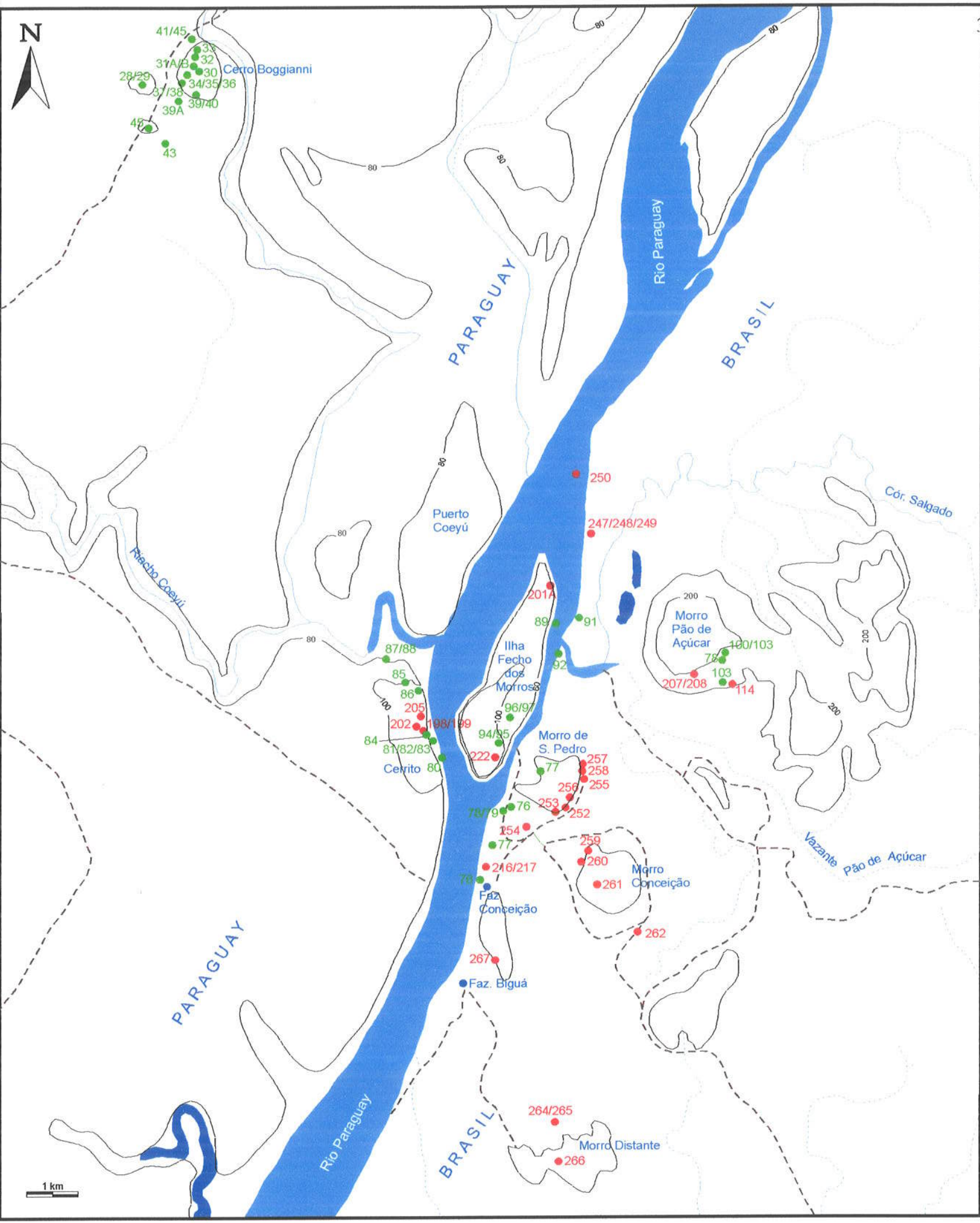

\section{Legenda}

...-. Caminhos e trilhas

.05 Amostra coletada neste trabalho

.05 Amostra coletada por Velázquez (1996)

Figura 07: Mapa de localização de amostras da região do Morro do Pão de Açúcar e adjacências, adaptado das folhas SF-21-V-D-II (Barranco Branco), SF-21-V-D-Y (Porto Murtinho), escalas 1:100.000, na parte brasileira e Carta Nacional, Puerto Guarani, Hoja $5378 \mathrm{III}, 1: 50.000$, no lado paraguaio. 


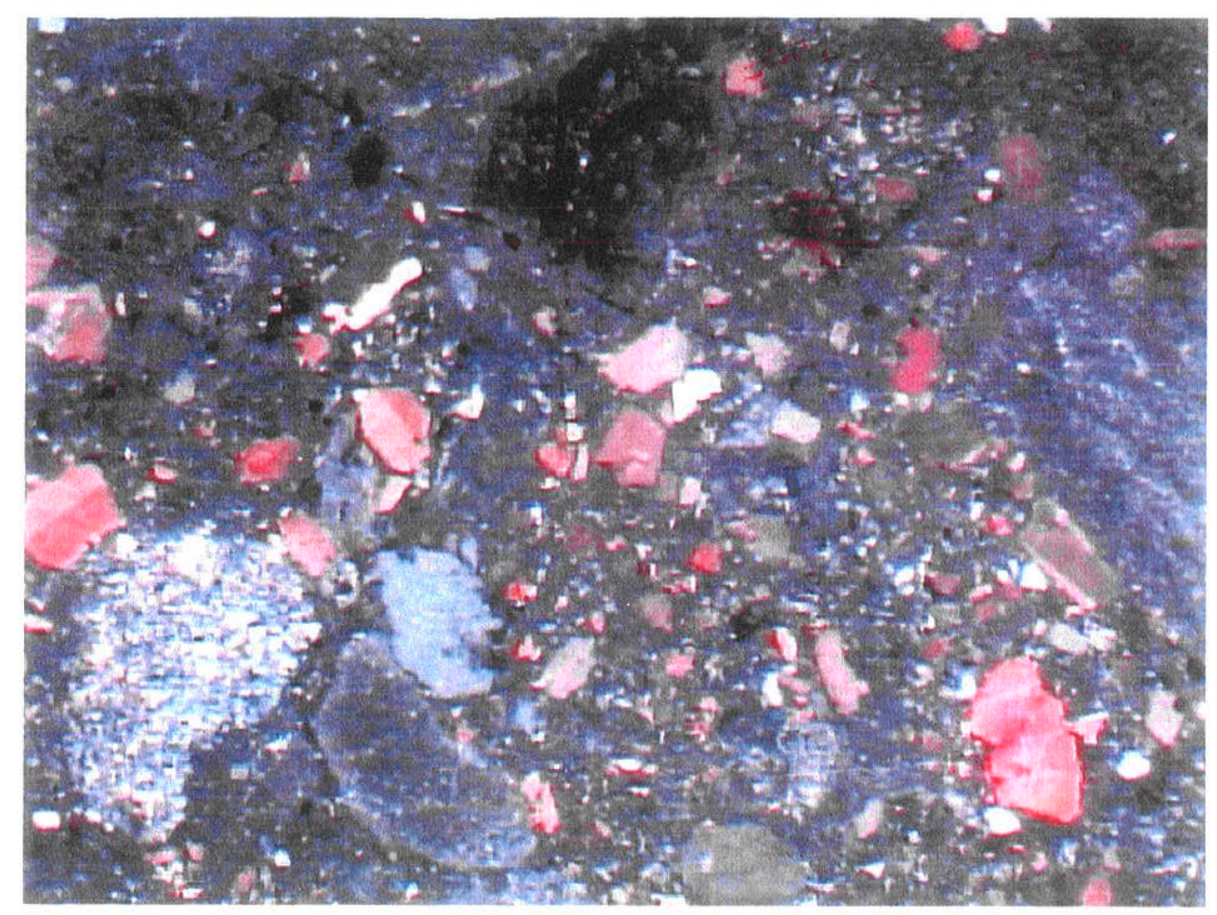

Fotomicrografia 04- RP-31B - Rocha piroclástica contendo enclaves de rochas alcalinas, gnaisses e graníticas diversas. Aumento 1,5X.

IV.2 - Cerrito

O maciço alcalino denominado Cerrito ocorre como um pequeno "stock" de nefelina sienitos com forma elipsoidal, cortado por pequenos veios e diques de fonolitos. Os nefelina sienitos são rochas de caráter plutônico que respondem por uma granulação média a grossa e cor branca a cinza-clara, como resultado da predominância de minerais félsicos (feldspato alcalino e nefelina) que perfazem, em média, cerca de $65 \%$ do volume de minerais da rocha. A granulação dessas rochas é muito variada e ampla, existindo desde litotipos médios até rochas pegmatóides, com os grãos mais desenvolvidos excedendo a $3 \mathrm{~cm}$ de eixo maior. As fotos 03 e 04 mostram os afloramentos onde ocorrem evidências de bandamento primário, com bandas félsicas se alternando com bandas máficas. As composições modais desta ocorrência, tanto os litotipos intrusivos quanto os subvulcânicos/ efusivos, plotam-se 
no campo 6' e 11 (alcali-feldspato sienito/traquito com feldspatóide e fonolitos, respectivamente) do diagrama QAP (Figura 10)

Ao microscópio, os nefelina sienitos de Cerrito apresentam textura alotriomórfica, intergranular, às vezes porfirítica, tendo como fenocristais de nefelina, piroxênio cálcico-sódico e feldspato de provável estrutura de sanidina.

O feldspato alcalino é o principal félsico dessas rochas, aparecendo com hábito tabular alongado, geralmente subédrico, exibindo intercrescimento pertítico a mesopertítico (formas de finas lamelas e/ou irregulares) e geminação segundo a lei de Carlsbad. Em geral, apresentam inclusões de piroxênio cálcico-sódico, nefelina e minerais acessórios.

A nefelina é incolor, anédrica a subédrica, podendo apresentar hábito prismático curto, ocorrendo nos interstícios da trama mineral.

O piroxênio cálcico-sódico é frequentemente incolor a verde-claro, possuindo estrutura de forte zoneamento composicional que se traduz pelas cores verde-claro

na parte central do grão e verde-oliva nas bordas. Em algumas amostras, o piroxênio apresenta zoneamento oscilatório (convoluto) e setorial.

O anfibólio, nem sempre está presente nos litotipos de Cerrito e quando aparece, tem composição predominantemente de natureza cálcico-sódico. Ocorre como um acessório (até $3 \%$ ), exibindo forte pelocroísmo nas cores amarela-escura a marron e birrefringência fraca a moderada.

A biotita possui pleocroísmo variando nas cores marron a vermelha (castanha), hábito placóide, formando quase sempre nos microssienitos, microfenocristais com inclusões de nefelina e opacos. 


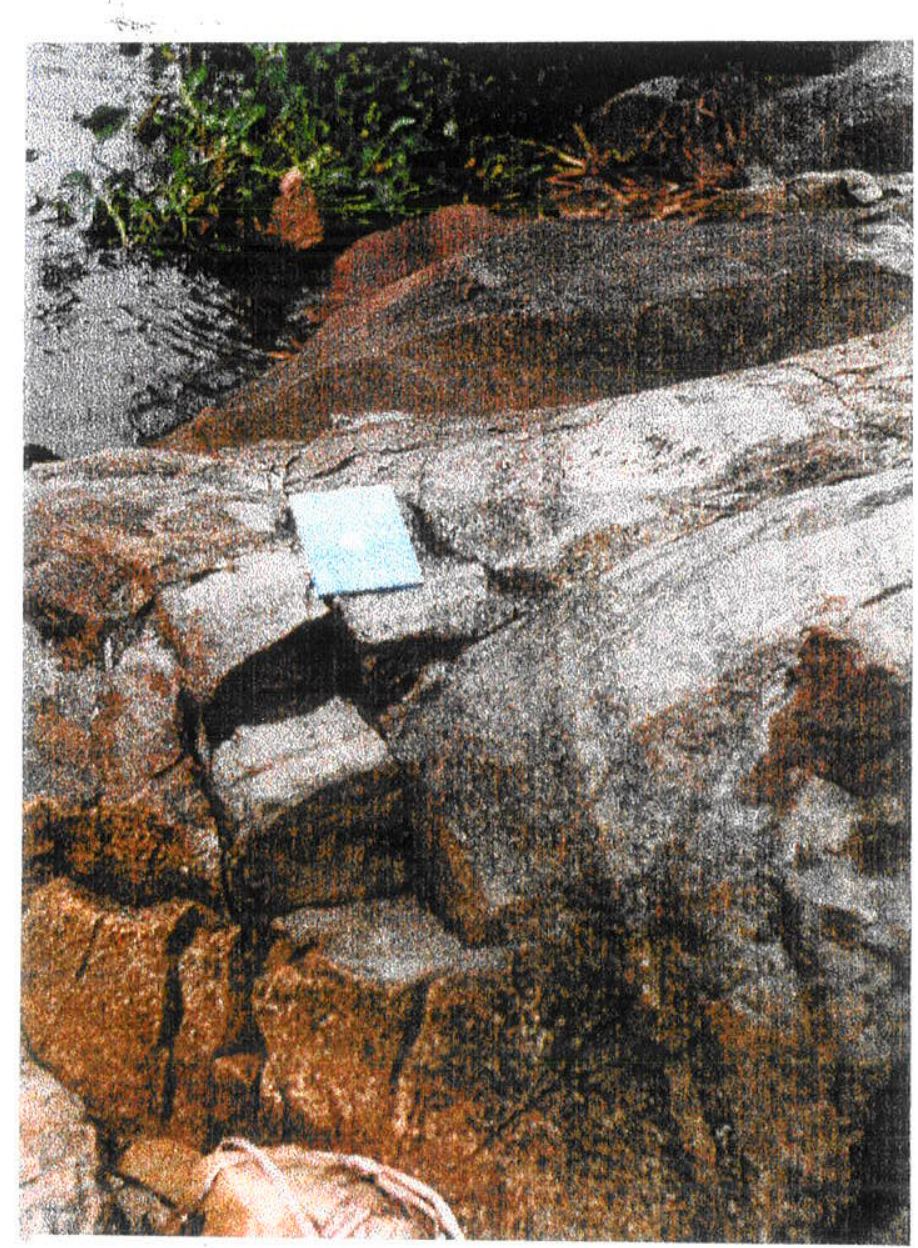

Foto 03 Alternância de bandas de cores diferentes(bandamento primário) na intrusão de Cerrito

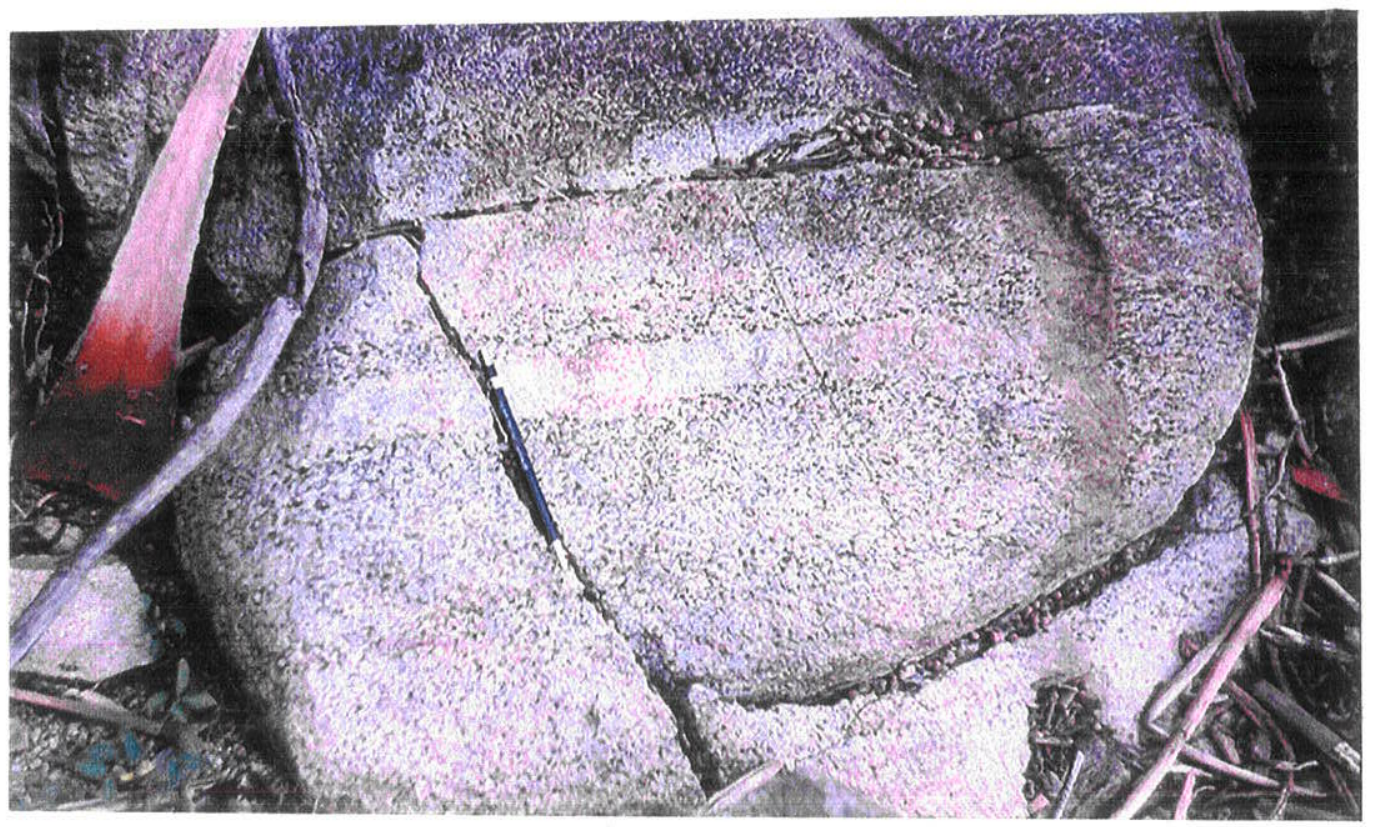

Foto 04 - Outro aspecto em detalhe) do bandamento de Cerrito 


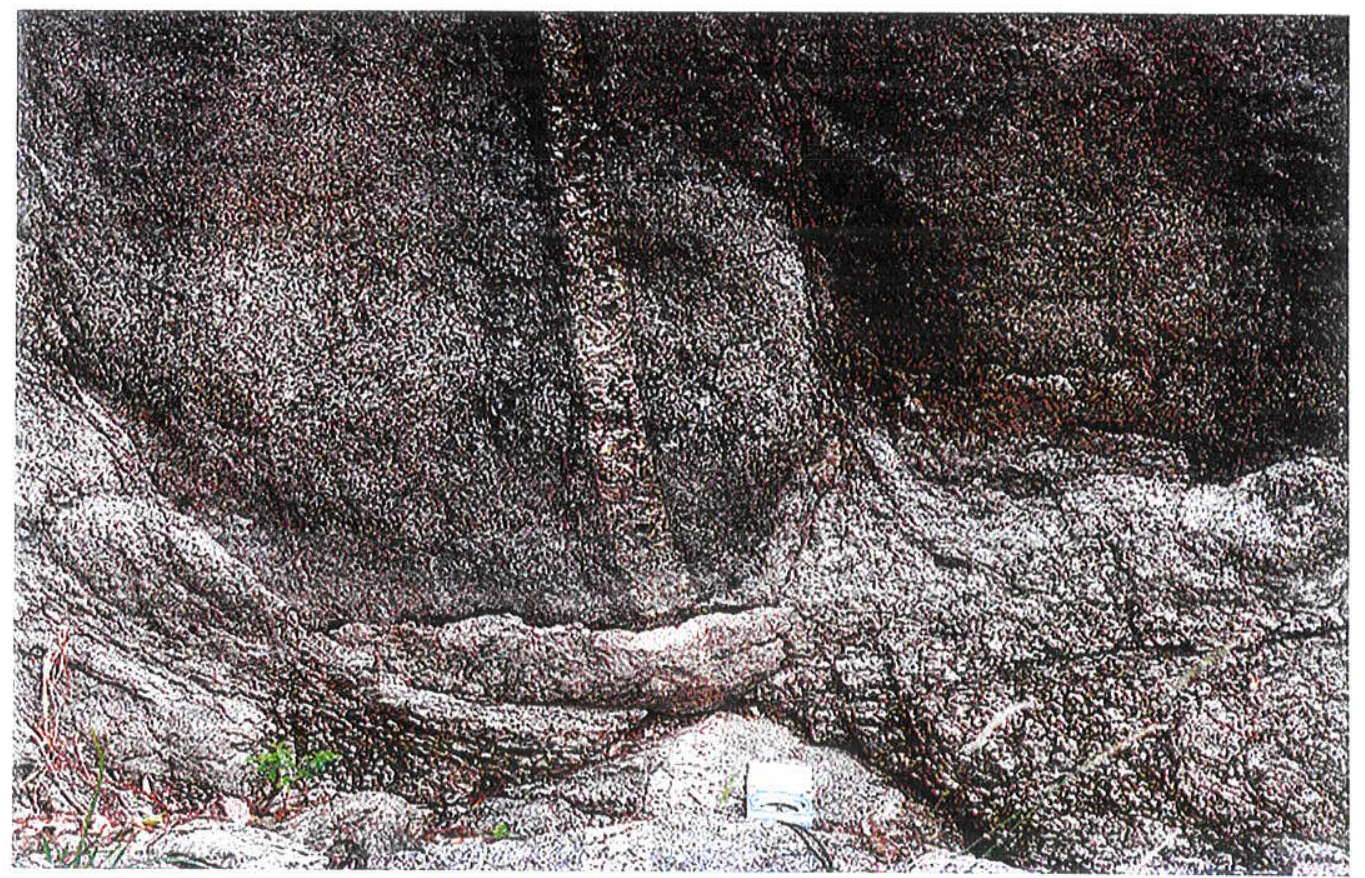

Foto 05 - Dique fonolítico subvertical em Cerrito, com falhas de rejeitos centimentricos

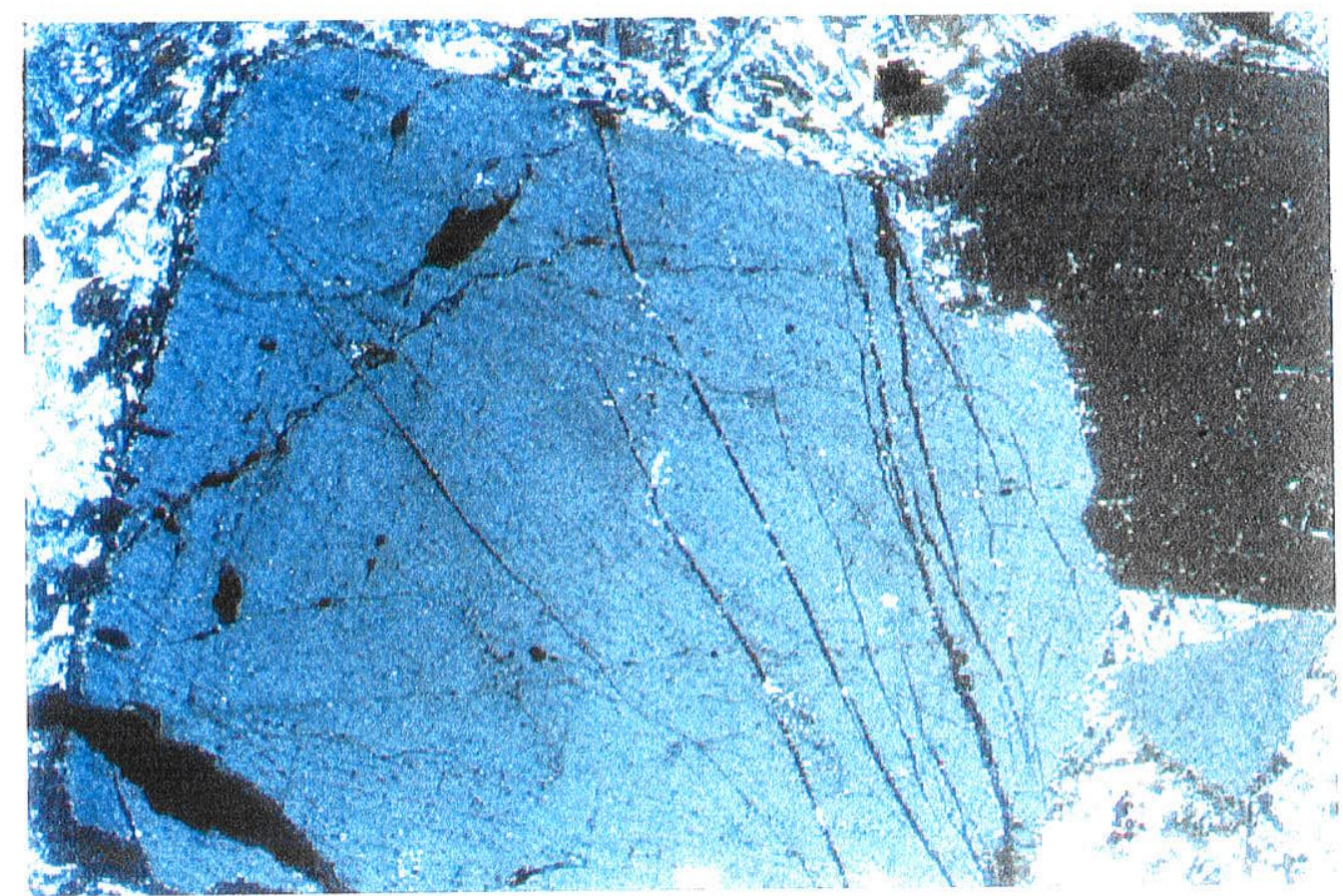

Fotomicrografia 05 - RP-85 - Traquifonolito com textura porfirítica. Destacam-se fenocristais de nefelina com zonação química Aumento 25X, polarizadores cruzados, filtro azul. 


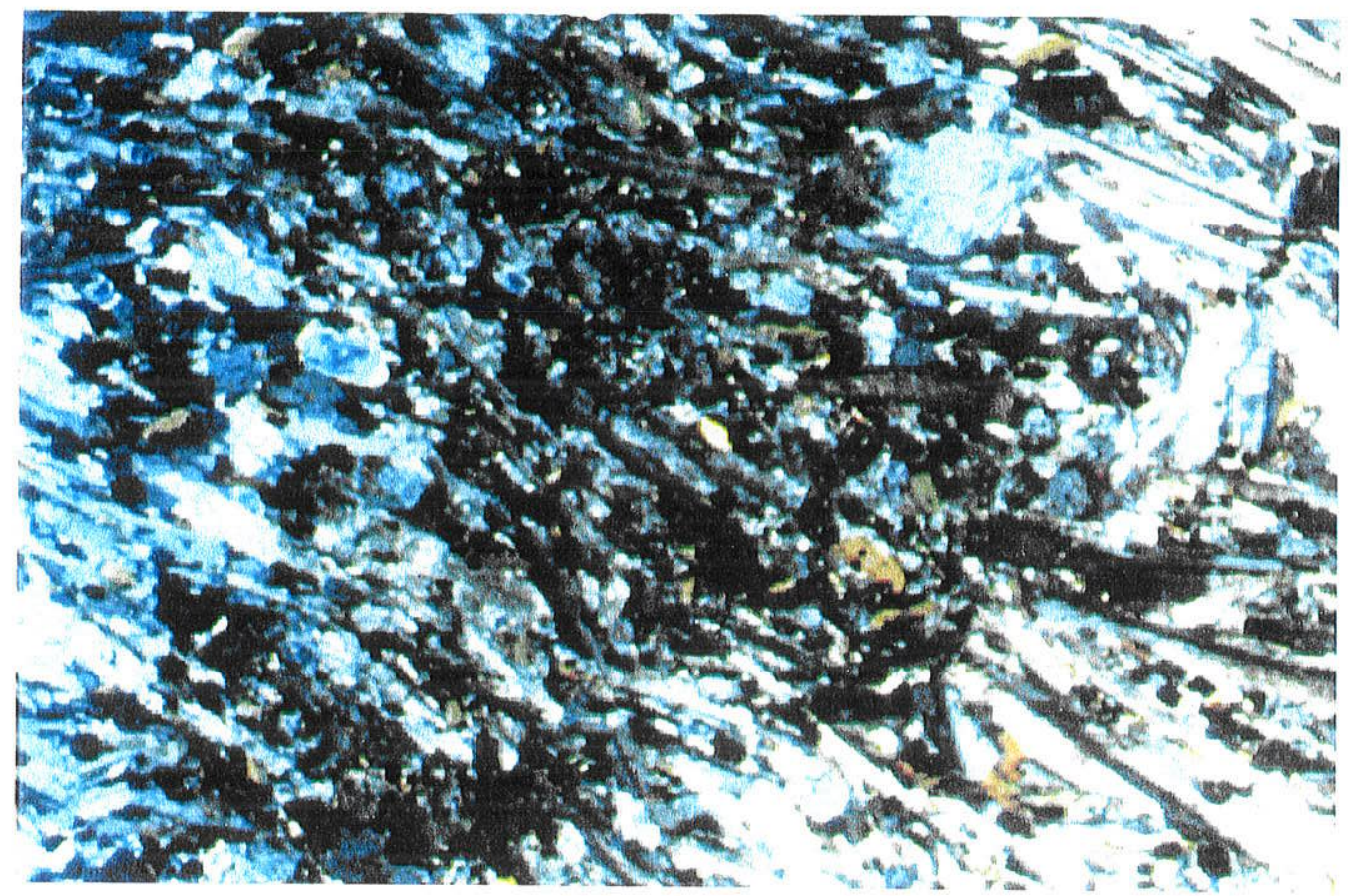

Fotomicrografia 06 - RP-88 - Traquito com microfenocristais de feldspato potássico com hábito tabular, orientados. Aumento 25X, polarizadores cruzados, filtro azul.

Os minerais acessórios se fazem representar por apatita, titanita, anfibólio e opacos. Cancrinita e carbonatos constituem os minerais de alteração (secundários).

Os diques fonolíticos que cortam o corpo Cerrito constituem-se de rochas mesocráticas, apresentando cor verde-escura e granulação fina a muito fina (Foto 05). Microscópicamente, esses diques apresentam textura microporfirítica em matriz criptocristalina com orientação de fluxo incipiente (Fotomicrografias 05 e 06). A mineralogia fundamental dos microfenocristais é constituída por feldspato alcalino (provavelmente ortoclásio) como fase principal, nefelina, egirina-augita e raramente biotita. Esses minerais ocorrem imersos em matriz criptocristalina cuja composição mineralógica mais provável é de feldspato alcalino. Os minerais acessórios identificados foram titanita, apatita e opacos.

A tabela 03 mostra uma síntese dos aspectos litológicos e petrográficos de Cerrito, discutidos neste ítem. 
Tabela 03 - Características litológicas da Província Alcalina Alto Paraguai: Cerrito

\begin{tabular}{|c|c|c|c|c|c|c|}
\hline \multirow[b]{2}{*}{ סू } & \multirow{2}{*}{$\begin{array}{l}\text { Feições } \\
\text { geologicas }\end{array}$} & \multirow{2}{*}{ Litotipos } & \multirow{2}{*}{ Estrutura/Textura } & \multicolumn{3}{|c|}{ Mineralogia $^{\star}$} \\
\hline & & & & félsicos & máficos & acessórios \\
\hline \multirow[b]{2}{*}{ 용 } & \multirow[b]{2}{*}{$\begin{array}{l}\text { stock circular, } \\
\text { área de } \sim 2 \mathrm{~km}^{2}\end{array}$} & $\begin{array}{l}\text { nefelina } \\
\text { sienitos } \\
\text { agpaíticos }\end{array}$ & $\begin{array}{l}\text { maciça, } \\
\text { inequigranular } \\
\text { média a grossa, } \\
\text { às vezes, } \\
\text { coronítica. } \\
\end{array}$ & $\begin{array}{l}\text { feldspato alcalino (Or } \text { rs } \\
\text { 94) micropertita } \\
\text { geminaçăo Carlsbad, } \\
\text { zoneamento normal, } \\
\text { nefelina, sodalita. }\end{array}$ & $\begin{array}{l}\text { egirina-augita (salitas) } \\
\text { zonaeamento setorial, } \\
\text { com bordas de } \mathrm{Fe}- \\
\text { edenita rica em Si, } \\
\text { biotita. }\end{array}$ & $\begin{array}{l}\text { apatita, titanita, zircão, } \\
\text { fluorita e opacos. }\end{array}$ \\
\hline & & $\begin{array}{l}\text { fonolitos } \\
\text { diques } \\
\text { traquíticos }\end{array}$ & $\begin{array}{l}\text { maciça, ás vezes } \\
\text { orientada, } \\
\text { microporfítica } \\
\text { (porfirotraquítica) } \\
\text { com matriz } \\
\text { afanítica. }\end{array}$ & 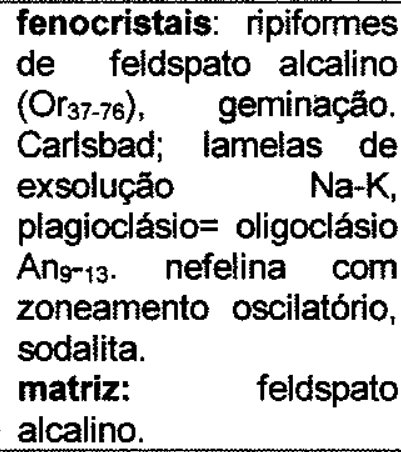 & $\begin{array}{l}\text { fenocristais:egirina- } \\
\text { augitar (salitas)e } \\
\text { anfibólio cálcico-sódico } \\
\text { (Fe-edenita). } \\
\text { microfenocristais de } \\
\text { biotita } \\
\text { matriz: egirina-augita, } \\
\text { anfibólio } \quad \text { sódico } \\
\text { (provavelmente } \quad \mathrm{Fe} \\
\text { edenita). }\end{array}$ & $\begin{array}{l}\text { apatita, titanita, zircão, } \\
\text { fluorita e opacos. }\end{array}$ \\
\hline
\end{tabular}




\section{IV.4 - Pão de Açucar}

O corpo alcalino conhecido como Pão de Acúcar é representado por uma elevação cuja altura excede a $400 \mathrm{~m}$. Ele constitui-se de uma intrusão circular cujo retrabalhamento por ciclos erosivos pós-cretácicos, modelou a forma de relevo atual, justificando o nome herdado (Foto 06). Ao seu redor ocorrem inúmeros corpos de dimensões menores, especialmente os "plugs" conhecidos como: São Pedro, Porto Conceição (denominação utilizada neste trabalho para designar um "plug" localizado à beira do rio Paraguai, nos domínios da Fazenda Conceição), Morro Conceição e Morro Distante (Figura 07).

A área aflorante do corpo principal é de aproximadamente $6,5 \mathrm{~km}^{2}$, sendo que o conjunto intrusivo pode abranger área de até $30 \mathrm{~km}^{2}$. Ressalta-se que esse corpo alcalino localiza-se em área de difícil acesso, sendo que a melhor maneira de se atingir essa elevação é por barco, atracando em seu flanco oeste. Por outros flancos da elevação $o$ acesso é muito difícil em razão da existência de pântanos quase que intransponiveis. Dentre as amostras provenientes do Morro Pão de Açúcar, apenas uma delas é caracterizada como nefelina sienito, sendo as demais de natureza extrusiva, com caracteristicas traquíticas (traquifonolitos). Duas dessas amostras são representativas do campo 11 do diagrama QAP (Figura 10), enquanto que as demais, são plotadas nos campos 6 e $6^{*}$, representativas de litotipos tais como: álcali-feldspato sienito e álcali-feldspato-quartzo sienito, respectivamente.

A investigaçăo macro e microscópica do nefelina sienito do Pão de Açúcar não revela diferenças significativas em relação às demais rochas assim constituídas de outros corpos da Província do Alto Paraguai. Elas freqüentemente possuem cor cinza-clara, granulação média a grossa, com estrutra inequigranular. Microscópicamente, apresenta cristais de feldspato potássico e ocasionalmente de anfibólio com dimensões maiores do que $1 \mathrm{~cm}$, que sobressaem as suas características subédricas. A biotita ocorre formando agregados, enquanto que a nefelina anédrica preenche interstícios da rocha. $O$ anfibólio é predominantemente de natureza cálcico-sódico. Como fases acessórias ocorrem apatita (comumente au- 


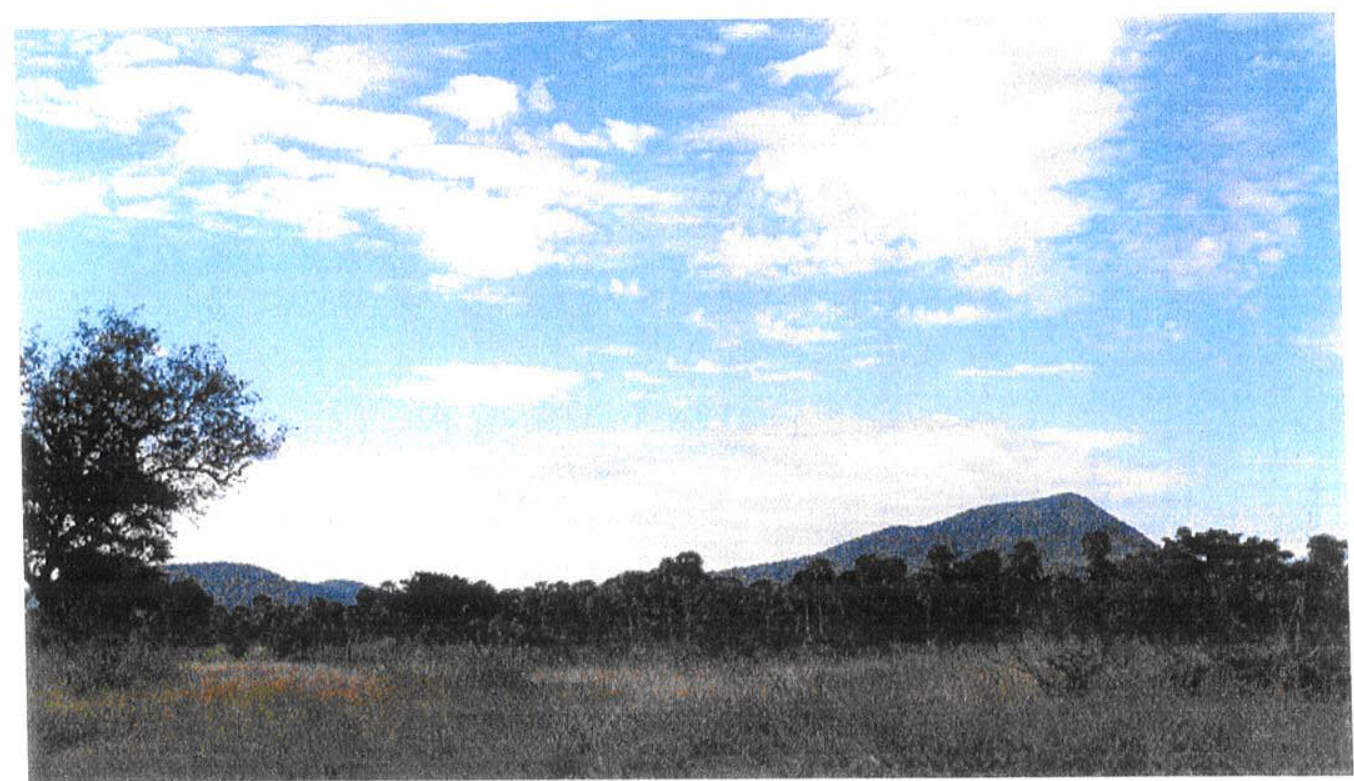

Foto 06 - Vista parcial (S para N) do Morro Pão de Açúcar e "plugs" adjacentes.

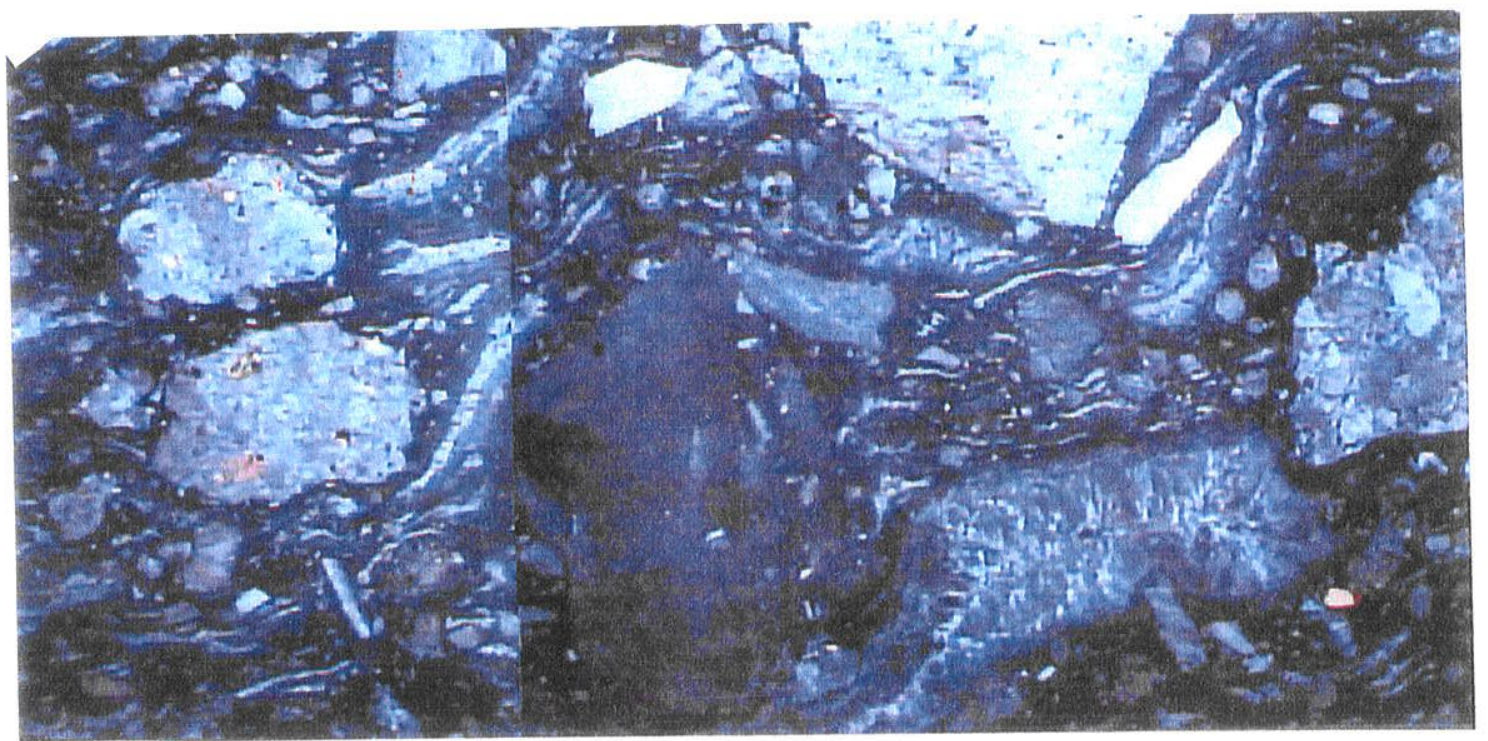

Fotomicrografia 07 -RP-109, Textura com aspecto ignimbrítico com fluxo orientado, onde podem ser observados microfenocristais de feldspato potássico, associados a fragmentos líticos, envolvidos por bandas félsicas em alternância com bandas máficas. Os materiais líticos correspondem, provavelmente, em suas composições modais, à nefelina sienitos, sienitos peralcalinos e traquitos. Aumento $1,5 \mathrm{X}$. 


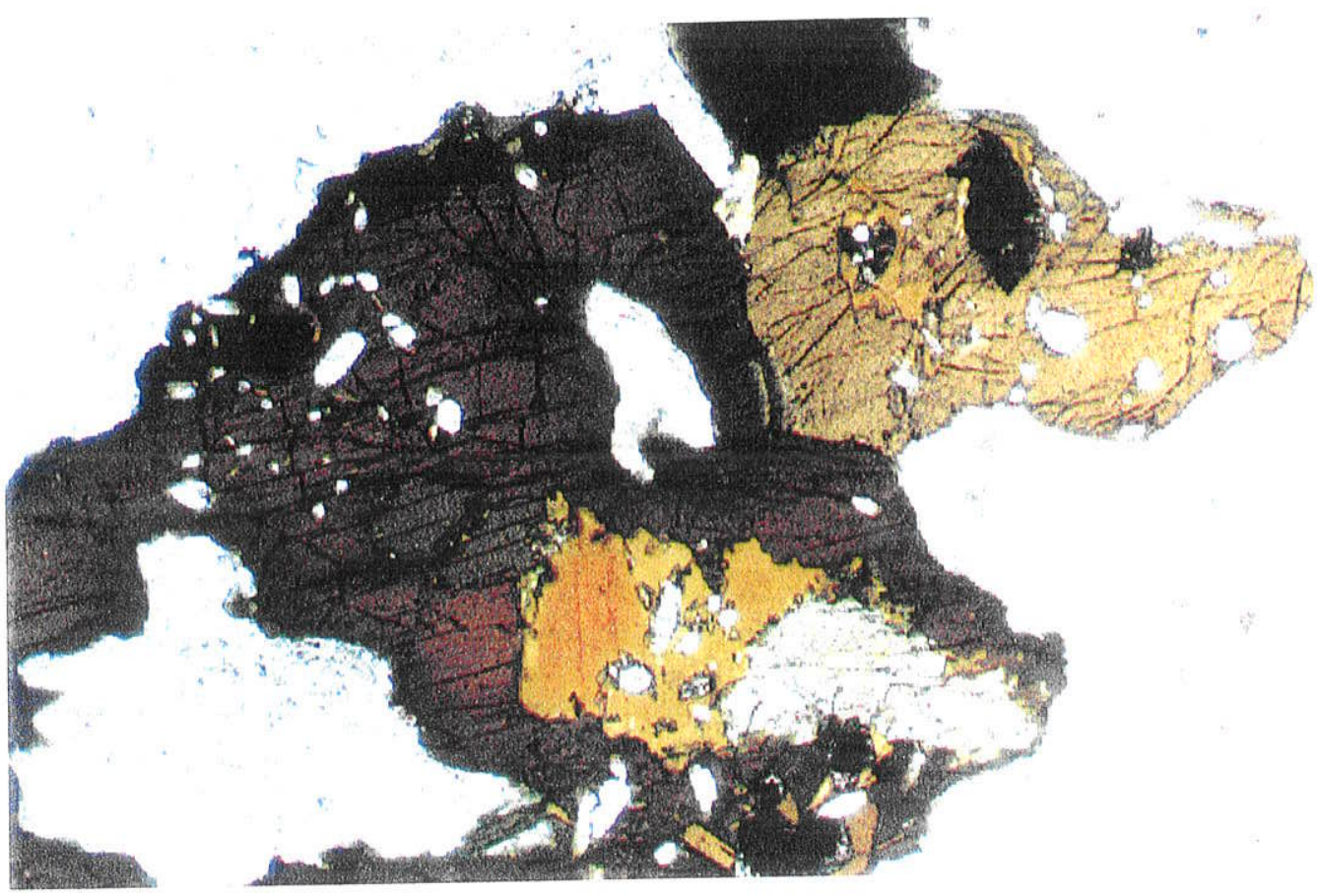

Fotomicrografia 08 - RP-78 - Quartzo sienito na qual são destacados microfenocristais apresentando núcleo de anfibólio marron e bordas de reação constituídas por biotita em elevado estágio de opacitização. Aumento 25X, polarizadores paralelos, filtro azul.

tomórfica), zircão e opacos.

Os traquitos são rochas preferencialmente porfiriticas, com fenocristais de feldspato potássico como fase mais importante e subordinadamente de piroxênio e biotita, imersos numa matriz predominantemente feldspática. $\mathrm{O}$ anfibólio quando presente, presumivelmente está relacionado a uma formação de "gaps" preenchidos por biotita (textura intrafasciculada?)

Ocorrem também nessas rochas, textura porfirotraquítica, onde se observam fenocristais de feldspato potássico e piroxênio incolor circundados por matriz fina, predominantemente feldspática, orientada. Além disso, pode ocorrer ainda texturas com aspecto ignimbrítico (Fotomicrografia 08). Nesse caso, observa-se fenocristais de feldspato potássico envolvidos por bandas félsicas em alternância com bandas de minerais máficos e enclaves líticos. Estes, possivelmente correspondem, em suas composições a nefelina sienitos, sienitos alcalinos e traquitos.

Os quartzo sienitos também estão presentes no corpo Pão de Açúcar, onde estão presentes microfenocristais de anfibólio cálcico-sódicos com bordas de reação biotíticas em elevado estágio de opacitização (Fotomicrografia 08). 
A tabela 04 apresenta, sintéticamente, aspectos gerais relativos à litologia e petrografia dos litotipos encontrados no Morro Pão de Açúcar.

N.5 - Ilha Fecho dos Morros

A localização deste corpo alcalino incide no flanco oeste do Morro Pão de Açucar, como pode ser visualisado na figura 07 . Seus litotipos podem ser descritos como rochas eminentemente pegmatíticas, já que os grãos de feldspato potássico e nefelina alcançam dimensões de até $5 \mathrm{~cm}$. de eixo maior (Foto 07). Ao exame macroscópico, a rocha pegmatóide pode ser definida como leucocrática, constituídas fundamentalmente por minerais de feldspato potássico e nefelina e subordinadamente por minerais máficos tais como: piroxênio, biotita e raramente anfibólio sódico (Fotomicrografia 09). Microscópicamente, sobressaem-se texturas inequigranulares e raramente coroniticas de piroxênios com bordas de anfibólio, podendo ocorrer ocasionalmente texturas poiquilíticas.

As rochas deste corpo, locam-se apenas no campo 11 do diagrama QAP, representativo de feldspatóide sienito, com textura pegmatítica.

O feldspato potássico (sanidina), frequentemente apresenta hábito tabular com cristais alongados, micro a mesopertítico, geminados segundo a lei de Carlsbad. São comuns cristais contendo zoneamento oscilatório (convoluto) e mais raramente, zoneamento em "patch".

A nefelina é incolor e mostra hábito subédrico, sendo ocasionalmente euédrica.

A sodalita tem a sua forma de ocorrência principal ocupando os espaços intersticiais da petrotrama.

O piroxênio, quando presente, ocorre sempre como fase sódico-cálcica. É geralmente incolor, euédrico a subédrico, com alta birrefringência. 
Tabela 04 - Características litológicas da Província Alcalina Alto Paraguai: Pão de Açúcar

\begin{tabular}{|c|c|c|c|c|c|c|}
\hline \multirow{2}{*}{ 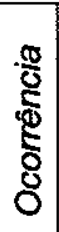 } & \multirow{2}{*}{$\begin{array}{l}\text { Feiçöes } \\
\text { geológicas }\end{array}$} & \multirow{2}{*}{ Litotipos } & \multirow{2}{*}{ Estrutura/Textura } & \multicolumn{3}{|c|}{ Mineralogia* } \\
\hline & & & & férsicos & máficos & acessórios \\
\hline \multirow{3}{*}{ 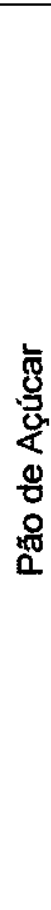 } & \multirow{3}{*}{$\begin{array}{l}\text { stock circular, } \\
\text { área de } 6.5 \mathrm{~km}^{2}\end{array}$} & $\begin{array}{l}\text { nefelina } \\
\text { sienitos } \\
\text { agpaíticos }\end{array}$ & $\begin{array}{l}\text { hipidiomórfica } \\
\text { equigranular } \\
\text { média a grossa. }\end{array}$ & $\begin{array}{l}\text { feldspato alcalino }\left(\mathrm{Or}_{44}\right. \\
\text { 92) - } \text { micropertita } \\
\text { geminaçáno Carlsbad, } \\
\text { zoneamento normal, } \\
\text { nefelina, sodalita. }\end{array}$ & $\begin{array}{l}\text { egirina-augita } \\
\text { zonaeamento em em } \\
\text { "patch" e setorial, } \\
\text { arfvdsonita, biotita. }\end{array}$ & $\begin{array}{l}\text { apatita, titanita, zircão e } \\
\text { opacos. }\end{array}$ \\
\hline & & $\begin{array}{l}\text { traquifonoli - } \\
\text { tos } \\
\text { agpaíticos }\end{array}$ & $\begin{array}{l}\text { aspecto } \\
\text { ignimbrítico com } \\
\text { fluxo orientado, } \\
\text { gran. fina } \\
\text { porfiro-traquitica, } \\
\text { coronítica. }\end{array}$ & $\begin{array}{l}\text { feldspato alcalino }\left(\mathrm{Or}_{43-}\right. \\
\text { 76), micropertítico } \\
\text { geminação Carlsbad; } \\
\text { fenocristais: feldspato } \\
\text { alcalino } \quad\left(\mathrm{Or}_{43-76)} \text {, }\right. \\
\text { micropertítico } \\
\text { geminação. Carisbad; } \\
\text { matriz: feldspato } \\
\text { alcalino criptocristalino }\end{array}$ & $\begin{array}{l}\text { egirina-augita com } \\
\text { bordas de edenita rica } \\
\text { em } \mathrm{Si} \text {, biotita. } \\
\text { fenocristais:egirina- } \\
\text { augita e anfibolio sódico } \\
\text { (arfvdsonita). } \\
\text { matriz: egirina-augita, } \\
\text { anfibólio sódico } \\
\text { (provavelmente } \\
\text { arfvdsonita) }\end{array}$ & $\begin{array}{l}\text { apatita; titanita; zircão e } \\
\text { opacos }\end{array}$ \\
\hline & & $\begin{array}{l}\text { quartzo } \\
\text { sienitos }\end{array}$ & $\begin{array}{l}\text { maciça, } \\
\text { equigranular, grã } \\
\text { média a fina, } \\
\text { poiquilitica e às } \\
\text { vezes possuindo } \\
\text { coroas de reação. } \\
\text { microporfirítico }\end{array}$ & $\begin{array}{l}\text { feldspato alcalino (Or }{ }_{44-}^{-} \\
\text {92) micro a mesopertítico } \\
\text { com padrăo } \\
\text { anastomosado, quartzo. }\end{array}$ & $\begin{array}{l}\text { egirina-augita, edenita } \\
\text { rica em sílica, biotita. }\end{array}$ & $\begin{array}{l}\text { apatita, titanita, zircão, } \\
\text { e opacos. }\end{array}$ \\
\hline
\end{tabular}


O anfibólio é de natureza cálcico-sódica a sódica, sendo também de ocorrência esporádica, principalmente nas rochas pegmatóides deste corpo. Exibe hábito prismático, forte pleocroísmo nas cores marron-escura.

A biotita apresenta cor marron a vermelha (castanha), forte pleocroísmo, hábito placóide e intercrescimento lamelar.

Apatita e titanita são os minerais acessórios mais comuns nessas rochas.

Os fonolitos associados a este corpo, ocorrem como diques verticais a subverticais, com espessura de até $80 \mathrm{~cm}$, possuindo cor verde escura e granulação fina.

Na tabela 05, são apresentados os resultados das principais características litológicas e petrográficas de Ilha Fecho dos Morros.

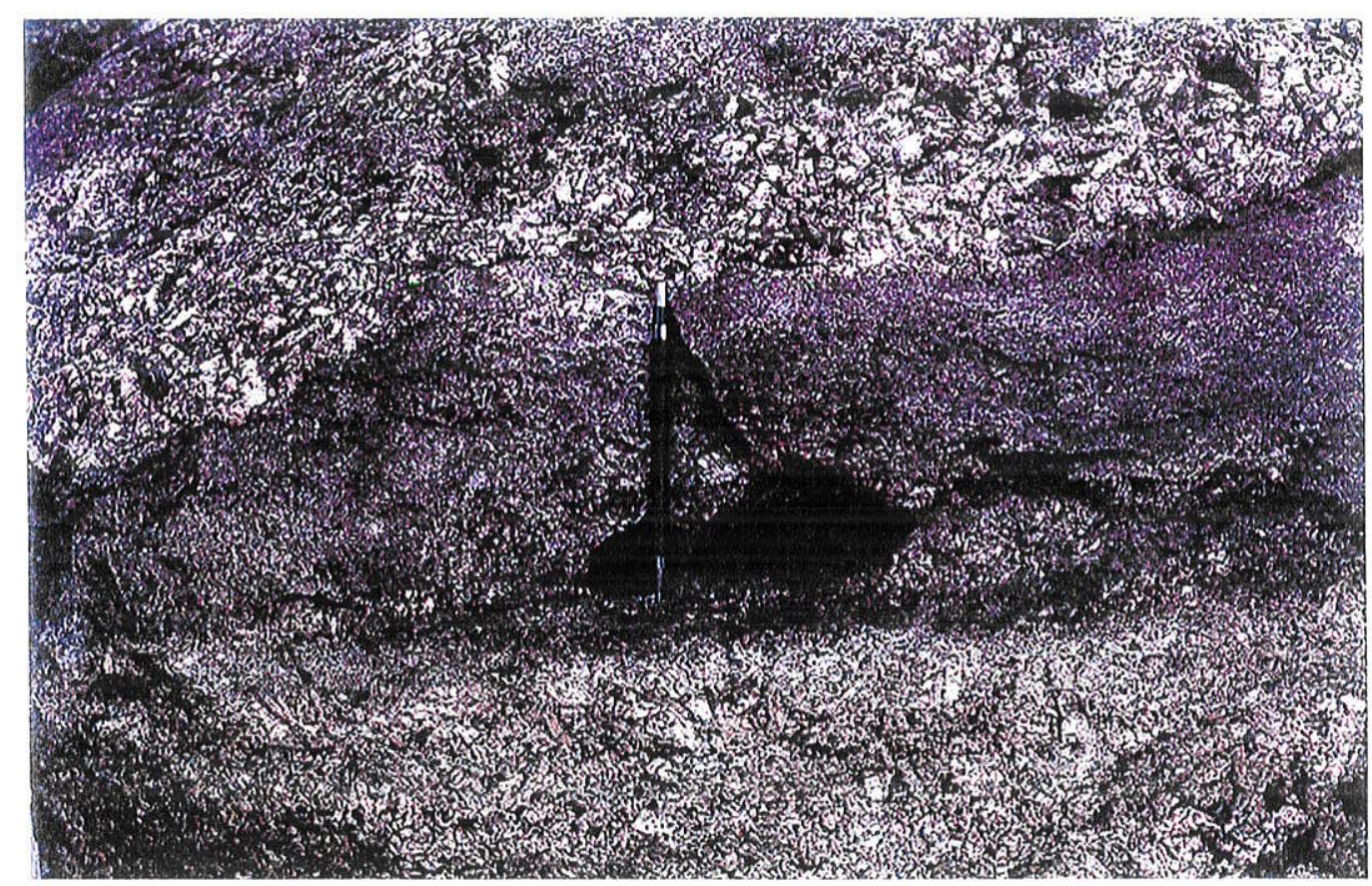

Foto 07 - llustração das rochas pegmatóides de Ilha Fecho dos Morros, onde se sobressaem como fases dominantes, cristais decimëtricos de feldspato potássico, nefelina e subordinadamente egirinaaugita. 
Tabela 05 - Características litológicas da Província Alcalina Alto Paraguai: llha Fecho dos Morros

\begin{tabular}{|c|c|c|c|c|c|c|}
\hline \multirow[b]{2}{*}{ 蛋 } & \multirow{2}{*}{$\begin{array}{l}\text { Feições } \\
\text { geologicas }\end{array}$} & \multirow{2}{*}{ Litotipos } & \multirow{2}{*}{ Estrutura/Textura } & \multicolumn{3}{|c|}{ Mineralogia ${ }^{\star}$} \\
\hline & & & & félsicos & máficos & acessórios \\
\hline \multirow[b]{2}{*}{ 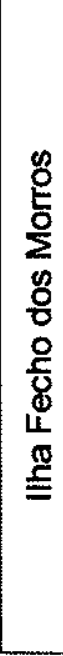 } & \multirow[b]{2}{*}{$\begin{array}{l}\text { stock circular, } \\
\text { área de } \sim 5 \mathrm{~km}^{2}\end{array}$} & $\begin{array}{l}\text { nefelina } \\
\text { sienitos } \\
\text { agpaiticos }\end{array}$ & $\begin{array}{l}\text { maciça, } \\
\text { equigranular } \\
\text { muito grossa } \\
\text { (pegmatítica) }\end{array}$ & $\begin{array}{l}\text { feldspato alcalino (Or76- } \\
\text { 95) - micropertita } \\
\text { geminação Carlsbad, } \\
\text { zoneamento normal, } \\
\text { nefelina, sodalita. }\end{array}$ & $\begin{array}{l}\text { egirina-augita, egirina, } \\
\text { edenita rica em sílica, } \\
\text { biotita. }\end{array}$ & $\begin{array}{l}\text { apatita, titanita, zircão e } \\
\text { opacos. }\end{array}$ \\
\hline & & $\begin{array}{l}\text { fonolitos } \\
\text { miasquíticos }\end{array}$ & $\begin{array}{l}\text { maciça, } \\
\text { equigranular text. } \\
\text { fina a porfirítica. }\end{array}$ & 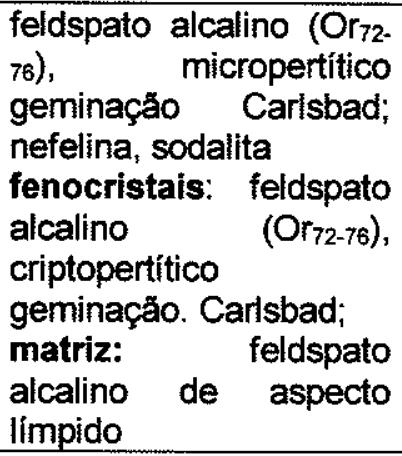 & $\begin{array}{l}\text { egirina-augita e egirina } \\
\text { biotita; } \\
\text { fenocristais:egirina- } \\
\text { augita e anfibólio sódico } \\
\text { (magnésio-arfvdsonita) } \\
\text { matriz: egirina-augita, } \\
\text { anfibólior sódico } \\
\text { (provavelmente Mg- } \\
\text { arfvdsonita) }\end{array}$ & $\begin{array}{l}\text { apatita; titanita; zircão e } \\
\text { opacos }\end{array}$ \\
\hline
\end{tabular}




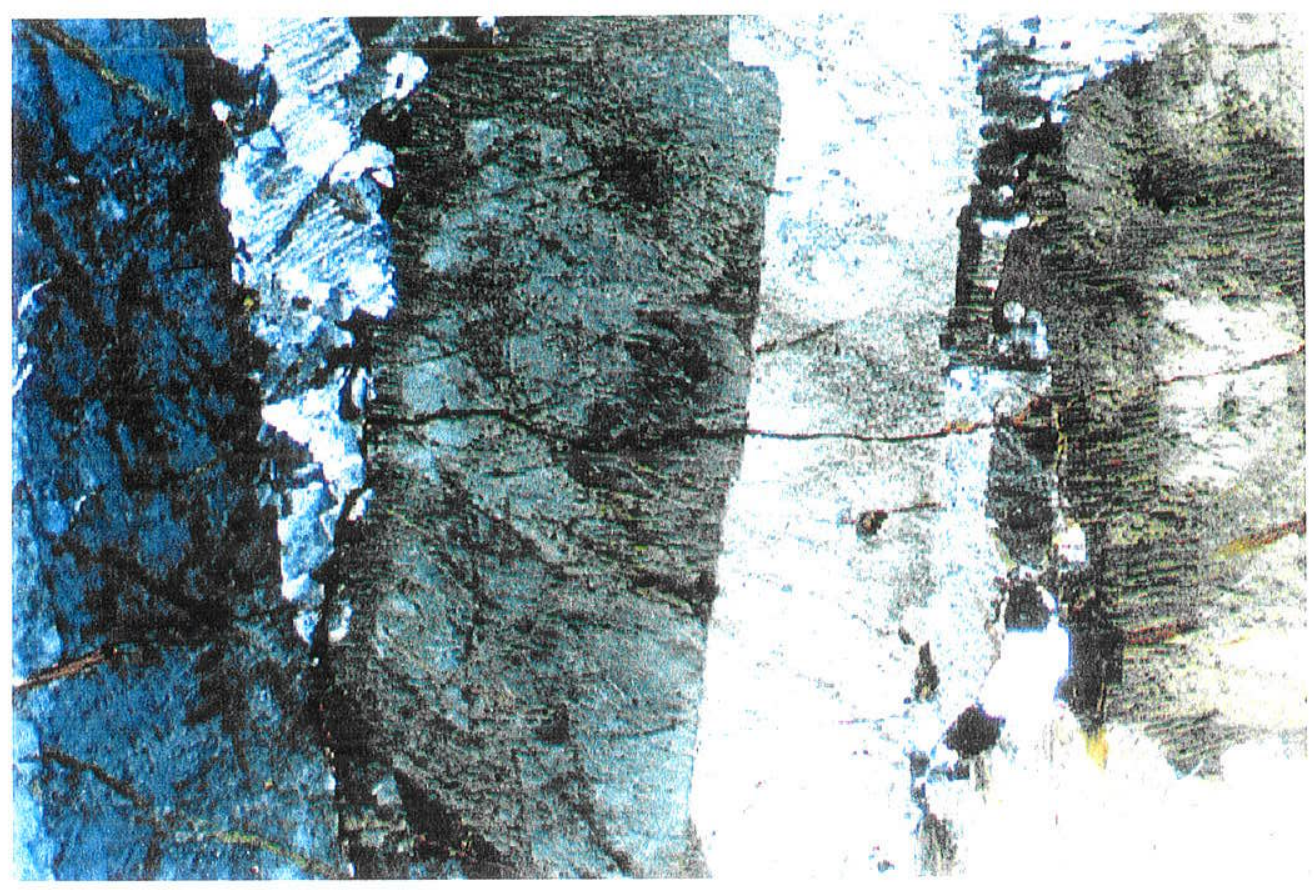

Fotomicrografia 09 - RP-91, Nefelína sienito com textura pegmatítica. A foto ilustra os grandes cristais de feldspato potássico com geminação Carlsbad e finas lamelas de intercrescimento pertítico. Aumento 25X, polarizadores cruzados, filtro azul.

\section{IV.6 - Morro de São Pedro, Cerro Pedreira, Porto Conceição, Morro Conceição e Morro Distante.}

Os corpos alcalinos reunidos com a denominação de Morro de São Pedro, Porto Conceição, Morro Conceição e Morro Distante, localizam-se nas proximidades da llha Fecho dos Morros, mais precisamente em sua parte sudeste (Figura 07). Cerro Pedreira localiza-se a aproximadamente $5 \mathrm{~km}$ a norte da cidade de Porto Murtinho (Figura 08). Tratam-se de várias estruturas de pequeno porte, formando elevações de até $150 \mathrm{~m}$ de altura, com forma irregular e área aflorante com até $1 \mathrm{~km}^{2}$ ) de área aflorante.

Ressalta-se a enorme dificuldade para se atingir os limites desses corpos, uma vez que os mesmos encontram-se circundados por pântanos que dificultam sobremaneira o acesso a eles. 
Em função da inexistência de denominaçōes geográficas dos corpos alcalinos das circunvizinhanças do Morro Pão de Açucar e liha Fecho dos Morros, foi adotado informalmente neste trabalho, para maior facilidade de localização, os nomes que estão presentes no subtitulo em destaque, com exceção do Morro de São Pedro, que consta nas cartas topográficas e nos referenciais informais da população daquela região. Destaca-se que elas estão assim agrupadas devido à grande semelhança petrográfica entre os litotipos dos vários corpos amostrados, bem como à proximidade geográfica dos corpos envolvidos, exceto Cerro Pedreira que dista aproximadamente $10 \mathrm{~km}$ dessa concentração de corpos alcalinos nas adjacências do Morro Pão de Açúcar.

Dentre as amostras coletadas nos domínios desses corpos, a predominância dos tipos petrográficos tende claramente para rochas mais saturadas em sílica do que os outros corpos da mesma província, sendo incomum a ocorrência de nefelina sienitos e muito freqüente a existência de sienitos alcalinos (campo $6^{\prime}$ ) e quartzo sienitos (campos 6 e $6^{*}$ ), como é o caso de Morro Conceição e Morro Distante, cujos litotipos foram plotados no campo 6 , representativo dos álcali-feldspato sienitos, enquanto que em Morro Conceição, as rochas mais representativas respondem por uma composição de alcali-feldspato sienito com feldspatóide (campo 6'). Por sua vez, as rochas do Morro de São Pedro, em sua maior parte, locam-se no campo dos sienitos com feldspatóide/fonolitos do campo 11 (Figura 10).

A granulação é grossa, estrutura maciça, textura isótropa, holocristalina, podendo ocorrer texturas hipidiomórficas em rochas de granulação mais fina. Alguns sienitos do corpo de São Pedro possuem nefelina e/ou sodalita ocupando interstícios na trama mineral e como fases que se hospedam em feldspatos alcalinos (Fotomicrografia 10) e minerais máficos como egirina-augita, anfibólio sódico e biotita complementam a trama (Fotomicrografia 11). As rochas quartzo sienítcas desses corpos diferem dos sienitos alcalinos devido à presença de quartzo ocupando interstícios, enquanto que no "plug" denominado Cerro Pedreira, é comum apresença de quatzo sienitos. 


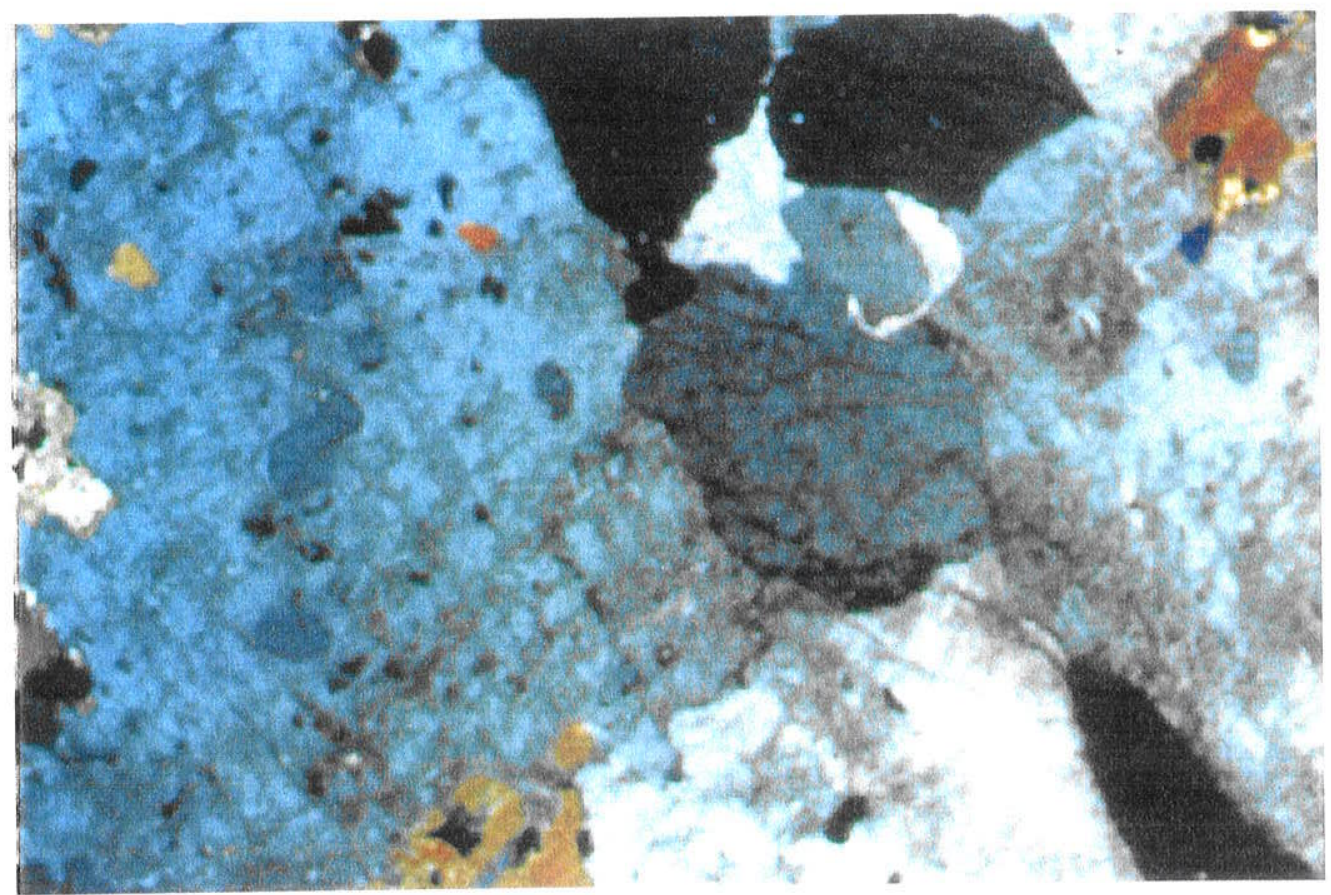

Fotomicrografia 10 - RP-255 Nefelina sienito do Morro São Pedro apresentando textura intergranular com domínios poiquilíticos (grãos de nefelina intersticiais e também, inclusos em feldspato potássico. Aumento 25X, polarizadores cruzados, filtro azul

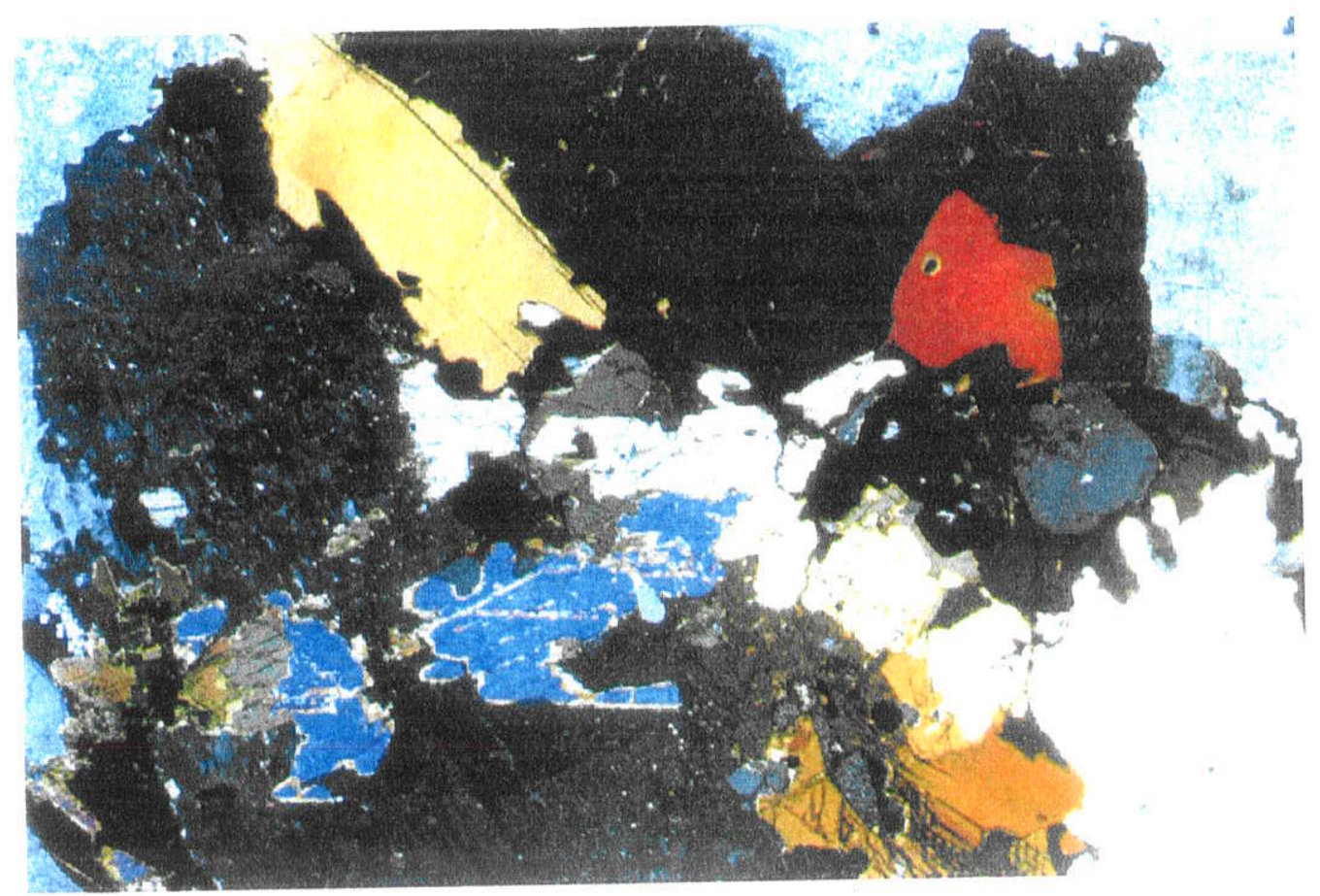

Fotomicrografia 11- RP-258, Nefelina sienito do Morro de São Pedro apresentando na trama minerais como: egirina-augita, anfibólio sódico, biotita e nefelina. Cancrinita ocorre sempre como alteração da nefelina. Aumento 25X, polarizadores cruzados, filtro azul. 
O feldspato alcalino é a fase mineral mais abundante em termos quantitativos e comumente forma microfenocristais circundados por matriz também eminentemente feldspática. $O$ hábito é tabular, subédrico, mostrando geminação segundo a lei de Carlsbad. Freqüentemente apresenta intercrescimento micro a mesopertítico com padrão irregular. Bordas de reação albíticas em microfenocristais de feldspato potássico são comuns, especialmente nas rochas de Morro Distante (Fotomicrografia 12).

O piroxênio, é geralmente xenomórfico, com pleocroismo variando nas tonalidades de cor verde, desde o verde-amarelado até o verde-escuro nas bordas. Petrográficamente, os piroxênios têm características de diopsídio nas amostras provenientes de São Pedro e de augita nas de Porto Conceição.

Os anfibólios têm forte pleocroísmo escuro nos tons do verde e hábito prismático, formando grãos subédricos, Composicionalmente, os anfibólios demonstram natureza cálcico-sódicas e sódicas.

A biotita tem pleocroísmo nas cores variando até marron-escuro, apresentando intercrescimento lamelar e asterismos.

Os minerais acessórios estão representados por titanita e ocasionalmente por zircão.

A fotomicrografia 13 mostra um sienito alcalino com textura porfirítica do "plug" de Morro Distante. Neles, a feição petrográfica mais marcante são os fenocristais de felsdpato alcalino ocorrendo quase sempre com bordas de reação mais albíticas.

As fotomicrografias 14 e 15 ressaltam, respectivamente, texturas de sobrecrescimento de feldspatos alcalinos e tamanho relativo dos cristais em rochas de Morro Conceição e Porto Conceição.

Resumidamente, são apresentadas as principais características petrográficas dos corpos estudados neste tópico, nas tabelas 06,07 e 08 . 


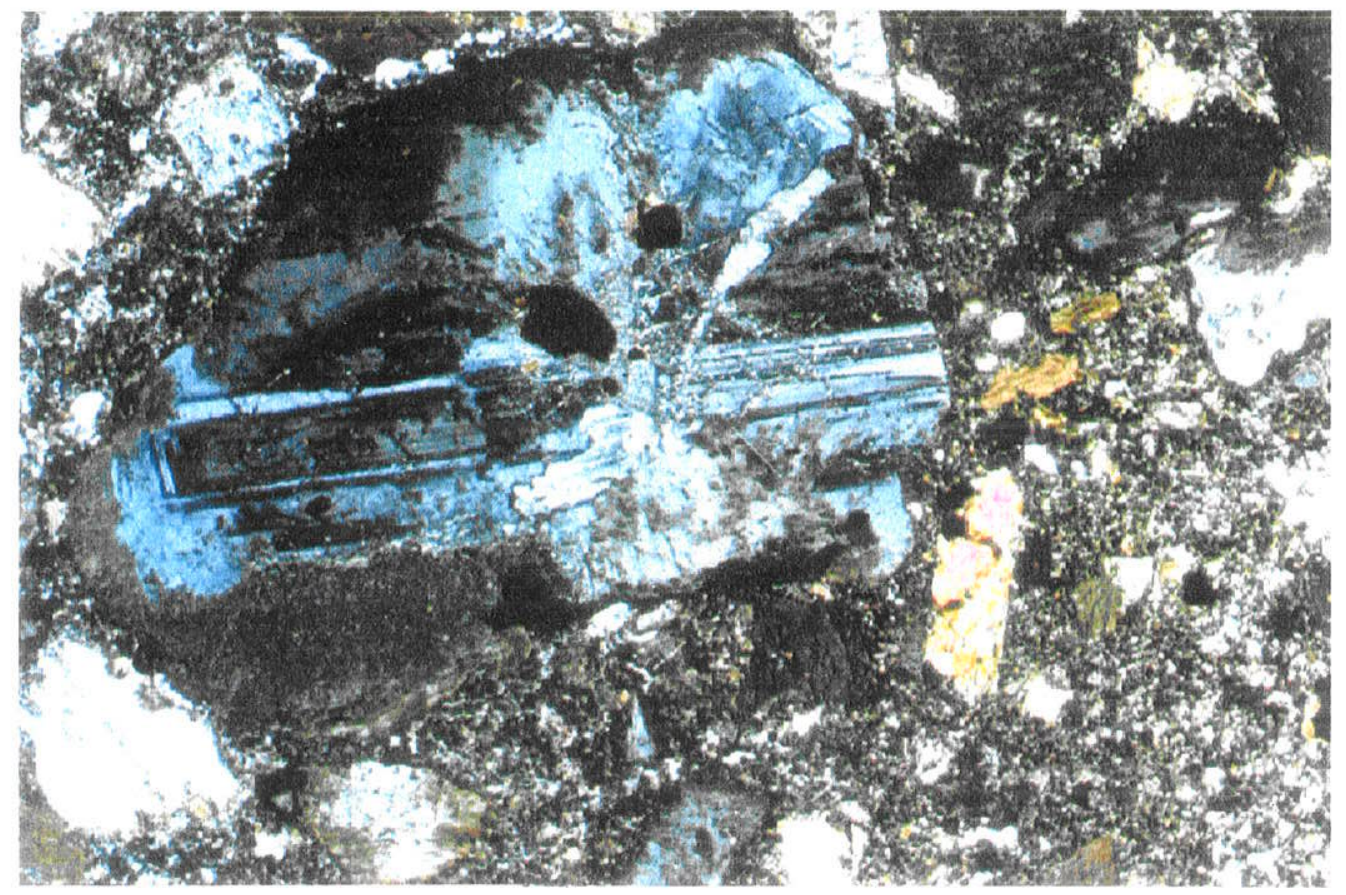

Fotomicrografia 12 - RP-264, Sienito alcalino de Morro Distante apresentando textura porfirítica. Os fenocristais de feldspato potássico exibem bordas de reação albíticas. Aumento 25X, polarizadores cruzados, filtros azul.

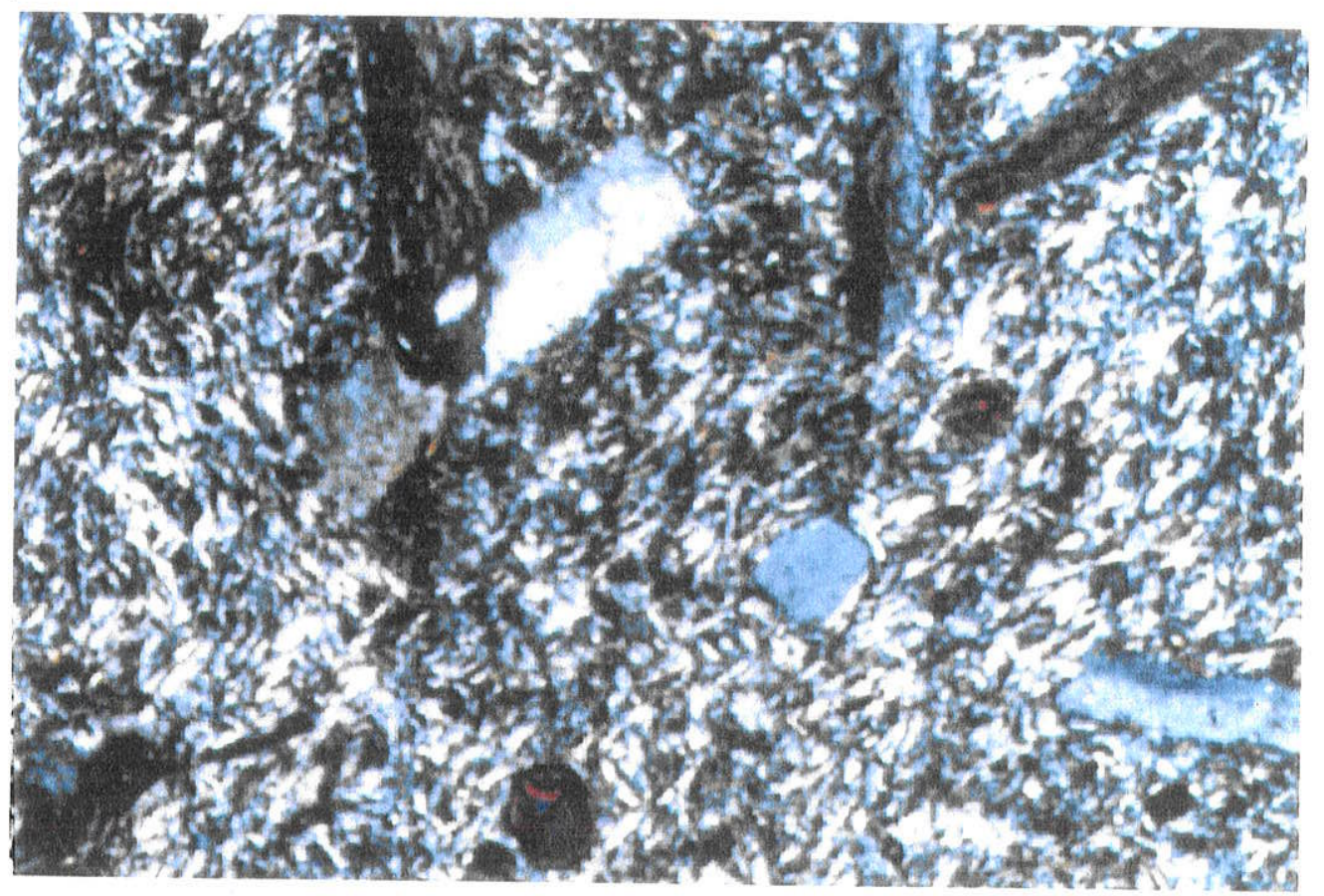

Fotomicrografia 13 - Outro aspecto textural das rochas de Morro Distante onde são destacadas as texturas microporfiríticas com cristais de feldspato potássico e matriz afanítica. 


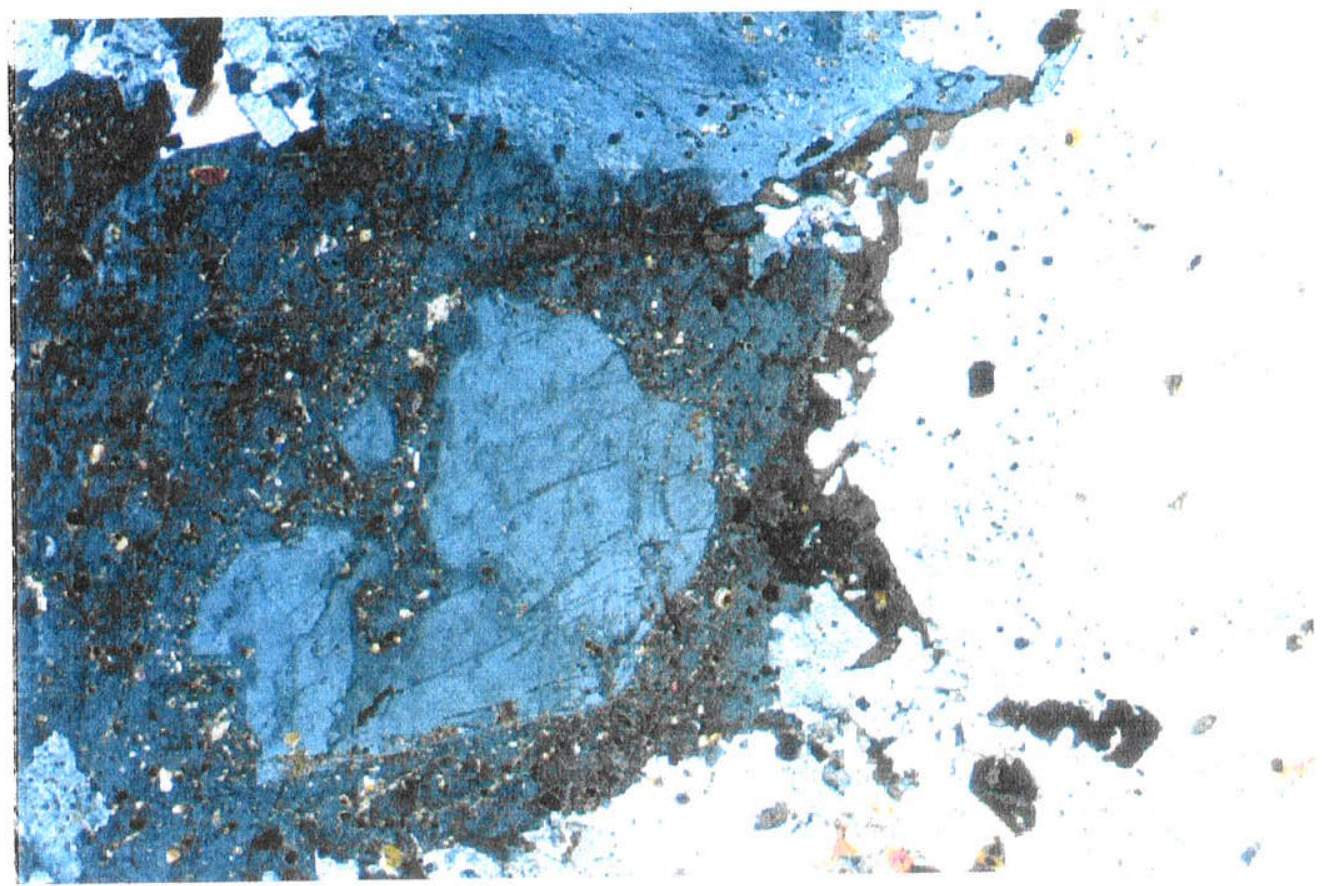

Fotomicrografia 14 RP-267, Microfenocristal de feldspato potássico apresentando texturas de sobrecrescimento de feldspatos, presentes nos litotipos subintrusivos de Morro Conceição.

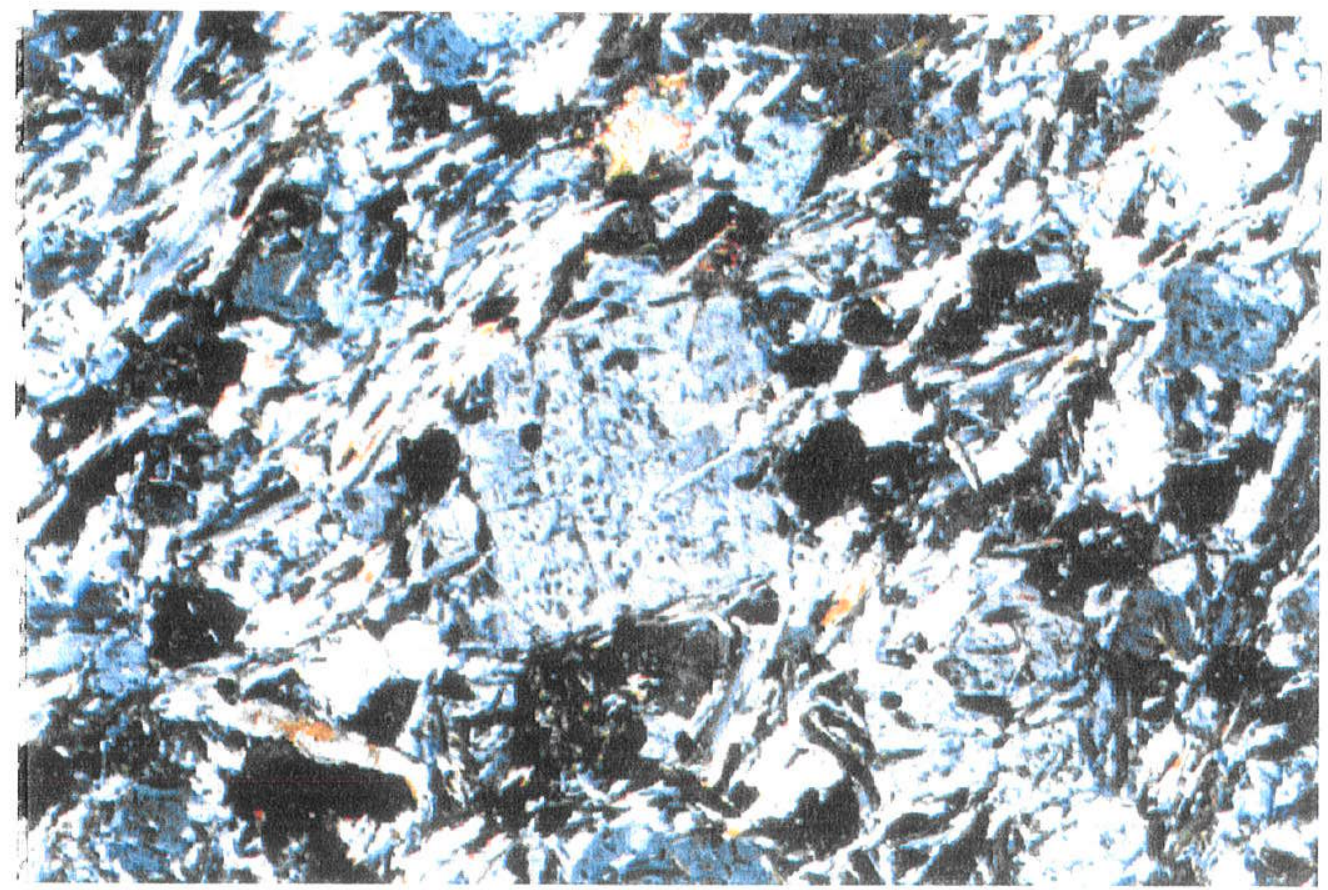

Fotomicrografia 15 - RP-259, Textura porfirítica com os fenocristais de nefelina apresentando imersa em matriz afanítica. 
Tabela 06 - Características litológicas da Província Alcalina Alto Paraguai: Morro de São Pedro

\begin{tabular}{|c|c|c|c|c|c|c|}
\hline \multirow{2}{*}{$\begin{array}{l}\frac{\pi}{0} \\
\frac{2}{90} \\
\frac{0}{0} \\
0\end{array}$} & \multirow{2}{*}{$\begin{array}{l}\text { Feições } \\
\text { geológicas }\end{array}$} & \multirow{2}{*}{ Litotipos } & \multirow{2}{*}{ Estrutura/Textura } & \multicolumn{3}{|c|}{ Mineralogia* } \\
\hline & & & & félsicos & máficos & acessórios \\
\hline \multirow{2}{*}{ 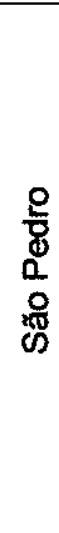 } & \multirow[b]{2}{*}{$\begin{array}{l}\text { stock circular, } \\
\text { área de } \sim 0,5 \mathrm{~km}^{2}\end{array}$} & $\begin{array}{l}\text { nefelina } \\
\text { sienitos } \\
\text { agpaíticos }\end{array}$ & $\begin{array}{l}\text { maciça, } \\
\text { equigranular } \\
\text { média a grossa, } \\
\text { coronitica, com } \\
\text { domínios } \\
\text { poiquilíticos }\end{array}$ & $\begin{array}{l}\text { feldspato alcalino (Or }{ }_{46-}- \\
\text { 84) - micropertitico com } \\
\text { padrão irregular, } \\
\text { geminação Carlsbad, } \\
\text { zoneamento normal, } \\
\text { nefelina, sodalita. }\end{array}$ & $\begin{array}{lr}\text { salitas } & \text { com } \\
\text { zonaeamento setorial, } \\
\text { com bordas de Fe }- \\
\text { edenita hornblenda, } \\
\text { biotita. }\end{array}$ & $\begin{array}{l}\text { titanita, zircão } \\
\text { carbonatos. }\end{array}$ \\
\hline & & $\begin{array}{l}\text { fonolitos } \\
\text { miasquíticos }\end{array}$ & $\begin{array}{l}\text { maciça, } \\
\text { orientação } \\
\text { incipiente (fluxo } \\
\text { ?) equigranular } \\
\text { média a fina, } \\
\text { porfiritico } \\
\text { coronítica. } \\
\end{array}$ & $\begin{array}{l}\text { feldspato alcalino }\left(\mathrm{Or}_{48-}-\right. \\
51) \text { micropertítico } \\
\text { geminação Carlsbad; } \\
\text { nefelina, }\end{array}$ & $\begin{array}{l}\text { salitas com bordas de } \\
\text { Fe-pargasita } \\
\text { hornblenda, biotita; }\end{array}$ & $\begin{array}{l}\text { apatita; titanita; zircão e } \\
\text { opacos }\end{array}$ \\
\hline
\end{tabular}


Tabela 07- Caracteristicas litológicas da Provincia Alcalina Alto Paraguai: Cerro Pedreira e Porto Conceição

\begin{tabular}{|c|c|c|c|c|c|c|}
\hline \multirow{2}{*}{$\begin{array}{l}\frac{\pi}{0} \\
\frac{2}{2} \\
\frac{8}{0} \\
0\end{array}$} & \multirow{2}{*}{ Feiçoes geologicas } & \multirow{2}{*}{ Litotipos } & \multirow{2}{*}{ Estrutura/Textura } & \multicolumn{3}{|c|}{ Mineralogia* } \\
\hline & & & & felsicos & máficos & acessórios \\
\hline \multirow{3}{*}{ 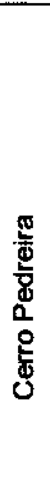 } & \multirow{3}{*}{$\begin{array}{l}\text { stock circular, área de } \\
\sim 0,1 \mathrm{~km}^{2}\end{array}$} & $\begin{array}{l}\text { sienitos } \\
\text { alcalinos } \\
\text { miasquíticos }\end{array}$ & $\begin{array}{l}\text { maciça, equigranular } \\
\text { seriada media a } \\
\text { grossa, is vezes, } \\
\text { coronítica. }\end{array}$ & $\begin{array}{l}\text { feldspato alcalino (Or} 70-96)- \\
\text { mesopertita do tipo string } \\
\text { pertita; plagioclásio oligoclásio } \\
\left(A n_{0-3.5}\right) \text { zoneamento normal., }\end{array}$ & $\begin{array}{l}\text { egirina-augita zoneamento } \\
\text { normal, edenita rica em sílica, } \\
\text { biotita. }\end{array}$ & $\begin{array}{l}\text { apatita, titanita, zircăo e } \\
\text { opacos. }\end{array}$ \\
\hline & & quartzo sienitos & $\begin{array}{l}\text { maciça, equigranular } \\
\text { média a grossa, } \\
\text { frequentemente } \\
\text { coronítica }\end{array}$ & 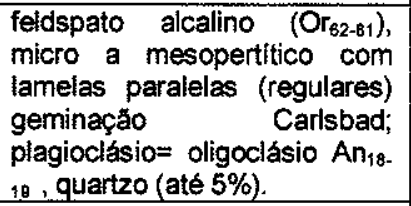 & $\begin{array}{l}\text { egirina-augita, zoneamento } \\
\text { normal, edenita rica em silica } \\
\text { biotita; }\end{array}$ & $\begin{array}{l}\text { apatita; titanita; zircåo e } \\
\text { opacos }\end{array}$ \\
\hline & & & $\begin{array}{l}\text { maciça, equigranular, } \\
\text { média a fina }\end{array}$ & $\begin{array}{lr}\text { feldspato alcalino } & \text { Or }_{70-88} \\
\text { micropertitico, } & \text { lamelas } \\
\text { irregulares, } & \text { geminaçăo } \\
\text { Carlsbad, quartzo (até 15\%) }\end{array}$ & edenita rica em sllica, biotita. & titanita, zircåo e opacos. \\
\hline \multirow{2}{*}{ 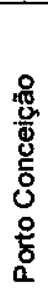 } & \multirow[t]{2}{*}{ plug área $\sim 0,1 \mathrm{~km}^{2}$} & $\begin{array}{l}\text { sienito alcalino } \\
\text { miasquitico }\end{array}$ & $\begin{array}{l}\text { maciça, equigranular } \\
\text { média a grossa }\end{array}$ & $\begin{array}{l}\text { feldspato alcalino } \mathrm{Or}_{02-3.5} \\
\text { micro a mesopertítico tipo } \\
\text { patch zoneamento oscilatorio; }\end{array}$ & $\begin{array}{l}\text { egirina-augita, arfvedsonita; } \\
\text { biotita. }\end{array}$ & apatita; titanita; opacos. \\
\hline & & quartzo sienitos & $\begin{array}{l}\text { maciça, equigranular, } \\
\text { média a grossa }\end{array}$ & $\begin{array}{l}\text { feldspato alcalino } \mathrm{Or}_{23-28} \text { micro } \\
\text { a mesopertítico, } \\
\text { plagioclásio=oligociasio/andesi } \\
\text { na }\left(\mathrm{An}_{26-35}\right) \text { quartzo. }\end{array}$ & $\begin{array}{l}\text { egirina-augita, arfvedsonita, } \\
\text { Fe-glaucofarnio e } \\
\text { biotita }\end{array}$ & titanita, apatita e opacos. \\
\hline
\end{tabular}


Tabela 08-Características litológicas da Província Alcalina Alto Paraguai: Morro Conceição e Morro Distante

\begin{tabular}{|c|c|c|c|c|c|c|}
\hline \multirow{2}{*}{ 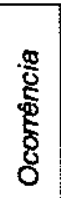 } & \multirow{2}{*}{ Feiçoes geologicas } & \multirow{2}{*}{ Litotipos } & \multirow{2}{*}{ Estrutura/Textura } & \multicolumn{3}{|c|}{ Mineralogia* } \\
\hline & & & & felsicos & máficos & acessórios \\
\hline 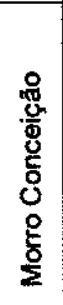 & $\begin{array}{l}\text { stock circular com } \\
\text { área de } \\
\text { aproximadamente } \\
1 \mathrm{~km}^{2}\end{array}$ & $\begin{array}{l}\text { sienitos } \\
\text { alcalinos } \\
\text { miasquíticos } \\
\text { (campo } 6^{\prime \prime} \text { do } \\
\text { diagrama QAP) }\end{array}$ & $\begin{array}{l}\text { maciça, inequigranular } \\
\text { seriada media a } \\
\text { grossa, as vezes, } \\
\text { porfiritica, rom } \\
\text { coronas, rexturas } \\
\text { simplectiticas. }\end{array}$ & $\begin{array}{l}\text { feldspato alcalino }\left(\mathrm{Or}_{10-82}\right)- \\
\text { mesopertita do tipo string } \\
\text { pertita; plagioclásio oligoclásio } \\
\left(\mathrm{An}_{15-28}\right) \text { zoneamento normal. }\end{array}$ & $\begin{array}{l}\text { eginina-augita zonada, } \\
\text { edenita e Fe-edenita, biotita } \\
\text { (presença de asterismos). } \\
\text { whoelerita/lavenita }\end{array}$ & apatita, titanita, zircăo opacos. \\
\hline 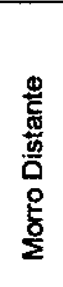 & $\begin{array}{c}\text { plug de forma } \\
\text { irregular, área de } \\
\text { aproximadamente } \\
1 \mathrm{~km}^{2}\end{array}$ & $\begin{array}{l}\text { quartzo sienitos } \\
\text { (campo } 6 \text { do } \\
\text { diagrama QAP). }\end{array}$ & $\begin{array}{l}\text { maciça, equigranular } \\
\text { média a fina }\end{array}$ & $\begin{array}{l}\text { feldspato alcalino } \mathrm{Or}_{3.5} \text {, micro } \\
\text { a mesopertítico tipo patch } \\
\text { pertita; } \quad \text { zoneamento } \\
\text { oscilatorio; plagioclásio= }=\mathrm{An}_{13.28} \\
\text { quartzo. }\end{array}$ & $\begin{array}{l}\text { egirina-augita arfvedsonita; } \\
\text { biotita. }\end{array}$ & apatita; titanita; opacos. \\
\hline
\end{tabular}




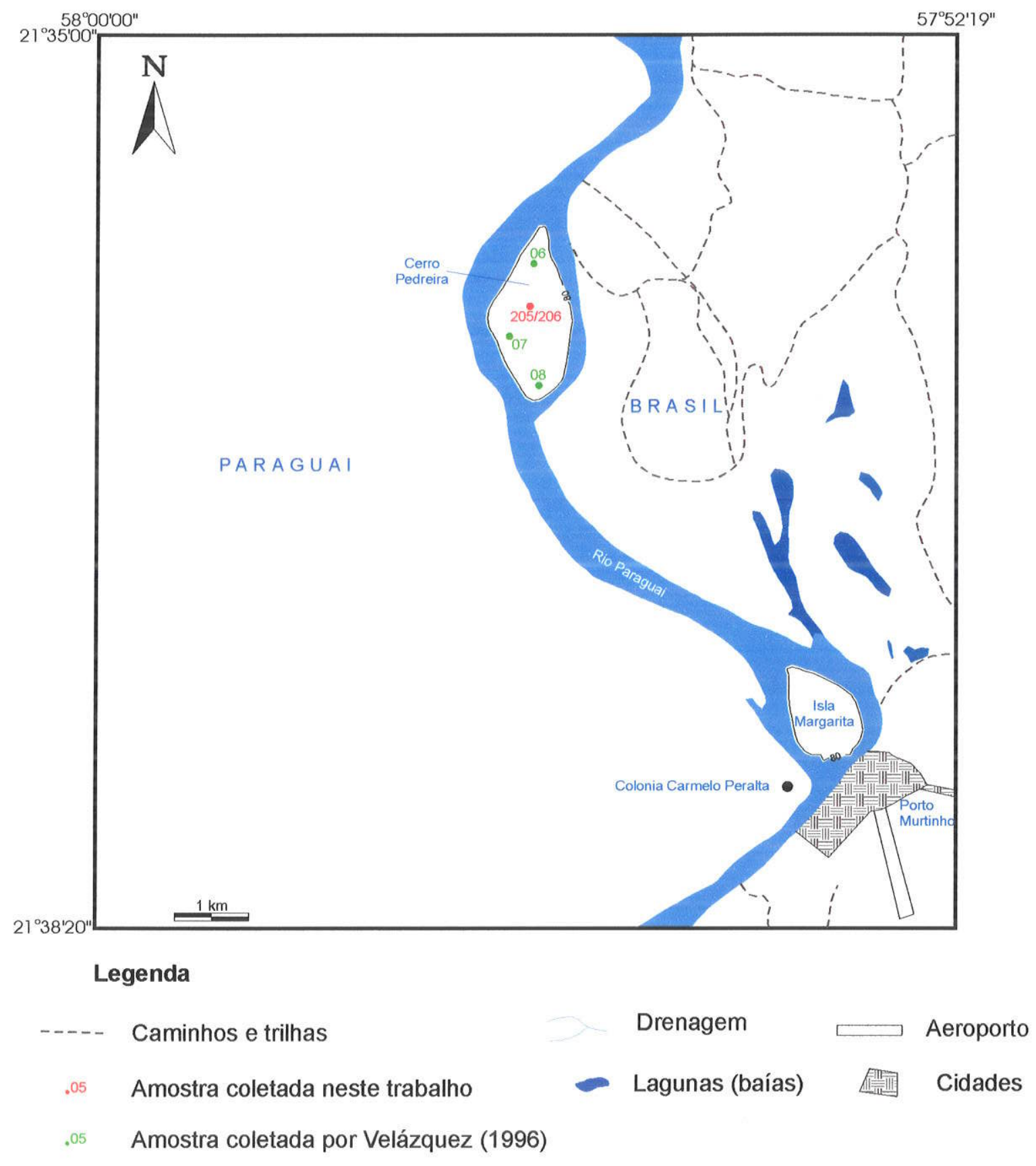

Figura 08: Mapa de localização de amostras da região de Porto Murtinho (MS). Folha Porto Murtinho (SF-21-V-D-Y), escala 1:100.000. 


\section{IV.7 - Cerro Siete Cabezas e Corpos Satélites}

Os corpos intrusivos que ocorrem com a denominação de Cerro Siete Cabezas e Corpos Satélites foram definidos por Velázquez (1996) em razão dessas rochas constituirem a feição geomórfica homônima, localizada na Folha Puerto Tres Palmas (Figura 09). O corpo maior é representado por um maciço alcalino com dimensões de "stock", de forma circular, perfazendo aproximadamente $4 \mathrm{~km}^{2}$ de diâmetro, com uma depressão central pronunciada. As fotos 08 e 09 permitem uma visualização parcial desta intrusão.

Os corpos alcalinos reunidos pela denominação de Satélite I e Satélite II representam pequenos "plugs" distando respectivamente 0,5 e $3,0 \mathrm{~km}$ do corpo principal.

Os litotipos intrusivos predominantes no corpo principal são os alcali-feldspato sienitos com feldspatóide e diques traquíticos (campo 6') e subordinadamente nefelina sienitos (campo 11). Nos corpos satélites as litologias mais abundantes são, em ordem crescente de ocorrência: alcali-feldspato-quartzo sienitos e alcalifeldspato sienitos (campos $6^{\star}$ e 6 , respectivamente).

Os alcali-feldspato sienitos são rochas de cor cinza-clara a cinza-escura, granulação grossa a média, com estrutura maciça e textura holocristalina., Entretanto, podem ocorrer tanto variedades de rochas com granulação mais fina e textura hipidiomórfica como litotipos de caráter eminentemente pegmatíticos. $O$ mineral mais abundante nessas rochas é o feldspato alcalino. Ao microscópio esse mineral apresenta-se com formas diversas, quase sempre anédricas, podendo ocasionalmente conter formas subédricas, com hábito tabular alongado. São comuns intercrescimentos micropertíticos, pertíticos ou mesopertíticos, com formas irregulares, anastomosadas ou como finas lamelas retilíneas. A geminação segundo a lei de Carlsbad é rara. Ocorrem, via de regra, inclusões euédricas de nefelina tendo o feldspato potássico como hospedeiro.

O piroxênio presente na intrusão principal tem caracteristicas de anfibólios cálcicos a cálcico-sódicos, no entanto, em algumas variedades de rocha, ocorre 
anfibólio sódico, sendo geralmente incolor a verde-claro, às vezes fraturado, quase sempre poiquilítica, possuindo ocasionalmente inclusões de feldspato potássico, biotita e minerais opacos. Nas fraturas ocorrem sempre reações de substituição deste mineral para anfibólio, constituindo coronas com núcleo incolor e bordas esverdeadas. $\mathrm{O}$ anfibólio é comumente representado por minerais cálcico-sódicos e sódicos. Tem pleocroísmo nas cores variando de verde a castanho escuro e ocorre preferencialmente relacionado à bordas de reação de piroxênios.

A biotita apresenta pleocroísmo variando nas cores marron a vermelha (castanha). Apresenta-se na forma de microfenocristais nas variedades petreográficas mais finas, contendo inclusões de feldspato potássico e titanita.

Os minerais acessórios fazem-se representar pelas seguintes fases: zircão, titanita, apatita e fluorita. enquanto que os secundários, pela cancrinita.

Os nefelina sienitos não diferem muito dos alcali-feldspato sienitos no que diz respeito à cor, granulação e aspecto textural. Entretanto, a ocorrência do feldspatóide xenomórfico intersticialmente é diagnóstica.

Os alcali-feldspato traquitos e litotipos associados dos corpos Satélite I e II, são felsitos de granulação fina, microporfiríticos, com microfenocristais de anfibólio sódico poiquilítico e matriz feldspática orientada. Estes litotipos diferem mineralógicamente dos sienitos da intrusão principal, por apresentar piroxênio augítico e anfibólio cálcico-sódico em sua constituição. Titanita, apatita e opacos complementam a trama, como minerais acessórios.

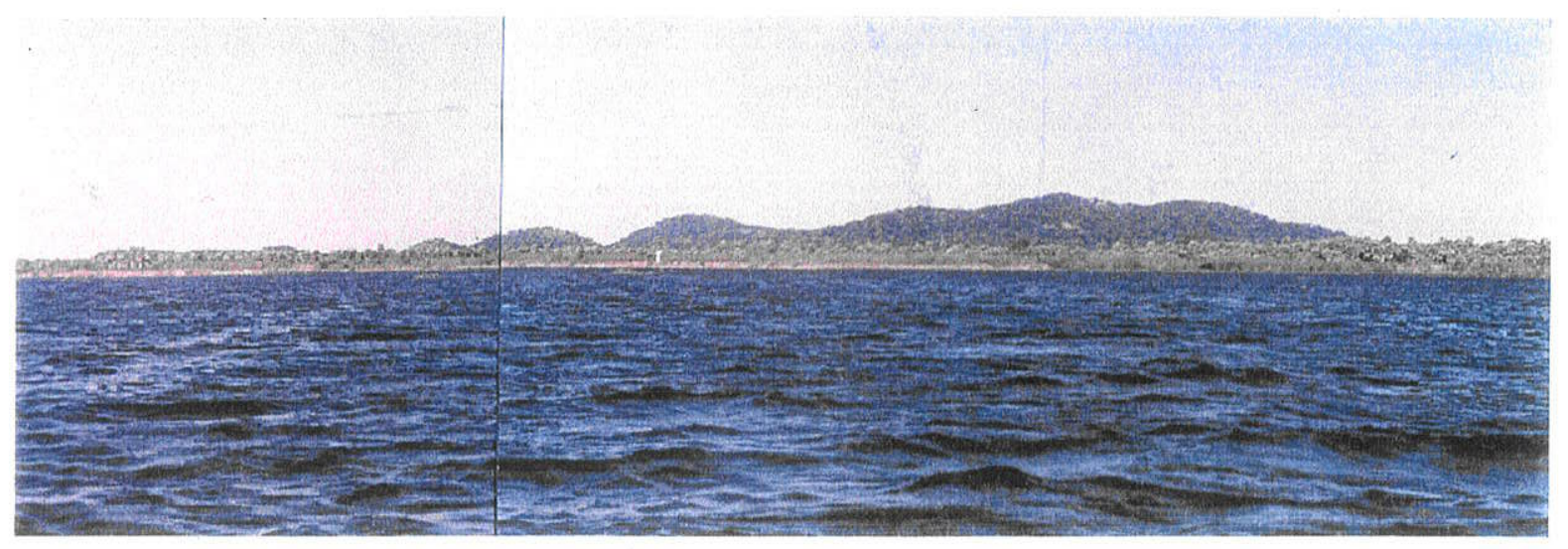

Foto 08 - Complexo intrusivo Cerro Siete Cabezas e Satélite. Vista de NE para SW. 


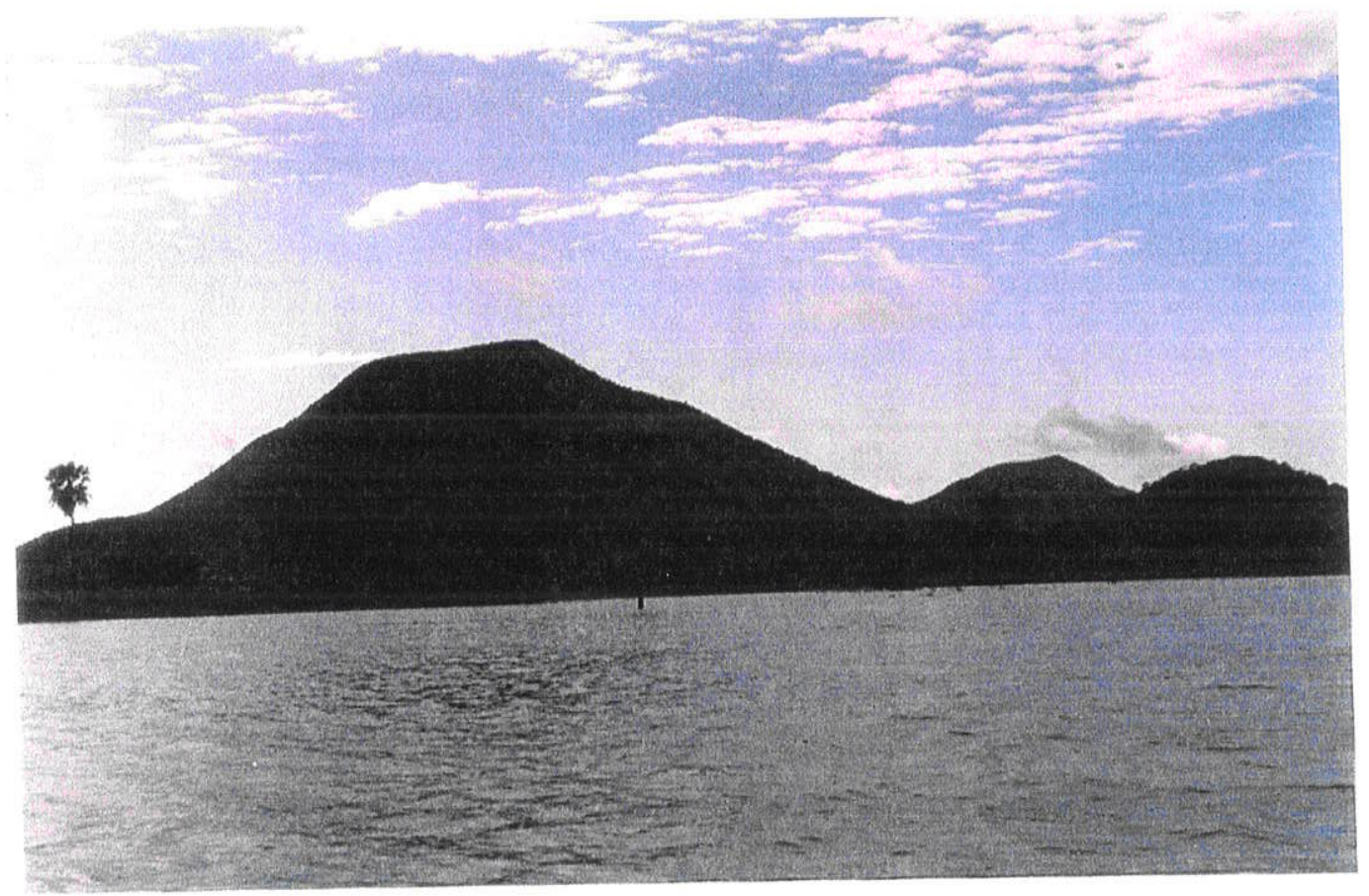

Foto 09 - Situação mais proximal do Complexo Alcalino Cerro Siete Cabezas e Satélite I, vista de E para W.

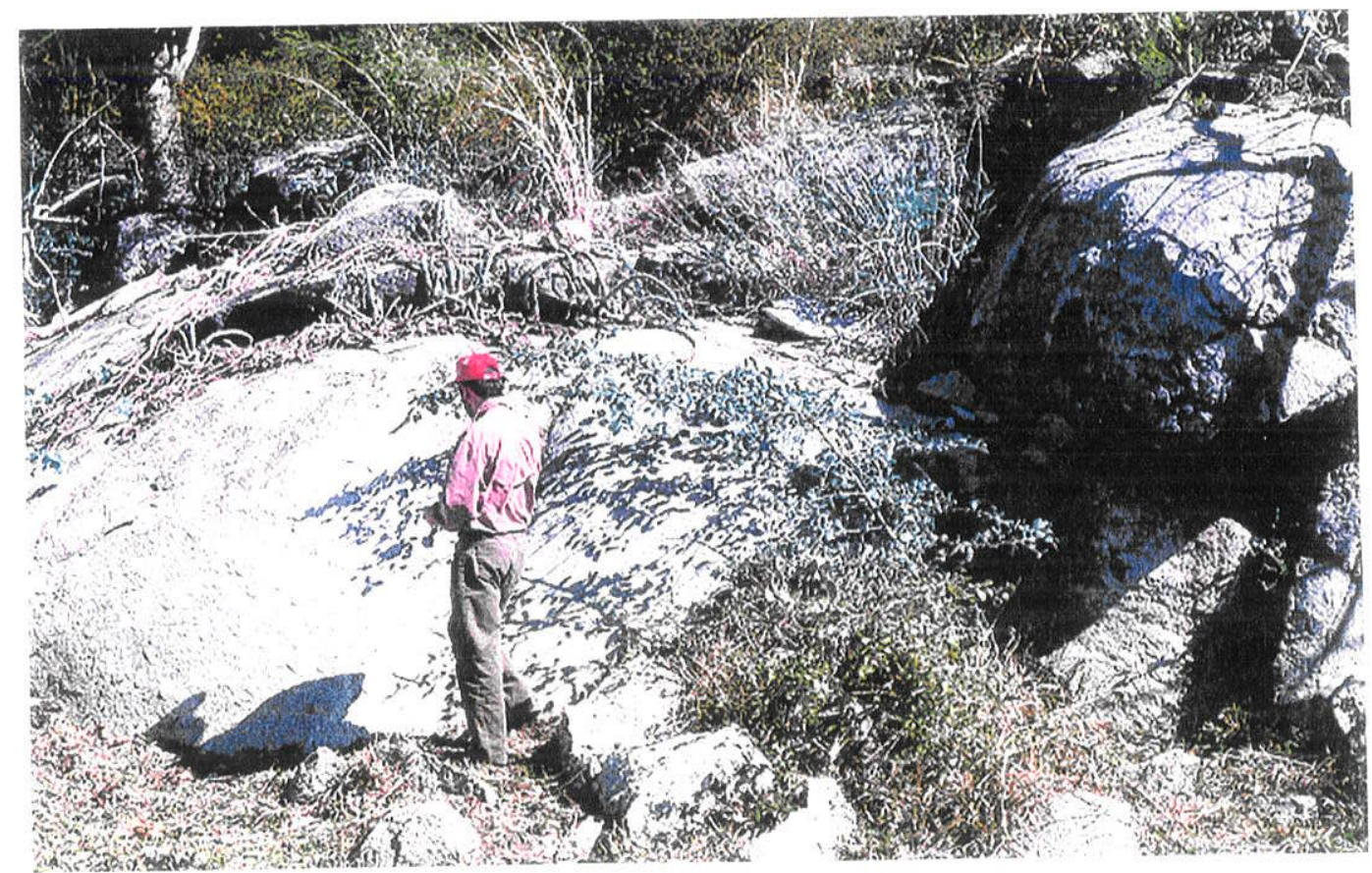

Foto 10 - Aspecto geral de um afloramento de nefelina sienito de Cerro Siete Cabezas. 


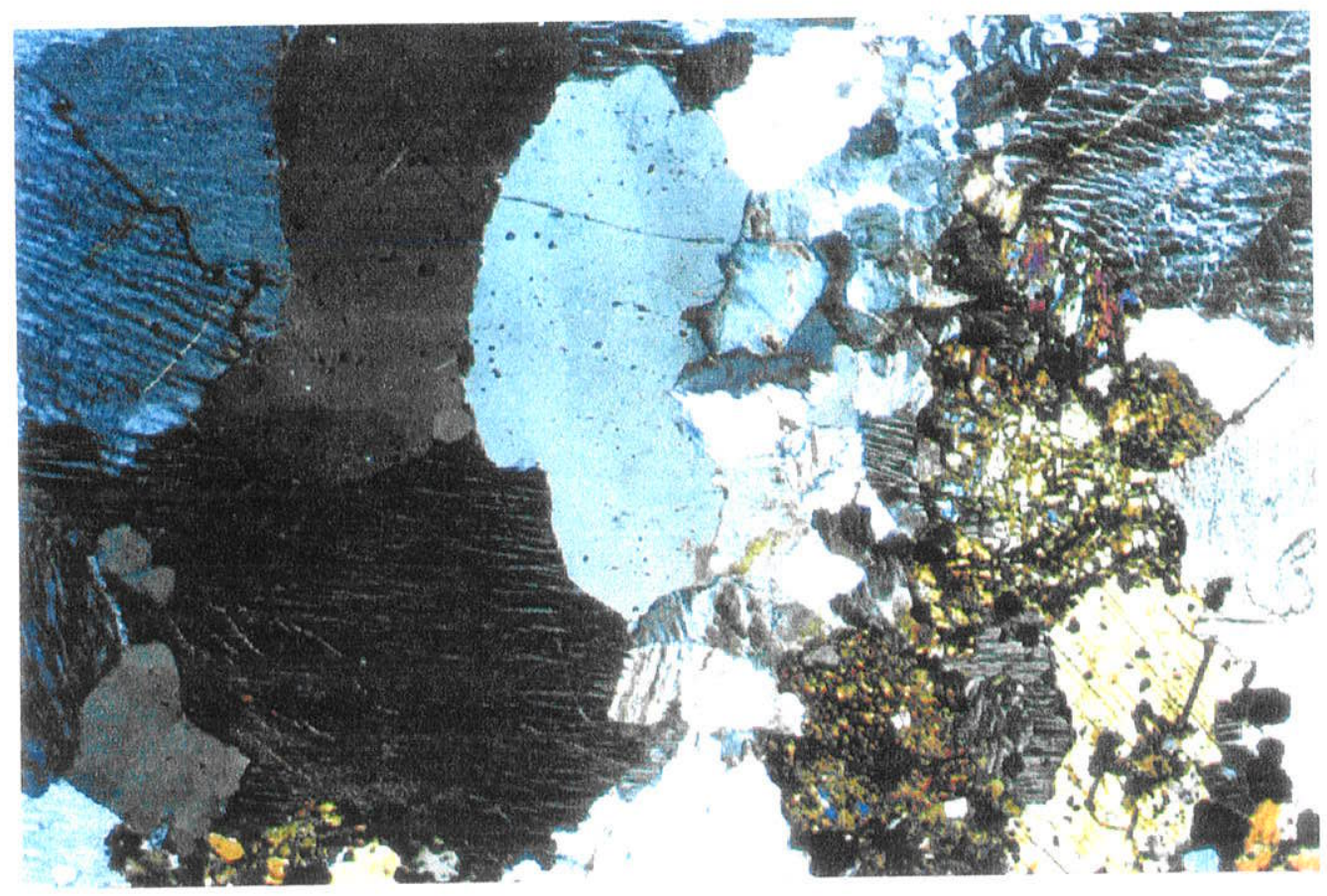

Fotomicrografia 16 - Quartzo sienito de CSC apresentando feldspatos com intercrescimento pertítico, cujas lamelas têm formas regulares. Fenocristais de titanita(à direita) são comuns. Aumento 25X, polarizadores cruzados, filtro azul.

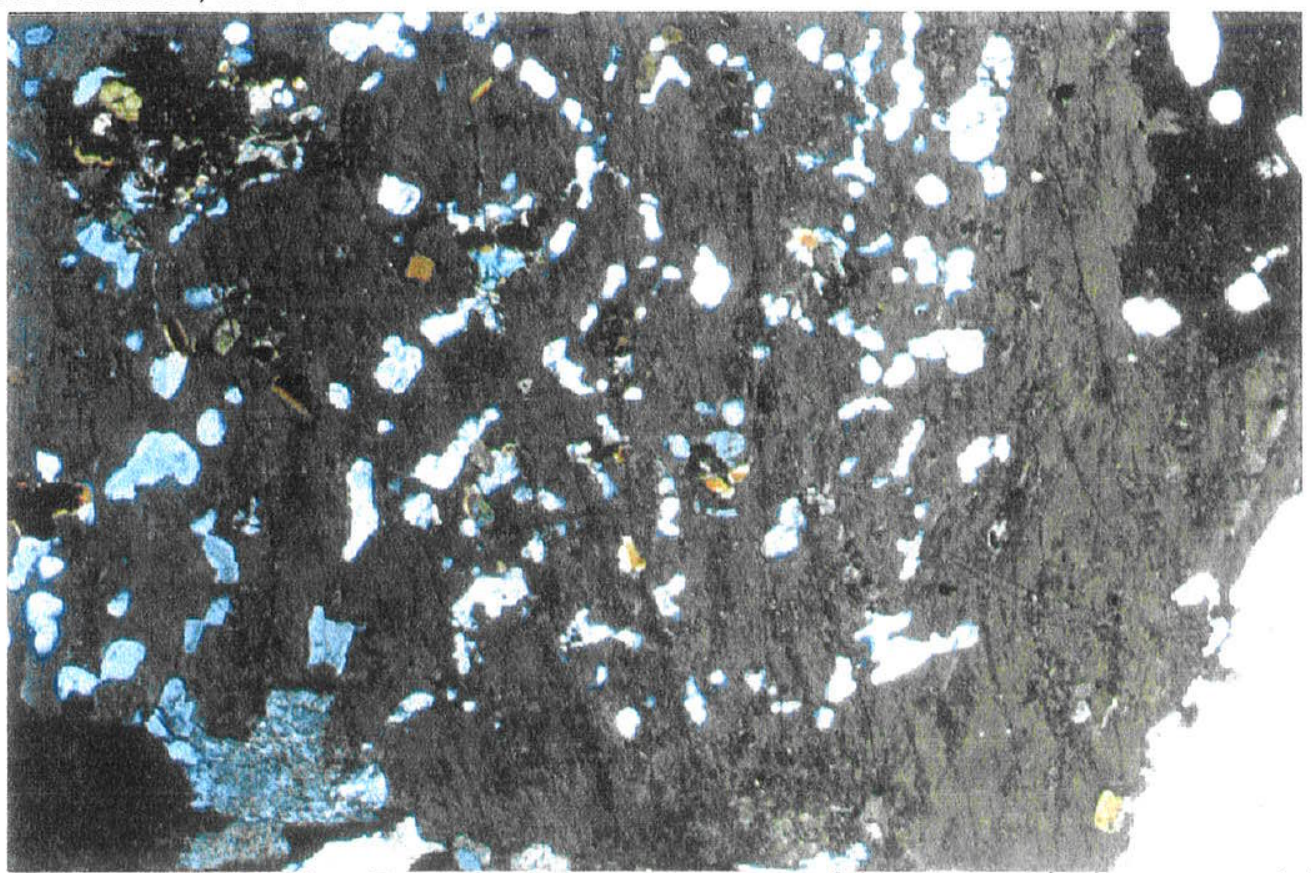

Fotomicrografia 17 - RP-234 - Fenocristal arredondado de feldspato potássico, com cristalização marginal de biotita em traquito de CSC. As inclusões maiores são de nefelina, egirina-augita e biotita. Aumento 25X, polarizadores cruzados, filtro azul 


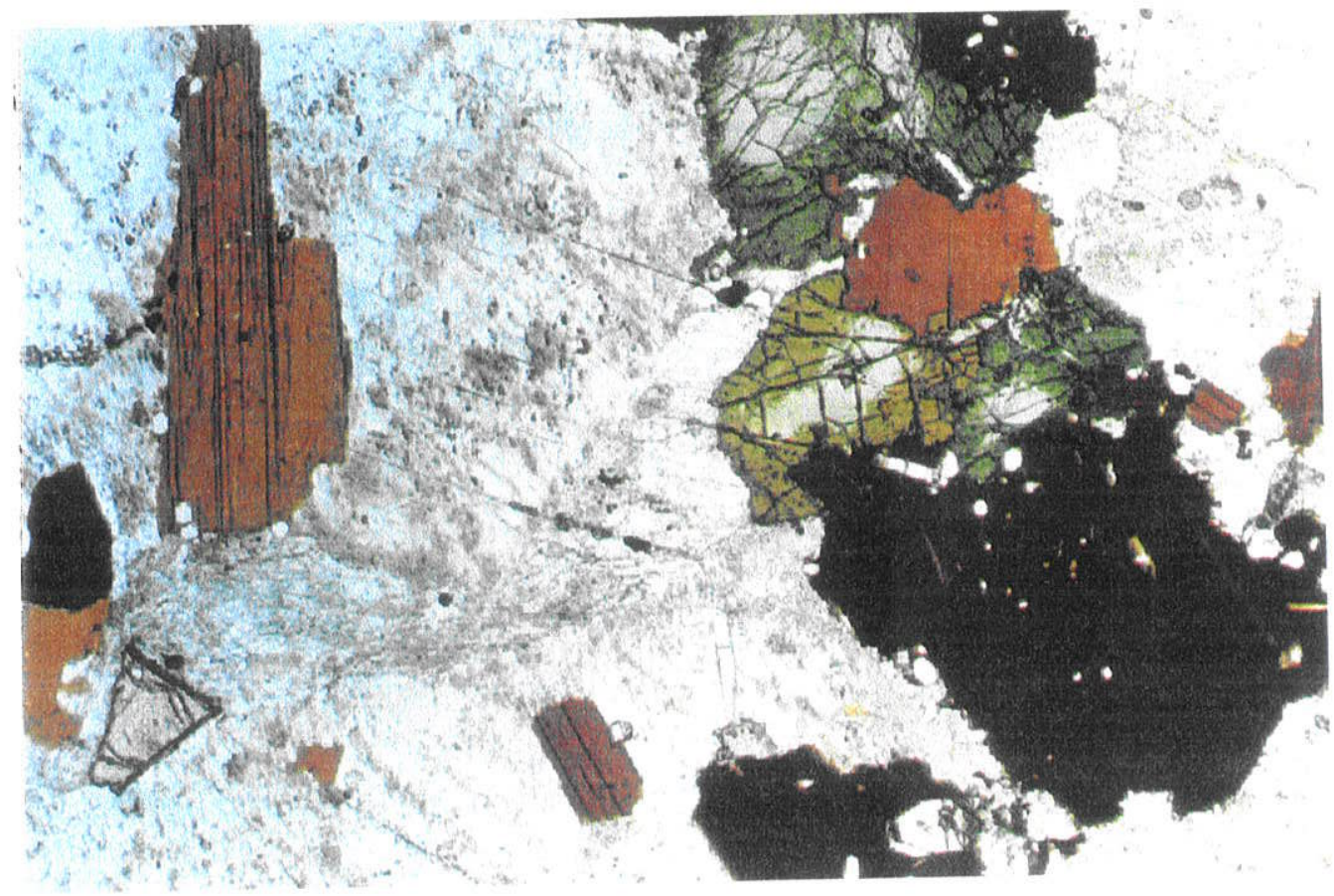

Fotomicrografia 18 -RP-242 - Bordas de reação egirina-augita/anfibólio sódico em sienito alcalino de CSC. Cristais de biotita com intercrescimento lamelar são comuns. Aumento 25X, polarizadores cruzados, filtro azul.

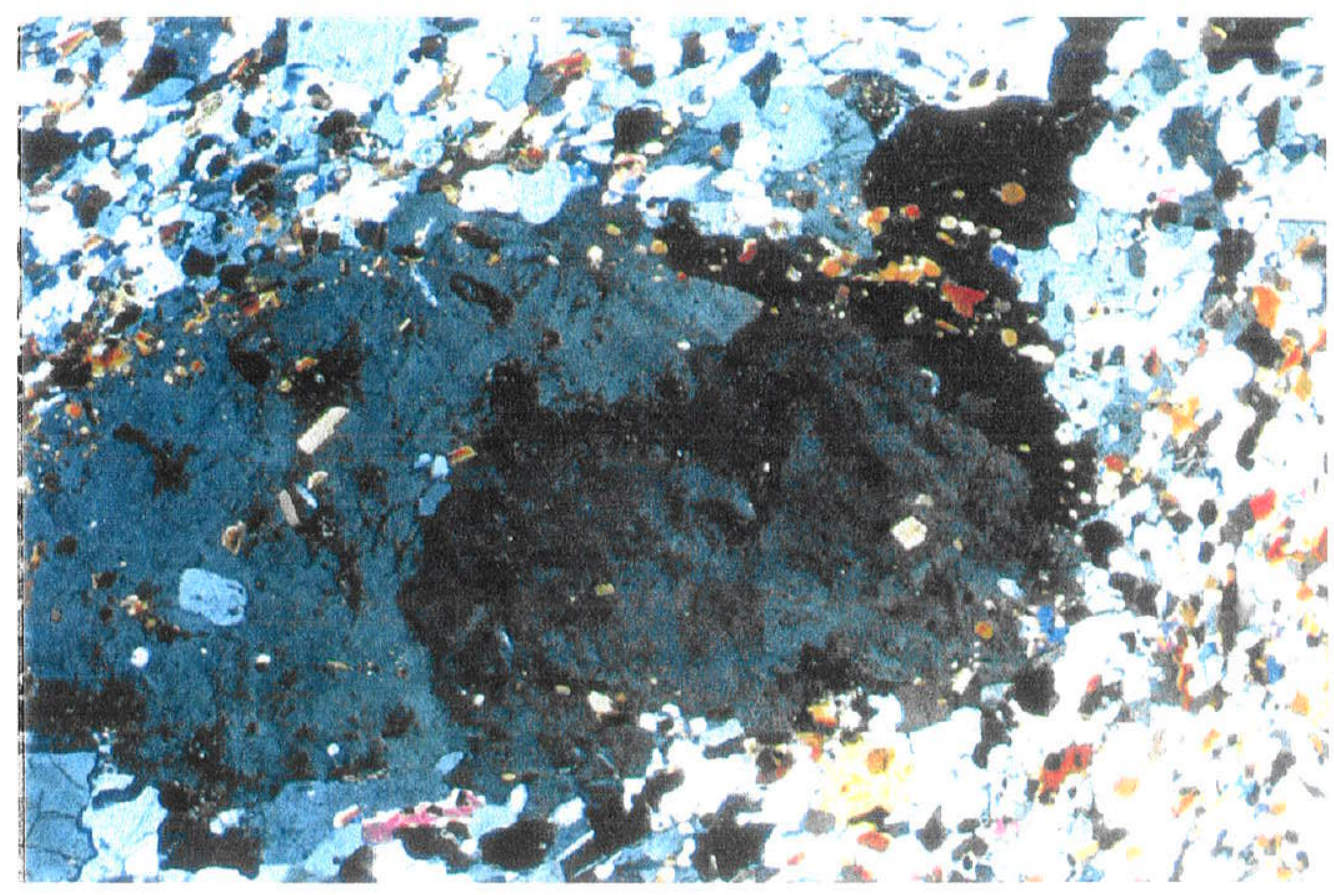

Fotomicrografia 19 - RP-236 - Fenocristal poiquilítico de nefelina em nefelina sienito de CSC. As inclusões são constituídas por: feldspato potássico, apatita e opacos. Aumento 25X, polarizadores cruzados, filtro azul. 
As fotomicrografias $16,17,18$ e 19 mostram relações texturais/estruturais dos quartzo sienitos, nefelina sienitos, traquifonolitos e sienitos alcalinos, respectivamente, presentes nas rochas pertencentes ao Cerro Siete Cabezas.

As características petrográficas de Cerro siete Cabezas e corpos Satélites são apresentadas resumidamente na tabela 09 . 
Tabela 09- Características litológicas da Província Alcalina Alto Paraguai: Cerro Siete Cabezas e Corpos Satélites

\begin{tabular}{|c|c|c|c|c|c|c|}
\hline \multirow{2}{*}{ לू. } & \multirow{2}{*}{ Feiçסes geologicas } & \multirow{2}{*}{ Litotipos } & \multirow{2}{*}{ Estrutura/Textura } & \multicolumn{3}{|c|}{ Mineralogia* } \\
\hline & & & & félsicos & máficos & acessórios \\
\hline \multirow{3}{*}{ 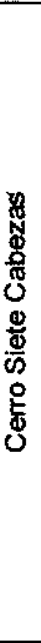 } & \multirow{3}{*}{$\begin{array}{l}\text { stock circular, área de } \\
4 \mathrm{~km}^{2}\end{array}$} & $\begin{array}{l}\text { sienitos } \\
\text { alcalinos } \\
\text { miasquíticos }\end{array}$ & $\begin{array}{l}\text { maciça, inequigranular } \\
\text { seriada media a } \\
\text { grossa }\end{array}$ & $\begin{array}{l}\text { feldspato alcalino }\left(\mathrm{Or}_{70-98}\right) \\
\text { mesopertita do tipo string } \\
\text { pertita; plagioclásio oligoclásio } \\
\left(\mathrm{An}_{0-3,5)}\right) \text { zoneamento normal., }\end{array}$ & $\begin{array}{l}\text { egirina-augita zonada, } \\
\text { n=edenita e b=Fe-pargas. } \\
\text { hornblenda; biotita. }\end{array}$ & apatita, titanita, zircåo opacos. \\
\hline & & $\begin{array}{l}\text { nefelina sienitos } \\
\text { agpaíticos }\end{array}$ & $\begin{array}{l}\text { maciça, equigranular } \\
\text { média a grossa }\end{array}$ & $\begin{array}{l}\text { feldspato alcalino }\left(\mathrm{Or}_{28.82}\right) \text {, } \\
\text { micropertitico tipo patch } \\
\text { pertita, geminaçăo Carlsbad; } \\
\text { nefelina. }\end{array}$ & $\begin{array}{l}\text { egirina-augita, } \\
\text { eudialita }\end{array}$ & apatita; titanita; fluorita opacos \\
\hline & & $\begin{array}{l}\text { diques } \\
\text { traquiticos } \\
\text { (campo 6' do } \\
\text { diagrama QAP) }\end{array}$ & $\begin{array}{l}\text { orientada, porfiritica } \\
\text { com matriz afanitica }\end{array}$ & $\begin{array}{l}\text { fenocristais: } r \text { feldspato } \\
\text { alcalino (Or }{ }_{46-64} \text { ), criptopertítico } \\
\text { com lamela tipo braid pertita, } \\
\text { gem. Carlsbad; } \\
\text { matriz: feldspato alcalino } \\
\text { limpido, sem pertita; } \\
\text { plagiociasio oligoclásio (An }{ }_{12-} \\
\text { 15), quartzo }\end{array}$ & $\begin{array}{l}\text { fenocristais:egirina-augita e } \\
\text { arfvdsonita. } \\
\text { matriz: egirina-augita, } \\
\text { arfudsonita }\end{array}$ & $\begin{array}{l}\text { apatita, titanita, zircăo, apatita } \\
\text { e opacos. }\end{array}$ \\
\hline \multirow{2}{*}{ Ф্ষ } & \multirow[t]{2}{*}{ plug, área $\sim 0,5 \mathrm{~km}^{2}$} & $\begin{array}{l}\text { sienito alcalino } \\
\text { miasquítico }\end{array}$ & $\begin{array}{l}\text { maciça, equigranular } \\
\text { media a grossa }\end{array}$ & $\begin{array}{l}\text { feldspato aicalino Or }{ }_{70-68,} \\
\text { micro a mesopertitico tipo } \\
\text { patch pertita; zoneamento } \\
\text { oscilatório; quartzo. }\end{array}$ & $\begin{array}{l}\text { eginina-augita arfvedsonita; } \\
\text { biotita. }\end{array}$ & apatita; titanita; opacos. \\
\hline & & quartzo sienitos & $\begin{array}{l}\text { maciça, equigranular, } \\
\text { média a grossa }\end{array}$ & $\begin{array}{l}\text { feldspato alcalino } \mathrm{Or}_{84-88} \text { micro } \\
\text { a mesopertítico, quartzo. }\end{array}$ & $\begin{array}{l}\text { egirina-augita, arfvedsonita, } \\
\text { Fe-glaucof. e } \\
\text { biotita }\end{array}$ & $\begin{array}{l}\text { titanita, zircăo, apatita } \mathrm{e} \\
\text { opacos }\end{array}$ \\
\hline \multirow[b]{2}{*}{ 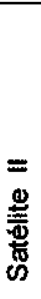 } & \multirow[t]{2}{*}{ Plug, área $\sim 0,25 \mathrm{~km}^{2}$} & $\begin{array}{l}\text { Sienito alcalino } \\
\text { miasquítico } \\
\text { (campo } 6^{\prime} \text { do } \\
\text { diagrama QAP) }\end{array}$ & $\begin{array}{l}\text { maciça, }{ }_{1} \text { equigran. } \\
\text { Média a grossa, } \\
\text { microporfirítica }\end{array}$ & $\begin{array}{l}\text { feldsp. Alcalino } \mathrm{Or}_{\mathrm{B} 1-84} \text { e plag. } \\
\text { Oligoclásio } \mathrm{An}_{12^{-18} \text { micro a }} \\
\text { mesopertítico. }\end{array}$ & $\begin{array}{l}\text { egirina-augita, arfvdsonita e } \\
\text { biotita, eudialita }\end{array}$ & $\begin{array}{l}\text { fitanita, apatita, zircăo e } \\
\text { opacos }\end{array}$ \\
\hline & & $\begin{array}{l}\text { qtzo sienitos e } \\
\text { alcali-feldspato } \\
\text { granito (campos } \\
6^{\star} \text { e } 2 \text { do } \\
\text { diagrama QAP) }\end{array}$ & $\begin{array}{l}\text { maciça, equigran. } \\
\text { Média a fina }\end{array}$ & $\begin{array}{l}\text { feldsp. Alcalino Or88-95 micro } \\
\text { a mesopertítico, quartzo }\end{array}$ & $\begin{array}{l}\text { eginina-augita. arfvdsonita e } \\
\text { biotita }\end{array}$ & $\begin{array}{l}\text { titanita, apatita, zirç̃o } \mathrm{e} \\
\text { opacos }\end{array}$ \\
\hline
\end{tabular}




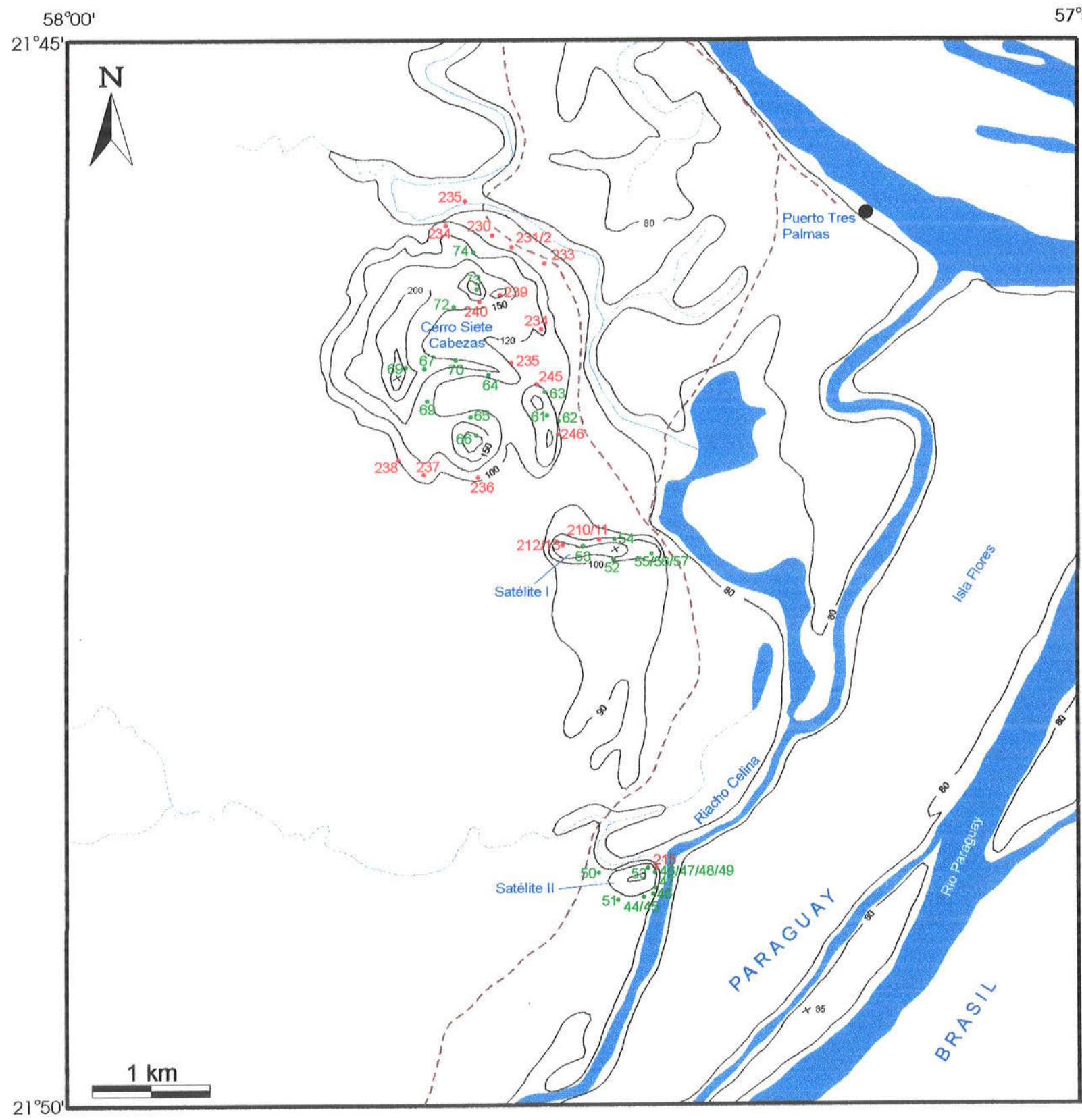

\section{Legenda}

.05 Amostra coletada neste trabalho Drenagem

Cidades

.05 Amostra coletada por Velázquez (1996)

Drenagem intermitente

Caminhos e trilhas

Figura 09: Mapa de localização de amostras da região do Cerro Siete Cabezas (PY). Carta Nacional, Puerto Tres Palmas (Hoja 5377 III), escala 1:50.000. 
Tabela 10 - Análises modais de rochas da Província Alcalina Alto Paraguai (\% vol.)

\begin{tabular}{|c|c|c|c|c|c|c|c|c|c|c|c|c|c|c|c|c|c|c|c|c|}
\hline minlamostras & 7 & 8 & 27 & 29 & 30 & $31 a$ & 32 & 33 & 35 & 37 & 39 & 42 & 43 & 44 & 45 & 46 & 50 & 51 & 52 & 56 \\
\hline k-feldspatos & 90.9 & 92.5 & 50.2 & 64 & 55 & 67 & 92.9 & 50.3 & 44.1 & 48 & 61.5 & 49.3 & 59 & 89 & 66.1 & 89.1 & 82.9 & 86.1 & 93.1 & 89.5 \\
\hline nefelina & - & - & 29.1 & 10.5 & 15.5 & 10 & - & 9.2 & 17.8 & 21 & 17.9 & 19.2 & 5.8 & - & - & - & - & - & - & - \\
\hline sodalita & - & - & 14.9 & 8.1 & 17.1 & 4.7 & - & 12.2 & 27.7 & 8 & 13.5 & 10.1 & 4.6 & - & - & - & - & - & - & - \\
\hline egirina-augita & 0.1 & 2.3 & 4.2 & 16.3 & 7 & 11.5 & 4.9 & 22.6 & 8.1 & 19.1 & 5.6 & 18.8 & 21.8 & 1.5 & 13.7 & - & 2.2 & 0.5 & 2.7 & 2 \\
\hline Na-anfibólios & 1.8 & - & 0.2 & - & 1 & 2.5 & 1.4 & 2.4 & 0.2 & - & - & 0.4 & 0.4 & 6 & - & 8 & 8.4 & 9.5 & 2.6 & 7.1 \\
\hline biotita & 6.2 & 3.4 & 0.5 & - & 0.1 & - & - & - & 0.1 & - & - & 1 & 1.1 & 1.1 & - & 1.1 & 3.5 & 1.2 & 1 & - \\
\hline titanita & 0.2 & - & - & 1 & 1.3 & 3.7 & 0.2 & 1.5 & 0.1 & 0.2 & 0.6 & - & $\operatorname{tr}$ & 1.5 & - & 0.5 & - & 0.4 & 0.3 & 0.1 \\
\hline apatita & - & 0.1 & - & $\operatorname{tr}$ & 0.5 & 0.2 & - & 1.1 & 1.5 & 0.1 & 0.1 & 0.1 & 0.2 & - & 0.3 & 0.2 & 0.1 & 0.2 & $\mathrm{tr}$ & $\mathrm{tr}$ \\
\hline quartzo & - & - & - & - & - & - & - & - & - & - & - & - & - & - & 17.9 & - & 0.9 & 0.8 & 0.2 & $\operatorname{tr}$ \\
\hline carbonatos* & - & - & - & - & - & $\operatorname{tr}$ & - & - & $\mathrm{tr}$ & $\operatorname{tr}$ & - & - & $\operatorname{tr}$ & - & - & - & - & - & - & - \\
\hline cancrinita $^{\star}$ & - & - & - & tr & 2.2 & $\operatorname{tr}$ & - & 0.5 & 0.3 & 0.2 & 0.4 & 0.4 & - & - & - & - & $\operatorname{tr}$ & - & - & - \\
\hline opacos & 0.8 & 1.6 & 0.8 & - & 0.2 & 0.3 & 0.5 & - & - & - & 0.3 & 0.4 & 1 & 0.8 & 1.9 & 1 & 1.4 & 1.2 & - & 1.2 \\
\hline eudialita & - & - & - & - & - & - & - & 0.1 & - & 2.2 & - & 0.2 & - & tr & - & - & 0.5 & - & - & - \\
\hline zeólita* & $=$ & - & - & - & - & - & - & - & - & 1.1 & $\operatorname{tr}$ & - & - & - & - & - & - & - & - & - \\
\hline zircão & - & - & tr & tr & tr & $\operatorname{tr}$ & tr & - & $\operatorname{tr}$ & $\operatorname{tr}$ & $\operatorname{tr}$ & tr & $\operatorname{tr}$ & $\operatorname{tr}$ & - & - & $\operatorname{tr}$ & $\operatorname{tr}$ & - & $\operatorname{tr}$ \\
\hline pectolita & - & - & - & - & - & tr & - & - & $\operatorname{tr}$ & - & - & - & - & - & - & - & - & - & - & - \\
\hline lavenita & - & - & - & - & - & - & - & - & - & - & - & tr & - & - & - & - & $\operatorname{tr}$ & - & - & - \\
\hline fluorita & - & - & - & - & - & - & - & - & $\operatorname{tr}$ & - & - & - & - & - & - & - & - & - & - & - \\
\hline Total & 100 & 99.9 & 99.9 & 99.9 & 99.9 & 99.9 & 99.9 & 99.9 & 99.9 & 99.9 & 99.9 & 99.9 & 99.9 & 99.9 & 99.9 & 99.9 & 99.9 & 99.9 & 99.9 & 99.9 \\
\hline
\end{tabular}

Obs. As amostras 7 e 8 são de Cerro Pedreira, 27 a 43 sấo de Cerro Boggiani, 44 a 50 pertencem a Satélite Il enquanto que 51 a 56 säo de Satélite l.

* Minerais de Alteração 
Tabela 11 - Análises modais de rochas da Província Alcalina Alto Paraguai (\% vol.)

\begin{tabular}{|c|c|c|c|c|c|c|c|c|c|c|c|c|c|c|c|c|c|c|c|c|}
\hline minlamostras & 58 & 62 & 74 & 78 & 85 & 88 & 91\# & 198 & 201A\# & 205 & 207 & 211 & 217 & 222 & 230 & 255 & 256 & 259 & 264 & 267 \\
\hline k-feldspatos & 91.5 & 41.1 & 71 & 84.6 & 64.6 & 69.5 & 58 & 71 & 64.6 & 80.9 & 72.4 & 90.4 & 80.7 & 70.2 & 74.3 & 59.2 & 68.7 & 89.2 & 79 & 83 \\
\hline nefelina & - & 11.5 & 4.7 & - & 0.7 & 6.1 & 20.5 & 7.6 & 14 & 10 & 7.7 & - & - & 17.6 & 6.3 & 29 & 15.9 & - & - & 6.2 \\
\hline sodalita & - & 3.5 & 3.5 & - & 0.6 & 1.4 & 6.2 & 6.5 & 7 & 5 & 2.7 & - & - & 4 & - & 2.1 & 3.7 & - & - & 1.9 \\
\hline egirina-augita & - & 2 & 7 & - & 23 & - & 0.5 & 7.8 & 4.1 & - & 0.5 & - & 1.7 & 7.1 & 2.7 & 2.3 & 1.6 & - & 1.4 & - \\
\hline Na-anfibólios & 5.3 & 28.7 & - & 7.4 & 0.6 & 9.8 & 9 & 0.5 & 3.5 & 2.1 & 15 & 7.8 & 9.3 & - & 2.8 & 4.9 & 7.8 & 5.9 & 10 & 3.6 \\
\hline biotita & 0.2 & 9.3 & 11 & 0.5 & 9 & 0.4 & 2 & 2.8 & 2.3 & 1 & 0.3 & $\operatorname{tr}$ & 7.9 & - & 12.5 & 1.4 & 0.2 & 1 & 7.2 & 3.8 \\
\hline titanita & 0.2 & 0.2 & 1 & 0.1 & 0.8 & $\operatorname{tr}$ & - & 2 & 1.2 & - & 0.4 & $\operatorname{tr}$ & $\operatorname{tr}$ & - & 0.6 & $\operatorname{tr}$ & 0.9 & 0.8 & 0.4 & 0.3 \\
\hline apatita & - & - & - & $\operatorname{tr}$ & - & 5.7 & 0.7 & tr & 1 & - & - & 0.2 & $\operatorname{tr}$ & - & 0.5 & $\operatorname{tr}$ & - & 0.2 & 0.1 & 0.2 \\
\hline quartzo & 1.7 & - & - & 5.1 & - & - & - & - & - & - & - & 0.8 & - & 1 & - & - & - & 2.1 & - & - \\
\hline carbonatos $^{\star}$ & - & - & - & - & - & - & - & - & - & - & - & - & tr & tr & - & - & $\operatorname{tr}$ & - & - & - \\
\hline cancrinita* & - & tr & 0.5 & - & - & 1 & - & $\operatorname{tr}$ & 0.3 & - & - & - & - & - & - & - & - & - & - & - \\
\hline opacos & 1 & 3.6 & 1 & 2.2 & 0.6 & 6.1 & 3.1 & 0.5 & 2 & 1 & 0.9 & 0.8 & 0.3 & - & 0.2 & 1 & 1.1 & 0.7 & 1.8 & 1 \\
\hline eudialita & - & - & - & - & - & - & - & 1.2 & - & - & - & - & - & tr & - & - & - & - & - & - \\
\hline zeólita & - & - & - & - & - & - & - & - & - & - & - & - & - & $\operatorname{tr}$ & - & - & - & - & - & - \\
\hline zircão & $\mathrm{tr}$ & - & - & $\operatorname{tr}$ & $\operatorname{tr}$ & - & - & $\operatorname{tr}$ & - & - & $\operatorname{tr}$ & - & $\operatorname{tr}$ & - & tr & - & $\operatorname{tr}$ & $\operatorname{tr}$ & $\operatorname{tr}$ & - \\
\hline fluorita & - & - & tr & - & - & - & - & - & - & - & - & - & - & - & - & - & - & - & - & - \\
\hline total & 99.9 & 99.9 & 99.9 & 99.9 & 99.9 & 100 & 100 & 99.9 & 100 & 100 & 99.9 & 100 & 99.9 & 99.9 & 99.9 & 99.9 & 99.9 & 99.9 & 99.9 & 100 \\
\hline
\end{tabular}

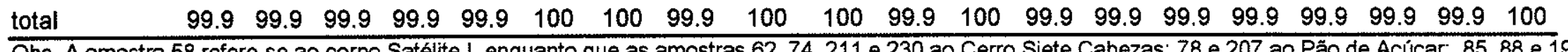
correspondem à Cerrito; 91, 201 e e 222 à lha Fecho dos Morros; 205 ao Cerro Pedreira; 217 e 267 ao Porto Conceiçăo; 255 e 256 ao Morro São Pedro e 264 ao Morro Distante.

- Minerais de Alteração

\# Rochas com estrutura pegmatóide 
Q

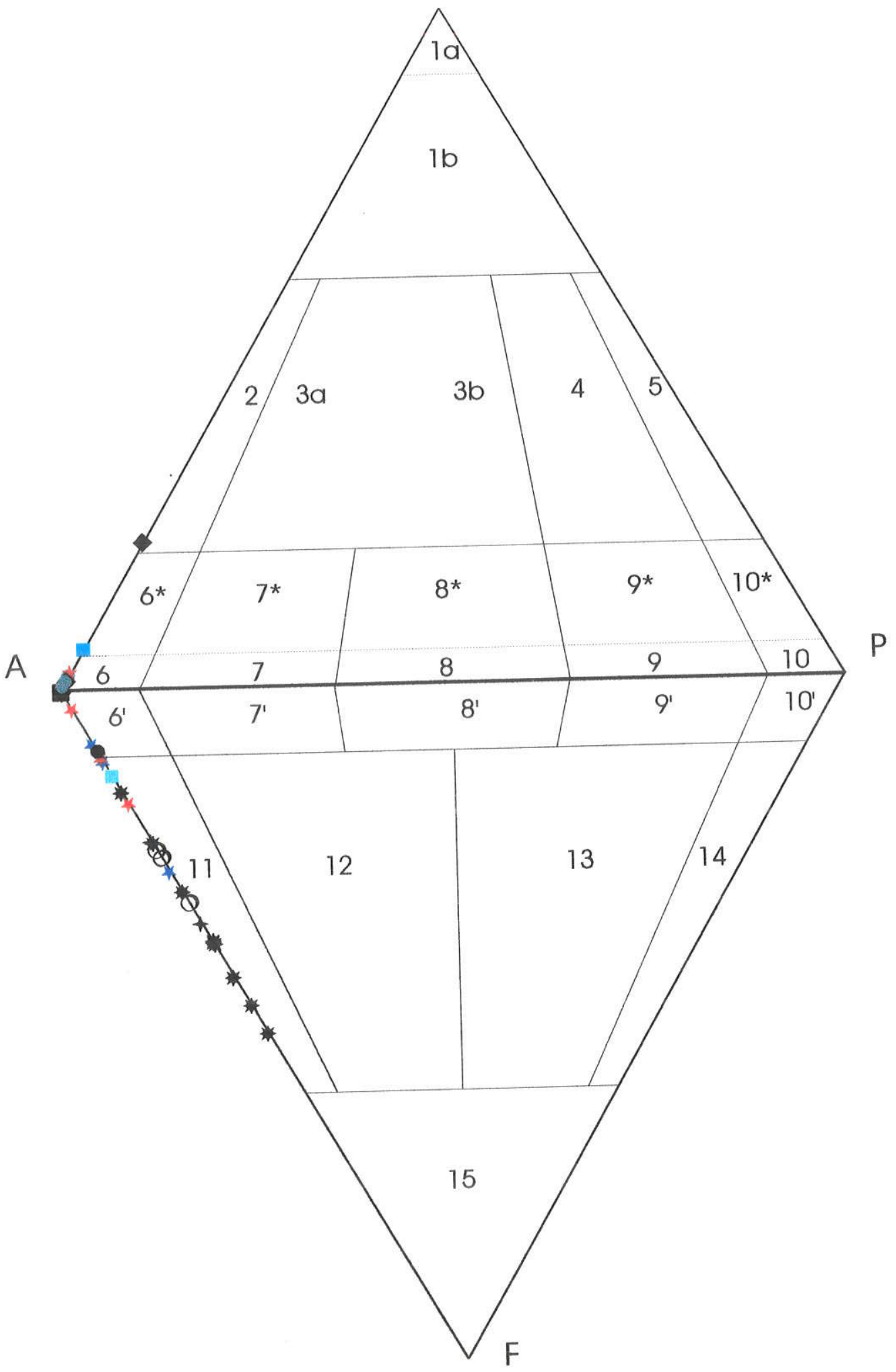

Figura 10 - Distribuição das rochas da Província Alcalina do Alto Paraguai. No triângulo superior, os símbolos estrela azul corresponde ao CSC, estrela vermelha ao $\mathrm{MC}$, quadrado cheio azul ao PA, círculo verde preenchido ao $\mathrm{SI}$ e losango preto ao SII. No inferior, a estrela vermelha representa o $\mathrm{C}$, a estrela negra $\mathrm{CB}$, a estrela azul o CSC, o círculo verde O CP, o círculo incolor o FDM, o círculo negro o PC, o quadrado incolor O MD, o quadrado azul o PA - losango negro o SII e a cruz negra o SP. 


\section{CAPÍTULO V - QUÍMICA MINERAL}

Trinta e uma amostras de rochas foram preparadas para estudos microquímicos abrangendo os litotipos diversos, pertencentes aos principais corpos das ocorrências alcalinas da Província Alcalina Alto Paraguai, tendo sido executadas cerca de 1166 análises quantitativas, com auxilio da microssonda eletrônica, por dispersão de comprimento de onda (WDS), distribuídas assim como se seguem: 357 análises de feldspatos, 262 de piroxênios, 231 de anfibólios, 173 de feldspatóides, 92 de biotitas, 21 de ilmenitas e 75 de magnetitas. Adicionalmente, foram efetuadas também cerca de 15 análises qualitativas a semiquantitativa, por meio de dispersão de energia (EDS) de minerais considerados especiais tais como eudialita, lavenita e outros.

Os resultados das análises (em óxidos) de minerais silicáticos e de opacos são àqueles apontados no item 1.4.3, locados em posições de núcleos, de bordas e de lamelas de intercrescimento dos cristais, com a finalidade específica de se investigar as suas tendências composicionais e possiveis zoneamentos químicos.

\section{V.1-Feldspatos}

Os feldspatos constituem-se nos minerais félsicos mais importantes sob o aspecto quantitativo das rochas sieníticas da Província Alcalina Alto Paraguai, estando presentes como a fase mais abundante em todas as amostras estudadas. Em sua grande maioria, tratam-se de feldspatos alcalinos, sendo que os plagioclásios ocorrem em apenas duas amostras de sienito alcalino provenientes de localidades distintas (Figura 07), sendo uma de Morro Conceição (Am. 259) e outra de Morro Distante (Am. 264).

Microscopicamente, os feldspatos alcalinos estão representados por indivíduos com formas subédricas e anédricas de variando desde fina a muito fina 
na matriz de fonolitos e traquitos, passando por grossa nos fenocristais desses mesmos litotipos, até muito grossas em rochas com textura pegmatítica, caso específico do corpo que aflora na llha Fecho dos Morros e subordinadamente dos pegmatitos do corpo de Cerrito.

As tabelas 12.0 a 12.23 apresentam os dados químicos pontuais dos feldspatos dos diversos corpos amostrados da Província Alcalina Alto Paraguai, consubstanciando os estudos petrográficos prévios de que a totalidade da população analítica abrangida, possui uma grande variabilidade composicional, indo da albita pura $\left(\mathrm{Ab}_{99}\right)$ até o ortoclásio $\left(\mathrm{Or}_{96}\right)$. A predominância, porém, é de minerais do grupo dos feldspatos alcalinos potássicos, especialmente em litotipos como os nefelina sienitos e fonolitos peralcalinos de Cerro Boggiani (tabelas 12.0 a 12.5 , figuras 11 e 12), nos sienitos alcalinos dos corpos Satélite II e Satélite I (tabelas 12.6 a 12.12 , figuras 13 e 14, respectivamente), nos sienitos nefelínicos de Cerro Siete Cabezas (tabelas 12.13 a 12.15 , figura 15), nos quartzo sienitos e traquifonolitos do Morro Pão de Açúcar (tabelas 12.16 e 12.17, figuras 16 e 17), nos sienitos nefelínicos da llha Fecho dos Morros (tabela 12.18, figura 23b) e de Cerrito (tabela 12.23, figura 18), nos quartzo sienitos de Cerro Pedreira (tabela 12.19, figura 19) e nos fonolitos de Morro de São Pedro (tabela 12.20, figura 20).

Nos sienitos alcalinos analisados provenientes das localidades de Morro Conceição e Morro Distante (tabelas 12.21 e 12.22), a predominância é de plagioclásios, como pode ser observado nos diagramas classificatórios (Figura 21 e 22), definindo composições variando do oligoclásio até a andesina. Nessas rochas também foram encontrados feldspatos alcalinos que correspondem ã albita pura, anortoclásio e sanidina em Morro Conceição e apenas albita pura e anortoclásio em Morro Distante.

Nos fonolitos peralcalinos porfiriticos de Porto Conceição (tabela 12,22) os feldspatos estão representados por microfenocristais de albita e grãos menores de anortoclásio, constituindo a matriz (figura 23a).

Nos sienitos alcalinos da e Satélite I e Satélite II freqüentemente são observados uma forte predominância de feldspatos contendo intercrescimento pertítico, micropertítico a mesopertítico, com raros cristais de feldspato potássico 
de aspecto límpido, sem estruturas resultantes da interferencia de processos de exsolução, coincidindo com o que se observa em práticamente todas as rochas da Província Alcalina Alto Paraguai. Tais intercrescimentos, por sua vez, exibem formas de vênulas irregulares, raramente anastomosadas, representativas da desmisturação de fases sódio-potássicas nos processos de cristalização magmática e tardi a pós-magmática, em condições de temperatura subsolidus. Nas rochas onde há predominância de intercrescimentos pertíticos, os feldspatos raramente apresentam geminação segundo a lei de Carlsbad ou Baveno.

A classificação dos feldspatos revela em sua maior parte, a concordância com os estudos petrográficos prévios, ainda que tenha sido detectada pela primeira vez na Província Alto Paraguai, a presença de plagioclásios (oligoclásio e andesina) em rochas dos corpos de Morro Conceição e Morro Distante. 
Tabela 12.0 - Composição quimica de feldspatos de Cerro Boggiani (\% peso)

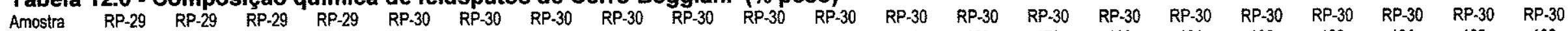
$\begin{array}{lllllllllllllllllllllll}\text { Anslise } & 35 & 38 & 39 & 52 & 162 & 163 & 164 & 165 & 170 & 171 & 172 & 175 & 176 & 179 & 180 & 181 & 182 & 183 & 184 & 185 & 186\end{array}$

Locaçăo C1G1n C1G3n C1G3b C5G5n C1G2n C1G2b C1G3n C1G3b C2G3n C3G1n $\quad$ C3G1b C4G2n $\quad$ C4G2b C4G4n C4G4b C5G1n C5G1b C5G2n C5G2b C5G3n C5G3b

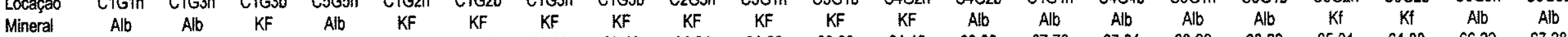

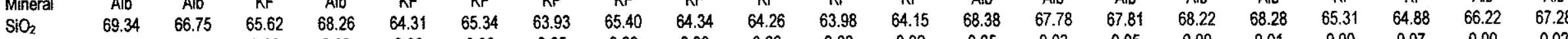

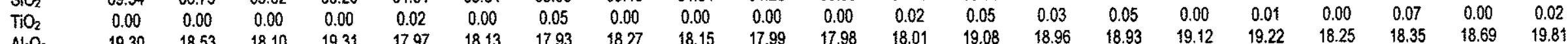

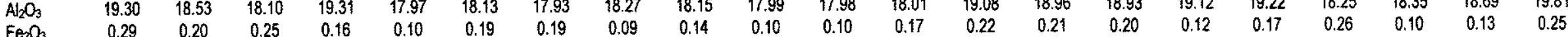

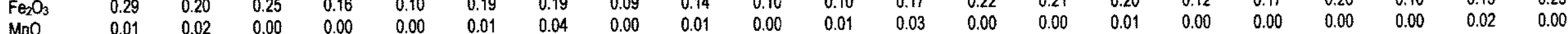

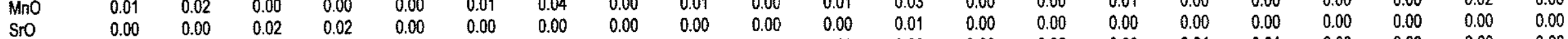

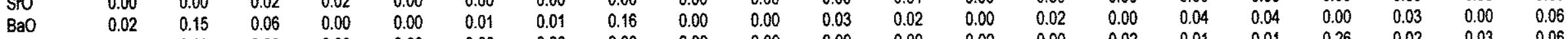

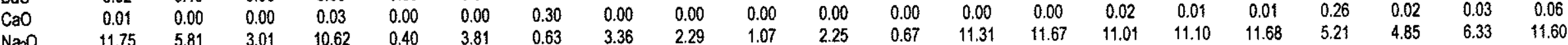

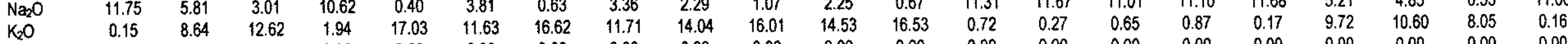

$\begin{array}{lllllllllllllllllllllll}\mathrm{MgO} & 0.00 & 0.00 & 0.00 & 0.00 & 0.00 & 0.00 & 0.00 & 0.00 & 0.00 & 0.00 & 0.00 & 0.00 & 0.00 & 0.00 & 0.00 & 0.00 & 0.00 & 0.00 & 0.00 & 0.00 & 0.00\end{array}$

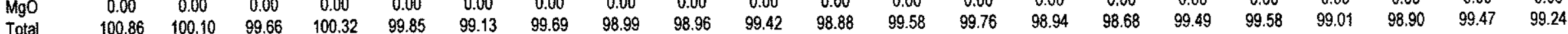

Fómula estrutural calculada na base de 32 átomos de oxigénio

\begin{tabular}{|c|c|c|c|c|c|c|c|c|c|c|c|c|c|c|c|c|c|c|c|c|c|}
\hline $\mathrm{Si}$ & $\begin{array}{l}6.025 \\
1.974\end{array}$ & $\begin{array}{l}6.029 \\
1.971\end{array}$ & $\begin{array}{l}6.039 \\
1.961\end{array}$ & $\begin{array}{l}6.001 \\
1.999\end{array}$ & $\begin{array}{l}6.019 \\
1.981\end{array}$ & $\begin{array}{l}6.030 \\
1.970\end{array}$ & $\begin{array}{l}6.014 \\
\{.986\end{array}$ & $\begin{array}{l}6.019 \\
1.981\end{array}$ & $\begin{array}{l}6.005 \\
1.995\end{array}$ & $\begin{array}{l}6.016 \\
1.984\end{array}$ & $\begin{array}{l}6.011 \\
1.990\end{array}$ & $\begin{array}{l}0.012 \\
1.988\end{array}$ & $\begin{array}{l}0.021 \\
1.979\end{array}$ & $\begin{array}{l}0.010 \\
1.983\end{array}$ & $\begin{array}{l}0.021 \\
1.979\end{array}$ & $\begin{array}{l}0.015 \\
1.985\end{array}$ & $\begin{array}{l}0.009 \\
1.991\end{array}$ & $\begin{array}{l}0.019 \\
1.981\end{array}$ & $\begin{array}{l}0.001 \\
1.999\end{array}$ & 1.996 & 2.060 \\
\hline $\mathrm{Fe}^{3+}$ & 0.019 & 0.014 & 0.017 & 0.011 & 0.007 & 0.013 & 0.013 & 0.006 & 0.010 & 0.007 & 0.007 & 0.012 & 0.014 & 0.014 & 0.013 & 0.008 & $0.0 \leqslant 2$ & 0.018 & 0.007 & 0.009 & 0.017 \\
\hline $\mathrm{Ti}$ & 0.000 & 0.000 & 0.000 & 0.000 & 0.002 & 0.000 & 0.004 & 0.000 & 0.000 & 0.000 & 0.000 & 0.002 & 0.003 & 0.002 & 0.003 & 0.000 & 0.001 & 0.000 & 0.005 & 0.000 & .001 \\
\hline $\mathrm{Mn}$ & 0.001 & 0.001 & 0.000 & 0.000 & 0.000 & 0.001 & 0.003 & 0.000 & 0.001 & 0.000 & 0.001 & 0.002 & 0.000 & 0.000 & 0.001 & 0.000 & 0.000 & 0.000 & 0.000 & 0.001 & 00 \\
\hline $\mathrm{Mg}$ & 0.000 & 0.001 & 0.000 & 0.000 & 0.000 & 0.000 & 0.000 & 0.000 & 0.000 & 0.000 & 0.000 & 0.000 & 0.000 & 0.000 & 0.000 & 0.000 & 0.000 & 0.000 & 0.000 & 0.000 & \\
\hline $\mathrm{Ba}$ & 0.001 & 0.005 & 0.002 & 0.000 & 0.000 & 0.000 & 0.000 & 0.006 & 0.000 & 0.000 & 0.001 & 0.001 & 0.000 & 0.001 & 0.000 & 0.001 & 0.004 & 0.000 & 0.001 & 0.000 & \\
\hline $\mathrm{Ca}$ & 0.001 & 0.000 & 0.000 & 0.003 & 0.000 & 0.000 & 0.030 & 0.000 & 0.000 & 0.000 & 0.000 & 0.000 & 0.000 & 0.000 & 0.001 & 0.001 & 0.001 & 0.026 & 0,002 & 0.003 & \\
\hline $\mathrm{Na}$ & 1.980 & 1.017 & 0.537 & 1.810 & 0.073 & 0.682 & 0.115 & 0.600 & 0.414 & 0.194 & 0.410 & 0.121 & 1.931 & 2.008 & 1.895 & 1.898 & $\{.992$ & 0.930 & 0.869 & 1.113 & \\
\hline K & 0.016 & 0.996 & 1.482 & 0.218 & 2.033 & 1.370 & 1.995 & 1.374 & 1.671 & 1.912 & 1.741 & 1.976 & 0.081 & 0.030 & 0.074 & 0.098 & 0.019 & 1.143 & $\$ .250$ & 0.932 & \\
\hline Cátions & 10.018 & 10.039 & 10.040 & 10.042 & 10.415 & 10.066 & 10.160 & 9.992 & 10.096 & $\{0.113$ & 10.162 & 10.115 & 10.029 & 10.057 & 9.987 & 10.007 & $\{0.027$ & 10.117 & 10.135 & 10.058 & \\
\hline$x$ & 8.018 & 8.014 & 8.017 & 8.011 & 8.009 & 8.013 & 8.017 & 8.006 & 8.010 & 8.007 & 8.008 & 8.014 & 8.017 & 8.017 & 8.016 & 8.008 & 8.043 & 8.018 & 8.012 & 8.009 & \\
\hline$z$ & 1.999 & 2.020 & 2.021 & 2.031 & 2.106 & 2.053 & 2.143 & 1.980 & 2.086 & 2.106 & 2.153 & 2.100 & 2.012 & 2.039 & 1.971 & 1.998 & 2.013 & 2.099 & 2.122 & 2.049 & \\
\hline \multicolumn{21}{|c|}{ Componentes Moleculares } & \\
\hline & 99.1 & 50.5 & 26.6 & 89.1 & 3.5 & 33.2 & 5.4 & 30.4 & 19.9 & 9.2 & 19.1 & 5.8 & 96 & 98.5 & 96.2 & 95 & 99 & 44.3 & 41 & 54.3 & \\
\hline & 0.1 & 0.0 & 0.0 & 0.1 & 0.0 & 0.0 & 1.4 & 0.0 & 0.0 & 0.0 & 0.0 & 0.0 & 0.0 & 0.0 & 0.1 & 0.1 & 0.0 & 1.2 & 0.1 & 0.1 & \\
\hline
\end{tabular}

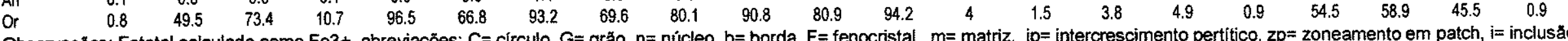

Observaçőes: Fetotal calculado como

Alb $=$ albita e KF= feldspato potássico. 
Tabela 12.1 - Composição química de feldspatos de Cerro Boggiani (\% peso)

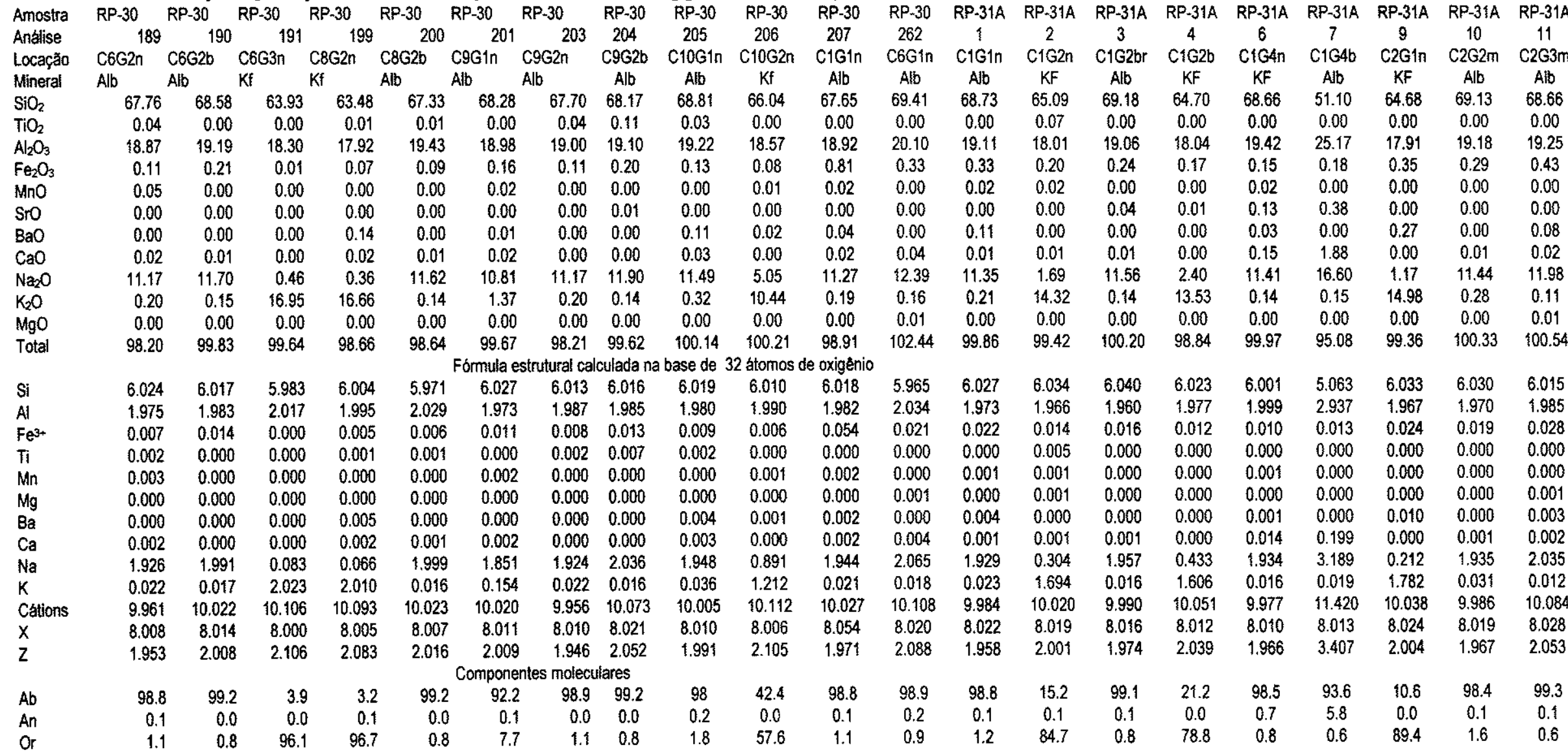


Tabela 12.2 - Composição química de feldspatos de Cerro Boggiani(\% peso)

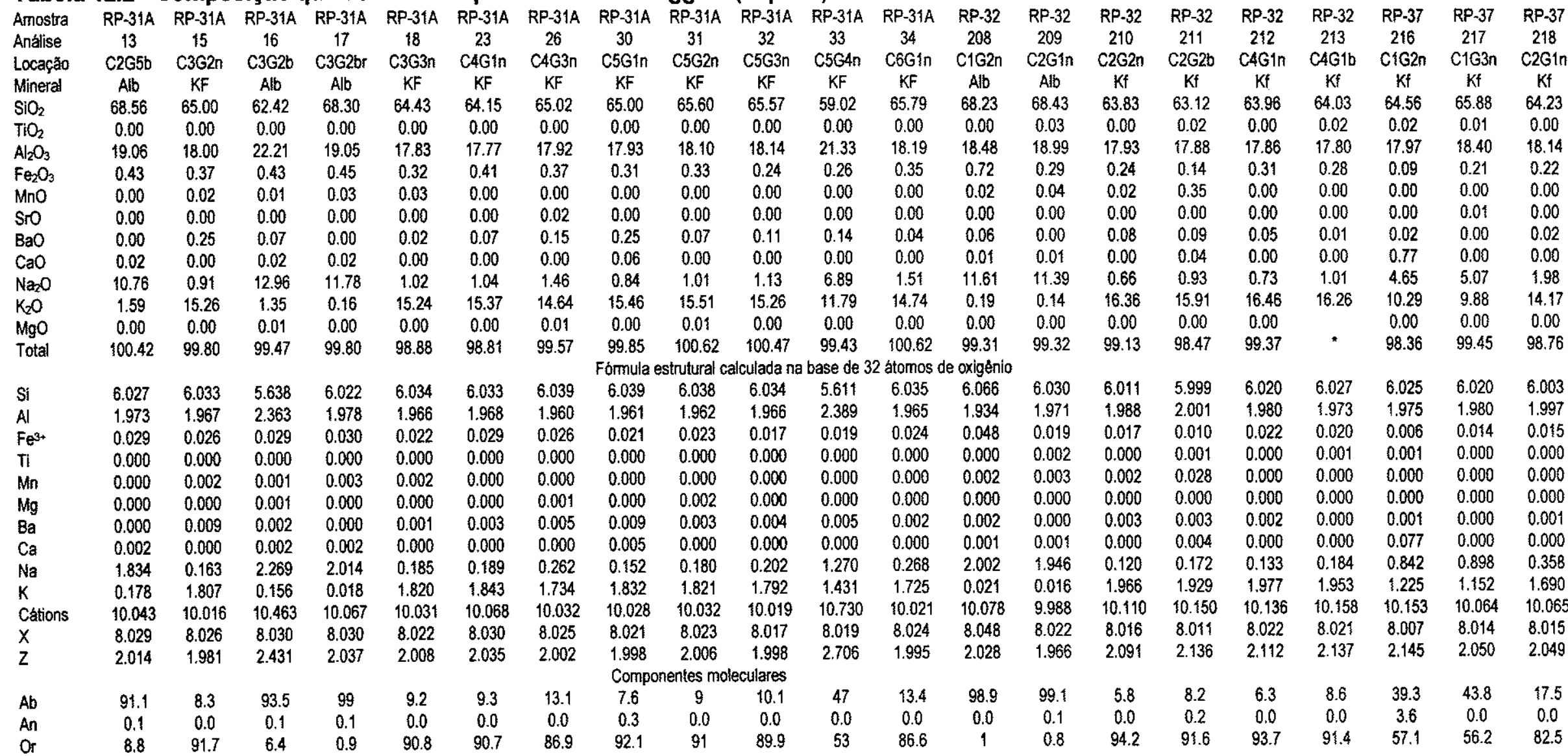


Tabela 12.3 - Composição química de feldspatos de Cerro Boggiani (\% peso)

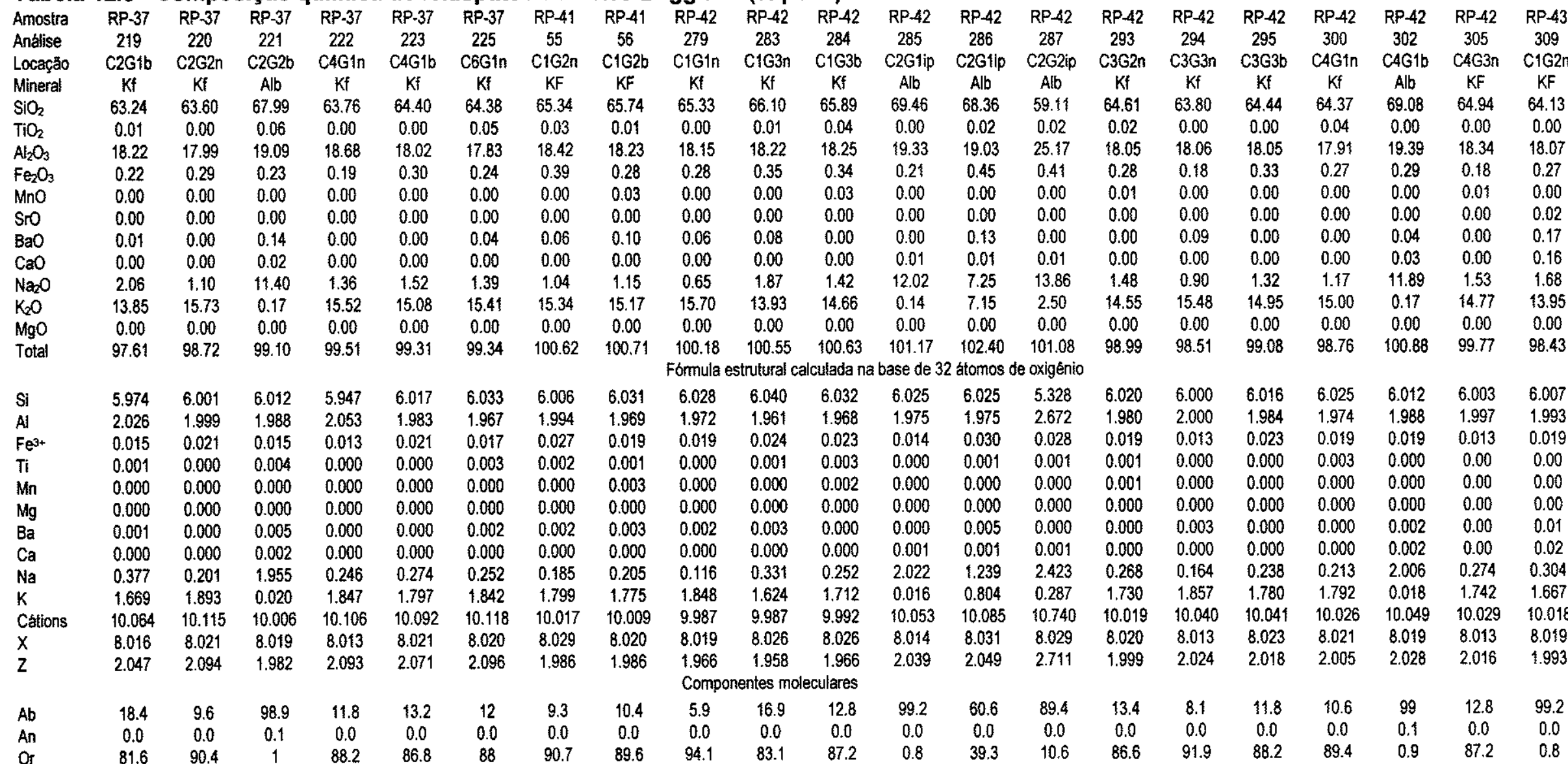

$\begin{array}{lcccccc}\text { Of } & 81.6 & 90.4 & 1 & 88.2 & 86.8 & 88 \\ \text { Observaçôes: Ferata calculado como } & \mathrm{Fe}^{3+} \text {, abreviaçóes como na tabela } & 12.0\end{array}$ 
Tabela 12.4 - Composição química de feldspatos de Cerro Boggiani (\% peso)

\begin{tabular}{|c|c|c|c|c|c|c|c|c|c|c|c|c|}
\hline Amostra & RP.43 & $R P-43$ & $\mathrm{RP}-43$ & RP.43 & RP-43 & $R P-43$ & RP-43 & $R P-43$ & $\mathrm{RP}-43$ & $R P-43$ & $R P-43$ & RP.43 \\
\hline Analise & 311 & 313 & 314 & 315 & 316 & 317 & 319 & 322 & 323 & 324 & 325 & 326 \\
\hline Locação & CiG4n & C2G1ip & C2G2ip & C2G2ip & C3G1ip & C3G1ip & $C 3 G 3 n$ & C4Gín & $\mathrm{C} 4 \mathrm{G} 1 \mathrm{br}$ & $C 4 G 2 n$ & C4G2br & C6Gín \\
\hline Mineral & $\mathrm{KF}$ & $A l b$ & Alb & $\mathrm{Kf}$ & Alb & Alb & Alb & $\mathrm{Kf}$ & Alb & $\mathrm{Kf}$ & Alb & $\mathrm{Kf}$ \\
\hline $\mathrm{SiO}_{2}$ & 65.08 & 68.29 & 67.00 & 66.26 & 68.42 & 68.72 & 68.66 & 63.62 & 67.94 & 64.45 & 68.52 & 64.82 \\
\hline $\mathrm{THO}_{2}$ & 0.06 & 0.04 & 0.03 & 0.00 & 0.09 & 0.04 & 0.00 & 0.00 & 0.02 & 0.05 & 0.00 & 0.07 \\
\hline $\mathrm{Al}_{2} \mathrm{O}_{3}$ & 18.14 & 19.10 & 19.59 & 18.71 & 19.20 & 19.37 & 19.12 & 18.01 & 19.15 & 18.21 & 19.27 & 18.36 \\
\hline $\mathrm{Fe}_{2} \mathrm{O}_{3}$ & 0.24 & 0.43 & 0.23 & 0.16 & 0.22 & 0.23 & 0.43 & 0.35 & 0.29 & 0.23 & 0.28 & 0.38 \\
\hline Mno & 0.01 & 0.02 & 0.04 & 0.01 & 0.04 & 0.01 & 0.00 & 0.04 & 0.00 & 0.04 & 0.01 & 0.00 \\
\hline Sro & 0.00 & 0.00 & 0.00 & 0.00 & 0.00 & 0.00 & 0.00 & 0.04 & 0.00 & 0.00 & 0.01 & 0.00 \\
\hline $\mathrm{BaO}$ & 0.10 & 0.00 & 0.01 & 0.01 & 0.05 & 0.00 & 0.05 & 0.19 & 0.03 & 0.15 & 0.06 & 0.07 \\
\hline $\mathrm{CaO}$ & 0.00 & 0.01 & 0.01 & 0.00 & 0.07 & 0.00 & 0.02 & 0.00 & 0.02 & 0.01 & 0.04 & 0.00 \\
\hline $\mathrm{Na}_{2} \mathrm{O}$ & 3.20 & 11.13 & $\$ 1.25$ & 6.29 & 11.92 & 11.83 & 11.76 & 2.09 & 11.48 & 3.19 & 11,39 & 4.06 \\
\hline $\mathrm{K}_{2} \mathrm{O}$ & 12.23 & 1.41 & 2.14 & 8.30 & 0.10 & 0.18 & 0.12 & 14.02 & 0.17 & 12.42 & 0.14 & 11.18 \\
\hline $\mathrm{MgO}$ & 0.00 & 0.00 & 0.00 & 0.00 & 0.00 & 0.00 & 0.00 & 0.00 & 0.00 & 0.00 & 0.00 & 0.00 \\
\hline \multirow[t]{2}{*}{ Total } & 99.05 & 100.42 & 100.28 & 99.73 & 100.11 & 100.38 & 100.16 & 98.31 & 99.09 & 98.75 & 99.71 & 98.93 \\
\hline & & & & & & & & & \multicolumn{4}{|c|}{ Fórmula estrutural calculada na base de 32 átomos de oxigênio } \\
\hline $\mathrm{Si}$ & 6.023 & 6.018 & 5.951 & 6.004 & 6.013 & 6.006 & 6.025 & 6.000 & 6.007 & 6.003 & 6.010 & 5.999 \\
\hline Al & 1.977 & 1.982 & 2.049 & 1.996 & 1.987 & 1.994 & 1.976 & 2.000 & 1.993 & 1.997 & 1.990 & 2.001 \\
\hline $\mathrm{Fe}^{3+}$ & 0.016 & 0.028 & 0.015 & 0.011 & 0.015 & 0.015 & 0.028 & 0.025 & 0.019 & 0.016 & 0.018 & 0.026 \\
\hline$T i$ & 0.004 & 0.003 & 0.002 & 0.000 & 0.006 & 0.002 & 0.000 & 0.000 & 0.001 & 0.004 & 0.000 & 0.005 \\
\hline$M n$ & 0.001 & 0.001 & 0.003 & 0.001 & 0.003 & 0.001 & 0.000 & 0.004 & 0.000 & 0.003 & 0.001 & 0.000 \\
\hline $\mathrm{Mg}$ & 0.000 & 0.000 & 0.000 & 0.000 & 0.000 & 0.000 & 0.000 & 0.000 & 0.000 & 0.000 & 0.000 & 0.000 \\
\hline $\mathrm{Ba}$ & 0.004 & 0.000 & 0.000 & 0.000 & 0.002 & 0.000 & 0.002 & 0.007 & 0.001 & 0.006 & 0.002 & 0.003 \\
\hline $\mathrm{Ca}$ & 0.000 & 0.001 & 0.001 & 0.000 & 0.006 & 0.000 & 0.002 & 0.000 & 0.002 & 0.001 & 0.004 & 0.000 \\
\hline $\mathrm{Na}$ & 0.575 & 1.901 & 1.937 & 1.104 & 2.031 & 2.004 & 2.001 & 0.382 & 1.968 & 0.576 & 1.936 & 0.728 \\
\hline K & 1.443 & 0.159 & 0.242 & 0.959 & 0.012 & 0.020 & 0.014 & 1.687 & 0.019 & 1.475 & 0.015 & 1.320 \\
\hline Cátions & 10.047 & 10.093 & 10.200 & 10.075 & 10.077 & 10.042 & 10.050 & 10.112 & 10.011 & 10.087 & 9.978 & 10.085 \\
\hline$x$ & 8.020 & 8.031 & 8.017 & 8.011 & 8.021 & 8.017 & 8.029 & 8.025 & 8.020 & 8.020 & 8.018 & 8.031 \\
\hline \multirow[t]{2}{*}{$z$} & 2.023 & 2.062 & 2.183 & 2.064 & 2.054 & 2.025 & 2.019 & 2.080 & 1.990 & 2.061 & 1.958 & 2.051 \\
\hline & & & & & & \multicolumn{7}{|c|}{ Componentes moleculares } \\
\hline $\mathrm{Ab}$ & 60.6 & 89.4 & 13.4 & 8.1 & 11.8 & 10.6 & 99.0 & 13.6 & 15.3 & 28.5 & 92.2 & 88.9 \\
\hline An & 0.0 & 0.0 & 0.0 & 0.0 & 0.0 & 0.0 & 0.1 & 0.0 & 0.8 & 0.0 & 0.0 & 0.0 \\
\hline Or & 39.3 & 10.6 & 86.6 & 91.9 & 88.2 & 89.4 & 0.9 & 86.4 & 83.9 & 71.5 & 7.7 & 11.1 \\
\hline
\end{tabular}


Tabela 12.5 - Composição química dos feldspatos de Cerro Boggiani (\% peso)

\begin{tabular}{|c|c|c|c|c|c|c|c|c|c|c|c|c|}
\hline Amostra & RP-43 & $\mathrm{RP}-43^{\circ}$ & RP-43 & RP-43 & RP-43 & RP-43 & RPA3 & RP-43 & RP-43 & RP43 & RP-43 & RP-43 \\
\hline Análise & 311 & 313 & 314 & 315 & 316 & 317 & 319 & 322 & 323 & 324 & 325 & 326 \\
\hline Locaçá & CIGAn & C2G1ip & C2G2ip & C2G2ip & C3G1ip & C3G1ip & C3G3n & C4GIn & CAGtbr & C4G2n & C4G $b r$ & C6G1n \\
\hline Mineral & $\mathrm{KF}$ & Alb & Alb & Kf & Alb & Alb & $A B b$ & $\mathrm{Kf}$ & Alb & $\mathrm{Kf}$ & Alb & Kf \\
\hline $\mathrm{SiO}_{2}$ & 65.08 & 68.29 & 67.00 & 66.26 & 68.42 & 68.72 & 68.66 & 63.62 & 67.94 & 64.45 & 68.52 & 64.82 \\
\hline $\mathrm{TiO}_{2}$ & 0.06 & 0.04 & 0.03 & 0.00 & 0.09 & 0.04 & 0.00 & 0.00 & 0.02 & 0.05 & 0.00 & 0.07 \\
\hline $\mathrm{Al}_{2} \mathrm{O}_{3}$ & 18.14 & 19.10 & 19.59 & 18.71 & 19.20 & 19.37 & 19.12 & 18.01 & 19.15 & 18.21 & 19.27 & 18.36 \\
\hline $\mathrm{Fe}_{2} \mathrm{O}_{3}$ & 0.24 & 0.43 & 0.23 & 0.16 & 0.22 & 0.23 & 0.43 & 0.35 & 0.29 & 0.23 & 0.28 & 0.38 \\
\hline $\mathrm{FeO}$ & 0.00 & 0.00 & 0.00 & 0.00 & 0.00 & 0.00 & 0.00 & 0.00 & 0.00 & 0.00 & 0.00 & 0.00 \\
\hline $\mathrm{MnO}$ & 0.01 & 0.02 & 0.04 & 0.01 & 0.04 & 0.01 & 0.00 & 0.04 & 0.00 & 0.04 & 0.01 & 0.00 \\
\hline $\mathrm{SrO}$ & 0.00 & 0.00 & 0.00 & 0.00 & 0.00 & 0.00 & 0.00 & 0.04 & 0.00 & 0.00 & 0.01 & 0.00 \\
\hline $\mathrm{BaO}$ & 0.10 & 0.00 & 0.01 & 0.01 & 0.05 & 0.00 & 0.05 & 0.19 & 0.03 & 0.15 & 0.06 & 0.07 \\
\hline $\mathrm{CaO}$ & 0.00 & 0.01 & 0.01 & 0.00 & 0.07 & 0.00 & 0.02 & 0.00 & 0.02 & 0.01 & 0.04 & 0.00 \\
\hline $\mathrm{Na}_{2} \mathrm{O}$ & 3.20 & 11.13 & 11.25 & 6.29 & 11.92 & 11.83 & 11.76 & 2.09 & 11.48 & 3.19 & 11.39 & 4.06 \\
\hline $\mathrm{K}_{2} \mathrm{O}$ & 12.23 & 1.41 & 2.14 & 8.30 & 0.10 & 0.18 & 0.12 & $\{4.02$ & 0.17 & 12.42 & 0.14 & 11.18 \\
\hline $\mathrm{MgO}$ & 0.00 & 0.00 & 0.00 & 0.00 & 0.00 & 0.00 & 0.00 & 0.00 & 0.00 & 0.00 & 0.00 & 0.00 \\
\hline Total & 99.05 & 100.42 & 100.28 & 99.73 & 100.11 & 100.38 & 100,16 & 98.31 & 99.09 & 98.75 & 99.71 & 98.93 \\
\hline \multicolumn{13}{|c|}{ Fómula estrutural calculada na base de 32 átomos de oxigénio } \\
\hline $\mathrm{Si}$ & 6.023 & 6.018 & 5.951 & 6.004 & 6.013 & 6.006 & 6.025 & 6 & 6.007 & 6.003 & 6.01 & 5.999 \\
\hline Al & 1.977 & 1.982 & 2.049 & 1.996 & 1.987 & 1.994 & 1.976 & 2 & 1.993 & 1.997 & 1.99 & 2.001 \\
\hline $\mathrm{Fe}^{3+}$ & 0.016 & 0.028 & 0.015 & 0.011 & 0.015 & 0.015 & 0.028 & 0.025 & 0.019 & 0.016 & 0.018 & 0.026 \\
\hline $\mathrm{Ti}$ & 0.004 & 0.003 & 0.002 & 0 & 0.006 & 0.002 & 0 & 0 & 0.001 & 0.004 & 0 & 0.005 \\
\hline $\mathrm{Fe}^{2+}$ & 0 & 0 & 0 & 0 & 0 & 0 & 0 & 0 & 0 & 0 & 0 & 0 \\
\hline $\mathrm{Mn}$ & 0.001 & 0.001 & 0.003 & 0.001 & 0.003 & 0.001 & 0 & 0.004 & 0 & 0.003 & 0.001 & 0 \\
\hline $\mathrm{Mg}$ & 0 & 0 & 0 & 0 & 0 & 0 & 0 & 0 & 0 & 0 & 0 & 0 \\
\hline $\mathrm{Ba}$ & 0.004 & 0 & 0 & 0 & 0.002 & 0 & 0.002 & 0.007 & 0.001 & 0.006 & 0.002 & 0.003 \\
\hline $\mathrm{Ca}$ & 0 & 0.001 & 0.001 & 0 & 0.006 & 0 & 0.002 & 0 & 0.002 & 0.001 & 0.004 & 0 \\
\hline $\mathrm{Na}$ & 0.575 & 1.901 & 1.937 & 1.104 & 2.031 & 2.004 & 2.001 & 0.382 & 1.968 & 0.576 & 1.936 & 0.728 \\
\hline K & 1.443 & 0.159 & 0.242 & 0.959 & 0.012 & 0.02 & 0.014 & $\{.687$ & 0.019 & 1.475 & 0.015 & 1.32 \\
\hline Cations & 10.047 & 10.093 & 40.2 & 10.075 & $\{0.077$ & 10.042 & 10.05 & 10.112 & 10.011 & 10.087 & 9.978 & 10.085 \\
\hline$x$ & 8.02 & 8.031 & 8.017 & 8.011 & $8.02\}$ & 8.017 & 8.029 & 8.025 & 8.02 & 8.02 & 8.018 & 8.031 \\
\hline Z & 2.023 & 2.062 & 2.183 & 2.064 & 2.054 & 2.025 & 2.019 & 2.08 & 1.99 & 2.061 & 1.958 & 2.051 \\
\hline \multicolumn{13}{|c|}{ Componentes Moleculares } \\
\hline$A b$ & 28.5 & 92.2 & 88.9 & 53.5 & 99.1 & 99 & 99.2 & 18.5 & 98.9 & 28.4 & 99 & 35.5 \\
\hline An & 0 & 0 & 0 & 0 & 0.3 & 0 & 0.1 & 0 & 0.1 & 0 & 0.2 & 0 \\
\hline or & 71.5 & 7.7 & 11.1 & 46.5 & 0.6 & 1 & 0.7 & 81.5 & $t$ & 71.9 & 0.8 & 64.5 \\
\hline
\end{tabular}

Observaç̋es: Fe 
Tabela 12.6 - Composição química dos feldspatos de Satélite II (\% peso)

\begin{tabular}{|c|c|c|c|c|c|c|c|c|c|c|c|c|c|c|c|c|c|c|c|c|}
\hline Amostra & RP-44 & RP-44 & RP-44 & RP-44 & RP-44 & RP-44 & RP-44 & RP-44 & $R P-44$ & $\mathrm{RP}-44$ & RP-44 & RP-44 & RP-44 & RP-44 & RP 44 & $R P-44$ & RP-44 & RP44 & RP-45 & $R P-45$ \\
\hline Análise & 328 & 329 & 330 & 331 & 332 & 333 & 334 & 83 & 84 & 85 & 86 & 87 & 88 & 89 & 91 & 91 & 92 & 93 & 337 & 338 \\
\hline Locaçăo & CiGin & C1G2n & $\mathrm{C}_{1 \mathrm{G} 2 \mathrm{~b}}$ & C2G1n & C2G2n & $\mathrm{C} 2 \mathrm{G} 2 \mathrm{~b}$ & C4G1n & C1G1ip & C1G2n & Cig2b & C2G1n & $\mathrm{C} 2 \mathrm{G} 1 \mathrm{~b}$ & C3G1ip & C3G1ip & C3G2ip & C3G2zp & C3G2n & C3G3n & C1Gín & C1Gii \\
\hline Mineral & Alb & $\mathrm{Kf}$ & Alb & $A B$ & $\mathrm{~K} \xi$ & $\mathrm{Kf}$ & Kf & $A B b$ & $\mathrm{KF}$ & KF & KF & $\mathrm{KF}$ & $A \mathrm{Ab}$ & KF & Alb & $\mathrm{KF}$ & Alb & $\mathrm{KF}$ & Alb & \\
\hline $\mathrm{SiO}_{2}$ & 67.549 & $64.32\}$ & 66.117 & 66.949 & 65.331 & 64.792 & 63.732 & 67.889 & 67,455 & 64.248 & 65.685 & 65.796 & 69.274 & 65.829 & 67.523 & 67.523 & 66.738 & 65.555 & 69.05 & 64.29 \\
\hline $\mathrm{TiO}_{2}$ & 0 & 0 & 0 & 0 & 0.014 & 0 & 0.053 & 0.002 & 0.031 & 0.063 & 0.012 & 0 & 0 & 0.039 & 0.056 & 0.056 & 0.03 & 0.088 & 0 & 0.079 \\
\hline $\mathrm{Al}_{2} \mathrm{O}_{3}$ & 19.44 & $\{8.576$ & 18.47 & 20.339 & 18.147 & 17.288 & 17.991 & 20.04 & 18.617 & 17.694 & 18.255 & 18.335 & 19.326 & 18.044 & $\{9.704$ & 19.704 & $\{8.876$ & 18.334 & 18.607 & 18.2 \\
\hline $\mathrm{Fe}_{2} \mathrm{O}_{3}$ & 0.155 & 0.155 & 0.453 & 0.066 & 0.325 & 0.924 & 0.117 & 0.102 & 0.336 & 0.331 & 0.21 & 0.109 & 0.233 & 0.287 & 0.152 & 0.152 & 0.228 & 0.261 & $\{.112$ & 0.75 \\
\hline $\mathrm{FeO}$ & 0 & 0 & 0 & 0 & 0 & 0 & 0 & 0 & 0 & 0 & 0 & 0 & 0 & 0 & 0 & 0 & 0 & 0 & 0 & 0 \\
\hline $\mathrm{MnO}$ & 0 & 0.011 & 0.002 & 0 & 0.038 & 0.024 & 0 & 0 & 0 & 0 & 0.017 & 0 & 0.004 & 0 & 0 & 0 & 0 & 0 & 0 & 0 \\
\hline SrO & 0 & 0 & 0 & 0 & 0 & 0 & 0 & 0 & 0 & 0 & 0 & 0 & 0 & 0 & 0 & 0 & 0 & 0 & 0 & 0 \\
\hline $\mathrm{BaO}$ & 0.041 & 0.14 & 0.044 & 0 & 0.11 & 0 & 0.009 & 0.035 & 0 & 0.089 & 0.041 & 0.088 & 0.042 & 0.033 & 0.107 & 0.107 & 0 & 0.089 & 0 & 0 \\
\hline $\mathrm{CaO}$ & 0.334 & 0 & 0 & 1.161 & 0.004 & 0 & 0 & 0.804 & 0 & 0 & 0.011 & 0 & 0.089 & 0 & 0.74 & 0.74 & 0.117 & 0.033 & 0 & 0 \\
\hline $\mathrm{Na}_{2} \mathrm{O}$ & 10.993 & 0.785 & 4.113 & 10.703 & 3.513 & 1.891 & 2.045 & 11.291 & 5.639 & 3.342 & 4.229 & 3.995 & 11.789 & 3.091 & 11.097 & 11.097 & 8.174 & 4.809 & 11.646 & 0.372 \\
\hline $\mathrm{K}_{2} \mathrm{O}$ & 0.374 & 15.512 & 10.503 & 0.224 & 11.518 & $\{3.635$ & 13.38 & 0.325 & 8.788 & 11.943 & 10.713 & 11.44 & 0.347 & 11.936 & 0.369 & 0.369 & 4.814 & 10.11 & 0.13 & 15.57 \\
\hline $\mathrm{MgO}$ & 0 & 0 & 0 & 0 & 0 & 0 & 0 & 0 & 0.002 & 0.001 & 0.004 & 0 & 0.009 & 0.004 & 0 & 0 & 0.013 & 0.003 & 0 & 0 \\
\hline Total & 98.89 & 99.5 & 99.7 & 99.44 & 99 & 98.55 & 97.33 & 100.49 & 100.87 & 97.71 & 99.18 & 99.76 & 101.11 & 99.26 & 99.75 & 99.75 & 98.99 & 99.28 & $\{00.55$ & 99.3 \\
\hline \multicolumn{21}{|c|}{ Fórmula estrutural calculada na base de 32 átomos de oxigénio } \\
\hline $\mathrm{Si}$ & 5.975 & 5.97 & 6.02 & 5.892 & 6.028 & 6.087 & 6.004 & 5.936 & 6.038 & 6.041 & 6.027 & 6.023 & 6.022 & 6.048 & 5.954 & 5.954 & 6.001 & 6.018 & 6.073 & 5.99 \\
\hline Al & 2.025 & 2.03 & 1.98 & 2.108 & 1.972 & 1.913 & 1.996 & 2.064 & 1.962 & 1.959 & 1.973 & 1.977 & 1.978 & 1.952 & 2.046 & 2.046 & 1.999 & 1.982 & 1.927 & 2.00 \\
\hline$e^{3+}$ & 0.01 & 0.011 & 0.031 & 0.004 & 0.023 & 0.065 & 0.008 & 0.007 & 0.023 & 0.023 & 0.014 & 0.008 & 0.015 & 0.02 & 0.0 & 0.8 & 0.0 & 0.0 & 0.074 & 0.0 \\
\hline$T$ & 0 & 0 & 0 & 0 & 0.001 & 0 & 0.004 & 0 & 0.002 & 0.004 & 0.001 & 0 & 0 & 0.003 & 0.004 & 0.004 & 0.002 & 0.008 & 0 & 0.0 \\
\hline $\mathrm{Fe}^{2+}$ & 0 & 0 & 0 & 0 & 0 & 0 & 0 & 0 & 0 & 0 & 0 & 0 & 0 & 0 & 0 & 0 & 0 & 0 & 0 & \\
\hline $\mathrm{Mn}$ & 0 & 0.001 & 0 & 0 & 0.003 & 0.002 & 0 & 0 & 0 & 0 & 0.001 & 0 & 0 & 0 & & 0 & 0 & 0 & 0 & \\
\hline $\mathrm{Mg}$ & 0 & 0 & 0 & 0 & 0 & 0 & 0 & 0 & 0 & 0 & 0.001 & 0 & 0.001 & 0.001 & 0 & 0 & 0.002 & 0 & 0 & \\
\hline $\mathrm{Ba}$ & 0.001 & 0.005 & 0.002 & 0 & 0.004 & 0 & 0 & 0.001 & 0 & 0.003 & 0.001 & 0.003 & 0.001 & 0.001 & 0.004 & 0.004 & 0 & 0.003 & 0 & \\
\hline $\mathrm{Ca}$ & 0.032 & 0 & 0 & 0.109 & 0 & 0 & 0 & 0.075 & 0 & 0 & 0.001 & 0 & 0.008 & 0 & 0.07 & 0.07 & 0.011 & 0.003 & 0 & 0 \\
\hline $\mathrm{Na}$ & 1.885 & 0.141 & 0.726 & & 0.629 & 0.344 & 0.374 & & 0.979 & 0.609 & 0.752 & 0.70 & 1.98 & & 1.897 & 1.8 & 1.4 & 0.8 & 1.986 & 0.06 \\
\hline K & 0.042 & 1.837 & 1.22 & 0.025 & 1.356 & $\{.634$ & 1.608 & 0.036 & 1.003 & 1.433 & 1.254 & 1.33 & 0.038 & 1.38 & 0.04 & 0.0 & 0.5 & $1 .\{84$ & .015 & \\
\hline Cátions & 9.971 & 10 & 9.981 & 9.964 & 10.02 & 10.045 & 9.994 & 10.034 & $\{0.007$ & 10.075 & 10.026 & 10.059 & 10.054 & 9.976 & 10.031 & 10.031 & $\{0.007$ & 10.073 & 10.075 & 9.9 \\
\hline$x$ & 8.01 & 8.011 & 8.031 & 8.004 & 8.024 & 8.065 & 8.012 & 8.007 & 8.025 & 8.027 & 8.015 & $8.00 B$ & 8.015 & 8.023 & 8.014 & 8.014 & 8.017 & 8.024 & 8.074 & 8.0 \\
\hline & 1.96 & 1.984 & 1.948 & 1.96 & 1.992 & 1.98 & 1.982 & 2.026 & 1.982 & 2.045 & 2.01 & 2.048 & 2.035 & 1.952 & 2.013 & 2.013 & 1.99 & 2.046 & 2.001 & \\
\hline & & & \multicolumn{18}{|c|}{ ulares } \\
\hline$A b$ & 96.2 & 7.1 & 37.3 & 93.2 & 31.7 & 17.4 & 18.9 & 94.5 & 49.4 & 29.8 & 37.5 & 34.7 & 97.7 & 28.3 & 94.4 & 94.4 & 71.7 & 41.9 & 99.3 & 3.5 \\
\hline An & 1.6 & 0 & 0 & 5.6 & 0 & 0 & 0 & 3.7 & 0 & 0 & 0 & 0 & 0.4 & 0 & 3.5 & 3.5 & 0.6 & 0.1 & 0 & \\
\hline Or & 2.1 & 92.9 & 62.7 & 1.3 & 68.3 & 82.6 & 81.1 & 1.8 & 50.6 & 70.2 & 62.5 & 65.3 & 1.9 & 71.7 & 2.1 & 2.1 & 27.8 & 58 & 0.7 & 96 \\
\hline
\end{tabular}




\section{Tabela 12.7 - Composição química dos feldspatos de Satélite II (\% peso)}

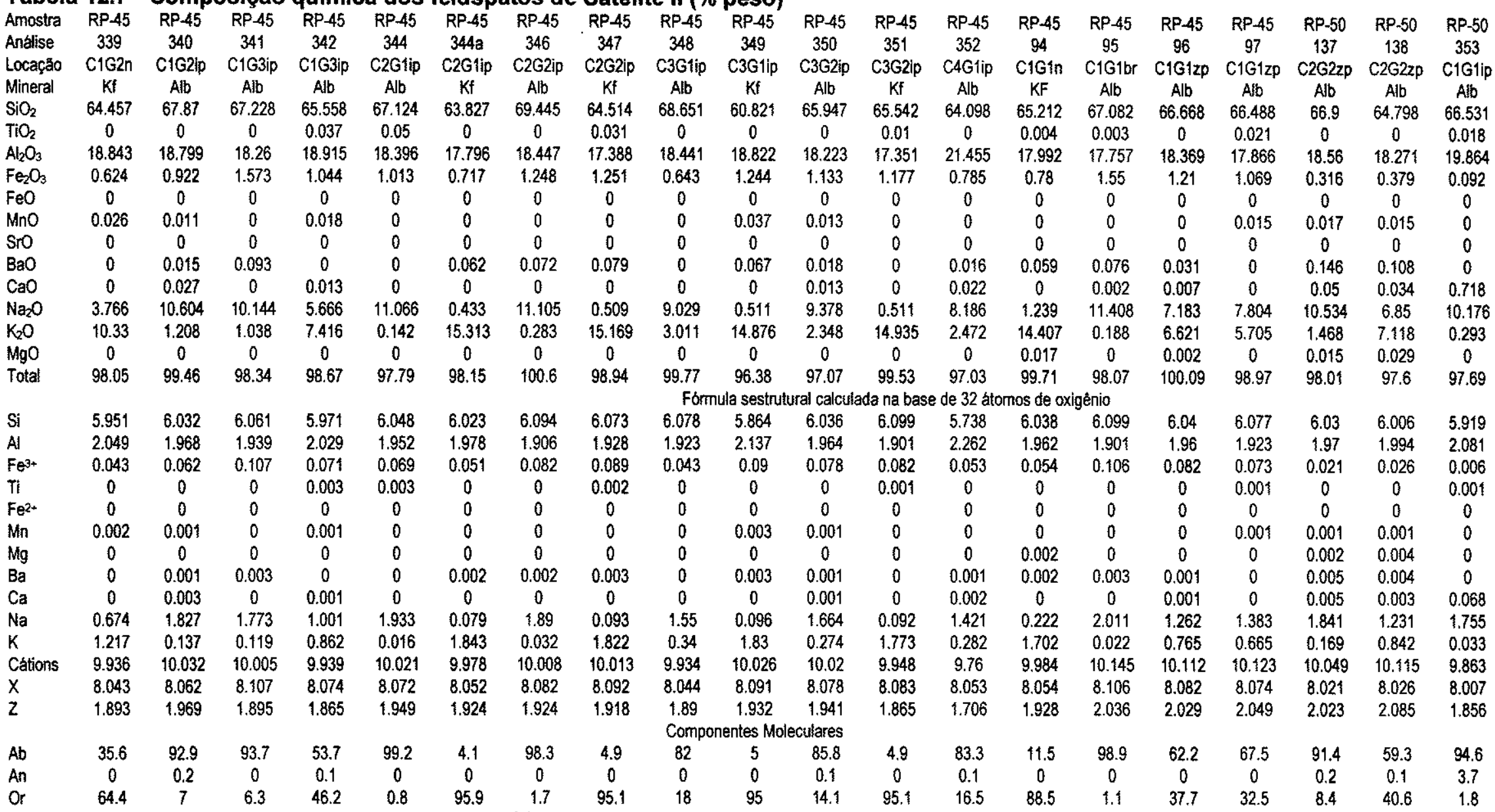

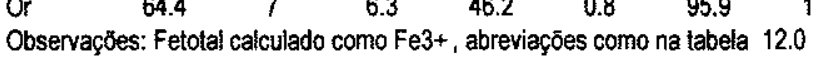


Tabela 12.8 - Composição química de feldspatos de Satélite II (\% peso)

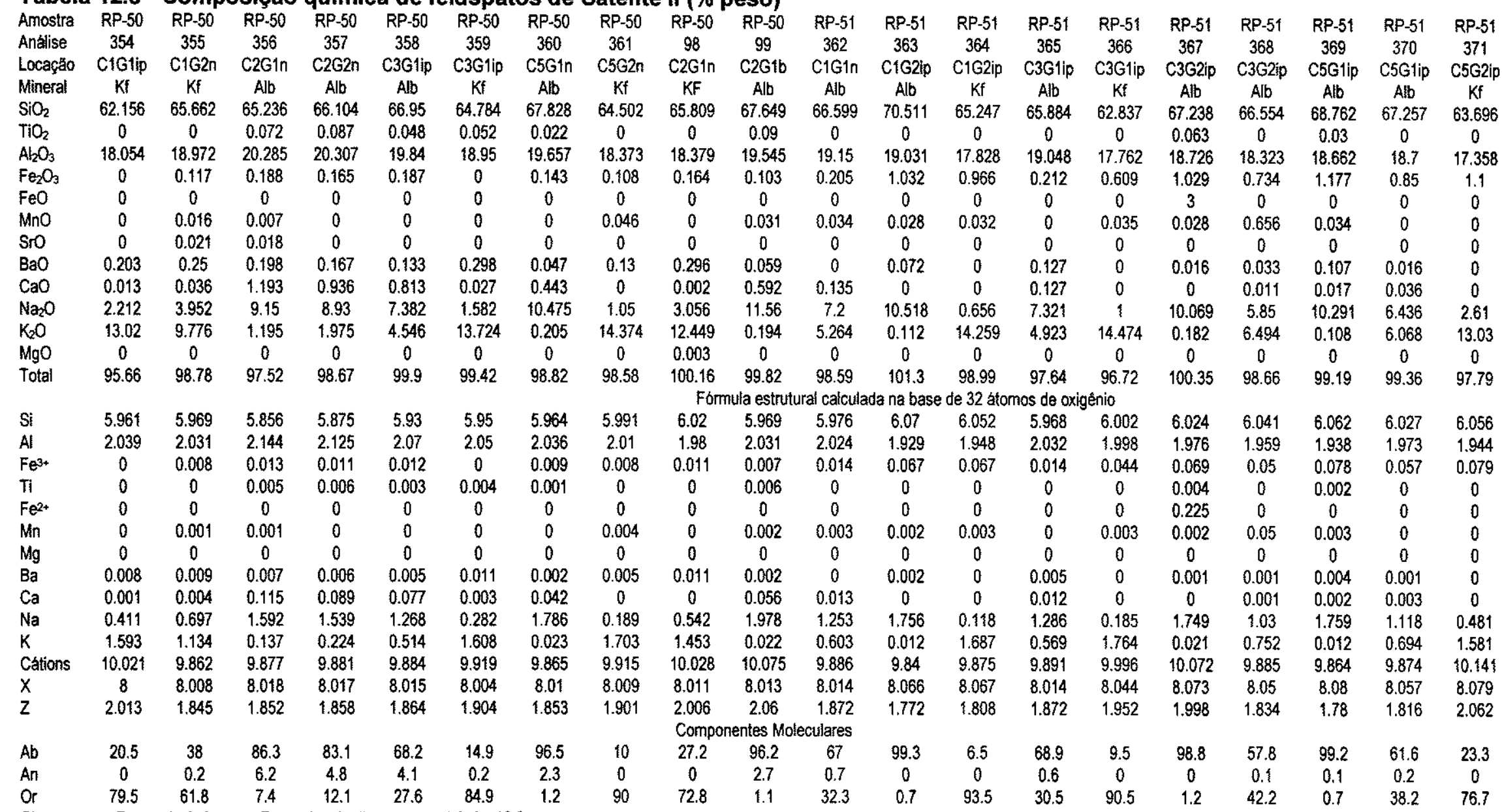


Tabela 12.9 - Composição química de feldspatos de Satélite II (\%"peso)

\begin{tabular}{|c|c|c|c|c|c|}
\hline \multirow{2}{*}{\multicolumn{6}{|c|}{ Amostra }} \\
\hline & & & RP-51 & & \\
\hline Análise & 372 & 373 & 374 & 375 & 376 \\
\hline Locação & C5G2ip & C6Glip & C6G1ip & C6G2ip & C6G2ip \\
\hline Mineral & $A b$ & $\mathrm{Kf}$ & $A B b$ & $\mathrm{Kf}$ & $A l b$ \\
\hline $\mathrm{SiO}_{2}$ & 67.96 & 65.45 & 67.4 & 64.18 & 68.34 \\
\hline $\mathrm{TiO}_{2}$ & 0 & 0 & 0 & 0 & 0 \\
\hline $\mathrm{Al}_{2} \mathrm{O}_{3}$ & 18.52 & 18.156 & 18.89 & 17.93 & 20.01 \\
\hline $\mathrm{Fe}_{2} \mathrm{O}_{3}$ & 1.5 & 1.09 & 1.5 & 0.84 & 0.12 \\
\hline $\mathrm{FeO}$ & 0 & 0 & 0 & 0 & 0 \\
\hline Mno & 0 & 0.041 & 0.03 & 0.04 & 0 \\
\hline Sro & 0 & 0 & 0 & 0 & 0 \\
\hline $\mathrm{BaO}$ & 0.11 & 0 & 0.12 & 0 & 0.05 \\
\hline $\mathrm{CaO}$ & 0 & 0 & 0.03 & 0 & 0.33 \\
\hline $\mathrm{Na}_{2} \mathrm{O}$ & 11.99 & 3.11 & 10.73 & 1.9 & 11.3 \\
\hline $\mathrm{K}_{2} \mathrm{O}$ & 0.12 & 11.93 & 1.85 & 14.67 & 0.54 \\
\hline $\mathrm{MgO}$ & 0 & 0 & 0 & 0 & 0 \\
\hline Total & 100.2 & 99.78 & 100.55 & 99.56 & 100.69 \\
\hline \multicolumn{6}{|c|}{ Formula estrutural calculada na base de 32 atomos de oxigénio } \\
\hline $\mathrm{Si}$ & 6.056 & 6.03 & 6.015 & 6.02 & 5.949 \\
\hline A! & 1.944 & 1.97 & 1.985 & 1.98 & 2.051 \\
\hline $\mathrm{Fe}^{3+}$ & 0.1 & 0.075 & 0.101 & 0.059 & 0.008 \\
\hline $\mathrm{Ti}$ & 0 & 0 & 0 & 0 & 0 \\
\hline $\mathrm{Fe}^{2+}$ & 0 & 0 & 0 & 0 & 0 \\
\hline $\mathrm{Mn}$ & 0 & 0.003 & 0.002 & 0.003 & 0 \\
\hline $\mathrm{Mg}$ & 0 & 0 & 0 & 0 & 0 \\
\hline $\mathrm{Ba}$ & 0.004 & 0 & 0.004 & 0 & 0.002 \\
\hline $\mathrm{Ca}$ & 0 & 0 & 0.003 & 0 & 0.031 \\
\hline $\mathrm{Na}$ & 2.072 & 0.556 & 1.857 & 0.346 & 1.907 \\
\hline $\mathrm{K}$ & 0.014 & 1.402 & 0.211 & 1.755 & 0.06 \\
\hline Cátions & 10.194 & 10.036 & 10.182 & $\{0.163$ & 10.01 \\
\hline $\mathrm{x}$ & 8.1 & 8.075 & 8.101 & 8.059 & 8.008 \\
\hline$z$ & 2.09 & 1.961 & 2.077 & 2.104 & 2 \\
\hline \multicolumn{6}{|c|}{ Componentes Moleculares } \\
\hline$A b$ & 99.3 & 28.4 & 89.7 & 16.5 & 95.4 \\
\hline An & 0 & 0 & 0.1 & 0 & 1.6 \\
\hline Or & 0.7 & 71.6 & 10.2 & 83.5 & 3 \\
\hline
\end{tabular}

Observaçōes: Fetotal calculado como Fe3+, abreviaçōes como na tabela 12.0 
Tabela 12.10 - Composição química de feldspatos de Satélite I (\% peso)

\begin{tabular}{|c|c|c|c|c|c|c|c|c|c|c|c|c|c|c|c|c|c|c|c|c|c|}
\hline Amostra & RP-51 & RP-51 & RP-51 & RP-51 & RP-51 & RP-52 & RP-52 & RP-52 & RP-52 & RP. 52 & RP-52 & RP-52 & RP-52 & RP-52 & RP-52 & RP-52 & RP-52 & RP-52 & RP-52 & RP-52 & RP-52 \\
\hline Análise & 372 & 373 & 374 & 375 & 376 & 377 & 378 & 379 & 380 & $38 i$ & 382 & 383 & 384 & 385 & 386 & 387 & 388 & 389 & 390 & 391 & 392 \\
\hline Locaçăo & C5G2ip & C6G1ip & C6G1ip & C6G2ip & C6G2ip & $\mathrm{C} 1 \mathrm{G} 2 \mathrm{n}$ & C1G3ip & CiG3ip & C2Glip & C2G1ip & C2G2ip & C2G2ip & C3G1n & C3G1b & C3G2n & $\mathrm{C} 3 \mathrm{G} 2 \mathrm{~b}$ & C3G3ip & C3G3ip & C5Glip & C5G1ip & $\mathrm{C} 5 \mathrm{G} 2 \mathrm{n}$ \\
\hline Mineral & $A b$ & $\mathrm{Kf}$ & $\mathrm{Alb}$ & $\mathrm{Kf}$ & Alb & $A b$ & $\mathrm{Alb}$ & $\mathrm{Kf}$ & $\mathrm{Alb}$ & $\mathrm{Kf}$ & Alb & $\mathrm{Kf}$ & Alb & Alb & Aib & Alb & $A b b$ & $\mathrm{Kf}$ & $K f$ & Alb & Alb \\
\hline $\mathrm{SiO}_{2}$ & 67.96 & 65.45 & 67.4 & 64.18 & 68.34 & 66.29 & 67.54 & 63.67 & 68.49 & 67.27 & 69.31 & 66.72 & 67.94 & 68.23 & 66.8 & 67.87 & 69.5 & 67.95 & 67.37 & 70.05 & 68.22 \\
\hline $\mathrm{TiO}_{2}$ & 0 & 0 & 0 & 0 & 0 & 0.04 & 0 & 0 & 0 & 0 & 0.01 & 0.08 & 0.03 & 0 & 0.01 & 0 & 0 & 0.06 & 0.03 & 0 & 0.05 \\
\hline $\mathrm{Al}_{2} \mathrm{O}_{3}$ & 18.52 & $\{8.156$ & 18.89 & 17.93 & 20.01 & 20.08 & 18.9 & 17.94 & 18.45 & 17.75 & 18.86 & 18.08 & 19.3 & 19.54 & 18.96 & 19.03 & 19.05 & 18.58 & 18.33 & 19.55 & $\{9.02$ \\
\hline $\mathrm{Fe}_{2} \mathrm{O}_{3}$ & 1.5 & 1.09 & 1.5 & 0.84 & 0.12 & 0.09 & 0.18 & 0.41 & 0.72 & 0.47 & 0.73 & 0.67 & 0.17 & 0.1 & 0.15 & 0.19 & 0.15 & 0.22 & 0.31 & 0.44 & 0.12 \\
\hline $\mathrm{FeO}$ & 0 & 0 & 0 & 0 & 0 & 0 & 0 & 0 & 0 & 0 & 0 & 0 & 0 & 0 & 0 & 0 & 0 & 0 & 0 & 0 & 0 \\
\hline $\mathrm{MnO}$ & 0 & 0.041 & 0.03 & 0.04 & 0 & 0 & 0.01 & 0 & 0.03 & 0.01 & 0.02 & 0.02 & 0 & 0.03 & 0.05 & 0 & 0 & 0.04 & 0 & 0 & 0 \\
\hline SrO & 0 & 0 & 0 & 0 & 0 & 0 & 0 & 0 & 0 & 0 & 0 & 0 & 0 & 0.01 & 0 & 0 & 0 & 0 & 0 & 0 & 0 \\
\hline $\mathrm{BaO}$ & 0.11 & 0 & 0.12 & 0 & 0.05 & 0.05 & 0.1 & 0 & 0.06 & 0.04 & 0.05 & 0 & 0 & 0.01 & 0.01 & 0.06 & 0.11 & 0 & 0.03 & 0 & 0.06 \\
\hline $\mathrm{CaO}$ & 0 & 0 & 0.03 & 0 & 0.33 & 0.39 & 0.11 & 0 & 0 & 0 & 0.01 & 0 & 0.24 & 0.41 & 0.2 & 0.16 & 0.07 & 0.01 & 0.02 & 0.02 & 0.21 \\
\hline $\mathrm{Na}_{2} \mathrm{O}$ & 11.99 & 3.11 & 10.73 & 1.9 & 11.3 & 10 & 6.94 & 2.43 & 11.587 & 1.17 & 11.9 & 3.26 & 8.19 & 10.45 & 8.55 & 7.74 & 8.11 & 4.06 & 3.34 & 10.8 & 7.76 \\
\hline $\mathrm{K}_{2} \mathrm{O}$ & 0.12 & 11.93 & 1.85 & 14.67 & 0.54 & 1.8 & 6.73 & 13.35 & 0.16 & 15.27 & 0.21 & 12.68 & 5.11 & 1.75 & 4.42 & 6.08 & 5.56 & 11.37 & 12.46 & 1.36 & 5.74 \\
\hline MgO & 0 & 0 & 0 & 0 & 0 & 0 & 0 & 0 & 0 & 0 & 0 & 0 & 0 & 0 & 0 & 0 & 0 & 0 & 0 & 0 & 0 \\
\hline Total & 100.2 & 99.78 & 100.55 & 99.56 & 100.69 & 98.74 & 100.51 & 97.8 & 99.5 & 101.98 & 101.1 & 101.51 & 100.98 & 100.52 & 99.15 & 101.1 & 102.55 & 102.29 & 101.89 & 102.19 & 101.18 \\
\hline \multicolumn{22}{|c|}{ Fórmula estrutural calculada na base de 32 átomos de oxigénio } \\
\hline $\mathrm{Si}$ & 6.056 & 6.03 & 6.015 & 6.02 & 5.949 & 5.896 & 6.017 & 6.007 & 6.074 & 6.103 & 6.058 & 6.065 & 5.995 & 5.982 & 5.996 & 6.014 & 6.048 & 6.051 & 6.059 & 6.021 & 6.023 \\
\hline Al & 1.944 & 1.97 & 1.985 & 1.98 & 2.051 & 2.103 & 1.983 & 1.993 & 1.927 & 1.897 & 1.941 & 1.935 & 2.005 & 2.018 & 2.004 & 1.986 & 1.952 & 1.949 & $\$ .941$ & 1.979 & 1.978 \\
\hline $\mathrm{Fe}^{3+}$ & 0.1 & 0.075 & 0.101 & 0.059 & 0.008 & 0.006 & 0.012 & 0.029 & 0.048 & 0.032 & 0.048 & 0.046 & 0.011 & 0.007 & 0.01 & 0.013 & 0.01 & 0.015 & 0.021 & 0.026 & 0.008 \\
\hline$\pi i$ & 0 & 0 & 0 & 0 & 0 & 0.003 & 0 & 0 & 0 & 0 & 0.001 & 0.005 & 0.002 & 0 & 0.001 & 0 & 0 & 0.004 & 0.002 & 0 & 0.003 \\
\hline $\mathrm{Fe}^{2+}$ & 0 & 0 & 0 & 0 & 0 & 0 & 0 & 0 & 0 & 0 & 0 & 0 & 0 & 0 & 0 & 0 & 0 & 0 & 0 & 0 & 0 \\
\hline Mn & 0 & 0.003 & 0.002 & 0.003 & 0 & 0 & 0.001 & 0 & 0.002 & 0.001 & 0.001 & 0.002 & 0 & 0.002 & 0.004 & 0 & 0 & 0.003 & 0 & 0 & 0 \\
\hline Mg & 0 & 0 & 0 & 0 & 0 & 0 & 0 & 0 & 0 & 0 & 0 & 0 & 0 & 0 & 0 & 0 & 0 & 0 & 0 & 0 & 0 \\
\hline $\mathrm{Ba}$ & 0.004 & 0 & 0.004 & 0 & 0.002 & 0.002 & 0.003 & 0 & 0.002 & 0.001 & 0.002 & 0 & 0 & 0 & 0 & 0.002 & 0.004 & 0 & 0.001 & 0 & 0.002 \\
\hline $\mathrm{Ca}$ & 0 & 0 & 0.003 & 0 & 0.031 & 0.037 & 0.011 & 0 & 0 & 0 & 0.001 & 0 & 0.023 & 0.039 & 0.019 & 0.015 & 0.007 & 0.001 & 0.002 & 0.002 & 0.02 \\
\hline $\mathrm{Na}$ & 2.072 & 0.556 & 1.857 & 0.346 & 1.907 & 1.725 & 1.199 & 0.445 & 1.992 & 0.206 & 2.017 & 0.575 & 1.401 & 1.777 & $\{.488$ & 1.325 & 1.368 & 0.701 & 0.582 & 1.8 & 1.328 \\
\hline K & 0.014 & 1.402 & 0.211 & 1.755 & 0.06 & 0.204 & 0.765 & 1.607 & 0.018 & 1.767 & 0.023 & $\{.47$ & 0.575 & 0.196 & 0.506 & 0.687 & 0.617 & 1.292 & 1.429 & 0.149 & 0.647 \\
\hline Cátions & 10.194 & 10.036 & 10.182 & 10.163 & 10.01 & 9.978 & 9.994 & 10.081 & 10.065 & 10.008 & 10.094 & 10.098 & 10.012 & 10.021 & 10.028 & 10.044 & 10.01 & 10.016 & 10.038 & 9.977 & $\{0.011$ \\
\hline $\mathrm{x}$ & 8.1 & 8.075 & 8.101 & 8.059 & 8.008 & 8.008 & 8.012 & 8.029 & 8.049 & 8.032 & 8.048 & 8.051 & 8.013 & 8.007 & 8.011 & 8.013 & 8.01 & 8.019 & 8.023 & 8.026 & 8.012 \\
\hline$z$ & 2.09 & 1.961 & 2.077 & 2.104 & 2 & 1.968 & 1.979 & 2.052 & 2.014 & 1.975 & 2.044 & 2.047 & 1.999 & 2.014 & 2.017 & 2.029 & 1.996 & 1.997 & 2.014 & 1.951 & 1.997 \\
\hline \multicolumn{22}{|c|}{ Componentes Moleculares } \\
\hline$A b$ & 99.3 & 28.4 & 89.7 & 16.5 & 95.4 & 87.7 & 60.7 & 21.7 & 99.1 & 10.4 & 98.8 & 28.1 & 70.1 & 88.3 & 73.9 & 65.4 & 68.7 & 35.2 & 28.9 & 92.3 & 66.6 \\
\hline An & 0 & 0 & 0.1 & 0 & 1.6 & 1.9 & 0.6 & 0 & 0 & 0 & 0 & 0 & 1.2 & 1.9 & 0.9 & 0.7 & 0.4 & 0.1 & 0.1 & 0.1 & 1 \\
\hline Or & 0.7 & 71.6 & 10.2 & 83.5 & 3 & $\{0.4$ & 38.7 & 78.3 & 0.9 & 89.6 & 1.1 & 71.9 & 28.8 & 9.7 & 25.1 & 33.9 & 31 & 64.8 & 71 & 7.6 & 32.4 \\
\hline
\end{tabular}

Observaçōes: Fetoal calculado como $\mathrm{Fe}^{3+}$, abreviações como na tabela 12.0 
Tabela 12.11 - Composição química de feldspatos de Satélite I (\% peso)

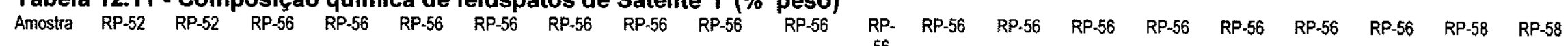

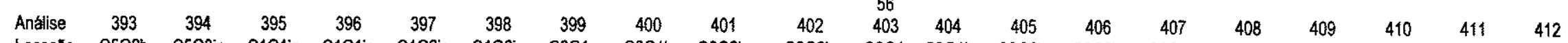

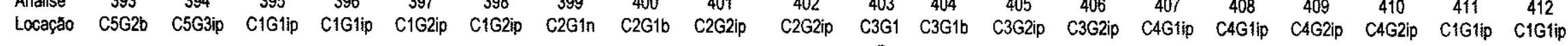

\begin{tabular}{|c|c|c|c|c|c|c|c|c|c|c|c|c|c|c|c|c|c|c|c|c|}
\hline Mineral & Alb & $\mathrm{Kf}$ & $\mathrm{Kf}$ & $\mathrm{Alb}$ & $\mathrm{Kf}$ & Alb & $\mathrm{Kf}$ & Alb & $\mathrm{Kf}$ & Alb & $\mathrm{Kf}$ & Kf & $\mathrm{Kf}$ & KI & Alb & $A B b$ & Alb & $\mathrm{Kf}$ & $\mathrm{Kf}$ & Alb \\
\hline $\mathrm{SiO}_{2}$ & 67.55 & 62.58 & 67.86 & 70.25 & 64.81 & 70.44 & 66.5 & 66.8 & 63.13 & 67.79 & 66.19 & 68.92 & 65.6 & 67.2 & 68.57 & 69.06 & 67.05 & 63.05 & 60.7 & 67.96 \\
\hline $\mathrm{TiO}_{2}$ & 0 & 0.05 & 0 & 0 & 0 & 0 & 0 & 0.04 & 0.04 & 0.02 & 0.04 & 0 & 0.03 & 0.01 & 0 & 0.01 & 0 & 0 & 0.05 & 0 \\
\hline $\mathrm{Al}_{2} \mathrm{O}_{3}$ & 18.82 & 17.6 & 17.97 & 18.39 & 18.04 & 19.07 & 18.2 & 18.46 & 18.82 & 18.55 & 17.95 & 18.55 & 17.95 & 18.36 & 18.94 & 18.72 & 8.71 & 17.53 & 17.45 & 19.28 \\
\hline $\mathrm{Fe}_{2} \mathrm{O}_{3}$ & 0.23 & 0.99 & 0.59 & 1.28 & 0.48 & 0.58 & 0.41 & 0.54 & 0.51 & 0.79 & 0.65 & 0.98 & 0.81 & 0.6 & 0.59 & 0.52 & 0.53 & 0.58 & 0.83 & 0.17 \\
\hline $\mathrm{MnO}$ & 0 & 0 & 0.01 & 0.02 & 0 & 0 & 0.02 & 0 & 0.01 & 0.03 & 0 & 0 & 0 & 0.03 & 0.02 & 0.08 & 0 & 0 & 0.03 & 0 \\
\hline Sro & 0 & 0 & 0 & 0 & 0 & 0 & 0 & 0 & 0 & 0 & 0 & 0 & 0 & 0 & 0 & 0 & 0 & 0 & 0 & 0 \\
\hline $8 \mathrm{aO}$ & 0.19 & 0.01 & 0.03 & 0.04 & 0 & 0 & 0.05 & 0.01 & 0.03 & 0 & 0 & 0 & 0.02 & 0.14 & 0 & 0.01 & 0 & 0 & 0.1 & 0 \\
\hline $\mathrm{CaO}$ & 0.13 & 0 & 0 & 0 & 0 & 0 & 0 & 0 & 0 & 0.02 & 0 & 0 & 0 & 0 & 0.02 & 0.01 & 0 & 0 & 0.06 & 0.15 \\
\hline $\mathrm{Na}_{2} \mathrm{O}$ & 7.56 & 1.99 & 5.58 & 11.55 & 1.08 & 11.36 & 2.01 & 7.85 & 0.84 & 10.92 & 2.78 & 11.26 & 2.75 & 5.49 & $\$ 1.78$ & 9.15 & 11.24 & 1.15 & 0.58 & 11.24 \\
\hline $\mathrm{K}_{2} \mathrm{O}$ & 6.02 & 13.61 & 8.88 & 0.09 & 15.37 & 0.74 & 14.46 & 6.01 & 15.07 & $\{.47$ & 13.12 & 0.71 & 13.5 & 9.07 & 0.19 & 4.01 & 0.42 & 15.04 & 14.73 & 0.31 \\
\hline $\mathrm{MgO}$ & 0 & 0 & 0 & 0 & 0 & 0 & 0 & 0 & 0 & 0 & 0 & 0 & 0 & 0 & 0 & 0 & 0 & 0 & 0 & 0 \\
\hline \multirow[t]{2}{*}{ Total } & 100.5 & 96.83 & 100.92 & 101.62 & 99.78 & 102.19 & 101.65 & 99.68 & 98.45 & 99.59 & $\begin{array}{c}100.7 \\
3\end{array}$ & 100.42 & 100.66 & 100.9 & 100.11 & 101.57 & 97.95 & 97.35 & 94.53 & 99.11 \\
\hline & & & & & & \multicolumn{15}{|c|}{ Fórmula estrutural calculada na base de 32 átomos de oxigénio } \\
\hline $\mathrm{Si}$ & 6.024 & 6.009 & 6.098 & 6.115 & 6.025 & 6.066 & 6.05 & 6.036 & 5.921 & 6.05 & 6.063 & 6.074 & 6.05 & 6.053 & 6.037 & 6.064 & 6.021 & 6.026 & 5.976 & 5.996 \\
\hline Al & 1.976 & 1.99 & 1.902 & 1.885 & 1.975 & 1.934 & 1.95 & 1.964 & 2.079 & 1.95 & 1.936 & 1.925 & 1.95 & 1.947 & 1.964 & 1.936 & 1.979 & 1.973 & 2.023 & 2.003 \\
\hline $\mathrm{Fe}^{3+}$ & 0.015 & 0.071 & 0.04 & 0.084 & 0.034 & 0.038 & 0.028 & 0.035 & 0.036 & 0.053 & 0.045 & 0.065 & 0.056 & 0.041 & 0.039 & 0.034 & 0.036 & 0.042 & 0.061 & 0.011 \\
\hline Ti & 0 & 0.004 & 0 & 0 & 0 & 0 & 0 & 0.003 & 0.003 & 0.001 & 0.003 & 0 & 0.002 & 0.001 & 0 & 0.001 & 0 & 0 & 0.004 & 0 \\
\hline $\mathrm{Fe}^{2+}$ & 0 & 0 & 0 & 0 & 0 & 0 & 0 & 0 & 0 & 0 & 0 & 0 & 0 & 0 & 0 & 0 & 0 & 0 & 0 & 0 \\
\hline $\mathrm{Mn}$ & 0 & 0 & 0.001 & 0.001 & 0 & 0 & 0.002 & 0 & 0.001 & 0.002 & 0 & 0 & 0 & 0.002 & 0.001 & 0.006 & 0 & 0 & 0.003 & 0 \\
\hline $\mathrm{Ba}$ & 0.007 & 0 & 0.001 & 0.001 & 0 & 0 & 0.002 & 0 & 0.001 & 0 & 0 & 0 & 0.001 & 0.005 & 0 & 0 & 0 & 0 & 0.004 & 0 \\
\hline $\mathrm{Ca}$ & 0.012 & 0 & 0 & 0 & 0 & 0 & 0 & 0 & 0 & 0.002 & 0 & 0 & 0 & 0 & 0.002 & 0.001 & 0 & 0 & 0.006 & 0.014 \\
\hline $\mathrm{Na}$ & 1.307 & 0.371 & 0.972 & 1.949 & 0.195 & 1.897 & 0.355 & 1.375 & 0.153 & 1.89 & 0.494 & 1.924 & 0.492 & 0.959 & 2.011 & 1.558 & 1.957 & 0.213 & 0.111 & 1.923 \\
\hline K & 0.685 & 1.667 & 1.018 & 0.01 & 1.823 & 0.081 & 1.678 & 0.693 & 1.803 & 0.167 & 1.533 & 0.08 & 1.588 & 1.042 & 0.021 & 0.449 & 0.048 & 1.834 & 1.85 & 0.035 \\
\hline Cátions & 10.033 & 10.112 & 10.033 & 10.046 & 10.052 & 10.016 & 10.067 & 10.106 & 9.998 & 10.115 & $\begin{array}{c}10.07 \\
4\end{array}$ & 10.068 & 10.14 & 10.055 & 10.075 & 10.049 & 10.041 & 10.088 & 10.042 & 9.982 \\
\hline$x$ & 8.015 & 8.074 & 8.04 & 8.084 & 8.034 & 8.038 & 8.028 & 8.038 & 8.039 & 8.054 & 8.047 & 8.064 & 8.058 & 8.042 & 8.04 & 8.035 & 8.036 & 8.041 & 8.064 & 8.01 \\
\hline \multirow[t]{2}{*}{ z } & 2.011 & 2.038 & 1.992 & 1.961 & 2.018 & 1.978 & 2.037 & 2.068 & 1.95 & 2.061 & 2.027 & 2.004 & 2.081 & 2.008 & 2.035 & 2.014 & 2.005 & 2.047 & 1.974 & $\$ .972$ \\
\hline & & & \multicolumn{18}{|c|}{ Componentes Moleculares } \\
\hline$A b$ & 65.2 & 18.2 & 48.8 & 99.5 & 9.7 & 95.9 & 17.5 & 66.5 & 7.8 & 91.8 & 24.4 & 96 & 23.7 & 47.9 & 98.9 & 77.6 & 97.6 & 10.4 & 5.6 & 97.5 \\
\hline An & 0.6 & 0 & 0 & 0 & 0 & 0 & 0 & 0 & 0 & 0.1 & 0 & 0 & 0 & 0 & 0.1 & 0 & 0 & 0 & 0.3 & 0.7 \\
\hline Or & 34.2 & 81.8 & 51.2 & 0.5 & 90.3 & 4.1 & 82.5 & 33.5 & 92.2 & 8.1 & 75.6 & 4 & 76.3 & 52.1 & 1 & 22.4 & 2.4 & 89.6 & 94.1 & 1.8 \\
\hline
\end{tabular}

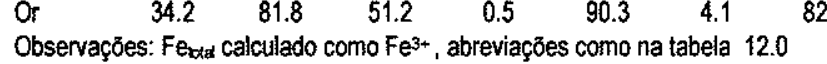




\begin{tabular}{|c|c|c|c|c|c|c|c|}
\hline Amosira & RP-58 & RP-58 & RP-58 & RP-58 & RP-58 & RP-58 & RP-58 \\
\hline Análise & 413 & 414 & 415 & 416 & 417 & 418 & 419 \\
\hline Locaçã̃o & C1G2ip & C1G2ip & C2G1ip & C2G1ip & C2G2ip & C2G2ip & C3G1ip \\
\hline Mineral & $A l b$ & Kf & Alb & $A B D$ & $A B b$ & $\mathrm{Kf}$ & Alb \\
\hline $\mathrm{SiO}_{2}$ & 69.28 & 67.08 & 68.18 & 69 & 69.47 & 67.45 & 70.55 \\
\hline $\mathrm{TiO}_{2}$ & 0.05 & 0.02 & 0 & 0.051 & 0.05 & 0.05 & 0.02 \\
\hline $\mathrm{Al}_{2} \mathrm{O}_{3}$ & 19.03 & 17.95 & 19.69 & 19.19 & 19 & 18.57 & 18.75 \\
\hline $\mathrm{Fe}_{2} \mathrm{O}_{3}$ & 0.2 & 0.4 & 0.3 & 0.28 & 0.22 & 0.15 & 0.63 \\
\hline $\mathrm{FeO}$ & 0 & 0 & 0 & 0 & 0 & 0 & 0 \\
\hline $\mathrm{MnO}$ & 0 & 0 & 0.01 & 0.01 & 0 & 0 & 0.03 \\
\hline Sto & 0 & 0 & 0 & 0 & 0 & 0 & 0 \\
\hline $\mathrm{BaO}$ & 0 & 0.02 & 0.05 & 0.03 & 0.05 & 0 & 0 \\
\hline $\mathrm{CaO}$ & 0.07 & 0.02 & 0.02 & 0.03 & 0.13 & 0 & 0 \\
\hline $\mathrm{Na}_{2} \mathrm{O}$ & 11.55 & 3.36 & 11.29 & 10.63 & 7.67 & 5.01 & 11.74 \\
\hline $\mathrm{K}_{2} \mathrm{O}$ & 0.19 & 11.65 & 0.24 & 1.39 & 6.04 & 10.15 & 0.1 \\
\hline $\mathrm{MgO}$ & 0 & 0 & 0 & 0 & 0 & 0 & 0 \\
\hline \multirow[t]{2}{*}{ Total } & 100.37 & 100.5 & 99.78 & 100.61 & 102.63 & 101.38 & 401.82 \\
\hline & & & \multicolumn{5}{|c|}{ Fómula estrutural calculada na base de 32 atomos de oxigênio } \\
\hline $\mathrm{Si}$ & 6.044 & 6.083 & 5.97 & 6.026 & 6.051 & 6.041 & 6.093 \\
\hline Al & 1.955 & 1.917 & 2.03 & 1.974 & 1.949 & 1.959 & 1.907 \\
\hline $\mathrm{Fe}^{3+}$ & 0.013 & 0.027 & 0.02 & 0.018 & 0.014 & 0.01 & 0.041 \\
\hline Ti & 0.003 & 0.001 & 0 & 0.003 & 0.003 & 0.003 & 0.001 \\
\hline $\mathrm{Fe}^{2+}$ & 0 & 0 & 0 & 0 & 0 & 0 & 0 \\
\hline $\mathrm{Mn}$ & 0 & 0 & 0.001 & 0.001 & 0 & 0 & 0.002 \\
\hline $\mathrm{Mg}$ & 0 & 0 & 0 & 0 & 0 & 0 & 0 \\
\hline $\mathrm{Ba}$ & 0 & 0.001 & 0.002 & 0.001 & 0.002 & 0 & 0 \\
\hline $\mathrm{Ca}$ & 0.007 & 0.002 & 0.002 & 0.003 & 0.012 & 0 & 0 \\
\hline $\mathrm{Na}$ & 1.954 & 0.591 & 1.917 & 1.8 & 1.295 & 0.87 & 1.966 \\
\hline $\mathrm{K}$ & 0.021 & 1.348 & 0.027 & 0.155 & 0.671 & 1.16 & 0.011 \\
\hline Cátions & 9.997 & 9.971 & 9.971 & 9.982 & 9.999 & 10.043 & 10.021 \\
\hline$x$ & 8.015 & $8.02 B$ & 8.02 & 8.021 & 8.017 & 8.013 & 8.042 \\
\hline \multirow[t]{2}{*}{$\hat{z}$} & 1.982 & 1.942 & 1.949 & 1.96 & 1.98 & 2.03 & 1.979 \\
\hline & \multicolumn{7}{|c|}{ Componentes Moleculares } \\
\hline$A b$ & 98.6 & 30.4 & 98.5 & 91.9 & 65.5 & 42.9 & 99.4 \\
\hline An & 0.4 & 0.1 & 0.1 & 0.2 & 0.6 & 0 & 0 \\
\hline Or & 1.1 & 69.4 & 1.4 & 7.9 & 33.9 & 57.1 & 0.6 \\
\hline
\end{tabular}

Observaçöes: Fe red calculado como $\mathrm{Fe}^{3+}$, abreviaçбes como na tabela 12.0 


\begin{tabular}{|c|c|c|c|c|c|c|c|}
\hline Amostra & RP-74 & RP-74 & RP-74 & RP.74 & RP-74 & RP.74 & RP-74 \\
\hline Análise & 904 & 909 & 910 & 911 & 912 & 913 & 914 \\
\hline Locaçãa & $C 1 G 4 n$ & C3Gin & C3G1b & $C 3 G 2 n$ & C3G3n & C3G4n & CAG1n \\
\hline Mineral & Alb & $\mathrm{Kf}$ & Alb & Kf & Alb & $\mathrm{Alb}$ & Alb \\
\hline $\mathrm{SiO}_{2}$ & 66.43 & 63.31 & 67.92 & 63.08 & 68.63 & 67.57 & 67.42 \\
\hline $\mathrm{TiO}_{2}$ & 0 & 0.01 & 0.03 & 0.01 & 0.05 & 0.08 & 0.05 \\
\hline $\mathrm{Al}_{2} \mathrm{O}_{3}$ & 19.02 & 18.02 & 19.45 & 18.01 & 19.56 & 19.39 & 19.42 \\
\hline $\mathrm{Fe}_{2} \mathrm{O}_{3}$ & 0.21 & 0.24 & 0.23 & 0.05 & 0.33 & 0.2 & 0.05 \\
\hline MnO & 0 & 0 & 0 & 0 & 0 & 0 & 0 \\
\hline Sro & 0.01 & 0 & 0 & 0 & 0.04 & 0 & 0 \\
\hline $\mathrm{BaO}$ & 0 & 0.14 & 0.08 & 0.27 & 0.04 & 0 & 0.03 \\
\hline $\mathrm{CaO}$ & 0 & 0 & 0.05 & 0 & 0.03 & 0.07 & 0 \\
\hline $\mathrm{Na}_{2} \mathrm{O}$ & 8.43 & 0.5 & 11.74 & 0.49 & 12.05 & 12.03 & 9.21 \\
\hline $\mathrm{K}_{2} \mathrm{O}$ & 4.84 & 15.98 & 0.1 & 15.98 & 0.22 & 0.17 & 4.18 \\
\hline $\mathrm{MgO}$ & 0.01 & 0 & 0 & 0 & 0 & 0 & 0 \\
\hline Total & 98.94 & 98.2 & 99.6 & 97.89 & 100.91 & 99.51 & 100.36 \\
\hline \multicolumn{8}{|c|}{ Fómula estrutural calculada na base de 32 stomos de oxigennio } \\
\hline Si & 5.982 & 5.992 & 5.982 & 5.987 & 5.99 & 5.98 & 5.974 \\
\hline Al & 2.017 & 2.008 & 2.017 & 2.013 & 2.01 & 2.021 & 2.026 \\
\hline $\mathrm{Fe}^{3+}$ & 0.014 & 0.017 & 0.015 & 0.004 & 0.022 & 0.013 & 0.003 \\
\hline $\mathrm{Ti}$ & 0 & 0.001 & 0.002 & 0.001 & 0.003 & 0.005 & 0.003 \\
\hline Mn & 0 & 0 & 0 & 0 & 0 & 0 & 0 \\
\hline $\mathrm{Mg}$ & 0.001 & 0 & 0 & 0 & 0 & 0 & 0 \\
\hline $\mathrm{Ba}$ & 0 & 0.005 & 0.003 & 0.01 & 0.001 & 0 & 0.001 \\
\hline $\mathrm{Ca}$ & 0 & 0 & 0.005 & 0 & 0.003 & 0.007 & 0 \\
\hline $\mathrm{Na}$ & 1.472 & 0.092 & 2.005 & 0.09 & 2.039 & 2.064 & 1.582 \\
\hline K & 0.556 & 1.929 & 0.011 & 1.935 & 0.024 & 0.019 & 0.472 \\
\hline Cátions & 10.042 & 10.049 & 10.043 & 10.05 & 10.093 & $\{0.109$ & 10.062 \\
\hline $\mathrm{x}$ & 8.013 & 8.018 & 8.016 & 8.005 & 8.025 & 8.019 & 8.006 \\
\hline$z$ & 2.029 & 2.026 & 2.024 & 2.035 & 2.067 & 2.09 & 2.055 \\
\hline \multicolumn{8}{|c|}{ Componentes Moleculares } \\
\hline$A B$ & 72.6 & 4.6 & 99.2 & 4.4 & 98.7 & 98.8 & 77 \\
\hline An & 0 & 0 & 0.2 & 0 & 0.1 & 0.3 & 0 \\
\hline Or & 27.4 & 95.4 & 0.5 & 95.6 & 1.2 & 0.9 & 23 \\
\hline
\end{tabular}

Observaç̧es: Fena calculado como $\mathrm{Fe}^{3+}$, abreviaçōes como na tabela 12.0 
Tabela 12.14 - Composição química de feldspatos de Cerro Siete Cabezas (\% peso)

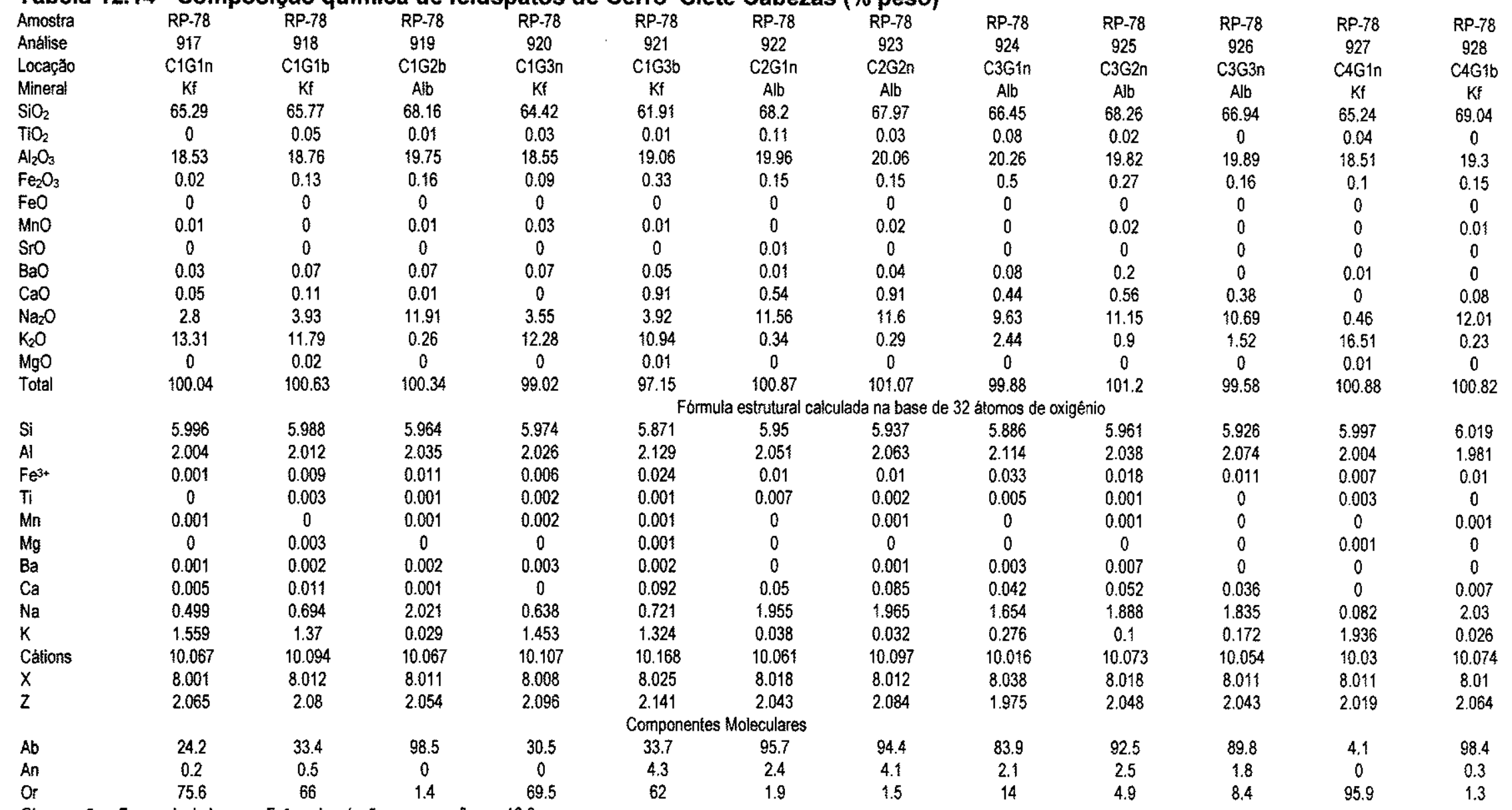


Tabela 12.15 - Composição química de feldspatos de Cerro Siete Cabezas (\% peso)

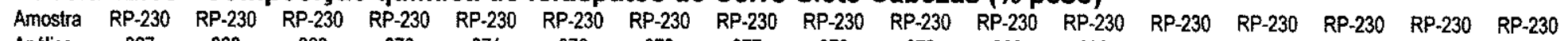

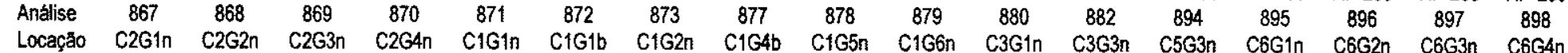
Mineral Alb Alb Alb Alb $\mathrm{Kf}$ Alb Alb Alb Alb Alb Alb Alb Alb Kf Alb Alb Alb

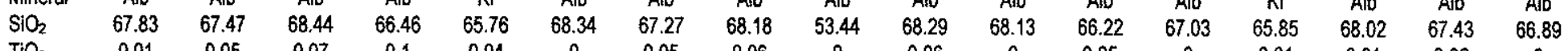

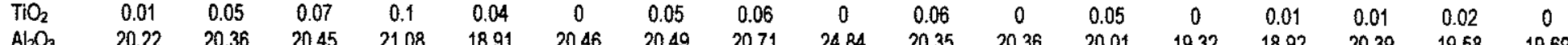

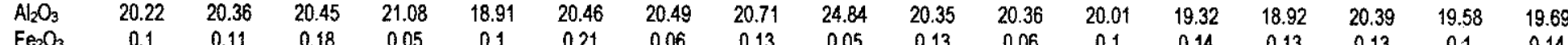

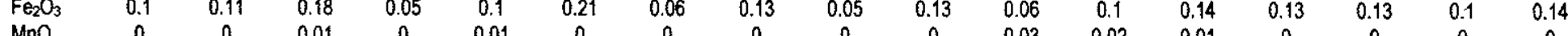

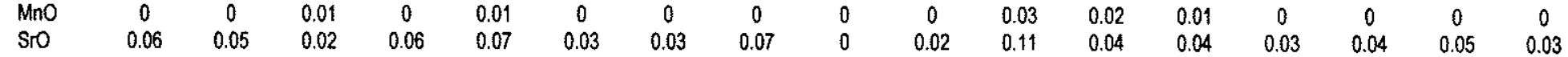

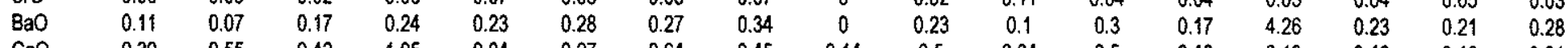

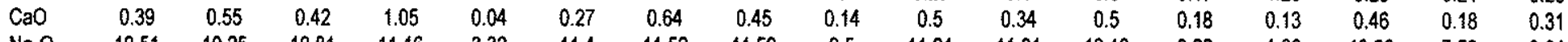

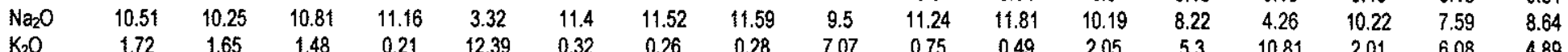

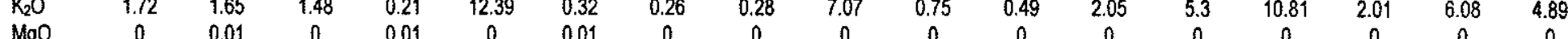

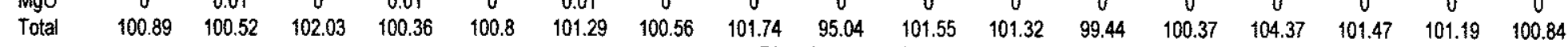

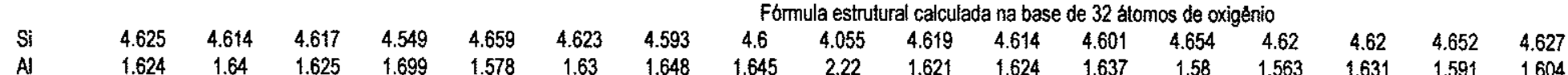
$\begin{array}{llllllllllllllllll}\mathrm{A} & 1.624 & 1.64 & 1.625 & 1.699 & 1.578 & 1.63 & 1.648 & 1.645 & 2.22 & 1.621 & 1.624 & 1.637 & 1.58 & 1.563 & 1.631 & 1.591 & 1.604 \\ \mathrm{Fe}^{3+} & 0.005 & 0.006 & 0.009 & 0.003 & 0.005 & 0.011 & 0.003 & 0.007 & 0.003 & 0.007 & 0.003 & 0.005 & 0.007 & 0.007 & 0.007 & 0.005 & 0.007\end{array}$

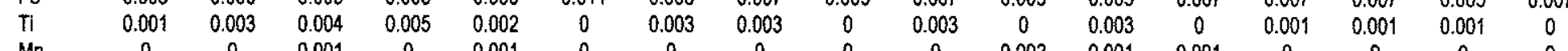

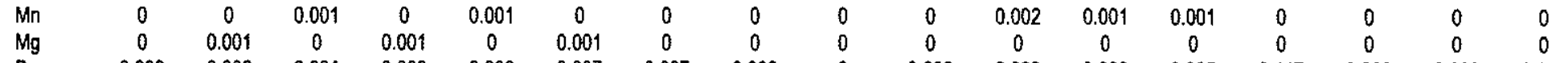

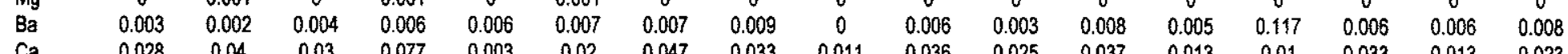
\begin{tabular}{llllllllllllllllll}
$\mathrm{Ca}$ & 0.028 & 0.04 & 0.03 & 0.077 & 0.003 & 0.02 & 0.047 & 0.033 & 0.011 & 0.036 & 0.025 & 0.037 & 0.013 & 0.01 & 0.033 & 0.013 & 0.023 \\
\hline & 1.39 & 1.359 & 1.414 & 1.481 & 0.456 & 1.495 & 1.525 & 1.516 & 1.398 & 1.474 & 1.551 & 1.373 & 1.107 & 0.58 & 1.346 & 1.015 & 1.159
\end{tabular}

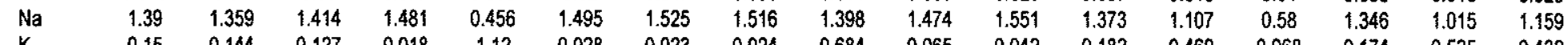

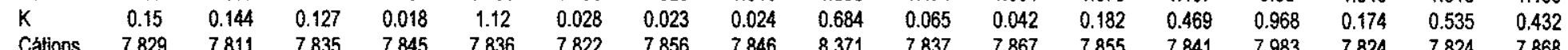

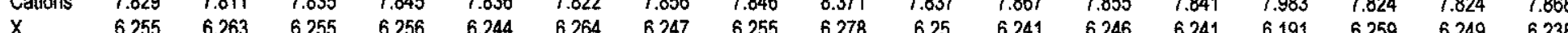

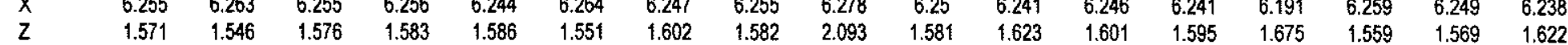

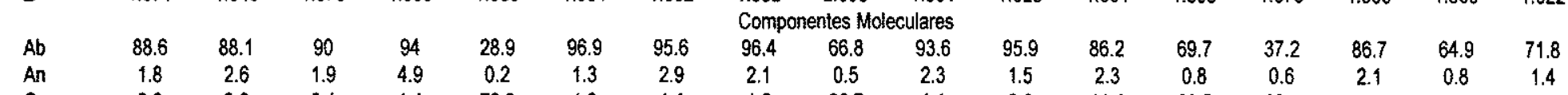

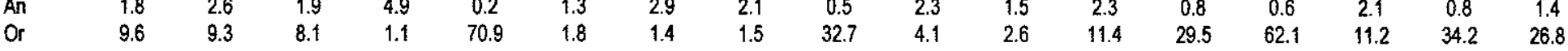

Observaçőes: Fe exta calculado como $\mathrm{Fe}^{3+}$, abreviaç̧es como na tabela 120 
Tabela 12.16 - Composiçẵo química de feldspatos de Pão de Açúcar (\% peso)

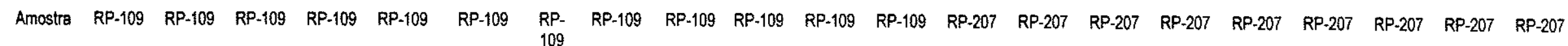

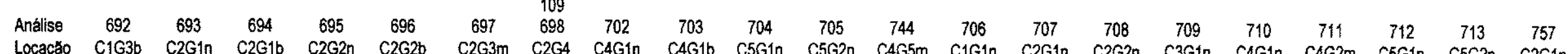
C5 C25 C2G1n

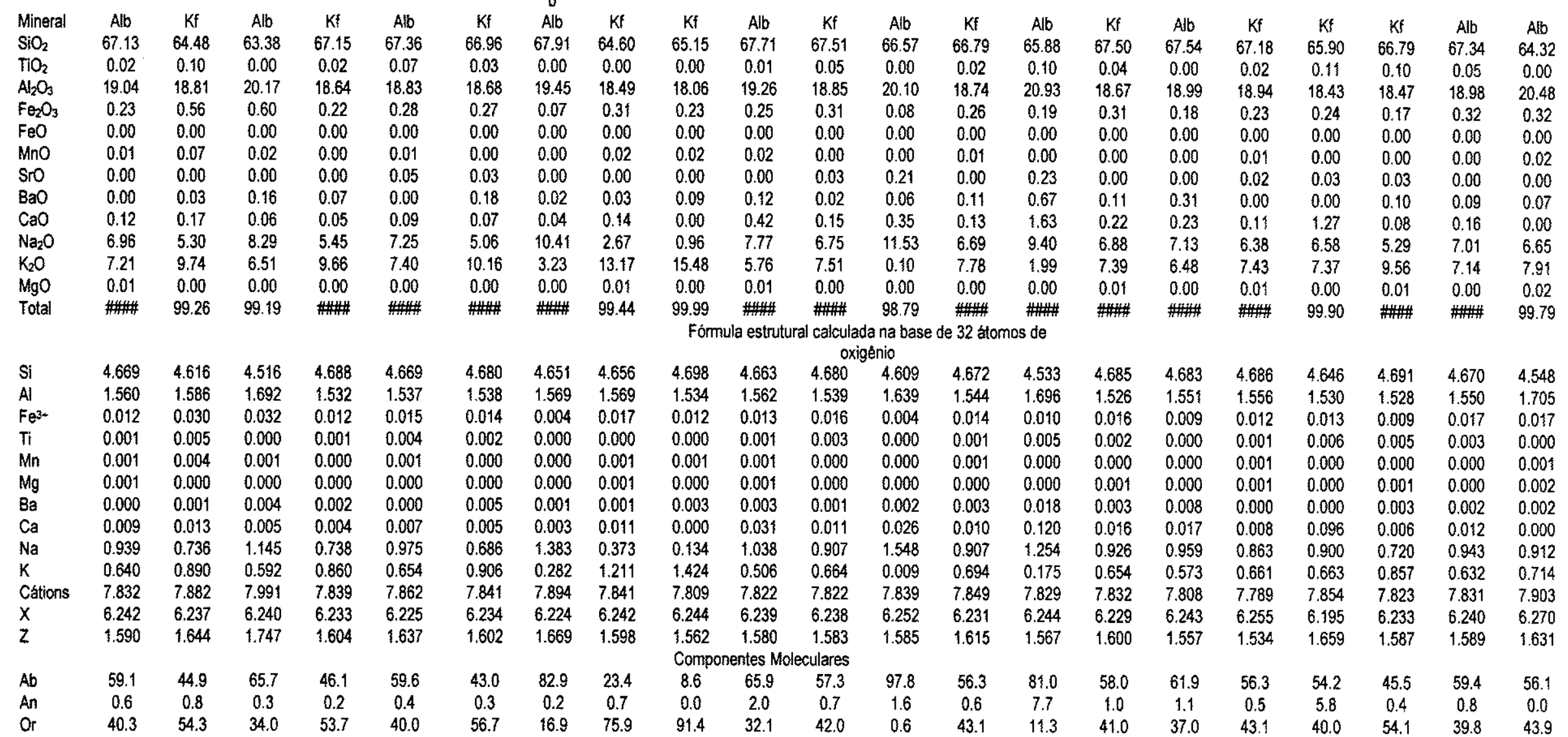

Observaçסes: Fe 
Tabela 12.17 - Composição química de feldspatos de Păo de Açúcar (\% peso)

\begin{tabular}{|c|c|c|c|c|c|c|c|c|c|}
\hline $\begin{array}{l}\text { Amostra } \\
\text { Análise }\end{array}$ & $\begin{array}{c}R P-207 \\
758\end{array}$ & $\begin{array}{c}\text { RP-207 } \\
760\end{array}$ & $\begin{array}{c}\text { RP-207 } \\
763\end{array}$ & $\begin{array}{c}\text { RP-207 } \\
776\end{array}$ & $\begin{array}{c}\text { RP-207 } \\
777\end{array}$ & $\begin{array}{c}\text { RP-207 } \\
778\end{array}$ & $\begin{array}{c}\text { RP-207 } \\
779\end{array}$ & $\begin{array}{c}\text { RP-207 } \\
780\end{array}$ & $\begin{array}{c}\text { RP-207 } \\
781\end{array}$ \\
\hline Locaçăo & $\mathrm{C} 2 \mathrm{G} 2 \mathrm{~m}$ & $\mathrm{C} 2 \mathrm{G} 4 \mathrm{~m}$ & $\mathrm{C} 3 \mathrm{G} 2 \mathrm{~m}$ & $\mathrm{C} 4 \mathrm{G} 5 \mathrm{~m}$ & C5Gin & C5G2n & $C 5 G 3 n$ & C5G4n & C5G5n \\
\hline Mineral & Kf & Kf & Kf & Alb & $A B D$ & $\mathrm{Kf}$ & $\mathrm{Kf}$ & $A l b$ & Alb \\
\hline $\mathrm{SiO}_{2}$ & 63.83 & 62.86 & 65.06 & 65.82 & 51.53 & 63.93 & 64.67 & 66.64 & 65.79 \\
\hline $\mathrm{TiO}_{2}$ & 0.00 & 0.00 & 0.00 & 0.00 & 0.00 & 0.00 & 0.00 & 0.00 & 0.00 \\
\hline $\mathrm{Al}_{2} \mathrm{O}_{3}$ & 18.28 & 18.28 & 18.95 & 20.31 & 27.70 & 18.46 & 18.50 & 19.22 & 18.82 \\
\hline $\mathrm{Fe}_{2} \mathrm{O}_{3}$ & 0.28 & 0.73 & 0.24 & 0.08 & 0.11 & 0.13 & 0.21 & 0.26 & 0.47 \\
\hline FeO & 0.00 & 0.00 & 0.00 & 0.00 & 0.00 & 0.00 & 0.00 & 0.00 & 0.00 \\
\hline $\mathrm{MnO}$ & 0.00 & 0.00 & 0.01 & 0.00 & 0.02 & 0.02 & 0.00 & 0.01 & 0.02 \\
\hline Sro & 0.15 & 0.02 & 0.12 & 0.02 & 0.00 & 0.17 & 0.05 & 0.03 & 0.05 \\
\hline $\mathrm{BaO}$ & 0.32 & 0.41 & 0.10 & 0.05 & 0.00 & 0.10 & 0.07 & 0.07 & 0.17 \\
\hline $\mathrm{CaO}$ & 0.01 & 0.00 & 0.08 & 0.02 & 0.00 & 0.05 & 0.05 & 0.05 & 0.01 \\
\hline $\mathrm{Na}_{2} \mathrm{O}$ & 3.22 & 0.88 & 6.50 & 11.57 & 14.19 & 5.84 & 5.53 & 11.81 & 11.96 \\
\hline $\mathrm{K}_{2} \mathrm{O}$ & 12.42 & 15.51 & 7.82 & 0.13 & 3.85 & 8.79 & 9.36 & 0.13 & 0.17 \\
\hline $\mathrm{MgO}$ & 0.00 & 0.00 & 0.01 & 0.01 & 0.00 & 0.00 & 0.00 & 0.00 & 0.00 \\
\hline \multirow[t]{2}{*}{ Total } & 98.36 & 98.67 & 98.77 & 97.99 & 97.40 & 97.32 & 98.39 & 98.19 & 97.41 \\
\hline & & & & & \multicolumn{3}{|c|}{ Fómula estrutural calculada na base } & 32 átomo & le Oxigénio \\
\hline $\mathrm{Si}$ & 4.651 & 4.628 & 4.636 & 4.596 & 3.825 & 4.643 & 4.653 & 4.648 & 4.641 \\
\hline Al & 1.568 & 1.585 & 1.590 & $\$ .670$ & 2.421 & 1.579 & 1.568 & 1.579 & 1.563 \\
\hline $\mathrm{Fe}^{3+}$ & 0.015 & 0.040 & 0.013 & 0.004 & 0.006 & 0.007 & 0.011 & 0.014 & 0.025 \\
\hline $\mathrm{Ti}$ & 0.000 & 0.000 & 0.000 & 0.000 & 0.000 & 0.000 & 0.000 & 0.000 & 0.000 \\
\hline $\mathrm{Mn}$ & 0.000 & 0.000 & 0.001 & 0.000 & 0.001 & 0.001 & 0.000 & 0.001 & 0.001 \\
\hline $\mathrm{Mg}$ & 0.000 & 0.000 & 0.001 & 0.001 & 0.000 & 0.000 & 0.000 & 0.000 & 0.000 \\
\hline $\mathrm{Ba}$ & 0.009 & 0.012 & 0.003 & 0.001 & 0.000 & 0.003 & 0.002 & 0.002 & 0.005 \\
\hline $\mathrm{Ca}$ & 0.001 & 0.000 & 0.006 & 0.001 & 0.000 & 0.004 & 0.004 & 0.004 & 0.001 \\
\hline $\mathrm{Na}$ & 0.455 & 0.126 & 0.898 & 1.567 & 2.042 & 0.822 & 0.772 & 1.597 & 1.636 \\
\hline $\mathrm{k}$ & 1.154 & 1.457 & 0.711 & 0.012 & 0.365 & 0.814 & 0.859 & 0.012 & 0.045 \\
\hline Cátions & 7.862 & 7.860 & 7.862 & 7.853 & 8.660 & 7.876 & 7.871 & 7.859 & 7.892 \\
\hline $\mathrm{x}$ & 6.234 & 6.253 & 6.239 & 6.270 & 6.252 & 6.229 & 6.232 & 6.241 & 6.229 \\
\hline \multirow[t]{2}{*}{$z$} & 1.619 & 1.595 & $\{.620$ & 1.582 & 2.408 & 1.644 & 1.637 & 1.616 & 1.658 \\
\hline & & & \multicolumn{7}{|c|}{ Componentes Moleculares } \\
\hline$A b$ & 28.3 & 8.0 & 55.6 & 99.2 & $84.8^{\circ}$ & 50.1 & 47.2 & 99.0 & 99.0 \\
\hline An & 0.1 & 0.0 & 0.4 & 0.1 & 0.0 & 0.2 & 0.2 & 0.2 & 0.1 \\
\hline Or & 71.7 & 92.0 & 44.0 & 0.8 & $\$ 5.2$ & 49.6 & 52.5 & 0.7 & 0.9 \\
\hline
\end{tabular}


Tabela 12.18 - Composição quimica de feldspatos da llha Fecho dos Morros (\% peso)

Amostra RP-91 RP-91 RP-91 RP-201A RP-201A RP-201A RP- RP-201A RP-201A RP-222 $\quad$ RP-222 RP-222 RP-222

$\begin{array}{llllllllllllll}\text { Análise } & 1042 & 1043 & 1044 & 1008 & 1009 & 1023 & 1024 & 1025 & 1026 & 1120 & 1122 & 1125 & 1126\end{array}$

Locaçấa C1G1n C1G2n C2Gin C2G1n C2Gib C4G4n $\begin{gathered}\text { C4G4 } \\ \text { C5G1n }\end{gathered}$

\begin{tabular}{|c|c|c|c|c|c|c|c|c|c|c|c|c|c|}
\hline Mineral & Alb & $A \mathrm{Ab}$ & $A B$ & $\mathrm{Kf}$ & $\mathrm{Kf}$ & Alb & Alb & Kf & Alb & $\mathrm{Kf}$ & $\mathrm{Kf}$ & $\mathrm{Kf}$ & $\mathrm{Kf}$ \\
\hline $\mathrm{SiO}_{2}$ & 67.56 & 66.75 & 66.96 & 65.65 & 66.22 & 69.73 & 68.47 & 66.65 & 66.79 & 65.83 & 65.77 & 65.47 & 65.41 \\
\hline $\mathrm{TiO}_{2}$ & 0.02 & 0.01 & 0.01 & 0.02 & 0.00 & 0.03 & 0.04 & 0.03 & 0.33 & 0.00 & 0.00 & 0.07 & 0.00 \\
\hline $\mathrm{Al}_{2} \mathrm{O}_{3}$ & 18.97 & 18.51 & $\{8.97$ & $\{8.73$ & 18.57 & 19.48 & $\{9.58$ & $\$ 8.46$ & 19.22 & 18.41 & 18.33 & 18.29 & 18.22 \\
\hline $\mathrm{Fe}_{2} \mathrm{O}_{3}$ & 0.59 & 0.38 & 0.70 & 0.25 & 0.33 & 0.15 & 0.11 & 0.31 & 2.87 & 0.00 & 0.07 & 0.10 & 0.04 \\
\hline $\mathrm{FeO}$ & 0.00 & 0.00 & 0.00 & 0.00 & 0.00 & 0.00 & 0.00 & 0.00 & 0.00 & 0.00 & 0.00 & 0.00 & 0.00 \\
\hline $\mathrm{MnO}$ & 0.00 & 0.00 & 0.03 & 0.00 & 0.01 & 0.01 & 0.02 & 0.02 & 0.04 & 0.00 & 0.02 & 0.01 & 0.00 \\
\hline SrO & 0.00 & 0.00 & 0.00 & 0.00 & 0.00 & 0.00 & 0.00 & 0.00 & 0.00 & 0.00 & 0.00 & 0.00 & 0.00 \\
\hline $\mathrm{BaO}$ & 0.00 & 0.04 & 0.00 & 0.11 & 0.16 & 0.00 & 0.45 & 0.11 & 0.15 & 0.00 & 0.09 & 0.01 & 0.00 \\
\hline $\mathrm{CaO}$ & 0.03 & 0.00 & 0.04 & 0.01 & 0.00 & 0.05 & 0.03 & 0.00 & 0.01 & 0.0 & 0.00 & 0.0 & 0.00 \\
\hline $\mathrm{Na}_{2} \mathrm{O}$ & 8.51 & 5.09 & 7.23 & $\{.37$ & 2.60 & 11.62 & 10.13 & 3.13 & 10.92 & 0.48 & 0.48 & 0.47 & 0.46 \\
\hline $\mathrm{K}_{2} \mathrm{O}$ & 4.55 & 10.32 & 6.62 & 15.02 & 13.19 & 0.23 & $\{.94$ & 12.64 & 0.72 & 16.24 & 16.12 & 16.21 & 15.98 \\
\hline $\mathrm{MgO}$ & 0.00 & 0.00 & 0.00 & 0.00 & 0.00 & 0.00 & 0.00 & 0.00 & 0.00 & 0.00 & 0.00 & 0.00 & 0.00 \\
\hline \multirow[t]{2}{*}{ Total } & \#\# & \#\#\# & \#\# & \#\#\# & \#\#\# & \#\#\# & \#\# & \#\#\#\# & \#\# & \#\#\# & \#\#\# & \#\#\# & \#\# \\
\hline & & & & \multicolumn{10}{|c|}{ Fómula estrutural calculada na base de 32 atomos de oxigênio } \\
\hline $\mathrm{Si}$ & 6.012 & 6.031 & 5.999 & 4.671 & 4.686 & 4.696 & 4.676 & 4.694 & 4.576 & 4.701 & 4.702 & 4.695 & 4.707 \\
\hline Al & 1.988 & 1.969 & 2.001 & 1.569 & 1.547 & & & 1.531 & & & & 1.545 & 1.544 \\
\hline $\mathrm{Fe}^{3+}$ & 0.039 & 0.026 & 0.047 & 0.013 & 0.018 & 0.008 & 0.006 & 0.016 & 0.1 & 0.000 & 0.004 & 0.005 & 0.002 \\
\hline $\mathrm{Ti}$ & 0.001 & 0.001 & 0.001 & 0.001 & 0.000 & 0.002 & 0.002 & 0.002 & 0.017 & 0.000 & 0.000 & 0.004 & 0.000 \\
\hline $\mathrm{Mn}$ & 0.000 & 0.000 & 0.002 & 0.000 & 0.001 & 0.001 & 0.001 & 0.001 & 0 & 0.000 & 0.001 & 0.001 & 0.000 \\
\hline $\mathrm{Mg}$ & 0.000 & 0.000 & 0.000 & 0.000 & 0.000 & & 0.000 & 0.000 & & & & 0.0 & 0.000 \\
\hline $\mathrm{Ba}$ & 0.000 & 0.001 & 0.000 & 0.003 & 0.004 & 0.000 & 0.012 & 0.003 & 0.0 & 0.000 & 0.003 & 0.000 & 0.00 \\
\hline $\mathrm{Ca}$ & 0.003 & 0.000 & 0.004 & 0.001 & 0.000 & 0.004 & 0.002 & 0.000 & 0.001 & 0.000 & 0.000 & 0.000 & 0.00 \\
\hline $\mathrm{Na}$ & 1.468 & 0.892 & 1.256 & 0.189 & 0.357 & 1.518 & 1.341 & 0.427 & 1.451 & 0.066 & 0.067 & 0.065 & 0.064 \\
\hline $\mathrm{K}$ & 0.517 & 1.189 & 0.757 & 1.363 & 1.191 & & 0.169 & 1.13 & 0.0 & 1.480 & $\$ .470$ & 1.483 & 1.467 \\
\hline Cátions & \#\# & \#\# & \#\# & 7.813 & 7.808 & 7.7 & 7.796 & 7.8 & 7.8 & $7.7 \mathrm{~s}$ & 7.793 & 7.798 & 7.784 \\
\hline$x$ & 8.040 & 8.027 & 8.048 & 6.254 & 6.251 & 6.251 & 6.259 & 6.243 & 6.292 & 6.249 & 6.249 & 6.249 & 6.253 \\
\hline \multirow[t]{2}{*}{$z$} & 1.988 & 2.082 & 2.019 & 1.556 & 1.553 & 1.543 & 1.525 & 1.567 & 1.521 & 1.546 & 1.541 & 1.549 & 1.53 \\
\hline & & \multicolumn{12}{|c|}{ Componentes Moleculares } \\
\hline$A b$ & 73.8 & 42.9 & 62.3 & 12.2 & 23.1 & 98.4 & 88.7 & 27.3 & 95.8 & 4. & 4.4 & 4.2 & 4.2 \\
\hline An & 0.2 & 0.0 & 0.2 & 0.1 & 0.0 & 0.3 & 0.1 & 0.0 & 0.1 & 0.0 & 0.0 & 0.0 & 0.0 \\
\hline Or & 26.0 & 57.1 & 37.5 & 87.8 & 76.9 & 1.3 & 11.2 & 72.7 & 4.2 & 95.7 & 95.6 & 95.8 & 95.8 \\
\hline
\end{tabular}

Observaçðes: Fe veat calculado como $\mathrm{Fe}^{3+}$, abreviaçōes como na tabela 12,0 
Tabela 12.19 - Composiçäo quimica de feldspatos de Cerro Pedreira (\% peso)

\begin{tabular}{|c|c|c|c|c|c|c|}
\hline $\begin{array}{l}\text { Amostra } \\
\text { Análise }\end{array}$ & $\begin{array}{c}\text { RP-205 } \\
1032\end{array}$ & $\begin{array}{c}\text { RP-205 } \\
1033\end{array}$ & $\begin{array}{c}\mathrm{RP}-205 \\
1034\end{array}$ & $\begin{array}{c}\text { RP-205 } \\
1035\end{array}$ & $\begin{array}{c}\text { RP-205 } \\
1040\end{array}$ & $\begin{array}{r}\text { RP-20 } \\
1041\end{array}$ \\
\hline Locação & C1G3n & C2G1n & $\mathrm{C} 2 \mathrm{G} 1 \mathrm{~b}$ & $\mathrm{C} 2 \mathrm{G} 2 \mathrm{n}$ & $C 4 G 2 n$ & $\mathrm{C}_{4} \mathrm{G}_{2}$ \\
\hline Mineral & Kf & Kf & Alb & $K f$ & Kf & $A l b$ \\
\hline $\mathrm{SiO}_{2}$ & 66.52 & 66.21 & 68.87 & 65.58 & 66.80 & 68.10 \\
\hline $\mathrm{TiO}_{2}$ & 0.00 & 0.00 & 0.07 & 0.10 & 0.04 & 0.09 \\
\hline $\mathrm{Al}_{2} \mathrm{O}_{3}$ & 18.82 & 18.27 & 19.00 & 18.52 & 18.58 & 19.65 \\
\hline $\mathrm{Fe}_{2} \mathrm{O}_{3}$ & 0.17 & 0.46 & 0.38 & 0.30 & 0.30 & 0.06 \\
\hline $\mathrm{FeO}$ & 0.00 & 0.00 & 0.00 & 0.00 & 0.00 & 0.00 \\
\hline MnO & 0.00 & 0.00 & 0.02 & 0.02 & 0.00 & 0.00 \\
\hline Sro & 0.00 & 0.00 & 0.00 & 0.00 & 0.00 & 0.00 \\
\hline $\mathrm{BaO}$ & 0.18 & 0.00 & 0.02 & 0.07 & 0.16 & 0.2 \\
\hline $\mathrm{CaO}$ & 0.00 & 0.00 & 0.01 & 0.00 & 0.00 & 0.3 \\
\hline $\mathrm{Na}_{2} \mathrm{O}$ & 4.23 & 2.15 & 9.71 & 2.08 & 4.44 & 10.17 \\
\hline $\mathrm{K}_{2} \mathrm{O}$ & 10.86 & 14.03 & 3.37 & $\{4.12$ & 10.29 & $\{.73$ \\
\hline $\mathrm{MgO}$ & 0.00 & 0.00 & 0.00 & 0.00 & 0.00 & 0.00 \\
\hline Total & 100.78 & 101.12 & 101.45 & 100.79 & 100.61 & 100 \\
\hline \multicolumn{7}{|c|}{ Formula estrutural calculada na base de 32 átomos de oxigênio } \\
\hline $\mathrm{Si}$ & 4.682 & 4.695 & 4.692 & 4.672 & 4.697 & \\
\hline Al & 1.560 & 1.526 & 1.524 & 1.554 & 1.538 & \\
\hline $\mathrm{Fe}^{3+}$ & 0.009 & 0.025 & 0.019 & 0.016 & 0.016 & \\
\hline $\mathrm{Ti}$ & 0.000 & 0.000 & 0.004 & 0.005 & 0.002 & 0.0 \\
\hline Mn & 0.000 & 0.000 & 0.001 & 0.001 & 0.000 & 0.000 \\
\hline $\mathrm{Mg}$ & 0.000 & 0.000 & 0.000 & 0.000 & 0.000 & \\
\hline $\mathrm{Ba}$ & 0.005 & 0.000 & 0.001 & 0.002 & 0.004 & \\
\hline $\mathrm{Ca}$ & 0.000 & 0.000 & 0.001 & 0.000 & 0.000 & \\
\hline $\mathrm{Na}$ & 0.577 & 0.296 & 1.283 & 0.287 & 0.605 & \\
\hline $\mathrm{k}$ & 0.975 & 1.269 & 0.293 & 1.283 & 0.923 & \\
\hline Cattions & 7.813 & 7.811 & 7.819 & 7.822 & 7.789 & \\
\hline$x$ & 6.251 & 6.246 & 6.239 & 6.247 & 6.253 & \\
\hline$z$ & 1.557 & 1.565 & 1.579 & 1.573 & 1.532 & \\
\hline \multicolumn{7}{|c|}{ Componentes Moleculares } \\
\hline$A b$ & 37.2 & 18.9 & 81.4 & 18.3 & 39.6 & 88 \\
\hline An & 0.0 & 0.0 & 0.1 & 0.0 & 0.0 & \\
\hline Or & 62.8 & 81.1 & 18.6 & 81.7 & 60.4 & 9.9 \\
\hline
\end{tabular}

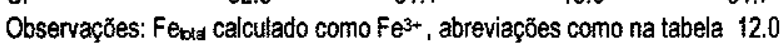


Tabela 12.20 - Composição química de feldspatos do Morro de São Pedro (\% peso)

\begin{tabular}{|c|c|c|c|c|c|c|c|}
\hline & & & & & & & \\
\hline Amostra & RP-255 & RP-255 & RP-256 & RP-256 & RP-256 & RP-256 & RP-256 \\
\hline Análise & 1131 & 1133 & 1137 & 1138 & 1142 & 1143 & 1144 \\
\hline Locaçăa & CiGin & C2Gin & C1Gtm & $\mathrm{C} 1 \mathrm{G} 2 \mathrm{~m}$ & C3Gtm & $\mathrm{C} 3 \mathrm{G} 2 \mathrm{~m}$ & C3G $3 m$ \\
\hline Mineral & $A B b$ & $A \mid b$ & Kf & $A B b$ & Alb & Alb & $\mathrm{Alb}$ \\
\hline $\mathrm{SiO}_{2}$ & 66.98 & 67.27 & 65.46 & 69.19 & 67.26 & 67.89 & 68.97 \\
\hline $\mathrm{THO}_{2}$ & 0.05 & 0.08 & 0.00 & 0.00 & 0.02 & 0.07 & 0.04 \\
\hline $\mathrm{Al}_{2} \mathrm{O}_{3}$ & 19.52 & 20.54 & 18.39 & 19.42 & 18.97 & 19.07 & 19.66 \\
\hline $\mathrm{Fe}_{2} \mathrm{O}_{3}$ & 0.18 & 0.17 & 0.09 & 0.08 & 0.17 & 0.18 & 0.01 \\
\hline $\mathrm{FeO}$ & 0.00 & 0.00 & 0.00 & 0.00 & 0.00 & 0.00 & 0.00 \\
\hline Mno & 0.02 & 0.03 & 0.00 & 0.00 & 0.01 & 0.00 & 0.00 \\
\hline Sro & 0.00 & 0.00 & 0.00 & 0.00 & 0.00 & 0.00 & 0.00 \\
\hline $\mathrm{BaO}$ & 0.17 & 0.35 & 0.00 & 0.00 & 0.00 & 0.00 & 0.12 \\
\hline $\mathrm{CaO}$ & 0.55 & 1.11 & 0.03 & 0.20 & 0.14 & 0.18 & 0.27 \\
\hline $\mathrm{Na}_{2} \mathrm{O}$ & 5.70 & 8.10 & 1.70 & 9.80 & 5.34 & 5.76 & 10.08 \\
\hline $\mathrm{K}_{2} \mathrm{O}$ & 7.94 & 3.75 & 14.43 & 2.48 & 8.76 & 8.45 & 1.49 \\
\hline $\mathrm{MgO}$ & 0.00 & 0.00 & 0.00 & 0.00 & 0.00 & 0.00 & 0.00 \\
\hline Total & 101.11 & 101.40 & 100.10 & 101.17 & 100.67 & 101.60 & 100.64 \\
\hline & & & Fórmul & urat calcu & na base o & 32 atomo & oxigénio \\
\hline Si & 4.651 & 4.601 & 4.691 & 4.698 & 4.691 & 4.689 & 4.690 \\
\hline Al & 1.596 & 1.654 & 1.552 & $\{.553$ & 1.558 & 1.551 & 1.574 \\
\hline $\mathrm{Fe}^{3+}$ & 0.009 & 0.009 & 0.005 & 0.004 & 0.009 & 0.009 & 0.001 \\
\hline $\mathrm{Ti}$ & 0.003 & 0.004 & 0.000 & 0.000 & 0.001 & 0.004 & 0.002 \\
\hline $\mathrm{Mn}$ & 0.001 & 0.002 & 0.000 & 0.000 & 0.001 & 0.000 & 0.000 \\
\hline $\mathrm{Mg}$ & 0.000 & 0.000 & 0.000 & 0.000 & 0.000 & 0.000 & 0.000 \\
\hline $\mathrm{Ba}$ & 0.005 & 0.009 & 0.000 & 0.000 & 0.000 & 0.000 & 0.003 \\
\hline $\mathrm{Ca}$ & 0.041 & 0.081 & 0.002 & 0.015 & 0.010 & 0.013 & 0.020 \\
\hline $\mathrm{Na}$ & 0.767 & 1.074 & 0.236 & 1.290 & 0.722 & 0.771 & 1.329 \\
\hline K & 0.703 & 0.327 & 1.319 & 0.215 & 0.780 & 0.745 & 0.129 \\
\hline Cations & 7.781 & 7.770 & 7.805 & 7.775 & 7.772 & 7.782 & 7.751 \\
\hline$x$ & 6.259 & 6.268 & 6.248 & 6.255 & 6.259 & 6.253 & 6.267 \\
\hline$z$ & $\{.517$ & 1.493 & 1.557 & 1.520 & 1.513 & 1.529 & 1.481 \\
\hline & & & Compon & Moleculare & & & \\
\hline$A b$ & 50.8 & 72.5 & 15.2 & 84.9 & 47.8 & 50.4 & 89.9 \\
\hline An & $\begin{array}{c}2.7 \\
46.5\end{array}$ & $\begin{array}{c}5.5 \\
22.1\end{array}$ & 0.1 & 1.0 & 0.7 & 0.9 & 1.4 \\
\hline Or & 46.5 & 22.1 & 84.7 & 14.1 & 51.6 & 48.7 & 8.7 \\
\hline
\end{tabular}

Observaçōes: Fe $e_{\text {tad }}$ calculado como $\mathrm{Fe}^{3+}$, abrevią̧бes como na tabela 12.0 
Tabela 12.21 - Composiçăo quimica de feldspatos de Morro Conceiçāo (\% peso)

\begin{tabular}{|c|c|c|c|c|c|c|c|c|}
\hline Amostra & RP-259 & $R P-259$ & RP-259 & RP-259 & RP-259 & $R P-259$ & RP-259 & RP-259 \\
\hline Análise & 1183 & 1184 & 1185 & 1186 & 1187 & 1188 & 1189 & 1190 \\
\hline Locação & C1Gin & C1G2n & C1G3n & $C 2 G 3 n$ & C2G4n & $\mathrm{C} 2 \mathrm{G} 5 \mathrm{n}$ & C3G1n & $\mathrm{C} 3 \mathrm{G} 2 \mathrm{n}$ \\
\hline Mineral & Alb & $\mathrm{Alb}$ & $\mathrm{Alb}$ & Alb & Alb & $\mathrm{Alb}$ & $\mathrm{Kf}$ & Alb \\
\hline $\mathrm{SiO}_{2}$ & 64.18 & 68.81 & 66.78 & 63.60 & 61.80 & 67.99 & 66.84 & 64.81 \\
\hline $\mathrm{TiO}_{2}$ & 0.07 & 0.07 & 0.00 & 0.07 & 0.09 & 0.15 & 0.04 & 0.12 \\
\hline $\mathrm{Al}_{2} \mathrm{O}_{3}$ & 22.32 & 20.12 & 19.10 & 22.10 & 24.32 & 19.74 & 18.54 & 22.23 \\
\hline $\mathrm{Fe}_{2} \mathrm{O}_{3}$ & 0.16 & 0.08 & 0.24 & 0.15 & 0.21 & 0.25 & 0.24 & 0.14 \\
\hline $\mathrm{FeO}$ & 0.00 & 0.00 & 0.00 & 0.00 & 0.00 & 0.00 & 0.00 & 0.00 \\
\hline Mno & 0.00 & 0.02 & 0.00 & 0.00 & 0.00 & 0.03 & 0.03 & 0.00 \\
\hline Sro & 0.00 & 0.00 & 0.00 & 0.00 & 0.00 & 0.00 & 0.00 & 0.00 \\
\hline $\mathrm{BaO}$ & 0.98 & 0.08 & 0.16 & 1.20 & 0.43 & 0.03 & 0.22 & 0.30 \\
\hline $\mathrm{CaO}$ & 3.23 & 0.57 & 0.43 & 3.10 & 5.57 & 0.78 & 0.09 & 3.30 \\
\hline $\mathrm{Na}_{2} \mathrm{O}$ & 7.99 & 10.27 & 6.41 & 7.29 & 7.39 & 8.82 & 4.16 & 8.64 \\
\hline $\mathrm{K}_{2} \mathrm{O}$ & 1.76 & 0.77 & 6.69 & 2.95 & 0.81 & 3.53 & 10.49 & 0.98 \\
\hline $\mathrm{MgO}$ & 0.00 & 0.00 & 0.00 & 0.00 & 0.00 & 0.00 & 0.00 & 0.00 \\
\hline \multirow[t]{2}{*}{ Total } & 100.69 & $\{00.79$ & 99.81 & 100.46 & 100.62 & 101.32 & 100.65 & 100.52 \\
\hline & & & & \multicolumn{5}{|c|}{ Fórmula estrutural calculada na base de 32 átomos de oxigênio } \\
\hline $\mathrm{Si}$ & 4.437 & 4.662 & 4.674 & 4.434 & 4.273 & 4.642 & 4.701 & 4.453 \\
\hline $\mathrm{Al}$ & 1.817 & 1.605 & 1.574 & 1.814 & 1.980 & 1.587 & 1.536 & 1.799 \\
\hline $\mathrm{Fe}^{3+}$ & 0.008 & 0.004 & 0.013 & 0.008 & 0.011 & 0.013 & 0.013 & 0.007 \\
\hline $\mathrm{Ti}$ & 0.004 & 0.004 & 0.000 & 0.004 & 0.005 & 0.008 & 0.002 & 0.006 \\
\hline $\mathrm{Mn}$ & 0.000 & 0.001 & 0.000 & 0.000 & 0.000 & 0.002 & 0.002 & 0.000 \\
\hline $\mathrm{Mg}$ & 0.000 & 0.000 & 0.000 & 0.000 & 0.000 & 0.000 & 0.000 & 0.000 \\
\hline $\mathrm{Ba}$ & 0.027 & 0.002 & 0.004 & 0.033 & 0.012 & 0.001 & 0.006 & 0.008 \\
\hline $\mathrm{Ca}$ & 0.239 & 0.041 & 0.032 & 0.232 & 0.413 & 0.057 & 0.007 & 0.243 \\
\hline $\mathrm{Na}$ & 1.071 & 1.349 & 0.870 & 0.985 & 0.991 & 1.168 & 0.567 & 1.151 \\
\hline $\mathrm{K}$ & 0.155 & 0.067 & 0.597 & 0.262 & 0.071 & 0.307 & 0.941 & 0.086 \\
\hline Cations & 7.785 & 7.737 & 7.768 & 7.805 & 7.768 & 7.786 & 7.781 & 7.761 \\
\hline$x$ & 6.266 & 6.275 & 6.261 & 6.260 & 6.269 & 6.250 & 6.252 & 6.265 \\
\hline \multirow[t]{2}{*}{$z$} & 1.492 & 1.460 & 1.503 & 1.512 & 1.487 & $\{.535$ & 1.523 & 1.488 \\
\hline & \multicolumn{8}{|c|}{ Componentes Moleculares } \\
\hline$A b$ & 73.1 & 92.6 & 58.0 & 66.6 & 67.2 & 76.2 & 37.4 & 77.8 \\
\hline$A n$ & 16.3 & 2.8 & 2.1 & 15.7 & 28.0 & 3.7 & 0.5 & 16.4 \\
\hline Or & 10.6 & 4.6 & 39.8 & 17.7 & 4.8 & 20.0 & 62.1 & 5.8 \\
\hline
\end{tabular}

Observaçőes: Fevta calculado comno $\mathrm{Fe}^{3+}$, abreviaçбos como na tabela 12.0 
Tabela 12.22 - Composiçāo química de feldspatos de Porto Conceição (\% peso)

$\begin{array}{lllllllllllllll}\text { Amostra RP-264 } & \text { RP-264 } & \text { RP-264 } & \text { RP-264 } & \text { RP-264 } & \text { RP-264 } & \text { RP- } & \text { RP-264 } & \text { RP-264 } & \text { RP-264 } & \text { RP-267 } & \text { RP-267 } & \text { RP-267 } & \text { RP-267 } & \text { RP-267 }\end{array}$

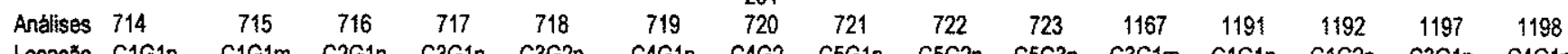
Locaçăo C1G1n C1G1m C2G1n C3G1n C3G2n C4G1n C4G2 C5G1n C5G2n C5G3n C3G1m C1G1n C1G2n C3G1n C4G1n

\begin{tabular}{|c|c|c|c|c|c|c|c|c|c|c|c|c|c|c|c|}
\hline $\begin{array}{l}\text { Mineral } \\
\mathrm{SiO}_{2}\end{array}$ & $\begin{array}{ll}\text { Alb } \\
61.18\end{array}$ & $\begin{array}{c}\text { Alb } \\
6674\end{array}$ & $\begin{array}{c}\text { Alb } \\
65.57\end{array}$ & $\begin{array}{c}\text { Alb } \\
6477\end{array}$ & Alb & Alb & Alb & $\begin{array}{l}\text { Alb } \\
6532\end{array}$ & $A i b$ & $A B b$ & Alb & Alb & Alb & Alb & Alb \\
\hline $\mathrm{SiO}_{2}$ & & & & & 61.90 & & & & 64.80 & 66.50 & 66.67 & 69.73 & 69.33 & 68.83 & 68.91 \\
\hline $\mathrm{THO}_{2}$ & 0.08 & 0.10 & 0.02 & 0.14 & 0.04 & 0.14 & 0.04 & 0.03 & 0.01 & 0.10 & 0.07 & 0.00 & 0.05 & 0.02 & 0.00 \\
\hline $\mathrm{Al}_{2} \mathrm{O}_{3}$ & 23.96 & 20.60 & 21.56 & 23.84 & 23.65 & 25.67 & 19.95 & 20.88 & 21.54 & 19.14 & 20.41 & 20.15 & 19.94 & 19.98 & 19.88 \\
\hline $\mathrm{Fe}_{2} \mathrm{O}_{3}$ & 0.44 & 0.44 & 0.21 & 0.42 & 0.44 & 0.38 & 0.19 & 0.53 & 0.42 & 0.65 & 0.12 & 0.14 & 0.15 & 0.14 & 0.11 \\
\hline $\mathrm{FeO}$ & 0.00 & 0.00 & 0.00 & 0.00 & 0.00 & 0.00 & 0.00 & 0.00 & 0.00 & 0.00 & 0.00 & 0.00 & 0.00 & 0.00 & 0.00 \\
\hline $\mathrm{MnO}$ & 0.02 & 0.01 & 0.02 & 0.00 & 0.01 & 0.00 & 0.02 & 0.01 & 0.00 & 0.05 & 0.00 & 0.02 & 0.00 & 0.01 & 0.00 \\
\hline Sro & 0.10 & 0.03 & 0.20 & 0.39 & 0.21 & 0.42 & 0.00 & 0.09 & 0.00 & 0.08 & 0.00 & 0.00 & 0.00 & 0.00 & 0.00 \\
\hline $\mathrm{BaO}$ & 0.02 & 0.00 & 0.06 & 0.34 & 0.16 & 0.13 & 0.06 & 0.06 & 0.15 & 0.31 & 0.00 & 0.04 & 0.10 & 0.18 & 0.05 \\
\hline $\mathrm{CaO}$ & 6.12 & 1.41 & 1.61 & 5.64 & 5.50 & 7.47 & 1.13 & 2.85 & 3.03 & 1.08 & 0.58 & 0.57 & 0.35 & 0.52 & 0.43 \\
\hline $\mathrm{Na}_{2} \mathrm{O}$ & 8.31 & 10.41 & 10.12 & 8.01 & 8.11 & 7.18 & 11.35 & 9.65 & 9.64 & 8.08 & 8.32 & 10.89 & 10.97 & 10.66 & 10.36 \\
\hline $\mathrm{K}_{2} \mathrm{O}$ & 0.39 & 0.80 & 0.83 & 0.71 & 0.62 & 0.52 & 0.31 & 0.46 & 0.53 & 4.65 & 3.95 & 0.17 & 0.22 & 0.20 & 0.70 \\
\hline $\mathrm{MgO}$ & 0.00 & 0.05 & 0.02 & 0.01 & 0.00 & 0.12 & 0.02 & 0.00 & 0.00 & 0.12 & 0.00 & 0.00 & 0.00 & 0.00 & 0.00 \\
\hline \multirow[t]{2}{*}{ Total } & \#\# & \#\# & \#\#\# & \#\#\# & \#\# & \#\# & \#\# & 99.79 & \#\#\# & \#\# & \#\# & \#\# & \#\#\# & \#\# & \#\# \\
\hline & & & & & \multicolumn{11}{|c|}{$\begin{array}{l}\text { Fómmula estrutural calculada na base de } 32 \text { atomos de } \\
\text { oxigênio }\end{array}$} \\
\hline$s i$ & 4.242 & 4.565 & 4.509 & 4.266 & 4.286 & 4.091 & 4.615 & 4.511 & 4.471 & 4.616 & 4.607 & 4.672 & 4.676 & 4.669 & 4.680 \\
\hline Al & 1.956 & 1.659 & 1.746 & 1.939 & 1.929 & 2.112 & 1.600 & 1.698 & 1.750 & 1.565 & 1.661 & 1.590 & $\{.584$ & 1.596 & 1.590 \\
\hline $\mathrm{Fe}^{3+}$ & 0.023 & 0.023 & 0.011 & 0.022 & 0.023 & 0.020 & 0.010 & 0.028 & 0.022 & 0.034 & 0.006 & 0.007 & 0.008 & 0.007 & 0.006 \\
\hline$T i$ & 0.004 & 0.005 & 0.001 & 0.007 & 0.002 & 0.007 & 0.002 & 0.002 & 0.001 & 0.005 & 0.004 & 0.000 & 0.003 & 0.001 & 0.000 \\
\hline $\mathrm{Mn}$ & 0.001 & 0.001 & 0.001 & 0.000 & 0.001 & 0.000 & 0.001 & 0.001 & 0.000 & 0.003 & 0.000 & 0.001 & 0.000 & 0.001 & 0.000 \\
\hline $\mathrm{Mg}$ & 0.000 & 0.005 & 0.002 & 0.001 & 0.000 & 0.012 & 0.002 & 0.000 & 0.000 & 0.012 & 0.000 & 0.000 & 0.000 & 0.000 & 0.000 \\
\hline $\mathrm{Ba}$ & 0.001 & 0.000 & 0.002 & 0.009 & 0.004 & 0.004 & 0.002 & 0.002 & 0.004 & 0.008 & 0.000 & 0.001 & 0.003 & 0.005 & 0.001 \\
\hline $\mathrm{Ca}$ & 0.455 & 0.103 & 0.119 & 0.417 & 0.408 & 0.559 & 0.082 & 0.211 & 0.224 & 0.080 & 0.043 & 0.041 & 0.025 & 0.038 & 0.031 \\
\hline $\mathrm{Na}$ & 1.117 & 1.384 & 1.349 & 1.073 & 1.089 & 0.973 & 1.498 & 1.292 & 1.290 & 1.088 & 1.145 & 1.415 & 1.434 & 1.402 & 1.364 \\
\hline$k$ & 0.034 & 0.070 & 0.073 & 0.063 & 0.055 & 0.046 & 0.027 & 0.041 & 0.047 & 0.412 & 0.348 & 0.015 & 0.019 & 0.017 & 0.061 \\
\hline Cátions & 7.834 & 7.812 & 7.815 & 7.806 & 7.801 & 7.828 & 7.841 & 7.788 & 7.813 & 7.831 & 7.784 & 7.743 & 7.755 & 7,741 & 7.734 \\
\hline$x$ & 6.225 & 6.252 & 6.267 & 6.234 & 6.240 & 6.230 & 6.227 & 6.239 & 6.244 & 6.220 & 6.278 & 6.269 & 6.271 & 6.273 & 6.276 \\
\hline \multirow[t]{2}{*}{2} & 1.608 & 1.560 & 1.546 & 1.563 & 1.557 & 1.594 & 1.612 & 1.547 & 1.565 & 1.603 & 1.506 & 1.473 & 1.481 & 1.463 & 1.457 \\
\hline & & \multicolumn{14}{|c|}{ Componentes Moleculares } \\
\hline$A b$ & 69.6 & 88.9 & 87.5 & 69.1 & 70.2 & 61.7 & 93.2 & 83.7 & 82.6 & 68.9 & 74.0 & 96.2 & 97.0 & 96.2 & 93.7 \\
\hline An & 28.3 & 6.6 & 7.7 & 26.9 & 26.3 & 35.4 & 5.1 & 13.7 & 14.3 & 5.1 & 2.9 & 2.8 & 1.7 & 2.6 & 2.1 \\
\hline Or & 2.1 & 4.5 & 4.7 & 4.1 & 3.5 & 2.9 & 1.7 & 2.7 & 3.0 & 26.1 & 23.1 & 1.0 & 1.3 & 1.2 & 4.2 \\
\hline
\end{tabular}

Observaçŏes: Fe $e_{\text {bat }}$ calculado como $\mathrm{Fe}^{3+}$, abreviações como na tabela 12.0 
Tabela 12.23 - Composiçāo química de feldspatos de Cerrito (\% peso)

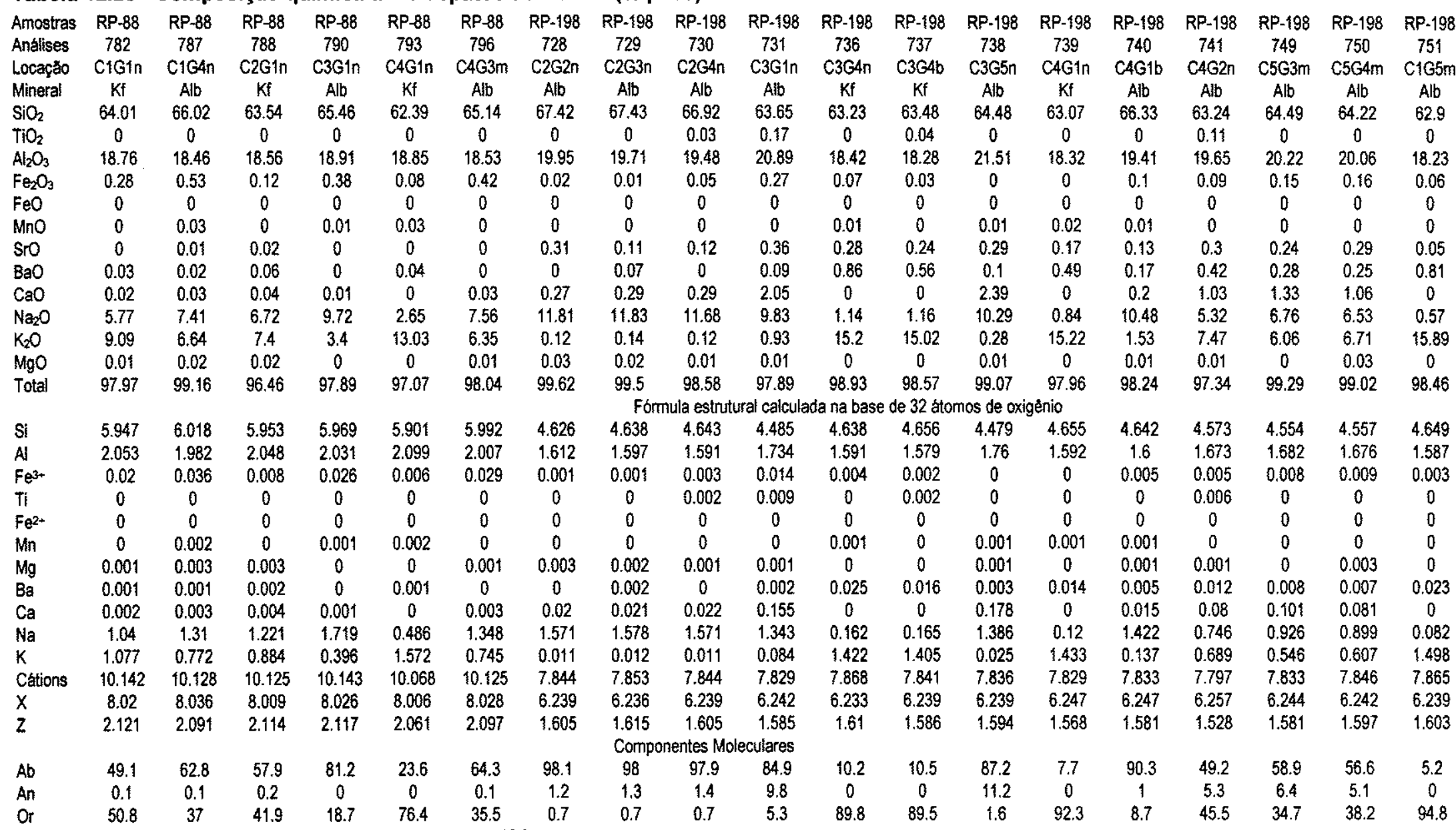

Observaçðes: $\mathrm{Fe}_{\text {xta }}$ calculado como $\mathrm{Fe}^{3+}$, abreviaçøes como na tabela 12.0 

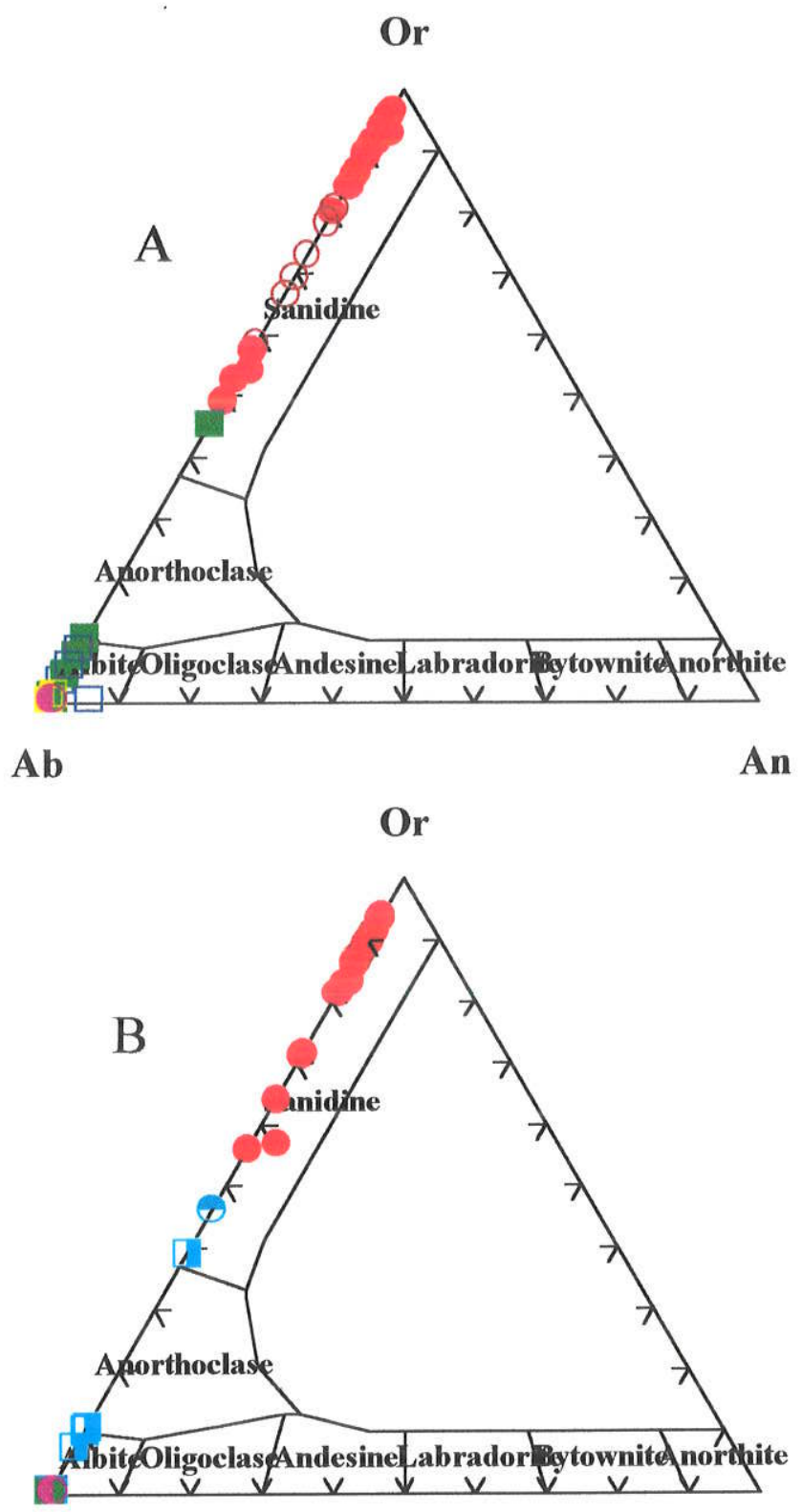

Ab

An

Figura 11 e 12 - Variação Composicional dos feldspatos de sienitos nefelínicos (acima) e fonolitos peralcalinos (inferior) de Cerro Boggiani expressas em proporções moleculares de ortoclásio, albita e anortita. No diagrama superior foram utilizadas as amostras RP-29, 30, 31B e 35; enquanto que no inferior, RP-32, 37, 41, 42 e 43.

Simbolos: núcleo de $k$-feldsp. $=$ círculos cheios, borda de $k$-feldsp.= círculos vazios, núcleo de albita $=$ quadrados cheios, borda de albita= quadrados vazios; matriz de $k$-feldsp.= cruzes; matriz albitica= $x i s ;$ inclusão= triângulos cheios; borda de reação $=$ círculo com metade lateral cheia; albita em intercrscimento pertitico $=$ quadrado com metade lateral cheia; feldspato potássico em intercrescimento pertítico $=$ círculo com metade superior cheia e feldspato potássico apresentando zoneamento em "patch"= quadrado com metade superior cheia. 


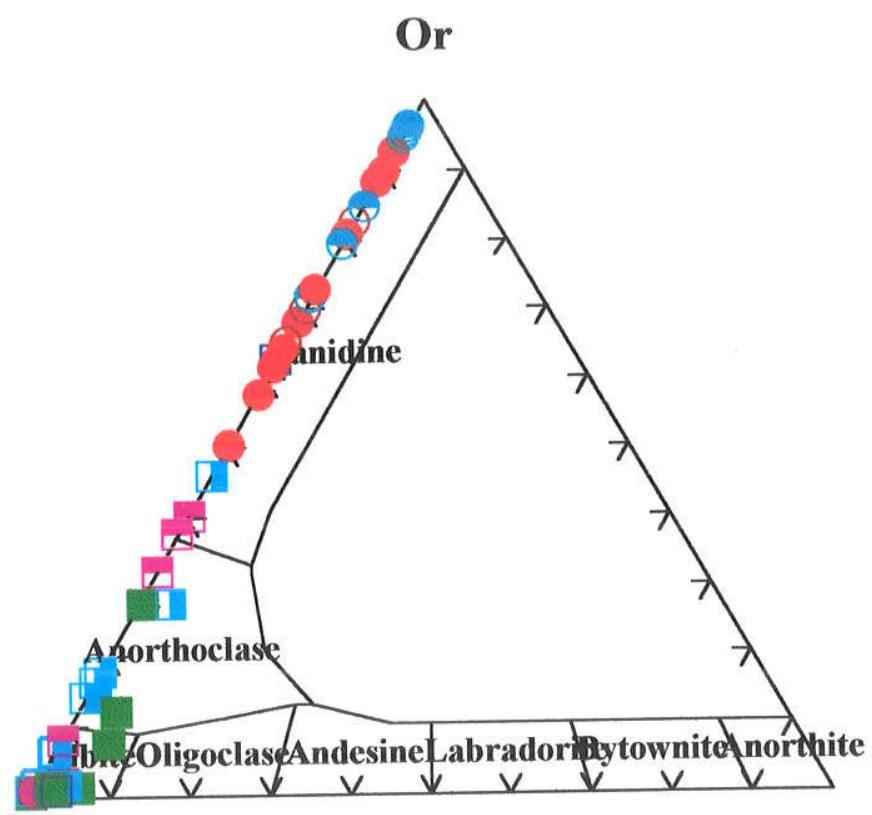

99

Ab

An

Figura 13 - Variação composicional dos feldspatos dos sienitos alcalinos. do corpo Satélite II expressas em proporçõesnas moleculares de Or-Ab-An, amostras 44, 46, 49, 50 e 51

Simbolos como na figura 11.

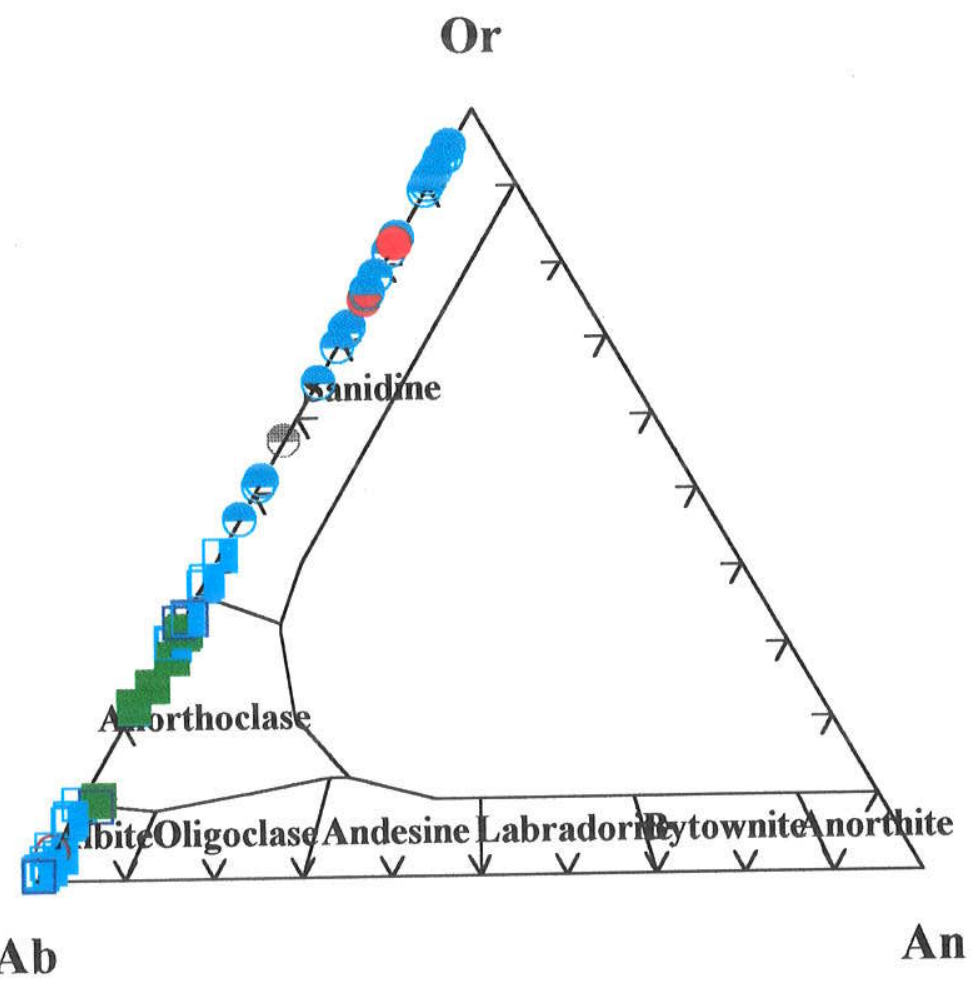

Figura 14 - Variação composicional de feldspatos dos sienitos alcalinos de Satélite I expressas em proporção molecular, amostras 51, 52, 56 e 58. Simbolos como na figura 11. 


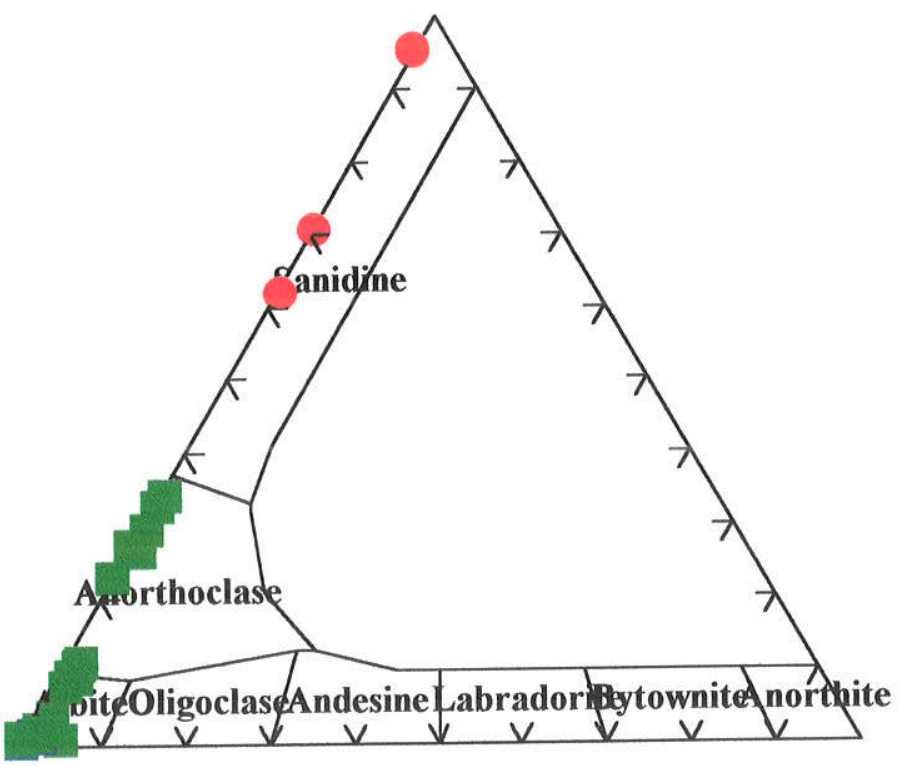

Ab

An

Figura 15 - Variação composicional de feldspatos dos nefelina sienitos de Cerro Siete Cabezas expressa em proporção molecular de Or-Ab-An. Amostras 74 e 230. Simbolos como na figura 11.

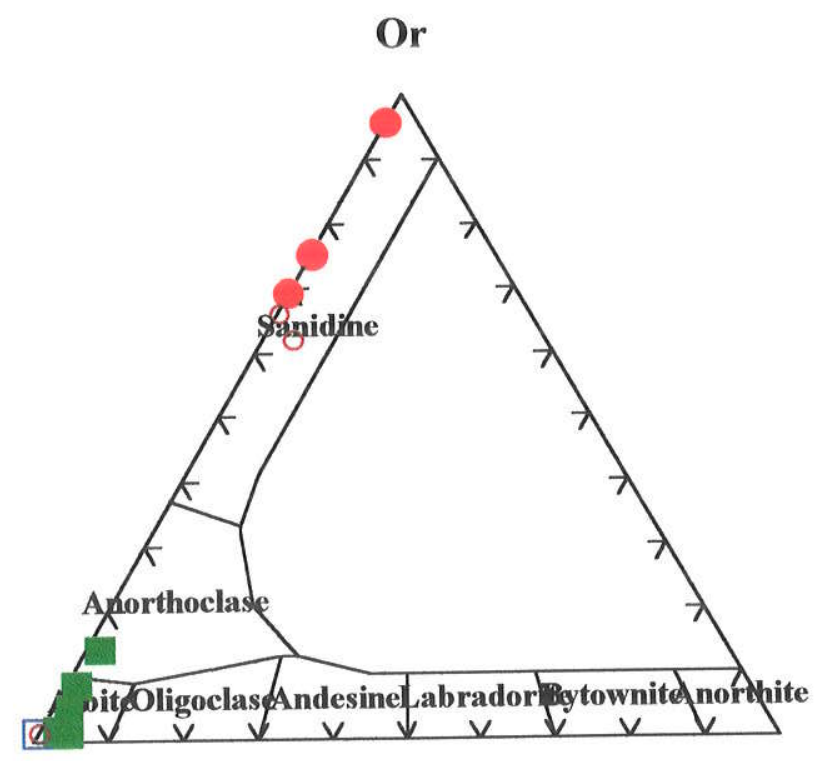

Ab

An

Figura 16 - Variação Composicional de feldspatos de quartzo sienito de Morro Pão de Açúcar, expressa em proporção molecular de Or-Ab-An, (RP-78). Simbolos como na figura 11. 


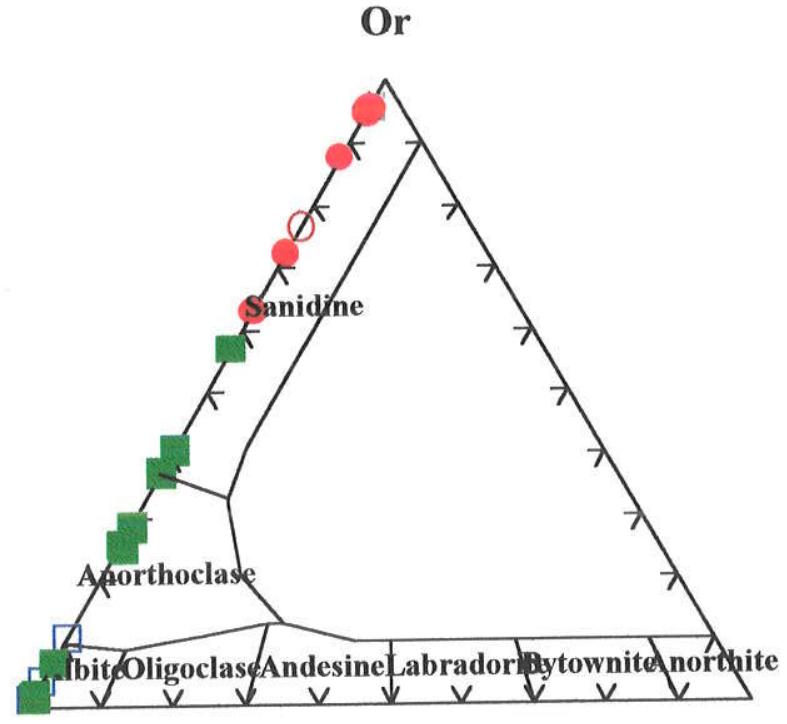

Ab

An

Figura 17 - Variação composicional de feldspatos das rochas de Pão de Açúcar expressas em proporções moleculares de Or-Ab-An. amostras 109 e 207 (traquifonolitos). Simbolos como na figura 11.

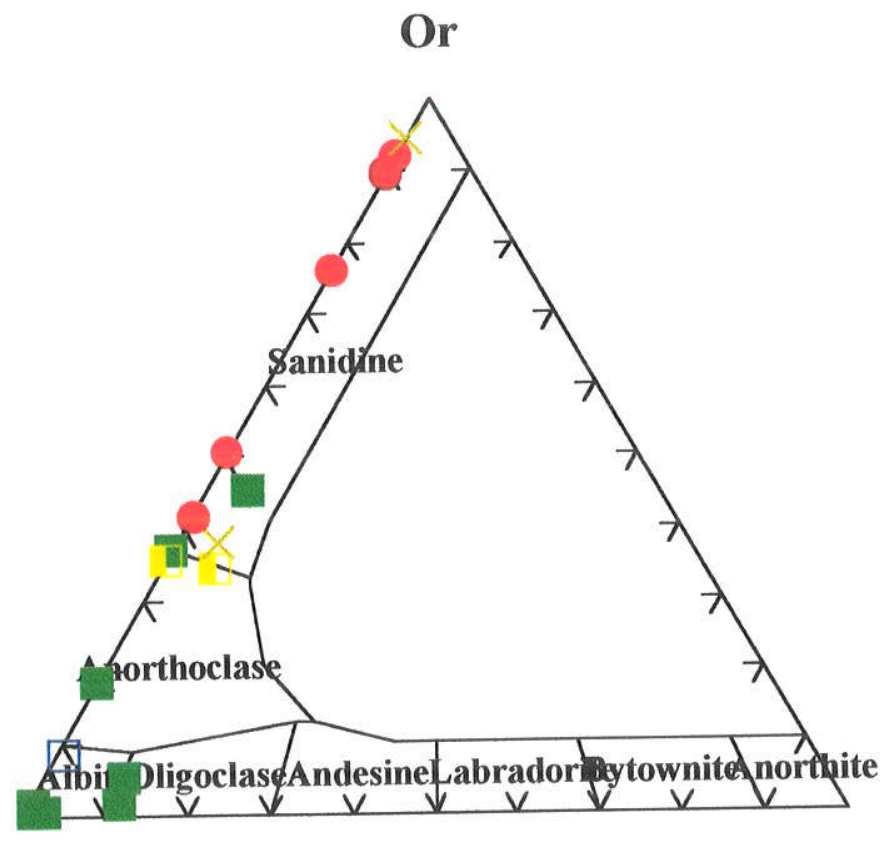

Ab

An

Figura 18 - Variação composicional dos feldspatos das rochas de Cerrito (RP-88 e 198), expressas em proporção molecular Or-Ab-An. Simbolos como na figura 11. 


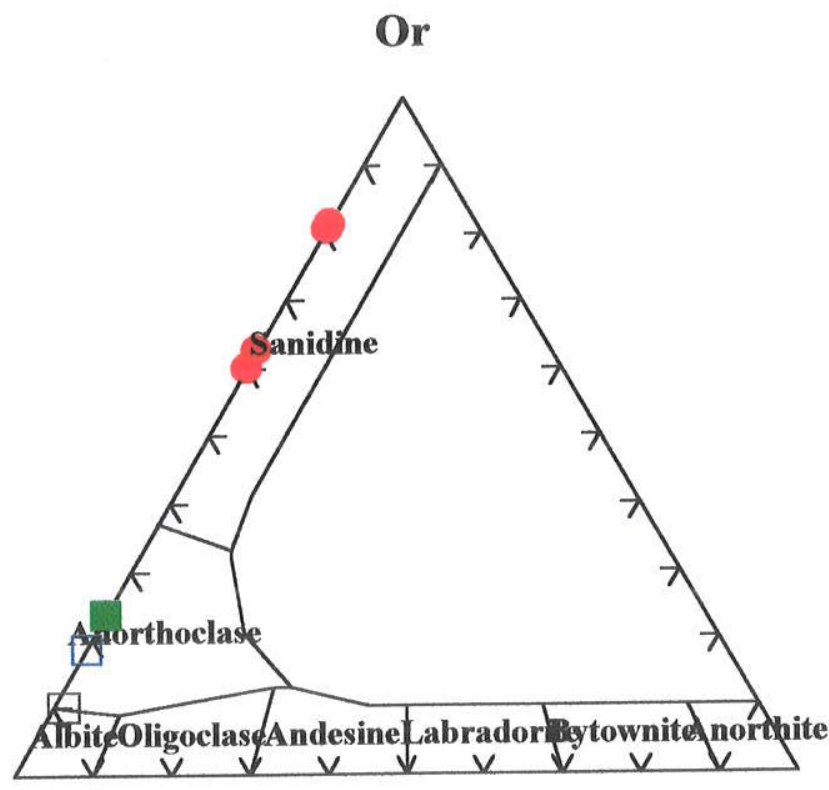

102

Ab

An

Figura 19 - Variação composicional de feldspatos em quartzo sienito Cerro Pedreira expressa em proporção molecular de Or-Ab-An. Simbolos como na figura 11

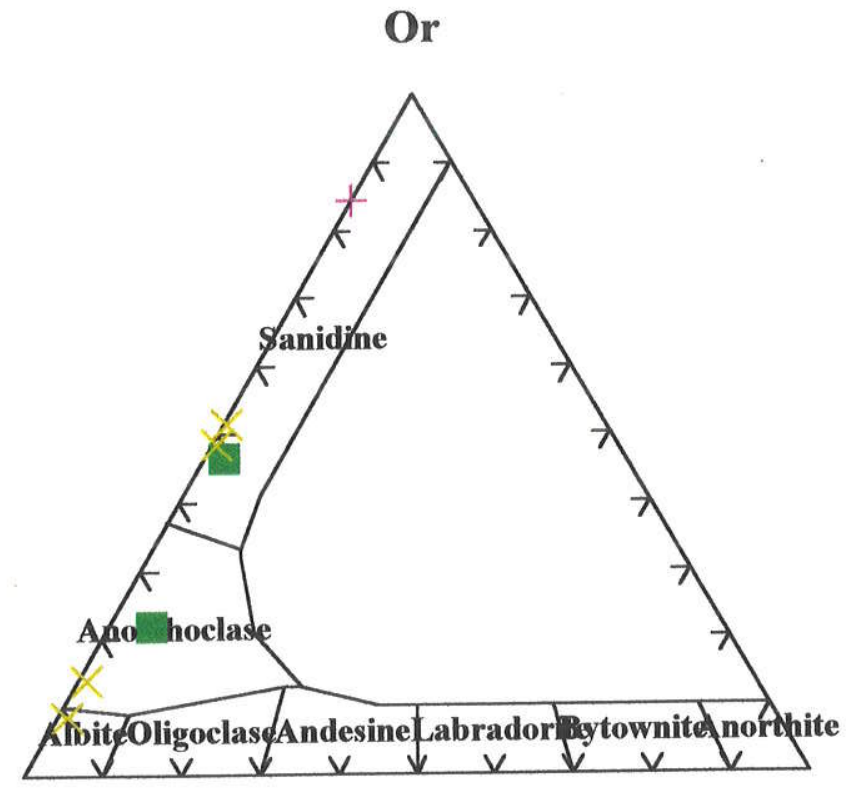

Ab

An

Figura 20 - Variação composicional de Feldspatos dos sienitos alcalinos de São Pedro expressas em proporção molecular de Or-Ab-An. Amostras utilizadas RP-255 e 256. Simbolos como na figura 11. 

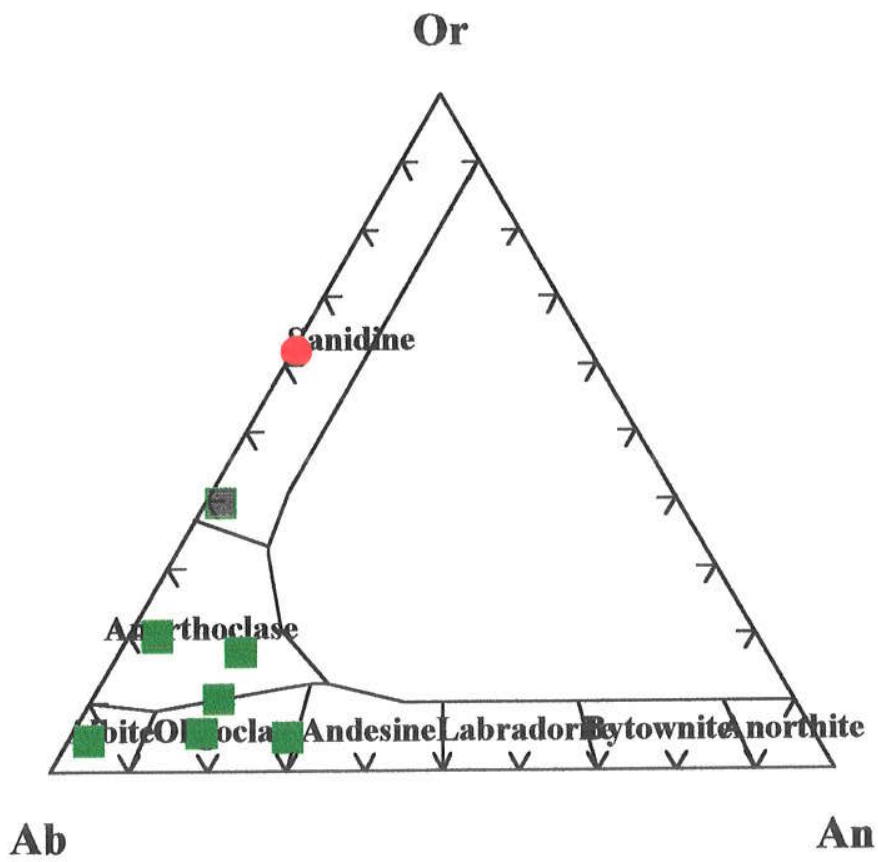

Figura 21 - Variação composicional de feldspatos dos sienitos alcalinos de Morro Conceição expressa em proporção molecular Or-Ab-An (RP-259). Simbolos como na figura 11.

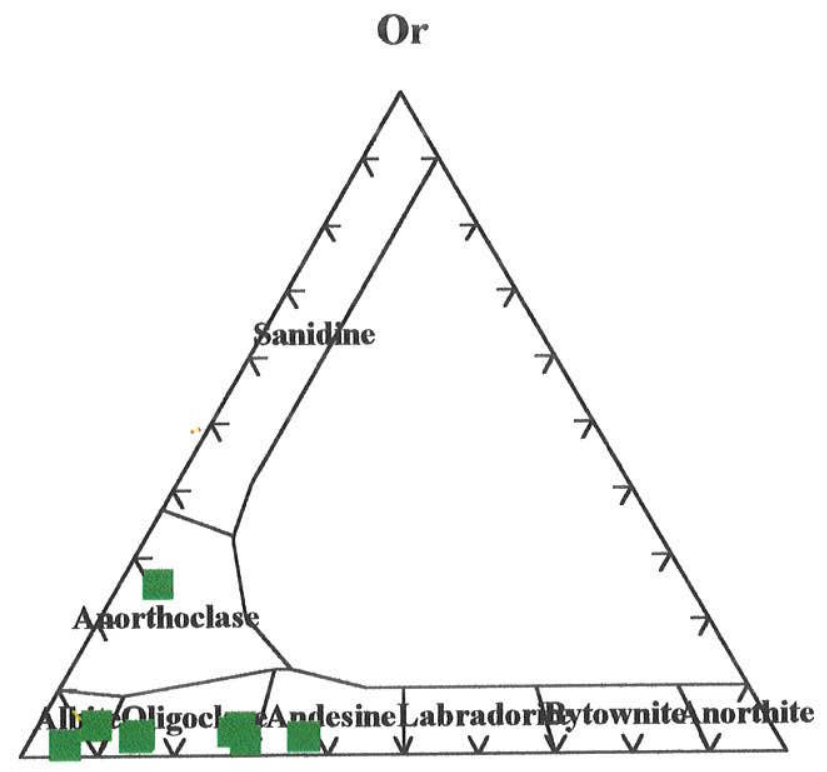

Ab

An

Figura 22 - Variação composicional de feldspatos em sienito alcalino de Morro Distante expressa em proporção molecular de Or-Ab-An (RP-264). Simbolos como na figura 11. 


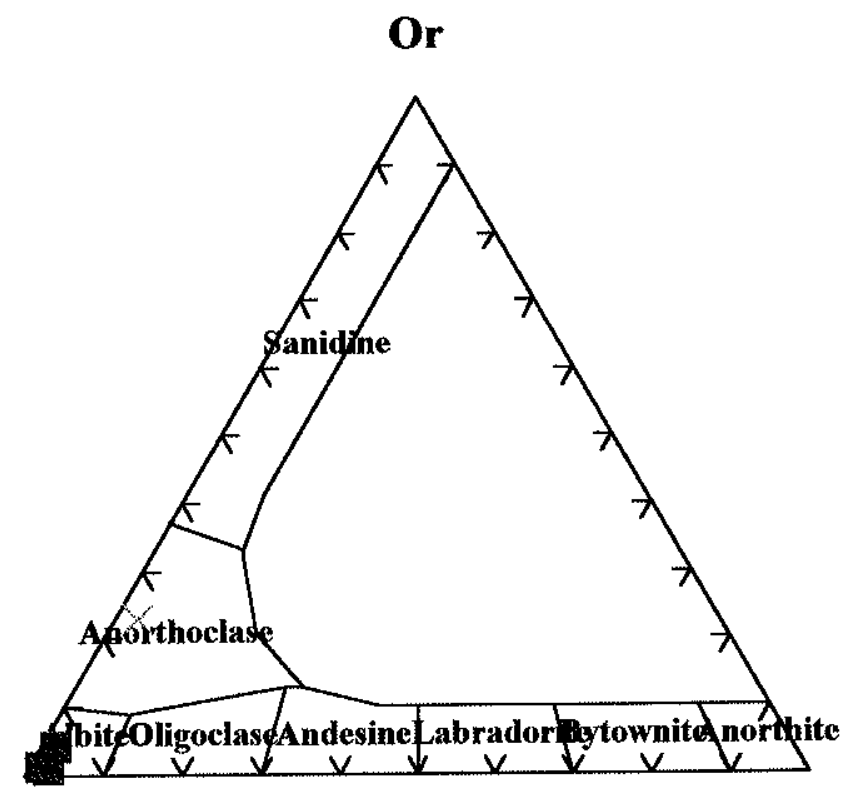

Ab

An

Figura 23a - Variação composicional de feldspatos de sienito alcalino de Porto Conceição expressa em proporção molecular de Or-Ab-An (RP-267). Simbolos como na figura 11.

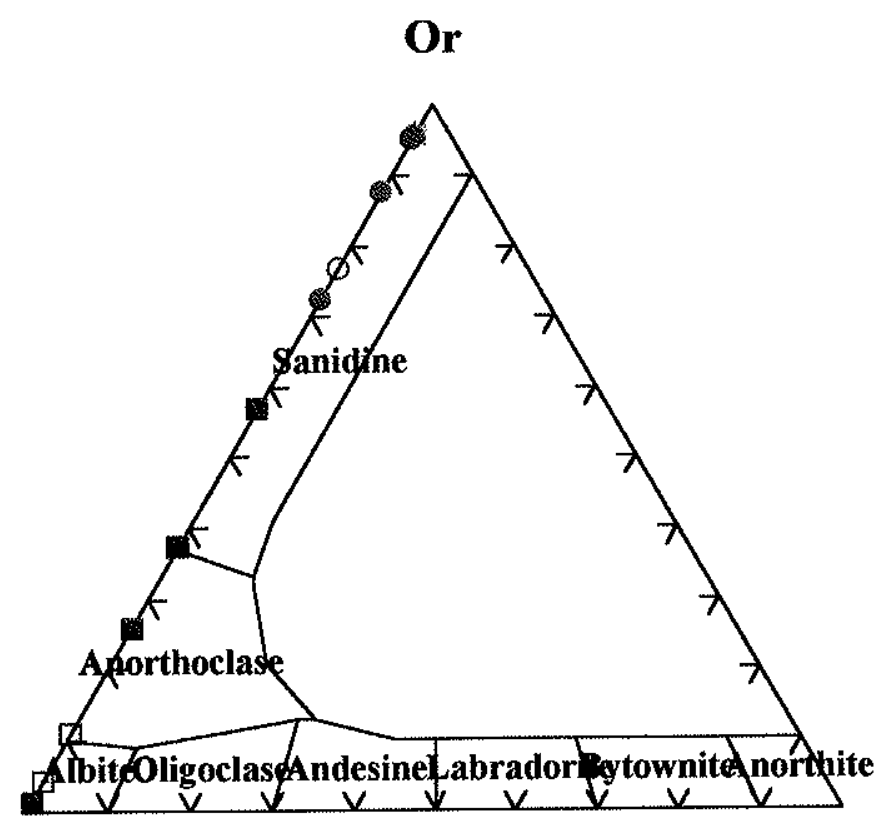

$\mathbf{A b}$

An

Figura 23b - Variação composicional de feldspatos de pegmatitos de llha Fecho dos Morros expressa em proporção molecular de Or-Ab-An (RP-267). Simbolos como na figura 11. 


\section{V.2 - Feldspatóides}

Os feldspatóides analisados resumem-se à nefelina e à sodalita e estão distribuídos em rochas de praticamente todos os corpos da Província Alcalina Alto Paraguai, com exceção de Satélite I e II, Cerro Pedreira, Morro Conceição e Morro Distante. Petrográficamente, os litotipos que apresentam esses minerais estão constituídos por sienitos nefelínicos, traquifonolitos, fonolitos peralcalinos e nefelina sienitos.

Os feldspatóides encontrados nessas rochas são predominantemente nefelinas e subordinadamente sodalitas. As nefelinas constituem fenocristais quase sempre euédricos, apresentando-se em seções retangulares curtas e hexagonais (basais), enquanto que os grãos pertencentes à matriz, via de regra, são xenomórficos e intersticiais, ocorrendo freqüentemente associados à cancrinita que constitui seu principal produto de alteração. A sodalita apresenta-se invariavelmente como grãos anédricos preenchendo interstícios.

\section{V.2.1 - Nefelinas}

As composições químicas das nefelinas podem ser visualizadas nas tabelas 13.0 a 13.7 , contendo as respectivas fórmulas estruturais expressa na base de 32 átomos de óxigênio, associadas aos recálculos das proporções moleculares dos componentes nefelina ( $\left.\mathrm{Ne}: \mathrm{NaAlSiO}_{4}\right)$, kalsilita (Ks: $\left.\mathrm{KAISiO}_{4}\right)$ e quartzo $\left(\mathrm{Qz}: \mathrm{SiO}_{2}\right)$. Por sua vez, as sodalitas estão representadas nas tabelas 13.8 a 13.10 , onde se observam apenas os mesmos cálculos de fórmula estrutural utilizados para as nefelinas.

As nefelinas de Cerro Boggiani apresentam uma relativa homogenidade em relação aos teores de $\mathrm{Na}_{2} \mathrm{O}$, situando-se ao redor de $16,5 \%$ enquanto que $\circ \mathrm{K}_{2} \mathrm{O}$ 
perfaz média de $5,5 \%$. Já nos fonolitos peralcalinos, os valores de $\mathrm{Na}_{2} \mathrm{O}$ são comparativamente semelhantes aos anteriores, com $\mathrm{K}_{2} \mathrm{O}$ situando-se entre 4,5 e $5,0 \%$, caracterizando uma provável tendência de enriquecimento em $\mathrm{SiO}_{2}$, relativamente aos sienitos nefelínicos. Estes valores geraimente persistem nos outros corpos de rochas congêneres da Província Alcalina Alto Paraguai, com pequenas variações detectadas no Complexo Siete Cabezas onde duas análises da amostra RP-74 apresentam valores de $\mathrm{K}_{2} \mathrm{O}$ maiores do que 7,0\% e ainda algumas amostras do corpo Cerrito que apresentam teores inferiores a 4,0\%.

$\mathrm{Na}$ comparação das tabelas 13.0 a 13.7 , verificam-se os altos teores de $\mathrm{Fe}_{2} \mathrm{O}_{3}$ da nefelina presente nos fonolitos peralcalinos de Cerro Boggiani, situados entre 0,57 e $1,30 \%$, conteúdos que se repetem nos traquifonolitos de Pão de Açúcar, nos sienitos nefelínicos da liha Fecho dos Morros, em algumas das amostras de nefelina sienitos de Cerro Siete Cabezas e Cerrito, não acompanhado pelos sienitos nefelínicos de Cerro Boggiani, São Pedro e Porto Conceição.

Os valores de $\mathrm{CaO}$ observados são nulos ou muito baixos em comparação aos reportados em Deer et al. (1963). Nesse sentido, Ruberti (1984) sugere que esses altos teores devem-se aos métodos convencionais de análise utilizados por aqueles autores, que refletem influências de impurezas de calcita e cancrinita provenientes de processos de alteração em nefelinas. Este erro é atualmente eliminado no direcionamento do feixe em análises via microssonda eletrônica, evitando-se feições com indícios de alterações.

Nos sienitos nefelínicos de Cerro Boggiani, os cristais de nefelinas exibem composições que variam nas seguintes proporções moleculares: $\mathrm{Ne}_{71,5-68} \mathrm{Ks}_{16,7-14,4}$ $Q z_{17,5-13,4}$ O maior conteúdo do componente quartzo $(Q z)$ é encontrado no núcleo de fenocristais de fonolitos peralcalinos desse corpo. Variações entre os núcleos e bordas desse componente observadas nos grãos analisados são insignificantes ou ausentes, o que provavelmente é o fator responsável pelo pequeno número de cristais zonados encontrados nas rochas desse corpo e de todos os outros da Província Alcalina Alto Paraguai.

Nos nefelina sienitos de Cerro Siete Cabezas, os fenocristais de nefelina possuem composições variáveis no intervalo de $\mathrm{Ne}$ 76-70 $\mathrm{Ks}_{22-13} \mathrm{Qz}_{16-1}$, coincidindo 
com os valores observados nos corpos Cerrito, llha Fecho dos Morros, Pão de Açúcar, São Pedro e Porto Conceição.

O exame dos componentes moleculares de $\mathrm{Ne}-\mathrm{Ks}-\mathrm{Qz}$ nas nefelinas de todos os corpos da Província Alcalina Alto Paraguai não revela tendências de enriquecimento em quartzo como parece indicar circustancialmente as ocorrências alcalinas de Banhadão (Ruberti, 1984), diques e pugs alcalinos do Vale do Ribeira (Vasconcelos, 1995), llha Monte de Trigo (Enrich \& Ruberti, 2000) etc.

Deer et al. (1963) sugerem que na estrutura da nefelina, o ferro trivalente ocupa principalmente as posições tetraédricas cuja soma catiônica de silício com alumínio deve perfazer valor teórico próximo a 16,0 a.f.u. (átomos por fórmula unitária). Como o silício (maior que 8,0 a.f.u.) apresenta teores maiores do que o alumínio (menor que 8,0 a.f.u.), a rede cristalina sempre apresenta valores menores que 8,0 a.f.u. átomos alcalinos, resultando em vacâncias neste "site" (sítio). Nesse sentido, Mitchell (1972) valendo-se dos trabalhos pioneiros de Donnay (1959) estabeleceu a seguinte fórmula geral, modificada em relação ao componente do ferro trivalente $\mathrm{K}_{x} \mathrm{Na}_{y} \mathrm{Ca}_{z} \square_{8}-(x+y+z) \mathrm{Al}_{(x+y+z)} \mathrm{Fe}_{\mathrm{w}} \mathrm{Si}_{16}-(x+y+2 z)+{ }_{w} \mathrm{O}_{32}$, onde representa as vacâncias estruturais.

Os diagramas ternários fundamentados nos componentes moleculares $\mathrm{Ne}$ Ks-Qz de Hamilton \& Mackenzie (1960) são mostrados para cada corpo portador de nefelina estudado da Província Alcalina Alto Paraguai (Figuras 24 a 29b), contendo isotermas e pontos $\mathrm{M}$ e $\mathrm{B}$ correspondentes respectivamente, às composições de Morozewicz e Buerguer. Esses diagramas foram construídos de modo a poder-se estimar temperaturas de equilibrio das nefelinas com base nos limites de solução sólida dos componentes moleculares $\mathrm{Ne}-\mathrm{Ks}-\mathrm{Qz}$ estabelecidos experimentalmente por Hamilton \& Mackenzie (1960) e Hamilton (1961).

$\mathrm{Na}$ figura 29b, tem-se a integração de todos os dados dos diversos corpos da província, onde se pode observar uma concentração de pontos no campo da solução sólida da nefelina, configurando uma grande similaridade na evolução composicional desses minerais, assinalado neste diagrama com a letra $\mathrm{C} e$ comparados à evolução composicional de nefelinas de outras províncias brasileiras (tendências A e B). Em relação à temperatura de cristalização (equilíbrio), conclui- 
se que as nefelinas da Província Alcalina Alto Paraguai mostram equilíbrios em um intervalo de temperatura maior do que $500^{\circ} \mathrm{C}$ e menor do que $1068^{\circ} \mathrm{C}$, sendo àquelas dos sienitos da llha Fecho dos Morros, as representativas de temperaturas de equilíbrio mais elevadas, correspondendo a um empobrecimento em potássio e a um enriquecimento em "excesso de sílica" em relação às de Cerrito e fonolitos peralcalinos de Cerro Boggiani, representativas das mais baixas temperaturas. Estes dados obtidos são amplamente coincidentes com aqueles encontrados na literatura.

\section{V.2.2 - Sodalitas}

Segundo Deer et al. (1963), o esqueleto tridimensional da sodalita é formado pela ligação de tetraedros de $\mathrm{SiO}_{4}$ e $\mathrm{AlO}_{4}$ em aproximadamente igual número, sendo cada oxigênio dos vértices, compartilhado por dois tetraedros. São formados então, unidades cubo-octaédricas do tipo gaiola, limitadas por seis anéis de quatro tetraedros paralelos a $\{100\}$ e oito anéis de 6 tetraedros paralelos a $\{111\}$. Os anéis com seus componentes definem um conjunto de canais que se interligam para formar grandes cavidades ocupadas por íons de $\mathrm{Cl}$, em coordenação tetraédrica com os ions de $\mathrm{Na}$.

As composições químicas das sodalitas da Província Alcalina Alto Paraguai são apresentadas nas tabelas 13.8 a 13.10 , onde se observa geralmente um discreto enriquecimento em $\mathrm{SiO}_{2}$ e $\mathrm{Al}_{2} \mathrm{O}_{3}$ em relação à maioria das análises apresentadas em Deer et al (1963). No entanto, três dessas análises mostra uma considerável substituição de $\mathrm{Na}$ por $\mathrm{K}$, principalmente no núcleo dos cristais, atingindo valores de até $3,5 \%$. 
Tabela 13.0 - Composição quimica de nefelinas de sienitos nefelínicos de Cerro Boggiani (\% peso)

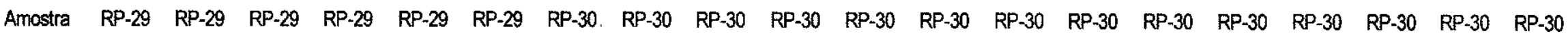

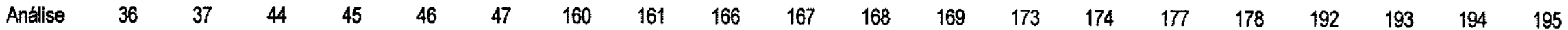
Locaça C1G2n C1G2b C5G1n C5G1b C5G2n C5G2b C1G1Fn C1G1Fb C2G1n C2G1b C2G2n C2G2b C4G1n C4Gib C4G3n C4G3b C7G3n C7G3b c7G4n C7G4b

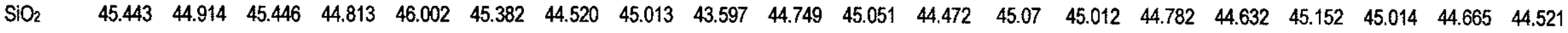
$\begin{array}{lllllllllllllllllllll}\mathrm{TiO}_{2} & 0 & 0.042 & 0.005 & 0 & 0 & 0 & 0 & 0 & 0.01 & 0 & 0 & 0 & 0.02 & 0.033 & 0 & 0.044 & 0.01 & 0 & 0 & 0.037\end{array}$

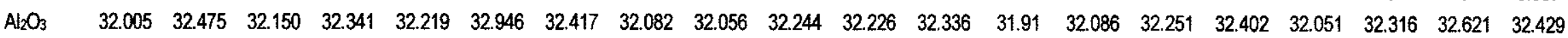
$\begin{array}{lllllllllllllllllllll}\mathrm{Fe}_{2} \mathrm{O}_{3} & 0.792 & 0.655 & 0.908 & 0.94 & 0.857 & 0.602 & 0.399 & 0.583 & 0.453 & 0.442 & 0.421 & 0.367 & 0.49 & 0.488 & 0.406 & 0.478 & 0.436 & 0.45 & 0.401 & 0.364\end{array}$ $\begin{array}{lllllllllllllllllllllll}\mathrm{MnO} & 0.023 & 0 & 0 & 0.013 & 0.037 & 0.006 & 0 & 0.035 & 0.013 & 0.034 & 0 & 0.035 & 0 & 0 & 0.004 & 0.02 & 0 & 0.026 & 0.001 & 0\end{array}$

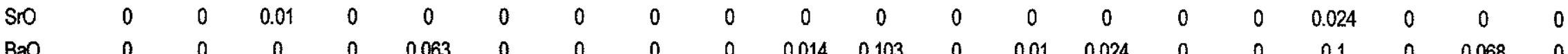
$\begin{array}{cccccccccccccccccccccc}\mathrm{CaO} & 0 & 0 & 0 & 0.008 & 0.006 & 0 & 0.002 & 0 & 0 & 0.011 & 0 & 0.006 & 0 & 0 & 0 & 0 & 0 & 0.003 & 0.035 & 0.004\end{array}$

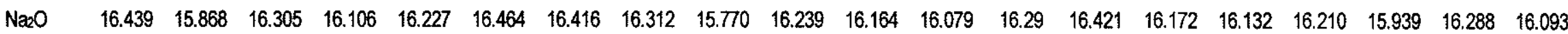
$\begin{array}{llllllllllllllllllllll}\mathrm{K}_{2} \mathrm{O} & 5.197 & 5.739 & 5.576 & 5.890 & 5.214 & 5.760 & 5.856 & 5.693 & 5.352 & 5.463 & 5.615 & 5.739 & 5.43 & 5.523 & 5.630 & 5.805 & 5.418 & 5.236 & 5.787 & 5.712\end{array}$ $\begin{array}{llllllllllllllllllllllll}\mathrm{Cl} & 0 & 0.001 & 0 & 0.001 & 0.004 & 0 & 0.001 & 0 & 0 & 0.021 & 0.006 & 0.002 & 0 & 0 & 0.012 & 0 & 0.007 & 0 & 0.008 & 0\end{array}$

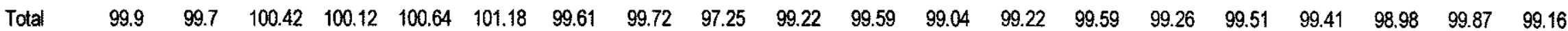

\begin{tabular}{|c|c|c|c|c|c|c|c|c|c|c|c|c|c|c|c|c|c|c|c|c|}
\hline \multirow[b]{2}{*}{$\mathrm{Si}$} & \multicolumn{20}{|c|}{ Fómula estrutural calculada na base de 32 átomos de oxigênio } \\
\hline & 58.674 & 8.601 & 8.648 & 8.573 & 8.707 & 8.574 & 8.558 & 8.631 & 8.553 & 8.611 & 8.640 & 8.582 & 8.667 & 8.635 & 8.616 & 8.577 & 8.667 & 8.651 & 8.558 & 8.577 \\
\hline Al & 7.194 & 7.324 & 7.204 & 7.286 & 7.181 & 7.330 & 7.339 & 7.244 & 7.406 & 7.307 & 7.278 & 7.349 & 7.226 & 7.249 & 7.307 & 7.333 & 7.245 & 7.314 & 7.361 & 7.358 \\
\hline$\pi$ & 0 & 0.006 & 0.001 & 0 & 0 & 0 & 0 & 0 & 0.001 & 0 & 0 & 0 & 0.003 & 0.005 & 0 & 0.006 & 0.001 & 0 & 0 & 0.005 \\
\hline $\mathrm{Fe}^{3}$ & 0.114 & 0.094 & 0.13 & 0.135 & 0.122 & 0.086 & 0.058 & 0.084 & 0.067 & 0.064 & 0.061 & 0.053 & 0.071 & 0.07 & 0.059 & 0.069 & 0.063 & 0.065 & 0.058 & 0.053 \\
\hline $\mathrm{Na}$ & 6.084 & 5.892 & 6.016 & 5.974 & 5.955 & 6.031 & 6.119 & 6.065 & 5.999 & 6.059 & 6.011 & 6.017 & 6.074 & 6.108 & 6.033 & 6.011 & 6.033 & 5.940 & 6.051 & 6.012 \\
\hline $\mathrm{Ca}$ & 0 & 0 & 0 & 0.002 & 0.001 & 0 & 0 & 0 & 0 & 0.002 & 0 & 0.001 & 0 & 0 & 0 & 0 & 0 & 0.001 & 0.007 & 0.001 \\
\hline 0 & $\cdots=32$ & 32 & 32 & 32 & 32 & 32 & 32 & 32 & 32 & 32 & 32 & 32 & 32 & 32 & 32 & 32 & 32 & 32 & 32 & 32 \\
\hline \multicolumn{21}{|c|}{ Componentes Moleculares } \\
\hline $\mathrm{Ne}$ & 70.14 & 68.5 & 69.57 & 69.72 & 68.41 & 70.34 & 71.5 & 70.27 & 70.14 & 70.4 & 69.57 & 70.13 & 70.08 & 70.74 & 70.02 & 70.08 & 69.61 & 68.68 & 70.82 & 70.11 \\
\hline Ks & 14.6 & 16.3 & 15.66 & 16.78 & 14.46 & 16.19 & 16.78 & 16.14 & 15.66 & 15.58 & 15.9 & 16.47 & 15.37 & 15.66 & 16.04 & 16.59 & 15.31 & 14.85 & 16.56 & 16.37 \\
\hline $\mathrm{Qzz}$ & 15.26 & 15.2 & 14.78 & 13.5 & 17.13 & 13.47 & 11.72 & 13.59 & 14.21 & 14.02 & 14.53 & 13.4 & 14.55 & 13.61 & 13.94 & 13.33 & 15.08 & 16.48 & 12.62 & 13.52 \\
\hline
\end{tabular}


Tabela 13.1 - Composição química de nefelinas de fonolitos peralcalinos de Cerro Boggiani (\% peso)

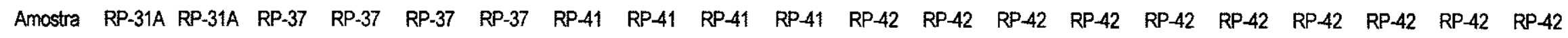
$\begin{array}{lllllllllllllllllllll}\text { Análise } & 5 & 14 & 214 & 215 & 224 & 226 & 53 & 54 & 59 & 60 & 280 & 281 & 282 & 288 & 289 & 290 & 291 & 296 & 298 & 299\end{array}$ Locação C1G3n C3G1n C1G1n C1G1b C4G2n C6G1n C1G1n C1G1b C1G4n C1G4b C1G2n C1G2b C1G3n C2G3n C2G3b C2G4n C2G4b C3G4n C3G5n C3G5b $\begin{array}{llllllllllllllllllllll}\mathrm{SiO}_{2} & 45.436 & 44.839 & 44.746 & 44.726 & 47.074 & 44.869 & 45.261 & 45.286 & 45.437 & 45.425 & 48.261 & 46.379 & 45.494 & 45.559 & 45.321 & 46.396 & 46.612 & 46.767 & 46.028 & 45.577\end{array}$

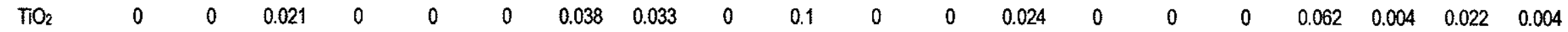

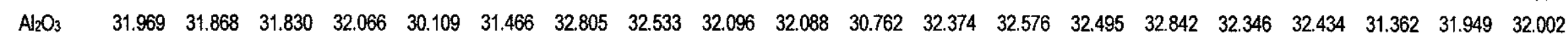

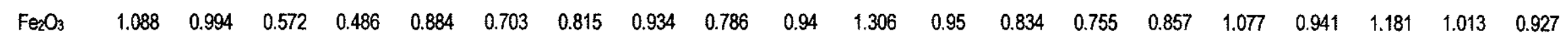
$\begin{array}{lllllllllllllllllllllll}\text { MnO } & 0 & 0 & 0 & 0 & 0.02 & 0 & 0.019 & 0.058 & 0.016 & 0.045 & 0.033 & 0 & 0 & 0.029 & 0.017 & 0 & 0 & 0.007 & 0 & 0.002\end{array}$ $\begin{array}{ccccccccccccccccccccc}\mathrm{SrO} & 0.016 & 0 & 0 & 0 & 0 & 0 & 0 & 0 & 0 & 0 & 0 & 0 & 0 & 0.022 & 0 & 0 & 0 & 0 & 0 & 0 \\ \mathrm{BaO} & 0.112 & 0.077 & 0 & 0.035 & 0.072 & 0 & 0.074 & 0 & 0.046 & 0.167 & 0 & 0 & 0 & 0 & 0 & 0.027 & 0.024 & 0.017 & 0.036 & 0.036\end{array}$ $\begin{array}{cccccccccccccccccccccc}\mathrm{C} a \mathrm{O} & 0 & 0.005 & 0 & 0 & 0.004 & 0 & 0.028 & 0.017 & 0.095 & 0 & 0 & 0 & 0 & 0.014 & 0 & 0.006 & 0 & 0 & 0 & 0\end{array}$

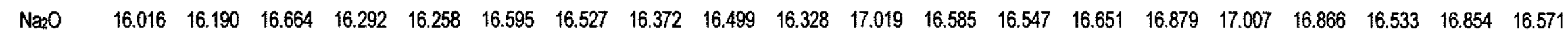
$\begin{array}{lllllllllllllllllllll}\mathrm{K}_{2} \mathrm{O} & 5.446 & 5.494 & 5.398 & 5.512 & 4.104 & 5.480 & 5.729 & 5.479 & 5.170 & 5.369 & 3.964 & 5.152 & 5.425 & 5.265 & 5.620 & 4.886 & 4.984 & 4.544 & 4.984 & 5.026\end{array}$ $\begin{array}{llllllllllllllllllllll}\mathrm{Cl} & 0 & 0.002 & 0.004 & 0 & 0 & 0.003 & 0 & 0 & 0 & 0.01 & 0.005 & 0 & 0.131 & 0 & 0.004 & 0 & 0 & 0.005 & 0.012 & 0\end{array}$

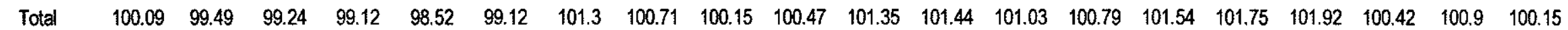
Fórmula estrutura calculada na base de 32 átomos de oxigênio

\begin{tabular}{|c|c|c|c|c|c|c|c|c|c|c|c|c|c|c|c|c|c|c|c|c|}
\hline $\mathrm{Si}$ & 8.670 & 8.622 & 8.623 & 8.621 & 9.030 & 8.662 & 8.557 & 8.593 & 8.657 & 8.644 & 9.008 & 8.708 & 8.611 & 8.627 & 8.549 & 8.691 & 8.709 & 8.841 & 8.702 & 8.677 \\
\hline $\mathrm{Al}$ & 7.184 & 7.217 & 7.224 & 7.278 & 6.802 & 7.154 & 7.304 & 7.270 & 7.202 & 7.191 & 6.762 & 7.158 & 7.261 & 7.247 & 7.296 & 7.136 & 7.137 & 6.982 & 7.113 & 7.175 \\
\hline $\mathrm{Ti}$ & 0 & 0 & 0.003 & 0 & 0 & 0 & 0.005 & 0.005 & 0 & 0.014 & 0 & 0 & 0.003 & 0 & 0 & 0 & 0.009 & 0.001 & 0.003 & 0.001 \\
\hline $\mathrm{Fe}^{3}$ & 0.156 & 0.144 & 0.083 & 0.07 & 0.127 & 0.102 & 0.116 & 0.133 & 0.113 & 0.134 & 0.183 & 0.134 & 0.119 & 0.107 & 0.122 & 0.152 & 0.132 & 0.168 & 0.144 & 0.133 \\
\hline $\mathrm{Na}$ & 5.926 & 6.036 & 6.227 & 6.089 & 6.047 & 6.212 & 6.059 & 6.024 & 6.096 & 6.025 & 6.159 & 6.038 & 6.073 & 6.114 & 6.174 & 6.177 & 6.110 & 6.060 & 6.178 & 6.117 \\
\hline $\mathrm{Ca}$ & 0 & 0.001 & 0 & 0 & 0.001 & 0 & 0.006 & 0.003 & 0.019 & 0 & 0 & 0 & 0 & 0.003 & 0 & 0.001 & 0 & 0 & 0 & 0 \\
\hline 0 & 32 & 32 & 32 & 32 & 32 & 32 & 32 & 32 & 32 & 32 & 32 & 32 & 32 & 32 & 32 & 32 & 32 & 32 & 32 & 32 \\
\hline K & 1.326 & 1.348 & 1.327 & 1.355 & 1.004 & 1.350 & 1.382 & 1.326 & 1.257 & 1.303 & 0.944 & 1.234 & 1.310 & 1.272 & 1.352 & 1.168 & 1.188 & 1.096 & 1.202 & 1.221 \\
\hline \multicolumn{21}{|c|}{ Componentes Moleculares } \\
\hline $\mathrm{Ne}$ & 68.35 & 70.02 & 72.21 & 70.63 & 66.98 & 71.72 & 70.91 & 70.15 & 70.73 & 69.7 & 68.37 & 69.34 & 70.53 & 70.92 & 72.22 & 71.09 & 70.16 & 68.54 & 71 & 70.5 \\
\hline Ks & 15.29 & 15.64 & 15.39 & 15.72 & 11.12 & 15.59 & 16.17 & 15.44 & 14.58 & 15.07 & 10.48 & 14.17 & $\uparrow 5.21$ & 14.75 & 15.81 & 13.44 & 13.64 & 12.4 & 13.81 & 14.07 \\
\hline$Q_{z}$ & 16.36 & 14.34 & 12.4 & 13.65 & 21.9 & 12.7 & 12.92 & 14.41 & 14.69 & 15.22 & 21.15 & 16.49 & 14.26 & 14.33 & 11.97 & 15.47 & 16.2 & 19.06 & 15.19 & 15.43 \\
\hline
\end{tabular}




\begin{tabular}{|c|c|c|c|c|c|c|}
\hline Amostra & RP-42 & $R P-42$ & $R P-42$ & $\mathrm{RP}-43$ & $R P-43$ & $R P-43$ \\
\hline Análise & 301 & 303 & 304 & 307 & 318 & 327 \\
\hline Locação & C4GIn & C4G2n & $\mathrm{C} 4 \mathrm{G} 2 \mathrm{~b}$ & C1G1n & C3G2n & C6G1n \\
\hline $\mathrm{SiO}_{2}$ & 44.987 & 46.103 & 44.747 & 44.576 & 44.664 & 44.651 \\
\hline $\mathrm{TiO}_{2}$ & 0.089 & 0.014 & 0.037 & 0 & 0 & 0.018 \\
\hline $\mathrm{Al}_{2} \mathrm{O}_{3}$ & 32.302 & 31.792 & 32.440 & 32.551 & 32.276 & 31.934 \\
\hline $\mathrm{Fe}_{2} \mathrm{O}_{3}$ & 0.826 & 0.943 & 0.842 & 716 & 0.817 & 1.166 \\
\hline $\mathrm{MnO}$ & 0.014 & 0 & 0.035 & 0.01 & 0.015 & 0.031 \\
\hline SrO & 0 & 0 & 0 & 0 & 0 & 0 \\
\hline $\mathrm{BaO}$ & 0.038 & 0.127 & 0 & 0.055 & 0.022 & 0.027 \\
\hline $\mathrm{CaO}$ & 0.012 & 0 & 0 & 0 & 0.008 & 0.002 \\
\hline $\mathrm{Na}_{2} \mathrm{O}$ & 16.152 & 16.776 & 16.578 & 16.532 & 16.213 & 15.499 \\
\hline $\mathrm{K}_{2} \mathrm{O}$ & 5.101 & 4.833 & 5.580 & 5.670 & 5.438 & 5.302 \\
\hline $\mathrm{Cl}$ & 0.006 & 0 & 0.006 & 0 & 0.005 & 0.025 \\
\hline Total & 99.53 & 100.59 & 100.24 & 815.39 & 99.46 & 98.66 \\
\hline \multicolumn{7}{|c|}{ Fórmula estrutural calculada na base de 32 átomos de oxigênio } \\
\hline $\mathrm{Si}$ & 8.615 & 8.734 & 8.550 & 1.464 & 8.582 & 8.630 \\
\hline Al & 7.284 & 7.093 & 7.293 & 1.259 & 7.304 & 7.269 \\
\hline Ti & 0.013 & 0.002 & 0.005 & 0 & 0 & 0.003 \\
\hline $\mathrm{Fe}^{3}$ & 0.119 & 0.134 & 0.121 & 17.674 & 0.118 & 0.169 \\
\hline $\mathrm{Na}$ & 5.997 & 6.163 & 6.142 & 1.053 & 6.041 & 5.809 \\
\hline $\mathrm{Ca}$ & 0.002 & 0 & 0 & 0 & 0.002 & 0 \\
\hline 0 & 32 & 32 & 32 & 32 & 32 & 32 \\
\hline K & 1.246 & 1.168 & 1.360 & 0.238 & 1.333 & 1.307 \\
\hline \multicolumn{7}{|c|}{ Componentes Moleculares } \\
\hline $\mathrm{Ne}$ & 69.64 & 70.56 & 71.84 & 71.93 & 70.42 & 67.31 \\
\hline Ks & 14.47 & 13.37 & 15.91 & 16.26 & 15.54 & 15.14 \\
\hline $\mathrm{Qz}$ & 15.89 & 16.06 & 12.26 & 11.82 & 14.04 & 17.54 \\
\hline
\end{tabular}


Tabela 13.3 - Composição química de nefelinas em nefelina sienitos de Cerro Siete Cabezas (\% peso)

$\begin{array}{llllllllllllllll}\text { Amostra } & \text { RP-74 } & \text { RP-74 } & \text { RP-74 } & \text { RP-74 } & \text { RP-74 } & \text { RP-74 } & \text { RP-74 } & \text { RP-74 } & \text { RP-74 } & \text { RP-230 RP-230 RP-230 RP-230 RP-230 RP-230 RP-230 }\end{array}$

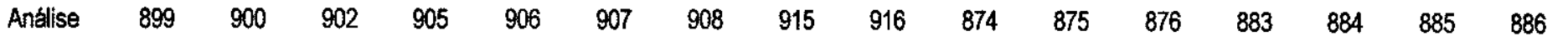

Locação C1G1b C1G1b C1G2b C2G2n C2G2b C2G3n C2G3b C4G2n C4G2b C1G3n C1G3b C1G4n C3G4n C3G4b C3G5n C3G5b

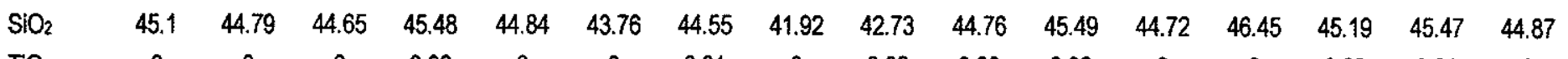

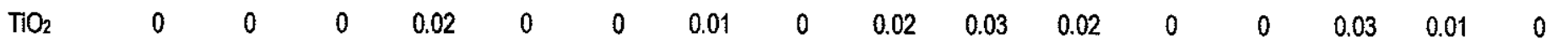

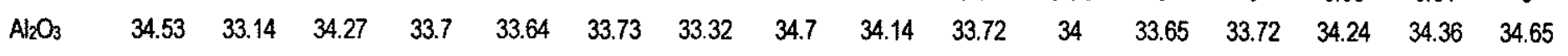

$\begin{array}{lllllllllllllllll}\mathrm{Fe}_{2} \mathrm{O}_{3} & 0.74 & 0.79 & 0.61 & 0.77 & 0.74 & 0.65 & 0.83 & 0.08 & 0.14 & 0.45 & 0.39 & 0.53 & 0.5 & 0.47 & 0.54 & 0.39\end{array}$

$\begin{array}{llllllllllllllllll}\mathrm{MnO} & 0 & 0.02 & 0.04 & 0 & 0 & 0 & 0.04 & 0.04 & 0.02 & 0.02 & 0.01 & 0 & 0 & 0 & 0 & 0.01\end{array}$

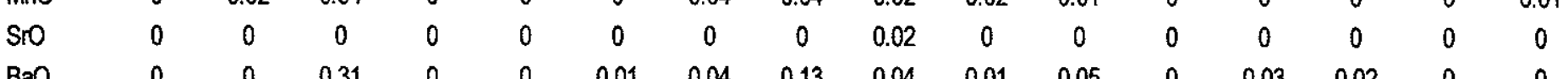

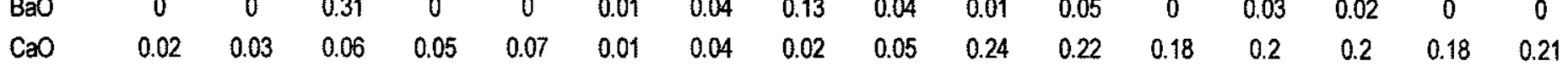

$\begin{array}{lllllllllllllllll}\mathrm{Na} 2 \mathrm{O} & 16.46 & 16.43 & 13.44 & 16.51 & 16.44 & 16.4 & 16.68 & 16.46 & 16.33 & 16.71 & 16.74 & 16.47 & 16.71 & 16.61 & 16.65 & 16.51\end{array}$

$\begin{array}{lllllllllllllllll}\mathrm{K}_{2} \mathrm{O} & 5.6 & 5.4 & 5.36 & 5.37 & 5.65 & 5.91 & 5.84 & 7.35 & 7.01 & 5.59 & 5.46 & 5.49 & 4.89 & 5.6 & 5.14 & 5.75\end{array}$

$\begin{array}{cccccccccccccccccc}\mathrm{Cl} & 0 & 0.01 & 0.04 & 0.02 & 0 & 0 & 0 & 0.01 & 0 & 0.01 & 0 & 0 & 0.01 & 0.02 & 0 & 0\end{array}$

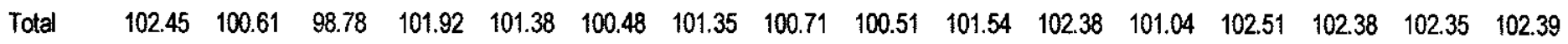

\begin{tabular}{llll}
\hline & Fórmula estrutural calculada na base de 32 átomos de oxigênio
\end{tabular}

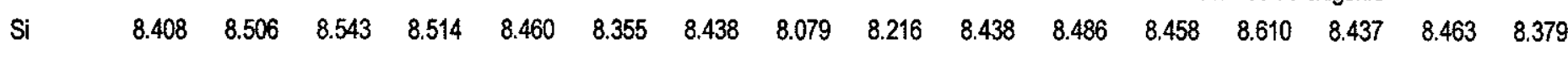

$\begin{array}{lllllllllllllllllll}\text { Al } & 7.581 & 7.412 & 7.722 & 7.430 & 7.474 & 7.584 & 7.432 & 7.876 & 7.730 & 7.486 & 7.469 & 7.495 & 7.361 & 7.528 & 7.531 & 7.620\end{array}$

$\begin{array}{llllllllllllllllll}71 & 0 & 0 & 0 & 0.003 & 0 & 0 & 0.001 & 0 & 0.003 & 0.004 & 0.003 & 0 & 0 & 0.004 & 0.001 & 0\end{array}$

$\begin{array}{lllllllllllllllll}\mathrm{Fe}^{3} & 0.104 & 0.113 & 0.088 & 0.108 & 0.105 & 0.093 & 0.118 & 0.012 & 0.02 & 0.064 & 0.055 & 0.075 & 0.07 & 0.066 & 0.076 & 0.055\end{array}$

$\begin{array}{lllllllllllllllllll}\mathrm{Na} & 5.950 & 6.050 & 4.986 & 5.993 & 6.014 & 6.072 & 6.126 & 6.151 & 6.088 & 6.108 & 6.055 & 6.040 & 6.006 & 6.013 & 6.009 & 5.978\end{array}$

$\begin{array}{lllllllllllllllllll}\mathrm{Ca} & 0.004 & 0.006 & 0.012 & 0.01 & 0.014 & 0.002 & 0.008 & 0.004 & 0.01 & 0.048 & 0.044 & 0.036 & 0.04 & 0.04 & 0.036 & 0.042\end{array}$

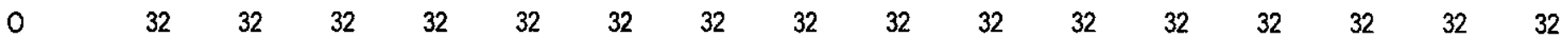

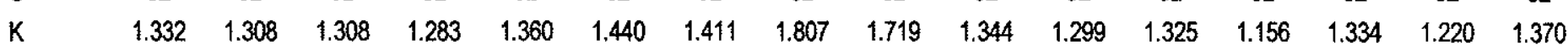

Componentes Moleculares

Ne $\quad \begin{array}{lllllllllllllllll} & 70.83 & 71.23 & 58.53 & 70.56 & 71.32 & 72.71 & 72.74 & 76.21 & 74.28 & 73.22 & 72.1 & 72.02 & 70.41 & 71.95 & 71.61 & 72.07\end{array}$

$\begin{array}{llllllllllllllllll}\text { Ks } & 15.86 & 15.4 & 15.35 & 15.1 & 16.13 & 17.24 & 16.75 & 22.39 & 20.97 & 16.11 & 15.47 & 15.8 & 13.55 & 15.96 & 14.54 & 16.52\end{array}$

$\begin{array}{lllllllllllllllll}\mathrm{Oz} & 13.31 & 13.37 & 26.12 & 14.34 & 12.55 & 10.05 & 10.51 & 1.4 & 4.75 & 10.67 & 12.43 & 12.18 & 16.04 & 12.09 & 13.85 & 11.42\end{array}$

Abreviaçōes como na tabela 13.0 
Tabela 13.4 - Composição química de nefelinas em sienitos nefelínicos de Cerrito (\% peso)

Amostra RP-88 RP-88 $\quad$ RP-88 $\quad$ RP-88 $\quad$ RP-88 RP-198 RP-198 RP-198 RP-198 RP-198 RP-198 RP-198 RP-198

$\begin{array}{llllllllllllll}\text { Análise } & 783 & 784 & 791 & 794 & 795 & 732 & 733 & 734 & 735 & 745 & 746 & 747 & 748\end{array}$

Locação C1G2n C1G2b C3G1n C4G2n C4G2b C3G2n C3G2b C3G3n C3G3b C5G1n C5G1b C5G2n C5G2b

$\begin{array}{lllllllllllllll}\mathrm{SiO}_{2} & 45.62 & 46.66 & 46.03 & 45.18 & 44.98 & 45.08 & 44.88 & 45.83 & 44.5 & 44.31 & 43.97 & 44.42 & 44.66\end{array}$

$\begin{array}{llllllllllllll}\mathrm{TiO}_{2} & 0 & 0 & 0 & 0 & 0.01 & 0 & 0.03 & 0 & 0.11 & 0 & 0 & 0 & 0\end{array}$

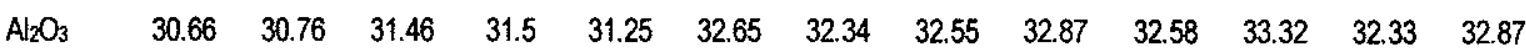

$\begin{array}{llllllllllllll}\mathrm{Fe}_{2} \mathrm{O}_{3} & 1.27 & 1.54 & 1.36 & 1.28 & 1.06 & 0.48 & 0.44 & 0.37 & 0.38 & 0.32 & 0.35 & 0.34 & 0.29\end{array}$

$\begin{array}{llllllllllllll}\mathrm{MnO} & 0 & 0.01 & 0 & 0.02 & 0 & 0 & 0.02 & 0.02 & 0 & 0 & 0 & 0 & 0\end{array}$

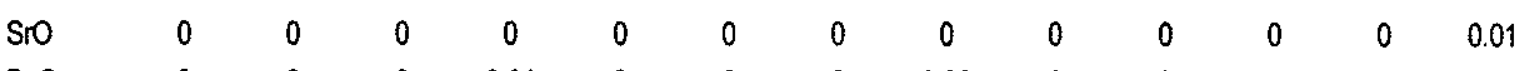

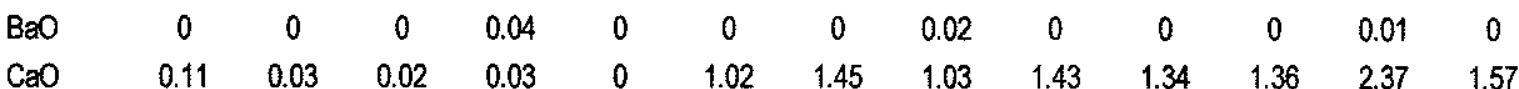

$\begin{array}{llllllllllllll}\mathrm{Na} 2 \mathrm{O} & 16.56 & 16.83 & 16.49 & 17.03 & 16.56 & 16.13 & 15.86 & 16.06 & 15.85 & 16.01 & 14.13 & 15.54 & 16.06\end{array}$

$\begin{array}{lllllllllllllll}\mathrm{K}_{2} \mathrm{O} & 4.36 & 4.17 & 4.77 & 4.97 & 4.95 & 4.29 & 4.51 & 4.2 & 4.64 & 4.45 & 4.07 & 3.76 & 4.57\end{array}$

$\begin{array}{llllllllllllll}\mathrm{Cl} & 0 & 0 & 0.01 & 0.01 & 0 & 0 & 0 & 0 & 0 & 0.32 & 0.04 & 0.02 & 0.01\end{array}$

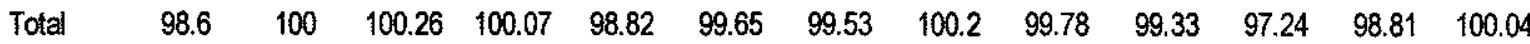

Fórmula estrutural calculada na base de 32 átomos de oxigênio

$\begin{array}{llllllllllllll}\mathrm{Si} & 8.801 & 8.863 & 8.744 & 8.643 & 8.689 & 8.592 & 8.584 & 8.668 & 8.498 & 8.522 & 8.527 & 8.541 & 8.510\end{array}$

A $\quad \begin{array}{lllllllllllllll} & 6.966 & 6.881 & 7.038 & 7.097 & 7.109 & 7.328 & 7.284 & 7.250 & 7.392 & 7.379 & 7.610 & 7.321 & 7.376\end{array}$

$\begin{array}{llllllllllllll}\pi & 0 & 0 & 0 & 0 & 0.001 & 0 & 0.004 & 0 & 0.016 & 0 & 0 & 0 & 0\end{array}$

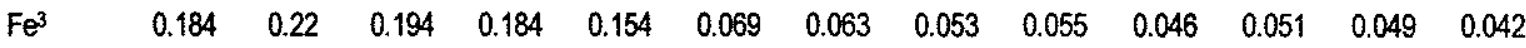

$\begin{array}{lllllllllllllll}\mathrm{Na} & 6.195 & 6.199 & 6.074 & 6.317 & 6.203 & 5.961 & 5.882 & 5.890 & 5.869 & 5.970 & 5.313 & 5.794 & 5.934\end{array}$

$\begin{array}{llllllllllllll}\text { Ca } & 0.023 & 0.006 & 0.004 & 0.006 & 0 & 0.208 & 0.297 & 0.209 & 0.293 & 0.276 & 0.283 & 0.488 & 0.321\end{array}$

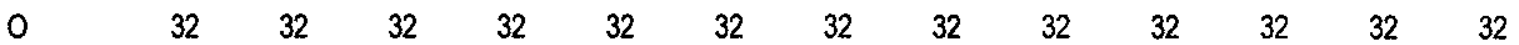

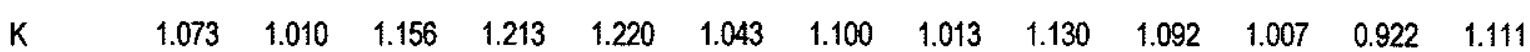
Componentes Moleculares

$\begin{array}{llllllllllllll}\text { Ne } & 70.76 & 70.04 & 69.53 & 73.19 & 71.39 & 72.91 & 73.62 & 71.39 & 74.18 & 74.91 & 66.74 & 76.59 & 75.42 \\ \text { Ks } & 12.26 & 11.41 & 13.23 & 14.05 & 14.04 & 12.76 & 13.77 & 12.28 & 14.28 & 13.7 & 12.65 & 12.19 & 14.12 \\ \text { Qz } & 16.98 & 18.55 & 17.24 & 12.76 & 14.57 & 14.33 & 12.62 & 16.33 & 11.54 & 11.39 & 20.61 & 11.22 & 10.46\end{array}$

Abreviaçöes como na tabela 13.0 
Tabela 13.5 - Composição química de nefelinas de sienitos nefelínicos da llha Fecho dos Morros (\% peso)

Amostra RP-201A RP-201A RP-201A RP-201A RP-201A RP-201A RP-201A RP-201A RP-201A RP-201A RP-201A RP-201A RP-201A RP-201A RP-222 RP-222 RP-222 RP-;

\begin{tabular}{|c|c|c|c|c|c|c|c|c|c|c|c|c|c|c|c|c|c|c|}
\hline Análise & 1005 & 1006 & 1007 & 1010 & 1011 & 1012 & 1013 & 1014 & 1015 & 1016 & 1017 & 1018 & 1021 & 1022 & $\$ 121$ & 1127 & 1128 & 11: \\
\hline Locação & C1G1n & C1G1b & C1Gín & C2GAn & $\mathrm{C} 2 \mathrm{G} 2 \mathrm{n}$ & $\mathrm{C} 2 \mathrm{G} 2 \mathrm{~b}$ & C3G1n & C3G1b & $C 3 G 2 n$ & $\mathrm{C} 3 \mathrm{G} 2 \mathrm{~b}$ & C3G3n & CAGin & C4G3n & CAG3b & $\mathrm{C}_{\mathrm{G}} 2 \mathrm{~m}$ & C4G1n & C4G1b & CAC \\
\hline $\mathrm{SiO}_{2}$ & 46.33 & 46.8 & 46.63 & 46.85 & 47.01 & 46.26 & 46.1 & 46.39 & 46.72 & 46.34 & 46.35 & 46.97 & 42.11 & 46.35 & 45.13 & 43.82 & 45.35 & 44. \\
\hline $\mathrm{TiO}_{2}$ & 0.1 & 0.05 & 0.02 & 0.04 & 0.02 & 0 & 0.01 & 0.02 & 0.01 & 0.05 & 0.01 & 0.04 & 0 & 0 & 0.06 & 0.01 & 0.05 & c \\
\hline $\mathrm{Al}_{2} \mathrm{O}_{3}$ & 32.43 & 32.92 & 32.48 & 32.13 & 32.17 & 32.4 & 32.36 & 32.41 & 32.15 & 32.16 & 32.18 & 31.67 & 32.4 & 32.16 & 32.88 & 33.74 & 32.85 & $2:$ \\
\hline $\mathrm{Fe}_{2} \mathrm{O}_{3}$ & 1.09 & 1.05 & 1.11 & 1.02 & 1.15 & 0.86 & 1.09 & 1.04 & 0.87 & 0.94 & 1.07 & 0.97 & 0.27 & 1.07 & 0.48 & 0.21 & 0.67 & 0.5 \\
\hline $\mathrm{MnO}$ & 0 & 0 & 0 & 0 & 0.01 & 0 & 0 & 0 & 0 & 0 & 0.03 & 0 & 0 & 0.02 & 0.02 & 0 & 0.02 & 0 \\
\hline Sro & 0 & 0 & 0 & 0 & 0 & 0 & 0 & 0 & 0 & 0 & 0 & 0 & 0 & 0 & 0 & 0 & 0 & 0 \\
\hline $\mathrm{BaO}$ & 0.08 & 0.06 & 0.04 & 0 & 0 & 0 & 0.06 & 0 & 0.05 & 0.01 & 0.03 & 0 & 0.03 & 0 & 0.05 & 0 & 0 & $0 . C$ \\
\hline $\mathrm{CaO}$ & 0.01 & 0 & 0.01 & 0.01 & 0.01 & 0.02 & 0 & 0 & 0 & 0 & 0.02 & 0 & 1.41 & 0 & 0 & 0 & 0.01 & 0 \\
\hline $\mathrm{Na} 2 \mathrm{O}$ & 16.28 & 14.83 & 16.38 & 16.48 & 16.5 & 16.6 & 16.64 & 16.28 & 16.34 & 16.43 & 16.21 & 15.95 & 16.63 & 16.64 & 15.56 & 15.36 & 15.67 & 15. \\
\hline $\mathrm{K}_{2} \mathrm{O}$ & 5.13 & 5.35 & 5.19 & 4.85 & 4.98 & 5.04 & 4.99 & 5.37 & 5.3 & 5.07 & 5.08 & 4.81 & 4.53 & 5.27 & 5.79 & 6.51 & 5.47 & 5.6 \\
\hline $\mathrm{Cl}$ & 0.01 & 0.01 & 0 & 0.01 & 0.01 & 0 & 0.01 & 0.01 & 0 & 0 & 0 & 0.01 & 0.02 & 0 & 0.07 & 0 & 0 & $0 . C$ \\
\hline \multirow[t]{2}{*}{ Total } & 101.46 & 101.07 & 101.86 & 101.39 & 101.86 & 101.18 & 101.26 & 101.52 & 101.44 & 101 & 100.98 & 100.42 & 97.4 & 101.51 & 100.04 & 99.65 & 100.09 & 99. \\
\hline & \multicolumn{18}{|c|}{ Fórmula estrutural calculada na base de 32 átomos de oxigênio } \\
\hline $\mathrm{Si}$ & 8.696 & 8.764 & 8.716 & 8.777 & 8.775 & 8.702 & 8.677 & 8.707 & 8.767 & 8.731 & 8.733 & 8.861 & 8.300 & 8.710 & 8.604 & 8.417 & 8.621 & 8.5 \\
\hline Al & 7.169 & 7.260 & 7.150 & 7.089 & 7.072 & 7.178 & 7.173 & 7.163 & 7.105 & 7.135 & 7.140 & 7.036 & 7.521 & 7.117 & 7.382 & 7.632 & 7.354 & 7.4: \\
\hline $\mathrm{TI}$ & 0.014 & 0.007 & 0.003 & 0.006 & 0.003 & 0 & 0.001 & 0.003 & 0.001 & 0.007 & 0.001 & 0.006 & 0 & 0 & 0.009 & 0.001 & 0.007 & 0.0 \\
\hline $\mathrm{Fe}^{3}$ & 0.154 & 0.148 & 0.156 & 0.144 & 0.161 & 0.122 & 0.154 & 0.147 & 0.123 & 0.133 & 0.152 & 0.138 & 0.04 & 0.151 & 0.069 & 0.03 & 0.096 & 0.0 \\
\hline $\mathrm{Na}$ & 5.925 & 5.385 & 5.937 & 5.987 & 5.972 & 6.055 & 6.073 & 5.925 & 5.945 & 6.002 & 5.922 & 5.834 & 6.356 & 6.063 & 5.752 & 5.721 & 5.776 & 5.7 \\
\hline $\mathrm{Ca}$ & 0.002 & 0 & 0.002 & 0.002 & 0.002 & 0.004 & 0 & 0 & 0 & 0 & 0.004 & 0 & 0.298 & 0 & 0 & 0 & 0.002 & 0 \\
\hline 0 & 32 & 32 & 32 & 32 & 32 & 32 & 32 & 32 & 32 & 32 & 32 & 32 & 32 & 32 & 32 & 32 & 32 & $3:$ \\
\hline K & 1.228 & 1.278 & 1.238 & 1.159 & 1.186 & 1.210 & 1.198 & 1.286 & 1.269 & 1.219 & 1.221 & 1.158 & 1.139 & 1.263 & 1.408 & 1.595 & 1.327 & 1.3 \\
\hline \multicolumn{19}{|c|}{ Componentes Moleculares } \\
\hline $\mathrm{Ne}$ & 68.17 & 61.44 & 68.15 & 68.24 & 68.09 & 69.65 & 69.99 & 68.05 & 67.81 & 68.74 & 67.87 & 65.84 & 82.5 & 69.61 & 66.85 & 67.97 & 67.03 & 66. \\
\hline Ks & 14.13 & 14.58 & 14.21 & 13.21 & $\nmid 3.52$ & 13.92 & 13.81 & 14.77 & 14.47 & 13.96 & 13.99 & 13.07 & 14.78 & 14.5 & 16.36 & 18.95 & 15.4 & \\
\hline Qz & 17.71 & 23.97 & 17.64 & 18.55 & 18.39 & 16.44 & 16.2 & 17.18 & 17.71 & 17.29 & 18.13 & 21.09 & 2.71 & 15.89 & 16.78 & 13.08 & 17.57 & \\
\hline
\end{tabular}

Abreviaçōes como na tabela 13.0 
Tabela 13.6 - Composição química de nefelinas de traquifonolito de Pão de Açúcar (\% peso)

Amostra RP-207 RP-207 RP-207 RP-207 RP-207 RP-207 RP-207 RP-207 RP-207 RP-207 RP-207 RP-207 RP-207 RP-207 RP-207

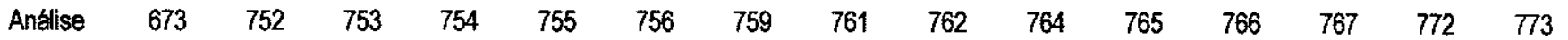
Locaçäo C4G2m C1G1n C1G1b C1G2n C1G2b C1G3n C2G3n C3G1n C3G1b c3G3n C3G3b C3G4n C3G4b C4G3n C4G3b

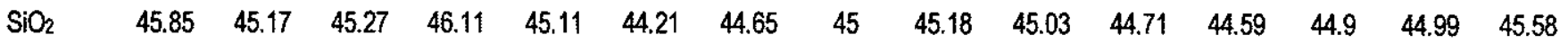

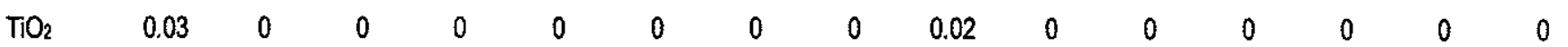

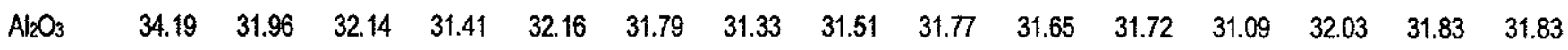

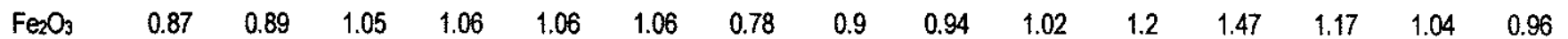
$\begin{array}{lllllllllllllllll}\mathrm{MnO} & 0 & 0.02 & 0.02 & 0.04 & 0.02 & 0 & 0.02 & 0.01 & 0.03 & 0 & 0 & 0.03 & 0.05 & 0 & 0\end{array}$

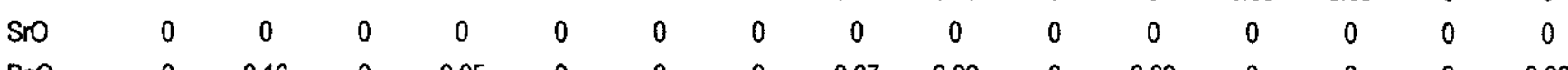

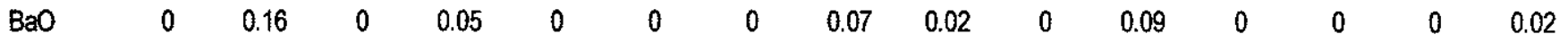
$\begin{array}{llllllllllllllll}\mathrm{CaO} & 0.05 & 0.02 & 0 & 0.02 & 0.01 & 0 & 0.02 & 0 & 0.03 & 0.04 & 0 & 0.03 & 0.04 & 0 & 0.02\end{array}$ $\begin{array}{llllllllllllllll}\mathrm{Na} 2 \mathrm{O} & 14.51 & 16.49 & 15.91 & 16.7 & 16.91 & 16.83 & 15.91 & 17.08 & 16.71 & 16.75 & 16.65 & 16.74 & 15.86 & 16.83 & 16.7\end{array}$ $\begin{array}{llllllllllllllll}\mathrm{K} 2 \mathrm{O} & 5.42 & 5.33 & 5.39 & 4.83 & 5.24 & 5.21 & 5.32 & 4.93 & 5.26 & 5.23 & 5.26 & 4.98 & 5.27 & 5.14 & 5.06\end{array}$ $\begin{array}{llllllllllllllllll}\mathrm{Cl} & 0 & 0.01 & 0.01 & 0 & 0 & 0 & 0.01 & 0.02 & 0.02 & 0 & 0.01 & 0 & 0 & 0.02 & 0.01\end{array}$

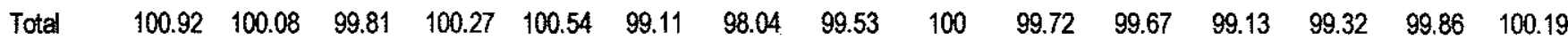
Fómula estrutural calculada na base de 32 átomos de oxigênio

\begin{tabular}{|c|c|c|c|c|c|c|c|c|c|c|c|c|c|c|c|}
\hline $\mathrm{Si}$ & 8.592 & 8.635 & 8.650 & 8.763 & 8.588 & 8.549 & 8.689 & 8.649 & 8.643 & 8.639 & 8.596 & 8.618 & 8.625 & 8.618 & 8.682 \\
\hline $\mathrm{Al}$ & 7.545 & 7.195 & 7.232 & 7.030 & 7.210 & 7.239 & 7.180 & 7.132 & 7.157 & 7.151 & 7.182 & 7.076 & 7.246 & 7.181 & 7.140 \\
\hline 11 & 0.004 & 0 & 0 & 0 & 0 & 0 & 0 & 0 & 0.003 & 0 & 0 & 0 & 0 & 0 & 0 \\
\hline$=e^{3}$ & 0.123 & 0.128 & 0.151 & 0.151 & 0.152 & 0.154 & 0.114 & 0.13 & 0.135 & 0.147 & 0.173 & 0.214 & 0.169 & 0.15 & 0.137 \\
\hline $\mathrm{Ja}$ & 5.272 & 6.112 & 5.895 & 6.154 & 6.242 & 6.310 & 6.003 & 6.366 & 6.198 & 6.231 & 6.207 & 6.273 & 5.908 & 6.251 & 6.168 \\
\hline $\mathrm{Ca}$ & 0.01 & 0.004 & 0 & 0.004 & 0.002 & 0 & 0.004 & 0 & 0.006 & 0.008 & 0 & 0.006 & 0.008 & 0 & 0.004 \\
\hline & 32 & 32 & 32 & 32 & 32 & 32 & 32 & 32 & 32 & 32 & 32 & 32 & 32 & 32 & 32 \\
\hline & 1.296 & 1.300 & 1.314 & 1.171 & 1.273 & 1.285 & 1.321 & 1.209 & 1.284 & 1.280 & 1.290 & 1.228 & 1.292 & 1.256 & 1.230 \\
\hline & & & \multicolumn{13}{|c|}{ Componentes Moleculares } \\
\hline le & 61.5 & 70.85 & 68.15 & 70.29 & 72.72 & 73.81 & 69.15 & 73.6 & 71.81 & 72.26 & 72.21 & 72.89 & 68.63 & 72.53 & 71.11 \\
\hline & 15.12 & 15.07 & 15.19 & 13.38 & 14.83 & 15.03 & 15.22 & $\$ 3.98$ & 14.88 & 14.84 & 15.01 & 14.27 & 15.01 & 14.57 & 14.18 \\
\hline $2 z$ & 23.38 & 14.08 & 16.66 & 16.33 & 12.45 & 11.16 & 15.63 & 12.42 & 13.31 & 12.9 & 12.79 & 12.84 & 16.37 & 12.89 & 14.71 \\
\hline
\end{tabular}

Abreviações como na tabela 13.0 
Tabela 13.7 - Composição química de nefelinas de nefelina sienitos de São Pedro (255) e Porto Conceição (267)(\% peso)

\begin{tabular}{|c|c|c|c|c|c|c|}
\hline Amostra & RP-255 & RP-255 & RP-267 & RP-267 & RP-267 & RP-267 \\
\hline Análise & 1135 & 1136 & 1193 & 1194 & 1195 & 1196 \\
\hline Locaçáo & C4G1n & C4G1b & C2G1n & $\mathrm{C} 2 \mathrm{G} 1 \mathrm{~b}$ & $C 2 G 2 n$ & $C 2 G 3 n$ \\
\hline $\mathrm{SiO}_{2}$ & 46.44 & 45.85 & 45.54 & 45.55 & 45.3 & 45.66 \\
\hline $\mathrm{TiO}_{2}$ & 0.02 & 0.01 & 0 & 0.01 & 0.02 & 0 \\
\hline $\mathrm{Al}_{2} \mathrm{O}_{3}$ & 33.24 & 33.76 & 33.18 & 33.1 & 33.18 & 33.41 \\
\hline $\mathrm{Fe}_{2} \mathrm{O}_{3}$ & 0.41 & 0.37 & 0.47 & 0.41 & 0.41 & 0.4 \\
\hline $\mathrm{MnO}$ & 0.03 & 0 & 0 & 0 & 0.01 & 0 \\
\hline Sro & 0 & 0 & 0 & 0 & 0 & 0 \\
\hline $\mathrm{BaO}$ & 0.08 & 0 & 0 & 0.02 & 0 & 0 \\
\hline $\mathrm{CaO}$ & 0.94 & 0.96 & 0.39 & 0.37 & 0.41 & 0.49 \\
\hline $\mathrm{Na} 2 \mathrm{O}$ & 15.12 & 15.37 & 15.29 & 15.68 & 15.68 & 14 \\
\hline $\mathrm{K}_{2} \mathrm{O}$ & 4.81 & 4.97 & 5.49 & 5.54 & 5.45 & 5.22 \\
\hline $\mathrm{Cl}$ & 0.02 & 0.02 & 0 & 0.01 & 0 & 0 \\
\hline Total & 101.11 & 101.31 & 100.36 & 100.69 & 100.46 & 99.18 \\
\hline \multicolumn{7}{|c|}{ Fórmula estrutural calculada na base de 32 átomos de oxigênio } \\
\hline $\mathrm{Si}$ & 8.694 & 8.584 & 8.622 & 8.612 & 8.583 & 8.683 \\
\hline $\mathrm{Al}$ & 7.328 & 7.443 & 7.398 & 7.370 & 7.404 & 7.482 \\
\hline $\mathrm{Ti}$ & 0.003 & 0.001 & 0 & 0.001 & 0.003 & 0 \\
\hline $\mathrm{Fe}^{3}$ & 0.058 & 0.052 & 0.067 & 0.058 & 0.058 & 0.057 \\
\hline $\mathrm{Na}$ & 5.488 & 5.579 & 5.613 & 5.749 & 5.761 & 5.162 \\
\hline $\mathrm{Ca}$ & 0.189 & 0.193 & 0.079 & 0.075 & 0.083 & 0.1 \\
\hline 0 & 32 & 32 & 32 & 32 & 32 & 32 \\
\hline K & 1.149 & 1.187 & 1.326 & 1.336 & 1.317 & 1.266 \\
\hline \multicolumn{7}{|c|}{ Componentes Moleculares } \\
\hline $\mathrm{Ne}$ & 65.99 & 68.05 & 66.32 & 67.94 & 68.44 & 60.85 \\
\hline Ks & 13.82 & 14.48 & 15.67 & 15.79 & 15.65 & 14.92 \\
\hline $\mathrm{Qz}$ & 20.19 & 17.47 & 18.02 & 16.27 & 15.91 & 24.22 \\
\hline
\end{tabular}

Abreviaçסes como na tabela 13.0 
Tabela 13.8 - Composição quimica de sodalitas em sienitos nefelinicos de Cerro Boggiani (\% peso)

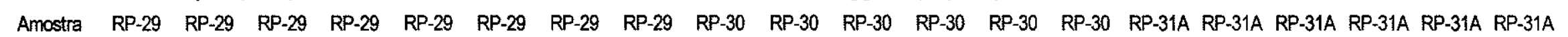

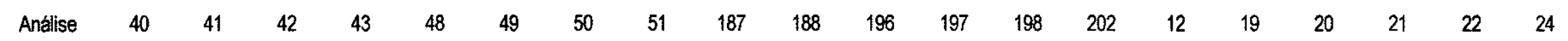
Locação C1G4n C1G4b C1G5n C1G5b C5G3n C5G3b C5G4n C5G4b C6G1n C6G1b C7G5n C7G5b C8G1n C9G1n C2G4n C3G4n C3G4b C3G5n C3G5b C4G2n $\begin{array}{llllllllllllllllllllll}\mathrm{SiO}_{2} & 37.308 & 37.556 & 38.142 & 37.403 & 37.800 & 37.664 & 37.599 & 37.669 & 36.486 & 37.148 & 42.495 & 41.824 & 38.144 & 40.874 & 36.224 & 37.879 & 37.687 & 37.844 & 37.466 & 37.745\end{array}$

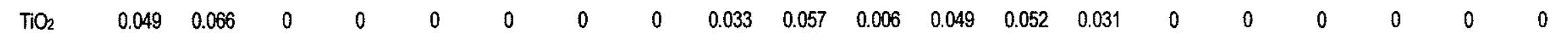

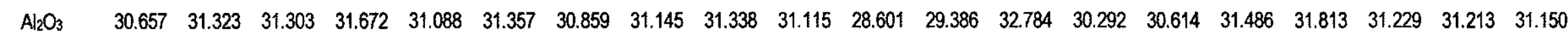
$\begin{array}{lllllllllllllllllllll}\mathrm{Fe}_{2} \mathrm{O}_{3} & 0.61 & 0.465 & 0.662 & 0.453 & 0.649 & 0.497 & 0.484 & 0.558 & 0.263 & 0.169 & 0.135 & 0.11 & 0.482 & 0.09 & 0.31 & 0.28 & 0.482 & 0.413 & 0.545 & 0.673\end{array}$ $\begin{array}{llllllllllllllllllllllll}\mathrm{MnO} & 0.037 & 0.002 & 0.002 & 0.011 & 0.032 & 0 & 0.008 & 0.037 & 0.018 & 0.015 & 0.02 & 0.032 & 0.029 & 0 & 0.019 & 0 & 0.011 & 0 & 0.037 & 0.013\end{array}$

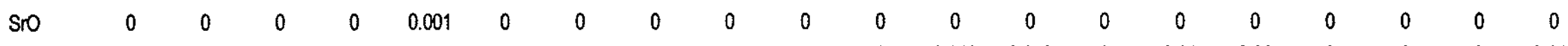

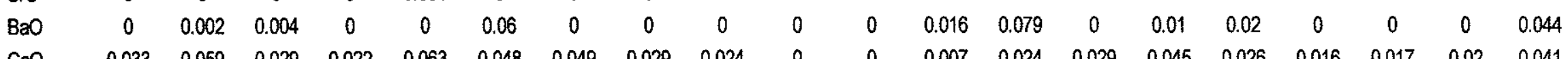
$\begin{array}{llllllllllllllllllllll}\mathrm{Na} 2 \mathrm{O} & 25.248 & 25.436 & 25.240 & 25.310 & 25.344 & 25.454 & 25.407 & 25.178 & 25.755 & 25.751 & 20.338 & 22.130 & 23.887 & 22.323 & 24.624 & 24.853 & 24.740 & 24.947 & 24.933 & 24.711\end{array}$

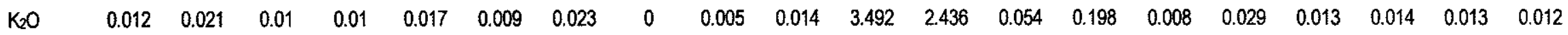

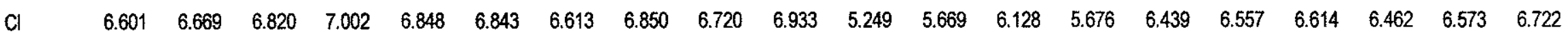
$\begin{array}{lllllllllllllllllllll}\text { Total } & 100.57 & 101.6 & 102.21 & 101.88 & 101.85 & 101.93 & 101.04 & 101.47 & 100.64 & 101.2 & 100.34 & 101.66 & 101.66 & 99.51 & 98.29 & 101.13 & 101.39 & 100.93 & 100.81 & 101.11\end{array}$ Fórmula estrutural calculada na base de 32 átomos de oxigênio

\begin{tabular}{|c|c|c|c|c|c|c|c|c|c|c|c|c|c|c|c|c|c|c|c|c|}
\hline $\mathrm{Si}$ & 7.744 & 7.711 & 7.779 & 7.677 & 7.755 & 7.721 & 7.762 & 7.751 & 7.594 & 7.690 & 8.624 & 8.425 & 7.718 & 8.317 & 7.683 & 7.775 & 7.720 & 7.783 & 7.736 & 7.774 \\
\hline Al & 7.494 & 7.573 & 7.519 & 7.656 & 7.511 & 7.570 & 7.502 & 7.547 & 7.681 & 7.586 & 6.835 & 6.971 & 7.812 & 7.259 & 7.647 & 7.611 & 7.675 & 7.564 & 7.590 & 7.556 \\
\hline $\mathrm{Ti}$ & 0.008 & 0.01 & 0 & 0 & 0 & 0 & 0 & 0 & 0.005 & 0.009 & 0.001 & 0.007 & 0.008 & 0.005 & 0 & 0 & 0 & 0 & 0 & 0 \\
\hline $\mathrm{Fe}^{3}$ & 0.095 & 0.072 & 0.102 & 0.07 & 0.1 & 0.077 & 0.075 & 0.086 & 0.041 & 0.026 & 0.021 & 0.017 & 0.073 & 0.014 & 0.049 & 0.043 & 0.074 & 0.064 & 0.085 & 0.104 \\
\hline $\mathrm{Na}$ & 10.162 & 10.126 & 9.982 & 10.073 & 10.081 & 10.118 & 10.170 & 10.046 & 10.394 & 10.336 & 8.003 & 8.644 & 9.371 & 8.808 & 10.127 & 9.891 & 9.827 & 9.949 & 9.982 & 9.869 \\
\hline $\mathrm{Ca}$ & 0.007 & 0.013 & 0.006 & 0.005 & 0.014 & 0.011 & 0.011 & 0.006 & 0.005 & 0 & 0 & 0.002 & 0.005 & 0.006 & 0.01 & 0.006 & 0.004 & 0.004 & 0.004 & 0.009 \\
\hline 0 & 32 & 32 & 32 & 32 & 32 & 32 & 32 & 32 & 32 & 32 & 32 & 32 & 32 & 32 & 32 & 32 & 32 & 32 & 32 & 32 \\
\hline$k$ & 0.003 & 0.006 & 0.003 & 0.003 & 0.004 & 0.002 & 0.006 & 0 & 0.001 & 0.004 & 0.904 & 0.626 & 0.014 & 0.051 & 0.002 & 0.008 & 0.003 & 0.004 & 0.003 & 0.003 \\
\hline
\end{tabular}
Abreviações como na tabela 13.0 
Tabela 13.9 - Composição química de sodalitas de rochas de Cerro Boggiani (\% peso)

\begin{tabular}{|c|c|c|c|c|c|c|c|c|c|c|}
\hline Amostra & RP-31A & RP-31A & RP-31A & RP-31A & RP-41 & $R P-41$ & $R P-42$ & $R P-43$ & $R P-43$ & $R P-43$ \\
\hline Análise & 25 & 27 & 28 & 29 & 57 & 58 & 292 & 310 & 320 & 321 \\
\hline Locação & C4G2b & C4GAn & C4G5n & C4G6n & C1G3n & C1G3b & C3G1n & C1G3n & C3G4n & $C 3 G 4 b$ \\
\hline $\mathrm{SiO}_{2}$ & 38.092 & 37.559 & 37.714 & 37.534 & 37.690 & 37.846 & 38.406 & 45.591 & 37.865 & 42.001 \\
\hline $\mathrm{TiO}_{2}$ & 0 & 0 & 0 & 0 & 0 & 0.009 & 0.005 & 0.009 & 0.005 & 0.035 \\
\hline $\mathrm{Al}_{2} \mathrm{O}_{3}$ & 30.950 & 31.706 & 31.803 & 31.662 & 31.709 & 31.820 & 33.818 & 28.442 & 33.694 & 30.526 \\
\hline $\mathrm{Fe}_{2} \mathrm{O}_{3}$ & 0.626 & 0.532 & 0.471 & 0.27 & 0.415 & 0.4 & 0.591 & 0.41 & 0.393 & 0.34 \\
\hline $\mathrm{MnO}$ & 0.056 & 0 & 0 & 0.024 & 0 & 0 & 0 & 0 & 0 & 0.018 \\
\hline Sro & 0 & 0 & 0 & 0 & 0 & 0 & 0 & 0 & 0 & 0 \\
\hline $\mathrm{BaO}$ & 0.07 & 0.009 & 0.054 & 0 & 0 & 0.012 & 0.057 & 0.025 & 0.011 & 0.043 \\
\hline $\mathrm{CaO}$ & 0.026 & 0.019 & 0.025 & 0.029 & 0.05 & 0.051 & 0.057 & 0.053 & 0.022 & 0.011 \\
\hline $\mathrm{Na}_{2} \mathrm{O}$ & 25.168 & 24.567 & 24.678 & 24.981 & 25.360 & 25.399 & 23.070 & 18.911 & 23.951 & 21.357 \\
\hline $\mathrm{K} 2 \mathrm{O}$ & 0.025 & 0.009 & 0.021 & 0.021 & 0.011 & 0.025 & 0.025 & 2.762 & 0.018 & 2.510 \\
\hline $\mathrm{Cl}$ & 6.672 & 7.185 & 6.311 & 6.925 & 6.966 & 7.019 & 7.028 & 4.675 & 6.583 & 5.731 \\
\hline Total & 101.69 & 101.59 & 101.08 & 101.45 & 102.2 & 102.58 & 103.06 & 100.88 & 102.54 & 102.57 \\
\hline \multicolumn{11}{|c|}{ Fórmula estrutural calculada na base de 32 átomos de oxigênio } \\
\hline $\mathrm{Si}$ & 7.807 & 7.723 & 7.727 & 7.717 & 7.703 & 7.708 & 7.693 & 8.999 & 7.620 & 8.360 \\
\hline Al & 7.470 & 7.677 & 7.673 & 7.666 & 7.632 & 7.632 & 7.978 & 6.612 & 7.985 & 7.156 \\
\hline$\pi$ & 0 & 0 & 0 & 0 & 0 & 0.001 & 0.001 & 0.001 & 0.001 & 0.005 \\
\hline $\mathrm{Fe}^{3}$ & 0.096 & 0.082 & 0.073 & 0.042 & 0.064 & 0.061 & 0.089 & 0.061 & 0.059 & 0.051 \\
\hline $\mathrm{Na}$ & 10.002 & 9.795 & 9.803 & 9.959 & 10.050 & 10.030 & 8.961 & 7.238 & 9.345 & 8.243 \\
\hline $\mathrm{Ca}$ & 0.006 & 0.004 & 0.005 & 0.006 & 0.011 & 0.011 & 0.012 & 0.011 & 0.005 & 0.002 \\
\hline 0 & 32 & 32 & 32 & 32 & 32 & 32 & 32 & 32 & 32 & 32 \\
\hline K & 0.007 & 0.002 & 0.005 & 0.006 & 0.003 & 0.006 & 0.006 & 0.696 & 0.005 & 0.637 \\
\hline
\end{tabular}




\begin{tabular}{|c|c|c|c|c|c|c|c|c|}
\hline Amostra & RP-88 & RP-88 & RP-88 & RP-207 & $R P-255$ & RP-256 & RP-256 & $R P-256$ \\
\hline Análise & 785 & 786 & 848 & 774 & 1134 & 1139 & 1140 & 1141 \\
\hline Locaçäo & C1G3n & C1G3b & $\mathrm{C} 2 \mathrm{G} 1 \mathrm{~m}$ & C4G4n & $\mathrm{C} 2 \mathrm{G} 2 \mathrm{i}$ & C1G3n & C1G3b & $\mathrm{C} 2 \mathrm{G} 1 \mathrm{i}$ \\
\hline $\mathrm{SiO}_{2}$ & 36.66 & 36.79 & 37.37 & 36.41 & 38.12 & 37.94 & 37.95 & 38.08 \\
\hline $\mathrm{TiO}_{2}$ & 0 & 0.01 & 0 & 0 & 0 & 0.02 & 0 & 0 \\
\hline $\mathrm{Al}_{2} \mathrm{O}_{3}$ & 31.42 & 31.5 & 33.39 & 31.67 & 32.71 & 32.17 & 32.26 & 32.26 \\
\hline $\mathrm{Fe}_{2} \mathrm{O}_{3}$ & 0.7 & 0.66 & 0.96 & 0.55 & 0.18 & 0.35 & 0.36 & 0.26 \\
\hline $\mathrm{MnO}$ & 0.01 & 0 & 0.04 & 0.01 & 0 & 0 & 0 & 0.01 \\
\hline Sro & 0 & 0 & 0 & 0.01 & 0 & 0 & 0 & 0 \\
\hline $\mathrm{BaO}$ & 0 & 0 & 0 & 0 & 0 & 0 & 0.12 & 0.1 \\
\hline $\mathrm{CaO}$ & 0.04 & 0.04 & 0.1 & 0.05 & 0.08 & 0.15 & 0.16 & 0.02 \\
\hline $\mathrm{Na} 2 \mathrm{O}$ & 22.57 & 22.57 & 18.52 & 22.09 & 24.24 & 24.64 & 24.2 & 24.1 \\
\hline $\mathrm{K}_{2} \mathrm{O}$ & 0.01 & 0 & 0.01 & 0.01 & 0.02 & 0.05 & 0.02 & 0.07 \\
\hline $\mathrm{Cl}$ & 6.91 & 7.04 & 7.01 & 6.92 & 4.53 & 4.53 & 4.62 & 4.58 \\
\hline Total & 98.32 & 98.62 & 97.4 & 97.72 & 99.88 & 99.85 & 99.69 & 99.48 \\
\hline \multicolumn{9}{|c|}{ Fórmula estrutural calculada na base de 32 átomos de oxigênio } \\
\hline $\mathrm{Si}$ & 7.738 & 7.746 & 7.818 & 7.719 & 7.726 & 7.720 & 7.733 & 7.763 \\
\hline Al & 7.810 & 7.811 & 8.226 & 7.907 & 7.808 & 7.709 & 7.741 & 7.745 \\
\hline Ti & 0 & 0.002 & 0 & 0 & 0 & 0.003 & 0 & 0 \\
\hline $\mathrm{Fe}^{3}$ & 0.111 & 0.104 & 0.151 & 0.088 & 0.027 & 0.054 & 0.055 & 0.04 \\
\hline $\mathrm{Na}$ & 9.237 & 9.215 & 7.512 & 9.081 & 9.526 & 9.721 & 9.561 & 9.526 \\
\hline $\mathrm{Ca}$ & 0.009 & 0.009 & 0.022 & 0.011 & 0.017 & 0.033 & 0.035 & 0.004 \\
\hline 0 & 32 & 32 & 32 & 32 & 32 & 32 & 32 & 32 \\
\hline$K$ & 0.003 & 0 & 0.003 & 0.003 & 0.005 & 0.013 & 0.005 & 0.018 \\
\hline
\end{tabular}




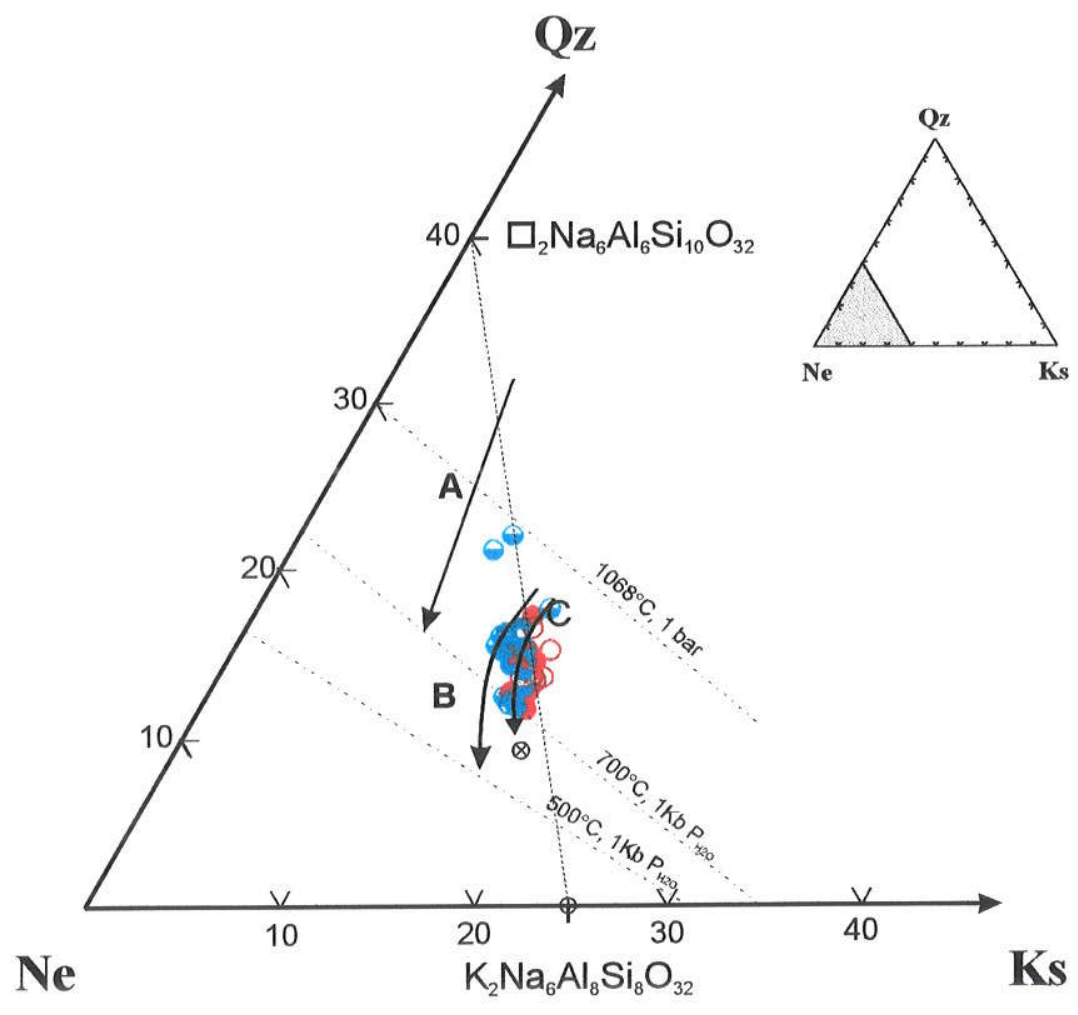

Figura 24 - Diagrama Ne- Ks-Qz apresentando a evolução composional das nefelinas das rochas de Cerro Boggiani. Temperaturas conforme Hamilton \& Mackenzie (1960) e Hamilton (1961). Trend evolutivo para as nefelinas de Square Top (Wilkinson \& Hendel, 1994) indicado com A e das rochas sieníticas da llha Monte de Trigo indicado por B (Enrich \& Ruberti, 2000) e C para nefelinas de Cerro Boggiani. Símbolos: núcleos de grãos em sienitos nefelínicos (círculos cheios); bordas de grãos em sienitos nefelínicos (círculos vazios); núcleos de grãos em fonolitos peralcalinos (ćrculos com metade inferior preenchidas) e bordas de grãos em fonolitos peralcalinos (círculos com metade superior preenchidas). 


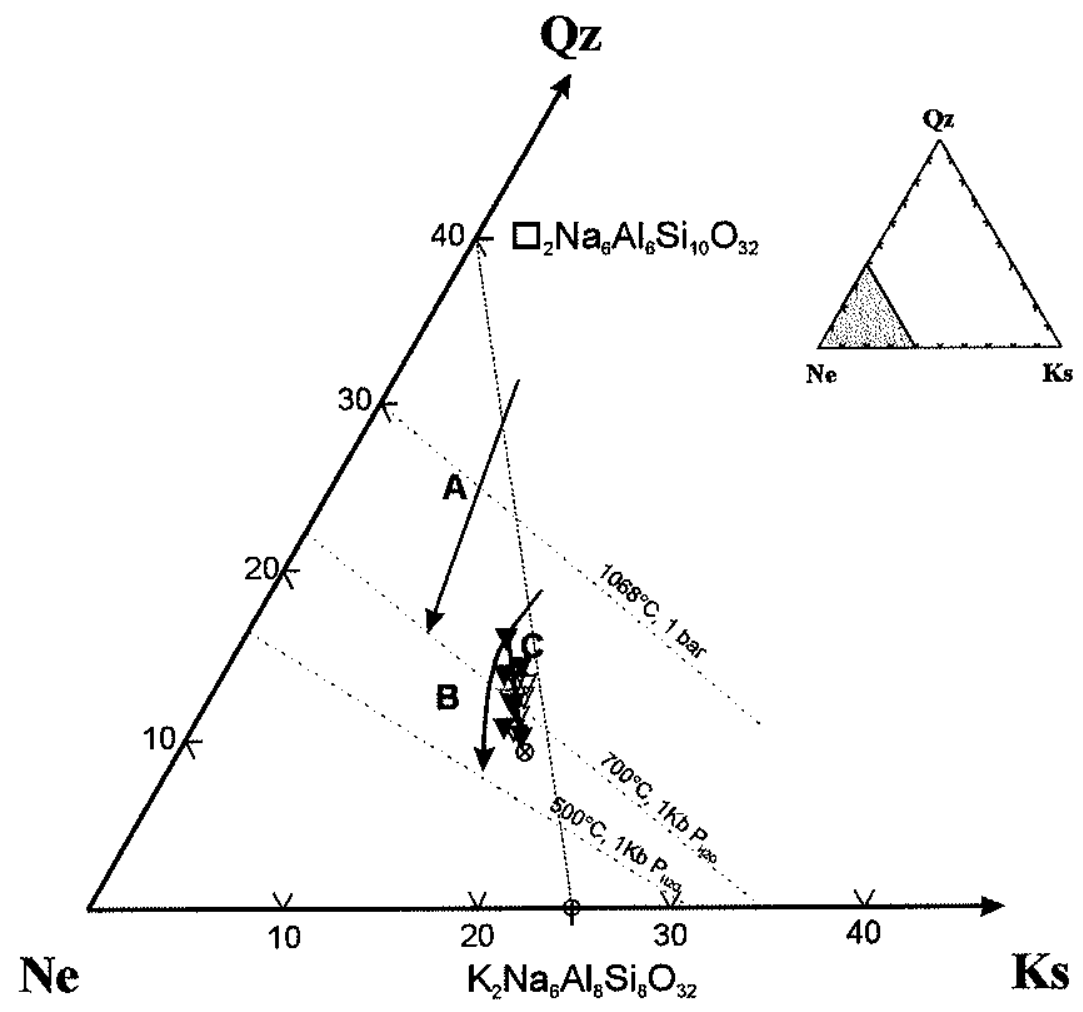

Figura 25 - Diagrama Ne -Ks-Qz apresentando a evolução composicional das nefelinas das rochas de Cerro Siete Cabezas.. Temperaturas conforme Hamilton \& Mackenzie (1960) e Hamilton (1961). Trend evolutivo para as nefelinas de Square Top (Wilkinson \& Hendel, 1994) (A), rochas sieníticas da Itha Monte de Trigo (Enrich \& Ruberti, 2000), e (C) para as rochas de Siete Cabezas. Símbolos: núcleo de grãos (triângulos cheios), bordas de grãos (triângulos vazios). 


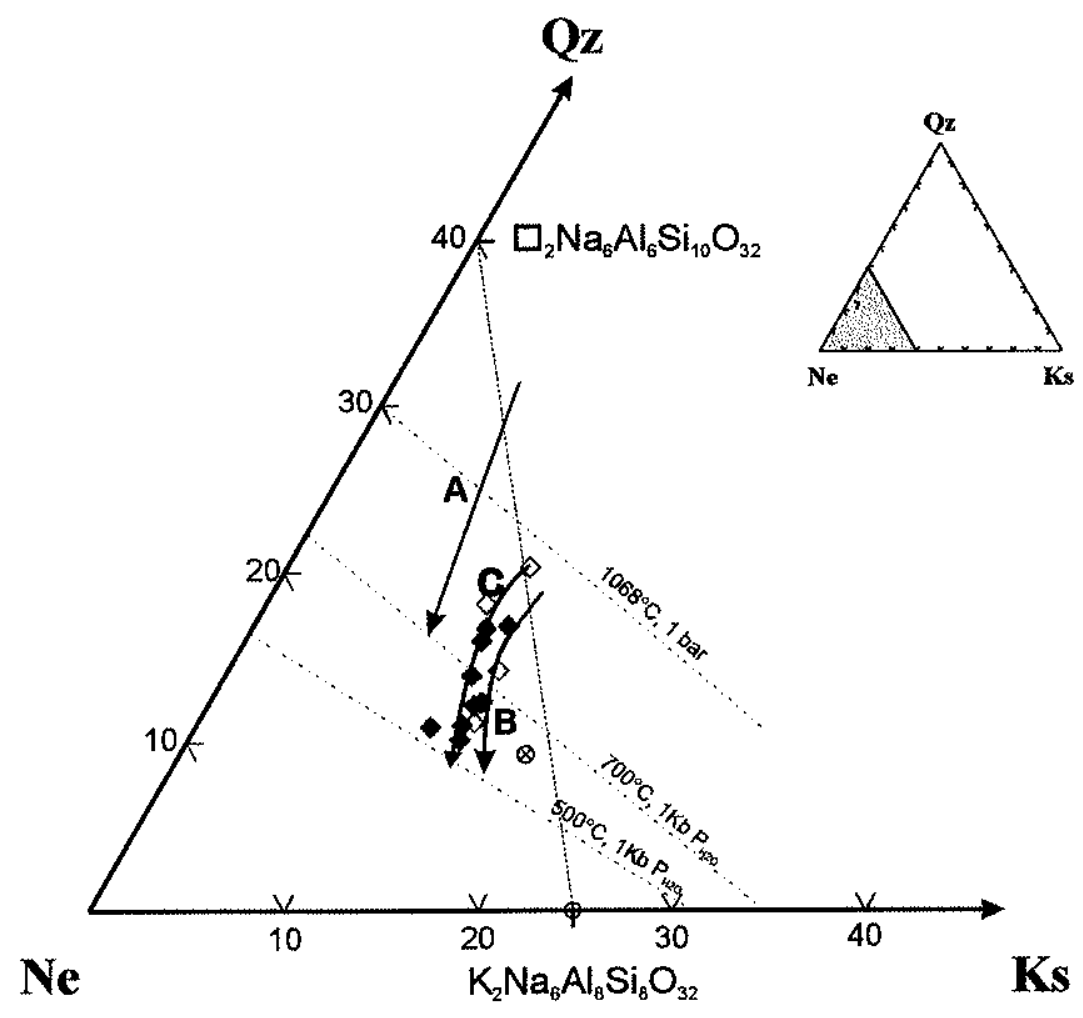

Figura 26 - Diagrama Ne -Ks -Qz mostrando a evolução composicional das nefelinas dos sienitos nefelínicos de Cerrito.(curva C) Temperaturas conforme Hamilton \& Mackenzie (1960) e Hamilton (1961). Trend evolutivo para as nefelinas de Square Top (Wilkinson \& Hendel, 1994) indicado com A e para as rochas sieníticas da liha Monte de Trigo (Enrich \& Ruberti, 2000) indicado por B. Símbolos: núcleo de grão (losângulo cheio), borda de grão (losângulo vazio). 


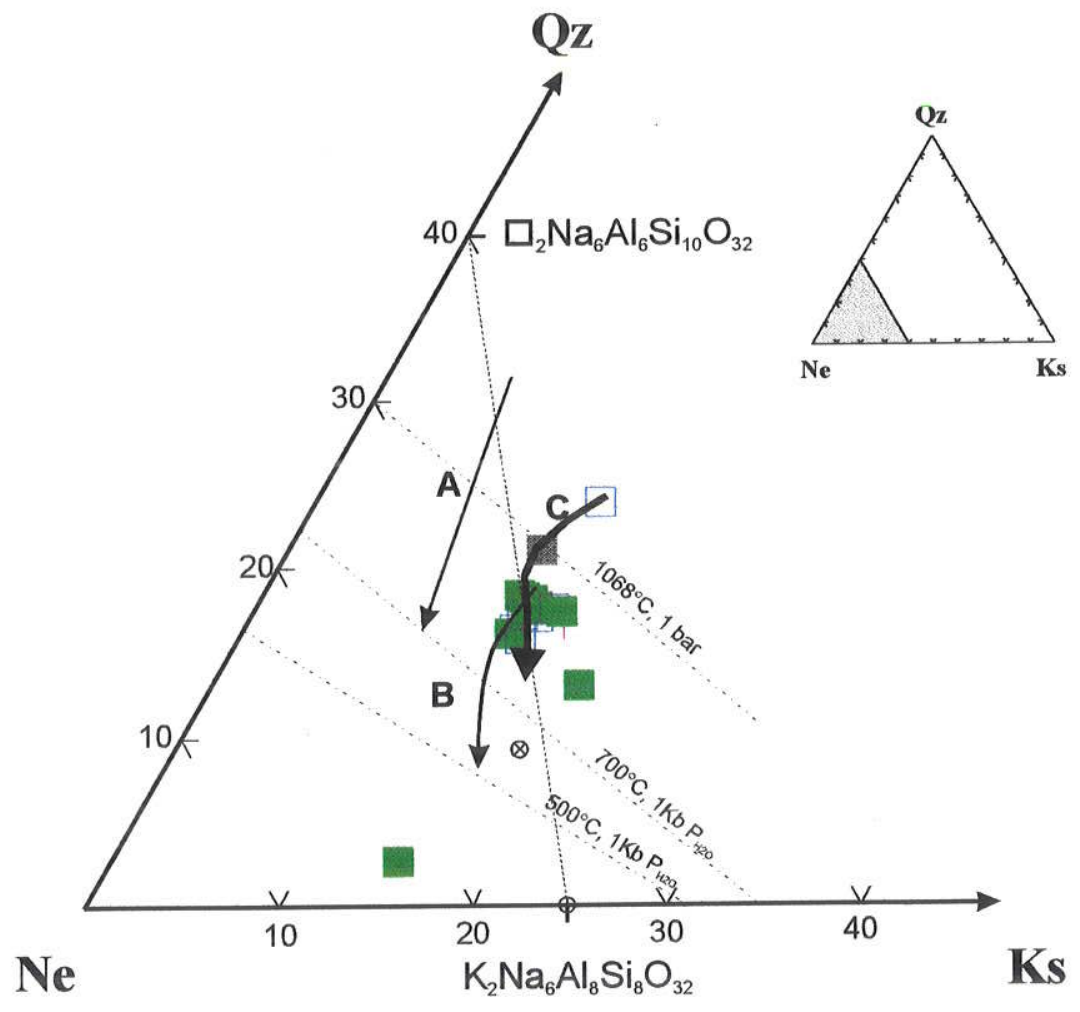

Figura 27 - Diagrama Ne - Ks- Qz mostrando a evolução composicional das nefelinas dos sienitos nefelínicos da llha Fecho dos Morros. Trend evolutivo para as nefelinas de Square Top (Wilkinson \& Hendel, 1994) indicado com A e para as rochas sieníticas da llha Monte de Trigo (Enrich \& Ruberti, 2000) indicado por B. Temperaturas conforme Hamilton \& Mackenzies (1960) e Hamilton (1961). Símbolos: núcleo dos grãos (quadrado cheio), borda dos grãos (quadrado vazio). 


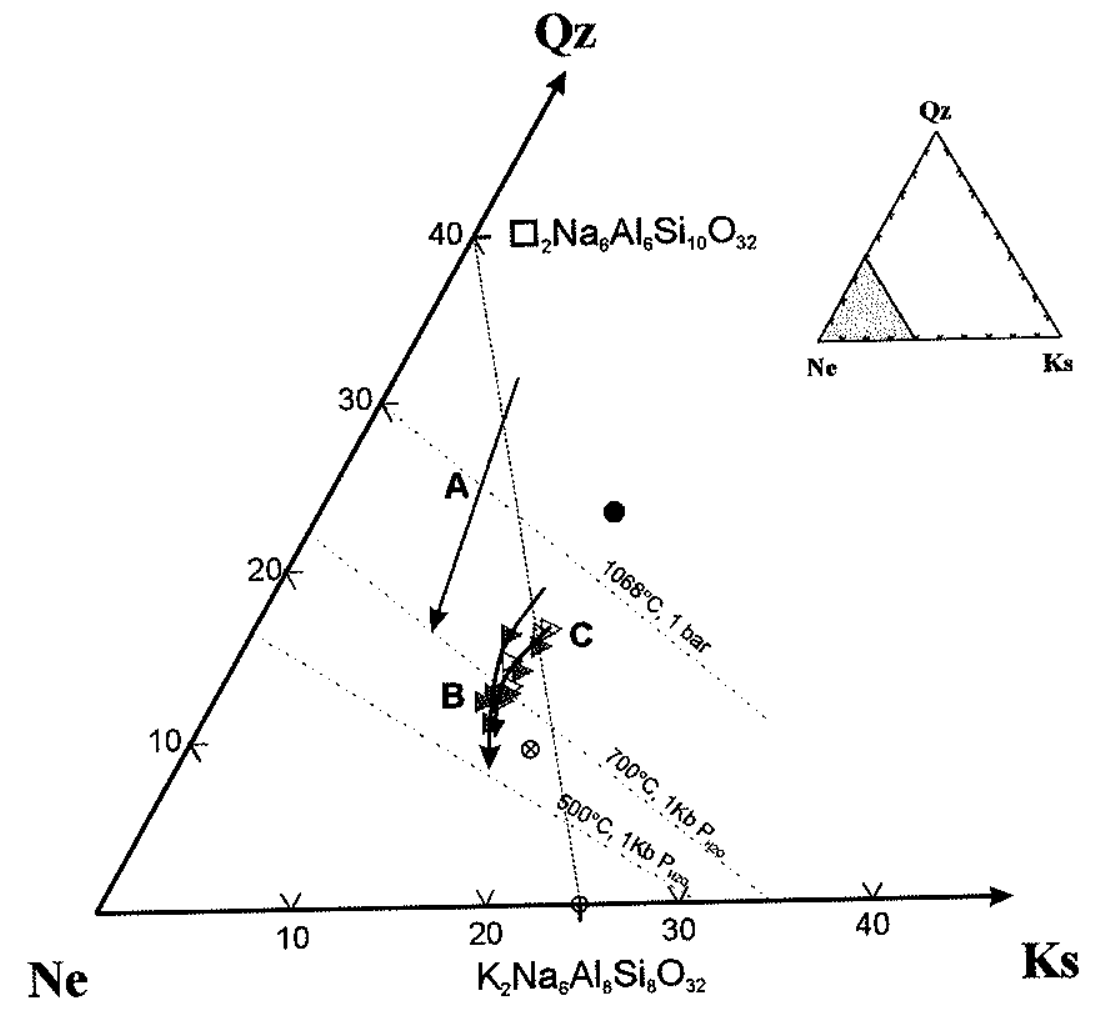

Figura 28 - Diagrama Ne- Ks-Qz apresentando a evolução composional das nefelinas das rochas de Morro Pão de Açucar. Temperaturas conforme Hamilton \& Mackenzie (1960) e Hamilton (1961). Trend evolutivo para as nefelinas de Square Top (Wilkinson \& Hendel, 1994) indicado com A e das rochas sieníticas da liha Monte de Trigo indicado por B (Enrich \& Ruberti, 2000) e C para nefelinas de Morro Pão de Açucar. Símbolos: núcleo de grãos (triângulo cheio), borda de grão (triângulo vazio). 


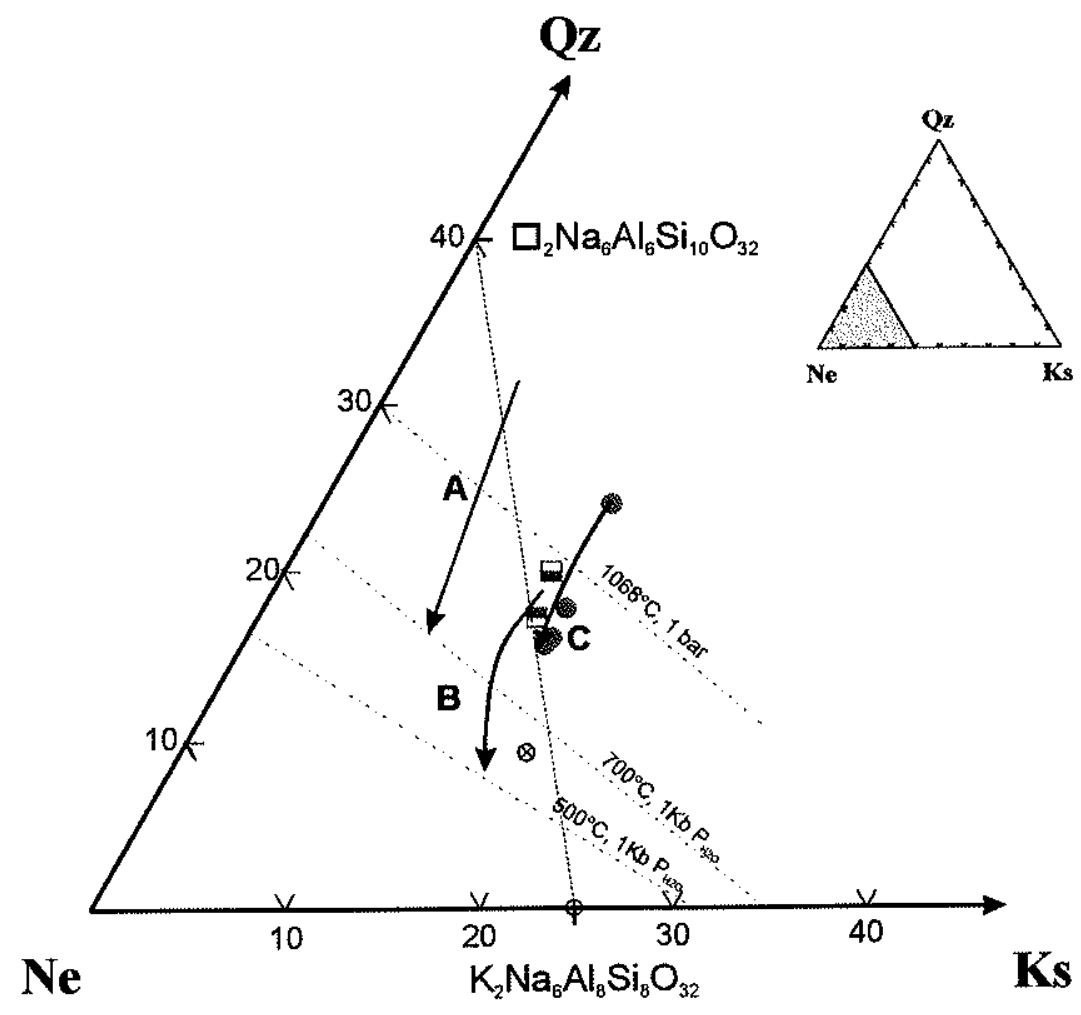

Figura 29a - Diagrama Ne- Ks-Qz apresentando a evolução composional das nefelinas das rochas de São Pedro e Porto Conceição. Temperaturas conforme Hamilton \& Mackenzie (1960) e Hamilton (1961). Trend evolutivo para as nefelinas de Square Top (Wilkinson \& Hendel, 1994) indicado com A e das rochas sieníticas da liha Monte de Trigo indicado por B (Enrich \& Ruberti, 2000) e C para nefelinas de São Pedro e Porto Conceição. Símbolos: grãos em sienito de Porto Conceição (círculo cheio), núcleo de grãos em sienito alcalino de São Pedro (quadrado com metade inferior preenchida), borda de grãos em sienito alcalino de São Pedro (quadrado com metade superior preenchidas). 


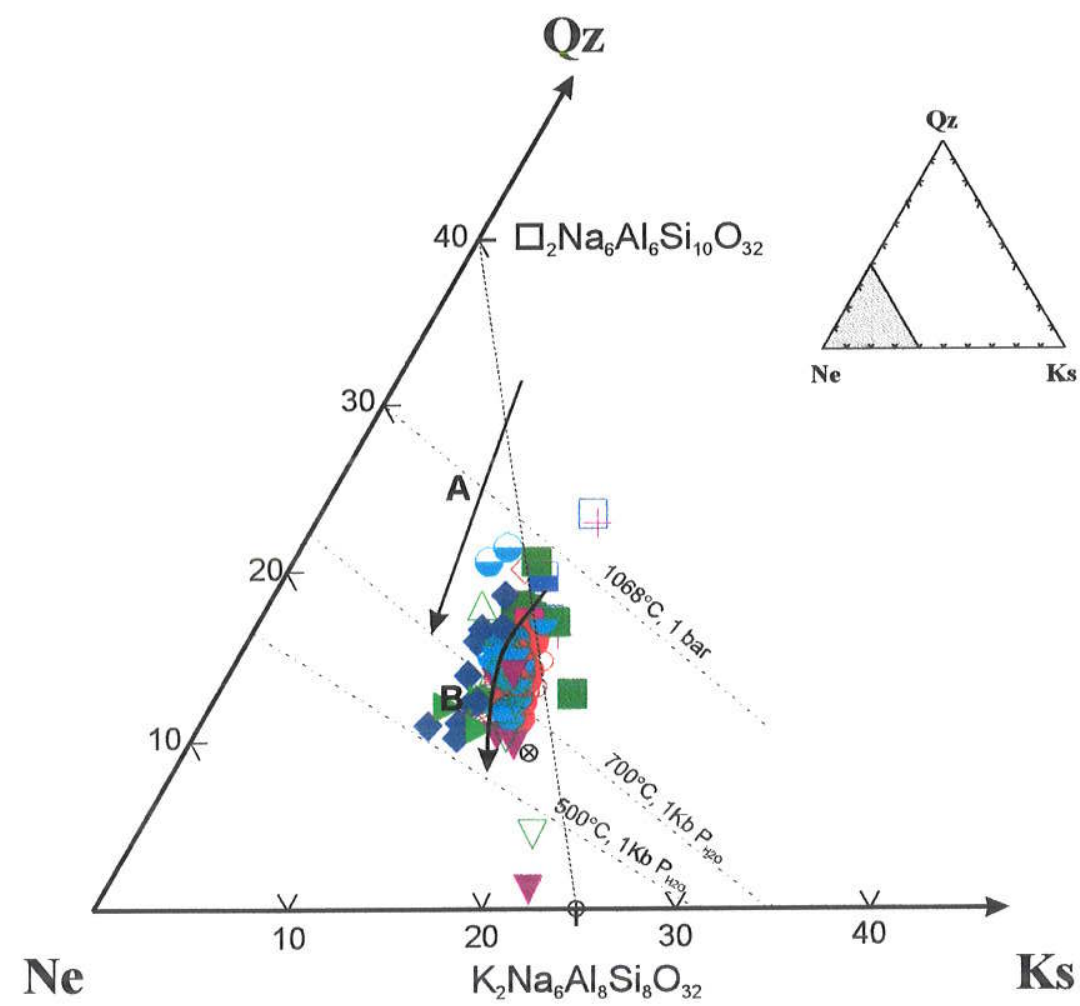

Figura 29b - Diagrama Ne -Ks- Qz mostrando a evolução composicional das nefelinas das rochas sieníticas da Província Alcalina Alto Paraguai, coincidindo com o trend evolutivo indicado com B para as rochas sieníticas da llha Monte de Trigo (Enrich \& Ruberti, 2000) e tendências para nefelinas de Square Top (Wilkinson Hendel, (1994) indicado por A Temperaturas conforme Hamilton \& Mackenzie (1960) e Hamilton (1961). Símbolos como nas Figuras de 24 a 29a. 


\section{V.3 - Anfibólios}

Os anfibólios representam, em termos quantitativos, a segunda fase máfica mais importante das rochas dos corpos da Província Alcalina Alto Paraguai, sendo encontrado em quase todos os litotipos. Ocorrem principalmente sob a forma de grãos primários isolados formando texturas glomeroporfiríticas e ainda como produtos de alterações pós-magmáticas substituindo piroxênios.

Segundo a International Mineralogical Association - IMA (Leake, 1978) a fórmula estrutural dos anfibólios é representada pela seguinte expressão:

$\mathrm{A}_{0.1} \mathrm{~B}_{2}{ }^{\mathrm{VI}} \mathrm{C}_{5}{ }^{\mathrm{N}} \mathrm{T}_{8} \mathrm{O}_{22}(\mathrm{OH}, \mathrm{F}, \mathrm{Cl})_{2}$ onde:

$\mathrm{T}=$ posições tetraédricas ocupadas por $\mathrm{Si}, \mathrm{Al}, \mathrm{Cr}^{3+}, \mathrm{Fe}^{3+} \mathrm{e} \mathrm{Ti}^{4+}$;

$\mathrm{C}=\mathrm{M} 1+\mathrm{M} 2+\mathrm{M} 3=$ posições octaédricas preenchidas por $\mathrm{Al}, \mathrm{Cr}, \mathrm{Ti}, \mathrm{Fe}^{3+}, \mathrm{Mg}, \mathrm{Fe}^{2+}$ e Mn;

$\mathrm{B}=\mathrm{M} 4=$ posições com número de coordenação 6 preenchidas por $\mathrm{Fe}^{2+}, \mathrm{Mn}, \mathrm{Mg}$, $\mathrm{Ca}$ e $\mathrm{Na}$;

$\mathrm{A}=$ posições com número de coordenação 12 preenchidas por $\mathrm{Na}$ e $\mathrm{K}$.

As análises químicas dos anfibólios estudados estão dispostas nas tabelas 14.0 a 14.16. Tendo em vista que a quantidade de $\mathrm{H}_{2} \mathrm{O}$ na estrutura mineral é incerta, a fórmula estrutural foi calculada na base de 23 oxigênios, assumindo que tenham $2(\mathrm{OH}, \mathrm{Cl}, \mathrm{F})$, sendo utilizada nos recálculos a opção de todo o $\mathrm{Fe}$ existente, considerado como $\mathrm{Fe}^{2+}$. Os cálculos estequiométricos foram feitos pelo método de balanço de carga (Robinson et al. 1981) empregados pelo programa AINPET 2.0 (Richard, 1995) que oferece cinco diferentes opções de recálculo, tendo-se utilizado aquele em que os cátions são reajustados para uma média entre $15 \mathrm{NK}$ e $13 \mathrm{CNK}$, ou seja, somente Ca e Na ocupam a posição M4, enquanto que a posição A é preenchida por $\mathrm{Na} \in \mathrm{K}$.

As classificações dos anfibólios estudados foram efetuadas conforme Hawthorne (1981, in Richard, 1995) acatando as modificações de Leake et al. (1997), segundo recomendações da IMA. Estas, propõem a utilização do termo sódico, em vez de alcalino, para os anfibólios que apresentam os seguintes 
parâmetros: $\mathrm{Na}_{\mathrm{B}}>1,50 ;\left(\mathrm{Mg}+\mathrm{Fe}^{2+}+\mathrm{Mn}^{2+}\right)>2,5 ; \quad\left(\mathrm{Al}^{\mathrm{Vl}}\right.$ ou $\left.\mathrm{Fe}^{3+}\right)>\mathrm{Mn}^{3+} ; \quad \mathrm{Li}<0,5 ; \quad(\mathrm{Mg}$ ou $\left.\mathrm{Fe}^{2+}\right)>\mathrm{Mn}^{2+}$.

Conforme os critérios estabelecidos pela IMA, os anfibólios presentes nas rochas da Província Alcalina Alto Paraguai foram, de uma maneira geral, classificados como cálcicos $(\mathrm{Ca}+\mathrm{Na})_{B} \geq 1,34, \mathrm{Na}_{B}<0,67$ e $\mathrm{Ca}_{B}>1,34$; sódicocálcicos $(\mathrm{Ca}+\mathrm{Na})_{\mathrm{B}} \geq 1,34$ e $\left.0,67 \leq \mathrm{Na}_{\mathrm{B}}<1,34\right)$; e sódicos $\left(\mathrm{Na}_{\mathrm{B}} \geq 1,34\right)$.

Nos sienitos nefelínicos de Cerro Boggiani, nefelina sienitos de Cerro Siete Cabezas, sienitos alcalinos de Satélite I e Satélite II, quartzo sienitos e traquifonolitos de Pão de Açúcar e os pegmatitos sieníticos de llha Fecho dos Morros ocorrem anfibólios tanto cálcicos como cálcico-sódicos e também sódicos (Figuras 30-A, 31-A, 32-A e 33-A). Nos sienitos nefelínicos de Cerrito, fonolitos de São Pedro e fonolitos e nos sienitos alcalinos de Morro Conceição, Morro Distante e Porto Conceição (Figuras 34-A, 35-A, 37-A, 38A e 39-A) os anfibólios existentes são estritamente de natureza cálcica.

Os anfibólios cálcicos dos sienitos nefelínicos de Cerro Boggiani correspondem à ferro-edenita rica em silica (Figura 30-B); os cálcico-sódicos à ferro richterita (Figura 30-C) enquanto que ferro eckermanita representa os sódicos (Figura 30-D).

Nos corpos alcalinos de Cerro Siete Cabezas e Satélites I e II os anfibólios cálcicos são geralmente a ferro-edenita rica em sílica e subordinadamente a edenita rica em sílica e ferro-pargasita hornblenda (Figuras 31-B e 31-C). Os anfibólios cálcico-sódicos estão representados predominantemente pela ferro richterita (Figura 31-D); enquanto que os anfibólios sódicos correspondem à ferro eckermanita, arfvedsonita e ferro glaucofânio (Figuras 31-E e 31-F). Estas classificações coincidem amplamente com àquelas encontradas para os anfibólios de outros corpos da Província Alcalina Alto Paraguai tais como: Pão de Açúcar (Figuras 32-B, 32-C, 32-D e 32-E) e llha Fecho dos Morros (Figura 33-B). Neste último apresentando também anfibólio sódico do tipo magnésio arfvedsonita (Figura 33-C).

Como anteriormente relatado, alguns corpos apresentam anfibólios exclusivamente de natureza cálcica, sendo classificados como se segue: ferro- 
edenita silícica em Cerrito (Figura 34-A e B); ferro-pargasita hornblenda, ferroedenita hornblenda e edenita hornblenda em São Pedro (Figuras 35-B e 35-C); edenita/ferro edenita em Morro Conceição (Figura 37-B); actinolita-hornblenda (Figura 39-B) e ferro-pargasita hornblenda e edenita (Figuras 39-C), em Morro Distante.

Adicionalmente aos anfibólios cálcicos que correspondem à edenita rica em sílica (Figura 36-D), Cerro Pedreira é o único corpo da província a apresentar anfibólios de Fe-Mg-Mn. Esses minerais possuem $\mathrm{Na}_{B} \leq 1,34$ e $(\mathrm{Ca}+\mathrm{Na})_{B} \leq 1,34$, e nas rochas estudadas foram classificados como antofilita e grunerita (Figuras 36-B e C).

Nos diagramas Ca-Mg-Fe*, K-Ca-Na e $\mathrm{Al}^{\mathrm{IV}}+\mathrm{Ca}$ versus $\mathrm{Si}+\mathrm{Na}+\mathrm{K}$ (Figura 40A, 40-B e 41) estão representadas as variações composicionais dos anfibólios da Província Alcalina Alto Paraguai. No primeiro, observa-se um "trend" evolutivo de enriquecimento em $\mathrm{Fe}^{*}$ para uma razão $\mathrm{Ca} / \mathrm{Mg}$ constante; o segundo apresenta um aumento de $\mathrm{Na}$ nos anfibólios das rochas mais diferenciadas, para valores de $\mathrm{K}$ praticamente constantes; e no terceiro, a tendência evolutiva corresponde a um processo de substituição de $\mathrm{Ca}+\mathrm{Al}{ }^{\prime \mathrm{V}}$ por $\mathrm{Si}+\mathrm{Na}$, semelhante àquelas encontradas em anfibólios das rochas alcalinas descritas em Neumann (1976), Giret et al. (1980), Conceição et al. (1991) e Sousa (1997). 


\begin{tabular}{|c|c|c|c|c|c|c|c|c|c|c|c|c|}
\hline Amostra & RP-30 & RP-43 & RP-43 & RP-43 & RP.43 & RP. 43 & RP-43 & $R P-43$ & $R P=43$ & $R P \cdot 43$ & RP- 43 & RP-43 \\
\hline Análise & 535 & 430 & 501 & 502 & 503 & 504 & 505 & 506 & 512 & 513 & 514 & 515 \\
\hline Locação & C6G1n & $\mathrm{C} 2 \mathrm{G} 3 \mathrm{n}$ & $\mathrm{C} 2 \mathrm{G} 1 \mathrm{~m}$ & $\mathrm{C} 2 \mathrm{G} 2 \mathrm{~m}$ & $\mathrm{C} 2 \mathrm{G} 3 \mathrm{Fn}$ & $\mathrm{C} 2 \mathrm{G} 3 \mathrm{Fb}$ & C2G4Fn & $\mathrm{C} 2 \mathrm{G} 4 \mathrm{Fb}$ & C6G1n & C6G1b & $\mathrm{C} 6 \mathrm{G} 2 \mathrm{~m}$ & C6G3m \\
\hline Mineral & Anf & Si-Ed & Si-Ed & Si-Ed & Si-Ed & Si-Ed & Si-Ed & Si-Ed & Si-Ed & SinEd & Si-Ed & Si-Ed \\
\hline $\mathrm{SiO}_{2}$ & 54 & 54.24 & 47.97 & 47.32 & 47.99 & 49.35 & 47.83 & 47.74 & 48.2 & 48.32 & 48.02 & 47.44 \\
\hline $\mathrm{TiO}_{2}$ & 0.43 & 0.56 & 1.52 & 1.49 & 1.66 & 1.07 & 1.51 & 1.64 & 1.71 & 1,66 & 1.74 & 1.78 \\
\hline $\mathrm{Al}_{2} \mathrm{O}_{3}$ & 1.42 & 8.08 & 5 & 5.17 & 3.81 & 3.06 & 3.83 & 3.5 & 3.73 & 3.69 & 3.75 & 3.76 \\
\hline $\mathrm{Cr}_{2} \mathrm{O}_{3}$ & 0 & 0 & 0 & 0.03 & 0 & 0.02 & 0.04 & 0.03 & 0 & 0 & 0.04 & 0 \\
\hline $\mathrm{FeO}$ & 15.95 & 14.69 & 19.71 & 20.02 & 20.3 & 19.44 & 20.03 & 19.94 & 19.65 & 19.6 & 19.69 & 19.88 \\
\hline $\mathrm{MnO}$ & 2.93 & 0.4 & 2.55 & 2 & 2.3 & 2.06 & 2.3 & 2.42 & 2.22 & 2.35 & 2.55 & 2.62 \\
\hline $\mathrm{MgO}$ & 11.68 & 1.9 & 7. & & 8.3 & 8.78 & 8.25 & 8.3 & 8.5 & 8. & 7.89 & 7.86 \\
\hline $\mathrm{CaO}$ & 1.75 & 6.24 & 3.82 & 3.26 & 3.69 & 2.86 & 3.93 & 3.87 & 3.4 & 3.37 & 3.31 & 3.48 \\
\hline $\mathrm{Na}_{2} \mathrm{O}$ & 8.6 & 7.2 & 7.33 & 7.44 & 6.86 & 7.76 & 6.74 & 7.04 & 7.19 & 7.3 & 7.45 & 7.11 \\
\hline $\mathrm{K}_{2} \mathrm{O}$ & 1.68 & 2.99 & 1.32 & 1.44 & 1.41 & 1.42 & 1.45 & 1.32 & 1.31 & 1.43 & 1.33 & 1.39 \\
\hline $\mathrm{F}$ & 1.45 & 0 & 1.1 & 1.12 & 1.36 & 1.26 & 1.21 & 1.22 & 1.37 & 1.19 & 1.21 & 1.15 \\
\hline $\mathrm{Cl}$ & 0 & 0 & 0 & 0.01 & 0 & 0 & 0.01 & & 0 & 0 & 0 & 0 \\
\hline $\mathrm{ZrO}_{2}$ & 0.1 & 0.4 & 0 & 0 & 0 & c & 0 & & 0 & 0 & 0 & 0 \\
\hline $\mathrm{ZnO}$ & 0.14 & 0 & 0 & 0 & 0 & 0 & 0 & c & 0 & 0 & 0 & 0 \\
\hline $\mathrm{BaO}$ & 0 & 0 & 0.03 & 0 & 0.01 & 0 & 0.06 & 0 & 0.11 & 0 & 0.09 & 0.03 \\
\hline Fotal & 100.18 & 96.89 & 98.01 & 97.04 & 97.7 & 97.08 & 97.22 & 97.46 & 97. & 97.36 & 97.07 & 96.5 \\
\hline $\mathrm{O}_{-} F_{-} \mathrm{CL}$ & 0.61 & 0 & & & 0.57 & 0. & 0.51 & & 0. & 0.5 & 0.51 & 0.48 \\
\hline OF $F$ & 0.61 & 0 & 0.47 & & & 0.53 & $0.5 \hat{1}$ & 0.51 & 0.58 & 0.5 & 0.51 & 0.48 \\
\hline O_CL & 0 & 0 & 0 & 0 & 0 & 0 & 0 & 0 & 0 & 0 & 0 & 0 \\
\hline Clotal & 99.57 & 96.89 & 97.54 & 96.57 & 97.2 & 96.55 & 96.71 & 96.95 & 96.9 & 96.86 & 96.56 & 96.02 \\
\hline \multicolumn{13}{|c|}{ Fórmula esirutural calculada na base de 23 átomos de oxigênio } \\
\hline $\mathrm{TSi}$ & 7.867 & 8.837 & 7.332 & 7.289 & 7.328 & 7.56 & 7.358 & 7.324 & 7.378 & 7.399 & 7.417 & 7,362 \\
\hline TAl & 0.133 & 0 & 0.668 & 0.711 & 0.672 & 0.44 & 0.642 & 0.676 & 0.622 & 0.601 & 0.583 & 0.638 \\
\hline $\mathrm{TFe}^{3+}$ & 0 & 0 & 0 & 0 & 0 & 0 & 0 & 0 & 0 & 0 & 0 & 0 \\
\hline Soma_T & 8 & 8.837 & 8 & 8 & 8 & 8 & 8 & 8 & 8 & 8 & 8 & 8 \\
\hline CAl & 0.111 & 1.5 & 0.232 & 0.226 & 0.014 & 0.112 & 0.052 & 0.036 & 0.051 & 0.065 & 0.099 & 0.049 \\
\hline $\mathrm{CCr}$ & 0 & 0 & 0 & 0.004 & 0 & 0.002 & 0.005 & 0.004 & 0 & 0 & 0.005 & 0 \\
\hline $\mathrm{CFe}^{3+}$ & 0.625 & 0 & 0.405 & & & & 0.645 & & 0.659 & 0.601 & 0.486 & 0.601 \\
\hline CTi & 0.047 & 0.069 & & & & & 0.175 & & 0.1 & 0.1 & 0.202 & 0.208 \\
\hline $\mathrm{CMg}$ & 2.537 & 0.478 & 1.7 & & & & 1.892 & 1.898 & 1.949 & 1.929 & 1.817 & 1.818 \\
\hline $\mathrm{CFe}^{2+}$ & 1.318 & 2.002 & 2.11 & & 1.8 & 1.93 & 1.932 & 1.925 & 1.857 & 1.91 & 2.058 & 1.979 \\
\hline CMn & 0.362 & 0.063 & 0.33 & 0.287 & 0.3 & 0.267 & 0.3 & 0.314 & 0.288 & 0.305 & 0.334 & 0.344 \\
\hline Soma_C & 5 & 5 & 5 & 5 & 5 & 5 & 5 & 5 & 5 & 5 & 5 & 5 \\
\hline $\mathrm{BCa}$ & 0.273 & 0.252 & 0.626 & 0.538 & 0.604 & 0.469 & 0.648 & 0.636 & 0.564 & 0.553 & 0.548 & 0.579 \\
\hline $\mathrm{BNa}$ & 1.727 & 1.748 & 1.374 & 1.462 & 1.396 & 1.531 & 1.352 & 1.364 & 1.436 & 1.447 & 1.452 & 1.421 \\
\hline Soma $B$ & 2 & 2 & 2 & 2 & 2 & 2 & 2 & 2 & 2 & 2 & 2 & 2 \\
\hline $\mathrm{ANa}$ & 0.717 & 0.546 & & & & 0.774 & 0.658 & 0.73 & 0.698 & 0.72 & 0.779 & 0.718 \\
\hline AK & 0.312 & 0.621 & & 0.283 & 0.275 & 0.278 & 0.285 & 0.258 & 0.256 & 0.279 & 0.262 & 0.275 \\
\hline Soma_A & 1.029 & 1.167 & 1.05 & 1.0 & 0.91 & 1.052 & 0.943 & 0.989 & 0.954 & 1 & 1.041 & 0.993 \\
\hline S_CAT - & 16.029 & 17,004 & 16.055 & 16.043 & 15.91 & 16.052 & 15.943 & 15.989 & 15.954 & 16 & 16.041 & 15.993 \\
\hline $\mathrm{CCL}$ & 0 & 0 & 0 & 0.003 & 0 & 0 & 0.003 & 0 & 0 & 0 & 0 & 0 \\
\hline $\mathrm{CF}$ & 0.668 & 0 & 0.537 & 0.546 & 0.657 & 0.61 & 0.589 & 0.592 & 0.663 & 0.576 & 0.591 & 0.564 \\
\hline & 23 & 23 & 23 & 23 & 23 & 23 & 23 & 23 & 23 & 23 & 23 & 23 \\
\hline
\end{tabular}

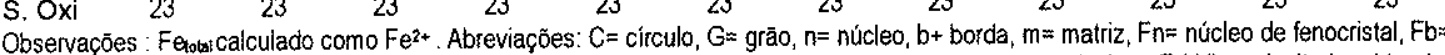
borda de fenocristal, $E d=$ edenita, Si-Ed=sílica edenita, Fe-Ed= ferro edenita, SiFeEd= sílica-ferro edenita, Ed-Hb= edenita-hornblenda, $\mathrm{Fe}-\mathrm{Ed}-\mathrm{Hb}=$ ferro-edenita-homblenda e $\mathrm{Fe}-\mathrm{Pg}-\mathrm{Hb}=$ ferro-pargasita-hornblenda 
Tabela 14.1 - Composição química dos anfibólios do corpo Satélite II (\% peso)

\begin{tabular}{|c|c|c|c|c|c|c|c|c|c|c|c|c|c|c|}
\hline Amostra & RP-44 & RP-44 & RP-44 & RP-44 & $R P-44$ & RP-44 & $R P_{n} 44$ & $\mathrm{RP} .44$ & RP-44 & RP-44 & RP-44 & $\mathrm{RP}-44$ & RP-44 & RP.44 \\
\hline Análise & 101 & 102 & 104 & 105 & 106 & 107 & 120 & 121 & 122 & 123 & 124 & 125 & 126 & 127 \\
\hline Locação & C1G1Fb & $\mathrm{C} 2 \mathrm{G} 2 \mathrm{~b}$ & $\mathrm{C} 2 \mathrm{G} 1 \mathrm{~b}$ & C4G1n & C4G1b & C4G2n & $\mathrm{C} 2 \mathrm{G} 2 \mathrm{n}$ & c1G1n & C1G1b & C3G1n & C $3 G 2 n$ & C4G1n & $C 4 G 2 n$ & $\mathrm{C} 4 \mathrm{G} 2 \mathrm{~b}$ \\
\hline Mineral & SiFeEd & SiFeEd & SiFeEd & SiFeEd & SiFeEd & SiFeEd & SiFeEd & SiFeEd & SiFeEd & SiFeEd & SiFeEd & SiFeEd & SiFeEd & SiFeEd \\
\hline $\mathrm{iO}_{2}$ & 47.187 & 47.917 & 48.791 & 49.659 & 48.08 & 48.273 & 49.349 & 45.241 & 44.532 & 45.781 & 48.891 & 48.659 & 47.103 & 48.493 \\
\hline $\mathrm{TiO}_{2}$ & 0.826 & 0.85 & 0.866 & 0.837 & 0.892 & 1.022 & 0.861 & 1.481 & 1.549 & 0.923 & 0.662 & 0.998 & 0.875 & 0.865 \\
\hline $\mathrm{Al}_{2} \mathrm{O}_{3}$ & 3.406 & 2.83 & 2.614 & 1.906 & 2.918 & 2.697 & 1.472 & 4.039 & 4.522 & 3.815 & 1.667 & 1.613 & 2.688 & 1.71 \\
\hline $\mathrm{Cr}_{2} \mathrm{O}_{3}$ & 0 & 0 & 0 & 0.0 & 0.006 & 0.014 & 0.022 & 0 & 0 & 0 & 0.001 & 0 & 0 & 0 \\
\hline 0 & 28.139 & 27.561 & 24.919 & 25.221 & 25.183 & 25.039 & 23.903 & 23.964 & 23.888 & 23.962 & 23.852 & 24.578 & 24.098 & 24.756 \\
\hline no & 1.478 & 1.606 & 1.5 & & & 1.516 & 1.46 & 1.376 & 1.391 & 1.545 & 1.468 & 1.651 & 1.36 & 1.583 \\
\hline go & 6.093 & 6.643 & 6.8 & 6.6 & 6.1 & 6.38 & 7.464 & 6.33 & 5.985 & 6.621 & 7.11 & 6.501 & 6.612 & 6.501 \\
\hline $\mathrm{aO}$ & 8.294 & 7.589 & 7.5 & 7.181 & 7.38 & 7.589 & 7.084 & 8.48 & 8.507 & 7.132 & 7.135 & 6.979 & 7.757 & 6.875 \\
\hline $\mathrm{a}_{2} \mathrm{O}$ & 3.483 & 3.711 & 3.788 & 3.756 & 3. & 3.9 & 4.0 & 3.493 & 3.426 & 3.615 & 3.856 & 4.055 & 3.637 & 3.948 \\
\hline 0 & 1.172 & 1.121 & 1.048 & 1.025 & 1.06 & 1.098 & 1.0 & 1.216 & 1.282 & 1.433 & 1.063 & 0.966 & 1.125 & 1.066 \\
\hline $\mathrm{F}$ & 0 & 0 & 0 & 0 & 0 & 0 & 0 & 1.0 & 1.037 & 1.3 & 1.334 & 1.116 & 1.125 & 1.165 \\
\hline 0 & 0 & 0 & 0 & 0 & 0 & 0 & 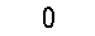 & 0.1 & 0.086 & 0.1 & 0.04 & 0.078 & 0.08 & 0.076 \\
\hline $\mathrm{ZrO}_{2}$ & 0 & 0 & 0 & 0 & 0 & 0 & 0 & 0.098 & 0.114 & 0.135 & 0.117 & 0 & 0.079 & 0.003 \\
\hline $\mathrm{ZnO}$ & 0.128 & 0.088 & 0.041 & 0.127 & 0.042 & 0.122 & 0.7 & 0.043 & 0.118 & 0.08 & 0.119 & 0.112 & 0.096 & 0.069 \\
\hline $\mathrm{aO}$ & 0 & 0 & 0 & 0 & 0 & 0 & 0 & 0 & 0.059 & 0.154 & 0 & 0 & 0 & 0 \\
\hline Total & 100.21 & 99.95 & 97.98 & 97.95 & 97.32 & 97.72 & 97.44 & 96.89 & 96.5 & 96.7 & 97.32 & 97.31 & 96.64 & 97.14 \\
\hline $\mathrm{O}_{-} \mathrm{F}_{-} \mathrm{Cl}$ & 0 & 0 & 0 & 0 & 0 & 0 & 0 & 0.46 & 0.46 & 0 & 0.57 & 0.49 & 0.49 & 0.51 \\
\hline O_F & 0 & 0 & 0 & 0 & 0 & 0 & 0 & 0.43 & 0.44 & 0.57 & 0.56 & 0.47 & 0.47 & 0.49 \\
\hline $\mathrm{O} C \mathrm{CL}$ & 0 & 0 & 0 & 0 & 0 & 0 & 0 & 0.02 & 0.02 & 0.04 & 0.01 & 0.02 & 0.02 & 0.02 \\
\hline Ctotal & 100.21 & 99.95 & 97.98 & 97.95 & 97.32 & 97.72 & 97.44 & 96.43 & 96.04 & 96.1 & 96.75 & 96.82 & 96.15 & 96.63 \\
\hline \multicolumn{15}{|c|}{ Fórmula estrutural calculada na base de 23 átomos de oxigênio } \\
\hline TSi & 7.159 & 7.226 & 7.475 & 7.606 & 7.457 & 7.474 & 7.62 & 7.194 & 7.138 & 7.241 & 7.644 & 7.626 & 7.459 & 7.605 \\
\hline TAl & 0.609 & & 0.4 & & 0.5 & 0.492 & 0.268 & 0.756 & 0.854 & 0.711 & 0.307 & 0.298 & 0.501 & 0.316 \\
\hline $\mathrm{TFe}^{3+}$ & 0.232 & 0.271 & 0.053 & 0.05 & 0.01 & 0.035 & 0.104 & 0.05 & 0.008 & 0.048 & 0.049 & 0.077 & 0.039 & 0.079 \\
\hline oma_T & 8 & 8 & 8 & 8 & 8 & 8 & 8 & 8 & 8 & 8 & 8 & 8 & 8 & 8 \\
\hline Al & 0 & c & c & & 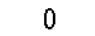 & 0 & 0 & 0 & 0 & c & 0 & 0 & 0 & 0 \\
\hline Cr & 0 & $c$ & 0 & & & 0.002 & 0.003 & 0 & 0 & 0 & 0 & 0 & 0 & 0 \\
\hline $\mathrm{Fe}^{3+}$ & 0.705 & & 0.513 & & 0.4 & 0.365 & 0.403 & 0.239 & 0.239 & 0.724 & 0.428 & 0.37 & 0.356 & 0.467 \\
\hline $\mathrm{Ti}$ & 0.094 & & 0.1 & & & & & 0.177 & 0.187 & 0.11 & 0.078 & 0.118 & 0.104 & 0.102 \\
\hline $\mathrm{CMg}$ & & & & & 1.4 & 1.473 & 1.72 & 1.501 & 1.43 & 1.561 & 1.657 & 1.519 & 1.561 & 1.52 \\
\hline $\mathrm{CFe}^{2+}$ & 2.6 & & 2.6 & 2.658 & 2.782 & 2.843 & 2.584 & 2.898 & 2.955 & 2.398 & 2.642 & 2.774 & 2.797 & 2.701 \\
\hline $\mathrm{CMn}$ & 0.19 & 0.205 & 0.195 & 0.203 & 0.209 & 0.199 & 0.191 & 0.185 & 0.189 & 0.207 & 0.194 & 0.219 & 0.182 & 0.21 \\
\hline Soma_C & 5 & 5 & 5 & 5 & 5 & 5 & 5 & 5 & 5 & 5 & 5 & 5 & 5 & 5 \\
\hline $\mathrm{BCa}$ & 1.348 & 1.226 & 1.241 & 1.179 & 1.227 & 1.259 & 1.173 & 1.445 & 1.461 & 1.209 & 1.195 & 1.172 & 1.316 & 1.155 \\
\hline $\mathrm{BNa}$ & 0.652 & 0.774 & 0.759 & 0.821 & 0.773 & 0.741 & 0.827 & 0.555 & 0.539 & 0.791 & 0.805 & 0.828 & 0.684 & 0.845 \\
\hline Soma_B & 2 & 2 & 2 & 2 & 2 & 2 & 2 & 2 & 2 & 2 & 2 & 2 & 2 & 2 \\
\hline ANa & 0.373 & & 0.36 & 0.294 & 0.42 & 0.446 & 0.38 & 0.522 & 0.526 & 0.317 & 0.364 & 0.404 & 0.433 & 0.356 \\
\hline AK & 0.227 & & 0.2 & 0.2 & 0.211 & 0.217 & 0.213 & 0.247 & 0.262 & 0.289 & 0.212 & 0.193 & 0.227 & 0.213 \\
\hline Soma_A & 0.6 & 0.527 & 0.571 & 0.494 & 0.632 & 0.663 & 0.593 & 0.768 & 0.788 & 0.607 & 0.576 & 0.597 & 0.66 & 0.569 \\
\hline S_CAT & 15.6 & 15.527 & 15.571 & 15.494 & 15.632 & 15.663 & 15.593 & 15.768 & 15.788 & 15.607 & 15.576 & 15.597 & 15.66 & 15.569 \\
\hline$\overline{C C L}$ & 0 & 0 & 0 & 0 & 0 & 0 & 0 & 0.027 & 0.023 & 0.043 & 0.011 & 0.021 & 0.021 & 0.02 \\
\hline $\mathrm{CF}$ & 0 & 0 & 0 & 0 & 0 & 0 & 0 & 0.517 & 0.526 & 0.673 & 0.66 & 0.553 & 0.563 & 0.578 \\
\hline 0 & 23 & 23 & 23 & 23 & 23 & 23 & 23 & 23 & 23 & 23 & 23 & 23 & 23 & 23 \\
\hline
\end{tabular}


Tabela 14.2 - Composição química de anfibólios do corpo Satélçite II (\% peso)

\begin{tabular}{|c|c|c|c|c|c|c|c|c|c|c|c|c|c|c|}
\hline Amostra & RP-44 & RP-44 & RP-44 & RP-44 & RP-44 & RP-44 & RP-44 & RP-44 & RP-44 & RP-44 & RP-44 & RP-44 & $R P=44$ & RP-44 \\
\hline Análise & 154 & 448 & 449 & 450 & 451 & 452 & 453 & 454 & 455 & 456 & 457 & 458 & 516 & 517 \\
\hline Locação & $C 4 G 2 b$ & C1Gín & C1G2n & $\mathrm{C} 1 \mathrm{G} 2 \mathrm{~b}$ & C1G3n & $\mathrm{C} 2 \mathrm{G} 1 \mathrm{n}$ & $\mathrm{C} 2 \mathrm{G} 1 \mathrm{~b}$ & $\mathrm{C} 2 \mathrm{G} 1 \mathrm{n}$ & C3G1n & C3Gíb & C4G1n & $\mathrm{C} 4 \mathrm{G} 1 \mathrm{~b}$ & C1G1Fn & C1G1Fb \\
\hline Mineral & SiFeEd & SiFeEd & SiFeEd & SiFeEd & SifeEd & SiFeEd & SiFeEd & SiFeEd & SiFeEd & SiFeEd & SiFeEd & SiFeEd & SiFeEd & SiFeEd \\
\hline $\mathrm{SiO}_{2}$ & 49.14 & 48.88 & 45.57 & 45.98 & 48.6 & 50.08 & 49.19 & 48.18 & 48.45 & 48.9 & 47.82 & 47.81 & 48.9 & 48.43 \\
\hline $\mathrm{TiO}_{2}$ & 0.637 & 0.93 & 1.5 & 1.3 & 0.75 & 0.81 & 0.96 & 0.89 & 0.82 & 0.83 & 1.02 & 1.03 & 0.66 & 0.7 \\
\hline $\mathrm{Al}_{2} \mathrm{O}_{3}$ & 2.196 & 2.24 & 4.51 & 4.23 & 2.18 & 1.73 & 1.95 & 2.88 & 2.47 & 2.09 & 2.9 & 2.72 & 2.05 & 1.87 \\
\hline $\mathrm{Cr}_{2} \mathrm{O}_{3}$ & 0 & 0 & 0 & 0 & 0 & 0 & 0 & 0 & 0.03 & 0 & 0 & 0 & 0 & 0 \\
\hline $\mathrm{FeO}$ & 24.519 & 23.66 & 24.37 & 24.98 & 23.86 & 23.9 & 24.19 & 24.08 & 23.75 & 23.75 & 24.85 & 25.9 & 24.04 & 24.84 \\
\hline $\mathrm{MnO}$ & 1.477 & 0.84 & 0.889 & 0.94 & 0.97 & 0.9 & 0.82 & 0.88 & 0.89 & 0.93 & 0.87 & 0.92 & 1.49 & 1.54 \\
\hline $\mathrm{MgO}$ & 7.186 & 7.44 & 6.36 & 6.3 & 7.72 & 7.72 & 7.67 & 7.1 & 7.26 & 7.49 & 6.65 & 6.12 & 7.46 & 6.85 \\
\hline $\mathrm{CaO}$ & 7.519 & 7.59 & 8.44 & 8.57 & 7.57 & 7.26 & 7.49 & 7.6 & 7.61 & 7.45 & 7.98 & 7.7 & 7.43 & 7.05 \\
\hline $\mathrm{Na}_{2} \mathrm{O}$ & 3.802 & 3.87 & 3.54 & 3.36 & 3.79 & 3.74 & 3.83 & 3.71 & 3.41 & 3.59 & 3.39 & 3.44 & 4.02 & 3.74 \\
\hline $\mathrm{K}_{2} \mathrm{O}$ & 1.022 & 1.11 & 1.33 & 1.19 & 1.03 & 1.03 & 1.03 & 1.62 & 1.02 & 1.11 & 1.09 & 1.11 & 1.06 & 0.87 \\
\hline $\mathrm{F}$ & 0 & 0 & 0 & 0 & 0 & 0 & 0 & 0 & 0 & 0 & 0 & 0 & 1.01 & 1.05 \\
\hline $\mathrm{Cl}$ & 0 & 0 & 0 & 0 & 0 & 0 & 0 & 0 & 0 & 0 & 0 & 0 & 0.06 & 0.1 \\
\hline $\mathrm{ZrO}_{2}$ & 0 & 0.02 & 0.09 & 0.029 & 0.05 & 0.03 & 0.1 & 0.13 & 0.03 & 0.08 & 0.08 & 0.06 & 0 & 0 \\
\hline $\mathrm{ZnO}$ & 0.118 & 0 & 0 & 0 & 0 & 0 & 0 & 0 & 0 & 0 & 0 & 0 & 0 & 0 \\
\hline $\mathrm{BaO}$ & 0 & 0 & 0 & 0 & 0 & 0 & 0 & 0 & 0 & 0 & 0 & 0 & 0.03 & 0 \\
\hline Total & 97.66 & 96.58 & 96.6 & 96.88 & 96.52 & 97.2 & 97.23 & 97.07 & 95.74 & 96.22 & 96.65 & 96.81 & 98.22 & 97.05 \\
\hline O_F_Cl. & 0 & 0 & 0 & 0 & 0 & 0 & 0 & 0 & 0 & 0 & 0 & 0 & 0.44 & 0.46 \\
\hline O.F & 0 & 0 & 0 & 0 & 0 & 0 & 0 & 0 & 0 & 0 & 0 & 0 & 0.43 & 0.44 \\
\hline $\mathrm{O}_{\mathrm{m}} \mathrm{CL}$ & 0 & 0 & 0 & 0 & 0 & 0 & 0 & 0 & 0 & 0 & 0 & 0 & 0.01 & 0.02 \\
\hline Ctolal & 97.66 & 96.58 & 96.6 & 96.88 & 96.52 & 97.2 & 97.23 & 97.07 & 95.74 & 96.22 & 96.65 & 96.81 & 97.78 & 96.59 \\
\hline \multicolumn{15}{|c|}{ Fórmula estrułural calculada na base de 23 átomos de oxigênio } \\
\hline TSi & 7.544 & 7.582 & 7.17 & 7.2 & 7.52 & 7.661 & 7.562 & 7.482 & 7.549 & 7.586 & 7.451 & 7.457 & 7.541 & 7.545 \\
\hline TAI & 0.397 & 0.409 & 0.83 & 0.78 & 0.397 & 0.312 & 0.353 & 0.518 & 0.451 & 0.382 & 0.532 & 0.5 & 0.372 & 0.343 \\
\hline $\mathrm{TFe}^{3+}$ & 0.059 & 0.009 & 0 & 0.02 & 0.083 & 0.028 & 0.085 & 0 & 0 & 0.032 & 0.017 & 0.044 & 0.087 & 0.112 \\
\hline Soma_T & 8 & 8 & 8 & 8 & 8 & 8 & 8 & 8 & 8 & 8 & 8 & 8 & 8 & 8 \\
\hline CAl & 0 & 0 & 0.006 & 0 & 0 & 0 & 0 & 0.009 & 0.002 & 0 & 0 & 0 & 0 & 0 \\
\hline $\mathrm{CCr}$ & 0 & 0 & 0 & 0 & 0 & 0 & 0 & 0 & 0.004 & 0 & 0 & 0 & 0 & 0 \\
\hline $\mathrm{CFe}^{3+}$ & 0.503 & 0.294 & 0.277 & 0.36 & 0.455 & 0.463 & 0.405 & 0.333 & 0.48 & 0.444 & 0.405 & 0.467 & 0.44 & 0.635 \\
\hline $\mathrm{CTi}$ & 0.074 & 0.109 & 0.178 & 0.153 & 0.087 & 0.093 & 0.111 & 0.104 & 0.096 & 0.097 & 0.12 & 0.121 & 0.077 & 0.082 \\
\hline $\mathrm{CMg}$ & 1.645 & 1.72 & 1.492 & 1.471 & 1.781 & 1.76 & 1.758 & 1.644 & 1.686 & 1.732 & 1.545 & 1.423 & 1.715 & 1.591 \\
\hline $\mathrm{CFe}^{2+}$ & 2.587 & 2.766 & 2.93 & 2.892 & 2.55 & 2.567 & 2.619 & 2.794 & $2.6\{5$ & 2.604 & 2.816 & 2.868 & 2.574 & 2.489 \\
\hline $\mathrm{CMn}$ & 0.192 & 0.11 & 0.118 & 0.125 & 0.127 & 0.117 & 0.107 & $0.1 \uparrow 6$ & 0.117 & 0.122 & 0.115 & 0.122 & 0.195 & 0.203 \\
\hline Soma_C & 5 & 5 & 5 & 5 & 5 & 5 & 5 & 5 & 5 & 5 & 5 & 5 & 5 & 5 \\
\hline $\mathrm{BCa}$ & 1.237 & 1.261 & 1.423 & 1.438 & 1.255 & 1.19 & 1.234 & 1.265 & 1.27 & 1.238 & 1.332 & 1.287 & 1.228 & 1.177 \\
\hline $\mathrm{BNa}$ & 0.763 & 0.739 & 0.577 & 0.562 & 0.745 & 0.81 & 0.766 & 0.735 & 0.73 & 0.762 & 0.668 & 0.713 & 0.772 & 0.823 \\
\hline Soma_B & 2 & 2 & 2 & 2 & 2 & 2 & 2 & 2 & 2 & 2 & 2 & 2 & 2 & 2 \\
\hline $\mathrm{ANa}$ & 0.369 & 0.425 & 0.503 & 0.458 & 0.392 & 0.299 & 0.375 & 0.382 & 0.301 & 0.318 & 0.356 & 0.327 & 0.43 & 0.306 \\
\hline AK & 0.2 & 0.22 & 0.267 & 0.238 & 0.203 & 0.201 & 0.202 & 0.321 & 0.203 & 0.22 & 0.217 & 0.221 & 0.209 & 0.173 \\
\hline Soma_A & 0.569 & 0.645 & 0.77 & 0.696 & 0.595 & 0.5 & 0.577 & 0.703 & 0.503 & 0.538 & 0.573 & 0.548 & 0.638 & 0.479 \\
\hline S_CAT & 15.569 & 15.645 & 15.77 & 15.696 & 15.595 & 15.5 & 15.577 & 15.703 & 15.503 & 15.538 & 15.573 & 15.548 & 15.638 & 15.479 \\
\hline $\overrightarrow{\mathrm{CCl}}$ & 0 & 0 & 0 & 0 & 0 & 0 & 0 & 0 & 0 & 0 & 0 & 0 & 0.016 & 0.026 \\
\hline $\mathrm{CF}$ & 0 & 0 & 0 & 0 & 0 & 0 & 0 & 0 & 0 & 0 & 0 & 0 & 0.493 & 0.517 \\
\hline S. Oxy & 23 & 23 & 23 & 23 & 23 & 23 & 23 & 23 & 23 & 23 & 23 & 23 & 23 & 23 \\
\hline
\end{tabular}


Tabela 14.3 - Composição química de anfibólios do corpo Satélite Il (\% peso)

\begin{tabular}{|c|c|c|c|c|c|c|c|c|c|c|c|c|c|c|}
\hline Amostra & $R P=44$ & RP-44 & RP-44 & RP-44 & RP-44 & RP-44 & RP-44 & RP-44 & RP.44 & RP-44 & RP-44 & RP-44 & RP-44 & RP-4 \\
\hline Análise & 518 & 519 & 520 & 521 & 522 & 523 & 524 & 525 & 526 & 527 & 528 & 529 & 530 & 531 \\
\hline Locaçẵo & C1G2Fn & $\mathrm{C} 1 \mathrm{G} 2 \mathrm{Fb}$ & $\mathrm{C} 2 \mathrm{G} 1 \mathrm{Fn}$ & $\mathrm{C} 2 \mathrm{G} 1 \mathrm{Fb}$ & $\mathrm{C} 2 \mathrm{G} 2 \mathrm{~m}$ & $\mathrm{C} 2 \mathrm{G} 3 \mathrm{~m}$ & C3GiFn & C3G1Fb & $\mathrm{C} 3 \mathrm{G} 2 \mathrm{Fn}$ & $\mathrm{C} 3 \mathrm{G} 2 \mathrm{Fb}$ & C4G1Fn & $\mathrm{C} 4 \mathrm{G} 1 \mathrm{Fb}$ & $\mathrm{C} 4 \mathrm{G} 2 \mathrm{Fn}$ & $\mathrm{C} 4 \mathrm{G}$ \\
\hline neral & SiFeEd & SiFeEd & SiFeEd & SiFeEd & SiFeEd & SiFeEd & SiFeEd & SiFeEd & SiFeEd & SiFeEd & SiFeEd & SiFeEd & SiFeEd & \\
\hline $\mathrm{O}_{2}$ & 49.23 & 49.99 & 47.9 & 46.98 & 53.49 & 47.42 & 49.63 & 49.18 & 48.14 & 48.93 & 47.73 & 49.14 & 47.97 & \\
\hline $\mathrm{IO}_{2}$ & 0.73 & 0.81 & 0.64 & 0.91 & 0.48 & 1.01 & 0.8 & 0.96 & 0.78 & 0.61 & 0.77 & 0.69 & 0.77 & \\
\hline $\mathrm{Al}_{2} \mathrm{O}_{3}$ & 2.1 & 1.72 & 2.59 & 3.54 & 9.96 & 3.34 & 1.49 & 2.05 & 2.74 & 2.3 & 3.14 & 2.23 & 2.96 & \\
\hline $\mathrm{Cr}_{2} \mathrm{O}_{3}$ & 0.01 & 0.01 & 0 & 0 & 0 & 0.01 & 0 & 0 & 0 & 0 & 0.02 & 0.02 & 0 & \\
\hline 0 & 22.85 & 22.62 & 24.12 & 24.74 & 14.5 & 24.63 & 23.76 & 24.44 & 24.71 & 24.24 & 24.39 & 23.82 & 24.18 & \\
\hline no & 1.47 & 1.6 & & 1.4 & 0.85 & 1.4 & & 1.45 & 1.48 & 1.59 & 1.44 & 1.4 & 1.39 & \\
\hline go & 8.1 & 8.42 & 7.18 & 6.7 & 3.78 & 6.76 & 7.5 & 7.29 & 6.62 & 6.7 & 6.92 & 7.53 & 7.15 & \\
\hline $\mathrm{aO}$ & 7.59 & 7.41 & 7.69 & 7.9 & 4.43 & 8.16 & 7.19 & 7.46 & 8.19 & 7.82 & 8.24 & 7.59 & 7.7 & \\
\hline $\mathrm{Na}_{2} \mathrm{O}$ & 3.6 & 3.86 & 3.49 & 3.45 & 3.66 & 3.38 & 3.68 & 3.73 & 3.1 & 3.25 & 3.32 & 3.71 & 3.42 & \\
\hline 0 & 1.05 & & 1.12 & 1.09 & 4.32 & 1.12 & 1.09 & 1.03 & 1.12 & 1.01 & 1.1 & 1.02 & 1.14 & \\
\hline & 1.12 & 1.1 & 1.05 & 0.92 & 0.27 & 0.93 & 1. & 1.11 & 0.89 & 0.63 & 1.11 & 0.96 & 1.12 & \\
\hline G & 0.07 & 0.05 & 0.09 & 0.1 & 0.09 & 0.07 & 0.03 & 0.04 & 0.08 & 0.07 & 0.08 & 0.08 & 0.06 & \\
\hline $\mathrm{ZrO}_{2}$ & 0 & 0 & 0 & 0 & 0 & 0 & 0 & 0 & 0 & 0 & 0 & 0 & 0 & \\
\hline Zno & 0 & 0 & 0 & 0 & 0 & 0 & 0 & 0 & 0 & 0 & 0 & 0 & 0 & \\
\hline $3 \mathrm{aO}$ & 0.03 & 0 & 0 & 0.01 & 0.02 & 0 & 0 & 0.1 & 0 & 0 & 0.03 & 0 & 0 & \\
\hline fotal & 97.99 & 98.67 & 97.29 & 97.7 & 5.85 & 98.31 & 97.79 & 98.86 & 97.85 & 97.15 & 98.29 & 98.19 & 97.88 & \\
\hline O_F_CL & & & & & & & & 0.48 & 0.39 & 0.28 & 0.49 & 0.42 & 0.49 & \\
\hline O_F & 0.47 & 0. & 14 & 0. & 0.11 & & 0.47 & 0.47 & 0.37 & 0.27 & 0.47 & 0.4 & 0.47 & \\
\hline $\mathrm{O} \ldots \mathrm{CL}$ & 0.02 & 0.01 & 0.02 & 0.02 & 0.02 & 0.02 & & 0.01 & 0.02 & 0.02 & 0.02 & 0.02 & 0.01 & \\
\hline otal & 97.5 & 98.18 & 96.83 & 97.33 & 95.72 & 97. & 97.32 & 98.48 & 97.46 & 96.87 & 97.8 & 97.77 & 97.39 & \\
\hline \multicolumn{15}{|c|}{ Fórmula esirutural calculada na base de 23 átomos de oxigênio } \\
\hline TSi & 7.552 & 7.605 & 7.457 & 7.297 & 8.272 & 7.33 & 7.647 & 7.535 & 7.473 & 7.599 & 7.391 & 7.548 & 7.416 & \\
\hline IAt & & 0.308 & & & 0 & 0.608 & & 0.37 & 0.501 & 0.401 & 0.573 & 0.403 & 0.539 & 0.4 \\
\hline $\mathrm{FFe}^{3+}$ & 0.069 & 0.087 & 0.069 & 0.055 & 0 & 0.057 & 0.082 & 0.095 & 0.026 & 0 & 0.037 & 0.048 & 0.045 & \\
\hline ma_T & 8 & 8 & 8 & 8 & 8.272 & 8 & 8 & 8 & 8 & 8 & 8 & 8 & 8 & \\
\hline Al & 0 & 0 & 0 & c & 1.814 & & 0 & ( & 0 & 0,02 & 0 & 0 & 0 & \\
\hline $\mathrm{Cr}$ & 0.001 & 0.001 & 0 & 0 & 0 & 0.001 & 0 & 0 & 0 & 0 & 0.002 & 0.002 & 0 & 0.0 \\
\hline $\mathrm{Fe}^{3+}$ & & & & 0.606 & 0 & 0.49 & 0.479 & 0.485 & 0.465 & 0.457 & 0.479 & 0.487 & 0.604 & \\
\hline & 0.084 & 0.093 & & & 0.056 & 0.118 & & & 0.091 & 0.071 & 0.09 & 0.08 & 0.09 & \\
\hline $\mathrm{Vg}$ & 1.861 & & & & & & 1.741 & 1665 & 1.532 & 1.551 & 1.597 & 1.724 & 1.648 & \\
\hline $\mathrm{e}^{2+}$ & & & & & 1.875 & 2.639 & $2 !$ & 2.551 & 2.717 & 2.691 & 2.642 & 2.525 & 2.476 & \\
\hline in & 0.191 & 0.206 & 0.187 & 0.184 & 0.111 & 0.194 & 0.187 & 0.188 & 0.195 & 0.209 & 0.189 & 0.182 & 0.182 & \\
\hline oma_C & 5 & 5 & 5 & 5 & 5 & 5 & 5 & 5 & 5 & 5 & 5 & 5 & 5 & \\
\hline $3 \mathrm{Ca}$ & 1.247 & 1.208 & 1.283 & 1.315 & 0.462 & 1.352 & 1.187 & 1.225 & 1.362 & 1.301 & 1.367 & 1.249 & 1.275 & 1.2 \\
\hline $\mathrm{Na}$ & 0.753 & 0.792 & 0.717 & 0.685 & & 0.648 & 0.813 & 0.775 & 0.638 & 0.699 & 0.633 & 0.751 & 0.725 & \\
\hline oma_B & 2 & 2 & 2 & 2 & 1.559 & 2 & 2 & 2 & 2 & 2 & 2 & 2 & 2 & \\
\hline $\mathrm{Na}$ & 0.318 & & & 0.354 & 0 & 0.366 & 0.287 & 0.333 & 0.295 & 0.28 & 0.364 & 0.354 & 0.301 & \\
\hline KK & 0.205 & & 0.222 & 0.21 & 0.852 & 0.221 & 0.214 & 0.201 & 0.222 & 0.2 & 0.217 & 0.2 & 0.225 & 0.2 \\
\hline Soma_A & 0.524 & 0.55 & 0.558 & 0.57 & 0.852 & 0.587 & 0.501 & 0.534 & 0.517 & 0.48 & 0.581 & 0.554 & 0.525 & 0.5 \\
\hline S_CAT & 15.524 & 15.55 & 15.558 & 15.57 & 15.684 & 15.587 & 15.501 & 15.534 & 15.517 & 15.48 & 15.581 & 15.554 & 15.525 & \\
\hline $\mathrm{CCL}$ & 0.018 & 0.013 & 0.024 & 0.026 & 0.024 & 0.018 & 0.008 & 0.01 & 0.021 & 0.018 & 0.021 & 0.021 & 0.016 & \\
\hline & 0.543 & 0.544 & 0.517 & 0.452 & 0.132 & 0.455 & 0.541 & 0.538 & 0.437 & 0.309 & 0.544 & 0.466 & 0.548 & \\
\hline
\end{tabular}

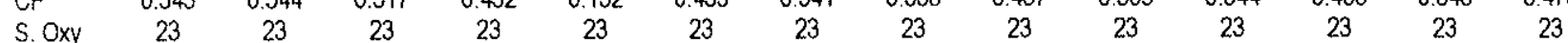

Observações: $\mathrm{Fe}^{2+} / \mathrm{Fe}^{3+}$ calculado por estequiometria. Abreviaçð̃es como na tabela 14.0 
Tabela 14.4 - Composição química de anfibólios do corpo Satélite | (\% peso)

\begin{tabular}{|c|c|c|c|c|c|c|c|c|c|c|c|c|c|c|}
\hline Amostra & RP-52 & RP- 52 & RP-52 & RP-52 & $\begin{array}{c}\text { RP. } 52 \\
558\end{array}$ & $\begin{array}{c}\text { RP-52 } \\
560\end{array}$ & $\begin{array}{c}\text { RP-52 } \\
567\end{array}$ & $\begin{array}{c}\text { RP-52 } \\
568\end{array}$ & $\begin{array}{c}\text { RP.52 } \\
595\end{array}$ & $\begin{array}{c}\text { RP-52 } \\
596\end{array}$ & $\begin{array}{c}\text { RP-52 } \\
597\end{array}$ & $\begin{array}{c}\text { RP.52 } \\
598\end{array}$ & $\begin{array}{c}\text { RP-52 } \\
599\end{array}$ & $\begin{array}{c}R P-52 \\
600\end{array}$ \\
\hline Análise & 553 & 554 & $\begin{array}{c}555 \\
\text { c1G2m }\end{array}$ & $\begin{array}{c}556 \\
\text { C1G3m }\end{array}$ & $\begin{array}{c}558 \\
\mathrm{C} 2 \mathrm{G} 1 \mathrm{Fb}\end{array}$ & $\begin{array}{c}560 \\
\mathrm{C} 2 \mathrm{G} 2 \mathrm{Fb}\end{array}$ & $\begin{array}{c}567 \\
\text { C5G1Fn }\end{array}$ & $\begin{array}{c}568 \\
\text { C5G1Fb }\end{array}$ & $\begin{array}{c}595 \\
\text { C6G1n }\end{array}$ & $\begin{array}{c}596 \\
\text { C6G1b }\end{array}$ & C5Gin & $\begin{array}{c}598 \\
\text { C5G1b }\end{array}$ & C5G2n & $\begin{array}{c}600 \\
\text { C5G2b }\end{array}$ \\
\hline Locaçäo & C1Gin & $\mathrm{C} 1 \mathrm{G} 2 \mathrm{~b}$ & $\mathrm{C} 1 \mathrm{G} 2 \mathrm{~m}$ & $\mathrm{C} 1 \mathrm{G} 3 \mathrm{~m}$ & $\mathrm{C} 2 \mathrm{G} 1 \mathrm{Fb}$ & $\mathrm{C} 2 \mathrm{G} 2 \mathrm{Fb}$ & C5G1Fn & CDGTFD & $\begin{array}{l}\text { CoGin } \\
\text { SiFeEd }\end{array}$ & SiFeEd & $\begin{array}{l}\text { CSGin } \\
\text { SiFeFEd }\end{array}$ & $\begin{array}{l}C 5610 \\
\text { SiFeFd }\end{array}$ & $\begin{array}{l}\mathrm{COS} 2 \mathrm{n} \\
\mathrm{SiFeFd}\end{array}$ & \\
\hline $\begin{array}{l}\text { Mineral } \\
\mathrm{SiO}_{2}\end{array}$ & $\begin{array}{c}\text { SiFeEd } \\
4798\end{array}$ & $\begin{array}{c}\text { SiFeEd } \\
4841\end{array}$ & $\begin{array}{c}\text { SiFeEd } \\
4796\end{array}$ & $\begin{array}{c}\text { SiFeEd } \\
4816\end{array}$ & $\begin{array}{c}\text { SiFeEd } \\
48.17\end{array}$ & $\begin{array}{l}\text { Si-Ed } \\
49.81\end{array}$ & $\begin{array}{c}\text { SiFeEd } \\
46.63\end{array}$ & $\begin{array}{c}\text { SiFeEd } \\
48.59\end{array}$ & $\begin{array}{c}\text { SiFeEd } \\
46.08\end{array}$ & $\begin{array}{c}\text { SiFeEd } \\
46.34\end{array}$ & $\begin{array}{c}\text { Siretd } \\
46.26\end{array}$ & $\begin{array}{c}\text { SifeEd } \\
46.43\end{array}$ & $\begin{array}{c}\text { Sifeedd } \\
48.24\end{array}$ & $\begin{array}{c}\text { SiFeEd } \\
46.71\end{array}$ \\
\hline $\begin{array}{l}\mathrm{TiO}_{2} \\
\mathrm{Sin}\end{array}$ & 1.15 & 0.8 & 1 & 0.82 & 1.27 & 0.68 & 1.71 & 0.98 & 1.73 & 1.6 & 1.54 & 1.6 & 0.91 & 0.99 \\
\hline $\mathrm{Al}_{2} \mathrm{O}_{3}$ & 3.26 & 2.23 & 2.63 & 2.33 & 2.4 & 2.41 & 3.84 & 2.52 & 3.41 & 3.31 & 3.58 & 3.78 & 3.05 & 4.13 \\
\hline $\mathrm{Cr}_{2} \mathrm{O}_{3}$ & 0 & 0 & 0 & 0 & 0 & 0 & 0 & 0 & 0 & 0 & 0 & 0 & 0 & 0 \\
\hline $\mathrm{FeO}$ & 26.38 & 29.53 & 29.89 & 29.31 & 30.52 & 16.54 & 26.01 & 24.57 & 28.35 & 28.73 & 27.21 & 27.34 & 26.4 & 26.39 \\
\hline $\mathrm{MnO}$ & 1.61 & 1.89 & 1.93 & 2.06 & 1.83 & 1.44 & 1.37 & 1.43 & 1.84 & 1.88 & 1.67 & 1.58 & 1.45 & 1.41 \\
\hline $\mathrm{MgO}$ & 5.35 & 4.13 & 4.02 & 4.19 & 3.29 & 9.85 & 5.91 & 6.32 & 3.78 & 3.52 & 4.57 & 4.49 & 5.95 & 5.57 \\
\hline $\mathrm{CaO}$ & 7.03 & 6.04 & 6.14 & 6.82 & 6.79 & 16.69 & 7.86 & 7.43 & 7.04 & 7.01 & 7.4 & 7.48 & 7.49 & 8.16 \\
\hline $\mathrm{Na}_{2} \mathrm{O}$ & 4.03 & 4.34 & 4.19 & 3.83 & 3.89 & 1.97 & 4.06 & 3.91 & 4.11 & 3.99 & 4.04 & 3.76 & 3.73 & 3.68 \\
\hline $\mathrm{K}_{2} \mathrm{O}$ & 1.33 & 1.06 & 1.11 & 1.13 & 1.19 & 0.41 & 1.24 & 1.15 & 1.27 & 1.27 & 1.21 & 1.21 & 1.21 & 1.31 \\
\hline $\mathrm{F}$ & 0 & 0 & 0 & 0 & 0 & 0 & 0 & 0 & 1.59 & 1.35 & 1.45 & 1.48 & 1.46 & 1.42 \\
\hline $\mathrm{Cl}$ & 0 & 0 & 0 & 0 & 0 & 0 & 0 & 0 & 0.08 & 0.07 & 0.09 & 0.08 & 0.03 & 0.04 \\
\hline $\mathrm{ZrO}_{2}$ & 0.01 & 0.08 & 0.07 & 0.02 & 0.03 & 0.04 & 0.06 & 0 & 0.13 & 0.1 & 0.09 & 0 & 0.05 & 0.07 \\
\hline $\mathrm{ZnO}$ & 0 & 0 & 0 & 0 & 0 & 0 & 0 & 0 & 0.11 & 0.13 & 0.1 & 0.13 & 0.15 & 0.09 \\
\hline $\mathrm{BaO}$ & 0 & 0 & 0 & 0 & 0 & 0 & 0 & 0 & 0 & 0 & 0 & 0 & 0 & 0 \\
\hline Total & 98.13 & 98.51 & 98.94 & 98.67 & 99.38 & 99.84 & 98.69 & 96.9 & 99.52 & 99.3 & 99.21 & 99.36 & 100.12 & 99.97 \\
\hline O_F_Cl & 0 & 0 & 0 & 0 & 0 & 0 & 0 & 0 & 0.69 & 0.58 & 0.63 & 0.64 & 0.62 & 0.61 \\
\hline OF & 0 & 0 & 0 & 0 & 0 & 0 & 0 & 0 & 0.67 & 0.57 & 0.61 & 0.62 & 0.61 & 0.6 \\
\hline O_Cl & 0 & 0 & 0 & 0 & 0 & 0 & 0 & 0 & 0.02 & 0.02 & 0.02 & 0.02 & 0.01 & 0.01 \\
\hline Ctotal & 98.13 & 98.51 & 98.94 & 98.67 & 99.38 & 99.84 & 98.69 & 96.9 & 98.83 & 98.72 & 98.58 & 98.72 & 99.5 & 99.36 \\
\hline \multicolumn{15}{|c|}{ Fórmula estrułurał calculada na base de 23 atomos de oxigênio } \\
\hline TSi & 7.418 & 7.484 & 7.384 & 7.451 & 7.461 & 7.811 & 7.203 & 7.567 & 7.279 & 7.319 & 7.279 & 7.274 & 7.405 & 7.239 \\
\hline TAl & 0.582 & 0.406 & 0.477 & 0.425 & 0.438 & 0.189 & 0.699 & 0.433 & 0.634 & 0.616 & 0.663 & 0.697 & 0.551 & 0.754 \\
\hline $\mathrm{TFe}^{3+}$ & 0 & 0.11 & 0.139 & 0.124 & 0.101 & 0 & 0.099 & 0 & 0.087 & 0.065 & 0.058 & 0.029 & 0.044 & 0.008 \\
\hline Soma_T & 8 & 8 & 8 & 8 & 8 & 8 & 8 & 8 & 8 & 8 & 8 & 8 & 8 & 8 \\
\hline $\mathrm{CAl}$ & 0.012 & 0 & 0 & 0 & 0 & 0.256 & 0 & 0.029 & 0 & 0 & 0 & 0 & 0 & 0 \\
\hline $\mathrm{CCr}$ & 0 & 0 & 0 & 0 & 0 & 0 & 0 & 0 & 0 & 0 & 0 & 0 & 0 & 0 \\
\hline $\mathrm{CFe}^{3+}$ & 0.504 & 0.819 & 0.889 & 0.725 & 0.586 & 0 & 0.338 & 0.285 & 0.412 & 0.45 & 0.386 & 0.454 & 0.575 & 0.456 \\
\hline $\mathrm{CTi}$ & 0.134 & 0.093 & 0.116 & 0.095 & 0.148 & 0.08 & 0.199 & 0.115 & 0.206 & 0.19 & 0.182 & 0.189 & 0.105 & 0.115 \\
\hline $\mathrm{CMg}$ & 1.233 & 0.952 & 0.923 & 0.966 & 0.76 & 2.303 & 1.361 & 1.467 & 0.89 & 0.829 & 1.072 & 1.049 & 1.362 & 1.287 \\
\hline $\mathrm{CFe}^{2+}$ & 2.907 & 2.888 & 2.82 & 2.943 & 3.266 & 2.169 & 2.923 & 2.915 & 3.246 & 3.279 & 3.137 & 3.099 & 2.77 & 2.957 \\
\hline CMn & 0.211 & 0.247 & 0.252 & 0.27 & 0.24 & 0.191 & 0.179 & 0.189 & 0.246 & 0.252 & 0.223 & 0.21 & 0.189 & 0.185 \\
\hline Soma_C & 5 & 5 & 5 & 5 & 5 & 5 & 5 & 5 & 5 & 5 & 5 & 5 & 5 & 5 \\
\hline $\mathrm{BCa}$ & 1.165 & 1 & 1.013 & 1.131 & 1.127 & 2 & 1,301 & 1.24 & 1.191 & 1.186 & 1.248 & 1.256 & 1.232 & 1.355 \\
\hline $\mathrm{BNa}$ & 0.835 & 1 & 0.987 & 0.869 & 0.873 & 0 & 0.699 & 0.76 & 0.809 & 0.814 & 0.752 & 0.744 & 0.768 & 0.645 \\
\hline Soma_B & 2 & 2 & 2 & 2 & 2 & 2 & 2 & 2 & 2 & 2 & 2 & 2 & 2 & 2 \\
\hline $\mathrm{ANa}$ & 0.373 & 0.301 & 0.264 & 0.28 & 0.295 & 0.599 & 0.517 & 0.42 & 0.45 & 0.408 & 0.48 & 0.398 & 0.342 & 0.461 \\
\hline AK & 0.262 & 0.209 & 0.218 & 0.223 & 0.235 & 0.082 & 0.244 & 0.228 & 0.256 & 0.256 & 0.243 & 0.242 & 0.237 & 0.259 \\
\hline Soma_A & 0.635 & 0.51 & 0.482 & 0.503 & 0.53 & 1.485 & 0.761 & 0.649 & 0.706 & 0.664 & 0.723 & 0.64 & 0.579 & 0.72 \\
\hline S_CAT' & 15.635 & 15.51 & 15.482 & 15.503 & 15.53 & 16.485 & 15.761 & 15.649 & 15.706 & 15.664 & 15.723 & 15.64 & 15.579 & 15.72 \\
\hline $\mathrm{CCL}$ & 0 & 0 & 0 & 0 & 0 & 0 & 0 & 0 & 0.021 & 0.019 & 0.024 & 0.021 & 0.008 & 0.011 \\
\hline$C F$ & 0 & 0 & 0 & 0 & 0 & 0 & 0 & 0 & 0.794 & 0.674 & 0.722 & 0.733 & 0.709 & 0.696 \\
\hline S. Oxy & 23 & 23 & 23 & 23 & 23 & 23 & 23 & 23 & 23 & 23 & 23 & 23 & 23 & 23 \\
\hline
\end{tabular}


Tabela 14.5 - Composição quimica dos anfibólios do corpo Satélite I (\% peso).

\begin{tabular}{|c|c|c|c|c|c|c|c|c|c|c|c|c|c|c|}
\hline $\begin{array}{l}\text { Amostra } \\
\text { Análise }\end{array}$ & $\begin{array}{c}\text { RP-52 } \\
601\end{array}$ & $\begin{array}{c}\text { RP-52 } \\
602\end{array}$ & $\begin{array}{c}\text { RP-52 } \\
603\end{array}$ & $\begin{array}{c}\text { RP.56 } \\
576\end{array}$ & $\begin{array}{c}\text { RP-56 } \\
578\end{array}$ & $\begin{array}{c}\text { RP-56 } \\
579\end{array}$ & $\begin{array}{c}R P-56 \\
581\end{array}$ & $\begin{array}{c}\text { RP-56 } \\
582\end{array}$ & $\begin{array}{c}\text { RP-56 } \\
583\end{array}$ & $\begin{array}{c}\text { RP.56 } \\
584\end{array}$ & $\begin{array}{c}\text { RP-56 } \\
585\end{array}$ & $\begin{array}{c}\mathrm{RP}-56 \\
586\end{array}$ & $\begin{array}{c}\text { RP-56 } \\
587\end{array}$ & $\begin{array}{c}R P-56 \\
588\end{array}$ \\
\hline Locação & C3Gin & C1G1n & C1G1b & C1G1Fb & $\mathrm{C} 4 \mathrm{G} 1 \mathrm{~m}$ & C6Gín & C5G1n & C5G1b & $\mathrm{C} 5 \mathrm{G} 2 \mathrm{n}$ & $\mathrm{C} 5 \mathrm{G} 2 \mathrm{~b}$ & C4Gín & $C 4 G 1 b$ & C3G1n & C3G1b \\
\hline Mineral & SiFeEd & SiFeEd & SiFeEd & SiFeEd & SiFeEd & SiFeEd & SiFeEd & SiFeEd & SiFeEd & SFFeEd & SiFeEd & SiFeEd & SiFeEd & SiFeEd \\
\hline $\mathrm{SiO}_{2}$ & 47.76 & 47.03 & 47.47 & 48.22 & 48.55 & 48.02 & 48.16 & 47.5 & 48.23 & 47.87 & 47.6 & 48.09 & 46.37 & 54.16 \\
\hline $\mathrm{TiO}_{2}$ & 1.48 & 1.34 & 1.3 & 1.72 & 1.64 & 1.65 & 1.66 & 1.63 & 1.68 & 1.79 & 1.82 & 1.88 & 1.89 & 0.81 \\
\hline $\mathrm{Al}_{2} \mathrm{O}_{3}$ & 2.85 & 3.41 & 3.38 & 1.54 & 1.61 & 1.63 & 1.56 & 1.94 & 1.53 & 1.59 & 1.73 & 1.72 & 2.99 & 8.26 \\
\hline $\mathrm{Cr}_{2} \mathrm{O}_{3}$ & 0 & 0 & 0 & 0 & 0 & 0 & 0 & 0 & 0 & 0 & 0 & 0 & 0 & 0 \\
\hline $\mathrm{FeO}$ & 29.05 & 26.03 & 25.9 & 32.09 & 31.43 & 32.24 & 31.04 & 30.9 & 31.36 & 31.59 & 31.19 & 30.93 & 30.83 & 21.57 \\
\hline $\mathrm{MnO}$ & 1.71 & 1.57 & 1.52 & 2.35 & 2.3 & 2.51 & 2.46 & 2.36 & 2.39 & 2.34 & 2.4 & 2.3 & 2.29 & 1.6 \\
\hline $\mathrm{MgO}$ & 3.59 & 5.49 & 5.7 & 1.19 & 1.57 & 1.4 & 1.33 & 1.24 & 1.36 & 1.36 & 1.56 & 1.47 & 1.58 & 0.99 \\
\hline $\mathrm{CaO}$ & 7.36 & 7.45 & 7.53 & 3.6 & 3.72 & 3.9 & 3.82 & 3.82 & 3.66 & 3.67 & 3.98 & 3.78 & 4.21 & 2.39 \\
\hline $\mathrm{Na}_{2} \mathrm{O}$ & 3.65 & 4.03 & 3.93 & 5.92 & 5.88 & 5.69 & 5.37 & 5.61 & 5.46 & 5.62 & 5.74 & 5.67 & 5.68 & 77 \\
\hline $\mathrm{K}_{2} \mathrm{O}$ & 1.19 & 1.21 & 1.22 & 1.3 & 1.28 & 1.28 & 1.26 & 1.34 & 1.29 & 1.27 & 1.24 & 1.25 & 1.3 & 1.5 \\
\hline $\mathrm{F}$ & 1 & 1.56 & 1.73 & 0 & 0 & 0 & 1.54 & 1.44 & 1.38 & 1.67 & 1.09 & 1.6 & 1.45 & 0.95 \\
\hline $\mathrm{Cl}$ & 0.08 & 0.05 & 0.05 & 0 & 0 & 0 & 0.06 & 0.04 & 0.07 & 0.05 & 0.05 & 0.07 & 0.05 & 0.05 \\
\hline $\mathrm{ZrO}_{2}$ & 0.08 & 0.05 & 0.07 & 0.07 & 0.08 & 0.02 & 0.15 & 0.11 & 0.09 & 0.12 & 0.1 & 0.07 & 0.15 & 0.15 \\
\hline $\mathrm{ZnO}$ & 0.12 & 0.11 & 0.13 & 0 & 0 & 0 & 0.23 & 0.17 & 0.12 & 0.15 & 0.19 & 0.17 & 0.21 & 0.09 \\
\hline $\mathrm{BaO}$ & 0 & 0 & 0 & 0 & 0 & 0 & 0 & 0 & 0 & 0 & 0 & 0 & 0 & 0 \\
\hline Total & 99.92 & 99.33 & 99.93 & 98 & 98.07 & 98.34 & 98.64 & 98.1 & 98.62 & 99.09 & 98.69 & 99 & 99 & 100.22 \\
\hline $\mathrm{O}_{-} \mathrm{F}_{-} \mathrm{CL}$ & 0.44 & 0.67 & 0.74 & 0 & 0 & 0 & 0.66 & 0.62 & 0.6 & 0.71 & 0.47 & 0.69 & 0.62 & 0.41 \\
\hline O.F & 0.42 & 0.66 & 0.73 & 0 & 0 & 0 & 0.65 & 0.61 & 0.58 & 0.7 & 0.46 & 0.67 & 0.61 & 0.4 \\
\hline O_CL & 0.02 & 0.01 & 0.01 & 0 & 0 & 0 & 0.01 & 0.01 & 0.02 & 0.01 & 0.01 & 0.02 & 0.01 & 0.01 \\
\hline Ctotal & 99.48 & 98.66 & 99.19 & 98 & 98.07 & 98.34 & 97.98 & 97.48 & 98.02 & 98.38 & 98.22 & 98.31 & 98.38 & 99.81 \\
\hline \multicolumn{15}{|c|}{ Fórmula estrutural calculada na base de 23 átomos de oxigénio } \\
\hline TSi & 7.451 & 7.336 & 7.358 & 7.651 & 7.672 & 7.58 & 7.704 & 7.652 & 7.686 & 7.634 & 7.597 & 7.667 & 7.406 & 8.248 \\
\hline TAl & 0.524 & 0.626 & 0.617 & 0.288 & 0.3 & 0.303 & 0.294 & 0.348 & 0.287 & 0.299 & 0.325 & 0.323 & 0.562 & 0 \\
\hline $\mathrm{TFe}^{3+}$ & 0.025 & 0.037 & 0.025 & 0.061 & 0.028 & 0.117 & 0.003 & 0 & 0.027 & 0.067 & 0.077 & 0.01 & 0.031 & 0 \\
\hline Soma_T & 8 & 8 & 8 & 8 & 8 & 8 & 8 & 8 & 8 & 8 & 8 & 8 & 8 & 8.248 \\
\hline $\mathrm{CAl}$ & 0 & 0 & 0 & 0 & 0 & 0 & 0 & 0.02 & 0 & 0 & 0 & 0 & 0 & 1.481 \\
\hline $\mathrm{CCr}$ & 0 & 0 & 0 & 0 & 0 & 0 & 0 & 0 & 0 & 0 & 0 & 0 & 0 & 0 \\
\hline $\mathrm{CFe}^{3+}$ & 0.4 & 0.399 & 0.416 & 0.63 & 0.618 & 0.71 & 0.665 & 0.587 & 0.712 & 0.686 & 0.575 & 0.583 & 0.675 & 0 \\
\hline Ti & 0.174 & 0.157 & 0.152 & 0.205 & 0.195 & 0.196 & 0.2 & 0.198 & 0.201 & 0.215 & 0.219 & 0.225 & 0.227 & 0.093 \\
\hline $\mathrm{CMg}$ & 0.835 & 1.277 & 1.317 & 0.281 & 0.3 & 0.329 & 0.317 & 0.298 & 0.323 & 0.323 & 0.371 & 0.349 & 0.376 & 0.225 \\
\hline $\mathrm{CFe}^{2+}$ & 3.366 & 2.96 & 2.916 & 3.568 & 3.508 & 3.429 & 3.485 & 3.576 & 3.441 & 3.46 & 3.51 & 3.531 & 3.412 & 2.747 \\
\hline CMn & 0.226 & 0.207 & 0.2 & 0.316 & 0.309 & 0.336 & 0.333 & 0.322 & 0.323 & 0.316 & 0.324 & 0.311 & 0.31 & 0.206 \\
\hline Soma $C$ & 5 & 5 & 5 & 5 & 5 & 5 & 5 & 5 & 5 & 5 & 5 & 5 & 5 & 5 \\
\hline $\mathrm{BCa}$ & 1.23 & 1.245 & 1.25 & 0.612 & 0.63 & 0.66 & 0.655 & 0.659 & 0.625 & 0.627 & 0.681 & 0.646 & 0.72 & 0.142 \\
\hline $\mathrm{BNa}$ & 0.77 & 0.755 & 0.75 & 1.388 & 1.37 & 1.34 & 1.345 & 1.341 & $\$ .375$ & 1.373 & 1.319 & 1.354 & 1.28 & 1.858 \\
\hline Soma_B & 2 & 2 & 2 & 2 & 2 & 2 & 2 & 2 & 2 & 2 & 2 & 2 & 2 & 2 \\
\hline $\mathrm{ANa}$ & 0.334 & 0.464 & 0.432 & 0.433 & 0.432 & 0.401 & 0.32 & 0.412 & 0.312 & 0.365 & 0.457 & 0.399 & 0.48 & 0.416 \\
\hline AK & 0.237 & 0.241 & 0.241 & 0.263 & 0.258 & 0.258 & 0.257 & 0.275 & 0.262 & 0.258 & 0.252 & 0.254 & 0.265 & 0.291 \\
\hline Soma_A & 0.571 & 0.705 & 0.673 & 0.697 & 0.69 & 0.659 & 0.577 & 0.687 & 0.574 & 0.623 & 0.71 & 0.653 & 0.744 & 0.707 \\
\hline S_CAT & 15.571 & 15.705 & 15.673 & 15.697 & 15.69 & 15.659 & 15.577 & 15.687 & 15.574 & 15.623 & 15.71 & 15.653 & 15.744 & 15.955 \\
\hline $\mathrm{CCL}$ & 0.021 & 0.013 & 0.013 & 0 & 0 & 0 & 0.016 & 0.011 & 0.019 & 0.014 & 0.014 & 0.019 & 0.014 & 0.013 \\
\hline CF & 0.493 & 0.77 & 0.848 & 0 & 0 & 0 & 0.779 & 0.734 & 0.695 & 0.842 & 0.55 & 0.807 & 0.732 & 0.458 \\
\hline S. Oxy & 23 & 23 & 23 & 23 & 23 & 23 & 23 & 23 & 23 & 23 & 23 & 23 & 23 & 23 \\
\hline
\end{tabular}


Tabela 14.6 - Composição quimica de anfibólios de Satèlite I (\% peso)

\begin{tabular}{|c|c|c|c|c|c|c|c|c|c|c|c|c|c|c|}
\hline Amostra & RP-56 & RP-56 & RP.56 & RP-56 & RP-56 & RP.56 & RP-58 & RP-58 & RP-58 & RP-58 & RP.5B & RP-58 & RP-58 & RP-58 \\
\hline Análise & 589 & 590 & 591 & 592 & 593 & 594 & 646 & 647 & 648 & 649 & 650 & 651 & 652 & 655 \\
\hline Locaçāo & C3G2n & $\mathrm{C} 3 \mathrm{G} 2 \mathrm{~b}$ & $\mathrm{C} 2 \mathrm{G} 1 \mathrm{n}$ & C2Gib & C1G1n & CiG1b & $\mathrm{C} 4 \mathrm{G} 2 \mathrm{~F} n$ & $\mathrm{C} 4 \mathrm{G} 2 \mathrm{Fb}$ & C4G3Fn & $\mathrm{C} 4 \mathrm{G} 3 \mathrm{Fb}$ & C3G1Fn & C3G1Fb & $\mathrm{C} 2 \mathrm{G} 1 \mathrm{Fn}$ & $\mathrm{C} 1 \mathrm{G} 1 \mathrm{Fb}$ \\
\hline Mineral & SiFeEd & SHFeEd & SiFeEd & SiFeEd & SiFeEd & SiFeEd & SiFeEd & SiFeEd & SiFeEd & SiFeEd & SiFeEd & SiFeEd & SiFeEd & SiFeEd \\
\hline $\mathrm{SiO}_{2}$ & 47.84 & 49.03 & 48.32 & 48.7 & 47.95 & 55.06 & 49.16 & 49.79 & 49.23 & 50.24 & 49.88 & 50.05 & 49.26 & 50.8 \\
\hline $\mathrm{THO}_{2}$ & 1.74 & 1.52 & 1.63 & 1.5 & 1.86 & 0.54 & 1.25 & 1.31 & 1.08 & 1.5 & 1.11 & 1.12 & 1.11 & 0.71 \\
\hline $\mathrm{Al}_{2} \mathrm{O}_{3}$ & 1.95 & 1.21 & 1.72 & 1.61 & 1.66 & 9 & 1.32 & 1.51 & 1.29 & 0.96 & $\{.24$ & 0.99 & 1.43 & 1.24 \\
\hline $\mathrm{Cr}_{2} \mathrm{O}_{3}$ & 0 & 0 & 0 & 0 & 0 & 0 & 0 & 0 & 0 & 0 & 0 & 0 & 0 & 0 \\
\hline $\mathrm{FeO}$ & 31.53 & 31.39 & 30.85 & 31.3 & 31.32 & 20.24 & 28.69 & 28.73 & 28.64 & 27.89 & 28.94 & 28.62 & 28.7 & 26.59 \\
\hline $\mathrm{MnO}$ & 2.4 & 2.25 & 2.18 & 2.27 & 2.35 & 1.15 & 1.78 & 1.65 & 1.79 & 1.78 & 1.85 & 1.79 & 1.86 & 1.8 \\
\hline $\mathrm{MgO}$ & 1.21 & 1.39 & 1.43 & 1.43 & 1.34 & 0.88 & 3.48 & 3.5 & 3.46 & 3.44 & 3.22 & 3.24 & 3.27 & 5.15 \\
\hline $\mathrm{CaO}$ & 3.86 & 3.4 & 3.74 & 3.65 & 4.08 & 1.39 & 4.42 & 4.52 & 4.55 & 4.24 & 4.53 & 4.49 & 4.49 & 5.23 \\
\hline $\mathrm{Na}_{2} \mathrm{O}$ & 5.64 & 5.6 & 5.89 & 5.6 & 5.55 & 5.76 & 5.45 & 5.43 & 5.58 & 5.66 & 5.32 & 5.42 & 5.61 & 5.02 \\
\hline $\mathrm{K}_{2} \mathrm{O}$ & 1.29 & 1.25 & 1.24 & 1.19 & 1.21 & 3.68 & 1.25 & 1.27 & 1.29 & 1.32 & 1.34 & 1.33 & 1.21 & 1.3 \\
\hline $\mathrm{F}$ & 1.47 & 1.33 & 1.18 & 1.28 & 1.69 & 0.7 & 1.94 & 1.38 & 1.85 & 1.52 & 1.59 & 1.25 & 1.96 & 2.09 \\
\hline $\mathrm{Cl}$ & 0.05 & 0.02 & 0.05 & 0.05 & 0.05 & 0.04 & 0.06 & 0.04 & 0.06 & 0.04 & 0.05 & 0.06 & 0.05 & 0.04 \\
\hline $\mathrm{ZrO}_{2}$ & 0.1 & 0.04 & 0.06 & 0.03 & 0.09 & 0.11 & 0.08 & 0.01 & 0.03 & 0.09 & 0.11 & 0 & 0 & 0.02 \\
\hline $\mathrm{ZnO}$ & 0.05 & 0.14 & 0.15 & 0.13 & 0.13 & 0.07 & 0.13 & 0.16 & 0.1 & 0.1 & 0.2 & 0.16 & 0.08 & 0.09 \\
\hline $\mathrm{BaO}$ & 0 & 0 & 0 & 0 & 0 & 0 & 0 & 0 & 0 & 0 & 0 & 0 & 0 & 0 \\
\hline Total & 99.13 & 98.57 & 98.44 & 98.74 & 99.28 & 98.62 & 99.01 & 99.3 & 98.95 & 98.78 & 99.38 & 98.52 & 99.03 & 100.08 \\
\hline O_F_CL & 0.63 & 0.56 & 0.51 & 0.55 & 0.72 & 0.3 & 0.83 & 0.59 & 0.79 & 0.65 & 0.68 & 0.54 & 0.84 & 0.89 \\
\hline O.F & 0.62 & 0.56 & 0.5 & 0.54 & 0.71 & 0.29 & 0.82 & 0.58 & 0.78 & 0.64 & 0.67 & 0.53 & 0.83 & 0.88 \\
\hline O_Cl & 0.01 & 0 & 0.01 & 0.01 & 0.01 & 0.01 & 0.01 & 0.01 & 0.01 & 0.01 & 0.01 & 0.01 & 0.01 & 0.01 \\
\hline Ctotal & 98.5 & 98.01 & 97.93 & 98.19 & 98.56 & 98.32 & 98.18 & 98.71 & 98.16 & 98.13 & 98.7 & 97.98 & 98.19 & 99.19 \\
\hline \multicolumn{15}{|c|}{ Fórmula estrutural calcułada na base de 23 átomos de oxigênio } \\
\hline TSi & 7.617 & 7.789 & 7.722 & 7.725 & 7.65 & 8.394 & 7.761 & 7.78 & 7.787 & 7.921 & 7.837 & 7.902 & 7.788 & 7.84 \\
\hline TAI & 0.366 & 0.211 & 0.278 & 0.275 & 0.312 & 0 & 0.239 & 0.22 & 0.213 & 0.079 & 0.163 & 0.098 & 0.212 & 0.16 \\
\hline $\mathrm{TFe}^{3+}$ & 0.018 & 0 & 0 & 0 & 0.038 & 0 & 0 & 0 & 0 & 0 & 0 & 0 & 0 & 0 \\
\hline Soma_T & 8 & 8 & 8 & 8 & 8 & 8.394 & 8 & 8 & 8 & 8 & 8 & 8 & 8 & 8 \\
\hline $\mathrm{CAl}$ & 0 & 0.016 & 0.045 & 0.026 & 0 & 1.616 & 0.007 & 0.058 & 0.027 & 0.099 & 0.066 & 0.086 & 0.054 & 0.065 \\
\hline $\mathrm{CCf}$ & 0 & 0 & 0 & 0 & 0 & 0 & 0 & 0 & 0 & 0 & 0 & 0 & 0 & 0 \\
\hline $\mathrm{CFe}^{3+}$ & 0.646 & 0.696 & 0.482 & 0.687 & 0.546 & 0 & 0.52 & 0.442 & 0.415 & 0.197 & 0.421 & 0.3 & 0.41 & 0.442 \\
\hline $\mathrm{CTi}$ & 0.208 & 0.182 & 0.196 & 0.179 & 0.223 & 0.062 & 0.148 & 0.154 & 0.128 & 0.178 & 0.131 & 0.133 & 0.132 & 0.082 \\
\hline CMg & 0.287 & 0.329 & 0.341 & 0.338 & 0.319 & 0.2 & 0.819 & 0.815 & 0.816 & 0.808 & 0.754 & 0.763 & 0.771 & 1.185 \\
\hline $\mathrm{CFe}^{2+}$ & 3.535 & 3.475 & 3.64 & 3.465 & 3.595 & 2.58 & 3.268 & 3.312 & 3.374 & 3.48 & 3.382 & 3.479 & 3.385 & 2.99 \\
\hline CMn & 0.324 & 0.303 & 0.295 & 0.305 & 0.318 & 0.148 & 0.238 & 0.218 & 0.24 & 0.238 & 0.246 & 0.239 & 0.249 & 0.235 \\
\hline Soma_C & 5 & 5 & 5 & 5 & 5 & 4.834 & 5 & 5 & 5 & 5 & 5 & 5 & 5 & 5 \\
\hline $\mathrm{BCa}$ & 0.658 & 0.579 & 0.64 & 0.62 & 0.697 & 0 & 0.748 & 0.757 & 0.771 & 0.716 & 0.763 & 0.76 & 0.761 & 0.865 \\
\hline $\mathrm{BNa}$ & 1.342 & 1.421 & 1.36 & 1.38 & 1.303 & 1.703 & 1.252 & 1.243 & 1.229 & 1.284 & 1.237 & 1.24 & 1.239 & 1.135 \\
\hline Soma_B & 2 & 2 & 2 & 2 & 2 & 1.703 & 2 & 2 & 2 & 2 & 2 & 2 & 2 & 2 \\
\hline $\mathrm{ANa}$ & 0.4 & 0.304 & 0.465 & 0.343 & 0.414 & 0 & 0.416 & 0.402 & 0.483 & 0.446 & 0.383 & 0.419 & 0.48 & 0.367 \\
\hline AK & 0.262 & 0.253 & 0.253 & 0.241 & 0.246 & 0.716 & 0.252 & 0.253 & 0.26 & 0.265 & 0.269 & 0.268 & 0.244 & 0.256 \\
\hline Soma $A$ & 0.662 & 0.557 & 0.718 & 0.584 & 0.661 & 0.716 & 0.668 & 0.655 & 0.743 & 0.712 & 0.652 & 0.687 & 0.724 & 0.623 \\
\hline S.CAT & 15.662 & 15.557 & 15.718 & 15.584 & 15.661 & 15.645 & 15.668 & 15.655 & 15.743 & 15.712 & 15.652 & $\{5.687$ & 15.724 & 15.623 \\
\hline $\mathrm{CCL}$ & 0.013 & 0.005 & 0.014 & 0.013 & 0.014 & 0.01 & 0.016 & 0.011 & 0.016 & 0.011 & 0.013 & 0.016 & 0.013 & 0.01 \\
\hline CF & 0.74 & 0.668 & 0.596 & 0.642 & 0.853 & 0.337 & 0.969 & 0.682 & 0.925 & 0.758 & 0.79 & 0.624 & 0.98 & 1.02 \\
\hline
\end{tabular}

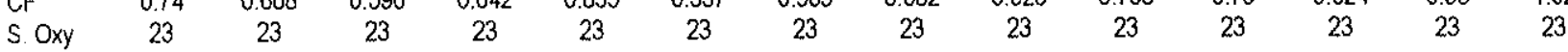


Tabela 14.7 - Composição quimica dos anfíbólios do corpo Pão de Açúcar (\% peso).

\begin{tabular}{|c|c|c|c|c|c|c|c|c|c|c|c|c|c|c|}
\hline Amostra & RP.78 & RP-78 & RP-78 & RP-78 & RP-78 & RP-78 & RP-78 & RP-78 & RP.78 & RP-78 & RP-78 & RP-78 & RP-78 & RP-78 \\
\hline Análise & 1005 & 952 & 953 & 954 & 955 & 957 & 958 & 959 & 960 & 961 & 962 & 963 & 964 & 996 \\
\hline Locaçāo & C3G1m & $\mathrm{C} 1 \mathrm{G} 4 \mathrm{n}$ & C1G4b & C1G5n & C1G5b & C1G6b & C2Gin & $\mathrm{C} 2 \mathrm{G} 1 \mathrm{~b}$ & $\mathrm{C} 2 \mathrm{G} 2 \mathrm{n}$ & $\mathrm{C} 2 \mathrm{G} 2 \mathrm{~b}$ & C3G1n & C3G1b & C5Gin & C1G1n \\
\hline Minerat & SiEd & Si-Ed & Si-Ed & Si-Ed & Si-Ed & Si-Ed & Si-Ed & Si-Ed & Si-Ed & Si-Ed & Si-Ed & Si-Ed & SirEd & Si-Ed \\
\hline $\mathrm{SiO}_{2}$ & 48.92 & 50.41 & 49.44 & 55.06 & 51.33 & 48.57 & 48.3 & 48.76 & 54.36 & 50.04 & 48.84 & 53.67 & 48.41 & 48.94 \\
\hline $\mathrm{TiO}_{2}$ & 1.09 & 0.62 & 0.79 & 0.11 & 0.6 & 1.08 & 1.21 & 0.93 & 0.22 & 0.82 & 0.99 & 0.33 & 0.95 & 1 \\
\hline $\mathrm{Al}_{2} \mathrm{O}_{3}$ & 4.59 & 3.99 & 4.21 & 0.67 & 2.99 & 4.49 & 4.82 & 4.57 & 1.1 & 4.44 & 4.54 & 1.81 & 4.36 & 4.64 \\
\hline $\mathrm{Cr}_{2} \mathrm{O}_{3}$ & 0 & 0 & 0 & 0 & 0 & 0 & 0 & 0 & 0 & 0 & 0 & 0 & 0 & 0 \\
\hline$=0$ & 15.36 & 14.01 & 13.57 & 11.81 & 16.5 & 15.64 & 16.29 & 15.31 & 15.03 & 15.59 & 15.38 & 12.34 & 14.78 & 16.37 \\
\hline $\mathrm{MnO}$ & 0.97 & 0.73 & 0.84 & 0.73 & 0.78 & 0.95 & 0.97 & 0.94 & 0.71 & 0.78 & 0.93 & 0.7 & 0.89 & 0.96 \\
\hline $\mathrm{MgO}$ & 12.67 & 14.44 & 13.99 & 16.11 & 12.7 & 12.27 & 12.29 & 12.59 & 14.22 & 12.5 & 12.48 & 16.09 & 13.38 & 12.7 \\
\hline $\mathrm{CaO}$ & 10.33 & 10.42 & 10.07 & 6.92 & 6.28 & 10.46 & 10.57 & 10.59 & 3.99 & 9.34 & 10.51 & 7.74 & 10.4 & 10.13 \\
\hline $\mathrm{Na}_{2} \mathrm{O}$ & 2.89 & 2.77 & 3.21 & 4.27 & 5. & 2.83 & 2.5 & 2.7 & 6 & 3.11 & 2.76 & 4.3 & 3.09 & 3.04 \\
\hline $\mathrm{K}_{2} \mathrm{O}$ & 0.61 & 0.59 & 0. & 0.54 & 0.58 & 0.63 & 0.65 & 0.6 & 0.62 & 0.71 & 0 & 0.61 & 0.66 & 0.7 \\
\hline $\mathrm{F}$ & 1.44 & 1.34 & 1.73 & 1.86 & 1.7 & 1.3 & 1.5 & 1.24 & 1.76 & 0.99 & 1.09 & 1.78 & 1.21 & 1.57 \\
\hline C & 0.14 & 0.09 & 0.11 & 0 & 0.09 & 0.11 & 0.14 & 0.08 & 0.02 & 0.09 & 0.11 & 0.08 & 0.12 & 0.13 \\
\hline $\mathrm{ZrO}_{2}$ & 0.01 & 0 & 0 & 0 & 0 & 0 & 0 & 0.03 & 0 & 0.05 & 0.03 & 0 & 0.09 & 0 \\
\hline $\mathrm{ZnO}$ & 0.09 & 0.07 & 0.08 & 0.097 & 0.02 & 0.02 & 0 & 0 & 0.07 & 0.01 & 0.06 & 0 & 0.04 & 0 \\
\hline $\mathrm{BaO}$ & 0 & 0 & 0 & 0 & 0 & 0 & 0 & 0 & 0 & 0 & 0 & 0 & 0 & 0 \\
\hline Total & 99.11 & 99.48 & 98.74 & 98.18 & 98.72 & 98.35 & 99.31 & 98.4 & 98.1 & 98.47 & 98.42 & 99.45 & 98.38 & 100.18 \\
\hline $\mathrm{O}_{-} \mathrm{F}_{-} \mathrm{CL}$ & 0.64 & 0.58 & 0.75 & 0.78 & 0.74 & 0.57 & 0.66 & 0.54 & 0.75 & 0.44 & 0.48 & 0.77 & 0.54 & 0.69 \\
\hline O.F & 0.61 & 0.56 & 0.73 & 0.78 & 0.72 & 0.55 & 0.63 & 0.52 & 0.74 & 0.42 & 0.46 & 0.75 & 0.51 & 0.66 \\
\hline O_Cl. & 0.03 & 0.02 & 0.02 & 0 & 0.02 & 0.02 & 0.03 & 0.02 & 0 & 0.02 & 0.02 & 0.02 & 0.03 & 0.03 \\
\hline Ctotal & 98.47 & 98.9 & 97.99 & 97.4 & 97.98 & 97.78 & 98.65 & 97.86 & 97.35 & 98.03 & 97.94 & 98.68 & 97.84 & 99.49 \\
\hline \multicolumn{15}{|c|}{ Fórmula esirutural calculada na base de 23 átomos de oxigênio } \\
\hline $\mathrm{TSi}$ & 7.251 & 7.327 & 7.311 & 7.914 & 7.52 & 7.27 & 7.163 & 7.268 & 7.835 & 7.374 & 7.282 & 7.671 & 7.207 & 7.181 \\
\hline TAI & 0.749 & 0.673 & 0.689 & 0.086 & 0.48 & 0.73 & 0.837 & 0.732 & 0.165 & 0.626 & 0.718 & 0.305 & 0.764 & 0.802 \\
\hline $\mathrm{TFe}^{3+}$ & 0 & 0 & 0 & 0 & 0 & 0 & 0 & 0 & 0 & 0 & 0 & 0.024 & 0.028 & 0.017 \\
\hline Soma_T & 8 & 8 & 8 & 8 & 8 & 8 & 8 & 8 & 8 & 8 & 8 & 8 & 8 & 8 \\
\hline CAl & 0.053 & 0.01 & 0.044 & 0.028 & 0.036 & 0.062 & 0.005 & 0.071 & 0.022 & 0.144 & 0.08 & 0 & 0 & 0 \\
\hline $\mathrm{COr}$ & 0 & 0 & 0 & 0 & 0 & 0 & 0 & 0 & 0 & 0 & 0 & 0 & 0 & 0 \\
\hline $\mathrm{CFe}^{3+}$ & 0.225 & 0.391 & 0.225 & 0.614 & 0.772 & 0.127 & 0.34 & 0.16 & 1.071 & 0.328 & 0.127 & 0.584 & 0.245 & 0.417 \\
\hline $\mathrm{CTi}$ & 0.122 & & & & 0.072 & 0.122 & 0.135 & 0.104 & 0.024 & 0.091 & 0.111 & 0.035 & 0.106 & 0.11 \\
\hline $\mathrm{CMg}$ & 2.8 & & 3.084 & 3.452 & 2.774 & 2.738 & 2.717 & 2.798 & 3.056 & 2.746 & 2.774 & 3.429 & 2.97 & 2.778 \\
\hline $\mathrm{CFe}^{2+}$ & 1.679 & 1.312 & 1.453 & 0.806 & 1.25 & 1.83 & 1.681 & 1.749 & 0.74 & 1.593 & 1.791 & 0.867 & 1.567 & 1.576 \\
\hline CMn & 0.122 & 0.09 & 0.105 & 0.089 & 0.097 & 0.12 & 0.122 & 0.119 & 0.087 & 0.097 & 0.117 & 0.085 & 0.112 & 0.119 \\
\hline Soma_C & 5 & 5 & 5 & 5 & 5 & 5 & 5 & 5 & 5 & 5 & 5 & 5 & 5 & 5 \\
\hline $\mathrm{BCa}$ & 1.641 & 1.623 & 1.596 & 1.066 & 0.986 & 1.678 & 1.68 & 1.691 & 0.616 & 1.475 & 1.679 & 1.185 & 1.659 & 1.593 \\
\hline $\mathrm{BNa}$ & 0.359 & 0.377 & 0.404 & 0.934 & 1.014 & 0.322 & 0.32 & 0.309 & 1,384 & 0.525 & 0.321 & 0.815 & 0.341 & 0.407 \\
\hline Soma_B & 2 & 2 & 2 & 2 & 2 & 2 & 2 & 2 & 2 & 2 & 2 & 2 & 2 & 2 \\
\hline $\mathrm{ANa}$ & 0.471 & 0.403 & 0.516 & 0.256 & 0.435 & 0.499 & 0.419 & 0.483 & 0.293 & 0.363 & 0.477 & 0.377 & 0.551 & 0.458 \\
\hline AK & 0.115 & 0.109 & 0.132 & 0.099 & 0.108 & 0.12 & 0.123 & 0.118 & 0.114 & 0.133 & 0.133 & 0.111 & 0.125 & 0.131 \\
\hline Soma_A & 0.587 & 0.513 & 0.648 & 0.355 & 0.543 & 0.619 & 0.542 & 0.601 & 0.407 & 0.497 & 0.61 & 0.488 & 0.676 & 0.589 \\
\hline S_CAT & 15.587 & 15.513 & 15.648 & 15.355 & 15.543 & 15.619 & 15.542 & 15.601 & 15.407 & 15.497 & 15.61 & 15.488 & 15.676 & 15.589 \\
\hline $\mathrm{CCL}$ & 0.035 & 0.022 & 0.028 & 0 & 0.022 & 0.028 & 0.035 & 0.02 & 0.005 & 0.022 & 0.028 & 0.019 & 0.03 & 0.032 \\
\hline $\mathrm{CF}$ & 0.675 & 0.616 & 0.809 & 0.845 & 0.788 & 0.615 & 0.704 & 0.585 & 0.802 & 0.461 & 0.514 & 0.805 & 0.57 & 0.729 \\
\hline S. Oxy & 23 & 23 & 23 & 23 & 23 & 23 & 23 & 23 & 23 & 23 & 23 & 23 & 23 & 23 \\
\hline
\end{tabular}


Tabela 14.8 - Composição química de anfibólios do Morro Pão de Açúcar (\% peso)

\begin{tabular}{|c|c|c|c|c|c|c|c|c|c|c|c|c|c|}
\hline Amostra & RP.78 & RP-78 & RP-109 & RP-109 & RP-109 & RP-109 & RP-207 & $R P-207$ & RP-207 & RP-207 & RP-207 & RP-207 & RP-20 \\
\hline Anàlise & 998 & 999 & 1006 & 630 & 636 & 657 & 834 & 835 & 836 & 837 & 840 & 841 & 842 \\
\hline Locaçāo & $\mathrm{C} 2 \mathrm{G} 1 \mathrm{n}$ & C3GIn & C4G1b & $\mathrm{C} 1 \mathrm{G} 1 \mathrm{~m}$ & $\mathrm{C} 2 \mathrm{G} 2 \mathrm{Fb}$ & $\mathrm{C} 4 \mathrm{G1n}$ & C1G1n & C1G1b & C1G2n & $\mathrm{C} 1 \mathrm{G} 2 \mathrm{~b}$ & C4G1n & C4G1b & $\mathrm{C} 4 \mathrm{G} 2 \mathrm{r}$ \\
\hline Mineral & Si-Ed & Si-Ed & Si-Fe-Ed & SiFe-Ed & Si-Ed & $\mathrm{Fe}-\mathrm{Ed}$ & Fe-Ed & Si-Ed & Si-Ed & Si-Ed & Si-Ed & Si-Ed & Si-Ed \\
\hline $\mathrm{iO}_{2}$ & 53.78 & 50.44 & 45.87 & 50.26 & 51.69 & 43.57 & 49.58 & 48.29 & 48.56 & 48.71 & 49.52 & 49.24 & 49.57 \\
\hline $\mathrm{TiO}_{2}$ & 0.26 & 0.61 & 1.84 & 0.54 & 0.51 & 2.41 & 2.64 & 2.58 & 2.38 & 2.64 & 2.66 & 2.83 & 2.24 \\
\hline $\mathrm{Al}_{2} \mathrm{O}_{3}$ & 1.44 & 3.54 & 4.77 & 8.24 & 1.76 & 7.67 & 3.67 & 4.06 & 3.74 & 4.03 & 3.69 & 4.13 & 3.37 \\
\hline $\mathrm{Cr}_{2} \mathrm{O}_{3}$ & 0 & 0.06 & 0 & 0 & 0 & 0 & 0 & 0 & 0 & 0 & 0 & 0 & 0 \\
\hline $\mathrm{eO}$ & 12.47 & 15.54 & 22.05 & 12.46 & 13.16 & 19.37 & 14.19 & 14.24 & 14.88 & 15.16 & 15.21 & 14.66 & 15.64 \\
\hline $\mathrm{AnO}$ & 0.73 & 1.12 & 1.89 & 1.16 & 1.45 & 1.66 & 0.87 & 1.26 & 1.17 & 1.24 & 0.95 & 0.85 & 0.94 \\
\hline $\mathrm{AgO}$ & $\{6.23$ & 14.08 & 6.91 & 6.6 & 8.92 & 8.7 & 12.4 & 12.9 & 11.44 & 11.55 & 11.98 & 12.13 & 11.42 \\
\hline $\mathrm{aO}$ & 9.87 & 10.34 & 6.11 & 16.07 & 20.21 & 9.77 & 6.61 & 6.29 & 6.68 & 6.62 & 6.46 & 66 & 5.9 \\
\hline $\mathrm{Na}_{2} \mathrm{O}$ & 2.6 & 1.72 & 5.38 & 5.35 & 2.11 & 3.55 & 5.4 & 5.75 & 5.42 & 5.58 & 5.65 & 5.83 & 5.74 \\
\hline $\mathrm{K}_{2} \mathrm{O}$ & 0.5 & 0.48 & 1.53 & 0.74 & 0.22 & 1.46 & 1.46 & 1.36 & 1.42 & 1.41 & 1.36 & 1.43 & 1.43 \\
\hline$F$ & 1.69 & 1.86 & 1.69 & 0 & 0 & 1.76 & 1.23 & 1.2 & 1.33 & 1.27 & 1.42 & 1.29 & 1.02 \\
\hline $\mathrm{Cl}$ & 0.02 & 0.16 & 0 & 0 & 0 & 0.02 & 0 & 0.01 & 0.01 & 0.01 & 0 & 0.01 & 0 \\
\hline $\mathrm{ZrO}_{2}$ & 0 & 0 & 0.47 & 0.27 & 0.22 & 0.31 & 0.79 & 0.76 & 0.61 & 0.58 & 0.67 & 0.62 & 0.93 \\
\hline $\mathrm{ZnO}$ & 0 & 0 & 0.03 & 0 & 0 & 0.1 & 0 & 0 & 0.01 & 0.08 & 0.07 & 0.12 & 0.03 \\
\hline $\mathrm{BaO}$ & 0.08 & 0 & 0 & 0 & 0 & 0 & 0 & 0 & 0 & 0 & 0 & 0 & 0 \\
\hline Total & 99.67 & 99.95 & 98.54 & 101.69 & 100.25 & 100.35 & 98.84 & 98.7 & 97.65 & 98.88 & 99.64 & 99.74 & 98.23 \\
\hline $\mathrm{OF}_{\mathrm{C}} \mathrm{CL}$ & 0.72 & 0.82 & 0.71 & 0 & 0 & 0.75 & 0.52 & 0.51 & 0.56 & 0.54 & 0.6 & 0.55 & 0.43 \\
\hline O_F & 0.71 & 0.78 & 0.71 & 0 & 0 & 0.74 & 0.52 & 0.51 & 0.56 & 0.53 & 0.6 & 0.54 & 0.43 \\
\hline O_CL & 0 & 0.04 & 0 & 0 & 0 & 0 & 0 & 0 & 0 & 0 & 0 & 0 & 0 \\
\hline Ctotal & 98.95 & 99.13 & 97.83 & 101.69 & 100.25 & 99.6 & 98.32 & 98.19 & 97.09 & 98.34 & 99.04 & 99.19 & 97.8 \\
\hline \multicolumn{14}{|c|}{ Fórmula estrutural calculada na base de 23 átomos de oxigênio } \\
\hline TSi & 7.69 & 7.282 & 7.166 & 8.006 & 8.434 & 6.664 & 7.41 & 7.198 & 7.406 & 7.33 & 7.378 & 7.333 & 7.482 \\
\hline TAl & 0.242 & 0.602 & 0.834 & 0 & 0 & 1.336 & 0.59 & 0.713 & 0.594 & 0.67 & 0.622 & 0.667 & 0.518 \\
\hline $\mathrm{TFe}^{3+}$ & 0.067 & 0.116 & 0 & 0 & 0 & 0 & 0 & 0.09 & 0 & 0 & 0 & 0 & 0 \\
\hline $\mathrm{ma}_{\mathrm{m}} \mathrm{T}$ & 8 & 8 & 8 & 8.006 & 8.434 & 8 & 8 & 8 & 8 & 8 & 8 & 8 & 8 \\
\hline il & 0 & 0 & 0.044 & 1.546 & 0.338 & 0.046 & 0.056 & 0 & 0.077 & 0.044 & 0.026 & 0.057 & 0.081 \\
\hline & 0 & 0.007 & 0 & 0 & 0 & 0 & 0 & 0 & 0 & 0 & 0 & 0 & 0 \\
\hline $\mathrm{CFe}^{3+}$ & 0.418 & 0.81 & 0.378 & 0 & 0 & 0.195 & 0 & 0.294 & 0 & 0 & 0.046 & 0 & 0.064 \\
\hline $\mathrm{CTI}$ & 0.028 & 0.066 & 0.216 & 0.065 & 0.063 & 0.277 & 0.297 & 0.289 & 0.273 & 0.299 & 0.298 & 0.317 & 0.254 \\
\hline $\mathrm{CMg}$ & 3.46 & 3.03 & 1.609 & 1.567 & 2.17 & 1.984 & 2.763 & 2.866 & 2.601 & 2.591 & 2.661 & 2.693 & 2.57 \\
\hline $\mathrm{e}^{2+}$ & 1.006 & 0.949 & 2.503 & 1.66 & 1.796 & 2.283 & 1.774 & 1.391 & 1.898 & 1.908 & 1.849 & 1.826 & 1.91 \\
\hline Un & 0.088 & 0.137 & 0.25 & 0.157 & 0.2 & 0.215 & 0.11 & 0.159 & 0.151 & 0.158 & 0.12 & 0.107 & 0.12 \\
\hline Soma $\mathrm{C}$ & 5 & 5 & 5 & 5 & 5 & 5 & 5 & 5 & 5 & 5 & 5 & 5 & 5 \\
\hline $\mathrm{BCa}$ & 1.512 & 1.599 & 1.023 & 2 & 2 & 1.601 & 1.059 & 1.004 & 1.091 & 1.067 & 1.031 & 1.053 & 0.954 \\
\hline $\mathrm{BNa}$ & 0.488 & 0.401 & 0.977 & 0 & 0 & 0.399 & 0.941 & 0.996 & 0.909 & 0.933 & 0.969 & 0.947 & 1.046 \\
\hline Soma_B & 2 & 2 & 2 & 2 & 2 & 2 & 2 & 2 & 2 & 2 & 2 & 2 & 2 \\
\hline $\mathrm{ANa}$ & 0.233 & 0.081 & 0.652 & 1.652 & 0.668 & 0.654 & 0.624 & 0.666 & 0.694 & 0.696 & 0.664 & 0.737 & 0.634 \\
\hline & 0.091 & 0.088 & & 0.15 & 0.046 & 0.285 & 0.278 & 0.259 & 0.276 & $0.27 \uparrow$ & 0.259 & 0.272 & 0.275 \\
\hline Soma_A & 0.324 & 0.169 & 0.957 & 2.54 & 1.813 & 0.939 & 0.902 & 0.925 & 0.97 & 0.966 & 0.922 & 1.008 & 0.91 \\
\hline CAT & 15.324 & 15.169 & 15.957 & 17.545 & 17.246 & $\{5.939$ & 15.902 & 45.925 & 15.97 & $\{5.966$ & 15.922 & 6.008 & $\{5.91$ \\
\hline $\mathrm{CCL}$ & 0.005 & 0.039 & 0 & 0 & 0 & 0.005 & 0 & 0.003 & 0.003 & 0.003 & 0 & 0.003 & 0 \\
\hline$C F$ & 0.764 & 0.849 & 0.835 & 0 & 0 & 0.851 & 0.581 & 0.566 & 0.641 & 0.604 & 0.669 & 0.608 & 0.487 \\
\hline $5.0 x y$ & 23 & 23 & 23 & 23 & 23 & 23 & 23.01 & 23 & 23.045 & 23.003 & 23 & 23.043 & 23 \\
\hline
\end{tabular}


Tabela 14.9 - Composição química dos anfibólios do corpo Pão de Açúcar (\% peso)

\begin{tabular}{|c|c|c|c|c|c|c|c|c|c|c|c|c|c|c|}
\hline Amosira & RP-207 & RP-207 & RP-207 & RP-207 & RP-207 & RP-207 & RP-207 & RP.207 & RP-207 & RP-207 & RP-207 & RP-207 & RP-207 & RP.207 \\
\hline Análise & 661 & 662 & 663 & 664 & 665 & 666 & 667 & 668 & 669 & 671 & 672 & 674 & 675 & 680 \\
\hline Locação & C1Gin & C1Gíb & $\mathrm{C} 1 \mathrm{G} 2 \mathrm{~m}$ & $\mathrm{C} 2 \mathrm{G} 1 \mathrm{~m}$ & C3G1m & C4Gim & C5G1m & c1G3m & $\mathrm{C} 2 \mathrm{G} 2 \mathrm{~m}$ & $C 3 G 2 n$ & $\mathrm{C} 3 \mathrm{G} 2 \mathrm{~b}$ & $\mathrm{C} 4 \mathrm{G} 3 \mathrm{~m}$ & $\mathrm{C} 5 \mathrm{G} 2 \mathrm{~m}$ & $\mathrm{c} 5 \mathrm{G} 1 \mathrm{~m}$ \\
\hline Mineral & Fe-Ed & $\mathrm{Fe}-\mathrm{Ed}$ & $\mathrm{Fe}-\mathrm{Ed}$ & Ed & EdrHbl & $\mathrm{Fe}-\mathrm{Ed}$ & $\mathrm{Fe}-\mathrm{Ed}$ & Fe-Ed & $\mathrm{Fe}-\mathrm{Ed}$ & Ed & $\mathrm{Fe}-\mathrm{Ed}$ & $\mathrm{Fe}-\mathrm{Ed}$ & $\mathrm{Fe}-\mathrm{Ed}$ & Ed \\
\hline $\mathrm{iO}_{2}$ & 43.36 & 43.67 & 43.61 & 43.47 & 42.26 & 43.4 & 43.04 & 43.17 & 42.77 & 43.44 & 43.65 & 43.26 & 44.05 & 44.77 \\
\hline $\mathrm{TiO}_{2}$ & 2.36 & 1.99 & 2.49 & 2.57 & 2.37 & 2.32 & 2.59 & 2.4 & 2.5 & 2.65 & 2.57 & 2.22 & 2.32 & 2.36 \\
\hline $\mathrm{Al}_{2} \mathrm{O}_{3}$ & 7.73 & 6.97 & 7.78 & 7.62 & 7.38 & 7.17 & 7.56 & 7.69 & 7.36 & 7.95 & 7.81 & 7.84 & 7.38 & 7.16 \\
\hline $\mathrm{Cr}_{2} \mathrm{O}_{3}$ & 0 & 0 & 0 & 0 & 0 & 0 & 0 & 0 & 0 & 0 & 0 & 0 & 0 & 0.03 \\
\hline $\mathrm{FeO}$ & 19.51 & 19.51 & 18.95 & 17.01 & 15.38 & 19.22 & 18.94 & 19.43 & 18.01 & 16.73 & 18.17 & 18.94 & 19.34 & 17.27 \\
\hline $\mathrm{MnO}$ & 1.73 & 1.73 & 1.71 & 1.51 & 1.42 & 1.77 & 1.76 & 1.74 & 1.65 & 1.48 & 1.61 & 1.71 & 1.75 & 1.52 \\
\hline $\mathrm{kgO}$ & 8.57 & 8.57 & 8.63 & 10 & 10.24 & 8.36 & 8.34 & 8.52 & 8.68 & 10.22 & 9.06 & 7.76 & 8.76 & 10.36 \\
\hline $\mathrm{aO}$ & 9.4 & 9.4 & 9.58 & 10.06 & 11.61 & 9.66 & 9.87 & 9.62 & 10.61 & 10.17 & 9.94 & 9.31 & 9.39 & 9.79 \\
\hline $\mathrm{Na}_{2} \mathrm{O}$ & 3.83 & 3.83 & 3.65 & 3.63 & 3.51 & 3.8 & 3.64 & 3.58 & 3.85 & 3.62 & 3.47 & 4.13 & 3.9 & 3.94 \\
\hline $\mathrm{K}_{2} \mathrm{O}$ & 1.45 & 1.45 & 1.42 & 1.42 & 1.35 & 1.47 & 1.42 & 1.48 & 1.4 & 1.46 & 1.46 & 1.69 & 1.4 & 1.45 \\
\hline$F$ & 0 & 0 & 0 & 0 & 0 & 0 & 0 & 1.72 & 3.03 & 1.74 & 1.46 & 1.62 & 1.61 & 2.06 \\
\hline $\mathrm{Cl}$ & 0 & 0 & 0 & 0 & 0 & 0 & 0 & 0.01 & 0.01 & 0.02 & 0 & 0.02 & 0 & 0.01 \\
\hline $\mathrm{ZrO}_{2}$ & 0.31 & 0.31 & 0.28 & 0.28 & 0.23 & 0.36 & 0.24 & 0.31 & 0.25 & 0.34 & 0,32 & 0.29 & 0.26 & 0 \\
\hline $\mathrm{ZnO}$ & 0 & 0 & 0 & 0 & 0 & 0 & 0 & 0.12 & 0.09 & 0.05 & 0.09 & 0.01 & 0.05 & 0 \\
\hline $\mathrm{BaO}$ & 0 & 0 & 0 & 0 & 0 & 0 & 0 & 0 & 0 & 0 & 0 & 0 & 0 & 0.05 \\
\hline Total & 98.25 & 97.43 & 98.1 & 97.57 & 95.75 & 97.53 & 97.4 & 99.79 & 100.21 & 99.87 & 99.61 & 98.8 & 100.21 & 100.77 \\
\hline O_F_Cl & 0 & 0 & 0 & 0 & 0 & 0 & 0 & 0.73 & 1.28 & 0.74 & 0.61 & 0.69 & 0.68 & 0.87 \\
\hline OF & 0 & 0 & 0 & 0 & 0 & 0 & 0 & 0.72 & 1.28 & 0.73 & 0.61 & 0.68 & 0.68 & 0.87 \\
\hline $\mathrm{O}_{-} \mathrm{Cl}$ & 0 & 0 & 0 & 0 & 0 & 0 & 0 & 0 & 0 & 0 & 0 & 0 & 0 & 0 \\
\hline CTotal & 98.25 & 97.43 & 98.1 & 97.57 & 95.75 & 97.53 & 97.4 & 99.06 & 98.93 & 99.13 & 99 & 98.11 & 99.53 & 99.9 \\
\hline \multicolumn{15}{|c|}{ Fómula estrutural calculada na base de 23 atomos de oxigênio } \\
\hline TSi & 6.647 & 6.764 & 6.685 & 6.665 & 6.695 & 6.747 & 6.688 & 6.645 & 6.722 & 6.622 & 6.688 & 6.774 & 6.721 & 6.754 \\
\hline TAl & 1.353 & 1.236 & 1.315 & 1.335 & 1.305 & 1.253 & 1.312 & 1.355 & 1.278 & 1.378 & 1.312 & 1.226 & 1.279 & 1.246 \\
\hline TFe ${ }^{3+}$ & 0 & 0 & 0 & 0 & 0 & 0 & 0 & 0 & 0 & 0 & 0 & 0 & 0 & 0 \\
\hline Soma_T & 8 & 8 & 8 & 8 & 8 & 8 & 8 & 8 & 8 & 8 & 8 & 8 & 8 & 8 \\
\hline CAl & 0.043 & 0.035 & 0.089 & 0.041 & 0.071 & 0.059 & 0.072 & 0.039 & 0.084 & 0.05 & 0.097 & 0.22 & 0.047 & 0.026 \\
\hline $\mathrm{CCr}$ & 0 & 0 & 0 & 0 & 0 & 0 & 0 & 0 & 0 & 0 & 0 & 0 & 0 & 0.004 \\
\hline $\mathrm{CFe}^{3+}$ & 0.255 & 0.181 & 0.142 & 0.039 & 0 & 0 & 0 & 0.228 & 0 & 0.044 & 0.043 & 0 & 0.203 & 0.085 \\
\hline $\mathrm{CTi}$ & 0.272 & 0.232 & 0.287 & 0.296 & 0.282 & 0.271 & 0.303 & 0.278 & 0.296 & 0.304 & 0.296 & 0.261 & 0.266 & 0.268 \\
\hline $\mathrm{CMg}$ & 1.959 & 1.979 & 1.972 & 2.286 & 2.418 & 1.937 & 1.932 & 1.955 & 2.034 & 2.323 & 2.069 & 1.811 & 1.993 & 2.33 \\
\hline $\mathrm{CFe}^{2+}$ & 2.247 & 2.347 & 2.287 & 2.142 & 2.038 & 2.499 & 2.461 & 2.273 & 2.367 & 2.089 & 2.286 & 2.48 & 2.265 & 2.094 \\
\hline $\mathrm{CMn}$ & 0.225 & 0.227 & 0.222 & 0.196 & 0.191 & 0.233 & 0.232 & 0.227 & 0.22 & 0.191 & 0.209 & 0.227 & 0.226 & 0.194 \\
\hline Soma_C & 5 & 5 & 5 & 5 & 5 & 5 & 5 & 5 & 5 & 5 & 5 & 5 & 5 & 5 \\
\hline $\mathrm{BCa}$ & 1.544 & 1.56 & 1.573 & 1.653 & 1.971 & 1.609 & 1.643 & 1.587 & 1.787 & 1.661 & 1.632 & 1.562 & 1.535 & 1.582 \\
\hline $\mathrm{BNa}$ & 0.456 & 0.44 & 0.427 & 0.347 & 0.029 & 0.391 & 0.357 & 0.413 & 0.213 & 0.339 & 0.368 & 0.438 & 0.465 & 0.418 \\
\hline Soma_B & 2 & 2 & 2 & 2 & 2 & 2 & 2 & 2 & 2 & 2 & 2 & 2 & 2 & 2 \\
\hline ANa & 0.683 & 0.71 & 0.658 & 0.732 & 1.049 & 0.754 & 0.74 & 0.655 & 0.96 & 0.731 & 0.663 & 0.816 & 0.689 & 0.735 \\
\hline$A K$ & 0.284 & 0.287 & 0.278 & 0.278 & 0.273 & 0.292 & 0.282 & 0.291 & 0.281 & 0.284 & 0.285 & 0.338 & 0.273 & 0.279 \\
\hline Soma A & 0.966 & 0.997 & 0.936 & 1.01 & 1.321 & 1.046 & 1.022 & 0.946 & 1.241 & 1.015 & 0.948 & 1.154 & 0.961 & 1.014 \\
\hline S._CAT & 15.966 & 15.997 & 15.936 & 16.01 & 16.321 & 16.046 & 16.022 & $\{5.946$ & $\$ 6.241$ & 16.015 & 15.948 & 16.154 & 15.961 & 16.014 \\
\hline $\mathrm{CCl}$ & 0 & 0 & 0 & 0 & 0 & 0 & 0 & 0.003 & 0.003 & 0.005 & 0 & 0.005 & 0 & 0.003 \\
\hline CF & 0 & 0 & 0 & 0 & 0 & 0 & 0 & 0.837 & 1.506 & 0.839 & 0.707 & 0.802 & 0.777 & 0.983 \\
\hline Som_oxy & 23 & 23 & 23 & 23 & 23.311 & 23.002 & 23.016 & 23 & 23.212 & 23 & 23 & $23 .\{16$ & 23 & 23 \\
\hline
\end{tabular}


Tabela 14.10 - Composição química de anfibólios do corpo Pão de Açúcar (\% peso)

\begin{tabular}{|c|c|c|c|c|c|c|c|c|c|c|c|c|c|}
\hline $\begin{array}{l}\text { Amostra } \\
\text { Análise }\end{array}$ & $\begin{array}{c}R P-207 \\
843\end{array}$ & $\begin{array}{c}\mathrm{RP}-207 \\
844\end{array}$ & $\begin{array}{c}\mathrm{RP}-207 \\
845\end{array}$ & $\begin{array}{c}R P-207 \\
862\end{array}$ & $\begin{array}{c}\text { RP-207 } \\
863\end{array}$ & $\begin{array}{c}\text { RP-207 } \\
864\end{array}$ & $\begin{array}{c}\text { RP-207 } \\
821\end{array}$ & $\begin{array}{c}R P-207 \\
822\end{array}$ & $\begin{array}{c}\mathrm{RP} \cdot 207 \\
828\end{array}$ & $\begin{array}{c}\text { RP-207 } \\
829\end{array}$ & $\begin{array}{c}\text { RP-207 } \\
830\end{array}$ & $\begin{array}{c}\text { RP-207 } \\
831\end{array}$ & $\begin{array}{c}\text { RP-207 } \\
832\end{array}$ \\
\hline $\begin{array}{l}\text { Análise } \\
\text { Locacâo }\end{array}$ & $\begin{array}{c}843 \\
\text { C4G3n }\end{array}$ & $\begin{array}{c}844 \\
\text { C5Gín }\end{array}$ & $\begin{array}{c}845 \\
\text { C5G1b }\end{array}$ & $\begin{array}{c}802 \\
\mathrm{C} 2 \mathrm{G} 1 \mathrm{Fn}\end{array}$ & $\mathrm{C} 2 \mathrm{G} 1 \mathrm{Fb}$ & C3G1Fn & C1G3Fn & C1G3Fb & C4G1n & C5Gin & C5G2n & C6G1n & $\mathrm{C} 2 \mathrm{G} 1 \mathrm{n}$ \\
\hline ineral & Si-Ed & Si-Ed & Si-Ed & Si-Ed & Si-Ed & Si-Ed & Si-Ed & Si-Ed & Si-Ed & Si-Ed & Si-Ed & Si-Ed & Si-Ed \\
\hline $\mathrm{O}_{2}$ & 49.52 & 49.77 & 48.92 & 49.53 & 48.82 & 48.56 & 49.76 & 49.27 & 49.71 & 49.03 & 49.37 & 52.31 & 45.96 \\
\hline $\mathrm{TiO}$ & 2 & 2.7 & 2.65 & 2.54 & 2.4 & 2.83 & & 2.64 & 2.15 & $\uparrow .95$ & 2.77 & 0.18 & 2.18 \\
\hline 0 & 3.22 & 4.05 & 3.9 & 3. & 4.1 & 3. & & 4.22 & 3. & 4.13 & 4.4 & 1.14 & 4.82 \\
\hline${ }_{2}$ & 0 & 0 & 0 & & 0.0 & & & 0.02 & 0.0 & 0 & 0.01 & 0.01 & 0 \\
\hline 0 & 16.07 & 11.13 & 15.16 & 14.16 & 16.49 & 13.8 & 11. & 12.24 & 15. & 14.62 & $\{1.27$ & 21. & 19.65 \\
\hline t & 1.05 & 0.67 & 0.93 & 0.95 & 1.3 & 0.8 & 0.6 & 0.74 & 0.9 & 0.81 & & 2.07 & 1.56 \\
\hline go & 11.41 & 14.62 & 11 & 12.05 & 10. & 12 & 13. & 13.5 & 11.58 & 12.16 & 14.55 & 8.59 & 8.22 \\
\hline & 5.7 & 7.77 & 7. & 7.84 & 5.4 & & & 76 & 5.8 & 6.65 & & 1.03 & 5.59 \\
\hline 2 & 5. & 4.94 & 5.2 & 5. & 6.32 & & & & 6.04 & 5.72 & & 8.68 & 6.18 \\
\hline 0 & 1.4 & 1.4 & 1. & 1. & 1. & 1. & 1.3 & & 1.46 & 1.47 & 1.3 & & 1.45 \\
\hline $\mathrm{F}$ & 1.3 & 1.58 & 0.9 & 1.16 & 1.14 & 1.4 & & & & 0 & 0 & 0 & 0 \\
\hline & 0 & 0 & 0 & & 0 & & 0 & & 0 & 0 & 0 & 0 & 0 \\
\hline $\mathrm{O}_{2}$ & 0.96 & 0.37 & 0. & c & 0 & 0 & 0.38 & 0.33 & 1.01 & 0.97 & 0.36 & 0.01 & 0.68 \\
\hline & 0 & 0 & 0 & 0 & 0 & 0 & 0 & & 0 & 0 & 0 & 0 & 0 \\
\hline 0 & 0 & 0 & 0 & 0.03 & 0.15 & 0 & 0 & 0 & 0 & 0 & 0 & 0 & 0 \\
\hline te & 98.61 & 99 & 98.38 & 99.56 & 98.43 & 97.8 & 98.69 & 97.76 & 98.04 & 97.51 & 97.92 & 96.75 & 96.29 \\
\hline F_Cl & 0.55 & 0.67 & 0.4 & 0.49 & 0.48 & 0.59 & 0 & 0 & 0 & 0 & 0 & 0 & 0 \\
\hline $\mathrm{F}$ & 0.55 & 0.67 & 0.4 & 0.49 & 0.48 & 0.59 & 0 & 0 & 0 & 0 & 0 & 0 & 0 \\
\hline $\mathrm{Cl}$ & 0 & 0 & 0 & 0 & 0 & 0 & 0 & 0 & 0 & 0 & 0 & 0 & 0 \\
\hline Folal & 98.06 & 98.33 & 97.98 & 99.07 & 97.95 & 97.21 & 98.69 & 97.76 & 98.04 & 97.51 & 97.92 & 96.75 & 96.29 \\
\hline $\mathrm{i}$ & 7.472 & 7.332 & 7.36 & 7.424 & 7.3 & 7.322 & 7.30 & 7.28 & 7.4 & 7.3 & 7.2 & 7.8 & 7.174 \\
\hline TAl & 0.528 & 0.668 & 0.64 & 0.576 & 0.66 & 0.678 & 0.694 & 0.708 & 0.538 & 0.623 & 0.735 & 0.126 & 0.826 \\
\hline $\mathrm{Fe}^{3+}$ & 0 & 0 & 0 & 0 & 0 & 0 & 0 & 0 & 0 & 0 & 0 & 0 & 0 \\
\hline$m a_{-} T$ & 8 & 8 & 8 & 8 & 8 & 8 & 8 & 8 & 8 & 8 & 8 & 8 & 8 \\
\hline 41 & 0.044 & 0.035 & 0.063 & 0.124 & 0.069 & 0.005 & 0.096 & 0.027 & 0.037 & 0.109 & 0.027 & 0.076 & 0.06 \\
\hline $\mathrm{Cr}$ & 0 & 0 & 0 & 0.001 & 302 & 0.002 & 0.001 & 0.002 & 0.004 & 0 & 0.001 & 0.0 & 0 \\
\hline $\mathrm{Fe}^{3+}$ & 0.171 & 0 & 0 & 0 & & 0 & 0 & 0 & 0.083 & 0 & 0 & 0.911 & 0.225 \\
\hline & 0.227 & 0.299 & 0.3 & 0.286 & 0.282 & 0.321 & 0.321 & 0.294 & 0.243 & 0.221 & 0.307 & 0.0 & 0.256 \\
\hline $\mathrm{Mg}$ & 2.567 & 3.211 & 2.611 & 2.692 & 2.403 & 2.816 & 3.025 & 3.069 & 2.591 & 2.728 & 3.192 & 1.928 & 1.913 \\
\hline $\mathrm{Fe}^{2+}$ & 1.856 & 1.371 & 1.907 & 1.775 & 1.904 & & & 1.515 & 1.92 & 1.84 & 1.387 & 1.799 & 2.34 \\
\hline & 0.134 & 0.084 & 0.119 & 0.121 & 0.171 & 0.114 & 0.086 & 0.093 & 0.123 & 0.103 & 0.086 & 0.264 & 0.206 \\
\hline ma_c & 5 & 5 & 5 & & 5 & 5 & 5 & 5 & 5 & 5 & 5 & 5 & 5 \\
\hline Bca & 0.926 & 1.226 & 1.157 & 1.259 & 0.871 & 1.089 & 1.277 & 1.216 & 0.944 & 1.072 & 1.279 & 0.166 & 0.935 \\
\hline na & 1.074 & 0.774 & 0.843 & 0.741 & 1.129 & 0.911 & 0.723 & 0.784 & 1.056 & 0.928 & 0.721 & 1.834 & 1.065 \\
\hline Soma_B & 2 & 2 & 2 & 2 & 2 & 2 & 2 & 2 & 2 & 2 & 2 & 2 & 2 \\
\hline & 0.653 & 0.638 & 0.701 & 0.988 & 0.714 & 0.761 & 0.726 & 0.754 & 0.702 & 0.741 & 0.708 & 0.7 & 0.805 \\
\hline 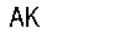 & 0.279 & 0.263 & & 0.262 & 0.27 & 0.277 & 0.255 & 0.257 & 0.283 & 0.282 & 0.259 & 0.23 & 0.289 \\
\hline Soma_A & 0.932 & 0.901 & 0.969 & 1.25 & 0.984 & 1.038 & 0.981 & 1.011 & 0.986 & 1.023 & 0.967 & 0.93 & 1.094 \\
\hline S._CAT & 15.932 & 15.901 & 15.969 & 16.25 & 15.984 & 16.038 & $15.98\}$ & 16.011 & 15.986 & 16.023 & 15.967 & 15.93 & 16.094 \\
\hline $\mathrm{CCl}$ & 0 & 0 & 0 & 0 & 0 & 0 & 0 & 0 & 0 & 0 & 0 & 0 & 0 \\
\hline & 0.62 & 0.736 & 0.447 & 0.55 & 0.542 & 0.672 & 0 & 0 & 0 & 0 & 0 & 0 & 0 \\
\hline$-U x y$ & 23 & 23.046 & 23.075 & 23.316 & 23 & 23.049 & 23.152 & 23.068 & 23 & 23.011 & 23.076 & 23 & 23 \\
\hline
\end{tabular}


Tabela 14.11 - Composição química de anfibólio de Cerro Siete Cabezas (\% peso)

Amostra RP-230 RP-230 RP-230 RP-230 RP-230 RP-230 RP-230

\begin{tabular}{|c|c|c|c|c|c|c|c|}
\hline & & & & & & & \\
\hline Análise & 930 & 951 & 966 & 967 & 968 & 969 & 970 \\
\hline Locação & C2Gin & C6G3m & $\mathrm{C} 2 \mathrm{G} 1 \mathrm{n}$ & C2Gib & C3G1n & C3G1D & $\mathrm{C} 4 \mathrm{G} 1 \mathrm{n}$ \\
\hline ineral & Si-Ed & Si-Ed & $\mathrm{Fe}-\mathrm{Ed}-\mathrm{Hb}$ & $\mathrm{Fe}-\mathrm{Ed}-\mathrm{H} b$ & Fe-Ed-Hb & Fe-Ed-Hb & $\mathrm{Fe}-\mathrm{Pg}-\mathrm{Hb}$ \\
\hline $\mathrm{SiO}_{2}$ & 47.21 & 48.46 & 40.87 & 40.29 & 41.32 & 41.03 & 39.42 \\
\hline $\mathrm{TiO}_{2}$ & 0.89 & 0.97 & 3.35 & 2.87 & 3.33 & 2.51 & 3.24 \\
\hline $\mathrm{Al}_{2} \mathrm{O}_{3}$ & 13.04 & 2.9 & 9.56 & 10.74 & 9.69 & 9.54 & 10.01 \\
\hline $\mathrm{Cr}_{2} \mathrm{O}_{3}$ & 0 & 0 & 0 & 0 & 0 & 0 & 0 \\
\hline 0 & 19.12 & 22.87 & 20.65 & 21.72 & 19.76 & 20.13 & 24.24 \\
\hline inc & 1.13 & 1.5 & 1.16 & 1.26 & & 1.31 & 1.35 \\
\hline $\mathrm{MgO}$ & 2.73 & 4.24 & 6.97 & 5.4 & 7.65 & 7.1 & 4.62 \\
\hline 0 & 6.74 & 7.98 & 10.27 & 9.88 & 10.26 & 10.21 & 9.45 \\
\hline o & 2.72 & 6.96 & 3.28 & 4.52 & 3.36 & 3.23 & 3.92 \\
\hline $\mathrm{K}_{2} \mathrm{O}$ & 5.53 & 0.75 & 1.44 & 1.54 & 1.44 & 1.43 & 1.57 \\
\hline $\mathrm{F}$ & 0 & 0 & & 0.69 & 1.01 & 0.59 & 0.44 \\
\hline $\mathrm{Cl}$ & 0 & 0 & & 0.01 & 0.04 & 0.02 & 0.02 \\
\hline $\mathrm{ZrO}_{2}$ & 0.09 & 0.53 & 0.35 & 0.42 & 0.35 & 0.3 & 0.44 \\
\hline 10 & 0 & 0 & 0.03 & 0.05 & 0.08 & 0.16 & 0.11 \\
\hline 0 & 0 & 0 & 0 & 0 & 0 & 0 & 0 \\
\hline Total & 99.2 & 97.16 & 98.84 & 99.39 & 99.49 & 97.64 & 98.83 \\
\hline OF. $\mathrm{Cl}$ & 0 & 0 & 38 & 0.29 & 0.43 & 0.25 & 0.19 \\
\hline OF & 0 & 0 & & 0.29 & 0.43 & 0.25 & 0.19 \\
\hline $\mathrm{O}_{-}^{-} \mathrm{Cl}$ & 0 & 0 & 1 & 0 & 0.01 & 0 & 0 \\
\hline CT̄otal & 99.2 & 97.16 & 98.46 & 99.1 & 99.06 & 97.39 & 98.64 \\
\hline \multicolumn{8}{|c|}{ Fórmula estrutural calculada na base de 23 átomos de oxigênio } \\
\hline TSi & 7.284 & 7.942 & 6.379 & 6.358 & 6.381 & 6.442 & 6.253 \\
\hline TAl & 0.716 & 0.058 & 1.621 & 1.642 & 1.619 & 1558 & 1.747 \\
\hline $\mathrm{TFe}^{3+}$ & 0 & 0 & & 0 & 0 & 0 & 0 \\
\hline Soma_T & 8 & 8 & 8 & 8 & 8 & 8 & 8 \\
\hline & 1.654 & 0.502 & 0.136 & 0.354 & 0.143 & 0.206 & 0.124 \\
\hline 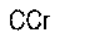 & 0 & 0 & & 0 & 0 & 0 & 0 \\
\hline $\mathrm{CFe}^{3+}$ & 0 & 0 & 0 & 0 & 0.017 & 0.055 & 0.114 \\
\hline$i_{i}$ & 0.103 & 0.12 & 0.393 & 0.341 & 387 & 0.296 & 0.387 \\
\hline & 0.628 & 1.036 & 1.622 & 1.27 & 1.761 & 1.681 & 1.093 \\
\hline $\mathrm{Fe}^{2+}$ & 2.467 & 3.135 & 2.695 & 2.866 & 2.535 & 2.588 & 3.102 \\
\hline CMn & 0.148 & 0.208 & 0.153 & 0.168 & 0.157 & 0.174 & 0.181 \\
\hline Soma_C & 5 & 5 & 5 & 5 & 5 & 5 & 5 \\
\hline $\mathrm{BCa}$ & 1.114 & 1.401 & 1.717 & 1.671 & 1.698 & 1.717 & 1.606 \\
\hline $\mathrm{BNa}$ & 0.814 & 0.599 & 0.283 & 0.329 & 0.302 & 0.283 & 0.394 \\
\hline Soma_B & 1.928 & 2 & 2 & 2 & 2 & 2 & 2 \\
\hline & 0 & 1.613 & 0.71 & 1.054 & 0.704 & 0.701 & 0.812 \\
\hline AK & 1.089 & 0.157 & 0.287 & 0.31 & 0.284 & 0.286 & 0.318 \\
\hline Soma_A & 1.089 & 1.77 & 0.997 & 1.364 & 0.987 & 0.987 & 1.13 \\
\hline S._CAT & 16.017 & 16.77 & & $\uparrow 6.364$ & 15.987 & 15.987 & 16.13 \\
\hline $\mathrm{CCl}$ & 0 & 0 & 0.008 & 0.003 & 0.01 & 0.005 & 0.005 \\
\hline $\mathrm{CF}$ & 0 & 0 & 0.434 & 0.344 & 0.493 & 0.293 & 0.221 \\
\hline$c 0$ & 23.638 & 23.927 & 23.008 & 23.214 & 23 & 23 & 23 \\
\hline
\end{tabular}

Observaçöes: $\mathrm{Fe}^{2+1} / \mathrm{Fe} \mathrm{e}^{3+}$ calculado por estequiometria. Abreviaçōes como na tabela 14.0 
Tabela 14.12 - Composição química de antibólios de Cerrito (\% peso)

\begin{tabular}{|c|c|c|c|c|}
\hline Amostra & RP-88 & RP-88 & $R P-88$ & $\begin{array}{c}\text { RP. } 88 \\
850\end{array}$ \\
\hline Análise & 846 & 847 & 849 & $\begin{array}{c}850 \\
\text { c4G1m }\end{array}$ \\
\hline $\begin{array}{l}\text { Locaçāo } \\
\text { Mineral }\end{array}$ & $\begin{array}{l}\text { C1G1m } \\
\text { Si-Ed }\end{array}$ & $\begin{array}{l}\text { C1G2m } \\
\text { Si-Ed }\end{array}$ & $\begin{array}{l}\text { C3G1m } \\
\text { Si-Ed }\end{array}$ & $\begin{array}{l}\text { C4G1m } \\
\text { Si-Ed }\end{array}$ \\
\hline $\mathrm{SiO}_{2}$ & 47.75 & 47.29 & 47.30 & 47.76 \\
\hline $\mathrm{TiO}_{2}$ & 1.61 & 1.83 & 1.62 & 1.51 \\
\hline $\mathrm{A}_{12} \mathrm{O}_{3}$ & 4.30 & 4.34 & 4.68 & 5.26 \\
\hline $\mathrm{Cr}_{2} \mathrm{O}_{3}$ & & & & \\
\hline $\mathrm{FeO}$ & 19.79 & 19.93 & 20.36 & 19.36 \\
\hline $\mathrm{MnO}$ & 1.60 & 1.63 & 1.56 & 1.45 \\
\hline MgO & 8.88 & 8.85 & 8.55 & 7.97 \\
\hline $\mathrm{CaO}$ & 5.35 & 4.97 & 5.06 & 4.65 \\
\hline $\mathrm{Na}_{2} \mathrm{O}$ & 6.02 & 6.13 & 6.39 & 6.35 \\
\hline $\mathrm{K}_{2} \mathrm{O}$ & 1.60 & 1.49 & 1.54 & 1.51 \\
\hline$F$ & 1.99 & 1.89 & 2.20 & 1.37 \\
\hline $\mathrm{Cl}$ & 0.01 & 0.01 & - & 0.02 \\
\hline $\mathrm{ZrO}_{2}$ & 0.52 & 0.51 & 0.68 & 0.59 \\
\hline $\mathrm{ZnO}$ & 0.15 & 0.10 & 0.04 & - \\
\hline $\mathrm{BaO}$ & - & & & \\
\hline Total & 99.57 & 98.97 & 99.98 & 97.80 \\
\hline O_F_CL & 0.84 & 0.80 & 0.93 & 0.58 \\
\hline$O F$ & 0.84 & 0.80 & 0.93 & 0.58 \\
\hline O_CL & & & & \\
\hline Ctotal & 98.73 & 98.17 & 99.05 & 97.22 \\
\hline \multicolumn{5}{|c|}{ Fórmula estrutural calculada na base de 23 átomos de oxigênio } \\
\hline TSi & 7.29 & 7.23 & 7.22 & 7.36 \\
\hline TAl & 0.71 & 0.77 & 0.78 & 0.64 \\
\hline $\mathrm{TFe}^{3+}$ & & - & & \\
\hline Soma_T & 8.00 & 8.00 & 8.00 & 8.00 \\
\hline CAl & 0.06 & 0.01 & 0.07 & 0.31 \\
\hline $\mathrm{CCr}$ & & - & & \\
\hline $\mathrm{CFe}^{3+}$ & 0.44 & 0.60 & 0.49 & 0.25 \\
\hline CTi & 0.19 & 0.21 & 0.1 & 0.18 \\
\hline $\mathrm{CMg}$ & 2.02 & 2.02 & 1.95 & 1.83 \\
\hline $\mathrm{CFe}^{2+}$ & 2.09 & 1.95 & 2.11 & 2.24 \\
\hline $\mathrm{CMn}$ & 0.21 & 0.21 & 0.20 & 0.19 \\
\hline Soma_C & 5.00 & 5.00 & 5.00 & 5.00 \\
\hline $\mathrm{BCa}$ & 0.88 & 0.81 & 0.83 & 0.77 \\
\hline $\mathrm{BNa}$ & 1.13 & 1.19 & 1.17 & 1.23 \\
\hline Soma_B & 2.00 & 2.00 & 2.00 & 2.00 \\
\hline $\mathrm{ANa}$ & 0.66 & 0.63 & 0.72 & 0.66 \\
\hline AK & 0.31 & 0.29 & 0.30 & 0.30 \\
\hline Soma_A & 0.97 & 0.92 & 1.02 & 0.96 \\
\hline S_CAT & 15.97 & 15.92 & 16.02 & 15.96 \\
\hline CCL. & 0.00 & 0.00 & & 0.05 \\
\hline CF & 0.96 & 0.91 & 1.06 & 0.67 \\
\hline S.Oxy & 23.00 & 23.00 & 23.00 & 23.00 \\
\hline
\end{tabular}

Observaçōes: $\mathrm{Fe}^{2+} / \mathrm{Fe}^{3+}$ calculado por estequiometria. Abreviações como na tabela 14.0 
Tabela 14.13 - Composição química de anfibólios de Cerro Pedreira (\% peso)

\begin{tabular}{|c|c|c|c|c|c|c|c|}
\hline & & & & & & & \\
\hline Amostra & RP-205 & RP-205 & RP.205 & RP-205 & RP-205 & $R P-205$ & RP-205 \\
\hline Análise & 1062 & 1063 & 1064 & 1065 & 1066 & 1067 & 1068 \\
\hline Locação & $\mathrm{C} 4 \mathrm{G} 2 \mathrm{n}$ & C3G1n & C3G1b & $C 3 G 2 n$ & C2Gín & C2G1b & C1Gin \\
\hline Mineral & $\mathrm{Fe}-\mathrm{Ed}$ & Fe-Ed & Fe-Ed & Fe-Ed & $\mathrm{Fe}-\mathrm{Ed}$ & $\mathrm{Fe}-\mathrm{Ed}$ & Fe-Ed \\
\hline $\mathrm{SiO}_{2}$ & 43.03 & 49.13 & 48.12 & 48.99 & 48.72 & 49.57 & 48.12 \\
\hline $\mathrm{TiO}_{2}$ & 5.05 & 3.04 & 2.66 & 2.65 & 2 & 1.9 & 3.11 \\
\hline $\mathrm{Al}_{2} \mathrm{O}_{3}$ & 256 & 4.45 & 3.95 & 4.18 & 3.52 & 3.06 & 4.73 \\
\hline $\mathrm{Cr}_{2} \mathrm{O}_{3}$ & 0 & 0 & 0 & 0 & 0 & 0 & 0 \\
\hline $\mathrm{FeO}$ & 32.2 & 10.4 & 16.62 & 11.24 & 17.13 & 16.59 & 12.92 \\
\hline $\mathrm{MnO}$ & 1 & 0.51 & 0.76 & 0.52 & 0.7 & 0.64 & 0.59 \\
\hline $\mathrm{MgO}$ & 3.16 & 15.49 & 11.11 & 14.77 & 11.28 & 116 & 13.45 \\
\hline $\mathrm{CaO}$ & 1.15 & 8.17 & 6.57 & 8.12 & 5.14 & 5.43 & 8.58 \\
\hline $\mathrm{Na}_{2} \mathrm{O}$ & 7.16 & 4.9 & 5.51 & 4.85 & 5.87 & 6.24 & 4.63 \\
\hline $\mathrm{K}_{2} \mathrm{O}$ & 1.65 & 1.31 & 1.49 & 1.42 & 1.83 & 1.51 & 1.36 \\
\hline$F$ & 0.18 & 1.73 & 1.29 & 1.45 & 1.23 & 1.34 & 1.33 \\
\hline $\mathrm{Cl}$ & 0.01 & 0.01 & 0.01 & 0 & 0 & 0.01 & 0.01 \\
\hline $\mathrm{ZrO}_{2}$ & 0 & 0 & 0 & 0 & 0 & 0 & 0 \\
\hline $\mathrm{ZnO}$ & 0 & 0 & 0 & 0 & 0 & 0 & 0 \\
\hline $\mathrm{BaO}$ & 0 & 0 & 0 & 0 & 0 & 0 & 0 \\
\hline Tolal & 97.15 & 99.14 & 98.09 & 98.19 & 97.42 & 97.89 & 98.83 \\
\hline $\mathrm{O}_{-} \mathrm{F} . \mathrm{Cl}$ & 0.08 & 0.73 & 0.55 & 0.61 & 0.52 & 0.57 & 0.56 \\
\hline $\mathrm{O} F$ & 0.08 & 0.73 & 0.54 & 0.61 & 0.52 & 0.56 & 0.56 \\
\hline $\mathrm{O} \_\mathrm{Cl}$ & 0 & 0 & 0 & 0 & 0 & 0 & 0 \\
\hline CTotal & 97.07 & 98.41 & 97.54 & 97.58 & 96.9 & 97.32 & 98.27 \\
\hline & & & Fórmul & rutural cal & la na base & 23 atomos & xigênio \\
\hline TSi & 6.794 & 7.186 & 7.284 & 7.257 & 7.356 & 7.466 & 7.159 \\
\hline TAl & 0.476 & 0.767 & 0.704 & 0.729 & 0.626 & 0.534 & 0.829 \\
\hline $\mathrm{TFe}^{3+}$ & 0.729 & 0 & 0.012 & 0 & 0.018 & 0 & 0 \\
\hline Soma_T & 8 & 8.287 & 8 & 8.281 & 8 & 8 & 8.335 \\
\hline $\mathrm{CAI}$ & 0 & 0 & 0 & 0 & 0 & 0.009 & 0 \\
\hline $\mathrm{CCr}$ & 0 & 0 & 0 & 0 & 0 & 0 & 0 \\
\hline $\mathrm{CFe}^{3+}$ & 1.092 & 0 & 0.074 & 0 & 0.456 & 0.23 & 0 \\
\hline $\mathrm{CTi}$ & 0.6 & 0 & 0.303 & 0 & 0.227 & 0.215 & 0 \\
\hline $\mathrm{CMg}$ & 0.744 & 3.378 & 2.507 & 3.261 & 2.539 & 2.605 & 2.983 \\
\hline $\mathrm{CFe}^{2+}$ & 2.43 & 1.272 & 2.019 & 1.392 & 1.688 & 1.86 & 1.607 \\
\hline $\mathrm{CMn}$ & 0.134 & 0.063 & 0.097 & 0.065 & 0.09 & 0.082 & 0.074 \\
\hline Soma_C & 5 & 5 & 5 & 5 & 5 & 5 & 5 \\
\hline $\mathrm{BCa}$ & 0.195 & 0.993 & 1.066 & 1.008 & 0.831 & 0.876 & 1.032 \\
\hline $\mathrm{BNa}$ & 1.805 & 1.007 & 0.934 & 0.992 & 1.169 & 1.124 & 0.968 \\
\hline Soma_B & 2 & 2 & 2 & 2 & 2 & 2 & 2 \\
\hline $\mathrm{ANa}$ & 0.387 & 0.383 & 0.683 & 0.401 & 0.55 & 0.699 & 0.368 \\
\hline AK & 0.332 & 0.244 & 0.288 & 0.268 & 0.352 & 0.29 & 0.258 \\
\hline Soma_A & 0.719 & 0.627 & 0.971 & 0.669 & 0.902 & 0.989 & 0.626 \\
\hline Soma CAT & 15.719 & 15.914 & 15.971 & 15.95 & 15.902 & 15.989 & 15.961 \\
\hline $\mathrm{CCl}$ & 0.003 & 0.002 & 0.003 & 0 & 0 & 0.003 & 0.003 \\
\hline CF & 0.09 & 0.8 & 0.618 & 0.679 & 0.587 & 0.638 & 0.626 \\
\hline Soma_Oxy & 23 & 23.001 & 23 & 23.036 & 23 & 23 & 23.085 \\
\hline
\end{tabular}

Observaçōes: $\mathrm{Fe}^{2+} / \mathrm{Fe}^{3+}$ calculado por estequiometria. Abreviações como na tabela 14.0 
Tabela 14.14 - Composição quimica de anfibólios do Morro de São Pedro (\% peso)

\begin{tabular}{|c|c|c|c|c|c|c|c|c|c|c|c|c|c|}
\hline $\begin{array}{l}\text { Amostra } \\
\text { Análise }\end{array}$ & $\begin{array}{c}\text { RP-255 } \\
1093\end{array}$ & $\begin{array}{c}\text { RP-255 } \\
1094\end{array}$ & $\begin{array}{c}\text { RP-255 } \\
1095\end{array}$ & $\begin{array}{c}\text { RP-255 } \\
1096\end{array}$ & $\begin{array}{c}\text { RP-255 } \\
1099\end{array}$ & $\begin{array}{c}\text { RP-255 } \\
1102\end{array}$ & $\begin{array}{c}\text { RP-255 } \\
1103\end{array}$ & $\begin{array}{c}\text { RP-255 } \\
1104\end{array}$ & $\begin{array}{c}\text { RP-255 } \\
1105\end{array}$ & $\begin{array}{c}\mathrm{RP}-256 \\
1106\end{array}$ & $\begin{array}{c}\text { RP-256 } \\
1107\end{array}$ & $\begin{array}{c}\text { RP-256 } \\
1108\end{array}$ & $\begin{array}{c}\text { RP-256 } \\
1114\end{array}$ \\
\hline Locação & C1G1Fn & $\mathrm{C} 1 \mathrm{G} 1 \mathrm{Fb}$ & $\mathrm{C} 1 \mathrm{G} 2 \mathrm{Fn}$ & $\mathrm{C} 1 \mathrm{G} 2 \mathrm{Fb}$ & $\mathrm{C} 2 \mathrm{G} 1 \mathrm{br}$ & C3Gib & C4Gín & $\mathrm{C} 4 \mathrm{G} 1 \mathrm{~b}$ & $\mathrm{C} 4 \mathrm{G} 2 \mathrm{~m}$ & C1Gin & C1G1b & $\mathrm{C} 1 \mathrm{G} 2 \mathrm{~m}$ & $\mathrm{C} 2 \mathrm{G} 1 \mathrm{~m}$ \\
\hline Mineral & $\mathrm{Fe} \cdot \mathrm{Pg}-\mathrm{Hb}$ & $\mathrm{Fe}-\mathrm{PgHb}$ & Fe-Pg-Hb & Fe.Pg-Hb & $\mathrm{Fe}-\mathrm{Pg}+\mathrm{Hb}$ & $\mathrm{Fe}-\mathrm{Pg}-\mathrm{Hb}$ & $\mathrm{Fe}-\mathrm{PgHb}$ & $\mathrm{Fe}-\mathrm{Pg}-\mathrm{Hb}$ & $\mathrm{Fe}-\mathrm{Pg}-\mathrm{Hb}$ & $\mathrm{Fe}-\mathrm{Pg}-\mathrm{Hb}$ & $\mathrm{Fe}-\mathrm{Pg}-\mathrm{H}$ b & $\mathrm{Fe}-\mathrm{PgHb}$ & $\mathrm{Fe}-\mathrm{Pg}-\mathrm{H}$ \\
\hline $\mathrm{SiO}_{2}$ & 41.12 & 40.92 & 40.77 & 40.81 & 40.57 & 42.94 & 40.72 & 41.01 & 40.41 & 42.05 & 42.12 & 41.72 & 41.82 \\
\hline $\mathrm{TiO}_{2}$ & 3.2 & 3.77 & 3.5 & 3.16 & 3.22 & 2.33 & 3.35 & 3.43 & 3.03 & 1.31 & 1.51 & 0.98 & 1.7 \\
\hline $\mathrm{Al}_{2} \mathrm{O}_{3}$ & 10.6 & 10.25 & 10.46 & 10.22 & 10.47 & 8.42 & 10.18 & 9.95 & 10.07 & 9.24 & 8.65 & 9.29 & 8.36 \\
\hline $\mathrm{Cr}_{2} \mathrm{O}_{3}$ & 0 & 0 & 0 & 0 & 0 & 0 & 0 & 0 & 0 & 0 & 0 & 0 & 0 \\
\hline $\mathrm{FeO}$ & 16.93 & 17.13 & 17.38 & 19.53 & 19.09 & 17.53 & 18.86 & 18.2 & 18.72 & 18.41 & 18.15 & 19.09 & 19.13 \\
\hline $\mathrm{MnO}$ & 0.84 & 0.85 & 0.82 & 0.84 & 0.9 & 0. & 0. & 0.83 & 0.88 & 1.26 & 1.33 & 1.26 & 1.64 \\
\hline igo & 9.66 & 9.2 & 9.59 & 8.3 & 8. & 8.85 & 8. & 8.92 & 8.45 & 9.66 & 9.57 & 9.17 & 8.49 \\
\hline $\mathrm{CaO}$ & 10.86 & 10.79 & 10.45 & 10.61 & 10.78 & 12 & 10.73 & 10.67 & 10.75 & 9.89 & 9.86 & 9.88 & 9.46 \\
\hline $\mathrm{Na}_{2} \mathrm{O}$ & 3.0 & 3.11 & & 3.1 & 3. & 2.77 & 3. & 3. & 3.21 & 3.57 & 3.51 & 3.46 & 3.73 \\
\hline $\mathrm{K}_{2} \mathrm{O}$ & 1.45 & 1.44 & 1.62 & 1.49 & 1.45 & 1.2 & & & 1.51 & 1.5 & 1.39 & 1.5 & 1.37 \\
\hline & 0.64 & 0.84 & 0.76 & 0.48 & 0.82 & 0.68 & & 0.62 & 0.68 & 1.36 & 1.24 & 1.36 & 1.21 \\
\hline $\mathrm{Cl}$ & 0.02 & 0.02 & 0.02 & 0.02 & 0. & 0.01 & 0.02 & 0 & 0.01 & 0.03 & 0.02 & 0.02 & 0.03 \\
\hline $\mathrm{ZrO}_{2}$ & 0.25 & 0.16 & 0.25 & 0.25 & 0.11 & 0.14 & 0. & 0.12 & 0.01 & 0.21 & 0.13 & 0.2 & 0.25 \\
\hline $\mathrm{ZnO}$ & 0 & 0 & 0 & 0 & 0 & 0 & 0 & 0 & 0 & 0 & 0 & 0 & 0 \\
\hline $\mathrm{BaO}$ & 0 & 0 & 0 & 0 & 0 & 0 & 0 & 0 & 0 & 0 & 0 & 0 & 0 \\
\hline Total & 98.63 & 98.48 & 98.69 & 98.84 & 99.1 & 98.54 & 98.73 & 98.29 & 97.73 & 98.49 & 97.48 & 97.98 & 97.19 \\
\hline$O_{-} F_{2} \mathrm{Cl}$ & 0.27 & 0.36 & 0.32 & 0.21 & & 0.2 & 0.21 & 0.26 & 0.29 & 0.58 & 0.53 & 0.58 & 0.52 \\
\hline O_F & 0.27 & 0.35 & 0.32 & 0.2 & 0.35 & 0.29 & 0.21 & 0.26 & 0.29 & 0.57 & 0.52 & 0.57 & 0.51 \\
\hline $\mathrm{O} \_\mathrm{Cl}$ & 0 & 0 & 0 & 0 & 0 & 0 & 0 & 0 & 0 & 0.01 & 0 & 0 & 0.01 \\
\hline Ctotal & 98.36 & 98.12 & 98.37 & 98.63 & 98.75 & 98.25 & 98.52 & 98.03 & 97.44 & 97.91 & 96.95 & 97.4 & 96.67 \\
\hline \multicolumn{14}{|c|}{ Fórmula estrutural calculada na base de 23 átomos de oxigênio } \\
\hline Si & 6.268 & 6.289 & 6.217 & 6.268 & 6.221 & 6.703 & 6.228 & 6.307 & 6.288 & 6.448 & 6.517 & 6.449 & 6.551 \\
\hline TAl & 1.732 & 1.711 & 1.783 & 1.732 & 1.779 & 1.297 & 1.772 & 1.693 & 1.712 & 1.552 & 1.483 & 1.551 & 1.44 \\
\hline $\mathrm{TFe}^{3+}$ & 0 & 0 & 0 & 0 & 0 & 0 & 0 & 0 & 0 & 0 & 0 & 0 & 0 \\
\hline Soma_T & 8 & 8 & 8 & 8 & 8 & 8 & 8 & 8 & 8 & 8 & 8 & 8 & 8 \\
\hline CAl & 0.171 & 0.144 & 0.096 & 0.117 & 0.112 & 0.25 & 0.062 & 0.109 & 0.133 & 0.116 & 0.094 & 0.14 & 0.093 \\
\hline $\mathrm{CCr}$ & 0 & 0 & 0 & 0 & 0 & 0 & 0 & 0 & 0 & 0 & 0 & 0 & 0 \\
\hline $\mathrm{CFe}^{3+}$ & 0.093 & 0 & 0.246 & 0.169 & 0.168 & 0 & 0.224 & 0.069 & 0.017 & 0.529 & 0.441 & 0.568 & 0.373 \\
\hline CTi & & 0.436 & 0.401 & 0.365 & 0.371 & 0.274 & 0.385 & 0.397 & 0.355 & 0.151 & 0.1 & 0.114 & 0.2 \\
\hline $\mathrm{Mg}$ & 2.195 & 2.108 & 2 & 1. & 1.952 & & 2.029 & 2.045 & 1.96 & 2.208 & 2.2 & 2.113 & 1.983 \\
\hline $\mathrm{CFe}^{2+}$ & 2.065 & 2.202 & 1.971 & 2.34 & 2.28 & & & 2.272 & 2.419 & 1.832 & 1.908 & 1.9 & 2.13 \\
\hline $\mathrm{CMn}$ & 0.108 & 0.111 & 0.106 & 0.109 & 0.117 & 0.128 & 0.111 & 0.108 & 0.116 & 0.164 & 0.174 & 0.165 & 0.218 \\
\hline Soma_C & 5 & 5 & 5 & 5 & 5 & 5 & 5 & 5 & 5 & 5 & 5 & 5 & 5 \\
\hline $\mathrm{BCa}$ & 1.774 & 1.777 & 1.707 & 1.746 & 1.771 & 2 & 1.758 & 1.758 & 1.792 & 1.625 & 1.635 & 1.636 & 1.588 \\
\hline $\mathrm{BNa}$ & 0.226 & 0.223 & 0.293 & 0.254 & 0.229 & 0 & 0.242 & 0.242 & 0.208 & 0.375 & 0.365 & 0.364 & 0.412 \\
\hline Soma_B & 2 & 2 & 2 & 2 & 2 & 2 & 2 & 2 & 2 & 2 & 2 & 2 & 2 \\
\hline $\mathrm{ANa}$ & 0.678 & 0.704 & 0.615 & 0.678 & 0.702 & 0.838 & 0.675 & 0.677 & 0.761 & 0.686 & 0.688 & 0.673 & 0.721 \\
\hline AK & 0.282 & 0.282 & 0.315 & 0.292 & 0.284 & & 0.283 & 0.286 & 0.3 & 0.293 & 0.274 & 0.306 & 0.274 \\
\hline Soma $A$ & 0.96 & 0.986 & 0.93 & 0.97 & 0.985 & 1.201 & 0.958 & 0.963 & 1.06 & 0.98 & 0.962 & 0.979 & 0.994 \\
\hline S._CAT & 15.96 & 15.986 & 15.93 & 15.97 & 15.985 & 16.201 & 15.958 & 15.963 & 16.06 & 15.98 & 15.962 & 15.979 & 15.994 \\
\hline $\mathrm{CCl}$. & 0.005 & 0.005 & 0.005 & 0.005 & 0.005 & & 0.005 & 0 & 0.003 & 0.008 & 0.005 & 0.005 & 0.00 \\
\hline$C F$ & 0.309 & 0.408 & 0.367 & 0.233 & 0.398 & & 0.237 & 0.302 & 0.335 & 0.659 & 0.607 & 0.665 & 0.599 \\
\hline & 23 & 23.034 & 23 & 23 & 23 & 23.413 & 23 & 23 & 23 & 23 & 23 & 23 & 23 \\
\hline
\end{tabular}


Tabela 14.15 - Composição química de anfibólios de Morro Conceição (\% peso)

\begin{tabular}{|c|c|c|c|c|}
\hline Amostra & RP- 259 & RP- 259 & RP-259 & $R P .259$ \\
\hline Análise & 1173 & $\{176$ & 1177 & 1180 \\
\hline Locacão & C3Gím & $\mathrm{C} 3 \mathrm{G} 3 \mathrm{~m}$ & $\mathrm{C} 2 \mathrm{G} 1 \mathrm{~m}$ & C1G1m \\
\hline Mineral & $\mathrm{Fe}-\mathrm{Pg}-\mathrm{Hb}$ & $\mathrm{Fe}-\mathrm{Pg}-\mathrm{Hb}$ & $\mathrm{Fe}-\mathrm{Pg}-\mathrm{Hb}$ & $\mathrm{Fe}-\mathrm{Pg}-\mathrm{Hb}$ \\
\hline $\mathrm{SiO}_{2}$ & 46.53 & 45.1 & 45.77 & 44.6 \\
\hline $\mathrm{TiO}_{2}$ & 1.08 & 1.73 & 1.91 & 2.02 \\
\hline $\mathrm{Al}_{2} \mathrm{O}_{3}$ & 6.39 & 5.93 & 6.44 & 6.38 \\
\hline $\mathrm{Cr}_{2} \mathrm{O}_{3}$ & 0 & 0 & 0 & 0 \\
\hline $\mathrm{FeO}$ & 15.84 & 22.29 & 16.39 & 20.56 \\
\hline $\mathrm{MnO}$ & 1.05 & 1.29 & 0.99 & 1.28 \\
\hline $\mathrm{MgO}$ & 13.31 & 9.07 & 12.17 & 9.93 \\
\hline $\mathrm{CaO}$ & 10.05 & 9.51 & 10.3 & 9.7 \\
\hline $\mathrm{Na}_{2} \mathrm{O}$ & 2.44 & 2.37 & 2.52 & 2.49 \\
\hline $\mathrm{K}_{2} \mathrm{O}$ & 0.93 & 0.97 & 1.08 & 1.06 \\
\hline$F$ & 1.6 & 1.37 & 1.75 & 1.6 \\
\hline $\mathrm{Cl}$ & 0.06 & 0.11 & 0.09 & 0.07 \\
\hline $\mathrm{ZrO}_{2}$ & 0 & 0 & 0 & 0 \\
\hline $\mathrm{ZnO}$ & 0 & 0 & 0 & 0 \\
\hline $\mathrm{BaO}$ & 0 & 0 & 0 & 0 \\
\hline Total & 99.28 & 99.74 & 99.41 & 99.69 \\
\hline $\mathrm{O}_{-} \mathrm{F}_{-} \mathrm{Cl}$ & 0.69 & 0.6 & 0.76 & 0.69 \\
\hline$O F$ & 0.67 & 0.58 & 0.74 & 0.67 \\
\hline $\mathrm{O} C \mathrm{Cl}$ & 0.01 & 0.02 & 0.02 & 0.02 \\
\hline Ctolal & 98.59 & 99.14 & 98.65 & 99 \\
\hline $\mathrm{TSi}$ & 6.808 & 6.767 & 6.802 & 6.686 \\
\hline TAl & 1.101 & 1.048 & 1.127 & 1.126 \\
\hline $\mathrm{TFe}^{3 *}$ & 0.091 & 0.185 & 0.071 & 0.187 \\
\hline Soma_T & 8 & 8 & 8 & 8 \\
\hline $\mathrm{CAl}$ & 0 & 0 & 0 & 0 \\
\hline $\mathrm{CCr}$ & 0 & 0 & 0 & 0 \\
\hline $\mathrm{CFe}^{3+}$ & 0.937 & 0.909 & 0.56 & 0.815 \\
\hline $\mathrm{CTi}$ & 0.119 & 0.195 & 0.214 & 0.228 \\
\hline $\mathrm{CMg}$ & 2.903 & 2.029 & 2.696 & 2.219 \\
\hline $\mathrm{CFe}^{2+}$ & 0.911 & 1.703 & 1.405 & 1.575 \\
\hline $\mathrm{CMn}$ & 0.13 & 0.164 & 0.125 & 0.163 \\
\hline Soma_C & 5 & 5 & 5 & 5 \\
\hline $\mathrm{BCa}$ & 1.576 & 1.529 & 1.64 & 1.558 \\
\hline $\mathrm{BNa}$ & 0.424 & 0.471 & 0.36 & 0.442 \\
\hline Soma_B & 2 & 2 & 2 & 2 \\
\hline $\mathrm{ANa}$ & 0.268 & 0.218 & 0.366 & 0.282 \\
\hline AK & 0.174 & 0.186 & 0.205 & 0.203 \\
\hline Soma_A & 0.441 & 0.404 & 0.571 & 0.485 \\
\hline Soma_Cat & 15.441 & 15.404 & 15.571 & 15.485 \\
\hline $\mathrm{CCl}$ & 0.015 & 0.028 & 0.023 & 0.018 \\
\hline $\mathrm{CF}$ & 0.74 & 0.65 & 0.822 & 0.759 \\
\hline Sum oxy & 23 & 23 & 23 & 23 \\
\hline
\end{tabular}

Obsenações: $\mathrm{Fe}^{2+1} \mathrm{Fe}^{3+}$ calculado por estequiometria. Abreviações como na tabela 14.0 
Tabela 14.16 - Composiçao química de anfibólios de Porto Conceição (\% peso)

\begin{tabular}{|c|c|c|c|c|c|c|c|c|c|c|c|c|c|}
\hline Amostra & RP.264 & RP-264 & RP-264 & RP-264 & RP-264 & RP-267 & $\mathrm{RP}-267$ & RP.267 & RP-267 & RP-267 & RP-267 & RP-267 & $\begin{array}{c}\text { RP-267 } \\
1182\end{array}$ \\
\hline nálise & 637 & 638 & 639 & 640 & 641 & 1165 & 1166 & 1169 & 1170 & 1171 & 1172 & 1181 & \\
\hline Locação & $\mathrm{C} 1 \mathrm{G} 1 \mathrm{~m}$ & $\mathrm{C} 1 \mathrm{G} 2 \mathrm{~F} n$ & $\mathrm{C} 1 \mathrm{G} 2 \mathrm{Fb}$ & C3G1n & $\mathrm{C} 3 \mathrm{G} 1 \mathrm{~b}$ & C4Gin & $C 4 G 2 n$ & $\mathrm{C} 2 \mathrm{G} 1 \mathrm{n}$ & C2Gib & C1GiFn & C1G1Fb & C3G1Fn & $\begin{array}{c}\text { C3G1Fb } \\
\text { Sit.Ed }\end{array}$ \\
\hline neral & $\begin{array}{l}\text { Si-Ed } \\
50.01\end{array}$ & $\begin{array}{l}\text { Si-Ed } \\
50.67\end{array}$ & $\begin{array}{l}\text { Si-Ed } \\
50.37\end{array}$ & $\begin{array}{l}\text { Si-Ed } \\
51.61\end{array}$ & $\begin{array}{l}\text { Si-Ed } \\
52.63\end{array}$ & $\begin{array}{l}\text { Si.Ed } \\
40.25\end{array}$ & $\begin{array}{l}\text { Si-Ed } \\
40.19\end{array}$ & $\begin{array}{l}\text { Si-Ed } \\
40.18\end{array}$ & & $\begin{array}{l}\text { Si-Ed } \\
40.54\end{array}$ & $\begin{array}{l}\text { Si-Ed } \\
40.63\end{array}$ & $\begin{array}{l}\text { Si-Ed } \\
40.15\end{array}$ & $\begin{array}{l}\text { Si-Ed } \\
40.41\end{array}$ \\
\hline $\begin{array}{l}\mathrm{TiO}_{2} \\
\end{array}$ & 1.01 & 0.76 & $\begin{array}{r}1.09 \\
1.09\end{array}$ & 0.14 & 0.18 & 2.02 & 1.96 & 3.47 & 3.32 & 3.93 & 3.36 & 3.29 & 3.19 \\
\hline${ }_{2} \mathrm{O}_{3}$ & 4.56 & 4.06 & 4.65 & 3.56 & 2.61 & 9.43 & 9.91 & & 10.51 & 10.48 & 10.55 & 10.8 & 10.32 \\
\hline$b_{3}$ & 0 & 0 & 0 & 0 & 0 & 0 & r & 0 & 0 & 0 & 0 & 0 & 0 \\
\hline 0 & 9.73 & 8.61 & 9.79 & 11.08 & 10.6 & 22.72 & 23.36 & 20.48 & 21.42 & 18.58 & 20.61 & 20.18 & 20.72 \\
\hline 10 & 0.98 & 0.86 & 0.9 & 2.24 & 2.06 & 1.29 & 1.28 & 1.14 & 1.32 & 1.06 & & & 1.27 \\
\hline & 17.62 & 17 & 17. & 17. & 17. & 6. & 6.08 & 7.45 & 6.8 & 8.4 & 7.67 & 7.62 & 73 \\
\hline & 10.76 & 10.6 & 11. & 9.78 & 10.05 & 10.09 & 10 & 10.76 & 10.59 & 10.99 & 10.83 & 10.84 & 10.86 \\
\hline 2 & 2.0 & 1. & 2. & 1 & & & 3.2 & & 2.93 & 3.1 & 3.07 & 3.07 & 3.01 \\
\hline $\mathrm{K}_{2} \mathrm{O}$ & 0.6 & 0.7 & 0.6 & 0.34 & 0.27 & & 1.5 & & 1. & 1.46 & 1.49 & 1.53 & 1.47 \\
\hline & 0 & 0 & 0 & 0 & 0 & 0.6 & 0.87 & 0.81 & 0 & 0.63 & 0.72 & 0.77 & 0.61 \\
\hline & 0 & c & 0 & 0 & 0 & 0.01 & 0.02 & 0.01 & 0.0 & 0.02 & 0.03 & 0.02 & 0.03 \\
\hline $\mathrm{O}_{2}$ & 0.02 & 0. & 0.0 & 0.02 & 0.02 & & 0 & & & & & 0 & \\
\hline & 0 & ( & 0 & 0 & 0 & & 0 & & ( & & 0 & 0 & \\
\hline 0 & 0 & 0 & 0 & 0 & 0 & ( & 0 & & 0 & & 0 & 0 & 0 \\
\hline tal & 97.42 & 95.41 & 97.81 & 97.53 & 97.36 & 97.98 & 98.45 & 99.09 & 98.98 & 99.19 & 100.01 & 99.42 & 99.19 \\
\hline $\mathrm{F}_{-} \mathrm{Cl}$ & 0 & 0 & 0 & 0 & 0 & & 0.37 & 0.34 & 0.22 & 0.27 & 0.31 & 0.33 & 0.26 \\
\hline$O F$ & 0 & c & 0 & 0 & 0 & 0.29 & 0.37 & 0.34 & 0.21 & 0.27 & 0. & 0.32 & 0.2 \\
\hline $\mathrm{Cl}$ & 0 & 0 & 0 & 0 & 0 & 0 & 0 & 0 & 0 & 0 & 0.01 & 0 & 0.01 \\
\hline tal & 97.42 & 95.41 & 97.81 & 97.53 & 97.36 & 97,69 & 98.08 & 98.75 & 98.76 & 98.92 & 99.7 & 99.09 & 98.93 \\
\hline \multicolumn{14}{|c|}{ Fórmula estrutural calculada na base de 23 átomos de oxigênio } \\
\hline $\mathrm{Si}$ & 7.115 & 7.304 & 7.183 & 7.253 & 7.395 & 6.322 & 6.293 & 6.207 & 6.186 & 6.2 & 6.204 & 6.1 & 6.235 \\
\hline 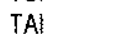 & 0.764 & 0.689 & 0.781 & & & 1.678 & 1.707 & 1.793 & 1.814 & 1.785 & 1.796 & 1.827 & 1.765 \\
\hline $\mathrm{Fe}^{3+}$ & 0.121 & 0.007 & 0.036 & 0.158 & 0.173 & 0 & 0 & & 0 & 0 & 0 & 0 & 0 \\
\hline ma_ $T$ & 8 & 8 & $B$ & 8 & 8 & 8 & 8 & & 8 & 8 & 8 & 8 & 8 \\
\hline & 0 & 0 & 0 & 0 & 0 & 0.067 & 0.121 & 0.086 & 0.098 & 0.107 & 0.101 & 0.128 & 0.111 \\
\hline & 0 & 0 & 0 & 0 & 0 & 0 & 0 & 0 & 0 & 0 & 0 & 0 & 0 \\
\hline$e^{3+}$ & 0.696 & 0.701 & 0.516 & 1.144 & 1.072 & 0.397 & 0.476 & 0.156 & 0.266 & 0 & 0.181 & 0.151 & 0.133 \\
\hline & & 0.082 & 0.117 & 0.01 & 0.019 & & & & 0.3 & 0.4 & 0.386 & 0. & 0.37 \\
\hline $\mathrm{Ag}$ & & 3.7 & & 3.574 & 3.664 & & & & & 1.92 & 1.746 & 1.747 & 1.679 \\
\hline$e^{2+}$ & 0.341 & 0.329 & 0.616 & 0 & 0 & 2.587 & 2.5 & 2.489 & & 2.382 & 2.45 & 2.444 & 2.541 \\
\hline & 0.118 & 0.105 & 0.11 & 0.267 & 0.245 & 0.172 & 0.17 & 0.149 & 0.173 & 0.138 & 0.136 & 0.15 & 0.166 \\
\hline ma_C & 5 & 5 & 5 & 5 & 5 & 5 & 5 & 5 & 5 & 5 & 5 & 5 & 5 \\
\hline $\mathrm{a}$ & 1.64 & 1.642 & 1.685 & 1.473 & & 1.698 & 1.678 & 1.781 & 1.753 & 1.805 & 1.772 & 1.786 & 1.795 \\
\hline & 0.36 & 0.358 & 0.315 & & & 0.302 & 0.322 & 0.219 & 0.247 & 0.195 & 0.228 & 0.214 & 0.205 \\
\hline$m a B$ & 2 & 2 & 2 & 1.936 & 1.908 & 2 & 2 & 2 & 2 & 2 & 2 & 2 & 2 \\
\hline & 0.217 & 0.058 & 0.26 & 0 & 0 & 0.74 & 0.665 & 0.668 & 0.631 & 0.727 & 0.681 & 0.701 & 0.696 \\
\hline & 0.116 & & & 0.061 & & & & & 0.294 & 0.2 & 0.29 & 0.3 & 0.289 \\
\hline $\mathrm{ma} A$ & 0.333 & 0.189 & 0.382 & 0.061 & 0.048 & 1.038 & & 0.963 & 0.924 & 1.012 & 0.971 & 1.001 & 0.98 \\
\hline m_. Cal & 15.333 & 15.189 & 15.382 & $\{4.997$ & 14.956 & 16.038 & 15.97 & 15.963 & 15.924 & 16.012 & 15.971 & 16.001 & \\
\hline-1. & 0 & 0 & 0 & 0 & 0 & 0.003 & 0.005 & & & & 0.008 & 0.005 & \\
\hline & 0 & 0 & 0 & 0 & 0 & 0.343 & 0.431 & 0.396 & 0.244 & 0.305 & 0.348 & 0.374 & 0.298 \\
\hline & 23 & 23 & 23 & 22.948 & 22.987 & 23 & 23 & 23 & 23 & 23.023 & 23 & 23 & \\
\hline
\end{tabular}



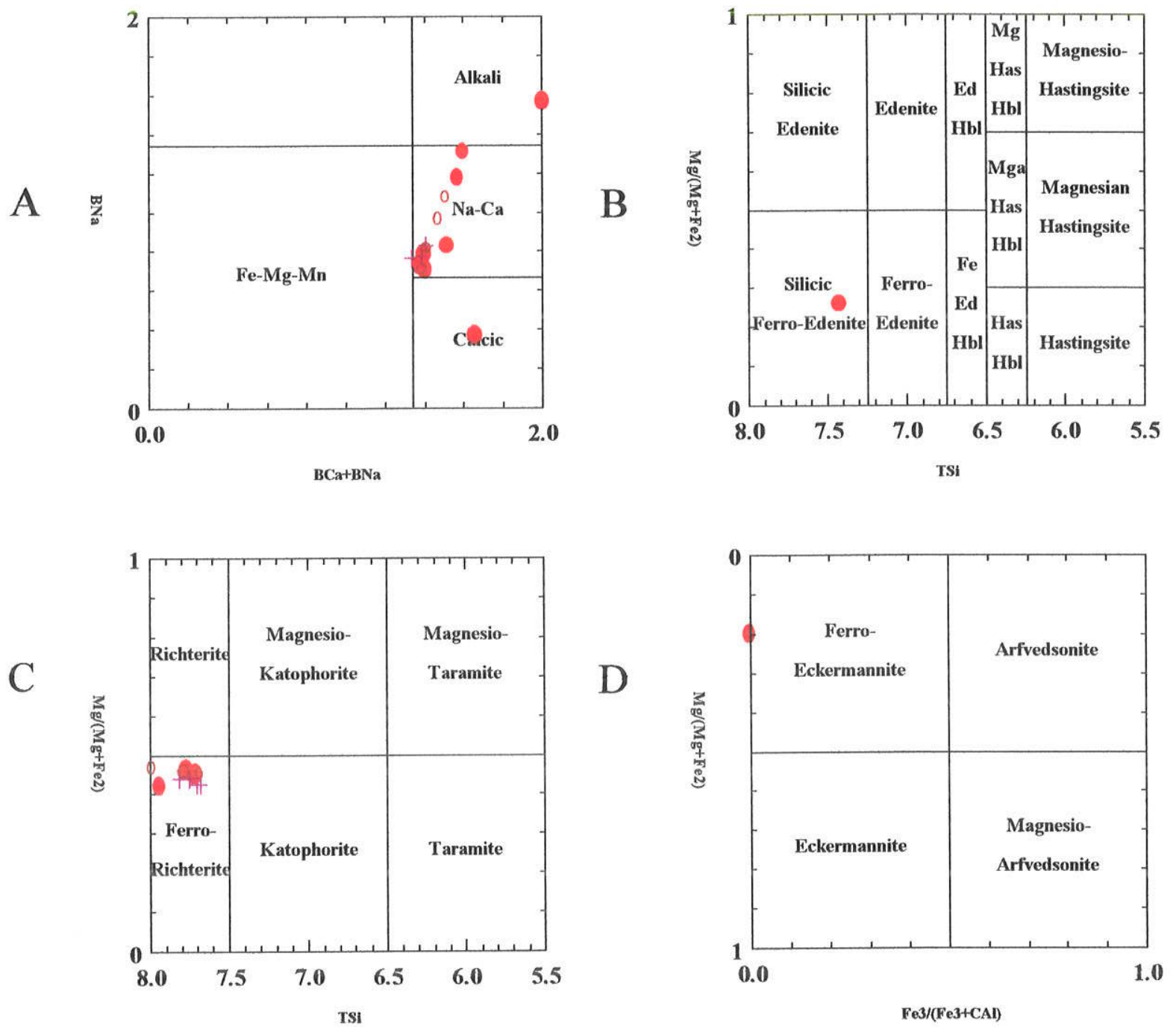

Figura 30 (A, B, C e D) Distribuição dos anfibólios das rochas de Cerro Boggiani sendo (A) todos os anfibólios, (B) anfibólios cálcicos, (C) anfibólios sódico-cálcicos e (D) anfibólios sódicos. Simbolos como na figura 40. 

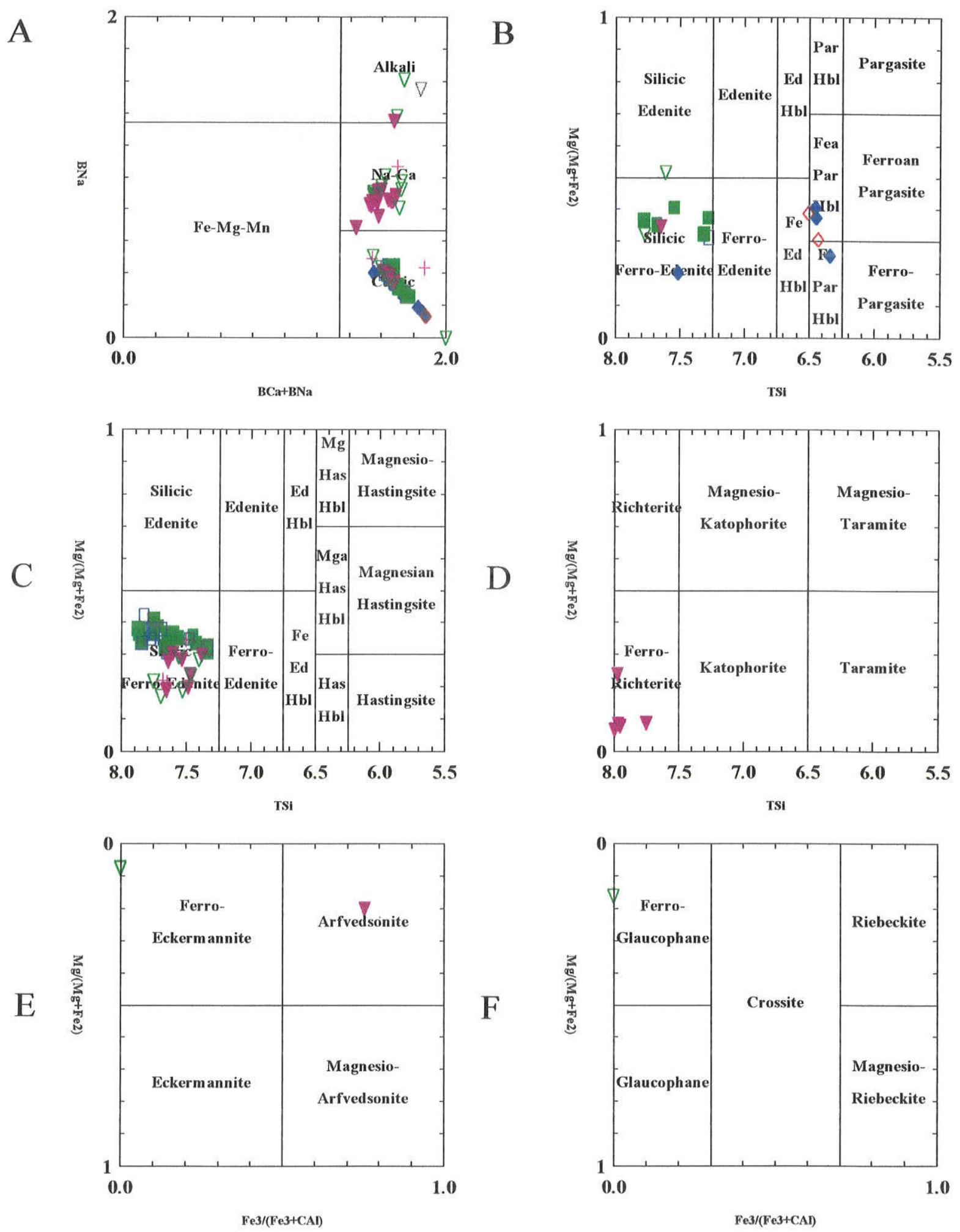

Figura 31 (A, B, C, D, E e F) Distribuição dos anfibólios das rochas do Complexo Cerro Siete Cabezas e Satélite I e II nos diagramas de classificação da IMA (Leake, 1978 e Leake et al. 1997). Símbolos como na figura 40. 

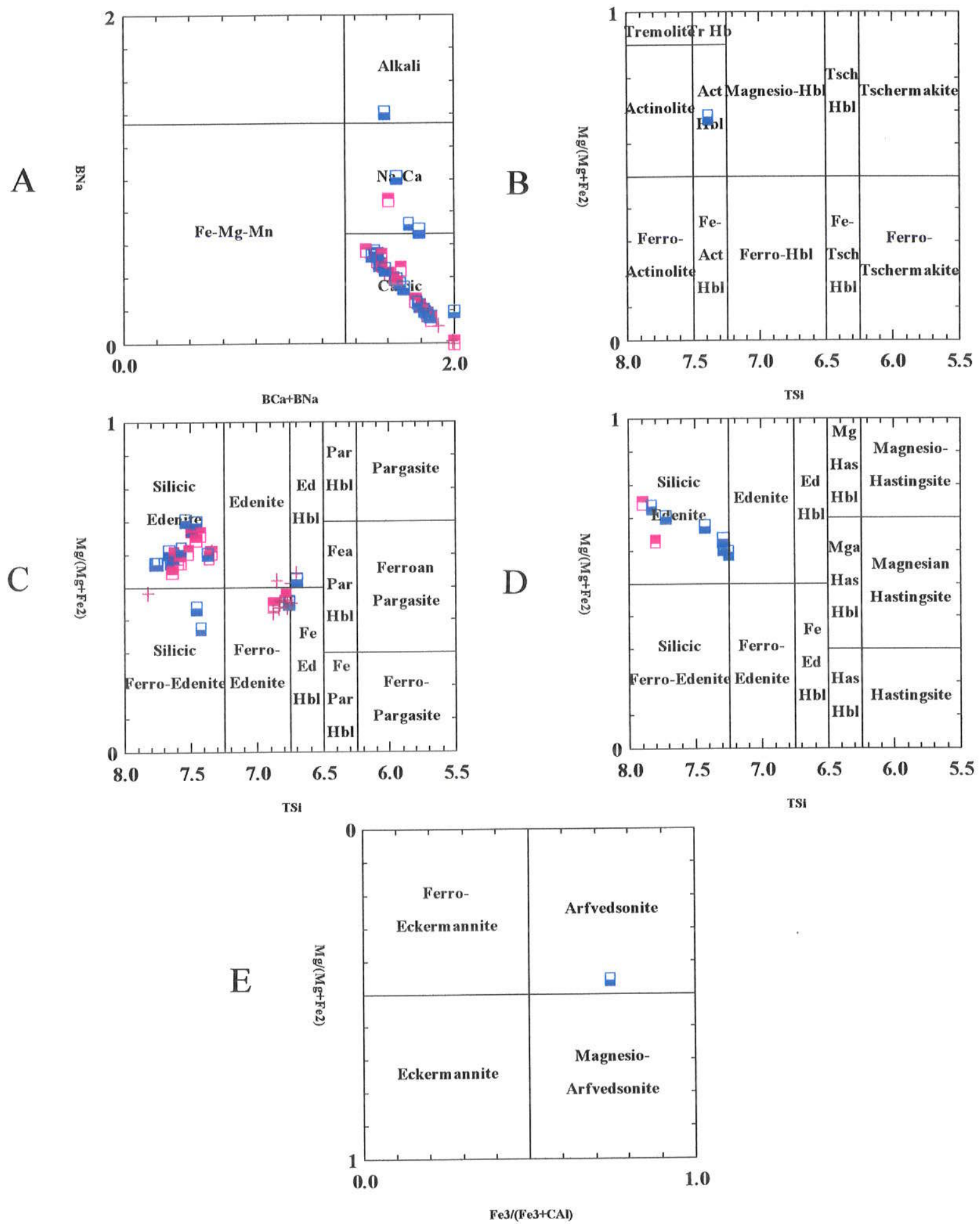

Figura 32 (A, B, C, D e E) Locação dos anfibólios das rochas do Morro Pão de Açúcar nos diagramas de classificação da IMA (Leake, 1978 e Leake et al. 1997). Símbolos como na figura 40. 

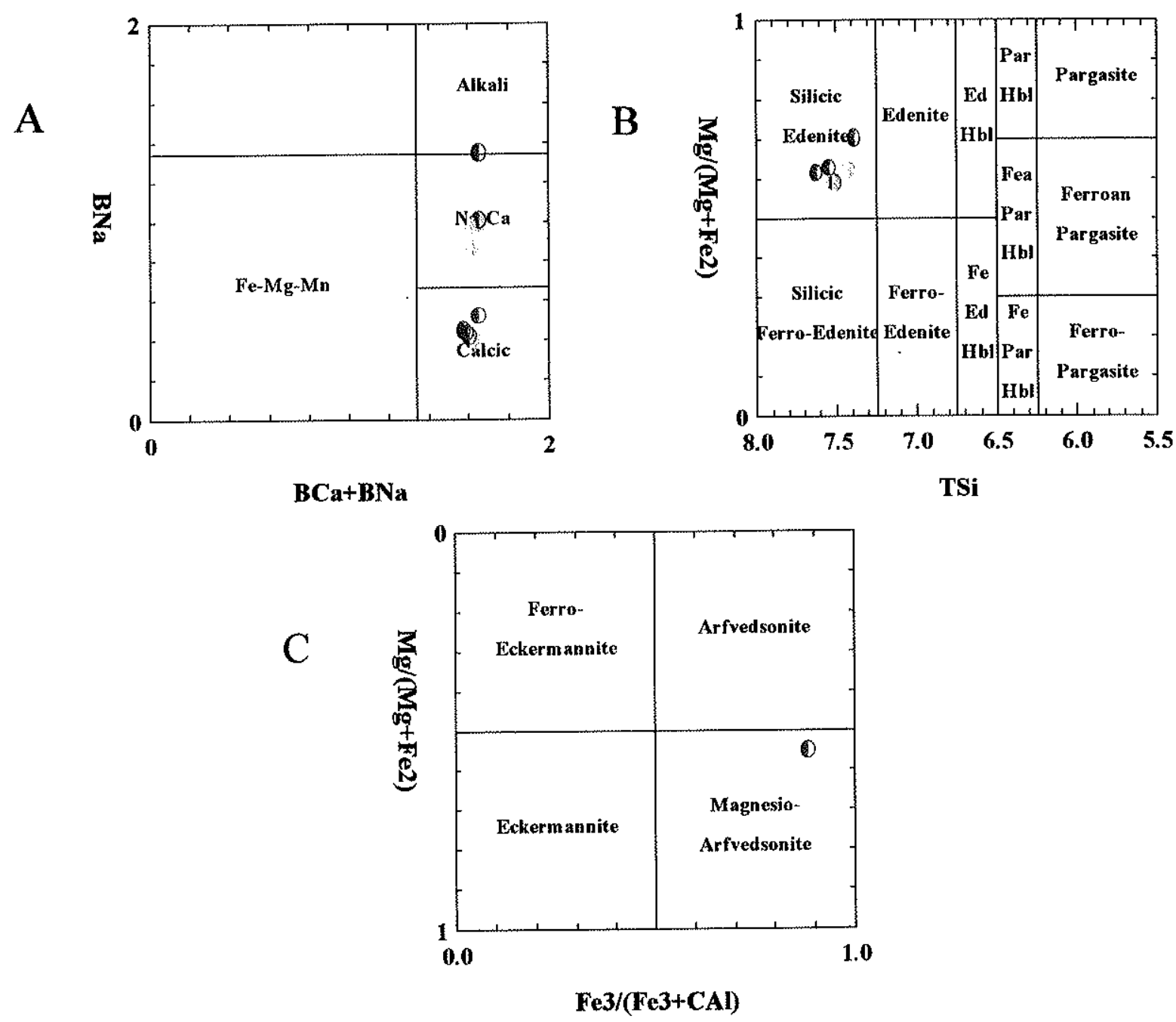

Figura 33 ( A, B e C) Locação dos anfibólios das rochas da llha Fecho dos Morros nos diagramas de classificação da IMA (Leake, 1978 e Leake et al. 1997). Símbolos como na figura 40. 
151
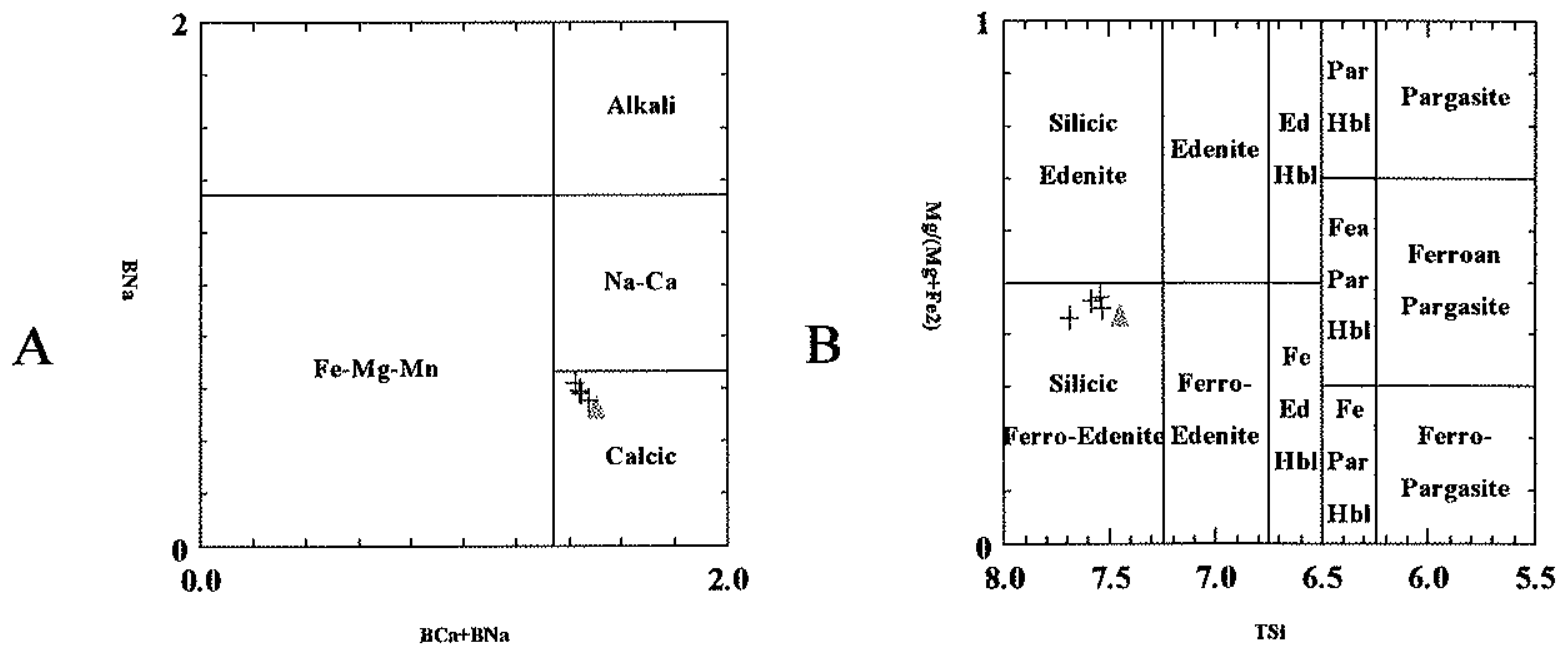

Figura 34 (A e B) Classificação dos anfibólios das rochas de Cerrito (Leake, 1978 e Leake et al. 1997). Símbolos como na figura 40.
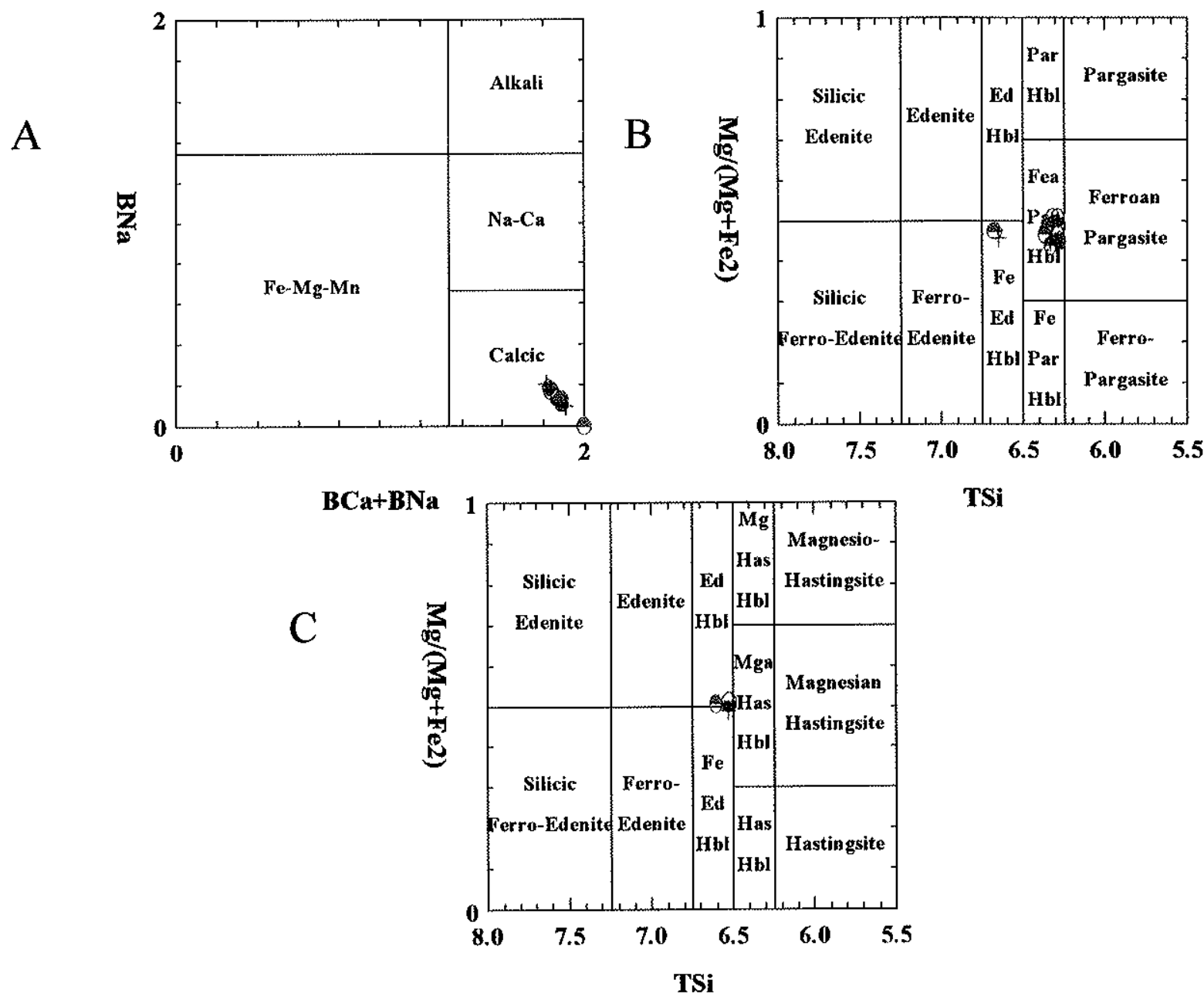

TSi

Figura 35 (A, B e C) Classificação dos anfibólios das rochas de São Pedro (Leake, 1978 e Leake et al. 1997). Símbolos como na figura 40. 

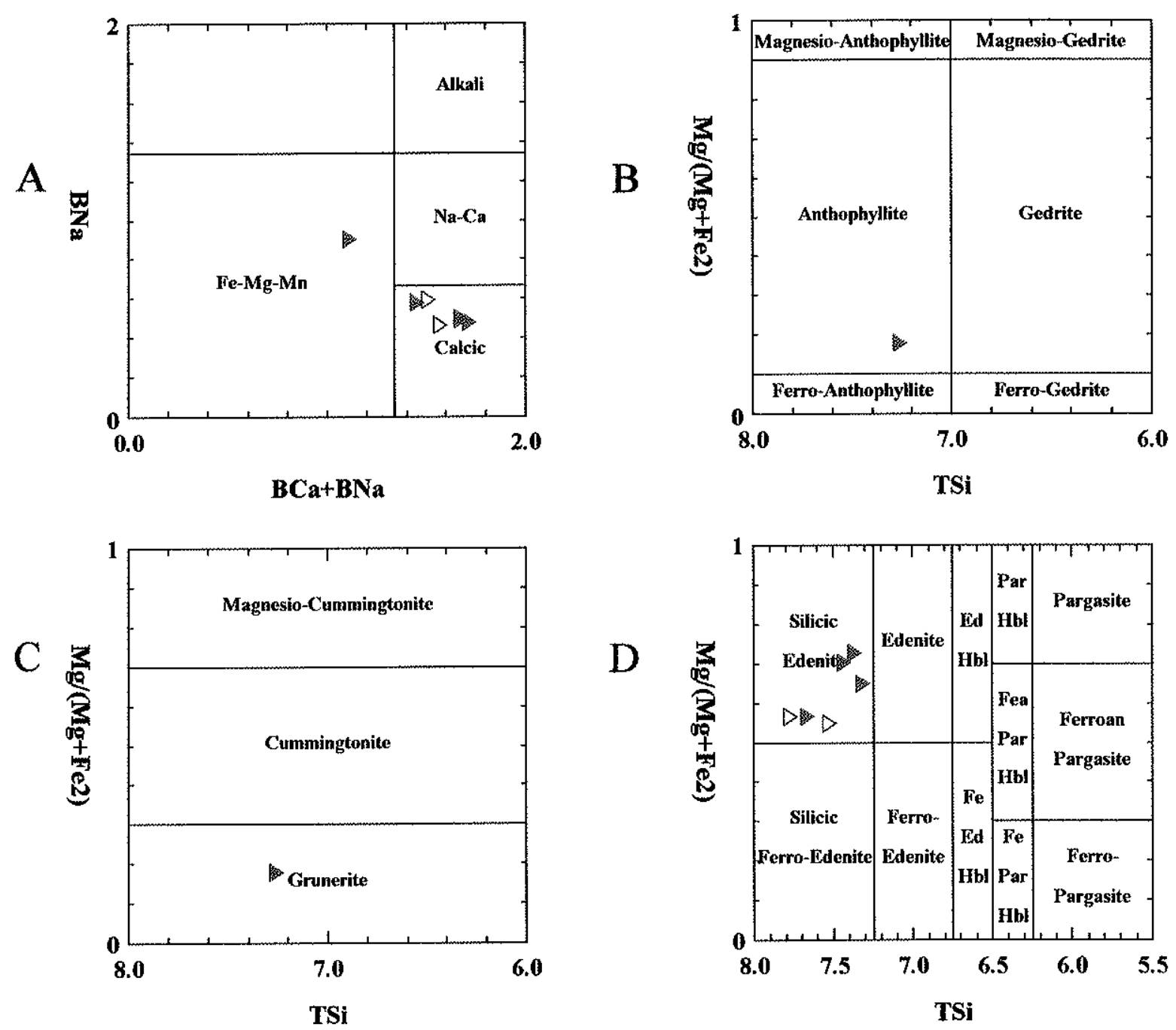

Figura 36 (A, B, C e D) Locação dos anfibólios das rochas de Cerro Pedreira nos diagramas de classificaçâo da IMA (Leake, 1978 e Leake et al 1997). Símbolos como na figura 40. 

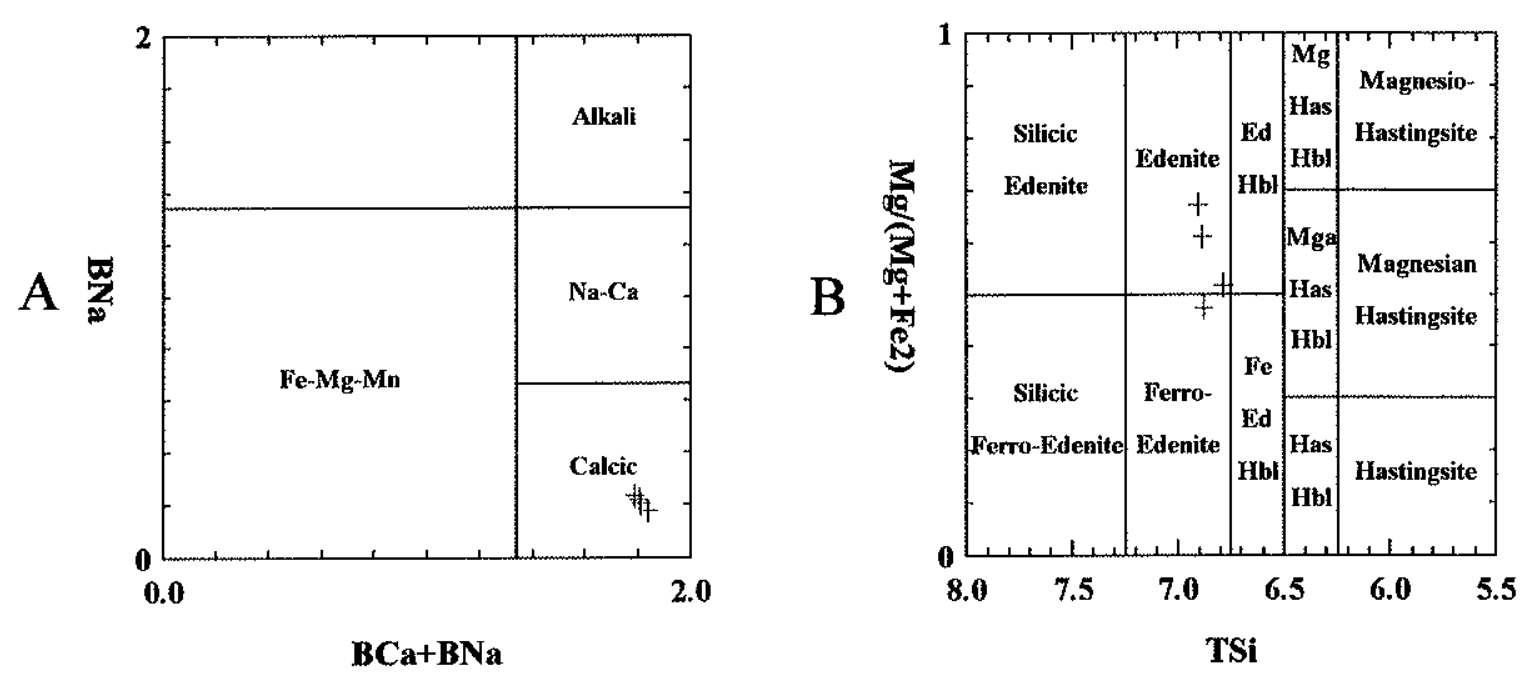

Figura 37 (A e B) Classificação dos anfibólios das rochas de Morro Conceição nos diagramas de classificação da IMA (Leake, 1978 e Leake et al. 1997). Símbolos como na figura 40

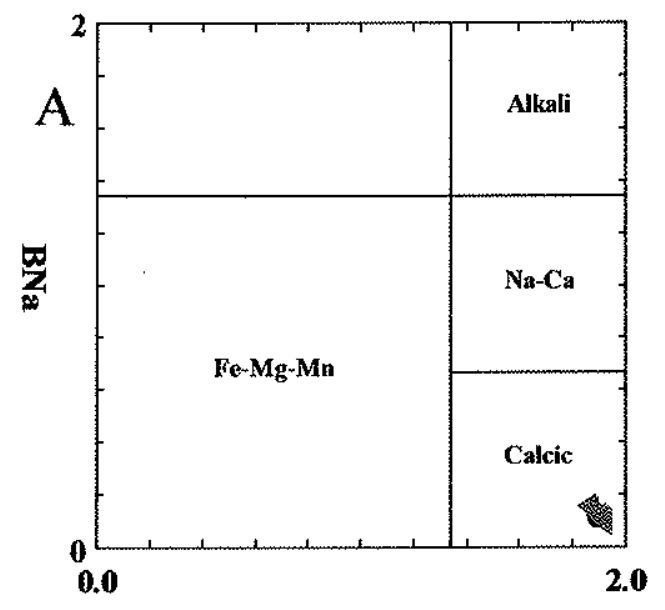

B
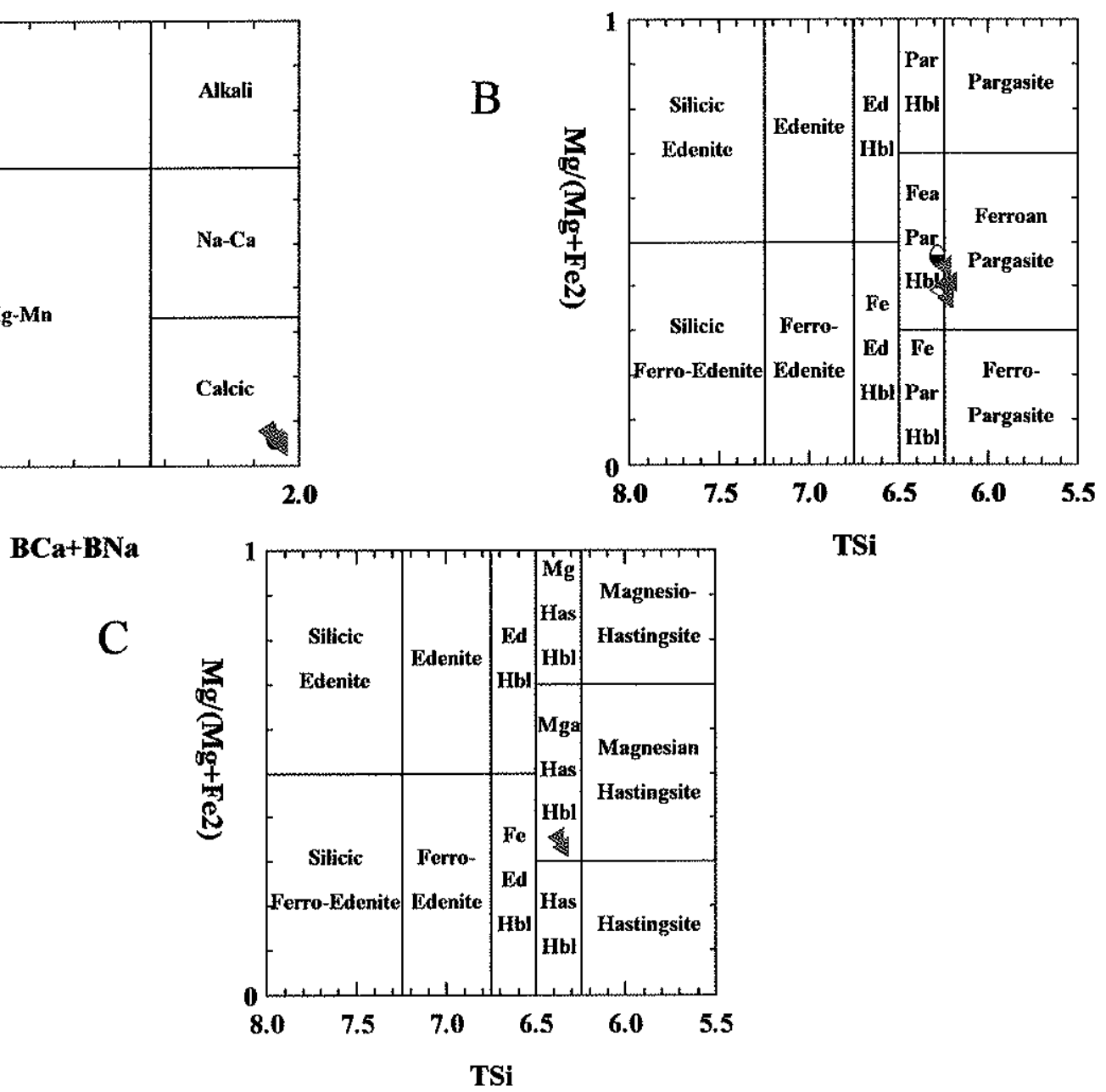

Figura 38 (A, B e C) Classificação dos anfibólios das rochas de Porto Conceição nos diagramas da IMA (Leake, 1978 e Leake et al. 1997). Símbolos como na figura 40. 

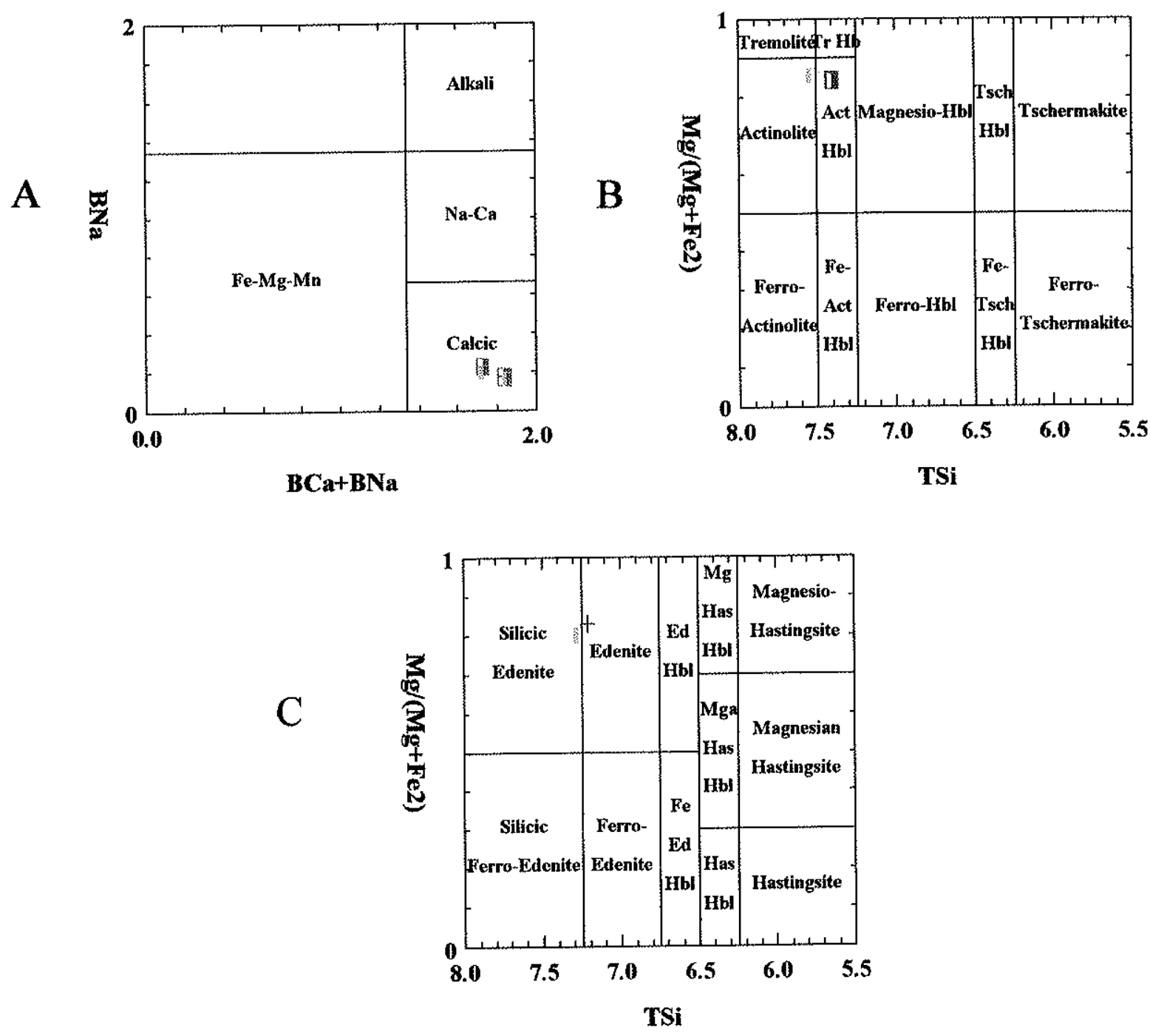

Figura 39 (A, B e C) Classificação dos anfibófios das rochas de Morro Dístante nos diagramas da IMA (Leake, 1978 e Leake et al. 1997). Símbolos como na figura 40. 

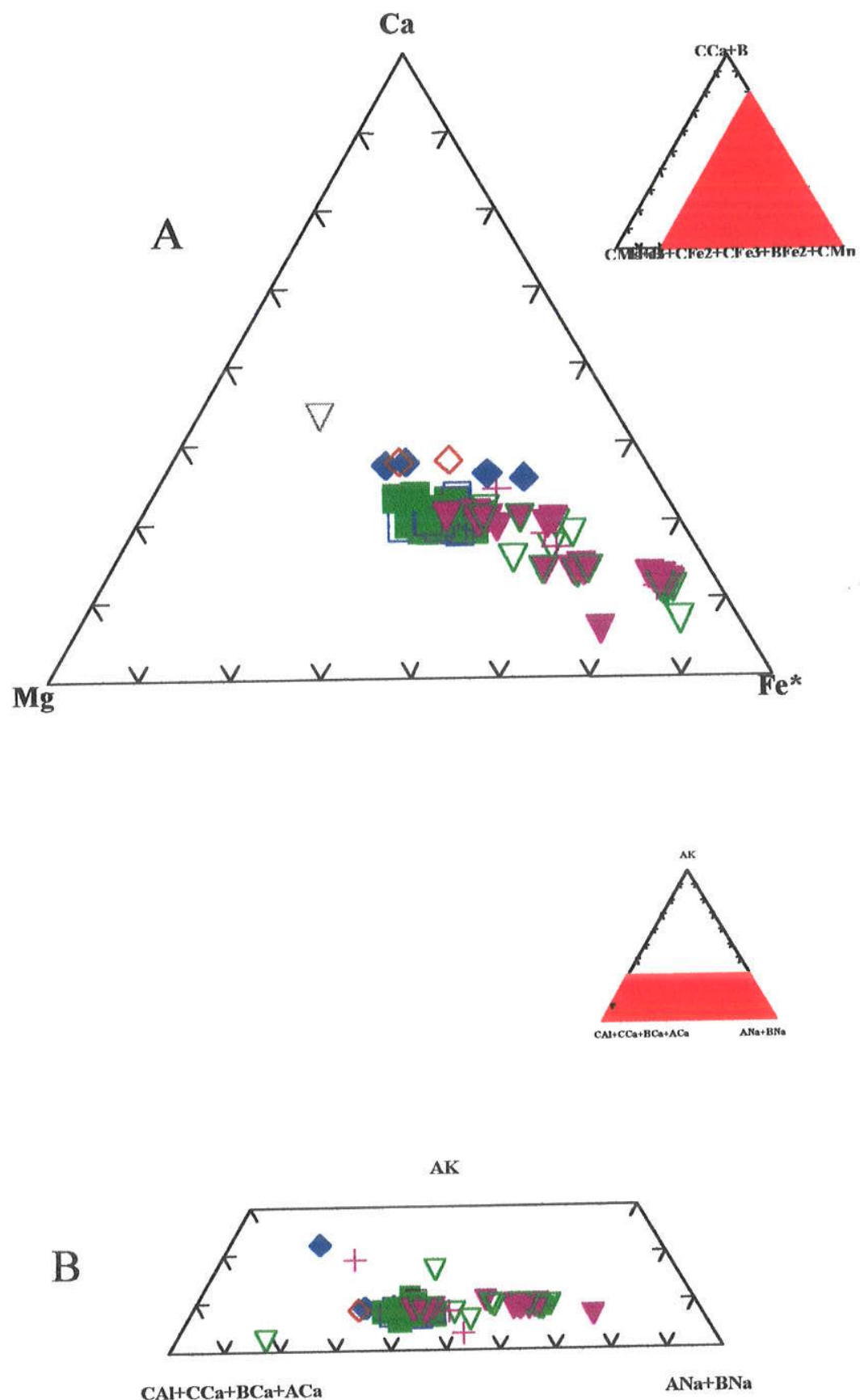

Figura 40 (A e B) Representação dos anfibólios da Província Alcalina Alto Paraguai nos diagramas (A), Mg-Ca-Fe* $\left(\mathrm{Fe}^{*}=\mathrm{Fe}^{2+}+\mathrm{Fe}^{3+}+\mathrm{Mn}\right)$ e $(\mathrm{B})$, Ca-K-Na. Símbolos: Cerro Boggiani (círculos cheios= núcleos de fenocristais, círculos vazios= bordas); Satélite I (triângulos, cheios=núcleos e vazios= bordas); Satélite II (quadrados, cheios $=$ núcleos e vazios $=$ bordas); Cerro Siete Cabezas (losagos, cheios= núcleos e vazios= bordas); Pão de Acúcar (quadrados com metade inferior cheio= núcleo e metade superior cheios= borda); llha Fecho dos Morros (círculos com metade ocidental cheio $=$ núcleo e metade oriental cheio $=$ borda); Cerro Pedreira (triângulo com ponta voltada para a direita $($ cheio $=$ núcleo e vazio= borda); São Pedro (círculos com metade inferior cheio= núcleo e metade superior= borda); Morro Distante (quadrados com metade oriental cheia= núcleo e metade ocidental cheia= borda); Porto Conceição (triângulo com ponta voltada para a esquerda, cheio $=$ núcleo e vazio= borda) e Cerrito (triângulo com ponta voltada para cima, cheio= núcleo e vazio= borda). 


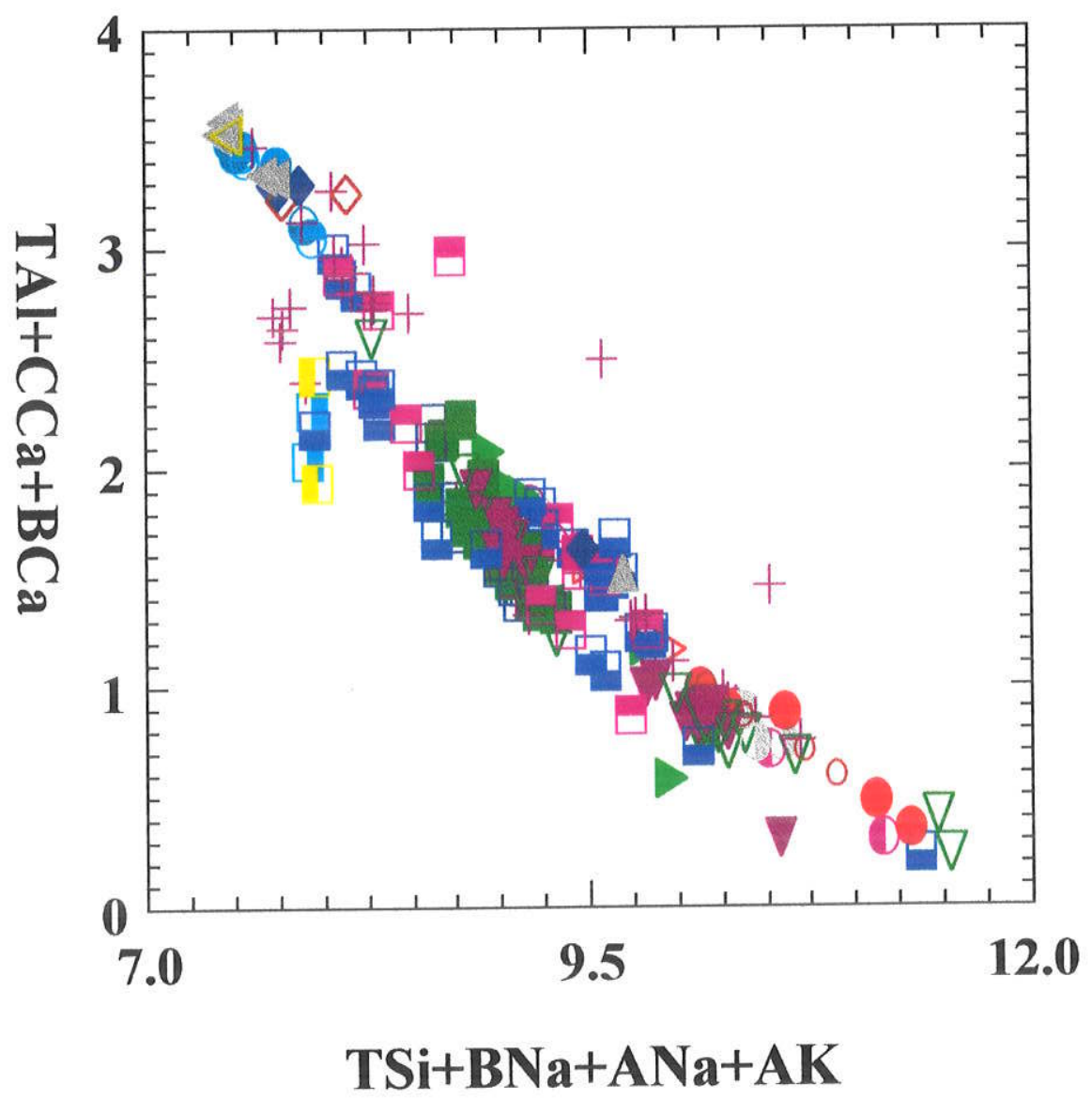

Figura 41 - Evolução composicional dos anfibólios das rochas da Província Alcalina Alto Paraguai no diagrama $\mathrm{TAl}+\mathrm{CCa}+\mathrm{BCa}$ versus $\mathrm{TSi}+\mathrm{BNa}+\mathrm{ANa}+\mathrm{AK}$. Símbolos como na figura 40. 
V.4-Piroxênios

Os piroxênios possuem uma fórmula estrutural padrão que pode ser definida pela seguinte expressão: $\mathrm{M}_{2} \mathrm{M}_{1} \mathrm{~T}_{2} \mathrm{O}_{6}$ onde $\mathrm{M} 2$ corresponde aos cátions em coordenação octaédrica irregular, M1 aos cátions em coordenação octaédrica regular e T aos cátios em coordenação tetraédrica.

Os piroxênios dos corpos alcalinos da Província Alto Paraguai representam a fase máfica mais importante em termos quantitativos. Excetuando-se dos quartzo sienitos encontrados no Morro Pão de Açúcar, dos sienitos nefelínicos de Cerrito e Porto Conceição e de sienitos alcalinos de Morro Conceição, todas as amostras analisadas de outros corpos são portadoras desse mineral.

A forma de ocorrência mais comum dos piroxênios é como fenocristais, microfenocristais, grãos menores pertencentes à matriz ou ainda em pequenos cristais inclusos quase sempre em feldspatos. Opticamente, apresentam-se em grãos incolores a verde-claros, com bordas comumente mais escuras, feição quase sempre indicativa de zoneamento químico, correspondendo geralmente a um enriquecimento em $\mathrm{Si}$ e $\mathrm{Al}$ e perda de Ti. Ocorrem como cristais isolados e/ou agregados granulares, por vezes interpenetrados e ocasionalmente apresentando zoneamento setorial. Associam-se às fases máficas importantes como anfibólios, micas e também aos minerais opacos. Freqüentemente apresentam texturas de processos de alteração pós-magmáticos, tendo como principais produtos minerais de anfibólios.

O tratamento analítico estabelecido aos piroxênios obedece estritamente ao recomendado pela International Mineralogical Association-IMA (Morimoto, 1989). Adicionalmente, optou-se pela aplicação de diagramas binários de variação composicional, onde são confrontados os diversos átomos por unidade de fórmula (a.f.u.) e o índice de diferenciação (mg\#) determinado pela razão $\mathrm{MgO} /(\mathrm{MgO}+$ FeO), com o objetivo específico de verificação das relações entre os cátions e as posições estruturais e a diferenciação. Foram utilizados ainda, diagramas ternários 
$\mathrm{Na}-\mathrm{Mg}-\mathrm{Fe}^{*}$ onde $\mathrm{Fe}^{*}=\mathrm{Fe}^{2+}+\left(\mathrm{Fe}^{3+}-\mathrm{Na}\right)$, para confirmação de possiveis tendências da evolução composicional desses minerais. 


\section{V.4.1 - Cerro Boggiani}

No corpo alcalino de Cerro Boggiani, foram distinguidos em termos petrográficos e geoquímicos, dois litotipos principais: sienitos nefelínicos e fonolitos peralcalinos. Os resultados analíticos dos piroxênios dessas rochas incluindo fórmula estrutural calculada na base de seis átomos de oxigênio e demais recálculos dos componentes moleculares executados pelo programa MINPET 2.0 (Richard, 1995) podem ser visualisados nas tabelas 15.0 a 15.7.

Algumas análises mostram teores médios de $\mathrm{Na}_{2} \mathrm{O}$ de $8,5 \%$ e máximos de até $13,8 \%$ enquanto que os valores de $\mathrm{TiO}_{2}$ raramente atingem $1,5 \%$. Do centro para as bordas dos grãos, observa-se geralmente um empobrecimento em $\mathrm{TiO}_{2} \mathrm{e}$ um relativo enriquecimento em $\mathrm{Al}_{2} \mathrm{O}_{3}$ e $\mathrm{SiO}_{2}$, correspondendo provavelmente à variação de coloração visualisada com instrumental óptico.

No diagrama Q-J da figura 42 os piroxênios de ambos os litotipos encontrados em Cerro Boggiani classificam-se indistintamente como cálcicosódicos e sódicos, coincidindo respectivamente com os domínios da egirina-augita e egirina do diagrama WEF-Jd-Ae (Figura 43). Segundo Velázquez (1996) esses fonolitos peralcalinos mostram maiores indices agpaíticos do que os sienitos nefelínicos, caracterizando rochas mais evoluídas.

O sítio tetraédrico dos piroxênios investigados estão quase totalmente ocupados por Si (Figura 44-A), restando ao Al, muito pouco, quantitativamente, desta posição (Figura 44-B).

As posições estruturais octaédricas regulares (M1) estão ocupadas preferencialmente por $\mathrm{Al}, \mathrm{Fe}^{3+}$ e Ti, observando-se empobrecimento em $\mathrm{Fe}^{3+}$ e Ti e enriquecimento em $\mathrm{Fe}^{2+}$ (Figuras 44-C, D, E e F), enquanto que os sítios octaédricos irregulares (M2) estão preenchidos por $\mathrm{Na}, \mathrm{Mn}$ e $\mathrm{Ca}$, caracterizando para o índice de diferenciação, correlação negativa para o $\mathrm{Na}$ e positivas para o $\mathrm{Mn}$ e Ca (Figuras 45-A, B, C e D). 


\begin{tabular}{|c|c|c|c|c|c|c|c|c|c|c|c|c|c|c|}
\hline Amostras & RP-29 & RP-29 & $R P-29$ & RP-29 & RP-29 & $\mathrm{RP}-29$ & RP-29 & RP-30 & RP-30 & RP-30 & RP-30 & RP-30 & RP-30 & RP-30 \\
\hline Análises & 62 & 63 & 64 & 65 & 66 & 67 & 68 & 227 & 228 & 229 & 230 & 231 & 232 & 233 \\
\hline Locação & C1G1b & C1G2n & $\mathrm{C} 1 \mathrm{G} 2 \mathrm{~m}$ & C4G1n & $\mathrm{C} 4 \mathrm{G} 1 \mathrm{~b}$ & C6G1n & C6G1b & $\mathrm{C} 1 \mathrm{G} 1 \mathrm{n}$ & C1G1b & C1G2n & $\mathrm{C} 1 \mathrm{G} 2 \mathrm{~b}$ & C4Gin & C4G1b & $C 4 G 2 n$ \\
\hline Minera! & $P x$ & Px & Px & Px & Px & $\mathrm{Px}$ & Px & Px & $\mathrm{Px}$ & Px & Px & Px & Px & $P x$ \\
\hline $\mathrm{SiO}_{2}$ & 51.386 & 51.519 & 51.55 & 51.928 & 51.579 & 51.805 & 51.828 & 52.69 & 50.78 & 52.75 & 52.65 & 52.1 & 53.09 & 52.63 \\
\hline $\mathrm{THO}_{2}$ & 1.05 & 0.628 & 1.088 & 0.762 & 1.811 & 1.412 & 1.137 & 2.08 & 1 & 1.6 & 1.18 & $\{.47$ & 0.91 & 1.53 \\
\hline $\mathrm{Al}_{2} \mathrm{O}_{3}$ & 0.961 & 1.019 & 0.951 & 0.731 & 0.858 & 0.953 & 0.904 & 1.04 & 2.41 & 0.97 & 0.91 & 1.62 & 1.03 & 0.9 \\
\hline $\mathrm{FeO}$ & 21.283 & 22.314 & 21.403 & 21.963 & 21.851 & 20.873 & 20.216 & 25.69 & 25.96 & 27.3 & 26.82 & 25.96 & 27.22 & 26.31 \\
\hline $\mathrm{Cr}_{2} \mathrm{O}_{3}$ & 0 & 0 & 0 & 0 & 0 & 0 & 0 & 0 & 0 & 0 & 0 & 0 & 0 & 0 \\
\hline MnO & 1.556 & 1.578 & 1.636 & 1.307 & 1.799 & 1.779 & 1.577 & 0.64 & 0.74 & 0.47 & 0.76 & 1.03 & 0.79 & 0.89 \\
\hline $\mathrm{NiO}$ & 0 & 0 & 0 & 0 & 0 & 0 & 0 & 0 & 0 & 0 & 0 & 0 & 0 & 0 \\
\hline $\mathrm{MgO}$ & 3.584 & 3.023 & 3.273 & 3.321 & 2.49 & 3.207 & 3.612 & 1.09 & 0.79 & 0.55 & 0.96 & 1.06 & 1.16 & 1.25 \\
\hline $\mathrm{CaO}$ & 10.64 & 9.952 & 10.053 & 10.277 & 9.485 & 10.521 & 10.347 & 3.89 & 3.94 & 2.85 & 3.19 & 3.22 & 2.31 & 5.39 \\
\hline $\mathrm{Na}_{2} \mathrm{O}$ & 7.35 & 7.816 & 7.85 & 7.644 & 8.153 & 7.632 & 7.801 & 11.71 & 10.57 & 12.39 & 12.2 & 11.83 & 12.51 & 10.96 \\
\hline $\mathrm{K}_{2} \mathrm{O}$ & 0.008 & 0.012 & 0.009 & 0 & 0 & 0 & 0 & 0.01 & 0.21 & 0.02 & 0.02 & 0.01 & 0 & 0 \\
\hline Zno & 0.11 & 0.08 & 0.045 & 0.072 & 0.084 & 0.053 & 0.116 & 0 & 0.03 & 0.06 & 0.07 & 0.1 & 0.02 & 0 \\
\hline $\mathrm{ZrO}_{3}$ & 0.271 & 0.522 & 0.279 & 0.113 & 0.125 & 0.229 & 0.276 & 0.47 & 0.74 & 0.57 & 0.53 & 0.9 & 0.96 & 0.47 \\
\hline Total & 97.93 & 97.94 & 97.86 & 98.01 & 98.11 & 98.24 & 97.54 & 98.84 & 96.43 & 98.96 & 98.76 & 98.4 & 99.04 & 99.86 \\
\hline \multicolumn{15}{|c|}{ Formula estrutural calculada na base de 6 átomos de oxigênio } \\
\hline $\mathrm{TSi}$ & 1.987 & 1.991 & 1.989 & 2.005 & 1.995 & 1.996 & 2.001 & 1.988 & 1.975 & 1.986 & 1.983 & 1.972 & 1.987 & 1.977 \\
\hline TAl & 0.013 & 0.009 & 0.011 & 0 & 0.005 & 0.004 & 0 & 0.012 & 0.025 & 0.014 & 0.017 & 0.028 & 0.013 & 0.023 \\
\hline $\mathrm{TFe}^{3+}$ & 0 & 0 & 0 & 0 & 0 & 0 & 0 & 0 & 0 & 0 & 0 & 0 & 0 & 0 \\
\hline M1Al & 0.031 & 0.037 & 0.032 & 0.033 & 0.034 & 0.04 & 0.041 & 0.034 & 0.085 & 0.029 & 0.023 & 0.044 & 0.032 & 0.017 \\
\hline M1Ti & 0.031 & 0.018 & 0.032 & 0.022 & 0.053 & 0.041 & 0.033 & 0.059 & 0.029 & 0.045 & 0.033 & 0.042 & 0.026 & 0.043 \\
\hline $\mathrm{M} 1 \mathrm{Fe}^{3+}$ & 0.472 & 0.522 & 0.503 & 0.485 & 0.477 & 0.452 & 0.474 & 0.717 & 0.689 & 0.8 & 0.819 & 0.769 & 0.837 & 0.718 \\
\hline $\mathrm{M} 1 \mathrm{Fe}^{2+}$ & 0.216 & 0.199 & 0.188 & 0.224 & 0.229 & 0.22 & 0.179 & 0.094 & 0.151 & 0.06 & 0.026 & 0.053 & 0.015 & 0.109 \\
\hline $\mathrm{A1Cr}$ & 0 & 0 & 0 & 0 & 0 & 0 & 0 & 0 & 0 & 0 & 0 & 0 & 0 & 0 \\
\hline M1Mg & 0.207 & 0.174 & 0.188 & 0.191 & 0.144 & 0.184 & 0.208 & 0.061 & 0.046 & 0.031 & 0.054 & 0.06 & 0.065 & 0.07 \\
\hline M1Ni & 0 & 0 & 0 & 0 & 0 & 0 & 0 & 0 & 0 & 0 & 0 & 0 & 0 & 0 \\
\hline $\mathrm{M} 2 \mathrm{Mg}$ & 0 & 0 & 0 & 0 & 0 & 0 & 0 & 0 & 0 & 0 & 0 & 0 & 0 & 0 \\
\hline $\mathrm{M} 2 \mathrm{Fe}^{2+}$ & 0 & 0 & 0 & 0 & 0 & 0 & 0 & 0 & 0.004 & 0 & 0 & 0 & 0 & 0 \\
\hline M2Mn & 0.051 & 0.052 & 0.053 & 0.043 & 0.059 & 0.058 & 0.052 & 0.02 & 0.024 & 0.015 & 0.024 & 0.033 & 0.025 & 0.028 \\
\hline $\mathrm{M} 2 \mathrm{Ca}$ & 0.441 & 0.412 & 0.416 & 0.425 & 0.393 & 0.434 & 0.428 & 0.157 & 0.164 & 0.115 & 0.129 & 0.131 & 0.093 & 0.217 \\
\hline $\mathrm{M} 2 \mathrm{Na}$ & 0.551 & 0.586 & 0.587 & 0.572 & 0.611 & 0.57 & 0.584 & 0.857 & 0.797 & 0.904 & 0.891 & 0.868 & 0.908 & 0.798 \\
\hline $\mathrm{M} 2 \mathrm{~K}$ & 0 & 0.001 & 0 & 0 & 0 & 0 & 0 & 0 & 0.01 & 0.001 & 0.001 & 0 & 0 & 0 \\
\hline Som_cat & 4 & 3.999 & 4 & 4 & 4 & 4 & 4 & 4 & 3.99 & 3.999 & 3.999 & 4 & 4 & 4 \\
\hline $\mathrm{Ca}$ & 48.192 & 49.242 & 49.169 & 48.167 & 47.651 & 48.435 & 49.416 & 47.249 & 42.154 & 52.133 & 55.324 & 47.202 & 47.017 & 51.192 \\
\hline $\mathrm{Mg}$ & 22.587 & 20.812 & 22.273 & 21.657 & 17,405 & 20.542 & 24.002 & 18.421 & 11.76 & 13.999 & 23.165 & 21.62 & 32.851 & 16.519 \\
\hline $\mathrm{Fe}^{2+}-\mathrm{Mn}$ & 29.222 & 29.946 & 28.558 & 30.176 & 34.943 & 34.023 & 26.582 & 34.33 & 46.085 & 33.868 & 21.511 & 31.177 & 20.133 & 32.289 \\
\hline Jd1 & 2.194 & 2.689 & 2.354 & 2.354 & 2.452 & 2.804 & 2.939 & 2.923 & 7.241 & 2.603 & 2.106 & 3.978 & 2.988 & 1.404 \\
\hline Ae1 & 36.773 & 40.059 & 40.251 & 38.171 & 41.94 & 37.668 & 38.818 & 70.368 & 61.624 & 78.897 & 78.952 & 74.12 & 81.086 & 65.47 \\
\hline CFTS1 & 0 & 0 & 0 & 0 & 0 & 0 & 0 & 0 & 0 & 0 & 0 & 0 & 0 & 0 \\
\hline CTTS\} & 0.898 & 0.692 & 0.778 & 0 & 0.386 & 0.266 & 0 & 1.028 & 2.172 & 1.268 & 1.562 & 2.514 & 1.217 & 1.931 \\
\hline CATS1 & 0 & 0 & 0 & 0 & 0 & 0 & 0 & 0 & 0 & 0 & 0 & 0 & 0 & 0 \\
\hline Wol & 30.25 & 29.354 & 29.348 & 30.105 & 28.151 & 30.563 & 30.604 & 12.418 & 11.829 & 9.08 & 10.136 & 9.225 & 7.362 & 16.241 \\
\hline En1 & 14.598 & 12.699 & 13.647 & 13.536 & 10.424 & 13.075 & 14.865 & 5.242 & 3.906 & 2.779 & 4.899 & 5.377 & 5.994 & 5.864 \\
\hline Fs1 & 15.286 & 14.506 & 13.622 & 15.834 & 16.648 & $\uparrow 5.625$ & 12.775 & 8.021 & 13.228 & 5.373 & 2.345 & 4.785 & 1.354 & 9.09 \\
\hline$Q$ & 0.864 & 0.785 & 0.792 & 0.84 & 0.766 & 0.839 & 0.815 & 0.312 & 0.365 & 0.206 & 0.208 & 0.244 & 0.172 & 0.395 \\
\hline$\sqrt{ }$ & 1.102 & 1.171 & 1.175 & 1.144 & 1.223 & 1.14 & 1.168 & 1.713 & 1.594 & 1.809 & 1.782 & 1.736 & 1.816 & 1.597 \\
\hline Wor & 31,79 & 30.32 & 30.831 & 31,073 & 30.181 & 32.192 & 31.936 & 14.982 & 15.22 & 11.267 & 12.241 & 12.494 & 8.955 & 19 \\
\hline En1 & 14.899 & 12.815 & 13.967 & 13.971 & 11.024 & 13.653 & 15.512 & 5.841 & 4.246 & 3.025 & 5.125 & 5.723 & 6.257 & 6.131 \\
\hline Fs1 & $53.3\}$ & 56.865 & 55.202 & 54.956 & 58.795 & 54.155 & 52.552 & 79.177 & 80.534 & 85.708 & 82.634 & 81.783 & 84.788 & 74.87 \\
\hline WEF & 45.353 & 41.67 & 41.847 & 43.54 & 40.282 & 44.02 & 42.58 & 16.265 & 19.634 & 10.866 & 11.55 & 13.742 & 9.789 & 20.974 \\
\hline Jdt & 3.374 & 3.848 & 3.529 & 3.617 & 3.945 & 4.495 & 4.581 & 3.812 & 8.815 & 3.111 & 2.434 & 4.696 & 3.347 & 1.802 \\
\hline Ae1 & 51.273 & 54,482 & 54.624 & 52.843 & 55.774 & 51.485 & 52.839 & 79.923 & 71.551 & 86.024 & 86.017 & 81.562 & 86.865 & 77.223 \\
\hline
\end{tabular}

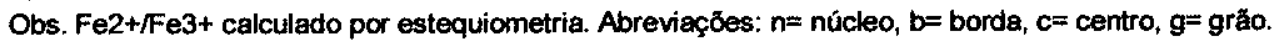


Tabela 15.1 - Composição química de piroxênios de Cerro Boggiani (\% peso)

\begin{tabular}{|c|c|c|c|c|c|c|c|c|c|c|c|c|c|c|}
\hline $\begin{array}{l}\text { Amostras } \\
\text { Analises }\end{array}$ & $\begin{array}{c}\text { RP-30 } \\
234\end{array}$ & $\begin{array}{c}\text { RP-30 } \\
235\end{array}$ & $\begin{array}{c}\text { RP-30 } \\
236\end{array}$ & $\begin{array}{c}\text { RP-30 } \\
237\end{array}$ & $\begin{array}{c}\text { RP-30 } \\
238\end{array}$ & $\begin{array}{c}\text { RP-30 } \\
239\end{array}$ & $\begin{array}{c}\mathrm{RP}-30 \\
246\end{array}$ & $\begin{array}{c}\text { RP-30 } \\
247\end{array}$ & $\begin{array}{c}\text { RP-30 } \\
248\end{array}$ & $\begin{array}{c}\text { RP.30 } \\
249\end{array}$ & $\begin{array}{c}\text { RP-30 } \\
250\end{array}$ & $\begin{array}{c}\text { RP-30 } \\
251\end{array}$ & $\begin{array}{c}\text { RP-30 } \\
252\end{array}$ & $\begin{array}{c}\text { RP-30 } \\
253\end{array}$ \\
\hline Locacãa & C5G1n & C5G1b & C5G2n & C5G3n & C5G3b & C6Gin & C1Gin & C1G2n & $\mathrm{C} 1 \mathrm{G} 2 \mathrm{~b}$ & C1G3n & C2G1n & $\mathrm{C} 2 \mathrm{G} 1 \mathrm{~b}$ & C3G1n & C3G1b \\
\hline Mineral & $P_{x}$ & $P x$ & $P x$ & $P x$ & $P x$ & $P x$ & $\mathrm{Px}$ & $P x$ & $P x$ & $P x$ & $P x$ & $P x$ & $P x$ & $P x$ \\
\hline $\mathrm{SiO}_{2}$ & 53.43 & 53.2 & 52.31 & 52.25 & 52.49 & 53.43 & 51.68 & 52.02 & 52.58 & 52.04 & 51.39 & 52.46 & 52.26 & 52.51 \\
\hline $\mathrm{TiO}_{2}$ & 0.66 & 0.44 & 0.77 & 0.38 & 2.56 & 0.66 & 1.73 & 1.02 & 1.62 & 0.97 & 1.12 & 3.49 & 1.16 & 1.6 \\
\hline $\mathrm{Al}_{2} \mathrm{O}_{3}$ & 1.16 & 1.11 & 1.55 & 0.98 & 0.88 & 1.16 & 0.99 & 0.91 & 0.94 & 0.9 & 0.98 & 0.85 & 0.93 & 0.96 \\
\hline $\mathrm{FeO}$ & 28.59 & 28.58 & 26.55 & 23.7 & 26.41 & 28.59 & 25.45 & 24.15 & 25.59 & 25.15 & 24.15 & 24.05 & 25.03 & 24.9 \\
\hline $\mathrm{Cr}_{2} \mathrm{O}_{3}$ & 0 & 0 & 0 & 0 & 0 & 0 & 0 & 0 & 0 & 0 & 0 & 0 & 0 & 0 \\
\hline $\mathrm{MnO}$ & 0.17 & 0.15 & 0.85 & 1.67 & 0.59 & 0.17 & 0.5 & 0.72 & 0.51 & 0.47 & 0.66 & 0.57 & 0.61 & 0.53 \\
\hline NiO & 0 & 0 & 0 & 0 & 0 & 0 & 0 & 0 & 0 & 0 & 0 & 0 & 0 & 0 \\
\hline $\mathrm{MgO}$ & 0.67 & 0.54 & 1.38 & 2.63 & 0.56 & 0.67 & 1.06 & 1.3 & 0.97 & 1.44 & 1.13 & 0.71 & 1.22 & 1.1 \\
\hline $\mathrm{CaO}$ & 1.04 & 0.83 & 4.1 & 9.94 & 2.94 & 1.04 & 4.96 & 4.43 & 3.03 & 3.98 & 7.13 & 2.1 & 5.63 & 4.45 \\
\hline $\mathrm{Na}_{2} \mathrm{O}$ & 13.38 & 13.57 & 11.49 & 8.28 & 12.15 & 13.38 & 11.51 & 11.71 & 12.62 & 12.13 & 9.95 & 13.15 & 10.87 & 11.78 \\
\hline $\mathrm{K}_{2} \mathrm{O}$ & 0.02 & 0.01 & 0.03 & 0 & 0 & 0.02 & 0.02 & 0 & 0 & 0.01 & 0 & 0.03 & 0.01 & 0 \\
\hline $\mathrm{ZnO}$ & 0.01 & 0.02 & 0.07 & 0.05 & 0.02 & 0.01 & 0 & 0 & 0 & 0 & 0 & 0 & 0 & 0 \\
\hline $\mathrm{ZrO}_{2}$ & 0.17 & 0.13 & 0.67 & 0.38 & 1.11 & 0.17 & 0.76 & 0.94 & 0.99 & 0.75 & 1.09 & 0.2 & 0.94 & 0.41 \\
\hline Total & 99.13 & 98.45 & 99.1 & 99.88 & 98.6 & 99.13 & 97.9 & 96.26 & 97.86 & 97.09 & 96.51 & 97.41 & 97.72 & 97.83 \\
\hline \multicolumn{15}{|c|}{ Fómula estrutural calculada na base de 6 átomos de oxigénio } \\
\hline TSi & 1.989 & 1.991 & 1.966 & 1.98 & 1.989 & 1.989 & 1.967 & 2 & 1.986 & 1.979 & 2 & 1.989 & 1.998 & 1.993 \\
\hline TAl & 0.011 & 0.009 & 0.034 & 0.02 & 0.011 & 0.011 & 0.033 & 0 & 0.014 & 0.021 & 0 & 0.011 & 0.002 & 0.007 \\
\hline $\mathrm{TFe}^{3+}$ & 0 & 0 & 0 & 0 & 0 & 0 & 0 & 0 & 0 & 0 & 0 & 0 & 0 & 0 \\
\hline M1Al & 0.04 & 0.04 & 0.035 & 0.024 & 0.028 & 0.04 & 0.011 & 0.041 & 0.028 & 0.019 & 0.045 & 0.026 & 0.04 & 0.036 \\
\hline MITi & 0.018 & 0.012 & 0.022 & 0.011 & 0.073 & 0.018 & 0.05 & 0.029 & 0.046 & 0.028 & 0.033 & 0.1 & 0.033 & 0.046 \\
\hline $\mathrm{M}^{1} \mathrm{Fe}^{3+}$ & 0 & 0 & 0.794 & 0.583 & 0.73 & 0 & 0.773 & 0.773 & 0 & 0 & 0.64 & 0.754 & 0.701 & 0.746 \\
\hline $\mathrm{M} 1 \mathrm{Fe}^{2+}$ & 0.89 & 0.894 & 0.041 & 0.168 & 0.107 & 0.89 & 0.037 & 0.003 & 0.808 & 0.8 & 0.147 & 0.009 & 0.099 & 0.045 \\
\hline $\mathrm{M} 1 \mathrm{Cr}$ & 0 & 0 & 0 & 0 & 0 & 0 & 0 & 0 & 0 & 0 & 0 & 0 & 0 & 0 \\
\hline M1Mg & 0.037 & 0.03 & 0.077 & 0.149 & 0.032 & 0.037 & 0.06 & 0.074 & 0.055 & 0.082 & 0.066 & 0.04 & 0.07 & 0.062 \\
\hline M1Ni & 0 & 0 & 0 & 0 & 0 & 0 & 0 & 0 & 0 & 0 & 0 & 0 & 0 & 0 \\
\hline $\mathrm{M} 2 \mathrm{Mg}$ & 0 & 0 & 0 & 0 & 0 & 0 & 0 & 0 & 0 & 0 & 0 & 0 & 0 & 0 \\
\hline $\mathrm{M}^{2} \mathrm{Fe}^{2+}$ & 0 & 0 & 0 & 0 & 0 & 0 & 0 & 0 & 0 & 0 & 0 & 0 & 0 & 0 \\
\hline M2Mn & 0.005 & 0.005 & 0.027 & 0.054 & 0.019 & 0.005 & 0.016 & 0.023 & 0.016 & 0.015 & 0.022 & 0.018 & 0.02 & 0.017 \\
\hline $\mathrm{M} 2 \mathrm{Ca}$ & 0.041 & 0.033 & 0.165 & 0.404 & 0.119 & 0.041 & 0.202 & 0.182 & 0.123 & 0.162 & 0.297 & 0.085 & 0.231 & 0.181 \\
\hline $\mathrm{M} 2 \mathrm{Na}$ & 0.966 & 0.985 & 0.838 & 0.608 & 0.893 & 0.966 & 0.849 & 0.873 & 0.924 & 0.894 & 0.751 & 0.967 & 0.806 & 0.867 \\
\hline M2K & 0.001 & 0 & 0.001 & 0 & 0 & 0.001 & 0.001 & 0 & 0 & 0 & 0 & 0.001 & 0 & 0 \\
\hline Som_cat & 3.999 & 4 & 3.999 & 4 & 4 & 3.999 & 3.999 & 4 & 4 & 4 & 4 & 3.999 & 4 & 4 \\
\hline $\mathrm{Ca}$ & 4.258 & 3.457 & 53.184 & 52.131 & 43.146 & 4.258 & 64.045 & 64.325 & 12.239 & 15.316 & 55.967 & 56.031 & 55.057 & 59.347 \\
\hline $\mathrm{Mg}$ & 3.817 & 3.13 & 24.907 & 19.192 & 11.435 & 3.817 & 19.044 & 26.264 & 5.452 & 7.71 & 12.342 & 26.358 & 16.6 & $20.4 \uparrow 2$ \\
\hline $\mathrm{Fe}^{2+}+\mathrm{Mn}$ & 91.925 & 93.413 & 21.908 & 28.677 & 45.419 & 91.925 & 16.911 & 9.411 & 82.309 & 76.974 & 31.692 & 17.611 & 28.343 & 20.241 \\
\hline Jd1 & 2.08 & 2.05 & 3.123 & 1.793 & 2.422 & 2.08 & 0.992 & 3.609 & $\{.456$ & 0.976 & 3.564 & 2.4 & 3.319 & 3.147 \\
\hline Ae1 & 47.868 & 48.653 & 71.624 & 43.987 & 75.177 & 47.868 & 72.95 & 73.425 & 46.939 & 45.188 & 56.013 & 85.447 & 63.571 & 71.924 \\
\hline CFTS1 & 0 & 0 & 0 & 0 & 0 & 0 & 0 & 0 & 0 & 0 & 0 & 0 & 0 & 0 \\
\hline CTIS1 & 0.547 & 0.468 & 1.94 & 0.815 & 0.992 & 0.547 & 2.867 & 0.026 & 0.733 & 1.103 & 0 & 1.043 & 0.155 & 0.569 \\
\hline CATS1 & 0 & 0 & 0 & 0 & 0 & 0 & 0 & 0 & 0 & 0 & 0 & 0 & 0 & 0 \\
\hline Wo1 & 1.596 & 1.245 & 12.773 & 29.553 & 9.384 & 1.596 & 14.72 & 16.077 & 5.688 & 7.262 & 23.59 & 6.697 & 18.977 & 15.101 \\
\hline En1 & 1.921 & 1.55 & 6.89 & $\uparrow 1.18$ & 2.75 & 1.921 & 5.229 & 6.575 & 2.86 & 4.211 & 5.202 & 3.641 & 5.768 & 5.39 \\
\hline Fs1 & 45.987 & 46.034 & 3.649 & 12.672 & 9.276 & 45.987 & 3.242 & 0.287 & 42.325 & 41.26 & 11.632 & 0.772 & 8.21 & 3.869 \\
\hline$Q$ & 0.969 & 0.958 & 0.283 & 0.721 & 0.258 & 0.969 & 0.3 & 0.26 & 0.986 & 1.043 & 0.51 & 0.134 & 0.399 & 0.288 \\
\hline J & 1.932 & 1.969 & 1.675 & 1.217 & 1.785 & 1.932 & 1.699 & 1.746 & 1.849 & 1.789 & 1.502 & 1.933 & 1.612 & 1.734 \\
\hline Wo1 & 4.258 & 3.457 & 14.955 & 29.744 & $\uparrow 1.855$ & 4.258 & 18.58 & 17.265 & 12.239 & 15.316 & 25.397 & 9.413 & 20.587 & 17.225 \\
\hline En1 & 3.817 & 3.13 & 7.004 & 10.95 & 3.142 & 3.817 & 5.525 & 7.05 & 5.452 & 7.71 & 5.6 & 4.428 & 6.207 & 5.924 \\
\hline Fs1 & 91.925 & 93.413 & 78.041 & 59.306 & 85.003 & 91.925 & 75.895 & 75.685 & 82.309 & 76.974 & 69.003 & 86.16 & 73.205 & 76.851 \\
\hline WEF & 33.524 & 32.832 & 15.638 & 38.884 & 13.416 & 33.524 & 15.676 & 13.978 & 35.149 & 37.181 & 26.131 & 7.3 & 20.629 & 14.956 \\
\hline Jd1 & 66.476 & 67.168 & 3.568 & 2.401 & 3.182 & 66.476 & 1.226 & 4.322 & 64.851 & 62.819 & 4.848 & 3.142 & 4.283 & 3.952 \\
\hline Ae1 & 0 & 0 & 80.794 & 58.715 & 83.402 & 0 & 83.098 & 81.701 & 0 & 0 & 69.021 & 89.559 & 75.088 & 81.092 \\
\hline
\end{tabular}

Observações de abreviaçס̃es como na tabela 15.0 
Tabela 15.2 - Composição química de piroxênios de Certo Boggiani (\% peso)

\begin{tabular}{|c|c|c|c|c|c|c|c|c|c|c|c|c|c|c|}
\hline $\begin{array}{l}\text { Amostras } \\
\text { Análises }\end{array}$ & $\begin{array}{c}\text { RP-30 } \\
254\end{array}$ & $\begin{array}{c}\text { RP-30 } \\
255\end{array}$ & $\begin{array}{c}\text { RP-30 } \\
256\end{array}$ & $\begin{array}{c}\text { RP-30 } \\
257\end{array}$ & $\begin{array}{c}\text { RP-30 } \\
258\end{array}$ & $\begin{array}{c}\mathrm{RP}-30 \\
259\end{array}$ & $\begin{array}{c}\text { RP-30 } \\
260\end{array}$ & $\begin{array}{c}\text { RP-30 } \\
261\end{array}$ & $\begin{array}{c}\text { RP-30 } \\
263\end{array}$ & $\begin{array}{c}\text { RP-30 } \\
264\end{array}$ & $\begin{array}{c}\text { RP-30 } \\
265\end{array}$ & $\begin{array}{c}\text { RP-30 } \\
266\end{array}$ & $\begin{array}{c}\text { RP-30 } \\
534\end{array}$ & $\begin{array}{c}\text { RP-31A } \\
73\end{array}$ \\
\hline Locaçăo & C4G1n & $\mathrm{C} 4 \mathrm{G} 1 \mathrm{~b}$ & $C 4 G 2 n$ & $\mathrm{C} 4 \mathrm{G} 2 \mathrm{~b}$ & C5G1n & $\mathrm{C} 5 \mathrm{G} 1 \mathrm{~b}$ & C5G1n & C6Gin & C7G1n & $C 7 \mathrm{G} 1 \mathrm{~b}$ & C10Gin & C10G1b & C6G1n & C3G1n \\
\hline Mineral & $P x$ & $P x$ & $P x$ & $P x$ & $\mathrm{Px}$ & $P x$ & $P x$ & $P x$ & $P x$ & $P x$ & Px & Px & $P x$ & $P x$ \\
\hline $\mathrm{SiO}_{2}$ & 52.67 & 52.46 & 52.2 & 52.5 & 53.56 & 53.28 & 53.22 & 52.92 & 52.4 & 52.34 & 52.24 & 52.38 & 52.71 & 51.489 \\
\hline $\mathrm{TiO}_{2}$ & 1.09 & 2.65 & 1.55 & 3.14 & 0.49 & 0.75 & 0.79 & 0.54 & 1.47 & 1.75 & 1.35 & 1.11 & 0.73 & 0.623 \\
\hline $\mathrm{Al}_{2} \mathrm{O}_{3}$ & 0.84 & 0.87 & 1.01 & 1.56 & 0.92 & 1.02 & 0.86 & 1.02 & 0.93 & 0.85 & 0.92 & 0.85 & 1.04 & 1.065 \\
\hline $\mathrm{FeO}$ & 25.16 & 25.34 & 25.76 & 23.67 & 27.5 & 26.85 & 26.22 & 23.83 & 25.17 & 24.86 & 24.82 & 24.9 & 25.77 & 22.713 \\
\hline $\mathrm{Cr}_{2} \mathrm{O}_{3}$ & 0 & 0 & 0 & 0 & 0 & 0 & 0 & 0 & 0 & 0 & 0 & 0 & 0 & 0 \\
\hline $\mathrm{MnO}$ & 0.5 & 0.41 & 0.33 & 0.44 & 0.14 & 0.09 & 0.26 & 0.83 & 0.57 & 0.51 & 0.64 & 0.59 & 0.99 & 1.394 \\
\hline $\mathrm{NiO}$ & 0 & 0 & 0 & 0 & 0 & 0 & 0 & 0 & 0 & 0 & 0 & 0 & 0 & 0 \\
\hline $\mathrm{MgO}$ & 1.39 & 0.82 & 0.85 & 0.86 & 0.58 & 0.74 & 1.15 & 2.16 & 1.1 & 1.08 & 1.16 & 1.26 & 1.77 & 2.876 \\
\hline $\mathrm{CaO}$ & 3.91 & 3.37 & 3.53 & 2.78 & 0.95 & 1.24 & 2.16 & 4.84 & 4.76 & 4.78 & 5.09 & 4.01 & 3.71 & 7.906 \\
\hline $\mathrm{Na}_{2} \mathrm{O}$ & 11.99 & 12.42 & 12.42 & 12.88 & 13.64 & 13.74 & $\{3.16$ & 14.74 & 11.62 & 11.31 & 11.2 & 11.8 & 11.72 & 8.688 \\
\hline $\mathrm{K}_{2} \mathrm{O}$ & 0 & 0.02 & 0 & 0 & 0 & 0 & 0.01 & 0 & 0 & 0 & 0 & 0.01 & 0 & 0 \\
\hline $\mathrm{ZnO}$ & 0 & 0 & 0 & 0 & 0 & 0 & 0 & 0 & 0 & 0 & 0 & 0 & 0 & 0.062 \\
\hline $\mathrm{ZrO}_{2}$ & 0.76 & 0.55 & 0.94 & 0.91 & 0.11 & 0.26 & 0.36 & 0.47 & 0.66 & 0.4 & 0.49 & 0.71 & 0.62 & 0.596 \\
\hline Total & 97.55 & 98.36 & 97.65 & 97.83 & 97.78 & 97.71 & 97.83 & 97.88 & 98.02 & 97.48 & 97.42 & 96.91 & 98.44 & 96.82 \\
\hline \multicolumn{15}{|c|}{ Fórmula estrutural calculada na base de 6 átomos de oxigênio } \\
\hline TSi & 1.998 & 1.98 & 1.979 & 1.979 & 2.012 & 1.998 & 1.998 & 1.991 & 1.989 & 2.003 & 1.999 & 2.003 & 1.985 & 2 \\
\hline Tal & 0.002 & 0.02 & 0.021 & 0.021 & 0 & 0.002 & 0.002 & 0.009 & 0.011 & 0 & 0.001 & 0 & 0.015 & 0 \\
\hline $\mathrm{TFe}^{3+}$ & 0 & 0 & 0 & 0 & 0 & 0 & 0 & 0 & 0 & 0 & 0 & 0 & 0 & 0 \\
\hline MTAI & 0.035 & 0.019 & 0.024 & 0.048 & 0.041 & 0.043 & 0.036 & 0.036 & 0.03 & 0.038 & 0.04 & 0.038 & 0.031 & 0.048 \\
\hline MATi & 0.031 & 0.075 & 0.044 & 0.089 & 0.014 & 0.021 & 0.022 & 0.015 & 0.042 & 0.05 & 0.039 & 0.032 & 0.021 & 0.018 \\
\hline $\mathrm{M} 1 \mathrm{Fe}^{\mathrm{j}+}$ & 0.786 & 0.76 & 0 & 0.736 & 0 & 0 & 0 & 0 & 0.752 & 0.695 & 0.714 & 0.767 & 0.798 & 0.57 \\
\hline $\mathrm{M}^{1} \mathrm{Fe}^{2+}$ & 0.012 & 0.04 & 0.817 & 0.011 & 0.864 & 0.842 & 0.823 & 0.75 & 0.046 & 0.101 & 0.08 & 0.029 & 0.014 & 0.168 \\
\hline $\mathrm{M} 1 \mathrm{Cr}$ & 0 & 0 & 0 & 0 & 0 & 0 & 0 & 0 & 0 & 0 & 0 & 0 & 0 & 0 \\
\hline M1Mg & 0.079 & 0.046 & 0.048 & 0.048 & 0.032 & 0.041 & 0.064 & 0.121 & 0.062 & 0.062 & 0.066 & 0.072 & 0.099 & 0.167 \\
\hline MINI & 0 & 0 & 0 & 0 & 0 & 0 & 0 & 0 & 0 & 0 & 0 & 0 & 0 & 0 \\
\hline $\mathrm{M} 2 \mathrm{Mg}$ & 0 & 0 & 0 & 0 & 0 & 0 & 0 & 0 & 0 & 0 & 0 & 0 & 0 & 0 \\
\hline $\mathrm{M} 2 \mathrm{Fe}^{2+}$ & 0 & 0 & 0 & 0 & 0 & 0 & 0 & 0 & 0 & 0 & 0 & 0 & 0 & 0 \\
\hline M2Mn & 0.016 & 0.013 & 0.011 & 0.014 & 0.004 & 0.003 & 0.008 & 0.026 & 0.018 & 0.017 & 0.021 & 0.019 & 0.032 & 0.046 \\
\hline $\mathrm{M} 2 \mathrm{Ca}$ & 0.159 & 0.136 & 0.143 & 0.112 & 0.038 & 0.05 & 0.087 & 0.195 & 0.194 & 0.196 & 0.209 & 0.164 & 0.15 & 0.329 \\
\hline $\mathrm{M} 2 \mathrm{Na}$ & 0.882 & 0.909 & 0.913 & 0.942 & 0.994 & 0.999 & 0.958 & 0.856 & 0.855 & 0.839 & 0.831 & 0.875 & 0.856 & 0.654 \\
\hline M2K & 0 & 0.001 & 0 & 0 & 0 & 0 & 0 & 0 & 0 & 0 & 0 & 0 & 0 & 0 \\
\hline Som_cat & 4 & 3.999 & 4 & 4 & 4 & 4 & 4 & 4 & 4 & 4 & 4 & 4 & 4 & 4 \\
\hline $\mathrm{Ca}$ & 59.886 & 57.861 & 14.075 & 60.559 & 4.072 & 5.322 & 8.841 & 17.858 & 60.381 & 52.265 & 55.508 & 57.811 & 50.881 & 46.366 \\
\hline $\mathrm{Mg}$ & 29.622 & 19.589 & 4.716 & 26.066 & 3.459 & $4.4 \uparrow 9$ & 6.549 & 11.089 & 19.415 & 16.431 & 17.601 & 25.275 & 33.776 & 23.468 \\
\hline $\mathrm{Fe}^{2+} \mathrm{Mn}$ & 10.492 & 22.55 & 81.21 & 13.375 & 92.47 & 90.258 & 84.61 & 71.052 & 20.205 & 31.304 & 26.891 & 16.914 & 15.344 & 30.166 \\
\hline Jd1 & 3.126 & 1.685 & 1.252 & 4.357 & 2.111 & 2.244 & $\{.876$ & 1.872 & 2.6 & 3.198 & 3.402 & 3.356 & 2.789 & 3.676 \\
\hline Ae1 & 74.836 & 78.672 & 46.271 & 80.244 & 49.416 & 49.46 & 47.71 & 42.677 & 71.285 & 66.873 & 66.653 & 73.401 & 73.729 & 45.967 \\
\hline CFTS1 & 0 & 0 & 0 & 0 & 0 & 0 & 0 & 0 & 0 & 0 & 0 & 0 & 0 & 0 \\
\hline CTTS1 & 0.191 & 1.73 & 1.095 & 1.867 & 0 & 0.087 & 0.091 & 0.479 & 0.991 & 0 & 0.093 & 0 & 1.335 & 0.02 \\
\hline CATS1 & 0 & 0 & 0 & 0 & 0 & 0 & 0 & 0 & 0 & 0 & 0 & 0 & 0 & 0 \\
\hline Wo1 & 13.857 & 10.305 & 6.369 & 8.223 & 1.983 & 2.491 & 4.404 & 9.67 & 15.733 & 16.364 & 17.499 & 14.405 & 12.05 & 24.942 \\
\hline En1 & 6.949 & 4.075 & 2.501 & 4.343 & 1.685 & 2.141 & 3.33 & 6.302 & 5.377 & 5.144 & 5.578 & 6.298 & 8.885 & 12.634 \\
\hline Fs1 & 1.041 & 3.533 & 42.512 & 0.966 & 44.806 & 43.577 & 42.589 & 39.001 & 4.013 & 8.421 & 6.774 & 2.539 & 1.213 & 12.761 \\
\hline$Q$ & 0.249 & 0.222 & 1.008 & 0.171 & 0.935 & 0.933 & 0.975 & 1.066 & 0.302 & 0.358 & 0.355 & 0.265 & 0.263 & 0.664 \\
\hline$J$ & 1.764 & 1.818 & $\uparrow .826$ & 1.883 & 1.987 & 1.998 & 1.916 & 1.713 & 1.71 & 1.678 & 1.662 & 1.75 & 1.712 & 4.309 \\
\hline Wo1 & 15.109 & 13.691 & 14.075 & $\{2.193$ & 4.072 & 5.322 & 8.841 & 17.858 & 18.039 & 18.321 & 19.147 & 15.624 & 13.705 & 25.72 \\
\hline En1 & 7.474 & 4.635 & 4.716 & 5.248 & 3.459 & 4.419 & 6.549 & $\$ 1.089$ & 5.8 & 5.76 & 6.072 & 6.831 & 9.098 & 13.018 \\
\hline$F s 1$ & 77,417 & 81.673 & 81.21 & 82.559 & 92.47 & 90.258 & 84.61 & 71.052 & 76.161 & 75.919 & 74.781 & 77.545 & 77.197 & 61.261 \\
\hline WEF & 13.077 & 11.47 & 35.812 & 8.964 & 32.093 & 31.902 & 33.903 & 38.942 & 15.785 & 18.261 & 18.447 & 13.971 & 14.668 & 35.159 \\
\hline Jd1 & 3.74 & 2.169 & 64.188 & 5.63 & 67.907 & 68.098 & 66.097 & 61.058 & 3.239 & 4.271 & 4.363 & 4.088 & 3.21 & 5.083 \\
\hline Aet & 83.182 & 86.361 & 0 & 85.406 & 0 & 0 & 0 & 0 & 80.976 & 77.467 & 77.189 & 81.941 & 82.122 & 59.758 \\
\hline
\end{tabular}

Observaçð̃es de abreviaçס̃es como na tabela 15.0 
Tabela 15.3 - Composição química de piroxénios de Cerro Boggiani (\% peso)

\begin{tabular}{|c|c|c|c|c|c|c|c|c|c|c|c|c|c|c|}
\hline Amostras & RP-31A & RP-31A & RP-31A & RP-3१A & RP-31A & RP-32 & RP-32 & RP-32 & RP-32 & RP-32 & RP-32 & RP-32 & RP-32 & RP-32 \\
\hline Análises & 74 & 76 & 77 & 81 & 82 & 240 & 241 & 242 & 243 & 244 & 245 & 267 & 268 & 269 \\
\hline Locação & $\mathrm{C} 3 \mathrm{G} 1 \mathrm{~b}$ & C5G1n & C5Gib & C1G2br & $C\{G 3 b$ & C1G1n & C1G2n & C1G3n & $\mathrm{C} 2 \mathrm{G} 1 \mathrm{n}$ & C3G1n & C3G2n & $\mathrm{C} 1 \mathrm{G} 1 \mathrm{Fn}$ & C1GAFD & C1G1n \\
\hline Mineraf & $P x$ & $P x$ & $P x$ & $P x$ & $P x$ & $P x$ & $P x$ & Px & $P x$ & $P x$ & $P x$ & $P_{x}$ & $P x$ & $P x$ \\
\hline $\mathrm{SiO}_{2}$ & 50.992 & 51.08 & 51.903 & 51.951 & 51.103 & 52.3 & 52.69 & 52.49 & 52.99 & 52.87 & 52.4 & 52.7 & 52.25 & 52.65 \\
\hline $\mathrm{TiO}_{2}$ & 0.906 & 0.719 & 0.911 & 0.699 & 0.69 & 1.13 & 0.72 & 3.22 & 1.22 & 1.42 & 0.65 & 2.38 & 2.35 & 1.57 \\
\hline $\mathrm{Al}_{2} \mathrm{O}_{3}$ & 1.087 & 1.079 & 0.988 & 1.064 & 1.13 & 0.28 & 1.29 & 0.5 & 0.62 & 0.32 & 1.13 & 0.3 & 1.39 & 0.32 \\
\hline $\mathrm{FeO}$ & 21.676 & 22.642 & 24.084 & 22.271 & 21.911 & 28.54 & 25.88 & 25.58 & 28.13 & 28.78 & 25.89 & 25.74 & 24.13 & 26.35 \\
\hline $\mathrm{Cr}_{2} \mathrm{O}_{3}$ & 0 & 0 & 0 & 0.008 & 0 & 0 & 0 & 0 & 0 & 0 & 0 & 0 & 0 & 0 \\
\hline $\mathrm{MnO}$ & 1.354 & 1.398 & 1.229 & 1.379 & 1.301 & 0.4 & 0.85 & 1.25 & 0.51 & 0.46 & 1.04 & 0.44 & 0.55 & 0.35 \\
\hline $\mathrm{NiO}$ & 0 & 0 & 0 & 0 & 0.03 & 0 & 0 & 0 & 0 & 0 & 0 & 0 & 0 & 0 \\
\hline $\mathrm{MgO}$ & 2.993 & 2.56 & 1.881 & 2.837 & 2.963 & 0.58 & 0.62 & 0.45 & 0.99 & 0.51 & 1.78 & 0.53 & 0.38 & 0.9 \\
\hline $\mathrm{CaO}$ & 8.554 & 8.115 & 5.16 & 8.095 & 8.391 & 1.11 & 1.54 & 1.13 & 1.9 & 1.36 & 5.43 & 1.47 & 1.89 & 1.56 \\
\hline $\mathrm{Na}_{2} \mathrm{O}$ & 8.415 & 8.798 & 10.519 & 8.875 & 8.544 & 13.47 & 12.88 & 13.45 & 12.86 & 12.98 & 10.74 & 13.4 & 12.97 & 13.55 \\
\hline $\mathrm{K}_{2} \mathrm{O}$ & 0 & 0.011 & 0.03 & 0 & 0.011 & 0 & 0 & 0.02 & 0 & 0.02 & 0.01 & 0 & 0 & 0 \\
\hline $\mathrm{ZnO}$ & 0.061 & 0.034 & 0.058 & 0.037 & 0.027 & 0.05 & 0 & 0 & 0 & 0.03 & 0.06 & 0 & 0 & 0 \\
\hline $\mathrm{ZrO}_{2}$ & 0.865 & 0.971 & 0.395 & 0.65 & 0.976 & 0.18 & 0.62 & 0.49 & 0.16 & 0.12 & 0.57 & 0.55 & 0.67 & 0.15 \\
\hline Total & 96.04 & 96.44 & 96.76 & 97.22 & 96.1 & 97.86 & 96.47 & 98.09 & 99.22 & 98.75 & 99.13 & 96.96 & 95.91 & 97.25 \\
\hline \multicolumn{15}{|c|}{ Fórmula estrutural calculada na base de 6 átomos de oxigênio } \\
\hline TSi & 1.996 & 1.992 & 2.002 & 2.005 & 1.996 & 1.976 & 2.014 & 1.982 & 1.98 & 1.992 & 1.976 & 2.006 & 2.009 & 1.99 \\
\hline TAl & 0.004 & 0.008 & 0 & 0 & 0.004 & 0.012 & 0 & 0.018 & 0.02 & 0.008 & 0.024 & 0 & 0 & 0.01 \\
\hline $\mathrm{TFe}^{3+}$ & 0 & 0 & 0 & 0 & 0 & 0 & 0 & 0 & 0 & 0 & 0 & 0 & 0 & 0 \\
\hline M1Al & 0.046 & 0.041 & 0.045 & 0.048 & 0.048 & 0 & 0.058 & 0.004 & 0.007 & 0.006 & 0.026 & 0.013 & 0.063 & 0.004 \\
\hline M1Ti & 0.027 & 0.021 & 0.026 & 0.02 & 0.02 & 0.032 & 0.021 & 0.091 & 0.034 & 0.04 & 0.018 & 0.068 & 0.068 & 0.045 \\
\hline $\mathrm{M}^{1} \mathrm{Fe}^{3+}$ & 0.543 & 0.591 & 0.686 & 0.565 & 0.562 & 0 & 0 & 0 & 0.876 & 0.871 & 0.746 & 0 & 0.75 & 0 \\
\hline$M 1 \mathrm{Fe}^{2+}$ & 0.167 & 0.147 & 0.091 & 0.154 & 0.154 & 0.902 & 0.827 & 0.808 & 0.004 & 0.036 & 0.07 & 0.819 & 0.026 & 0.833 \\
\hline $\mathrm{M} 1 \mathrm{Cr}$ & 0 & 0 & 0 & 0 & 0 & 0 & 0 & 0 & 0 & 0 & 0 & 0 & 0 & 0 \\
\hline $\mathrm{M} 1 \mathrm{Mg}$ & 0.175 & 0.149 & 0.108 & 0.163 & 0.173 & 0.033 & 0.035 & 0.025 & 0.055 & 0.029 & 0.1 & 0.03 & 0.022 & 0.051 \\
\hline M1Ni & 0 & 0 & 0 & 0 & 0.001 & 0 & 0 & 0 & 0 & 0 & 0 & 0 & 0 & 0 \\
\hline $\mathrm{M} 2 \mathrm{Mg}$ & 0 & 0 & 0 & 0 & 0 & 0 & 0 & 0 & 0 & 0 & 0 & 0 & 0 & 0 \\
\hline $\mathrm{M} 2 \mathrm{Fe}^{2+}$ & 0 & 0 & 0 & 0 & 0 & 0 & 0 & 0 & 0 & 0 & 0 & 0 & 0 & 0 \\
\hline M2Mn & 0.045 & 0.046 & 0.04 & 0.045 & 0.043 & 0.013 & 0.028 & 0.04 & 0.016 & 0.015 & 0.033 & 0.014 & 0.018 & 0.011 \\
\hline $\mathrm{M} 2 \mathrm{Ca}$ & 0.359 & 0.339 & 0.213 & 0.335 & 0.351 & 0.045 & 0.063 & 0.046 & 0.076 & 0.055 & 0.219 & 0.06 & 0.078 & 0.063 \\
\hline $\mathrm{M} 2 \mathrm{Na}$ & 0.639 & 0.665 & 0.787 & 0.664 & 0.647 & 0.987 & 0.954 & 0.985 & 0.932 & 0.948 & 0.785 & 0.989 & 0.967 & 0.993 \\
\hline M2K & 0 & 0.001 & 0.001 & 0 & 0.001 & 0 & 0 & 0.001 & 0 & 0.001 & 0 & 0 & 0 & 0 \\
\hline Som_cat & 4 & 3.999 & 3.999 & 4 & 3.999 & 4 & 4 & 3.999 & 4 & 3.999 & 4 & 4 & 4 & 4 \\
\hline $\mathrm{Ca}$ & 48.126 & 49.747 & 47,463 & 48.016 & 48.755 & 4.529 & 6.616 & 4.976 & 50.407 & 41.029 & 51.864 & 6.491 & 54.368 & 6.594 \\
\hline $\mathrm{Mg}$ & 23.43 & 21.836 & 23.921 & 23.414 & 23.954 & 3.293 & 3.706 & 2.757 & 36.545 & 21.408 & 23.656 & 3.256 & 15.209 & 5.294 \\
\hline $\mathrm{Fe}^{2+}+\mathrm{Mn}$ & 28.445 & 28.418 & 28.916 & 28.57 & 27.291 & 92.179 & 89.677 & 92.267 & 13.048 & 37.563 & 24.48 & 90.253 & 30.423 & 88.112 \\
\hline JdA & 3.467 & 3.156 & 3.739 & 3.674 & 3.65 & 0 & 3.088 & 0.221 & 0.698 & 0.545 & 2.245 & 0.708 & 5.762 & 0.22 \\
\hline Ae1 & 44.224 & 48.013 & 61.933 & 46.786 & 45.234 & 50.189 & 47.681 & 52.645 & 86.667 & 88.304 & 64.597 & 51.388 & 82.766 & 50.972 \\
\hline CFTS 1 & 0 & 0 & 0 & 0 & 0 & 0 & 0 & 0 & 0 & 0 & 0 & 0 & 0 & 0 \\
\hline CTTS1 & 0.274 & 0.653 & 0 & 0 & 0.273 & 0.634 & 0 & 0.971 & 1.861 & 0.784 & 1.568 & 0 & 0 & 0.514 \\
\hline CATS1 & 0 & 0 & 0 & 0 & 0 & 0 & 0 & 0 & 0 & 0 & 0 & 0 & 0 & 0 \\
\hline Wo1 & 26.513 & 25.405 & 17.768 & 25.432 & 26.232 & 1.652 & 3.354 & 1.481 & 5.272 & 4.355 & 17.094 & 3.158 & 7.128 & 2.743 \\
\hline En1 & 13.041 & 11.438 & 9.012 & 12.401 & 13.023 & 1.661 & 1.879 & 1.359 & 5.171 & 2.681 & 8.512 & 1.584 & 1.994 & 2.614 \\
\hline Fs1 & 12.481 & 11.336 & 7.548 & 11.707 & 11.588 & 45.864 & 43.998 & 43.323 & 0.333 & 3.331 & 5.983 & 43.161 & 2.349 & 42.937 \\
\hline$Q$ & 0.701 & 0.635 & 0.412 & 0.652 & 0.677 & 0.979 & 0.926 & 0.879 & 0.135 & 0.119 & 0.39 & 0.909 & 0.125 & 0.947 \\
\hline J & 1.278 & 1.33 & 1.573 & 1.328 & 1.294 & 1.974 & 1.909 & 1.969 & 1.864 & 1.896 & 1.571 & 1.978 & 1.934 & 1.986 \\
\hline Wo1 & 27.856 & 26.646 & 18.731 & 26.527 & 27.382 & 4.529 & 6.616 & 4.976 & 7.411 & 5.462 & 18.765 & 6.491 & 8.714 & 6.594 \\
\hline En1 & 13.561 & 11.696 & 9.501 & 12.935 & 13.453 & 3.293 & 3.706 & 2.757 & 5.373 & 2.85 & 8.559 & 3.256 & 2.438 & 5.294 \\
\hline$F_{s 1}$ & 58.583 & 61.659 & 71.768 & 60.538 & 59.165 & 92.179 & 89.677 & 92.267 & 87.216 & 91.687 & 72.676 & 90.253 & 88.848 & 88.112 \\
\hline WEF & 36.851 & 33.874 & 22.322 & 34.419 & 35.755 & 33.454 & 33.301 & 31.811 & 7.491 & 6.59 & 21.218 & 31.83 & 6.895 & 32.539 \\
\hline Jd1 & 4.98 & 4.296 & 4.768 & 5.173 & 5.088 & 0 & 66.699 & 68.189 & 0.779 & 0.62 & 2.692 & 68.17 & 7.206 & 67.461 \\
\hline $\mathrm{Ae} 1$ & 58.169 & 61.83 & 72.91 & 60.408 & 59.157 & 0.987 & 0 & 0 & 91.729 & 92.789 & 76.09 & 0 & 85.899 & 0 \\
\hline
\end{tabular}

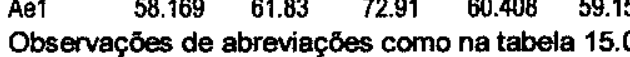




\begin{tabular}{|c|c|c|c|c|c|c|c|c|c|c|c|c|c|c|}
\hline Amostras & RP-32 & RP-32 & RP-32 & RP-32 & RP-32 & RP-32 & RP-37 & RP-37 & RP-37 & $R P-41$ & RP-41 & RP-41 & RP-41 & RP-41 \\
\hline Análises & 270 & 271 & 272 & 273 & 274 & 275 & 276 & 277 & 536 & 118 & 118 & 119 & 120 & 69 \\
\hline Locaçăa & $\mathrm{C} 2 \mathrm{G} 1 \mathrm{n}$ & $\mathrm{C} 2 \mathrm{G} 1 \mathrm{~b}$ & C3G1n & C3G1b & $\mathrm{C} 5 \mathrm{G} 1 \mathrm{n}$ & C5G1b & C1G1n & C1G1b & C4G1n & C1G5m & C1G5n & C1G6n & $\mathrm{C} 1 \mathrm{G} 7 \mathrm{~m}$ & C1G1n \\
\hline $\begin{array}{l}\text { Mineral } \\
\mathrm{SiO}\end{array}$ & $\begin{array}{c}P x \\
5257\end{array}$ & $\begin{array}{c}P x \\
5226\end{array}$ & $\begin{array}{c}P x \\
524\end{array}$ & $\begin{array}{c}P x \\
5267\end{array}$ & $\begin{array}{c}\text { Px } \\
5275\end{array}$ & $\begin{array}{c}P x \\
52.9\end{array}$ & $\begin{array}{c}P_{x} \\
51.47\end{array}$ & $\begin{array}{c}\text { Px } \\
51.17\end{array}$ & $\begin{array}{c}P x \\
50.3\end{array}$ & $\begin{array}{c}P x \\
51.661\end{array}$ & $\begin{array}{c}P x \\
51.661\end{array}$ & $\begin{array}{c}P x \\
50.767\end{array}$ & $\begin{array}{c}\text { Px } \\
50.767\end{array}$ & $\begin{array}{c}\text { Px } \\
51.092\end{array}$ \\
\hline $\mathrm{TiO}_{2}$ & 2.41 & 1.87 & 1.87 & 0.89 & 4.91 & 3.99 & 0.87 & 0.92 & 11.36 & 1.119 & 1.119 & 0.891 & 0.891 & 0.95 \\
\hline $\mathrm{Al}_{2} \mathrm{O}_{3}$ & 0.39 & 0.29 & 0.26 & 0.88 & 0.64 & 0.75 & 0.99 & 1.02 & 1.23 & 0.956 & 0.956 & 1.051 & 1.051 & 0.973 \\
\hline $\mathrm{FeO}$ & 25.66 & 27.41 & 25.64 & 26.21 & 21.1 & 21.52 & 25.63 & 24.94 & 24.85 & 23.065 & 23.065 & 25.717 & 25.717 & 25.248 \\
\hline $\mathrm{Cr}_{2} \mathrm{O}_{3}$ & 0 & 0 & 0 & 0 & 0 & 0 & 0 & 0 & 0 & 0.018 & 0.018 & 0 & 0 & 0 \\
\hline $\mathrm{MnO}$ & 0.53 & 0.31 & 0.41 & 0.4 & 1.2 & 1.2 & 0.68 & 0.63 & 0.85 & 1.17 & 1.17 & 1.068 & 1.068 & 1.207 \\
\hline $\mathrm{NiO}$ & 0 & 0 & 0 & 0 & 0 & 0 & 0 & 0 & 0 & 0.003 & 0.003 & 0 & 0 & 0 \\
\hline $\mathrm{MgO}$ & 0.47 & 0.58 & 0.63 & 0.7 & 1.5 & 1.52 & 0.94 & 0.74 & 1.02 & 2.397 & 2.397 & 0.808 & 0.808 & 0.918 \\
\hline $\mathrm{CaO}$ & 1.12 & 1.6 & 1.77 & 1.39 & $\$ .88$ & 2.58 & 7.96 & 7.45 & 8.47 & 7.039 & 7.039 & 7.304 & 7.304 & 7.667 \\
\hline $\mathrm{Na}_{2} \mathrm{O}$ & $\{3.84$ & 13.27 & 13.34 & 13.6 & 13.14 & 13.06 & 9.48 & 9.74 & 8.89 & 9.354 & 9.354 & 9.276 & 9.276 & 9.087 \\
\hline $\mathrm{K}_{2} \mathrm{O}$ & 0.01 & 0 & 0 & 0 & 0 & 0 & 0.01 & 0.02 & 0 & 0.009 & 0.009 & 0.014 & 0.014 & 0.003 \\
\hline Zno & 0 & 0 & 0 & 0 & 0 & 0 & 0 & 0 & 0 & 0.054 & 0.054 & 0.081 & 0.081 & 0 \\
\hline $\mathrm{ZrO}_{2}$ & 0.96 & 0.12 & 0.25 & 0.24 & 0.5 & 0.44 & 0.63 & 0.71 & 0.99 & 0.835 & 0.835 & 0.707 & 0.707 & 1.06 \\
\hline Total & 97 & 97.59 & 96.32 & 96.74 & 97.12 & 97.52 & 98.03 & 96.63 & 106.97 & 96.85 & 96.85 & 96.98 & 96.98 & 97.15 \\
\hline \multicolumn{15}{|c|}{ Fórmula estrutural calculada na base de 6 átomos de oxigénio } \\
\hline TSi & 1.993 & 1.981 & 2.004 & 1.996 & 1.998 & 1.993 & 1.987 & 1.998 & 1.835 & 2.003 & 2.003 & 1.989 & 1.989 & 1.998 \\
\hline TAI & 0.007 & 0.013 & 0 & 0.004 & 0.002 & 0.007 & 0.013 & 0.002 & 0.053 & 0 & 0 & 0.011 & 0.011 & 0.002 \\
\hline $\mathrm{TFe}^{3+}$ & 0 & 0 & 0 & 0 & 0 & 0 & 0 & 0 & 0.112 & 0 & 0 & 0 & 0 & 0 \\
\hline M1AI & 0.011 & 0 & 0.012 & 0.036 & 0.027 & 0.027 & 0.032 & 0.045 & 0 & 0.044 & 0.044 & 0.037 & 0.037 & 0.043 \\
\hline M1Ti & 0.069 & 0.053 & 0.054 & 0.025 & 0.14 & 0.113 & 0.025 & 0.027 & 0.312 & 0.033 & 0.033 & 0.026 & 0.026 & 0.028 \\
\hline $\mathrm{M} 1 \mathrm{Fe}^{3+}$ & 0 & 0 & 0 & 0 & 0.66 & 0 & 0.641 & 0.642 & 0.17 & 0.589 & 0.589 & 0.627 & 0.627 & 0.593 \\
\hline $\mathrm{M} 1 \mathrm{Fe}^{2+}$ & 0.814 & 0.869 & 0.82 & 0.831 & 0.008 & 0.678 & 0.187 & 0.173 & 0.463 & 0.159 & 0.159 & 0.215 & 0.215 & 0.233 \\
\hline $\mathrm{M} 1 \mathrm{Cr}$ & 0 & 0 & 0 & 0 & 0 & 0 & 0 & 0 & 0 & 0.001 & 0.001 & 0 & 0 & 0 \\
\hline $\mathrm{M} 1 \mathrm{Mg}$ & 0.027 & 0.033 & 0.036 & 0.04 & 0.085 & 0.085 & 0.054 & 0.043 & 0.055 & 0.139 & 0.139 & 0.047 & 0.047 & 0.054 \\
\hline$M 1 \mathrm{Ni}$ & 0 & 0 & 0 & 0 & 0 & 0 & 0 & 0 & 0 & 0 & 0 & 0 & 0 & 0 \\
\hline M2Mg & 0 & 0 & 0 & 0 & 0 & 0 & 0 & 0 & 0 & 0 & 0 & 0 & 0 & 0 \\
\hline $\mathrm{M}^{2} \mathrm{Fe}^{2+}$ & 0 & 0 & 0 & 0 & 0 & 0 & 0 & 0 & 0.014 & 0 & 0 & 0 & 0 & 0 \\
\hline M2Mn & 0.017 & 0.01 & 0.013 & 0.013 & 0.039 & 0.038 & 0.022 & 0.021 & 0.026 & 0.038 & 0.038 & 0.035 & 0.035 & 0.04 \\
\hline $12 \mathrm{Ca}$ & 0.045 & 0.065 & 0.073 & 0.056 & 0.076 & 0.104 & 0.329 & 0.312 & 0.331 & 0.292 & 0.292 & 0.307 & 0.307 & 0.321 \\
\hline $\mathrm{M} 2 \mathrm{Na}$ & 1.017 & 0.976 & 0.989 & 0.999 & 0.965 & 0.954 & 0.71 & 0.737 & 0.629 & 0.703 & 0.703 & 0.705 & 0.705 & 0.689 \\
\hline M2K & 0 & 0 & 0 & 0 & 0 & 0 & 0 & 0.001 & 0 & 0 & 0 & 0.001 & 0.001 & 0 \\
\hline Som_cat & 4 & 4 & 4 & 4 & 4 & 4 & 4 & 3.999 & 4 & 4 & 4 & 3.999 & 3.999 & 4 \\
\hline $\mathrm{Ca}$ & 5.04 & 6.654 & 7.701 & 6.007 & 36.701 & 11.497 & 55.601 & 56.842 & 37.233 & 46.538 & 46.538 & 50.709 & 50.709 & 49.597 \\
\hline $\mathrm{Mg}$ & 2.943 & 3.356 & 3.814 & 4.209 & 40.744 & 9.424 & 9.136 & 7.856 & 6.239 & 22.05 & 22,05 & 7.805 & 7.805 & 8.263 \\
\hline$=\mathrm{e}^{2+} \mathrm{Mn}$ & 92.017 & 89.99 & 88.485 & 89.783 & 22.555 & 79.079 & 35.263 & 35.302 & 56.529 & 31.412 & 31.412 & 41.486 & 41.486 & 42.141 \\
\hline $\mathrm{dd} \mathrm{f}^{-}$ & 0.557 & 0 & 0.611 & 1.845 & 2.369 & 1.463 & 2.483 & 3.534 & 0 & 3.374 & 3.374 & 2.902 & 2.902 & 3.286 \\
\hline $\mathrm{Aet}$ & 52.918 & 50.223 & 50.973 & 50.042 & 82.7 & 50.911 & 52.993 & 54.798 & 42.155 & 51.023 & 51.023 & 52.44 & 52,44 & 49.855 \\
\hline CFTS1 & 0 & 0 & 0 & 0 & 0 & 0 & 0 & 0 & 0 & 0 & 0 & 0 & 0 & 0 \\
\hline CTIS1 & 0.358 & 0.667 & 0 & 0.194 & 0.147 & 0.364 & 1.033 & 0.171 & 3.542 & 0 & 0 & 0.902 & 0.902 & 0.169 \\
\hline CATS1 & 0 & 0 & 0 & 0 & 0 & 0 & 0 & 0 & 0 & 0 & 0 & 0 & 0 & 0 \\
\hline Wo1 & 2.032 & 2.679 & 3.782 & 2.736 & 6.578 & 5.353 & 24.688 & 24.45 & 18.65 & 22.605 & 22.605 & 23.153 & 23.153 & 24.6 \\
\hline Ent & 1.395 & 1.688 & 1.873 & 2.053 & 7.466 & 4.687 & 4.226 & 3.403 & 3.719 & 10.71 & 10.71 & 3.703 & 3.703 & 4.127 \\
\hline Fs 1 & 42.74 & 44.743 & 42.762 & 43.129 & 0.739 & 37.222 & 14.576 & 13.645 & 31.934 & 12.288 & 12,288 & 16.9 & 16.9 & 17.963 \\
\hline$Q$ & 0.886 & 0.967 & 0.928 & 0.927 & 0.169 & 0.868 & 0.57 & 0.527 & 0.863 & 0.59 & 0.59 & 0.569 & 0.569 & 0.608 \\
\hline 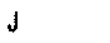 & 2.035 & 1.951 & 1.978 & 1.999 & 1.93 & 1.908 & 1.419 & 1.475 & 1.258 & 1.406 & 1.406 & 1.409 & 1.409 & 1.378 \\
\hline Wo1 & 5.04 & 6.654 & 7.701 & 6.007 & 8.791 & 11.497 & 26.702 & 26.191 & 28.273 & 24.022 & 24.022 & 24.889 & 24.889 & 25.897 \\
\hline En1 & 2,943 & 3.356 & 3.814 & 4.209 & 9.759 & 9.424 & 4.387 & 3.62 & 4.737 & 11.382 & 11.382 & 3.831 & 3.831 & 4.314 \\
\hline $\mathrm{Fs} 1$ & 92.017 & 89.99 & 88.485 & 89.783 & 81.449 & 79.079 & 68.911 & 70.189 & 66.989 & 64.596 & 64.596 & 71.28 & 71.28 & 69.789 \\
\hline WEF & 30.729 & 33.362 & 32.25 & 31.975 & 9.723 & 32.191 & 29.44 & 27.102 & 41.417 & 30.879 & 30.879 & 30.022 & 30.022 & 31.973 \\
\hline Jd1 & 69.271 & 0 & 67.75 & 68.025 & 3.532 & 67.809 & 3.334 & 4.751 & 0 & 4.77 & 4.77 & 3.897 & 3.897 & 4.562 \\
\hline Ae1 & 0 & 0.976 & 0 & 0 & 86.744 & 0 & 67.226 & 68.147 & 58.583 & 64.351 & 64.351 & 66.081 & 66.081 & 63.465 \\
\hline
\end{tabular}

Observaçőes de abreviações como na tabela 15.0 


\begin{tabular}{|c|c|c|c|c|c|c|c|c|c|c|c|c|c|c|c|}
\hline Amostras & RP-41 & RP-41 & $R P-42$ & RP-42 & RP-42 & RP-42 & RP-42 & RP-42 & RP-42 & RP-42 & $R P-42$ & RP-42 & RP-42 & RP-42 & RP-42 \\
\hline Análises & 71 & 72 & 538 & 539 & 540 & 541 & 542 & 543 & 544 & 545 & 546 & 547 & 548 & 549 & 550 \\
\hline Locaçãa & C1G2n & C1G2b & C1G1n & CiG1b & C1G2m & C1G1m & $\mathrm{C} 2 \mathrm{G} 1 \mathrm{~m}$ & C2G2n & $\mathrm{C} 2 \mathrm{G} 2 \mathrm{~b}$ & C2G3m & C3G1n & $C 3 G 2 n$ & $\mathrm{C} 3 \mathrm{G} 2 \mathrm{~b}$ & C3G3m & C4G1m \\
\hline Mineral & $P x$ & Px & $P x$ & Px & Px & Px & $P x$ & $P x$ & $P x$ & Px & Px & $P x$ & Px & $P x$ & $P x$ \\
\hline $\mathrm{SiO}_{2}$ & 51.724 & 51.758 & 51.53 & 51.54 & 50.88 & 50.69 & 51.28 & 51.19 & 50.98 & 51.74 & 51.34 & 50.19 & 51.24 & 51.64 & 51.31 \\
\hline $\mathrm{THO}_{2}$ & 0.996 & 0.845 & 0.76 & 0.8 & 0.72 & 0.85 & 0.73 & 0.86 & 0.73 & 0.96 & 0.79 & 0.95 & 0.86 & 0.78 & 0.81 \\
\hline $\mathrm{Al}_{2} \mathrm{O}_{3}$ & 0.944 & 1.091 & 1.03 & 1 & 1.18 & 1.01 & 1.02 & 1.37 & 0.97 & 1.05 & 1.01 & 1.04 & 0.98 & 1.03 & 1.09 \\
\hline $\mathrm{FeO}$ & 26.228 & 26.098 & 25.92 & 26.15 & 25.67 & 26.82 & 25.65 & 25.84 & 26.6 & 26.06 & 26.38 & 25.67 & 25.95 & 25.96 & 26.58 \\
\hline $\mathrm{Cr}_{2} \mathrm{O}_{3}$ & 0 & 0 & 0 & 0 & 0 & 0 & 0 & 0 & 0 & 0 & 0 & 0 & 0 & 0 & 0 \\
\hline $\mathrm{MnO}$ & 0.924 & 1.027 & 1.19 & 1.02 & 1.03 & 1.11 & 1.25 & $\uparrow .11$ & 1.23 & 1.07 & 1.03 & 1.15 & 1.08 & 1.01 & 1.05 \\
\hline $\mathrm{NiO}$ & 0 & 0 & 0 & 0 & 0 & 0 & 0 & 0 & 0 & 0 & 0 & 0 & 0 & 0 & 0 \\
\hline $\mathrm{MgO}$ & 0.728 & 0.822 & 0.91 & 0.73 & 0.83 & 0.76 & 1.15 & 0.91 & 1.09 & 0.98 & 0.83 & 0.81 & 0.91 & 0.79 & 0.71 \\
\hline $\mathrm{CaO}$ & 5.611 & 6.416 & 8.31 & 5.83 & 6.41 & 7.51 & 8.48 & 6.91 & 8.92 & 5.08 & 7.34 & 8.02 & 7.76 & 7.39 & 6.41 \\
\hline $\mathrm{Na}_{2} \mathrm{O}$ & 10.281 & 9.852 & 8.23 & 10.15 & 9.65 & 9.01 & 8.66 & 9.48 & 8.22 & 10.61 & 9.29 & 8.7 & 8.98 & 9.04 & 9.71 \\
\hline $\mathrm{K}_{2} \mathrm{O}$ & 0.006 & 0.016 & 0 & 0.02 & 0.07 & 0 & 0.01 & 0.03 & 0.01 & 0.05 & 0 & 0.02 & 0.03 & 0.09 & 0 \\
\hline $\mathrm{ZnO}$ & 0.111 & 0 & 0 & 0 & 0 & 0 & 0 & 0 & 0 & 0 & 0 & 0 & 0 & 0 & 0 \\
\hline $\mathrm{ZrO}_{2}$ & 0.748 & 0.725 & 0.7 & 0.7 & 1.03 & 0.8 & 0.95 & 0.91 & 0.8 & 1.01 & 0.96 & 0.96 & 0.66 & 0.77 & 0.85 \\
\hline Total & 97.55 & 97.93 & 97.88 & 97.24 & 96.44 & 97.76 & 98.23 & 97.7 & 98.75 & 97.6 & 98.01 & 96.55 & 97.79 & 97.73 & 97.67 \\
\hline \multicolumn{16}{|c|}{ Formula estrutural calculada na base de 6 atomos de oxigênio } \\
\hline $\mathrm{TSi}$ & 2.002 & 1.998 & 2.016 & 2 & 1.994 & 1.977 & 1.989 & 1.984 & 1.978 & 1.991 & 1.99 & 1.982 & 1.994 & 2.01 & 1.991 \\
\hline TAl & 0 & 0.002 & 0 & 0 & 0.006 & 0.023 & 0.011 & 0.016 & 0.022 & 0.009 & 0.01 & 0.018 & 0.006 & 0 & 0.009 \\
\hline $\mathrm{TFe}^{3+}$ & 0 & 0 & 0 & 0 & 0 & 0 & 0 & 0 & 0 & 0 & 0 & 0 & 0 & 0 & 0 \\
\hline M1Al & 0.043 & 0.048 & 0.047 & 0.045 & 0.049 & 0.024 & 0.035 & 0.047 & 0.022 & 0.039 & 0.037 & 0.031 & 0.039 & 0.047 & 0.041 \\
\hline M1Ti & 0.029 & 0.025 & 0.022 & 0.023 & 0.021 & 0.025 & 0.021 & 0.025 & 0.021 & 0.028 & 0.023 & 0.028 & 0.025 & 0.023 & 0.024 \\
\hline MIFe $^{3+}$ & 0.667 & 0.643 & 0.499 & 0.673 & $0.65 t$ & 0.63 & 0.585 & 0.632 & 0.576 & 0.709 & 0.625 & 0.597 & 0.595 & 0.573 & 0.651 \\
\hline $\mathrm{M}^{2} \mathrm{Fe}^{2+}$ & 0.182 & 0.2 & 0.349 & 0.176 & 0.19 & 0.245 & 0.247 & 0.206 & 0.287 & 0.13 & 0.23 & 0.251 & 0.249 & 0.272 & 0.212 \\
\hline $\mathrm{M} 1 \mathrm{Cr}$ & 0 & 0 & 0 & 0 & 0 & 0 & 0 & 0 & 0 & 0 & 0 & 0 & 0 & 0 & 0 \\
\hline M1Mg & 0.042 & 0.047 & 0.053 & 0.042 & 0.048 & 0.044 & 0.066 & 0.053 & 0.063 & 0.056 & 0.048 & 0.048 & 0.053 & 0.046 & 0.041 \\
\hline M1Ni & 0 & 0 & 0 & 0 & 0 & 0 & 0 & 0 & 0 & 0 & 0 & 0 & 0 & 0 & 0 \\
\hline M2Mg & 0 & 0 & 0 & 0 & 0 & 0 & 0 & 0 & 0 & 0 & & 0 & 0 & 0 & 0 \\
\hline $\mathrm{M} 2 \mathrm{Fe}^{2+}$ & 0 & 0 & 0 & 0 & 0 & 0 & 0 & 0 & 0 & 0 & 0 & 0 & 0 & 0 & 0 \\
\hline $\mathrm{M} 2 \mathrm{Mn}$ & 0.03 & 0.034 & 0.039 & 0.034 & 0.034 & 0.037 & 0.041 & 0.036 & 0.04 & 0.035 & 0.034 & 0.038 & 0.036 & 0.033 & 0.035 \\
\hline $\mathrm{M} 2 \mathrm{Ca}$ & 0.233 & 0.265 & 0.348 & 0.242 & 0.269 & 0.314 & 0.352 & 0.287 & 0.371 & 0.209 & 0.305 & 0.3 & 0.324 & 0.308 & 0.267 \\
\hline $\mathrm{M} 2 \mathrm{Na}$ & 0.772 & 0.738 & 0.624 & 0.764 & 0.733 & 0.682 & 0.651 & 0.713 & 0.618 & 0.792 & 0.698 & 0.666 & 0.678 & 0.682 & 0.731 \\
\hline M2K & 0 & 0.001 & 0 & 0.001 & 0.004 & 0 & 0 & 0.001 & 0 & 0.002 & 0 & 0.001 & 0.001 & 0.004 & 0 \\
\hline Som_cat & 4 & 3.999 & 4 & 3.999 & 3.996 & 4 & 4 & 3.999 & 4 & 3.998 & 4 & 3.999 & 3.999 & 3.996 & 4 \\
\hline $\mathrm{Ca}$ & 47.746 & 48.58 & 44.101 & 49.059 & 49.68 & 49.087 & 49.857 & 49.352 & 48.687 & 48.63 & 49.427 & 50.196 & 48.939 & 46.731 & 48.136 \\
\hline $\mathrm{Mg}$ & 8.619 & 8.66 & 6.719 & 8.547 & 8.951 & 6.912 & 9.408 & 9.043 & 8.278 & 13.053 & 7.777 & 7.054 & 7.985 & 6.951 & 7.419 \\
\hline $\mathrm{Fe}^{2+}-\mathrm{Mn}$ & 43.635 & 42.76 & & 42.3 & & 44.001 & 40.736 & 41.605 & 43.035 & 38.317 & 42.797 & 42. & 43.076 & 46.3 & 44.445 \\
\hline $\mathrm{Jd1}$ & 3.501 & 3.84 & 3.452 & 3.708 & 3.908 & 1.854 & 2.675 & 3.735 & $\{.668$ & 3.256 & 2.853 & 2.365 & 2.996 & 3.596 & 3.279 \\
\hline Aet & 59.308 & 55.176 & 41.962 & 58.704 & 55.302 & 51.212 & 46.794 & 52.975 & 44.515 & 63.48 & 51.647 & 48.77 & 49.056 & 48.71 & 55.181 \\
\hline CFTS1 & 0 & 0 & 0 & 0 & 0 & 0 & 0 & 0 & 0 & 0 & 0 & 0 & 0 & 0 & 0 \\
\hline CTTS1 & 0 & 0.125 & 0 & 0.022 & 0.468 & 1.759 & 0.861 & 1.232 & 1.59 & 0.743 & 0.745 & 1.342 & 0.446 & 0 & 0.707 \\
\hline CATS1 & 0 & 0 & 0 & 0 & 0 & 0 & 0 & 0 & 0 & 0 & 0 & 0 & 0 & 0 & 0 \\
\hline Wo1 & 18.934 & 21.089 & 25.338 & 19.761 & 21.161 & 22.681 & 25.886 & 21.561 & 26.08 & 16.859 & 23.048 & 24.666 & 24,354 & 23.473 & 20.618 \\
\hline En1 & 3.418 & & & 3.447 & & 3.441 & 5.047 & 4.177 & 4.705 & 4.725 & 3.744 & 3.655 & 4.047 & 3.491 & 3.286 \\
\hline $\mathrm{Fs} 1$ & 14.839 & 15.988 & 25.388 & 14.359 & 15.264 & 19.052 & 18.737 & 16.321 & 21.442 & 10.938 & 17.962 & 19.201 & 19.101 & 20. & 16.928 \\
\hline$Q$ & 0.457 & 0.513 & 0.751 & 0.46 & 0.508 & 0.603 & 0.666 & 0.545 & 0.721 & 0.396 & 0.583 & 0.638 & 0.626 & 0.626 & 0.519 \\
\hline 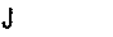 & 1.543 & 1.475 & 1.249 & 1.527 & $\{.467$ & 1.363 & 1.302 & 1.425 & 1.237 & 1.583 & 1.397 & 1.333 & 1.355 & 1.365 & 1.461 \\
\hline Wo1 & 20.164 & 22.322 & 27.026 & 20.774 & 22.558 & 24.721 & 27.276 & 23.646 & 27.726 & 18.385 & 24.549 & 26.651 & 25.751 & 25.008 & 22.123 \\
\hline En1 & 3.64 & 3.979 & 4.118 & 3.619 & 4.064 & 3.481 & & & 4.714 & 4.935 & 3.862 & 3.745 & 4.202 & 3.72 & 3.409 \\
\hline Fs 1 & 76.196 & 73.698 & 68.857 & 75.606 & 73.378 & 71.798 & 67.577 & 72.021 & 67.559 & 76.68 & 71.589 & 69.604 & 70.048 & 71.272 & 74.468 \\
\hline WEF & 24.001 & 27.027 & 38.747 & 24.441 & 26.976 & 31.933 & 35.176 & 28.98 & 38.111 & 21.385 & 30.635 & 33.66 & 32.789 & 32.583 & 27.478 \\
\hline Jd1 & 4.608 & 5.075 & 5.319 & 4.78 & 5.073 & 2.477 & 3.683 & 4.917 & 2.313 & 4.076 & 3.833 & 3.26 & 4.141 & 5.133 & 4.295 \\
\hline Ae1 1 & 71.391 & 67.898 & 55.934 & 70.779 & 67.951 & 65.59 & 61.141 & 66.103 & 59.576 & 74.539 & 65.532 & 63.08 & 63.07 & 62.284 & 68.227 \\
\hline
\end{tabular}


Tabela 15.6 - Composiçăo química de piroxênios de Cerro Boggiani (\% peso)

\begin{tabular}{|c|c|c|c|c|c|c|c|c|c|c|c|c|c|c|}
\hline $\begin{array}{l}\text { Amostras } \\
\text { Análises }\end{array}$ & $\begin{array}{c}\text { RP. } 42 \\
551\end{array}$ & $\begin{array}{c}R P-43 \\
425\end{array}$ & $\begin{array}{c}\mathrm{RP}-43 \\
426\end{array}$ & $\begin{array}{c}\text { RP-43 } \\
427\end{array}$ & $\begin{array}{c}\text { RP-43 } \\
428\end{array}$ & $\begin{array}{c}R P-43 \\
429\end{array}$ & $\begin{array}{c}\text { RP-43 } \\
431\end{array}$ & $\begin{array}{c}\text { RP.43 } \\
432\end{array}$ & $\begin{array}{c}\text { RP.43 } \\
433\end{array}$ & $\begin{array}{c}\text { RP-43 } \\
434\end{array}$ & $\begin{array}{c}R P-43 \\
435\end{array}$ & $\begin{array}{c}\text { RP-43 } \\
436\end{array}$ & $\begin{array}{c}\text { RP-43 } \\
437\end{array}$ & $\begin{array}{c}\text { RP-43 } \\
438\end{array}$ \\
\hline Locaçăo & C4G2m & C1G1m & $\mathrm{C}_{1 \mathrm{G} 2 \mathrm{~m}}$ & C1G3m & $\mathrm{C} 2 \mathrm{G} 1 \mathrm{~m}$ & $\mathrm{C} 2 \mathrm{G} 2 \mathrm{~m}$ & C3GIn & C3G1b & $\mathrm{C} 3 \mathrm{G} 2 \mathrm{~m}$ & C3G3m & C3GAm & C4Gin & CAG1b & C4G2n \\
\hline Mineral & $P x$ & $P x$ & $P x$ & $P x$ & Px & $P x$ & $\mathrm{Px}$ & $P x$ & Px & $P x$ & $P x$ & Px & $P x$ & Px \\
\hline $\mathrm{SiO}_{2}$ & & 51.46 & 51.32 & 51.78 & 51.81 & 51.01 & 51,64 & 51.51 & 50.54 & 51.47 & 52.74 & 51.77 & 51.52 & 51.4 \\
\hline $\mathrm{TiO}_{2}$ & 2 & 0.76 & 0.65 & 0.61 & 0.64 & 0.59 & 0.49 & 0.67 & 0.55 & 0.58 & 0.57 & 0.65 & 0.53 & 0.52 \\
\hline $\mathrm{Al}_{2} \mathrm{O}_{3}$ & 1.35 & 1.27 & 1.05 & 1.19 & 1.33 & 1.28 & 1.17 & 1.07 & 1.23 & 1.27 & 2.4 & 1.15 & 1.29 & 1.35 \\
\hline $\mathrm{FeO}$ & 24.96 & 22.38 & 22.68 & 23.51 & 23.52 & 21.97 & 22.51 & 22.29 & 21.43 & 22.12 & 21.08 & 21.88 & 22.01 & 22.04 \\
\hline $\mathrm{Cr}_{2} \mathrm{O}_{3}$ & 0 & 0 & 0 & 0 & 0 & 0 & 0 & 0 & 0 & 0 & 0 & 0 & 0 & 0 \\
\hline $\mathrm{MnO}$ & 1.3 & 0.75 & 0.74 & 0.69 & 0.59 & 0.64 & 0.71 & 0.72 & 0.61 & 0.66 & 0.73 & 0.82 & 0.61 & 0.67 \\
\hline NiO & 0 & 0 & 0 & 0 & 0 & 0 & 0 & 0 & 0 & 0 & 0 & 0 & 0 & 0 \\
\hline $\mathrm{MgO}$ & 0.92 & 2.71 & 2.63 & 2.27 & 2.46 & 3.04 & 2.89 & 2.87 & 3.31 & 3.12 & 2.96 & 3.34 & 3.35 & 3.4 \\
\hline $\mathrm{CaO}$ & 8.25 & 8.47 & 7.79 & 6.91 & 6.83 & 9.22 & 8.7 & 8.68 & 9.86 & 9.08 & 8.82 & 9.21 & 9.64 & 9.69 \\
\hline $\mathrm{Na}_{2} \mathrm{O}$ & 8.72 & 8.57 & 9 & 9.33 & 9.66 & 8.24 & 8.43 & 8.54 & 7.73 & 8.28 & 8.66 & 8.28 & 8.13 & 7.94 \\
\hline $\mathrm{K}_{2} \mathrm{O}$ & 0.01 & 0.03 & 0.02 & 0.01 & 0 & 0.03 & 0 & 0.02 & 0.03 & 0.05 & 0.03 & 0.01 & 0.04 & 0 \\
\hline $\mathrm{ZnO}$ & 0 & 0 & 0 & 0 & 0 & 0 & 0 & 0 & 0 & 0 & 0 & 0 & 0 & 0 \\
\hline $\mathrm{ZrO}_{2}$ & 0.94 & 0.69 & 0.8 & 0.73 & 0.57 & 0.63 & 0.59 & 0.65 & 0.39 & 0.32 & 0.67 & 0.66 & 0.47 & 0.39 \\
\hline Total & 98.34 & 96.4 & 95.88 & 96.3 & 96.84 & 96.02 & 96.54 & 96.37 & 95.29 & 96.63 & 97.99 & 97.11 & 97.12 & 97.01 \\
\hline \multicolumn{15}{|c|}{ Fórmula estrutural calculada na base de 6 atomos de oxigénio } \\
\hline TSi & 1.973 & 2.005 & 2.005 & 2.015 & 1.998 & 1.994 & 2.01 & 2.006 & 1.994 & 2 & 2.01 & 2 & 1.991 & 1.992 \\
\hline TAI & 0.027 & 0 & 0 & 0 & 0.002 & 0.006 & 0 & 0 & 0.006 & 0 & 0 & 0 & 0.009 & 0.008 \\
\hline $\mathrm{TFe}^{3+}$ & 0 & 0 & 0 & 0 & 0 & 0 & 0 & 0 & 0 & 0 & 0 & 0 & 0 & 0 \\
\hline M†Al & 0.035 & 0.058 & 0.048 & 0.055 & 0.058 & 0.053 & 0.054 & 0.049 & 0.052 & 0.058 & 0.108 & 0.052 & 0.05 & 0.053 \\
\hline$M 4 T i$ & 0.058 & 0.022 & 0.019 & 0.018 & 0.019 & 0.017 & 0.014 & 0.02 & 0.016 & 0.017 & 0.016 & 0.019 & 0.015 & 0.015 \\
\hline $\mathrm{M}^{1} \mathrm{Fe}^{3+}$ & 0.531 & 0.535 & 0.586 & 0.584 & 0.629 & 0.543 & 0.535 & 0.545 & 0.514 & 0.535 & 0.48 & 0.53 & 0.539 & 0.521 \\
\hline $\mathrm{M}^{1} \mathrm{Fe}^{2+}$ & 0.279 & 0.194 & 0.155 & 0.182 & 0.129 & 0.175 & 0.198 & 0.182 & 0.193 & 0.184 & 0.192 & 0.177 & 0.172 & 0.193 \\
\hline $\mathrm{M} 1 \mathrm{Cr}$ & 0 & 0 & 0 & 0 & 0 & 0 & 0 & 0 & 0 & 0 & 0 & 0 & 0 & 0 \\
\hline $\mathrm{M} 1 \mathrm{Mg}$ & 0.053 & 0.157 & 0.153 & 0.132 & 0.141 & 0.177 & 0.168 & 0.167 & 0.195 & 0.181 & 0.168 & 0.192 & 0.193 & 0.196 \\
\hline M1Ni & 0 & 0 & 0 & 0 & 0 & 0 & 0 & 0 & 0 & 0 & 0 & 0 & 0 & 0 \\
\hline M2Mg & 0 & 0 & 0 & 0 & 0 & 0 & 0 & 0 & 0 & 0 & 0 & 0 & 0 & 0 \\
\hline $\mathrm{M} 2 \mathrm{Fe}^{2+}$ & 0 & 0 & 0 & 0 & 0 & 0 & 0 & 0 & 0 & 0 & 0 & 0 & 0 & 0 \\
\hline M2Mn & 0.043 & 0.025 & 0.024 & 0.023 & 0.019 & 0.021 & 0.023 & 0.024 & 0.02 & 0.022 & 0.024 & 0.027 & 0.02 & 0.022 \\
\hline $\mathrm{M} 2 \mathrm{Ca}$ & 0.343 & 0.354 & 0.326 & 0.288 & 0.282 & 0.386 & 0.363 & 0.362 & 0.417 & 0.378 & 0.36 & 0.381 & 0.399 & 0.402 \\
\hline $\mathrm{M} 2 \mathrm{Na}$ & 0.656 & 0.648 & 0.682 & 0.704 & 0.722 & 0.625 & 0.636 & 0.645 & 0.591 & 0.624 & 0.64 & 0.62 & 0.609 & 0.597 \\
\hline M2K & 0 & 0.001 & 0.001 & 0 & 0 & 0.001 & 0 & 0.001 & 0.002 & 0.002 & 0.001 & 0 & 0.002 & 0 \\
\hline Som_cat & 4 & 3.999 & 3.999 & 4 & 4 & 3.999 & 4 & 3.999 & 3.998 & 3.998 & 3.999 & 4 & 3.998 & 4 \\
\hline $\mathrm{Ca}$ & 47.787 & 48.465 & 49.506 & 46.169 & 49.33 & 50.85 & 48.245 & 49.341 & 50.536 & 49.451 & 48.419 & 49.027 & 50.897 & 49.428 \\
\hline $\mathrm{Mg}$ & 7.415 & 21.575 & 23.255 & 21.103 & 24.722 & 23.328 & 22.299 & 22.7 & 23.605 & 23.642 & 22.609 & 24.738 & 24.61 & 24.131 \\
\hline $\mathrm{Fe}^{2+}+\mathrm{Mn}$ & 44.799 & 29.96 & 27.239 & 32.727 & 25.948 & 25.822 & 29.456 & 27.96 & 25.859 & 26.907 & 28.971 & 26.235 & 24.493 & 26.441 \\
\hline Jd1 & 2.635 & 4.305 & 3.668 & 4.176 & 4.551 & 3.914 & 3.929 & 3.619 & 3.686 & 4.219 & 7.911 & 3.815 & 3.623 & 3.841 \\
\hline Ae1 & 46.672 & 43.632 & 48.177 & 49.776 & 52.097 & 41.976 & 42.686 & 44.007 & 38.745 & 41.53 & 39.194 & 41.446 & 40.812 & 39.125 \\
\hline CFTS1 & 0 & 0 & 0 & 0 & 0 & 0 & 0 & 0 & 0 & 0 & 0 & 0 & 0 & 0 \\
\hline CTTS1 & 1.998 & 0 & 0 & 0 & 0.186 & 0.405 & 0 & 0 & 0.404 & 0.026 & 0 & 0 & 0.645 & 0.596 \\
\hline CATS1 & 0 & 0 & 0 & 0 & 0 & 0 & 0 & 0 & 0 & 0 & 0 & 0 & 0 & 0 \\
\hline W01 & 23.76 & 26.119 & 24.76 & 22.064 & 21.945 & 27.899 & 26.583 & 26.706 & 29.426 & 27.586 & 26.449 & 27.796 & 28.375 & 28.378 \\
\hline Ent & 3.997 & 11.627 & 11.631 & 10.085 & 11.091 & 12.985 & 12.287 & 12.286 & 13.933 & 13.201 & 12.35 & 14.026 & 14.032 & 14.145 \\
\hline Fst & 20.938 & 14.318 & 11.764 & 13.898 & 10.13 & 12.82 & 14.515 & 13.382 & 13.805 & 13.437 & 14.095 & 12.918 & 12.513 & 13.915 \\
\hline$Q$ & 0.675 & 0.705 & 0.634 & 0.601 & 0.553 & 0.738 & 0.728 & 0.71 & 0.805 & 0.743 & 0.72 & 0.751 & 0.764 & 0.792 \\
\hline J & 1.313 & 1.295 & 1.364 & 9.408 & 1.444 & 1.249 & 1.272 & 1.29 & 1.183 & 1.247 & 1.28 & 1.241 & 1.218 & 1.193 \\
\hline Wo1 & 27,463 & 27.952 & 26.196 & 23.857 & 23.489 & 29.642 & 28.199 & 28.328 & 31.129 & 29.095 & 29.43 & 29.16 & 30.16 & 30.137 \\
\hline En1 & 4.261 & 12.444 & 12.306 & 10.905 & 11.771 & 13.599 & 13.033 & $\{3.033$ & 14.54 & 13.91 & 13.742 & 14.714 & 14.583 & $\uparrow 4.7 \uparrow 3$ \\
\hline Fs1 & 68.276 & 59.605 & 61.498 & 65.239 & 64.74 & 56.759 & 58.768 & 58.639 & 54.331 & 56.995 & 56.828 & 56.126 & 55.257 & 55.151 \\
\hline WEF & 35.358 & 36.038 & 32.571 & 30.709 & 28.366 & 37.809 & 37.147 & 36.27 & 41.084 & 37.991 & 36.755 & 38.531 & 39.159 & 40.552 \\
\hline Jd1 & 4.006 & 6.278 & 5.135 & 5.921 & 6.047 & 5.565 & 5.73 & 5.269 & 5.364 & 6.044 & 11.593 & 5.525 & 5.147 & 5.52 \\
\hline Ae1 & 60.636 & 57.684 & 62.294 & 63.369 & 65.587 & 56.626 & 57.123 & 58.461 & 53.552 & 55.965 & 51.652 & 55.944 & 55.693 & 53.928 \\
\hline
\end{tabular}
Observaçōes de abreviaçōes como na tabela 15.0 
Tabela 15.7 - Composiçăo quimica de piroxênios de Cerro Boggiani (\% peso)

\begin{tabular}{|c|c|c|c|c|c|c|c|c|c|c|c|c|c|}
\hline Amostras & RP-43 & RP-43 & RP-43 & RP-43 & RP.43 & RP-43 & RP-43 & RP-43 & RP-43 & RP-43 & RP-43 & RP-43 & RP-43 \\
\hline Análises & 439 & 440 & 441 & 442 & 444 & 445 & 446 & 447 & 507 & 508 & 509 & 510 & 511 \\
\hline Locação & C5G1n & C5G1b & $\mathrm{C} 6 \mathrm{G} 1 \mathrm{~m}$ & C6G1n & C7Gin & C7G1b & $\mathrm{C} 7 \mathrm{G} 2 \mathrm{~m}$ & C7G3m & C3G5m & $\mathrm{C} 3 \mathrm{G} 6 \mathrm{Fn}$ & $\mathrm{C} 3 \mathrm{G} 6 \mathrm{Fb}$ & $\mathrm{C} 4 \mathrm{G} 3 \mathrm{~m}$ & $C 4 G 4 n$ \\
\hline Mineral & $P x$ & Px & $P x$ & $P_{x}$ & $P x$ & $P x$ & $P x$ & $P x$ & $P x$ & Px & Px & $P x$ & $P_{x}$ \\
\hline $\mathrm{SiO}_{2}$ & 51.72 & 50.16 & 51.4 & 51.1 & 51.7 & 51.78 & 51.44 & 51.57 & 50.96 & 51.69 & 51.22 & 51.63 & 51.46 \\
\hline $\mathrm{TiO}_{2}$ & 0.65 & 0.93 & 0.51 & 0.67 & 1.21 & 1.09 & 0.5 & 1.21 & 0.61 & 0.47 & 0.37 & 0.73 & 0.44 \\
\hline $\mathrm{Al}_{2} \mathrm{O}_{3}$ & 1.19 & 1.44 & 1.16 & 1.14 & 0.86 & 1.08 & 1.17 & 0.97 & 1.11 & 1.36 & 1.12 & 1.18 & 1.22 \\
\hline $\mathrm{FeO}$ & 23.66 & 22.6 & 23.04 & 22.23 & 22.53 & 23.04 & 22.87 & 22.84 & 22.33 & 23.77 & 23.88 & 23.11 & 22.46 \\
\hline $\mathrm{Cr}_{2} \mathrm{O}_{3}$ & 0 & 0 & 0 & 0 & 0 & 0 & 0 & 0 & 0.02 & 0.01 & 0 & 0.03 & 0 \\
\hline Mino & 0.63 & 0.43 & 0.8 & 0.71 & 0.68 & 0.62 & 0.67 & 0.67 & 1.14 & 0.96 & 0.09 & 0.96 & 1.14 \\
\hline $\mathrm{NiO}$ & 0 & 0 & 0 & 0 & 0 & 0 & 0 & 0 & 0 & 0 & 0 & 0 & 0 \\
\hline $\mathrm{MgO}$ & 2.11 & 1.79 & 2.74 & 3.16 & 2.76 & 3.04 & 2.68 & 2.68 & 3.24 & 2.13 & 2.35 & 2.57 & 3.57 \\
\hline $\mathrm{CaO}$ & 6.31 & 6.09 & 8.33 & 8.9 & 6.42 & 8.43 & 8.05 & 7.3 & 9.46 & 6.63 & 6.93 & 7.6 & 9.68 \\
\hline $\mathrm{Na}_{2} \mathrm{O}$ & 10.06 & 10.39 & 8.91 & 8.32 & 9.71 & 8.79 & 8.99 & 9.5 & 7.92 & 9.59 & 9.22 & 9.45 & 8.09 \\
\hline $\mathrm{K}_{2} \mathrm{O}$ & 0 & 0 & 0.03 & 0 & 0.02 & 0 & 0.03 & 0.27 & 0 & 0 & 0 & 0.02 & 0 \\
\hline $\mathrm{ZnO}$ & 0 & 0 & 0 & 0 & 0 & 0 & 0 & 0 & 0 & 0 & 0 & 0 & 0 \\
\hline $\mathrm{ZrO}_{2}$ & 0.57 & 0.51 & 0.66 & 0.77 & 2.07 & 1.08 & 0.71 & 0.86 & 0 & 0 & 0 & 0 & 0 \\
\hline Total & 96.33 & 93.83 & 96.92 & 96.23 & 95.89 & 97.87 & 96.4 & 97.01 & 96.79 & 96.61 & 95.18 & 97.28 & 98.06 \\
\hline \multicolumn{14}{|c|}{ Fórmula estrutural calculada na base de 6 atomos de oxigênio } \\
\hline TSi & 2.002 & 1.983 & 1.988 & 1.994 & 2.01 & 1.986 & 1.998 & 1.986 & 1.985 & 2.003 & 2.015 & 1.985 & 1.972 \\
\hline TAI & ( & 0.017 & 0.012 & 0.006 & 0 & 0.014 & 0.002 & 0.014 & 0.015 & 0 & 0 & 0.015 & 0.028 \\
\hline $\mathrm{TFe}^{3+}$ & 0 & 0 & 0 & 0 & 0 & 0 & 0 & 0 & 0 & 0 & 0 & 0 & 0 \\
\hline MIAl & 0.054 & 0.05 & 0.041 & 0.046 & 0.039 & 0.035 & 0.052 & 0.03 & 0.036 & 0.062 & 0.052 & 0.038 & 0.028 \\
\hline MITi & 0.019 & 0.028 & 0.015 & 0.02 & 0.035 & 0.031 & 0.015 & 0.035 & 0.018 & 0.014 & 0.011 & 0.021 & 0.013 \\
\hline $11 \mathrm{Fe}^{3+}$ & 0.659 & 0.707 & 0.611 & 0.55 & 0.603 & 0.569 & 0.599 & 0.637 & 0.541 & 0.624 & 0.599 & 0.639 & 0.576 \\
\hline $\mathrm{M}_{1} \mathrm{Fe}{ }^{2+}$ & 0.107 & 0.04 & 0.134 & 0.175 & 0.13 & 0.17 & 0.143 & 0.099 & 0.186 & 0.146 & 0.187 & 0.104 & 0.144 \\
\hline $\mathrm{M} 1 \mathrm{Cr}$ & 0 & 0 & 0 & 0 & 0 & 0 & 0 & 0 & 0.001 & 0 & 0 & 0.001 & 0 \\
\hline $\mathrm{M} 1 \mathrm{Mg}$ & 0.122 & 0.106 & 0.158 & 0.184 & 0.16 & 0.174 & 0.155 & 0.154 & 0.188 & 0.123 & 0.138 & 0.147 & 0.204 \\
\hline MINi & 0 & 0 & 0 & 0 & 0 & 0 & 0 & 0 & 0 & 0 & 0 & 0 & 0 \\
\hline $\mathrm{M} 2 \mathrm{Mg}$ & 0 & 0 & 0 & c & 0 & 0 & 0 & 0 & 0 & c & 0 & 0 & 0 \\
\hline $\mathrm{M} 2 \mathrm{Fe}^{2+}$ & 0 & 0 & 0 & 0 & 0 & 0 & 0 & 0 & 0 & 0 & 0 & 0 & 0 \\
\hline M2Mn & 0.021 & 0.014 & 0.026 & 0.023 & 0.022 & 0.02 & 0.022 & 0.022 & 0.038 & 0.032 & 0.003 & 0.031 & 0.037 \\
\hline $\mathrm{M} 2 \mathrm{Ca}$ & & & & 72 & 267 & 0.346 & 0.335 & 0.301 & 0.39 & 0.275 & 0.292 & 0.313 & 0.398 \\
\hline $\mathrm{M} 2 \mathrm{Na}$ & 0.755 & 0.797 & 0.668 & 0.629 & 732 & 0.654 & 0.677 & 0.709 & 0.598 & 0.721 & 0.703 & 0.704 & 0.601 \\
\hline M2K & 0 & 0 & 0.001 & 0 & & 0 & 0.001 & 0.013 & 0 & 0 & 0 & 0.001 & 0 \\
\hline Som_cat & 4 & 4 & 3.999 & 4 & 3.999 & 4 & 3.999 & 3.987 & 4 & 4 & 4 & 3.999 & 4 \\
\hline $\mathrm{Ca}$ & 51.216 & 61.72 & 52.016 & 49.298 & 46.144 & 48.78 & 51.095 & 52.305 & 48.944 & 47.809 & 47.152 & 52.585 & 50.785 \\
\hline $\mathrm{Mg}$ & 23.829 & 25.241 & 23.806 & 24.354 & 27,602 & 24.476 & 23.668 & 26.718 & 23.324 & 21.3 & 22.248 & 24.742 & 26.06 \\
\hline $\mathrm{Fe}^{2+} \mathrm{Mn}$ & 24.954 & 13.039 & 24.177 & 26.347 & 26.254 & 26.744 & 25.237 & 20.977 & 27.733 & & 30.6 & 22.673 & 23.155 \\
\hline Jd1 & 4.356 & 4.204 & 3.125 & 394 & 3.052 & 2.613 & 3.934 & 2.341 & & & & 3.004 & 2.044 \\
\hline Aet & 56.274 & 62.167 & 48.1 & 42.866 & 3.763 & 46.036 & 47.779 & 54.264 & 41.145 & 52.063 & 49.358 & 52.565 & 42.592 \\
\hline CFTS1 & 0 & 0 & 0 & 0 & 0 & 0 & 0 & 0 & 0 & 0 & 0 & 0 & 0.148 \\
\hline CTTS1 & 0 & 1.383 & 0.918 & 0.456 & 0 & 1.018 & 0.145 & 1.105 & 1.118 & 0 & 0 & 1.205 & 0.942 \\
\hline CATS1 & 0 & 0 & 0 & 0 & 0 & 0 & 0 & 0 & 0 & 0 & 0 & 0 & 0 \\
\hline Wo1 & 21.014 & 20.113 & 25.491 & 26.887 & 20.729 & 24.763 & 25.386 & 22.488 & 27.759 & 21.763 & 22.132 & 23.455 & 28.422 \\
\hline Ent & 9.777 & 8.791 & 12.087 & 13.508 & 12.399 & & 11.826 & 12.052 & & & & 11.603 & 15.144 \\
\hline Fs1 & & & & & & & 10.93 & 7.75 & 13.611 & 11.538 & 14.136 & 8.17 & 10.708 \\
\hline$Q$ & & & & 0.731 & & 0.69 & 0.634 & 0.554 & 0.769 & 0.544 & 0.617 & 0.564 & 0.746 \\
\hline J & 1.51 & & 1.336 & 1.259 & 1.464 & 1.308 & 1.354 & 1.419 & 1.196 & 1.441 & 1.407 & 1.409 & 1.203 \\
\hline Wo1 & 22.367 & & 27.082 & 28.517 & 22.619 & 27.077 & 26.691 & 24.842 & 29.289 & 22.936 & 23.971 & 25.356 & 29.263 \\
\hline En1 & 10.406 & 9.377 & 12.395 & 14.088 & 13.53 & 13.586 & 12.364 & 12.689 & 13.957 & 10.253 & 11.31 & 11.93 & 15.016 \\
\hline$F_{s 1}$ & 67.227 & 67.695 & 60.524 & 57.395 & 63.851 & 59.337 & 60.945 & 62.469 & 56.754 & & 64.719 & 62.714 & 55.721 \\
\hline WEF & 25.281 & 20.785 & 33.18 & 37.48 & 28.36 & 35.199 & 32.623 & 28.871 & 40.272 & 28.547 & 30.575 & 29.703 & 39.428 \\
\hline Jd1 & 5.682 & 5.275 & 4. 187 & 4.843 & 4.393 & 3.764 & 5.342 & 3.189 & 3.689 & 6.46 & 5.534 & 3.957 & 2.765 \\
\hline Ae1 & 69.036 & 73.941 & 62.633 & 57.677 & 67.247 & 61.037 & 62.035 & 67.94 & 56.039 & 64.993 & 63.891 & 66.34 & 57.807 \\
\hline
\end{tabular}




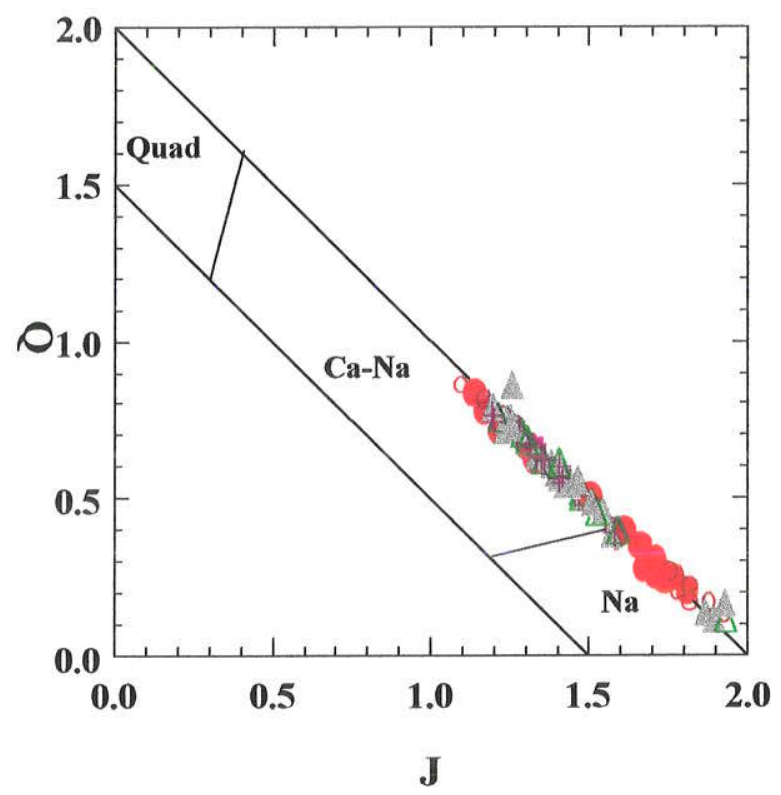

Figura 42- Composição dos piroxênios das rochas de Cerro Boggiani no diagrama Q-J de classificação do IMA (Morimoto, 1989). Estão representados os seguintes litotipos: sienito nefelínicos (círculos) e fonolitos peralcalinos (triângulos).

Símbolos: núcleos de fenocristais e de outros grãos em sienitos nefelínicos (círculos preenchidos); bordas de fenocristais e outros grãos em sienitos nefelínicos (círculos vazios); núcleos de fenocristais e outros grãos em fonolitos peralcalinos (triângulos preenchidos), bordas de fenocristais e outros grãos em rochas fonolíticas (triângulos vazios) grãos pertencentes à matriz da rocha (cruzes) e inclusões (xis);borda de reação (quadrado semi-cheio)

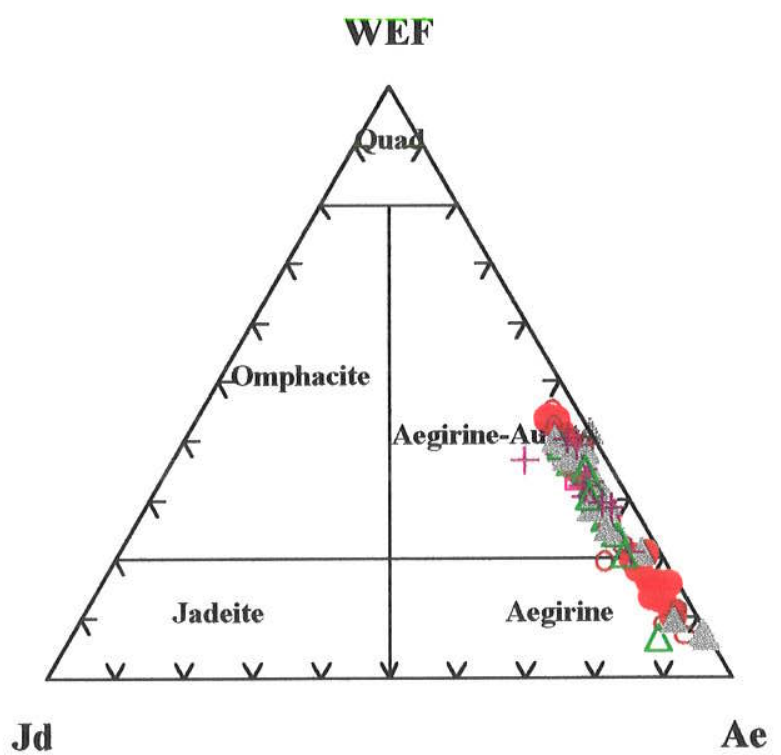

Figura 43 Locação dos piroxênios de Cerro Boggiani no diagrama WEF-Jd-Ae. Simbolos como na figura 42. 


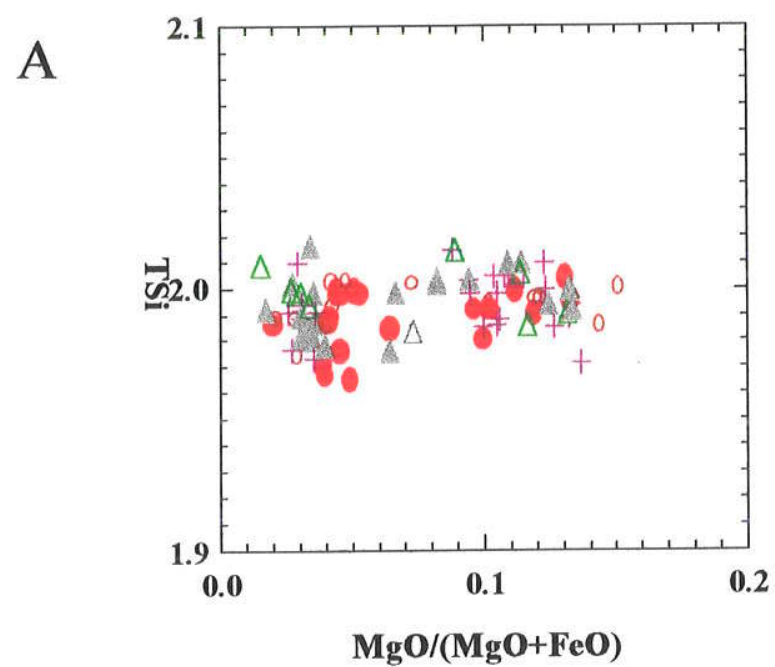

B
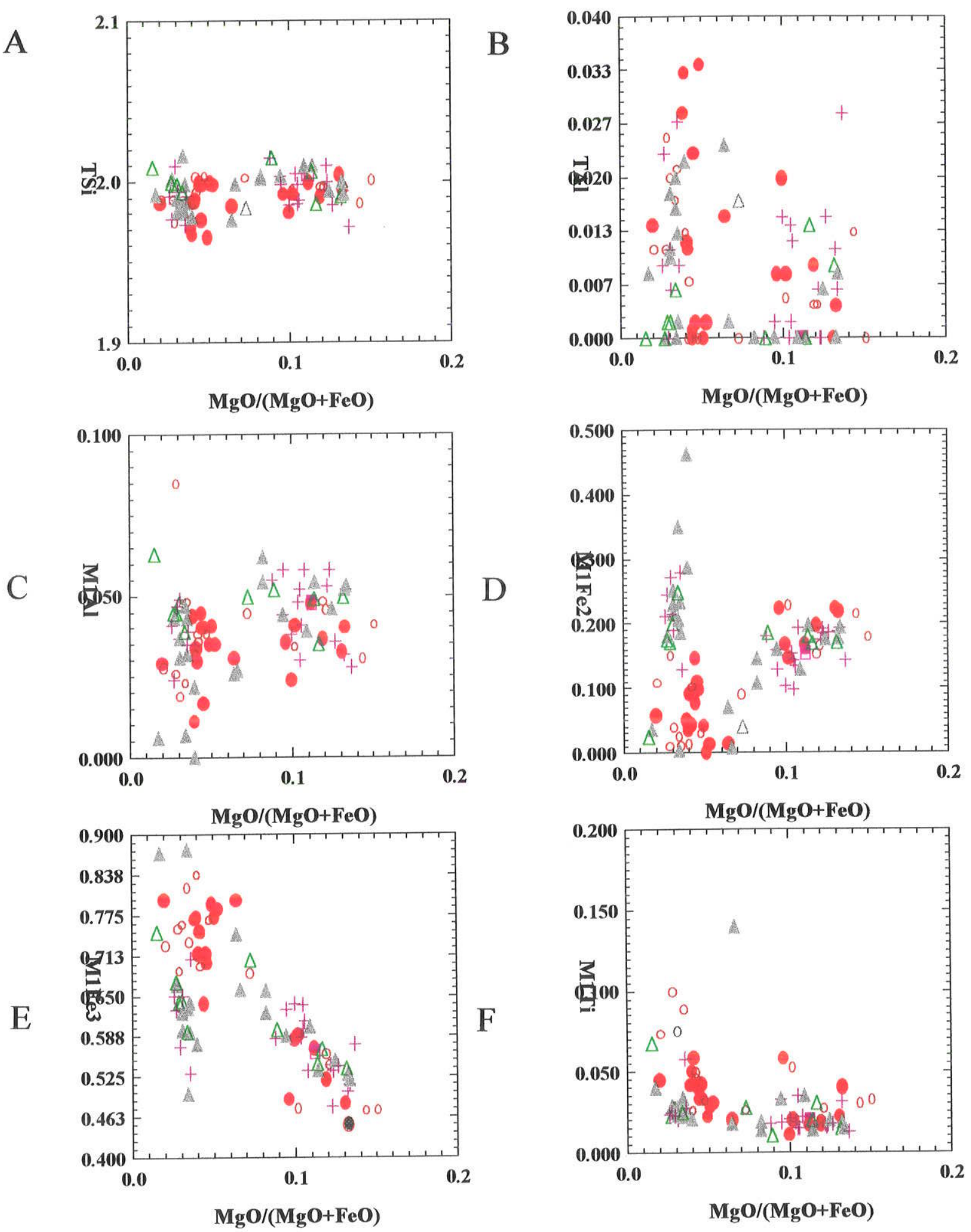

Figura 44 (A, B, C, D, E e F) Diagramas de variação composicional de piroxênios das rochas de Cerro Boggiani. Símbolos como na figura 42. 

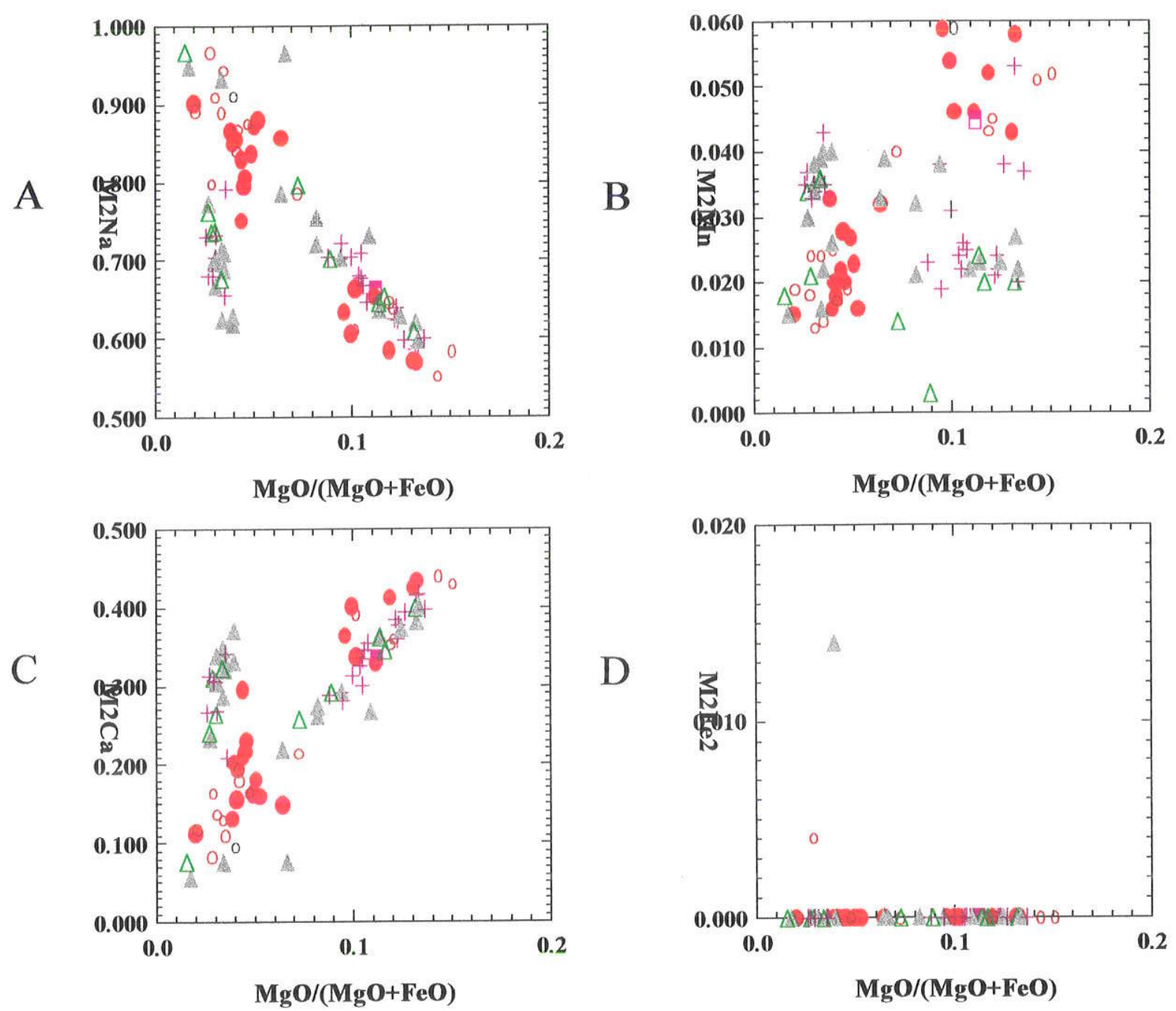

Figuras 45 (A, B, C e D) - Diagramas de variação composicional dos piroxênios de Cerro Boggiani. Símbolos como na Figura 42. 


\section{V.4.2 - Cerro Siete Cabezas e Corpos Satélites I e II}

Os piroxênios analisados no Complexo Alcalino Siete Cabezas são oriundos exclusivamente de nefelina sienitos, no estanto, encontram-se ainda agrupados sob esta denominação, os sienitos alcalinos provenientes dos corpos Satélite 1 e Satélite II, geograficamente associados.

Os resultados analíticos dos piroxênios dessas rochas estão disponibilizados nas tabelas 15.8 a 15.14, perfazendo um total correspondente a 78 análises.

Contrariamente às amostras de Cerro Boggiani, os piroxênios das rochas de Siete Cabezas não demonstram enriquecimento em $\mathrm{TiO}_{2}$ cujos valores raramente excedem a $1 \%$ de porcentagem de peso. Comportamento similar é creditado ao $\mathrm{Al}_{2} \mathrm{O}_{3}$ onde os teores esporadicamente atingem a $1,7 \%$. Os teores de $\mathrm{Na}_{2} \mathrm{O}$ das amostras de Satélite I situam-se entre 0,6 e 6,6\%, valores similares aos exibidos pelo corpo principal, diferentemente do corpo Satélite II que apresentam concentrações médias de $9 \%$.

Os piroxênios das rochas do Complexo Cerro Siete Cabezas coincidem indistintamente do tipo petrográfico, com os domínios do Quad e Cálcico-Sódicos do diagrama Q-J da Figura 46-A. Os piroxênios do campo do Quad têm composição de salita e ferrossalita (Figura 46-B), enquanto que os cálcico-sódicos correspondem às egirina-augitas (Figura 46-C).

As posições tetraédricas estão quase totalmente ocupadas por $\mathrm{Si}$ e ocasionalmente por $\mathrm{Al}$, sendo definida correlação negativa de Si e positiva de Al em relação ao índice de diferenciação (Figuras 47-A e B). Os sítios octaédricos regulares (M1) estão preferencialmente preenchidos por $\mathrm{Al}, \mathrm{Ti}, \mathrm{Fe}^{2+}$ e $\mathrm{Fe}^{3+}$, enquanto os irregulares (M2) por $\mathrm{Mn}, \mathrm{Ca} e \mathrm{Fe}^{2+}$.

A observação dos diagramas contidos nas figuras 47-C, D, E e F e ainda dos das figuras 48-A, B, C e D indicam que os piroxênios dos nefelina sienitos do corpo maior são mais enriquecidos em $\mathrm{Fe}^{2+}, \mathrm{Ti}, \mathrm{Mn}$ e $\mathrm{Ca}$, sendo muito mais evoluídos do que os dos corpos satélites (Satélite I e Satélite II), representados por sienitos 
alcalinos. Estes, apresentam-se menos diferenciados do que os nefelina sienitos oriundos do corpo principal. 


\begin{tabular}{|c|c|c|c|c|c|c|c|c|c|c|c|c|c|c|}
\hline Amostras & RP-44 & RP-44 & RP-45 & RP-45 & RP-45 & RP-45 & RP-45 & $R P-45$ & RP-45 & RP-45 & RP-45 & $R P-45$ & RP-45 & $R P-45$ \\
\hline Anállses & 100 & 103 & 108 & 108 & 109 & 110 & 111 & 112 & 113 & 114 & $\$ 15$ & 128 & 129 & 130 \\
\hline Locação & C1G1Fn & $\mathrm{C} 2 \mathrm{G} 1 \mathrm{Fb}$ & C1Gin & C1G2n & $\mathrm{C}_{1 \mathrm{G} 2 \mathrm{~b}}$ & C2G1n & $\mathrm{C} 2 \mathrm{G} 1 \mathrm{~b}$ & C3G1n & C3G1b & C5G1n & $\mathrm{C} 5 \mathrm{G} 1 \mathrm{~b}$ & $\mathrm{C} 2 \mathrm{G} 2 \mathrm{~m}$ & C1G1n & C1G1b \\
\hline Mineral & $P x$ & $P x$ & Px & Px & $P x$ & Px & Px & $P x$ & $P x$ & $P x$ & Px & $P x$ & $P x$ & $P x$ \\
\hline $\mathrm{SiO}_{2}$ & 51.343 & 51.285 & 51.101 & 51.101 & 50.992 & 50.737 & 51.321 & 51.502 & 51.432 & 51.207 & 50.79 & 51.863 & 50.262 & 51.079 \\
\hline $\mathrm{TiO}_{2}$ & 0.662 & 0.661 & 0.214 & 0.214 & 0.192 & 0.184 & 0.188 & 0.096 & 0.145 & 0.269 & 0.287 & 0.312 & 0.154 & 0.251 \\
\hline $\mathrm{Al}_{2} \mathrm{O}_{3}$ & 1.075 & 1.073 & 0.224 & 0.224 & 0.262 & 0.363 & 0.215 & 0.241 & 0.25 & 0.239 & 0.663 & 0.319 & 0.237 & 0.247 \\
\hline $\mathrm{FeO}$ & 25.04 & 22.483 & 29.584 & 29.584 & 29.401 & 29.309 & 29.302 & 29.39 & 29.062 & 28.86 & 28.765 & 29.008 & 29.26 & 29.358 \\
\hline $\mathrm{Cr}_{2} \mathrm{O}_{3}$ & 0 & 0 & 0 & 0 & 0 & 0 & 0 & 0 & 0 & 0.008 & 0 & 0 & 0 & 0.02 \\
\hline Mno & 1.399 & 1.397 & 1.791 & 1.791 & 1.757 & 1.934 & 1.732 & 1.777 & 1.751 & 1.429 & 1.588 & 1.653 & 1.776 & 1.739 \\
\hline NiO & 0.005 & 0.005 & 0 & 0 & 0 & 0.013 & 0 & 0.036 & 0 & 0 & 0 & 0.002 & 0 & 0.045 \\
\hline $\mathrm{MgO}$ & 2.515 & 2.511 & 0.269 & 0.269 & 0.266 & 0.254 & 0.255 & 0.285 & 0.226 & 0.353 & 0.365 & 0.106 & 0.281 & 0.248 \\
\hline $\mathrm{CaO}$ & 7.629 & 7.619 & 5.341 & 5.341 & 5.638 & 5.657 & 5.948 & 5.619 & 5.407 & 5.348 & 4.542 & 4.735 & 5.279 & 5.073 \\
\hline $\mathrm{Na}_{2} \mathrm{O}$ & 8.926 & 8.893 & 9.792 & 9.792 & 9.569 & 9.597 & 9.493 & 9.706 & 9.71 & 9.854 & 10.117 & 10.172 & 9.66 & 9.82 \\
\hline $\mathrm{K}_{2} \mathrm{O}$ & 0 & 0 & 0 & 0 & 0 & 0.001 & 0 & 0.003 & 0.002 & 0 & 0.009 & 0 & 0.003 & 0.002 \\
\hline Zno & 0.142 & 0.141 & 0.066 & 0.066 & 0.034 & 0.039 & 0.081 & 0.042 & 0.074 & 0.068 & 0.031 & 0.058 & 0.065 & 0.063 \\
\hline $\mathrm{ZrO}_{2}$ & 0 & 0 & 0 & 0 & 0 & & 0 & 0 & 0 & 0 & 0 & 0.243 & 0.167 & 0.196 \\
\hline Total & 98.74 & 96.07 & 98.38 & 98.38 & 98.11 & 98.09 & 98.54 & 98.7 & 98.06 & 97.63 & 97.16 & 98.23 & 96.98 & 97.94 \\
\hline \multicolumn{15}{|c|}{ Fórmula estrutural calculada na base de 6 átomos de oxigénio } \\
\hline $\mathrm{TSi}$ & 2.007 & 2.008 & 1.987 & 1.987 & 1.99 & 1.98 & 1.996 & 1.995 & 2.005 & 2 & 1.987 & 2.012 & 1.982 & 1.994 \\
\hline TAI & 0 & 0 & 0.01 & 0.01 & 0.01 & 0.017 & 0.004 & 0.005 & 0 & 0 & 0.013 & 0 & 0.011 & 0.006 \\
\hline $\mathrm{TFe}^{3+}$ & 0 & 0 & 0.003 & 0.003 & 0 & 0.004 & 0 & 0 & 0 & 0 & 0 & 0 & 0 & 0 \\
\hline M1AI & 0.049 & 0.049 & 0 & 0 & 0.002 & 0 & 0.006 & 0.006 & 0.011 & 0.011 & 0.018 & 0.015 & 0 & 0.005 \\
\hline M1Ti & 0.019 & 0.019 & 0.006 & 0.006 & 0.006 & 0.005 & 0.005 & 0.003 & 0.004 & 0.008 & 0.008 & 0.009 & 0.005 & 0.007 \\
\hline $\mathrm{MiFe}^{3+}$ & 0.573 & 0.571 & 0.739 & 0.739 & 0.721 & 0.736 & 0.703 & 0.722 & 0.703 & 0.719 & 0 & 0 & 0 & 0 \\
\hline $\mathrm{MIFe}^{2+}$ & 0.163 & 0.165 & 0.22 & 0.22 & 0.238 & 0.217 & 0.25 & 0.23 & 0.244 & 0.224 & 0.941 & 0.941 & 0.965 & 0.958 \\
\hline $\mathrm{M} 1 \mathrm{Cr}$ & 0 & 0 & 0 & 0 & 0 & 0 & 0 & 0 & 0 & 0 & 0 & 0 & 0 & 0.001 \\
\hline $\mathrm{M} 1 \mathrm{Mg}$ & 0.147 & 0.147 & 0.016 & 0.016 & 0.015 & 0.015 & 0.015 & 0.016 & 0.013 & 0.021 & 0.021 & 0.006 & 0.017 & 0.014 \\
\hline MiNi & 0 & 0 & 0 & 0 & 0 & 0 & 0 & 0.001 & 0 & 0 & 0 & 0 & 0 & 0.001 \\
\hline M2Mg & 0 & 0 & 0 & 0 & 0 & 0 & 0 & 0 & 0 & 0 & 0 & 0 & 0 & 0 \\
\hline $\mathrm{M}^{2} \mathrm{Fe}^{2+}$ & 0 & 0 & 0 & 0 & 0 & 0 & 0 & 0 & 0 & 0 & 0 & 0 & 0 & 0 \\
\hline M2Mn & 0.046 & 0.046 & 0.059 & 0.059 & 0.058 & 0.064 & 0.057 & 0.058 & 0.058 & 0.047 & 0.053 & 0.054 & 0.059 & 0.057 \\
\hline $\mathrm{M} 2 \mathrm{Ca}$ & 0.319 & 0.32 & 0.222 & 0.222 & 0.236 & 0.237 & 0.248 & 0.233 & 0.226 & 0.224 & 0.19 & 0.197 & 0.223 & 0.212 \\
\hline $\mathrm{M} 2 \mathrm{Na}$ & 0.676 & 0.675 & 0.738 & 0.738 & 0.724 & 0.726 & 0.716 & 0.729 & 0.734 & 0.746 & 0.768 & 0.765 & 0.739 & 0.743 \\
\hline M2K & 0 & 0 & 0 & 0 & 0 & 0 & 0 & 0 & 0 & 0 & 0 & 0 & 0 & 0 \\
\hline Som_cat & 4 & 4 & 4 & 4 & 4 & 4 & 4 & 4 & 4 & 4 & 4 & 4 & 4 & 4 \\
\hline $\mathrm{Ca}$ & 47.297 & 47.2 & 43.061 & 43.061 & 43.06 & 44.415 & 43.503 & 43.317 & 41.734 & 43.422 & 15.794 & 16.423 & 17.648 & 17.076 \\
\hline Mg & 21.695 & 21.644 & 3.018 & 3.018 & 2.827 & 2.775 & 2.595 & 3.057 & 2.427 & 3.988 & 1.766 & 0.512 & 1.307 & 1.162 \\
\hline $\mathrm{Fe}^{2+} \mathrm{Mn}$ & 31.008 & 31.155 & 53.921 & 53.921 & 54.113 & 52.81 & 53.902 & 53.626 & 55.839 & 52.591 & 82.44 & 83.065 & 81.045 & 81.762 \\
\hline Jd1 & 3.79 & 3.788 & 0 & 0 & 0.142 & 0 & 0.476 & 0.531 & 0.943 & 0.905 & 0.932 & 0.763 & 0 & 0.259 \\
\hline $\mathrm{Ae} 1$ & 48.022 & 47.909 & 61.728 & 61.728 & 59.529 & 60.781 & 57.794 & 59.769 & 59.356 & 60.546 & 39.049 & 39.314 & 38.017 & 38.291 \\
\hline CFTS1 & 0 & 0 & 0.076 & 0.076 & 0 & 0.787 & 0 & 0 & 0 & 0 & 0 & 0 & 0 & 0 \\
\hline CTTS1 & 0 & 0 & 0.523 & 0.523 & 0.464 & 0.452 & 0.326 & 0.231 & 0 & 0 & 0.44 & 0 & 0.235 & 0.33 \\
\hline CATS1 & 0 & 0 & 0 & 0 & 0 & 0 & 0 & 0 & 0 & 0 & 0 & 0 & 0 & 0 \\
\hline Wo1 & 24.469 & 24.474 & 18.005 & 18.005 & 18.962 & 18.556 & $\uparrow 9.848$ & 19.054 & 18.551 & 18.429 & 9.472 & 10.308 & 11.242 & 10.672 \\
\hline Ent & 11.224 & 11.223 & 1.304 & 1.304 & 1.275 & 1.237 & 1.203 & 1.361 & 1,079 & 1.692 & 1.108 & 0.321 & 0.85 & 0.748 \\
\hline Fs1 & 12.495 & 12.607 & 18.364 & 18.364 & 19.627 & 18.187 & 20.352 & 19.054 & 20.071 & 18.427 & 48.999 & 49.293 & 49.655 & 49.7 \\
\hline$Q$ & 0.629 & 0.631 & 0.458 & 0.458 & 0.489 & 0.469 & 0.513 & 0.48 & 0.483 & 0.468 & 1.153 & 1.144 & 1.204 & 1.185 \\
\hline J & 1.353 & 1.35 & 1.476 & 1.476 & 1.448 & 1.452 & 1.432 & 1.458 & 1.468 & 1.493 & 1.535 & 1.531 & 1.477 & 1.486 \\
\hline Wo1 & 25.598 & 25.596 & 17.672 & 17.672 & 18.579 & 18.599 & 19.474 & 18.508 & 18.15 & 18.132 & 15.794 & 16.423 & 17.648 & 17.076 \\
\hline En1 & 11.741 & 11.737 & 1.238 & 1.238 & 1.22 & 1.162 & $1,\{62$ & 1.306 & 1.056 & 1.665 & 1.766 & 0.512 & 1.307 & 1.162 \\
\hline Fs1 & 62.661 & 62.666 & 81.09 & 81.09 & 80.201 & 80.24 & 79.365 & 80.186 & 80.794 & 80.203 & 82.44 & 83.065 & 81.045 & 81.762 \\
\hline WEF & 33.3 & 33.399 & 25.924 & 25.924 & 27.433 & 26.829 & 28.465 & 26.967 & 26.935 & 25.668 & 43.988 & 43.918 & 46.107 & 45.529 \\
\hline Jd1 & 5.305 & 5.306 & 0 & 0 & 0.173 & 0 & 0.59 & 0.644 & 1.174 & 1.12 & 56.012 & 56.082 & 0 & 54.471 \\
\hline Ae1 & 61.394 & 61.295 & 74.076 & 74.076 & 72.394 & 73.171 & 70.945 & 72.389 & 71.892 & 73.212 & 0 & 0 & 0.739 & 0 \\
\hline
\end{tabular}

Observaçżes de abreviaçōes como na tabela 15.0 


\begin{tabular}{|c|c|c|c|c|c|c|c|c|c|c|c|c|c|c|}
\hline $\begin{array}{l}\text { Amostras } \\
\text { Análises }\end{array}$ & $\begin{array}{c}\text { RP-A5 } \\
131\end{array}$ & $\begin{array}{c}\text { RP-45 } \\
132\end{array}$ & $\begin{array}{c}\text { RP-45 } \\
133\end{array}$ & $\begin{array}{c}\mathrm{RP}-45 \\
134\end{array}$ & $\begin{array}{c}\mathrm{RP}-45 \\
135\end{array}$ & $\begin{array}{c}\text { RP-45 } \\
459\end{array}$ & $\begin{array}{c}\text { RP-45 } \\
460\end{array}$ & $\begin{array}{c}\text { RP- } 45 \\
461\end{array}$ & $\begin{array}{c}\text { RP. } 45 \\
462\end{array}$ & $\begin{array}{c}\text { RP-45 } \\
463\end{array}$ & $\begin{array}{c}\text { RP-45 } \\
464\end{array}$ & $\begin{array}{c}\mathrm{RP}-45 \\
465\end{array}$ & $\begin{array}{c}\text { RP-45 } \\
466\end{array}$ & $\begin{array}{c}\text { RP- } 45 \\
467\end{array}$ \\
\hline Locação & CiG2n & C2Gin & C3G1n & C4G1n & C5G1n & C1G1Fn & C1G1Fb & C1G2n & $C 1 G 2 b$ & $\mathrm{C} 1 \mathrm{G} 3 \mathrm{~m}$ & $\mathrm{C} 2 \mathrm{G} 1 \mathrm{~m}$ & $\mathrm{C} 2 \mathrm{G} 2 \mathrm{n}$ & $\mathrm{C} 2 \mathrm{G} 2 \mathrm{Fb}$ & C2G3Fr \\
\hline Mineral & Px & $P x$ & $P x$ & Px & Px & $P x$ & Px & Px & $P x$ & $P x$ & Px & $P x$ & Px & Px \\
\hline $\mathrm{SiO}_{2}$ & 51.207 & 51.054 & 51.064 & 51.058 & 51.274 & 51.06 & 51.43 & 51.34 & 50.88 & 50.6 & 50.88 & 50.76 & 51.21 & 50.93 \\
\hline $\mathrm{TiO}_{2}$ & 0.188 & 0.241 & 0.243 & 0.2 & 0.133 & 0.63 & 0.47 & 0.2 & 0.14 & 0.12 & 0.24 & 0.24 & 0.22 & 0.18 \\
\hline $\mathrm{Al}_{2} \mathrm{O}_{3}$ & 0.261 & 0.239 & 0.249 & 0.214 & 0.253 & 0.33 & 0.28 & 0.28 & 0.24 & 0.3 & 0.19 & 0.23 & 0.25 & 0.24 \\
\hline $\mathrm{FeO}$ & 27.985 & 29.712 & 29.394 & 28.622 & 29.206 & 27.23 & 29.32 & 28.4 & 27.76 & 28.04 & 28.63 & 28.06 & 28.67 & 28.91 \\
\hline $\mathrm{Cr}_{2} \mathrm{O}_{3}$ & 0.001 & 0.014 & 0.001 & 0 & 0.012 & 0 & 0 & 0 & 0 & 0 & 0 & 0 & 0 & 0 \\
\hline $\mathrm{MnO}$ & 1.665 & 1.739 & 1.797 & 1.887 & 1.677 & 1.25 & 0.88 & 1.14 & 1.09 & 1 & 1.04 & 1.1 & 1.1 & 1.09 \\
\hline $\mathrm{NiO}$ & 0.028 & 0.007 & 0 & 0.005 & 0.008 & 0 & 0 & 0 & 0 & 0 & 0 & 0 & 0 & 0 \\
\hline $\mathrm{MgO}$ & 0.379 & 0.236 & 0.239 & 0.355 & 0.498 & 0.07 & 0.11 & 0.34 & 0.29 & 0.27 & 0.3 & 0.29 & 0.28 & 0.26 \\
\hline $\mathrm{CaO}$ & 4.97 & 4.467 & 5.439 & 5.026 & 5.133 & 4.22 & 4.36 & 4.96 & 5.2 & 5.14 & 5.16 & 5.7 & 5.03 & 5.57 \\
\hline $\mathrm{Na}_{2} \mathrm{O}$ & 9.844 & 10.078 & 9.594 & 10.078 & 9.953 & 10 & 10.28 & 9.64 & 9.51 & 9.53 & 9.58 & 9.19 & 9.67 & 9.44 \\
\hline $\mathrm{K}_{2} \mathrm{O}$ & 0.019 & 0.015 & 0 & 0.003 & 0.003 & 0 & 0 & 0.03 & 0.03 & 0.03 & 0.03 & 0.03 & 0 & 0 \\
\hline $\mathrm{ZnO}$ & 0.045 & 0 & 0 & 0.057 & 0.057 & 0 & 0 & 0 & 0 & 0 & 0 & 0 & 0 & 0 \\
\hline $\mathrm{ZrO}_{2}$ & 0.167 & 0.193 & 0.099 & 0.012 & 0.092 & 1.46 & 0.18 & 0.17 & 0.17 & 0.17 & 0.26 & 0.19 & 0.23 & 0.15 \\
\hline Total & 96.59 & 97.8 & 98.02 & 97.51 & 98.21 & 94.79 & 97.13 & 96.33 & 95.14 & 95.03 & 96.05 & 95.6 & 96.43 & 96.62 \\
\hline \multicolumn{15}{|c|}{ Fórmula estrutural calculada na base de 6 átomos de oxigénio } \\
\hline TSi & 2.018 & 1.991 & 1.994 & 1.993 & 1.99 & 2.047 & 2.014 & 2.031 & 2.037 & 2.029 & 2.021 & 2.03 & 2.025 & 2.015 \\
\hline TAI & 0 & 0.009 & 0.006 & 0.007 & 0.01 & 0 & 0 & 0 & 0 & 0 & 0 & 0 & 0 & 0 \\
\hline $\mathrm{TFe}^{3+}$ & 0 & 0 & 0 & 0 & 0 & 0 & 0 & 0 & 0 & 0 & 0 & 0 & 0 & 0 \\
\hline MIAI & 0.012 & 0.002 & 0.006 & 0.003 & 0.001 & 0.046 & 0.013 & 0.013 & 0.011 & 0.014 & 0.009 & 0.011 & 0.012 & 0.011 \\
\hline M1Ti & 0.006 & 0.007 & 0.007 & 0.006 & 0.004 & 0.019 & 0.014 & 0.006 & 0.004 & 0.004 & 0.007 & 0.007 & 0.007 & 0.005 \\
\hline$M 1 F e^{3+}$ & 0 & 0 & 0 & 0 & 0 & 0 & 0 & 0 & 0 & 0 & 0 & 0 & 0 & 0 \\
\hline $\mathrm{M} 1 \mathrm{Fe}^{2+}$ & 0.922 & 0.969 & 0.96 & 0.934 & 0.948 & 0.913 & 0.96 & 0.94 & 0.93 & 0.94 & 0.951 & 0.939 & 0.948 & 0.956 \\
\hline $\mathrm{MiCr}$ & 0 & 0 & 0 & 0 & 0 & 0 & 0 & 0 & 0 & 0 & 0 & 0 & 0 & 0 \\
\hline $\mathrm{M} 1 \mathrm{Mg}$ & 0.022 & 0.014 & 0.014 & 0.021 & 0.029 & 0.004 & 0.006 & 0.02 & 0.017 & 0.016 & 0.018 & 0.017 & 0.017 & 0.015 \\
\hline M1Ni & 0.001 & 0 & 0 & 0 & 0 & 0 & 0 & 0 & 0 & 0 & 0 & 0 & 0 & 0 \\
\hline $\mathrm{M} 2 \mathrm{Mg}$ & 0 & 0 & 0 & 0 & 0 & 0 & 0 & 0 & 0 & 0 & 0 & 0 & 0 & 0 \\
\hline $\mathrm{M} 2 \mathrm{Fe}^{2+}$ & 0 & 0 & 0 & 0 & 0 & 0 & 0 & 0 & 0 & 0 & 0 & 0 & 0 & 0 \\
\hline M2Mn & 0.056 & 0.057 & 0.059 & 0.062 & 0.055 & 0.042 & 0.029 & 0.038 & 0.037 & 0.034 & 0.035 & 0.037 & 0.037 & 0.037 \\
\hline $\mathrm{M} 2 \mathrm{Ca}$ & 0.21 & 0.187 & 0.228 & 0.21 & 0.213 & 0.181 & 0.183 & 0.21 & 0.223 & 0.221 & 0.22 & 0.244 & 0.213 & 0.236 \\
\hline $\mathrm{M} 2 \mathrm{Na}$ & 0.752 & 0.762 & 0.726 & 0.763 & 0.749 & 0.777 & 0.781 & 0.74 & 0.738 & 0.741 & 0.738 & 0.713 & 0.742 & 0.724 \\
\hline M2K & 0.001 & 0.001 & 0 & 0 & 0 & 0 & 0 & 0.002 & 0.002 & 0.002 & 0.002 & 0.002 & 0 & 0 \\
\hline Som_cat & 3.999 & 3.999 & 4 & 4 & 4 & 4 & 4 & 3.998 & 3.998 & 3.998 & 3.998 & 3.998 & 4 & 4 \\
\hline $\mathrm{Ca}$ & 17.343 & 15.214 & 18.048 & 17.123 & 17.14 & 15.889 & 15.519 & 17,402 & 18.483 & 18.232 & 17.95 & 19.74 & 17.546 & 18.972 \\
\hline $\mathrm{Mg}$ & 1.84 & 1.118 & 1.103 & 1.683 & 2.314 & 0.367 & 0.545 & 1.66 & 1.434 & 1.333 & 1.452 & 1.397 & 1.359 & 1.232 \\
\hline $\mathrm{Fe}^{2+}-\mathrm{Mn}$ & 80.817 & 83.668 & 80.848 & 81.194 & 80.547 & 83.745 & 83.936 & 80.938 & 80.082 & 80.436 & 80.598 & 78.863 & 81.095 & 79.796 \\
\hline Jd1 & 0.635 & 0.119 & 0.286 & 0.163 & 0.066 & 0.831 & 0.669 & 0.683 & 0.593 & 0.738 & 0.461 & 0.566 & 0.607 & 0.579 \\
\hline $\mathrm{Ae} 1$ & 38.848 & 39.36 & 37.395 & 39.405 & 38.563 & 40.612 & 39.772 & 38.095 & 38.148 & 37.939 & 37.892 & 36.744 & 38.027 & 36.902 \\
\hline CFTS1 & 0 & 0 & 0 & 0 & 0 & 0 & 0 & 0 & 0 & 0 & 0 & 0 & 0 & 0 \\
\hline CTTS1 & 0 & 0.366 & 0.308 & 0.305 & 0.2 & 0 & 0 & 0 & 0 & 0 & 0 & 0 & 0 & 0 \\
\hline CATS1 & 0 & 0 & 0 & 0 & 0 & 0 & 0 & 0 & 0 & 0 & 0 & 0 & 0 & 0 \\
\hline Wo1 & 11.001 & 9.294 & 11.496 & 10.597 & 10.806 & 9.664 & 9.478 & 11.002 & 11.681 & 11.503 & 11.391 & 12.759 & $\{1.104$ & 12.22 \\
\hline En1 & 1.167 & 0.71 & 0.722 & 1.071 & 1.486 & 0.223 & 0.333 & 1.049 & 0.906 & 0.841 & 0.921 & 0.903 & 0.86 & 0.794 \\
\hline Fs1 & 48.349 & 50.151 & 49.793 & 48.459 & 48.879 & 48.671 & 49.748 & 49.171 & 48.673 & 48.98 & 49.334 & 49.028 & 49.402 & 49.506 \\
\hline$Q$ & 1.154 & 1.17 & 1.201 & 1.165 & 1.19 & 1.098 & 1.15 & 1.17 & 1.17 & 1.177 & 1.188 & 1.2 & 1.178 & 1.208 \\
\hline J & 1.505 & 1.524 & 1.453 & 1.526 & 1.498 & 1.555 & 1.561 & 1.479 & 1.477 & 1.482 & 1.476 & 1.425 & 1.483 & 1.448 \\
\hline Wo1 & 17.343 & 15.214 & 18.048 & 17.123 & 17.14 & 15.889 & 15.519 & 17.402 & 18.483 & 18.232 & 17.95 & 19.74 & 17.546 & 18.972 \\
\hline En1 & 1.84 & 1.118 & 1.103 & 1.683 & 2.314 & 0.367 & 0.545 & 1.66 & 1.434 & 1.333 & 1.452 & 1.397 & 1.359 & 1.232 \\
\hline Fs1 & 80.817 & 83.668 & 80.848 & 81.194 & 80.547 & 83.745 & 83.936 & 80.938 & 80.082 & 80.436 & 80.598 & 78.863 & 81.095 & 79.796 \\
\hline WEF & 44.577 & 44.596 & 46.462 & 44.588 & 45.395 & 42.323 & 43.022 & 44.96 & 44.974 & 44.974 & 45.326 & 46.469 & 45.026 & 46.215 \\
\hline Jd1 & 55.423 & 55.404 & 53.538 & 55.412 & 54.605 & 57.677 & 56.978 & 55.04 & 55.026 & 55.026 & 54.674 & 53.531 & 54.974 & 53.785 \\
\hline $\mathrm{Ae} 1$ & 0 & 0 & 0 & 0 & 0 & 0 & 0 & 0 & 0 & 0 & 0 & 0 & 0 & 0 \\
\hline
\end{tabular}

Observaçōes de abreviações como na tabela 15.0 
Tabela 15.10 - Composição química de piroxênios de Satélite II (\% peso)

\begin{tabular}{|c|c|c|c|c|c|c|c|c|c|c|c|c|c|c|}
\hline $\begin{array}{l}\text { Amostras } \\
\text { Análises }\end{array}$ & $\begin{array}{c}\text { RP-45 } \\
468\end{array}$ & $\begin{array}{c}\text { RP-45 } \\
469\end{array}$ & $\begin{array}{c}\text { RP-45 } \\
470\end{array}$ & $\begin{array}{c}\text { RP-45 } \\
471\end{array}$ & $\begin{array}{c}\text { RP.45 } \\
472\end{array}$ & $\begin{array}{c}\text { RP-45 } \\
473\end{array}$ & $\begin{array}{c}\text { RP-45 } \\
474\end{array}$ & $\begin{array}{c}\text { RP-45 } \\
475\end{array}$ & $\begin{array}{c}\text { RP-45 } \\
476\end{array}$ & $\begin{array}{c}\text { RP-45 } \\
477\end{array}$ & $\begin{array}{c}\text { RP-45 } \\
478\end{array}$ & $\begin{array}{c}\text { RP-45 } \\
479\end{array}$ & $\begin{array}{c}\text { RP-45 } \\
480\end{array}$ & $\begin{array}{c}\text { RP-45 } \\
481\end{array}$ \\
\hline Locaçäo & $\mathrm{C} 2 \mathrm{G} 3 \mathrm{Fb}$ & C2G3Fn & C2G5Fn & $\mathrm{C} 2 \mathrm{G} 5 \mathrm{Fb}$ & C3G1Fn & $\mathrm{C} 3 \mathrm{G} 1 \mathrm{Fb}$ & $\mathrm{C} 3 \mathrm{G} 2 \mathrm{Fn}$ & $\mathrm{C} 3 \mathrm{G} 2 \mathrm{Fb}$ & CAGIFn & $\mathrm{C} 4 \mathrm{G} 1 \mathrm{Fb}$ & $\mathrm{C} 4 \mathrm{G} 2 \mathrm{Fn}$ & $\mathrm{C} 4 \mathrm{G} 2 \mathrm{Fb}$ & C5G1Fn & C5GIFb \\
\hline Mineral & Px & $\mathrm{Px}$ & Px & Px & Px & Px & $P_{x}$ & Px & Px & $P x$ & $P_{x}$ & $\mathrm{Px}$ & Px & Px \\
\hline $\mathrm{SiO}_{2}$ & 51.23 & 51.23 & 51.34 & 50.8 & 50.97 & 50.76 & 50.39 & 51.06 & 51.22 & 50.59 & 51.23 & 50.94 & 50.97 & 51.1 \\
\hline $\mathrm{TiO}_{2}$ & 0.22 & 0.24 & 0.2 & 0.23 & 0.17 & 0.23 & 0.25 & 0.14 & 0.17 & 0.28 & 0.28 & 0.12 & 0.37 & 0.13 \\
\hline $\mathrm{Al}_{2} \mathrm{O}_{3}$ & 0.19 & 0.25 & 0.25 & 0.23 & 0.27 & 0.28 & 0.25 & 0.23 & 0.28 & 0.53 & 0.25 & 0.48 & 0.26 & 0.22 \\
\hline $\mathrm{FeO}$ & 28.04 & 29.03 & 29.42 & 28.3 & 29.11 & 29.08 & 28.46 & 28.59 & 29.11 & 28.44 & 28.2 & 28.31 & 28.32 & 28.51 \\
\hline $\mathrm{Cr}_{2} \mathrm{O}_{3}$ & 0 & 0 & 0 & 0 & 0 & 0 & 0 & 0 & 0 & 0 & 0 & 0 & 0 & 0 \\
\hline $\mathrm{MnO}$ & 1.08 & 1.1 & 1.08 & 1.06 & 1.18 & 1.13 & 1.09 & 1.03 & 0.95 & 1.01 & 0.93 & 1.07 & 0.96 & 1.09 \\
\hline NiO & 0 & 0 & 0 & 0 & 0 & 0 & 0 & 0 & 0 & 0 & 0 & 0 & 0 & 0 \\
\hline $\mathrm{MgO}$ & 0.31 & 0.24 & 0.27 & 0.31 & 0.33 & 0.3 & 0.32 & 0.28 & 0.12 & 0.16 & 0.32 & 0.28 & 0.45 & 0.33 \\
\hline $\mathrm{CaO}$ & 5.35 & 4.84 & 5.41 & 5.07 & 5.46 & 5.3 & 5.36 & 5.15 & 4.96 & 5.16 & 4.53 & 4.61 & 5.44 & 5.34 \\
\hline $\mathrm{Na}_{2} \mathrm{O}$ & 9.3 & 9.76 & 9.46 & 9.46 & 9.39 & 9.61 & 9.54 & 9.66 & 10.05 & 9.58 & 10.1 & 9.69 & 9.54 & 9.48 \\
\hline $\mathrm{K}_{2} \mathrm{O}$ & 0 & 0.02 & 0.01 & 0.01 & 0 & 0.02 & 0 & 0 & 0 & 0.02 & 0 & 0 & 0.2 & 0.01 \\
\hline $\mathrm{ZnO}$ & 0 & 0 & 0 & 0 & 0 & 0 & 0 & 0 & 0 & 0 & 0 & 0 & 0 & 0 \\
\hline $\mathrm{ZrO}_{2}$ & 0.14 & 0.14 & 0.02 & 0.29 & 0.17 & 0.17 & 0.1 & 0.17 & 0.1 & 0.07 & 0.07 & 0.07 & 0.6 & 0.18 \\
\hline Total & 95.72 & 96.71 & 97.44 & 95.47 & 96.88 & 96.71 & 95.66 & 96.14 & 96.86 & 95.77 & 95.84 & 95.5 & 96.51 & 96.21 \\
\hline \multicolumn{15}{|c|}{ Formula estrutural caiculada na base de 6 átomos de oxigénio } \\
\hline TSi & 2.045 & 2.021 & 2.016 & 2.031 & 2.012 & 2.004 & 2.009 & 2.024 & 2.012 & 2.015 & 2.028 & 2.031 & $2,0\{3$ & 2.027 \\
\hline TAI & 0 & 0 & 0 & 0 & 0 & 0 & 0 & 0 & 0 & 0 & 0 & 0 & 0 & 0 \\
\hline $\mathrm{TFe}^{3+}$ & 0 & 0 & 0 & 0 & 0 & 0 & 0 & 0 & 0 & 0 & 0 & 0 & 0 & 0 \\
\hline MTAl & 0.009 & 0.012 & 0.012 & 0.011 & 0.013 & 0.013 & 0.012 & 0.011 & 0.013 & 0.025 & 0.012 & 0.023 & 0.012 & 0.01 \\
\hline M1Ti & 0.007 & 0.007 & 0.006 & 0.007 & 0.005 & 0.007 & 0.007 & 0.004 & 0.005 & 0.008 & 0.008 & 0.004 & 0.011 & 0.004 \\
\hline $\mathrm{M} 1 \mathrm{Fe}^{3+}$ & 0 & 0 & 0 & 0 & 0 & 0 & 0 & 0 & 0 & 0 & 0 & 0 & 0 & 0 \\
\hline$M 1 \mathrm{Fe}^{2+}$ & 0.936 & 0.958 & 0.966 & 0.946 & 0.961 & 0.96 & 0.949 & 0.948 & 0.957 & 0.947 & 0.934 & 0.944 & 0.935 & 0.946 \\
\hline $\mathrm{M} 1 \mathrm{Cr}$ & 0 & 0 & 0 & 0 & 0 & 0 & 0 & 0 & 0 & 0 & 0 & 0 & 0 & 0 \\
\hline $\mathrm{M} 1 \mathrm{Mg}$ & 0.018 & 0.014 & 0.016 & 0.018 & 0.019 & 0.018 & 0.019 & 0.017 & 0.007 & 0.009 & 0.019 & 0.017 & 0.026 & 0.02 \\
\hline M1Ni & 0 & 0 & 0 & 0 & 0 & 0 & 0 & 0 & 0 & 0 & 0 & 0 & 0 & 0 \\
\hline M2Mg & 0 & 0 & 0 & 0 & 0 & 0 & 0 & 0 & 0 & 0 & 0 & 0 & 0 & 0 \\
\hline $\mathrm{M} 2 \mathrm{Fe} \mathrm{e}^{2+}$ & 0 & 0 & 0 & 0 & 0 & 0 & 0 & 0 & 0 & 0 & 0 & 0 & 0 & 0 \\
\hline M2Mn & 0.037 & 0.037 & 0.036 & 0.036 & 0.039 & 0.038 & 0.037 & 0.035 & 0.032 & 0.034 & 0.031 & 0.036 & 0.032 & 0.037 \\
\hline $\mathrm{M} 2 \mathrm{Ca}$ & 0.229 & 0.205 & 0.228 & 0.217 & 0.231 & 0.224 & 0.229 & 0.219 & 0.209 & 0.22 & 0.192 & 0.197 & 0.23 & 0.227 \\
\hline $\mathrm{M} 2 \mathrm{Na}$ & 0.72 & 0.746 & 0.72 & 0.733 & 0.719 & 0.736 & 0.738 & 0.743 & 0.766 & 0.74 & 0.775 & 0.749 & 0.73 & 0.729 \\
\hline M2K & 0 & 0.001 & 0.001 & 0.001 & 0 & 0.001 & 0 & 0 & 0 & 0.001 & 0 & 0 & 0.01 & 0.001 \\
\hline Som_cat & 4 & 3.999 & 3.999 & 3.999 & 4 & 3.999 & 4 & 4 & 4 & 3.999 & 4 & 4 & 3.99 & 3.999 \\
\hline $\mathrm{Ca}$ & 18.758 & 16.862 & 18.275 & 17.834 & 18.462 & 18.083 & $\uparrow 8.559$ & 17.963 & 17.343 & 18.182 & 16.341 & 16.498 & 18.804 & 18.468 \\
\hline $\mathrm{Mg}$ & 1.512 & 1.163 & 1.269 & 1.517 & 1.553 & 1.424 & 1.542 & 1.359 & 0.584 & 0.784 & 1.606 & 1.394 & 2.164 & 1.588 \\
\hline $\mathrm{Fe}^{2+}+\mathrm{Mn}$ & 79.73 & 81.974 & 80.456 & 80.649 & 79.985 & 80.493 & 79.9 & 80.678 & 82.073 & 81.034 & 82.053 & 82.108 & 79.032 & 79.944 \\
\hline $\mathrm{dd} 1{ }^{-}$ & 0.469 & 0.604 & 0.599 & 0.565 & 0.65 & 0.672 & 0.607 & 0.558 & 0.669 & 1.296 & 0.607 & 1.182 & 0.626 & 0.535 \\
\hline Aef 1 & 37.354 & 38.252 & 36.741 & 37.742 & 36.588 & 37.328 & 37.519 & 38.002 & 38.839 & 37.334 & 39.774 & 38.108 & 37.696 & 37.431 \\
\hline CFTS1 & 0 & 0 & 0 & 0 & 0 & 0 & 0 & 0 & 0 & 0 & 0 & 0 & 0 & 0 \\
\hline CTIS1 & 0 & 0 & 0 & 0 & 0 & 0 & 0 & 0 & 0 & 0 & 0 & 0 & 0 & 0 \\
\hline CATS1 & 0 & 0 & 0 & 0 & 0 & 0 & 0 & 0 & 0 & 0 & 0 & 0 & 0 & 0 \\
\hline Wo1 & 12.023 & 10.633 & 11.791 & 11.336 & 11.965 & 11.564 & 11.836 & 11.359 & 10.774 & 11.481 & 10.008 & 10.329 & 11.91 & 11.809 \\
\hline En1 & 0.969 & 0.734 & 0.819 & 0.964 & 1.006 & 0.911 & 0.983 & 0.859 & 0.363 & 0.495 & 0.984 & 0.873 & 1.371 & 1.015 \\
\hline $\mathrm{Fs} 1$ & 49.185 & 49.779 & 50.05 & 49.392 & 49.791 & 49.526 & 49.055 & 49.221 & 49.356 & 49.394 & 48.628 & 49.508 & 48.397 & 49.21 \\
\hline$Q$ & 1.183 & 1.176 & 1.21 & 1.182 & 1.212 & 1.202 & 1.197 & 1.183 & 1.172 & 1.177 & 1.145 & 1.158 & 1.192 & 1.192 \\
\hline j & 1.44 & 1.493 & 1.441 & 1.467 & 1.438 & 1.471 & 1.475 & 1.485 & 1.531 & 1.48 & 1.551 & 1.498 & 1.461 & 1.458 \\
\hline Wo1 & 18.758 & 16.862 & 18,275 & 17.834 & 18.462 & 18.083 & 18.559 & 17.963 & 17.343 & 18.182 & 16.341 & 16.498 & 18.804 & 18.468 \\
\hline En1 & 1.512 & 1.163 & 1.269 & 1.517 & 1.553 & 1.424 & 1.542 & 1.359 & 0.584 & 0.784 & 1.606 & 1.394 & 2.164 & 1.588 \\
\hline$F s 1$ & 79.73 & 81.974 & 80.456 & 80.649 & 79.985 & 80.493 & 79.9 & 80.678 & 82.073 & 81.034 & 82.053 & 82.108 & 79.032 & 79.944 \\
\hline WEF & 45.867 & 44.828 & 46.368 & 45.363 & 46.528 & 45.729 & 45.546 & 45.054 & 44.016 & 45.008 & 43.128 & 44.343 & 45.588 & 45.731 \\
\hline $\mathrm{dd} 1$ & 54.133 & 55.172 & 53.632 & 54.637 & 53.472 & 54.271 & 54.454 & 54.946 & 55.984 & 54.992 & 56.872 & 55.657 & 54.412 & 54.269 \\
\hline $\mathrm{Ae} 1$ & 0 & 0 & 0 & 0 & 0 & 0 & 0 & 0 & 0 & 0 & 0 & . & 0 & \\
\hline
\end{tabular}

Observaçðes de abreviações como na tabela 15.0 
Tabela 15.11 - Composição química de piroxênios de Satélite II (\% peso)

\begin{tabular}{|c|c|c|c|c|c|}
\hline \multicolumn{6}{|l|}{ Amostras } \\
\hline Análises & 482 & 483 & 532 & 533 & 117 \\
\hline Locação & $\mathrm{C} 5 \mathrm{G} 2 \mathrm{Fn}$ & $\mathrm{C} 5 \mathrm{G} 2 \mathrm{Fb}$ & C1G1Fn & C1G1Fb & C3G1b \\
\hline Mineral & Px & $P x$ & Px & $P_{x}$ & Px \\
\hline $\mathrm{SiO}_{2}$ & 51.34 & 50.82 & 51.02 & 51.32 & 51.279 \\
\hline $\mathrm{TiO}_{2}$ & 0.31 & 0.15 & 0.2 & 0.19 & 0.661 \\
\hline $\mathrm{Al}_{2} \mathrm{O}_{3}$ & 0.23 & 0.23 & 0.22 & 0.26 & 1.073 \\
\hline $\mathrm{FeO}$ & 28.61 & 28.12 & 28.94 & 28.75 & 22.484 \\
\hline $\mathrm{Cr}_{2} \mathrm{O}_{3}$ & 0 & 0 & 0 & 0.01 & 0 \\
\hline $\mathrm{MnO}$ & 1.06 & 1.12 & 1.73 & 1.7 & 1.397 \\
\hline $\mathrm{NiO}$ & 0 & 0 & 0 & 0 & 0.005 \\
\hline $\mathrm{MgO}$ & 0.36 & 0.25 & 0.29 & 0.27 & 2.511 \\
\hline $\mathrm{CaO}$ & 4.59 & 4.62 & 5.29 & 5.03 & 7.62 \\
\hline $\mathrm{Na}_{2} \mathrm{O}$ & 9.99 & 9.95 & 9.48 & 9.8 & 8.892 \\
\hline $\mathrm{K}_{2} \mathrm{O}$ & 0 & 0 & 0.01 & 0 & 0 \\
\hline $\mathrm{ZnO}$ & 0 & 0 & 0 & 0 & 0.109 \\
\hline $\mathrm{ZrO}_{2}$ & 0.07 & 1.28 & 0 & 0 & 0 \\
\hline Total & 96.49 & 95.26 & 97.18 & 97.33 & 96.03 \\
\hline \multicolumn{6}{|c|}{ Fórmula estrutural na base de 6 átomos de oxigênio } \\
\hline TSi & 2.023 & 2.027 & 2.009 & 2.011 & 2.007 \\
\hline Ta! & 0 & 0 & 0 & 0 & 0 \\
\hline $\mathrm{TFe}^{3+}$ & 0 & 0 & 0 & 0 & 0 \\
\hline M1Al & 0.011 & 0.011 & 0.01 & 0.012 & 0.049 \\
\hline M1Ti & 0.009 & 0.005 & 0.006 & 0.006 & 0.019 \\
\hline $\mathrm{M} \mathrm{Fe}^{3+}$ & 0 & 0 & 0 & 0 & 0 \\
\hline $\mathrm{M} 1 \mathrm{Fe}^{2+}$ & 0.943 & 0.938 & 0.953 & 0.942 & 0.736 \\
\hline $\mathrm{M} 1 \mathrm{Cr}$ & 0 & 0 & 0 & 0 & 0 \\
\hline M1Mg & 0.021 & 0.015 & 0.017 & 0.016 & 0.147 \\
\hline M1Ni & 0 & 0 & 0 & 0 & 0 \\
\hline M2Mg & 0 & 0 & 0 & 0 & 0 \\
\hline $\mathrm{M} 2 \mathrm{Fe}^{2+}$ & 0 & 0 & 0 & 0 & 0 \\
\hline M2Mn & 0.035 & 0.038 & 0.058 & 0.056 & 0.046 \\
\hline $\mathrm{M} 2 \mathrm{Ca}$ & 0.194 & 0.197 & 0.223 & 0.211 & 0.32 \\
\hline M2Na & 0.763 & 0.77 & 0.724 & 0.745 & 0.675 \\
\hline M2K & 0 & 0 & 0.001 & 0 & 0 \\
\hline Som_cat & 4 & 4 & 3.999 & 4 & 4 \\
\hline $\mathrm{Ca}$ & 16.242 & 16.617 & 17.841 & 17.232 & 25.598 \\
\hline $\mathrm{Mg}$ & 1.772 & 1.251 & 1.361 & 1.287 & 11.737 \\
\hline $\mathrm{Fe}^{2+}-\mathrm{Mn}$ & 81.986 & 82.131 & 80.798 & 81.481 & 62.665 \\
\hline Jd1 & 0.556 & 0.563 & 0.532 & 0.627 & 2.635 \\
\hline Ae 1 & 39.178 & 39.521 & 37.241 & 38.282 & 33.321 \\
\hline CFTSI & 0 & 0 & 0 & 0 & 0 \\
\hline CTTS: & 0 & 0 & 0 & 0 & 0 \\
\hline CATS1 & 0 & 0 & 0 & 0 & 0 \\
\hline Wo1 & 10.088 & 10.284 & 11.639 & 11.035 & 17.026 \\
\hline En1 & 1,101 & 0.774 & 0.888 & 0.824 & 7.806 \\
\hline Fs1 & 49.078 & 48.858 & 49.7 & 49.232 & 39.212 \\
\hline$Q$ & 1.158 & 1.15 & 1.193 & 1.169 & 1.202 \\
\hline J & 1.527 & 1.539 & 1.448 & 1.49 & 1.35 \\
\hline Wo1 & 16.242 & 16.617 & 17,841 & 17.232 & 25.598 \\
\hline En1 & 1.772 & 1.251 & 1.361 & 1.287 & 11.737 \\
\hline Fs1 & 81.986 & 82.131 & 80.798 & 81,481 & 62.665 \\
\hline WEF & 43.869 & 43.566 & 46.355 & 45.143 & 48.05 \\
\hline Jd1 & 56.131 & 56.434 & 53.645 & 54.857 & 51.95 \\
\hline $\mathrm{Ae} 1$ & 0 & 0 & 0 & 0 & 0 \\
\hline
\end{tabular}

Observaçőes de abreviaçóes como na tabela 15.0 
Tabela 15.12 - Composição química de piroxênios de Satélite I (\% peso)

\begin{tabular}{|c|c|c|c|c|c|c|c|c|c|c|}
\hline & & & & & & & & & & \\
\hline $\begin{array}{l}\text { Amostras } \\
\text { Análises }\end{array}$ & $\begin{array}{c}\text { RP-52 } \\
557\end{array}$ & $\begin{array}{c}\text { RP-52 } \\
559\end{array}$ & $\begin{array}{c}\text { RP-52 } \\
561\end{array}$ & $\begin{array}{c}\text { RP-52 } \\
562\end{array}$ & $\begin{array}{c}\text { RP-52 } \\
563\end{array}$ & $\begin{array}{c}\text { RP-52 } \\
565\end{array}$ & $\begin{array}{c}\text { RP-52 } \\
569\end{array}$ & $\begin{array}{c}\text { RP-52 } \\
570\end{array}$ & $\begin{array}{c}\text { RP-52 } \\
604\end{array}$ & $\begin{array}{c}\text { RP-56 } \\
576\end{array}$ \\
\hline Locação & C2G1Fn & $\mathrm{C} 2 \mathrm{G} 2 \mathrm{Fn}$ & C3G1Fn & $\mathrm{C} 3 \mathrm{G} 1 \mathrm{Fb}$ & C3G2Fn & $\mathrm{C} 4 \mathrm{G} 1 \mathrm{Fn}$ & C6G1Fn & C6GiFb & C4GIn & C2Gín \\
\hline Mineral & Px & $P x$ & $P x$ & $P x$ & Px & $P x$ & Px & Px & $P x$ & $P x$ \\
\hline $\mathrm{SiO}_{2}$ & 52.45 & 51.56 & 51.61 & 50.85 & 51.63 & 51.64 & 50.91 & 50.55 & 51.66 & 49.02 \\
\hline $\mathrm{TiO}_{2}$ & 0.3 & 0.27 & 0.33 & 0.16 & 0.33 & 0.27 & 0.14 & 0.3 & 1 & 0.38 \\
\hline $\mathrm{Al}_{2} \mathrm{O}_{3}$ & 0.41 & 0.53 & 0.75 & 0.52 & 0.65 & 0,65 & 0.58 & 0.45 & 1.07 & 0.5 \\
\hline $\mathrm{FeO}$ & 15.26 & 18.03 & 15.75 & 18.75 & 16.03 & 16.54 & 17,38 & 19.92 & 25.3 & 27.94 \\
\hline $\mathrm{Cr}_{2} \mathrm{O}_{3}$ & 0 & 0 & 0 & 0 & 0 & 0 & 0 & 0 & 0 & 0 \\
\hline $\mathrm{MnO}$ & 1.43 & 1.72 & 1.54 & 1,68 & 1.53 & 1.59 & 1.76 & 1.81 & 1.17 & 1.65 \\
\hline $\mathrm{NiO}$ & 0 & 0 & 0 & 0 & 0 & 0 & 0 & 0 & 0 & 0 \\
\hline $\mathrm{MgO}$ & 9.54 & 7.86 & 8.83 & 6.74 & 9.54 & 9.05 & 7.8 & 6.23 & 1 & 0.45 \\
\hline $\mathrm{CaO}$ & 22.3 & 20.94 & 20.63 & 20.33 & 20.91 & 21.02 & 20.93 & 20.86 & 6.46 & 10.49 \\
\hline $\mathrm{Na}_{2} \mathrm{O}$ & 0.61 & 0.76 & 1.15 & 1.26 & 0.69 & 0.9 & 0.84 & 0.81 & 9.55 & 6.67 \\
\hline $\mathrm{K}_{2} \mathrm{O}$ & 0 & 0.02 & 0 & 0.01 & 0.02 & 0.02 & 0 & 0.01 & 0.02 & 0.03 \\
\hline $\mathrm{ZnO}$ & 0 & 0 & 0 & 0 & 0 & 0 & 0 & 0 & 0.12 & 0 \\
\hline $\mathrm{ZrO}_{2}$ & 0.05 & 0.08 & 0.07 & 0.06 & 0.08 & 0.04 & 0.06 & 0.09 & 0.76 & 0.29 \\
\hline Total & 102.3 & 101.69 & 100.59 & 100.3 & 101.33 & 101.68 & 100.34 & 100.94 & 97.35 & 97.13 \\
\hline \multicolumn{11}{|c|}{ Fórmula estrutural na base de 6 átomos de oxigênio } \\
\hline TSi & 1.971 & 1.972 & 1.971 & 1.975 & 1.961 & 1.957 & 1.969 & 1.968 & 2.011 & 1.97 \\
\hline TAl & 0.018 & 0.024 & 0.029 & 0.024 & 0.029 & 0.029 & 0.026 & 0.021 & 0 & 0.024 \\
\hline $\mathrm{TFe}^{3+}$ & 0 & 0 & 0 & 0 & 0 & 0 & 0 & 0 & 0 & 0 \\
\hline M1Al & 0 & 0 & 0.005 & 0 & 0 & 0 & 0 & 0 & 0.049 & 0 \\
\hline M1Ti & 0.008 & 0.008 & 0.009 & 0.005 & 0.009 & 0.008 & 0.004 & 0.009 & 0.029 & 0.011 \\
\hline $\mathrm{M}^{1} \mathrm{Fe}^{3+}$ & 0 & 0 & 0 & 0 & 0 & 0 & 0 & 0 & 0 & 0 \\
\hline $\mathrm{M}^{1} \mathrm{Fe}^{2+}$ & 0.457 & 0.544 & 0.482 & 0.605 & 0.451 & 0.481 & 0.546 & 0.63 & 0.823 & 0.939 \\
\hline $\mathrm{M} 1 \mathrm{Cr}$ & 0 & 0 & 0 & 0 & 0 & 0 & 0 & 0 & 0 & 0 \\
\hline$M 1 \mathrm{Mg}$ & 0.535 & 0.448 & 0.503 & 0.39 & 0.54 & 0.511 & 0.45 & 0.362 & 0.058 & 0.027 \\
\hline M1Ni & 0 & 0 & 0 & 0 & 0 & 0 & 0 & 0 & 0 & 0 \\
\hline M2Mg & 0 & 0 & 0 & 0 & 0 & 0 & 0 & 0 & 0 & 0 \\
\hline $\mathrm{M} 2 \mathrm{Fe}^{2+}$ & 0.023 & 0.033 & 0.021 & 0.004 & 0.059 & 0.043 & 0.016 & 0.019 & 0 & 0 \\
\hline $\mathrm{M} 2 \mathrm{Mn}$ & 0.046 & 0.056 & 0.05 & 0.055 & 0.049 & 0.051 & 0.058 & 0.06 & 0.039 & 0.056 \\
\hline $\mathrm{M} 2 \mathrm{Ca}$ & 0.898 & 0.858 & 0.844 & 0.846 & 0.851 & 0.853 & 0.867 & 0.87 & 0.269 & 0.452 \\
\hline M2Na & 0.044 & 0.056 & 0.085 & 0.095 & 0.051 & 0.066 & 0.063 & 0.061 & 0.721 & 0.52 \\
\hline M2K & 0 & 0.001 & 0 & 0 & 0.001 & 0.001 & 0 & 0 & 0.001 & 0.002 \\
\hline Som_cat & 4 & 3.999 & 4 & 4 & 3.999 & 3.999 & 4 & 4 & 3.999 & 3.998 \\
\hline $\mathrm{Ca}$ & 45.87 & 44.262 & 44.435 & 44.514 & 43.648 & 43.994 & 44.78 & 44.853 & 22.647 & 30.646 \\
\hline $\mathrm{Mg}$ & 27.304 & 23.117 & 26.463 & 20.534 & 27.708 & 26.355 & 23.22 & 18.639 & 4.878 & 1.829 \\
\hline $\mathrm{Fe}^{2+}+\mathrm{Mn}$ & 26.826 & 32.621 & 29.102 & 34.953 & 28.643 & 29.651 & 32.001 & 36.509 & 72.475 & 67.524 \\
\hline $\mathrm{dd} 1$ & 0 & 0 & 0.268 & 0 & 0 & 0 & 0 & 0 & 2.619 & 0 \\
\hline Ae1 & 2.272 & 2.955 & 4.132 & 4.915 & 2.653 & 3.43 & 3.243 & 3.174 & 35.921 & 26.885 \\
\hline CFTS1 & 0 & 0 & 0 & 0 & 0 & 0 & 0 & 0 & 0 & 0 \\
\hline CTTS1 & 0.433 & 0.4 & 0.49 & 0.241 & 0.483 & 0.393 & 0.21 & 0.452 & 0 & 0.592 \\
\hline CATS1 & 0 & 0 & 0 & 0 & 0 & 0 & 0 & 0 & 0 & 0 \\
\hline Wo1 & 45.462 & 43.825 & 43.134 & 43.353 & 43.108 & 43.239 & 44.447 & 44.355 & 14.386 & 22.702 \\
\hline En1 & 27.319 & 23.097 & 25.98 & 20.109 & 27.672 & 26.138 & 23.156 & 18.62 & 3.098 & 1.39 \\
\hline Fst & 24.514 & 29.723 & 25.996 & 31.382 & 26.084 & 26.799 & 28.944 & 33.398 & 43.976 & 48.43 \\
\hline$Q$ & 1.912 & 1.883 & 1.85 & 1.846 & 1.9 & 1.869 & 1.88 & 1.881 & 1.151 & 1.418 \\
\hline $\mathbf{J}$ & 0.089 & 0.113 & 0.17 & 0.19 & 0.102 & 0.132 & 0.126 & 0.122 & 1.441 & 1.039 \\
\hline Wo1 & 45.87 & 44.262 & 44.435 & 44.514 & 43.648 & 43.994 & 44.78 & 44.853 & 22.647 & 30.646 \\
\hline En1 & 27.304 & 23.117 & 26.463 & 20.534 & 27.708 & 26.355 & 23.22 & 18.639 & 4.878 & 1.829 \\
\hline Fs1 & 26.826 & 32.621 & 29.102 & 34.953 & 28.643 & 29.651 & 32.001 & 36.509 & 72.475 & 67.524 \\
\hline WEF & 95.656 & 94.505 & 91.772 & 90.921 & 95.045 & 93.617 & 93.892 & 94.07 & 45.212 & 58.64 \\
\hline $\mathrm{Jd} 1$ & 0 & 0 & 8.228 & 0 & 0 & 0 & 0 & 0 & 54.788 & 0 \\
\hline Ae1 & 0.044 & 0.057 & 0 & 0.095 & 0.052 & 0.067 & 0.063 & 0.062 & 0 & 0.521 \\
\hline
\end{tabular}


Tabela 15.13 - Composição química de piroxênios de Cerro Siete Cabezas (\% peso)

\begin{tabular}{|c|c|c|c|c|c|c|c|c|c|c|c|c|c|c|}
\hline Amostra & RP-74 & RP.74 & RP-74 & RP-74 & RP-74 & RP-74 & RP-74 & RP-230 & RP-230 & $R P-230$ & RP-230 & RP-230 & RP-230 & RP-230 \\
\hline Análises & 944 & 945 & 946 & 947 & 974 & 975 & 976 & 929 & 931 & 932 & 933 & 934 & 935 & 936 \\
\hline Locaçåa & CIG1Fn & C4G1Fn & C4G1Fb & C4G2m & C1G1n & $\mathrm{C} 2 \mathrm{G} 1 \mathrm{n}$ & $\mathrm{C} 2 \mathrm{G} 2 \mathrm{n}$ & C1G1n & $\mathrm{C} 2 \mathrm{G} 2$ incl & C2G3incl & C2G4incl & C3Gin & $C 3 G 1 b$ & C5G1n \\
\hline Mineral & Px & $\mathrm{Px}$ & Px & Px & Px & Px & Px & $P x$ & $\mathrm{Px}$ & $\mathrm{Px}_{x}$ & Px & Px & Px & Px \\
\hline $\mathrm{SiO}_{2}$ & 50.18 & 50.28 & 50.64 & 50.5 & 50.85 & 49.67 & 51.13 & 51.59 & 51.13 & 50.16 & 51.3 & 50.41 & 51.15 & 51.19 \\
\hline $\mathrm{TiO}_{2}$ & 0.45 & 0.34 & 0.45 & 0.54 & 0.46 & 0.28 & 0.32 & 0.54 & 0.38 & 0.48 & 0.47 & 0.47 & 0.4 & 0.49 \\
\hline $\mathrm{Al}_{2} \mathrm{O}_{3}$ & 1.71 & 1.18 & 1.08 & 1.12 & 1.05 & 1.24 & 1.1 & 1.23 & 1.41 & 1.28 & 1.32 & 1.34 & 1.25 & 1.36 \\
\hline $\mathrm{FeO}$ & 18.74 & 18.76 & 21.22 & 23.07 & 22.24 & 20.06 & 19.22 & 10.37 & 12.97 & 13.26 & 13.48 & 12.97 & 12.27 & 14.92 \\
\hline $\mathrm{Cr}_{2} \mathrm{O}_{3}$ & 0 & 0 & 0 & 0 & 0 & 0 & 0 & 0 & 0 & 0 & 0 & 0 & 0 & 0 \\
\hline $\mathrm{MnO}$ & 1.38 & 1.52 & 1.22 & 1.06 & 1.05 & 1.56 & 1.28 & 0.91 & 1.11 & 1.13 & 1.08 & 1.04 & 1.03 & 1.15 \\
\hline $\mathrm{NiO}$ & 0 & 0 & 0 & 0 & 0 & 0 & 0 & 0 & 0 & 0 & 0 & 0 & 0 & 0 \\
\hline $\mathrm{MgO}$ & 4.5 & 4.92 & 3.27 & 2.29 & 2.77 & 4.07 & 4.85 & 12.07 & 9.99 & 9.5 & 9.67 & 10.15 & 10.31 & 10.47 \\
\hline $\mathrm{CaO}$ & $\{5.67$ & $\{4.43$ & 11.67 & 10.03 & 10.49 & 15.43 & 14.47 & 21.77 & 21.93 & 21.66 & 21.84 & 21.72 & 22.15 & 21.82 \\
\hline $\mathrm{Na}_{2} \mathrm{O}$ & 4.64 & 5.46 & 6.64 & 7.65 & 7.38 & 4.66 & 5.32 & 1.16 & 1.13 & 1.16 & 1.14 & 1.01 & 1.05 & 1.13 \\
\hline $\mathrm{K}_{2} \mathrm{O}$ & 0.08 & 0.02 & 0 & 0.01 & 0.01 & 0 & 0.01 & 0.01 & 0 & 0.01 & 0.01 & 0.02 & 0.02 & 0 \\
\hline $\mathrm{ZnO}$ & 0 & 0 & 0 & 0 & 0.03 & 0.13 & 0 & 0 & 0 & 0 & 0 & 0 & 0 & 0 \\
\hline $\mathrm{ZrO}_{2}$ & 0.44 & 0.24 & 0.43 & 0.71 & 1.03 & 0.52 & 0.33 & 0.03 & 0.16 & 0.18 & 0.19 & 0.17 & 0.15 & 0.13 \\
\hline Total & 97.35 & 96.91 & 96.19 & 96.27 & 96.33 & 97.1 & 97.7 & 99.65 & 100.05 & 98.64 & 100.31 & 99.13 & 99.63 & 99.53 \\
\hline \multicolumn{15}{|c|}{ Formula estrutural calculada na base de 6 átomos de oxigênio } \\
\hline TSi & 1.968 & 1.966 & 2 & 1.992 & 2.002 & 1.966 & 1.988 & 1.938 & 1.94 & 1.935 & 1.946 & 1.93 & 1.944 & 1.945 \\
\hline TAl & 0.032 & 0.034 & 0 & 0.008 & 0 & 0.034 & 0.012 & 0.054 & 0.06 & 0.058 & 0.054 & 0.06 & 0.056 & 0.055 \\
\hline $\mathrm{TFe}^{3+}$ & 0 & 0 & 0 & 0 & 0 & 0 & 0 & 0 & 0 & 0 & 0 & 0 & 0 & 0 \\
\hline M1Al & 0.047 & 0.02 & 0.05 & 0.044 & 0.049 & 0.023 & 0.038 & 0 & 0.003 & 0 & 0.005 & 0 & 0 & 0.006 \\
\hline M1TI & 0.013 & 0.01 & 0.013 & 0.016 & 0.014 & 0.008 & 0.009 & 0.015 & 0.011 & 0.014 & 0.013 & 0.014 & 0.011 & 0.014 \\
\hline MiFe $e^{3+}$ & 0 & 0 & 0 & 0 & 0 & 0 & 0 & 0 & 0 & 0 & 0 & 0 & 0 & 0 \\
\hline $\mathrm{M}^{2} \mathrm{Fe}^{2+}$ & 0.615 & 0.613 & 0.701 & 0.761 & 0.732 & 0.664 & 0.625 & 0.309 & 0.411 & 0.428 & 0.428 & 0.407 & 0.39 & 0.379 \\
\hline $\mathrm{M} 1 \mathrm{Cr}$ & 0 & 0 & 0 & 0 & 0 & 0 & 0 & 0 & 0 & 0 & 0 & 0 & 0 & 0 \\
\hline M1Mg & 0.263 & 0.287 & 0.193 & 0.135 & 0.163 & 0.24 & 0.281 & 0.676 & 0.565 & 0.546 & 0.547 & 0.579 & 0.584 & 0.593 \\
\hline $\mathrm{M} 1 \mathrm{Ni}$ & 0 & 0 & 0 & 0 & 0 & 0 & 0 & 0 & 0 & 0 & 0 & 0 & 0 & 0 \\
\hline M2Mg & 0 & 0 & 0 & 0 & 0 & 0 & 0 & 0 & 0 & 0 & 0 & 0 & 0 & 0 \\
\hline $\mathrm{M} 2 \mathrm{Fe} 2$ & 0 & 0 & 0 & 0 & 0 & 0 & 0 & 0.017 & 0 & 0 & 0 & 0.008 & 0 & 0 \\
\hline M2Mn & 0.046 & 0.05 & 0.041 & 0.035 & 0.035 & 0.052 & 0.042 & 0.029 & 0.036 & 0.037 & 0.035 & 0.034 & 0.033 & 0.037 \\
\hline $\mathrm{M} 2 \mathrm{Ca}$ & 0.659 & 0.604 & 0.494 & 0.424 & 0.442 & 0.654 & 0.603 & 0.876 & 0.891 & 0.895 & 0.888 & 0.891 & 0.902 & 0.888 \\
\hline $\mathrm{M} 2 \mathrm{Na}$ & 0.353 & 0.414 & 0.508 & 0.585 & 0.563 & 0.358 & 0.401 & 0.085 & 0.083 & 0.087 & 0.084 & 0.075 & 0.077 & 0.083 \\
\hline M2K & 0.004 & 0.001 & 0 & 0.001 & 0.001 & 0 & 0 & 0 & 0 & 0 & 0 & 0.001 & 0.001 & 0 \\
\hline Sum_cat & 3.996 & 3.999 & 4 & 3.999 & 3.999 & 4 & 4 & 4 & 4 & 4 & 4 & 3.999 & 3.999 & 4 \\
\hline $\mathrm{Ca}$ & 41.621 & 38.874 & 34.58 & 31.284 & 32.244 & 40.622 & 38.864 & 45.95 & 46.828 & 46.963 & 46.796 & 46.422 & 47.241 & 46.823 \\
\hline $\mathrm{Mg}$ & 16.63 & 18.442 & 13.482 & 9.938 & 11.847 & 14.909 & 18.125 & 35.447 & 29.681 & 28.659 & 28.829 & 30.184 & 30.595 & 31.261 \\
\hline $\mathrm{Fe}^{2+}+\mathrm{Mn}$ & 41.749 & 42.685 & 51.938 & 58.778 & 55.91 & 44.469 & 43.011 & 18.603 & 23.491 & 24.378 & 24.374 & 23.394 & 22.163 & 21.916 \\
\hline Jd1 & 2.504 & 1.049 & 2.646 & 2.293 & 2.561 & 1.226 & 1.999 & 0 & 0.134 & 0 & 0.267 & 0 & 0.023 & 0.296 \\
\hline Ae1 & 16.347 & 20.567 & 24.177 & 28.444 & 27.099 & 17.439 & 19.021 & 4.329 & 4.127 & 4.46 & 4.066 & 3.872 & 3.985 & 3.988 \\
\hline CFTS1 & 0 & 0 & 0 & 0 & 0 & 0 & 0 & 0 & 0 & 0 & 0 & 0 & 0 & 0 \\
\hline CTTS1 & 0.701 & 0.521 & 0.003 & 0.438 & 0 & 0.435 & 0.49 & 0.777 & 0.556 & 0.712 & 0.689 & 0.69 & 0.585 & 0.721 \\
\hline CATS1 & 0 & 0 & 0 & 0 & 0 & 0 & 0 & 0 & 0 & 0 & 0 & 0 & 0 & 0 \\
\hline Wo1 & 34.081 & 30.969 & 26.046 & 21.812 & 23.274 & 33.714 & 31.063 & 43.861 & 45.133 & 45.043 & 44.914 & 44.732 & 45.564 & 44.988 \\
\hline En1 & 13.898 & 14.939 & 10.156 & 7.068 & 8.551 & 12.533 & 14.715 & 34.436 & 28.959 & 27.922 & 28.094 & 29.534 & 29.888 & 30.517 \\
\hline Fs1 & 32.469 & 31.955 & 36.972 & 39.945 & 38.515 & 34.653 & 32.713 & 16.597 & 21.092 & 21.863 & 21.97 & 21.171 & 19.954 & 19.49 \\
\hline$Q$ & 1.537 & 1.505 & 1.387 & 1.319 & 1.337 & 1.558 & 1.509 & 1.878 & 1.868 & 1.869 & 1.862 & 1.886 & 1.877 & 1.86 \\
\hline J & 0.706 & 0.828 & 1.017 & 1.17 & 1.127 & 0.715 & 0.802 & 0.169 & 0.166 & 0.174 & 0.168 & 0.15 & 0.155 & 0.166 \\
\hline Wot & 41.621 & 38.874 & 34.58 & 31.284 & 32.244 & 40.622 & 38.864 & 45.95 & 46.828 & 46.963 & 46.796 & 46.422 & 47.241 & 46.823 \\
\hline En1 & 16.63 & 18.442 & 13.482 & 9.938 & 11.847 & 14.909 & 18.125 & 35.447 & 29.681 & 28.659 & 28.829 & 30.184 & 30.595 & 31.261 \\
\hline Fst & 41.749 & 42.685 & 51.938 & 58.778 & 55.91 & 44.469 & 43.011 & 18.603 & 23.491 & 24.378 & 24.374 & 23.394 & 22.163 & 21.916 \\
\hline WEF & 69.153 & 65.258 & 58.406 & 53.659 & 54.913 & 69.25 & 65.912 & 91.859 & 91.968 & 91,656 & 91.877 & 92.753 & 92,502 & 91.931 \\
\hline Jd1 & 30.847 & 34.742 & 41.594 & 46.341 & 45.087 & 30.75 & 34,088 & 0 & 8.032 & 0 & 8.123 & 0 & 7.498 & 8.069 \\
\hline Aet & 0 & 0 & 0 & 0 & 0 & 0 & 0 & 0.085 & 0 & 0.087 & 0 & 0.076 & 0 & 0 \\
\hline
\end{tabular}

Observaçðes de abreviaçð̃es como na tabela 15.0 
Tabela 15.14 - Composição química de piroxênios de Cerro Siete Cabezas (\% peso)

\begin{tabular}{|c|c|c|c|c|c|c|c|}
\hline Amostra. & RP-230 & RP-230 & RP_230 & RP_-230 & RP. 230 & RP_230 & RP_23n \\
\hline Análises & 937 & 938 & 939 & 940 & 941 & 942 & 943 \\
\hline Locaçăo & C5G1b & C5G2Fn & $\mathrm{C} 5 \mathrm{G} 2 \mathrm{Fb}$ & C6G1Fn & C6G1Fb & C6G2Fn & C6G2FD \\
\hline Mineral & $\mathrm{Px}$ & Px & Px & Px & $P_{x}$ & Px & Px \\
\hline $\mathrm{SiO}_{2}$ & 51.71 & 51.3 & 50.26 & 50.76 & 51.36 & 51.65 & 51.02 \\
\hline $\mathrm{TiO}_{2}$ & 0.5 & 0.35 & 0.54 & 0.49 & 0.47 & 0.47 & 0.49 \\
\hline $\mathrm{Al}_{2} \mathrm{O}_{3}$ & 1.32 & 1.4 & 1.33 & 1.41 & 1.33 & 1.42 & 1.37 \\
\hline $\mathrm{FeO}$ & 12.06 & 11.7 & 14.91 & 13.05 & 12.6 & 11.51 & 12.62 \\
\hline $\mathrm{Cr}_{2} \mathrm{O}_{3}$ & 0 & 0 & 0 & 0 & 0 & 0 & 0 \\
\hline $\mathrm{MnO}$ & 1.06 & 1.05 & 1.21 & 1.14 & 1.13 & 0.96 & 1.12 \\
\hline $\mathrm{NiO}$ & 0 & 0 & 0 & 0 & 0 & 0 & 0 \\
\hline $\mathrm{MgO}$ & 9.68 & 9.85 & 8.03 & 9.31 & 10.07 & 10.79 & 10.21 \\
\hline $\mathrm{CaO}$ & 21.88 & $2\} .7$ & 21.43 & 21.77 & 21.99 & 21.87 & 21.7 \\
\hline $\mathrm{Na}_{2} \mathrm{O}$ & 1.3 & 1.57 & 1.59 & 1.52 & 1.25 & 0.99 & 1.09 \\
\hline $\mathrm{K}_{2} \mathrm{O}$ & 0.01 & 0.06 & 0 & 0 & 0 & 0 & 0 \\
\hline $\mathrm{ZnO}$ & 0 & 0 & 0 & 0 & 0 & 0 & 0 \\
\hline $\mathrm{ZrO}_{2}$ & 0.15 & 0.21 & 0.16 & 0.21 & 0.1 & 0.16 & 0.16 \\
\hline Total & 99.52 & 98.98 & 99.3 & 99.45 & 100.2 & 99.66 & 99.62 \\
\hline \multicolumn{8}{|c|}{ Fórmula estrutural calculada na base de 6 átomos de oxigénio } \\
\hline$T S \mathbf{i}$ & 1.969 & 1.955 & 1.938 & 1.937 & 1.942 & 1.957 & 1.942 \\
\hline TAl & 0.031 & 0.045 & 0.06 & 0.063 & 0.058 & 0.043 & 0.058 \\
\hline $\mathrm{TFe}^{3+}$ & 0 & 0 & 0 & 0 & 0 & 0 & 0 \\
\hline M1Al & 0.029 & 0.018 & 0 & 0 & 0.002 & 0.021 & 0.003 \\
\hline M1Ti & 0.014 & 0.01 & 0.016 & 0.014 & 0.013 & 0.013 & 0.014 \\
\hline${\mathrm{M} 1 \mathrm{Fe}^{3+}}^{3+}$ & 0 & 0 & 0 & 0 & 0 & 0 & 0 \\
\hline $\mathrm{MMFe}^{2+}$ & 0.384 & 0.373 & 0.481 & 0.416 & 0.398 & 0.356 & 0.402 \\
\hline $\mathrm{M} 1 \mathrm{Cr}$ & 0 & 0 & 0 & 0 & 0 & 0 & 0 \\
\hline $\mathrm{M} 1 \mathrm{Mg}$ & 0.55 & 0.56 & 0.462 & 0.53 & 0.568 & 0.61 & 0.579 \\
\hline M1Ni & 0 & 0 & 0 & 0 & 0 & 0 & 0 \\
\hline $\mathrm{M} 2 \mathrm{Mg}$ & 0 & 0 & 0 & 0 & 0 & 0 & 0 \\
\hline $\mathrm{M} 2 \mathrm{Fe} 2$ & 0 & 0 & 0 & 0 & 0 & 0.008 & 0 \\
\hline M2Mn & 0.034 & 0.034 & 0.04 & 0.037 & 0.036 & 0.031 & 0.036 \\
\hline $\mathrm{M} 2 \mathrm{Ca}$ & 0.893 & 0.886 & 0.885 & 0.89 & 0.891 & 0.888 & 0.885 \\
\hline $\mathrm{M} 2 \mathrm{Na}$ & 0.096 & 0.116 & 0.119 & 0.112 & 0.092 & 0.073 & 0.08 \\
\hline M2K & 0 & 0.003 & 0 & 0 & 0 & 0 & 0 \\
\hline Sum_cat & 4 & 3.997 & 4 & 4 & 4 & 4 & 4 \\
\hline $\mathrm{Ca}$ & 47.982 & 47.831 & 47,414 & 47.521 & 47.058 & 46.905 & 46.525 \\
\hline $\mathrm{Mg}$ & 29.537 & 30.209 & 24.72 & 28.277 & 29.984 & 32.199 & 30.458 \\
\hline $\mathrm{Fe}^{2+} \mathrm{Mn}$ & 22.481 & 21.959 & 27.866 & 24.202 & 22.958 & 20,896 & 23.018 \\
\hline $\mathrm{Jdt}$ & 1.483 & 0.941 & 0 & 0.021 & 0.079 & 1.07 & 0.174 \\
\hline $\mathrm{Ae} 1$ & 3.534 & 5.198 & 6.107 & 5.751 & 4.624 & 2.689 & 3.959 \\
\hline CFTS1 & 0 & 0 & 0 & 0 & 0 & 0 & 0 \\
\hline CTTSI & 0.745 & 0.518 & 0.805 & 0.722 & 0.686 & 0.692 & 0.721 \\
\hline CATS1 & 0 & 0 & 0 & 0 & 0 & 0 & 0 \\
\hline Wo1 & 45.683 & 45.214 & 44.677 & 44.955 & 45.033 & 45.196 & 44.744 \\
\hline En1 & 28.58 & 28.883 & 23.712 & 27,179 & 29.431 & 31.501 & 29.764 \\
\hline Fs1 & 19.975 & 19.246 & 24.699 & 21.372 & 20.447 & 18.851 & 20.638 \\
\hline Q & 1.826 & 1.819 & 1.828 & 1.836 & 1.857 & 1.862 & 1.866 \\
\hline J & 0.192 & 0.232 & 0.238 & 0.225 & 0.183 & 0.145 & 0.161 \\
\hline Wo1 & 47.982 & 47.831 & 47.414 & 47.521 & 47.058 & 46.905 & 46.525 \\
\hline En1 & 29.537 & 30.209 & 24.72 & 28.277 & 29.984 & 32.199 & 30.458 \\
\hline $\mathrm{Fs} 1$ & 22.481 & 21.959 & 27.866 & 24.202 & 22.958 & 20.896 & 23.018 \\
\hline WEF & 90.646 & 88.869 & 88.705 & 89.278 & 91.173 & 92,863 & 92.201 \\
\hline Jd1 & 9.354 & 11.131 & 0 & 10.722 & 8.827 & 7.137 & 7.799 \\
\hline Ae1 & 0 & 0 & 0.119 & 0 & 0 & 0 & 0 \\
\hline
\end{tabular}

Observações de abreviações como na tabela 15.0 
A
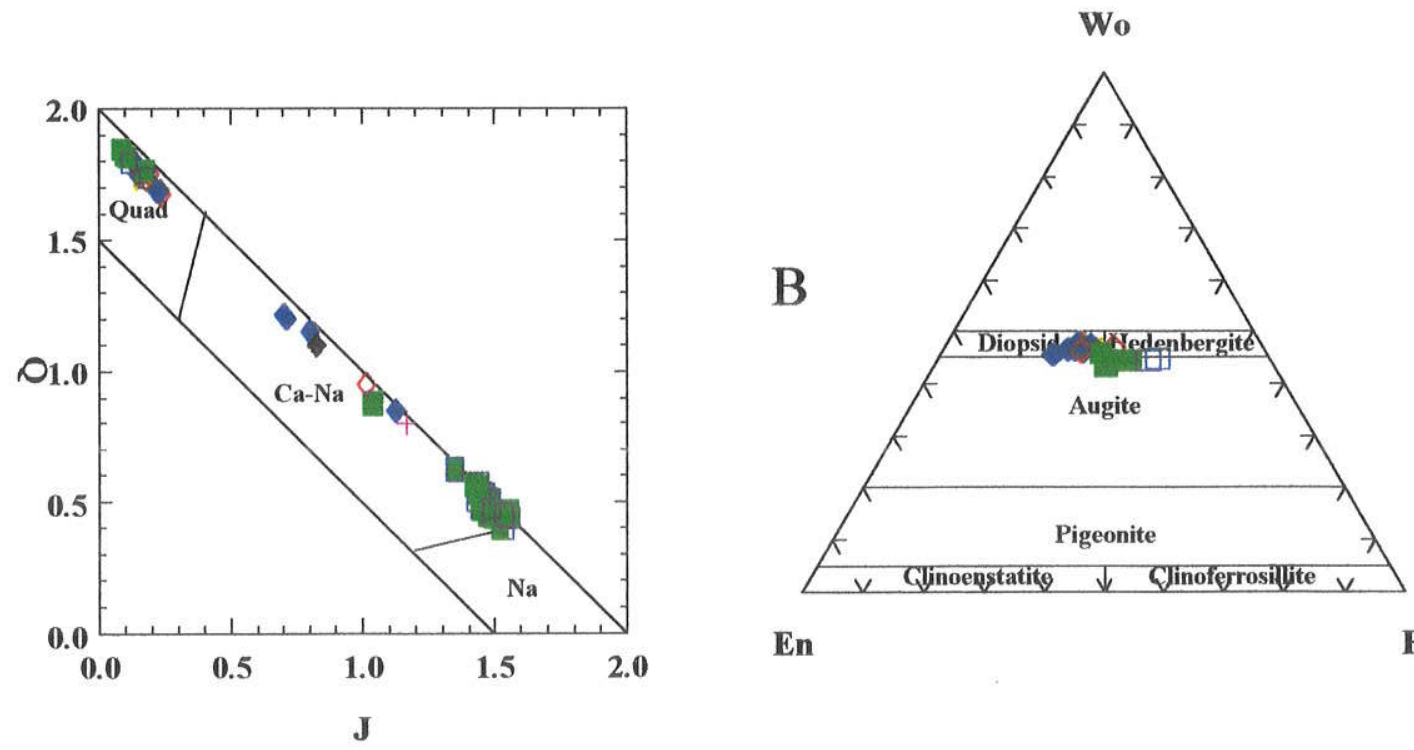

En

Fs

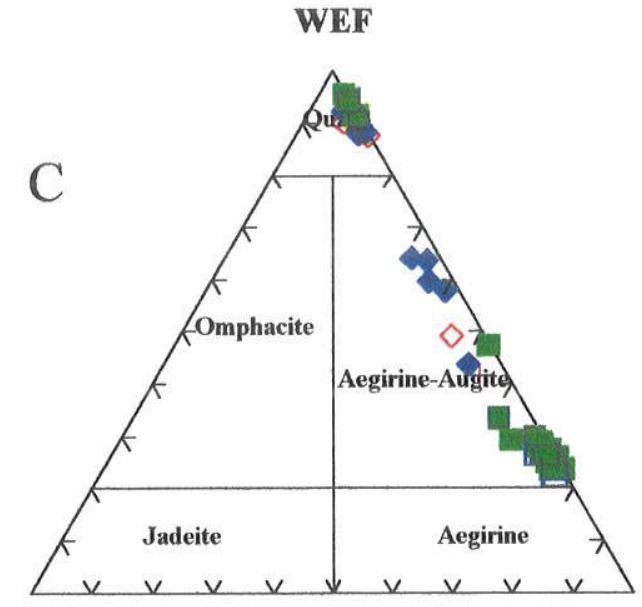

Jd

Ae

Figura 46 (A, B e C) - Distribuição dos piroxênios das rochas de Cerro Siete Cabezas e Satélites I e II nos diagramas de classificação do IMA (Morimoto, 1989) ]. Símbolos: núcleos de fenocristais e outros grãos em sienitos alcalinos (quadrados cheios); bordas de fenocristais e outros em sienitos alcalinos (quadrados vazios); núcleos de cristais em nefelina sienitos (losangos cheios) e bordas de grãos em nefelina sienitos (losangos vazios); grãos da matriz (cruzes); inclusões (xis), borda de reação, quadrado semi-cheio. 


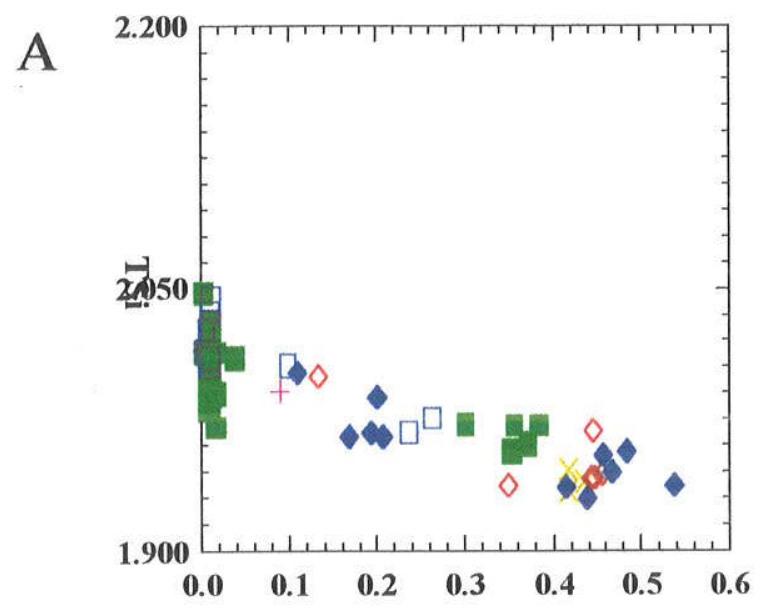

B
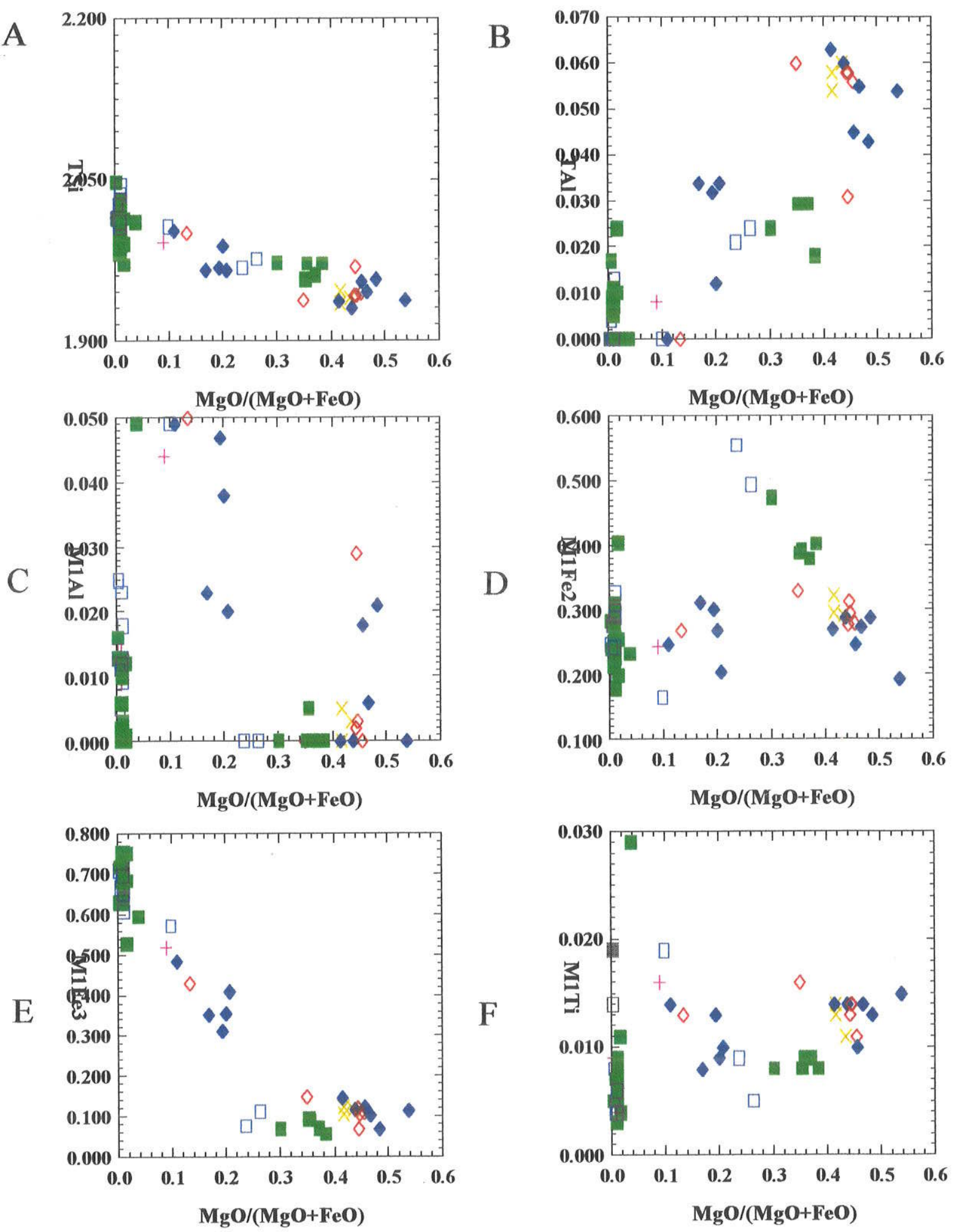

Figura 47 (A, B, C, D, E e F) Diagramas de variação composicional de piroxênios das rochas de Cerro Siete Cabezas, Satélite I e Satélite II. Símbolos como na figura 46. 

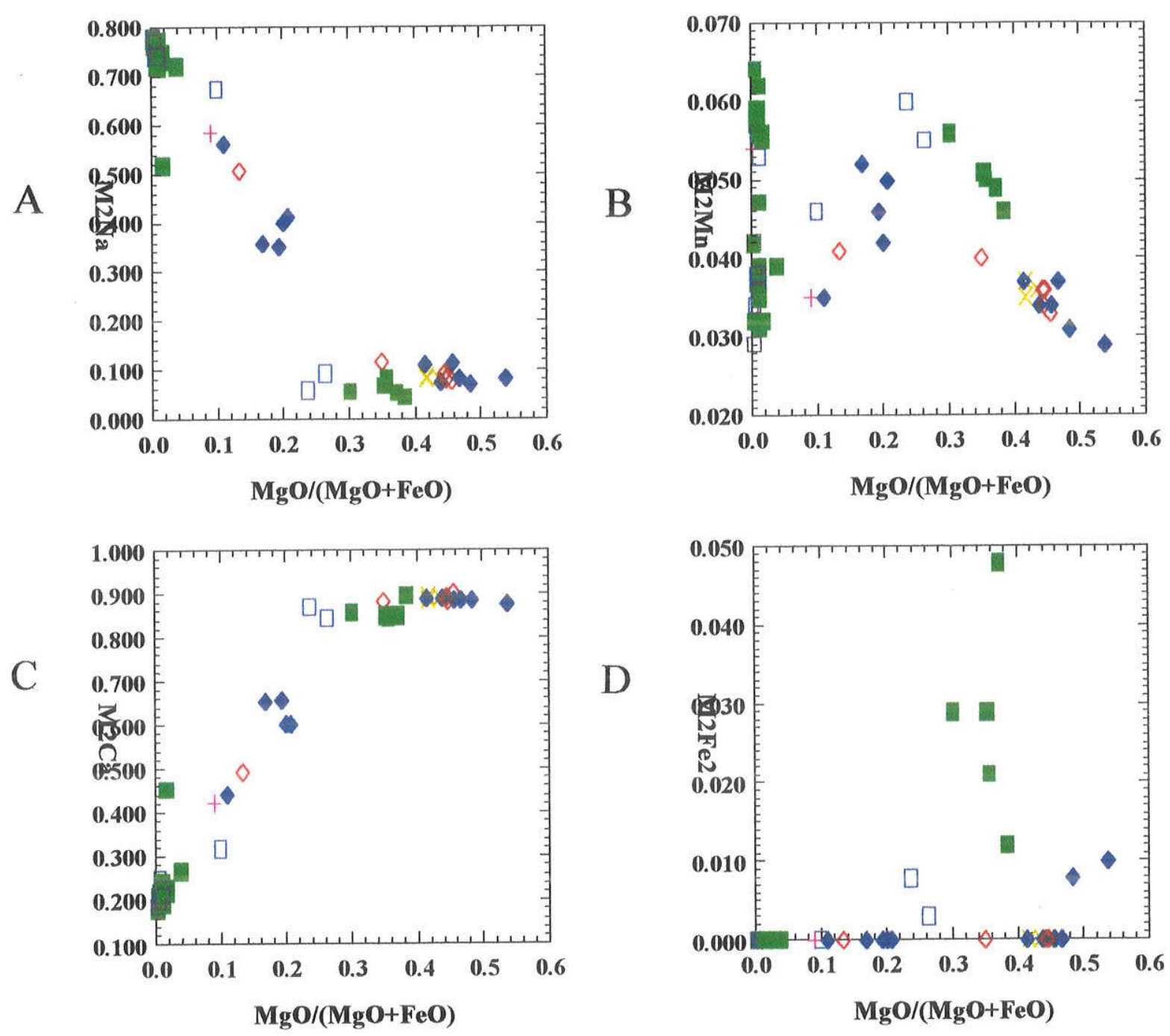

Figura 48 (A, B, C e D) - Diagramas de variação composicional de piroxênios de Cerro Siete Cabezas e corpos Satélites I e II. Símbolos como na figura 46. 
V.4.3 - Ilha Fecho dos Morros

Os piroxênios que ocorrem nos litotipos pertencentes à liha Fecho dos Morros apresentam-se preferencialmente como cristais bem desenvolvidos (granulação muito grossa), chegando a constituir, por vezes, texturas pegmatíticas. Trata-se de sienitos nefelínicos, cujos litotipos predominam nos afloramentos mais característicos da itha. Suas composições químicas podem ser observadas nas tabelas 15.15 e 15.16 juntamente com as fórmulas estruturais, calculada na base de seis átomos de oxigênio e componentes moleculares.

$\mathrm{Na}$ observação da tabela 15.15 constata-se que os teores de CaO mostram acentuado enriquecimento na amostra 201-A (média de 21\%) e empobrecimento em $\mathrm{Na}_{2} \mathrm{O}$, com teor médio de 1,5\%. Por outro lado, os teores de $\mathrm{Na}_{2} \mathrm{O}$ dos piroxênios de sienitos nefelínicos das demais amostras estudadas apresentam valores de até $10,2 \%$.

Os piroxênios dos sienitos nefelínicos da liha Fecho dos Morros plotam-se nos campos Quad, cálcicos-sódicos e sódicos. Os piroxênios do Quad classificamse como salitas no diagrama Wo-En-Fs (Figura 49-A), enquanto que os cálcicosódicos e sódicos correspondem respectivamente às egirina-augita e egirina no diagrama WEF-Jd-Ae (Figura.49-B)

0 exame das fórmulas estruturais indica que, excetuando-se 2 amostras, todos os sítios tetraédricos estão ocupados por $\mathrm{Si}$, não necessitando de preenchimento de $\mathrm{Al}$ na posição $Z$ (Figuras 50-A e B). As posições octaédricas regulares M1 estão ocupadas por $\mathrm{Al}^{\mathrm{V}}, \mathrm{Fe}^{3+}, \mathrm{Ti}_{\text {e }} \mathrm{Fe}^{2+}$ (Figuras 50-C, D, E e F), ao passo que as irregulares $\mathrm{M} 2$ são preenchidas por $\mathrm{Na}$, Mn e Ca (Figuras 51-A, B, C e D. 
Tabela 15.15 - Composição quimica de piroxênios da llha de Fecho dos Morros (\% peso)

Amostra RP-91 RP-91 RP-91. RP-91. RP-91. RP-91. RP-91. RP-91. RP-201A RP-201A

$\begin{array}{lllllllllll}\text { Análises } & 1052 & 1153 & 1053 & 1054 & 1057 & 1058 & 1059 & 1060 & 1073 & 1077\end{array}$

Locação C4G1n C1G1n C4G1b C4G2n C3G1n C3G2n C2G1n C1Gin C4G1n C1G1n

$\begin{array}{lllllllllll}\text { Mineral } & P x & P x & P x & P x & P x & P x & P x & P x & P x & P x\end{array}$

$\begin{array}{lllllllllll}\mathrm{SiO}_{2} & 51.36 & 51.45 & 51.57 & 51.07 & 51.76 & 51.62 & 51.92 & 51.23 & 52.42 & 52.31\end{array}$

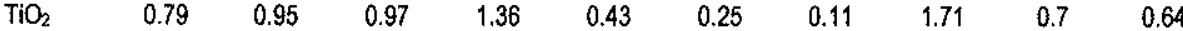

$\begin{array}{lllllllllll}\mathrm{Al}_{2} \mathrm{O}_{3} & 0.26 & 0.24 & 0.19 & 0.25 & 0.44 & 0.29 & 0.26 & 0.26 & 1.21 & 0.89\end{array}$

$\begin{array}{lllllllllll}\mathrm{FeO} & 27.97 & 27.91 & 28.4 & 26.98 & 28.21 & 27.4 & 25 & 26.93 & 8.69 & 9.91\end{array}$

$\begin{array}{ccccccccccc}\mathrm{Cr}_{2} \mathrm{O}_{3} & 0 & 0.02 & 0 & 0 & 0 & 0 & 0 & 0 & 0 & 0.03\end{array}$

$\begin{array}{lllllllllll}\mathrm{MnO} & 0.85 & 0.81 & 0.75 & 0.92 & 0.72 & 0.78 & 1.17 & 0.92 & 0.54 & 0.53\end{array}$

$\begin{array}{ccccccccccc}\mathrm{NiO} & 0 & 0 & 0 & 0 & 0 & 0 & 0 & 0 & 0 & 0 \\ \mathrm{MgO} & 1.15 & 1.15 & 0.78 & 1.3 & 1.09 & 1.32 & 2.89 & 1.42 & 13.35 & 12.1\end{array}$

$\begin{array}{lllllllllll}\mathrm{CaO} & 4.1 & 3.16 & 2.87 & 4.82 & 3.12 & 3.8 & 7.16 & 2.35 & 21.23 & 20.45\end{array}$

$\begin{array}{lllllllllll}\mathrm{Na}_{2} \mathrm{O} & 10.05 & 10.55 & 10.66 & 9.63 & 10.74 & 10.37 & 8.7 & 11.23 & 1.39 & 1.68\end{array}$

$\begin{array}{ccccccccccc}\mathrm{K}_{2} \mathrm{O} & 0 & 0 & 0.01 & 0 & 0.01 & 0.01 & 0.01 & 0.01 & 0 & 0.02 \\ \mathrm{ZnO} & 0 & 0 & 0 & 0 & 0 & 0 & 0 & 0 & 0 & 0\end{array}$

$\begin{array}{lllllllllll}\mathrm{ZrO}_{2} & 0 & 0 & 0 & 0 & 0 & 0 & 0 & 0 & 0 & 0\end{array}$

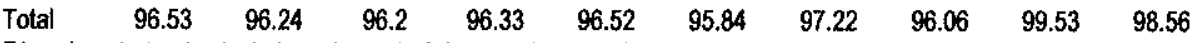

Fórmula estrutural calculada na base de 6 átomos de oxigénio

\begin{tabular}{|c|c|c|c|c|c|c|c|c|c|c|}
\hline TSi & 2.015 & 2.017 & 2.026 & 2.013 & 2.018 & 2.027 & 2.015 & 1.998 & 1.952 & 1.977 \\
\hline TAl & 0 & 0 & 0 & 0 & 0 & 0 & 0 & 0.002 & 0.048 & 0.023 \\
\hline $\mathrm{TFe}^{3+}$ & 0 & 0 & 0 & 0 & 0 & 0 & 0 & 0 & 0 & 0 \\
\hline M1AI & 0.012 & 0.011 & 0.009 & 0.012 & 0.02 & 0.013 & 0.012 & 0.01 & 0.005 & 0.017 \\
\hline$T i$ & 0.023 & 0.028 & 0.029 & 0.04 & 0.013 & 0.007 & 0.003 & 0.05 & 0.02 & 0.018 \\
\hline $\mathrm{Fe}^{3+}$ & 0 & 0 & 0 & 0 & 0 & 0 & 0 & 0 & 0 & 0 \\
\hline $\mathrm{Fe}^{2+}$ & 0.897 & 0.893 & 0.917 & 0.872 & 0.904 & 0.9 & 0.811 & 0.857 & 0.235 & 0.282 \\
\hline $\mathrm{Cr}$ & 0 & 0.001 & 0 & 0 & 0 & 0 & 0 & 0 & 0 & 0.001 \\
\hline $\mathrm{Mg}$ & 0.067 & 0.067 & 0.046 & 0.076 & 0.063 & 0.077 & 0.167 & 0.083 & 0.741 & 0.682 \\
\hline $\mathrm{Ni}$ & 0 & 0 & 0 & 0 & 0 & 0 & 0 & 0 & 0 & 0 \\
\hline $\mathrm{Mg}$ & 0 & 0 & 0 & 0 & 0 & 0 & 0 & 0 & 0 & 0 \\
\hline $\mathrm{Fe} 2$ & 0.02 & 0.022 & 0.016 & 0.017 & 0.016 & 0 & 0 & 0.022 & 0.036 & 0.031 \\
\hline $\mathrm{Mn}$ & 0.028 & 0.027 & 0.025 & 0.031 & 0.024 & 0.026 & 0.038 & 0.03 & 0.017 & 0.017 \\
\hline $2 \mathrm{Ca}$ & 0.172 & 0.133 & 0.121 & 0.204 & 0.13 & 0.16 & 0.298 & 0.098 & 0.847 & 0.828 \\
\hline $12 \mathrm{Na}$ & 0.764 & 0.802 & 0.812 & 0.736 & 0.812 & 0.789 & 0.655 & 0.849 & 0.1 & 0.123 \\
\hline $12 \mathrm{~K}$ & 0 & 0 & 0.001 & 0 & 0 & 0.001 & 0 & 0 & 0 & 0.001 \\
\hline um_cat & 4 & 4 & 3.999 & 4 & 4 & 3.999 & 4 & 4 & 4 & 3.999 \\
\hline & 14.537 & 11.624 & 10.743 & 16.963 & 11.46 & 13.748 & 22.644 & 9.013 & 45.156 & 45.004 \\
\hline & 5.673 & 5.886 & 4.062 & 6.366 & 5.571 & 6.645 & 12.717 & 7.578 & 39.509 & 37.051 \\
\hline $2+\mathrm{Mn}$ & 79.79 & 82.49 & 85.195 & 76.672 & 82.969 & 79.607 & 64.639 & 83.409 & 15.335 & 17.945 \\
\hline & 0.625 & 0.578 & 0.46 & 0.609 & 1.049 & 0.696 & 0.615 & 0.538 & 0.238 & 0.858 \\
\hline & 39.156 & 41.257 & 42.035 & 38.02 & 41.135 & 40.304 & 33.306 & 43.978 & 4.885 & 5.514 \\
\hline TS1 & 0 & 0 & 0 & 0 & 0 & 0 & 0 & 0 & 0 & 0 \\
\hline TS1 & 0 & 0 & 0 & 0 & 0 & 0 & 0 & 0.088 & 1.001 & 0.934 \\
\hline CATS1 & 0 & 0 & 0 & 0 & 0 & 0 & 0 & 0 & 0 & 0 \\
\hline & 8.968 & 6.924 & 6.318 & 10.684 & 6.767 & 8.296 & 15.414 & 5.057 & 42.234 & 41.594 \\
\hline & 3.5 & 3.506 & 2.389 & 4.009 & 3.29 & 4.01 & 8.657 & 4.325 & 37.828 & 35.012 \\
\hline & 47.751 & 47.734 & 48.799 & 46.678 & 47.759 & 46.694 & 42.009 & 46.015 & 13.814 & 16.086 \\
\hline & 1.157 & 1.115 & 1.099 & $\{.169$ & 1.113 & 1.137 & 1.276 & 1.059 & 1.858 & 1.823 \\
\hline & 4.529 & 1.604 & 1.624 & 1.472 & 1.624 & 1.579 & 1.309 & 1.699 & 0.201 & 0.246 \\
\hline & 14.537 & 11.624 & 10.743 & 16.963 & 11.46 & 13.748 & 22.644 & 9.013 & 45.156 & 45.004 \\
\hline & 5.673 & 5.886 & 4.062 & 6.366 & 5.571 & 6.645 & 12.717 & 7.578 & 39.509 & 37.051 \\
\hline & 79.79 & 82.49 & 85.195 & 76.672 & 82.969 & 79.607 & 64.639 & 83.409 & 15.335 & 17.945 \\
\hline & 43.673 & 41.586 & 40.913 & 44.91 & 41.189 & 42.41 & 50.103 & 39.078 & 90.333 & 88.197 \\
\hline & 56.327 & 58.414 & 59.087 & 55.09 & $58.81 \uparrow$ & 57.59 & 49.897 & 60.922 & 9.667 & 11.803 \\
\hline & 0 & 0 & 0 & 0 & 0 & 0 & 0 & 0 & 0 & 0 \\
\hline
\end{tabular}

Observaçס̃es de abreviaçðos como na tabela 15.0 
Tabela 15.16 - Composição química dos piroxênios da llha Fecho dos Morros (\% peso)

\begin{tabular}{|c|c|c|c|c|c|c|c|c|}
\hline Amostra & RP-222 & RP-222 & RP-222 & $R P \cdot 222$ & $R P-222$ & RP-222 & $\mathrm{RP}-222$ & RP-222 \\
\hline Análises & 1084 & 1085 & 1086 & 1088 & 1089 & 1090 & 1091 & 1092 \\
\hline Locação & $\mathrm{C} 1 \mathrm{G} 1 \mathrm{~m}$ & $\mathrm{C} 1 \mathrm{G} 2 \mathrm{~m}$ & $\mathrm{C} 1 \mathrm{G} 3 \mathrm{~m}$ & $\mathrm{C} 2 \mathrm{G} 1 \mathrm{~m}$ & $\mathrm{C} 3 \mathrm{G} 1 \mathrm{~m}$ & C4G1m & $\mathrm{C} 4 \mathrm{G} 2 \mathrm{~m}$ & C5G1m \\
\hline Mineral & Px & Px & Px & $P x$ & $\mathrm{Px}$ & Px & Px & Px \\
\hline $\mathrm{SiO}_{2}$ & 52.06 & 51.78 & 52.45 & 52.98 & 52.32 & 51.67 & 51.81 & 52.19 \\
\hline $\mathrm{TiO}_{2}$ & 2.63 & 3.16 & 3.19 & 2.69 & 1.96 & 1.84 & 2.1 & 2.69 \\
\hline $\mathrm{Al}_{2} \mathrm{O}_{3}$ & 0.94 & 0.86 & 0.84 & 0.91 & 0.99 & 1.14 & 0.94 & 0.97 \\
\hline $\mathrm{FoO}$ & 26.02 & 25.24 & 24.52 & 25.16 & 26.91 & 26.79 & 26.11 & 25.43 \\
\hline $\mathrm{Cr}_{2} \mathrm{O}_{3}$ & 0 & 0 & 0 & 0 & 0 & 0 & 0 & 0 \\
\hline $\mathrm{MnO}$ & 0.47 & 0.67 & 0.62 & 0.57 & 0.44 & 0.45 & 0.61 & 0.48 \\
\hline $\mathrm{NiO}$ & 0 & 0 & 0 & 0 & 0 & 0 & 0 & 0 \\
\hline $\mathrm{MgO}$ & 0.81 & 0.98 & 1.1 & 1.05 & 0.55 & 0.59 & 0.9 & 0.82 \\
\hline $\mathrm{CaO}$ & 2.07 & 1.64 & 1.75 & 1.28 & 1.45 & 1.82 & 2.58 & 2.11 \\
\hline $\mathrm{Na}_{2} \mathrm{O}$ & 11.76 & 12.36 & 11.1 & 12.35 & 12.27 & 11.97 & 11.71 & 11.94 \\
\hline $\mathrm{K}_{2} \mathrm{O}$ & 0 & 0 & 0.03 & 0.09 & 0.03 & 0.02 & 0.01 & 0 \\
\hline $\mathrm{ZnO}$ & 0 & 0 & 0 & 0 & 0 & 0 & 0 & 0 \\
\hline $\mathrm{ZrO}_{2}$ & 0.28 & 0.11 & 0.14 & 0.08 & 0.36 & 0.36 & 0.24 & 0.17 \\
\hline Total & 96.76 & 96.69 & 95.6 & 97.08 & 96.92 & 96.29 & 96.77 & 96.63 \\
\hline \multicolumn{9}{|c|}{ Fórmula estrutural calculada na base de 6 áłomos de oxigénio } \\
\hline TSi & 2.011 & $1.99\}$ & 2.058 & 2.026 & 2.012 & 2.002 & 1.999 & 2.014 \\
\hline TAI & 0 & 0.009 & 0 & 0 & 0 & 0 & 0.001 & 0 \\
\hline $\mathrm{TFe}^{3+}$ & 0 & 0 & 0 & 0 & 0 & 0 & 0 & 0 \\
\hline M1Al & 0.043 & 0.03 & 0.039 & 0.041 & 0.045 & 0.052 & 0.042 & 0.044 \\
\hline M1Ti & 0.076 & 0.091 & 0.094 & 0.077 & 0.057 & 0.054 & 0.061 & 0.078 \\
\hline M1Fe ${ }^{3+}$ & 0 & 0 & 0 & 0 & 0 & 0 & 0 & 0 \\
\hline $\mathrm{M}^{1} \mathrm{Fe}^{2+}$ & 0.834 & 0.812 & 0.803 & 0.805 & 0.865 & 0.86 & 0.842 & 0.821 \\
\hline $\mathrm{M} 1 \mathrm{Cr}$ & 0 & 0 & 0 & 0 & 0 & 0 & 0 & 0 \\
\hline MiMg & 0.047 & 0.056 & 0.064 & 0.06 & 0.032 & 0.034 & 0.052 & 0.047 \\
\hline MiNi & 0 & 0 & 0 & 0 & 0 & 0 & 0 & 0 \\
\hline M2Mg & 0 & 0 & 0 & 0 & 0 & 0 & 0 & 0 \\
\hline M2Fe2 & 0.007 & 0 & 0.002 & 0 & 0 & 0.008 & 0 & 0 \\
\hline M2Mn & 0.015 & 0.022 & 0.021 & 0.018 & 0.014 & 0.015 & 0.02 & 0.016 \\
\hline $\mathrm{M} 2 \mathrm{Ca}$ & 0.086 & 0.068 & 0.074 & 0.052 & 0.06 & 0.076 & 0.107 & 0.087 \\
\hline $\mathrm{M} 2 \mathrm{Na}$ & 0.881 & 0.922 & 0.844 & 0.916 & 0.915 & 0.899 & 0.876 & 0.893 \\
\hline M2K & 0 & 0 & 0.002 & 0.004 & 0.001 & 0.001 & 0 & 0 \\
\hline Sum_cat & 4 & 4 & 3.998 & 3.996 & 3.999 & 3.999 & 4 & 4 \\
\hline $\mathrm{Ca}$ & 8.669 & 7.059 & 7.639 & 5.607 & 6.153 & 7.613 & 10.448 & 8.986 \\
\hline $\mathrm{Mg}$ & 4.72 & 5.869 & 6.681 & 6.399 & 3.247 & 3.434 & 5.071 & 4.859 \\
\hline $\mathrm{Fe}^{2+}-\mathrm{Mn}$ & 86.611 & 87.073 & 85.681 & 87.994 & 90.6 & 88.954 & 84.481 & 86.154 \\
\hline Jd1 & 2.307 & 1.611 & 2.17 & 2.231 & 2.394 & 2.77 & 2.22 & 2.385 \\
\hline Ae1 & 45.21 & 48.016 & 45.132 & 47.856 & 46.53 & 45.169 & 44.468 & 45.947 \\
\hline CFTS1 & 0 & 0 & 0 & 0 & 0 & 0 & 0 & 0 \\
\hline CTIS1 & 0 & 0.486 & 0 & 0 & 0 & 0 & 0.055 & 0 \\
\hline CATS1 & 0 & 0 & 0 & 0 & 0 & 0 & 0 & 0 \\
\hline W01 & 4.622 & 3.152 & 4.113 & 2.855 & 3.19 & 4.023 & 5.626 & 4.719 \\
\hline En1 & 2.516 & 3.025 & 3.598 & 3.258 & 1.683 & 1.815 & 2.757 & 2.552 \\
\hline Fst & 45.345 & 43.709 & 44.987 & 43.8 & 46.203 & 46.224 & 44.874 & 44.397 \\
\hline$Q$ & 0.973 & 0.935 & 0.942 & 0.917 & 0.956 & 0.978 & 1.001 & 0.955 \\
\hline J & 1.762 & 1.843 & 1.689 & 1.832 & 1.829 & 1.798 & 1.752 & 1.787 \\
\hline Wo1 & 8.669 & 7.059 & 7.639 & 5.607 & 6.153 & 7.613 & 10.448 & 8.986 \\
\hline En1 & 4.72 & 5.869 & 6.681 & 6.399 & 3.247 & 3.434 & 5.071 & 4.859 \\
\hline $\mathrm{Fs} 1$ & 86.611 & 87.073 & 85.681 & 87.994 & 90.6 & 88.954 & 84.481 & 86.154 \\
\hline WEF & 35.938 & 34.182 & 36.315 & 33.807 & 34,669 & 35.559 & 36.814 & 35.204 \\
\hline Jd1 & 64.062 & 65.818 & 63.685 & 66.193 & 65.331 & 64.441 & 63.186 & 64.796 \\
\hline Ae 1 & 0 & 0 & 0 & 0 & 0 & 0 & 0 & 0 \\
\hline
\end{tabular}

Observaçőes de abreviaçðes como na tabela $\mathbf{1 5 . 0}$ 


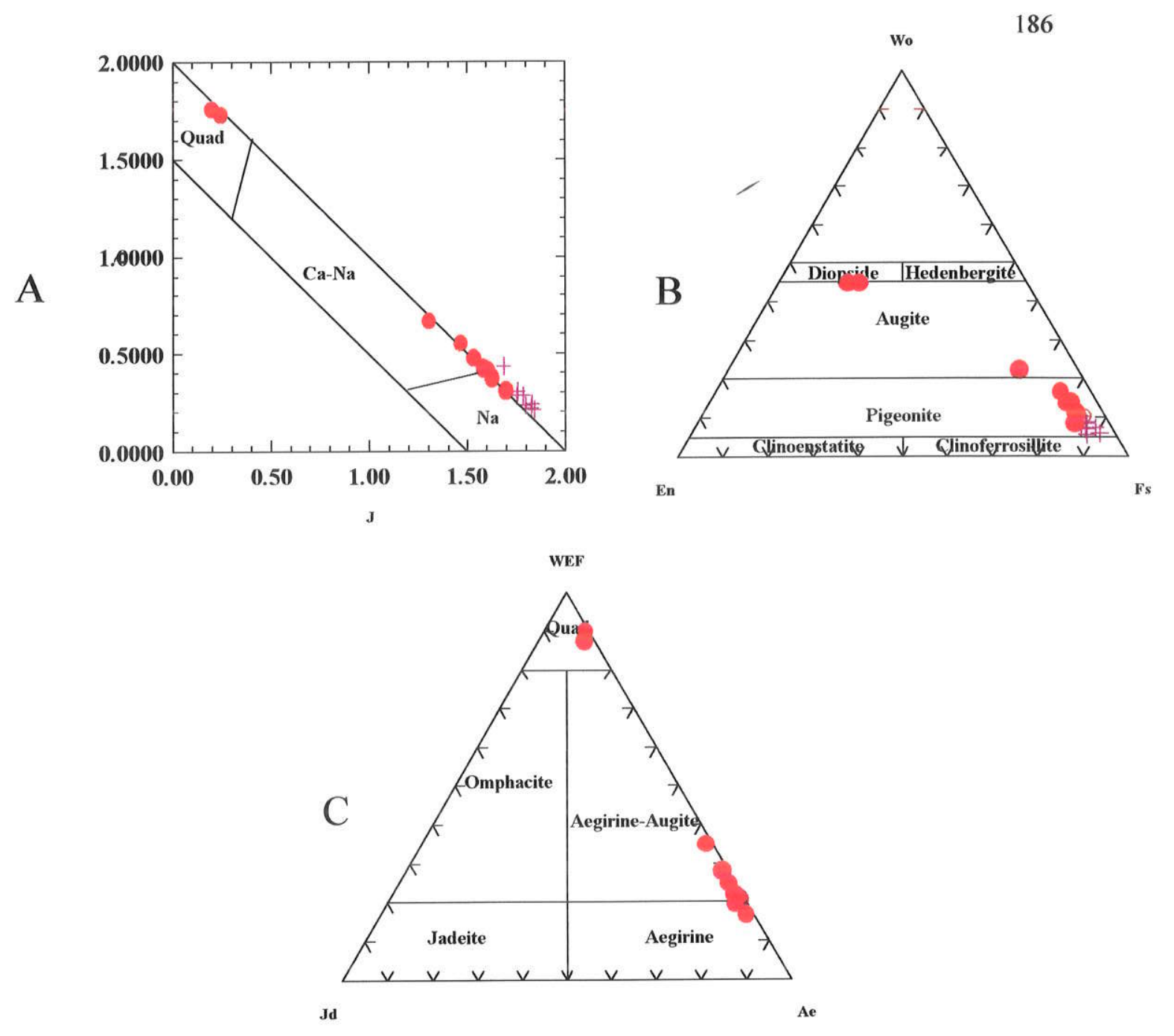

Figura 49 (A, B e C) -.Distribuição dos piroxênios das rochas da llha Fecho dos Morros nos diagaramas do IMA (Morimoto, 1989). Simbolos como na figura 42. 

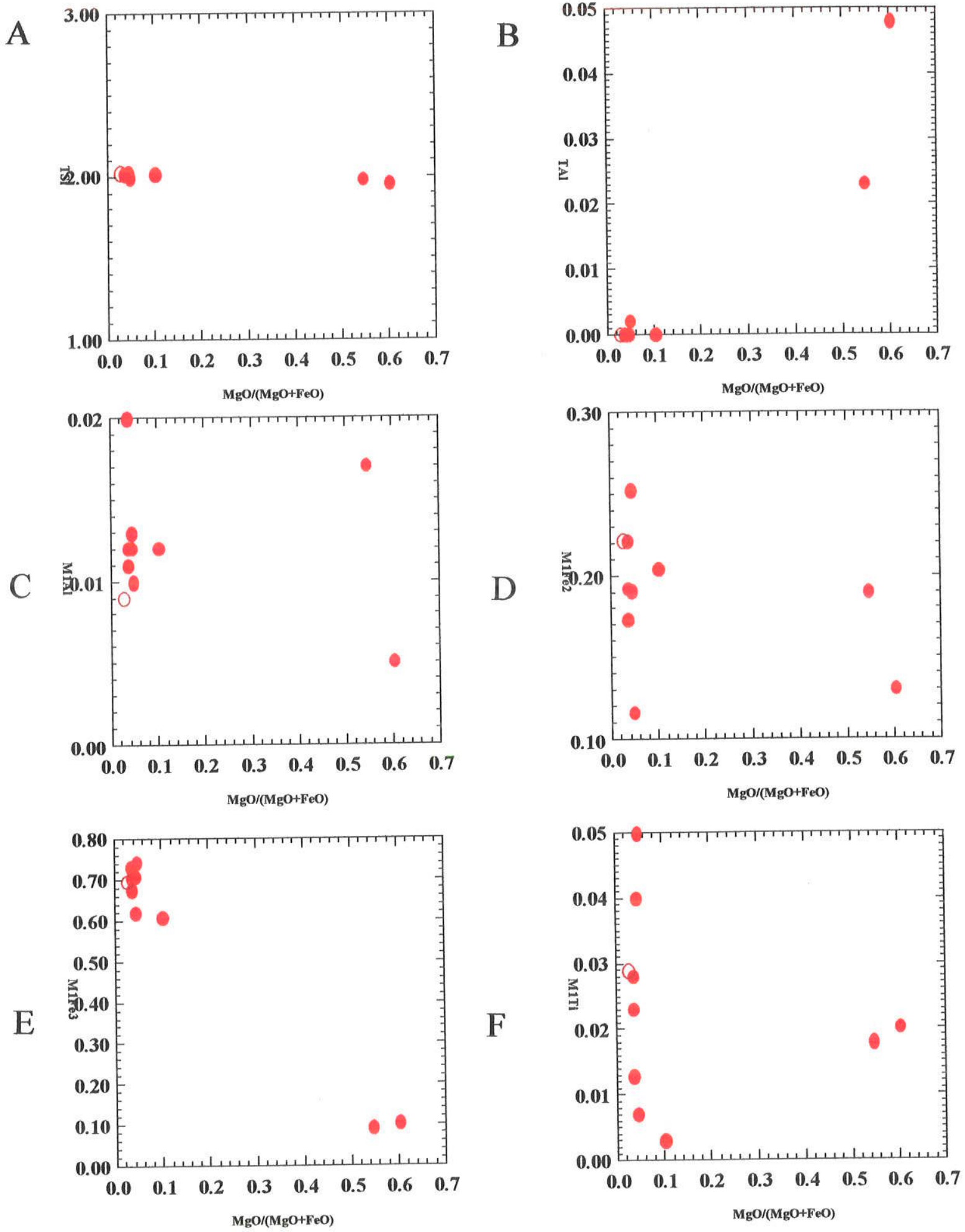

Figura 50 (A, B, C, D,E e F) - Diagramas de variação composicional dos piroxênios das rochas da llha Fecho dos Morros. Símbolos como na figura 42. 

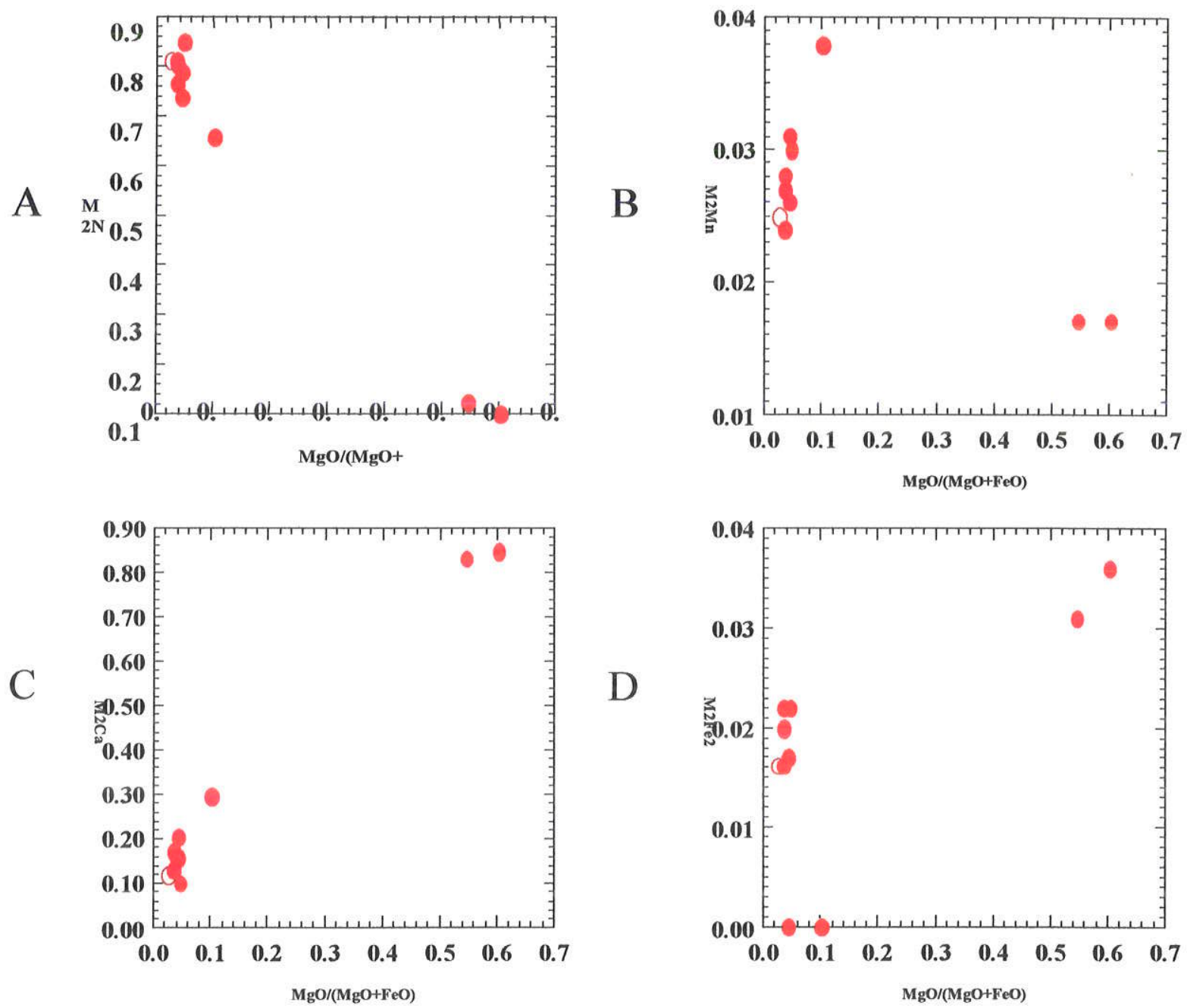

Figura 51 (A, B, C e D) -Diagramas de variação composicional dos piroxênios das rochas da llha Fecho dos Morros. Simbolos como na figura 42. 
V.4.4- Cerrito

Petrograficamente, as rochas de Cerrito contendo piroxênio estão representadas por litotipos de granulação variável de média a grossa, existindo, por vezes, rochas com textura pegmatítica. Composicionalmente, correspondem a sienitos nefelínicos.

Contando com uma quantidade de 19 análises presentes nas tabelas $15.17 \mathrm{e}$ 15.18, os piroxênios de Cerrito apresentam concentrações de $\mathrm{TiO}_{2}$ entre 0,8 e $1,58 \%$ e de $\mathrm{Al}_{2} \mathrm{O}_{3}$ entre 1,9 e $3,25 \%$.

Diferentemente dos termos cálcico-sódicos e sódicos das rochas dos outros corpos aqui estudados, os piroxênios dos sienitos nefelínicos do maciço de Cerrito locam-se apenas no campo do Quad do diagrama Q-J e Wo-Jd-Ae (Figuras 52-A e C), sendo classificados no diagrama Wo-En-Fs como salitas (Figura 52-B).

As variações iônicas junto às posições estruturais ocupadas estão representadas nas figuras 53-A, B, C, D, E e F e 54-A, B, C e D. Nelas, pode-se verificar os altos teores de Si (1,9 a 2,0 a.f.u.) no grupo tetraédrico, ocupado preferencialmente por este cátion e secundariamente por $\mathrm{Al}^{\mathrm{IV}}$, enquanto que as posições octaédricas regulares $\mathrm{M} 1$ estão preenchidas por $\mathrm{Al}^{\mathrm{Vl}}, \mathrm{Ti} \mathrm{Fe}^{3+}$ e $\mathrm{Fe}^{2+}$. $\mathrm{As}$ posições irregulares $\mathrm{M} 2$ estão ocupadas por $\mathrm{Na}, \mathrm{Fe}^{2+}, \mathrm{Mn}$ e Ca. Nota-se enriquecimento em $\mathrm{Al}^{\mathrm{lV}}$ e Ti e empobrecimento em $\mathrm{Al}^{\mathrm{VI}}, \mathrm{Fe}^{3+}$ e $\mathrm{Fe}^{2+}$ na posição $\mathrm{M} 1$, enquanto que na posição M2 o $\mathrm{Ca}$ se enriquece, com conseqüente perda de $\mathrm{Na}$, $\mathrm{Fe}^{2+}$ e $\mathrm{Mn}$. 


\begin{tabular}{|c|c|c|c|c|c|c|c|c|c|c|c|c|c|c|}
\hline Amostra & RP-198 & RP-198 & RP-198 & RP-198 & RP-198 & RP-198 & RP-198 & RP-198 & RP-198 & RP-198 & RP-198 & RP-198 & RP-198 & RP-198 \\
\hline Análises & 798 & 799 & 800 & 801 & 802 & 804 & 805 & 806 & 807 & 808 & 809 & 810 & 811 & 813 \\
\hline Locaçåo & C1G1Fn & $\mathrm{C1G} 1 \mathrm{Fb}$ & C1G2Fn & $\mathrm{C} 1 \mathrm{G} 2 \mathrm{Fb}$ & C1G3m & $\mathrm{C} 2 \mathrm{G} 2 \mathrm{Fn}$ & $\mathrm{C} 2 \mathrm{G} 2 \mathrm{Fb}$ & $\mathrm{C} 2 \mathrm{G} 3 \mathrm{Fn}$ & $\mathrm{C} 2 \mathrm{G} 3 \mathrm{Fb}$ & C3G1n & C3Gib & C3G2n & C3G2b & $C 4 G 2 n$ \\
\hline Mineral & Px & $P x$ & Px & Px & $P x$ & $P x$ & $P x$ & $P x$ & $P_{x}$ & $P x$ & $P x$ & $\mathrm{Px}$ & Px & $P x$ \\
\hline $\mathrm{SiO}_{2}$ & 51.76 & 51.65 & 51.24 & 51.55 & 52.59 & 51.47 & 51.54 & 51.3 & 51.65 & 50.3 & 51.32 & 51.5 & 51.42 & 52.16 \\
\hline $\mathrm{TiO}_{2}$ & 0.99 & 1.17 & 1.13 & 1.24 & 0.83 & 1.3 & 1.31 & 1.24 & 1.08 & 1.58 & 1.39 & 1.04 & 1.49 & 0.8 \\
\hline $\mathrm{Al}_{2} \mathrm{O}_{3}$ & 2.43 & 2.69 & 2.61 & 2.56 & 1.9 & 2.96 & 2.64 & 2.84 & 2.67 & 3.76 & 2.91 & 2.64 & 2.85 & 2.18 \\
\hline $\mathrm{FeO}$ & 7.62 & 7.26 & 7.39 & 7.11 & 8.19 & 6.84 & 6.68 & 7.48 & 7.32 & 7.65 & 7.23 & 7.08 & 6.96 & 7.59 \\
\hline $\mathrm{Cr}_{2} \mathrm{O}_{3}$ & 0 & 0 & 0 & 0 & 0.26 & 0 & 0.01 & 0 & 0 & 0 & 0 & 0.02 & 0 & 0.03 \\
\hline MnO & 0.48 & 0.48 & 0.46 & 0.46 & 0.53 & 0.42 & 0.45 & 0.46 & 0.46 & 0.45 & 0.49 & 0.41 & 0.42 & 0.51 \\
\hline $\mathrm{NiO}$ & 0 & 0 & 0 & 0 & 0 & 0 & 0 & 0 & 0 & 0 & 0 & 0 & 0 & 0 \\
\hline $\mathrm{MgO}$ & 13.28 & 13.66 & 13.55 & 13.67 & 13.5 & 13.82 & 14.03 & 13.38 & 13.82 & 13.03 & 13.33 & 13.24 & 13.72 & 13.69 \\
\hline $\mathrm{CaO}$ & 22.05 & 22.26 & 22.26 & 22.11 & 22.18 & 22.36 & 22.45 & 22.26 & 22.21 & 22.06 & 22.44 & 22.42 & 22.31 & 22.25 \\
\hline $\mathrm{Na}_{2} \mathrm{O}$ & 1.01 & 1.04 & 1.04 & 1.01 & 1.01 & 1.02 & 0.96 & 1.04 & 1 & 1.08 & 1.02 & 1.03 & 0.99 & 1.01 \\
\hline $\mathrm{K}_{2} \mathrm{O}$ & 0 & 0 & 0 & 0.01 & 0.03 & 0 & 0 & 0.01 & 0 & 0.04 & 0 & 0 & 0.03 & 0 \\
\hline Zno & 0 & 0 & 0 & 0 & 0 & 0 & 0 & 0 & 0 & 0 & 0 & 0 & 0 & 0 \\
\hline $\mathrm{ZrO}_{2}$ & 0.18 & 0.26 & 0.27 & 0.21 & 0.15 & 0.26 & 0.21 & 0.14 & 0.22 & 0.14 & 0.12 & 0.15 & 0.24 & 0.33 \\
\hline Total & 99.62 & 100.21 & 99.68 & 99.72 & 101.02 & 100.19 & 100.07 & 100.01 & 100.21 & 99.95 & 100.13 & 99.38 & 100.19 & 100.22 \\
\hline \multicolumn{15}{|c|}{ Formula estrutural calculada na base de 6 atomos de oxigênio } \\
\hline TSi & 1.925 & 1.906 & 1.901 & 1.912 & 1.933 & 1.897 & 1.901 & 1.899 & 1.905 & 1.865 & 1.898 & 1.917 & 1.898 & 1.926 \\
\hline TAI & 0.075 & 0.094 & 0.099 & 0.088 & 0.067 & 0.103 & 0.099 & 0.101 & 0.095 & 0.135 & 0.102 & 0.083 & 0.102 & 0.074 \\
\hline $\mathrm{TFe}^{3+}$ & 0 & 0 & 0 & 0 & 0 & 0 & 0 & 0 & 0 & 0 & 0 & 0 & 0 & 0 \\
\hline M1Al & 0.032 & 0.023 & 0.015 & 0.023 & 0.015 & 0.025 & 0.016 & 0.023 & 0.021 & 0.029 & 0.025 & 0.033 & 0.021 & 0.021 \\
\hline MiTi & 0.028 & 0.032 & 0.032 & 0.035 & 0.023 & 0.036 & 0.036 & 0.035 & 0.03 & 0.044 & 0.039 & 0.029 & 0.041 & 0.022 \\
\hline M1Fe $e^{3+}$ & 0 & 0 & 0 & 0 & 0 & 0 & 0 & 0 & 0 & 0 & 0 & 0 & 0 & 0 \\
\hline $\mathrm{M}^{\prime} \mathrm{Fe}^{2+}$ & 0.204 & 0.193 & 0.204 & 0.186 & 0.215 & 0.18 & 0.176 & 0.204 & 0.189 & 0.207 & 0.201 & 0.202 & 0.182 & 0.203 \\
\hline $\mathrm{M} 1 \mathrm{Cr}$ & 0 & 0 & 0 & 0 & 0.008 & 0 & 0 & 0 & 0 & 0 & 0 & 0.001 & 0 & 0.001 \\
\hline $\mathrm{M} 1 \mathrm{Mg}$ & 0.736 & 0.751 & 0.75 & 0.756 & 0.74 & 0.759 & 0.772 & 0.738 & 0.76 & 0.72 & 0.735 & 0.735 & 0.755 & 0.754 \\
\hline MiNi & 0 & 0 & 0 & 0 & 0 & 0 & 0 & 0 & 0 & 0 & 0 & 0 & 0 & 0 \\
\hline M2Mg & 0 & 0 & 0 & 0 & 0 & 0 & 0 & 0 & 0 & 0 & 0 & 0 & 0 & 0 \\
\hline M2Fe2 & 0.033 & 0.031 & 0.026 & 0.034 & 0.037 & 0.031 & 0.03 & 0.028 & 0.036 & 0.03 & 0.022 & 0.018 & 0.032 & 0.032 \\
\hline M2Mn & 0.015 & 0.015 & 0.014 & 0.014 & 0.016 & 0.013 & 0.014 & 0.014 & 0.014 & 0.014 & 0.015 & 0.013 & 0.013 & 0.016 \\
\hline $\mathrm{M} 2 \mathrm{Ca}$ & 0.879 & 0.88 & 0.885 & 0.878 & 0.873 & 0.883 & 0.887 & 0.883 & 0.878 & 0.876 & 0.889 & 0.894 & 0.882 & 0.88 \\
\hline M2Na & 0.073 & 0.074 & 0.075 & 0.073 & 0.072 & 0.073 & 0.069 & 0.075 & 0.072 & 0.078 & 0.073 & 0.074 & 0.071 & 0.072 \\
\hline M2K & 0 & 0 & 0 & 0 & 0.001 & 0 & 0 & 0 & 0 & 0.002 & 0 & 0 & 0.001 & 0 \\
\hline Sum_cat & 4 & 4 & 4 & 4 & 3.999 & 4 & 4 & 4 & 4 & 3.998 & 4 & 4 & 3.999 & 4 \\
\hline $\mathrm{Ca}$ & 47.06 & 47.049 & 47.116 & 46.999 & 46.426 & 47.313 & 47.222 & 47.282 & 46.742 & 47.424 & 47.726 & 48.016 & 47.303 & 46.718 \\
\hline $\mathrm{Mg}$ & 39.436 & 40.172 & 39.905 & 40.431 & 39.317 & 40.688 & 41.062 & 39.544 & 40.468 & 38.975 & 39.447 & 39.454 & 40.475 & 39.996 \\
\hline $\mathrm{Fe}^{2+}+\mathrm{Mn}$ & 13.504 & 12.779 & 12.979 & 12.57 & 14.258 & 12 & 11.716 & $\$ 3.174$ & 12.79 & $\$ 3.601$ & 12.826 & 12.53 & 12.222 & 13.286 \\
\hline JD1 & 1.659 & 1.175 & 0.792 & 1.209 & 0.771 & 1.306 & 0.818 & 1.191 & 1.08 & 1.507 & 1.297 & 1.72 & 1.117 & 1.062 \\
\hline$A E 1$ & 2.125 & 2.68 & 3.068 & 2.583 & 3.015 & 2.479 & 2.733 & 2.705 & 2.616 & 2.65 & 2.511 & 2.136 & 2.639 & 2.665 \\
\hline CFTS1 & 0 & 0 & 0 & 0 & 0 & 0 & 0 & 0 & 0 & 0 & 0 & 0 & 0 & 0 \\
\hline CTTS1 & 1.439 & 1.683 & 1.627 & 1.794 & 1.184 & 1.871 & 1.88 & 1.794 & 1.549 & 2.303 & 2.013 & 1.514 & 2,15 & 1.145 \\
\hline CATS1 & 0 & 0 & 0 & 0 & 0 & 0 & 0 & 0 & 0 & 0 & 0 & 0 & 0 & 0 \\
\hline WO1 & 44.21 & 43.918 & 44.022 & 43.775 & 43.879 & 43.973 & 44.009 & 44.003 & 43.813 & 43.5 & 44.277 & 44.97 & 43.699 & 44.217 \\
\hline EN1 & 38.253 & 38.935 & 38.663 & 39.201 & 38.163 & 39,425 & 39.902 & 38.299 & 39.273 & 37.642 & 38.26 & 38.194 & 39.231 & 38.834 \\
\hline $\mathrm{FS} 1$ & 12.313 & 11.609 & 11.829 & 11.438 & $\uparrow 2.988$ & 10.946 & 10.658 & 12.011 & 11.669 & 12.398 & $\uparrow 1.64 \uparrow$ & 11.458 & 11.164 & 12.078 \\
\hline Q & 1.852 & 1.855 & 1.864 & 1.855 & 1.865 & 1.853 & 1.865 & 1.853 & 1.863 & 1.833 & 1.848 & 1.85 & 1.852 & 1.868 \\
\hline 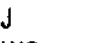 & 0.146 & 0.149 & 0.15 & 0.145 & 0.144 & 0.146 & 0.137 & 0.149 & 0.143 & 0.155 & 0.146 & 0.149 & 0.142 & 0.145 \\
\hline wo & 47.06 & 47.049 & 47.116 & 46.999 & 46.426 & 47.313 & 47.222 & 47.282 & 46.742 & 47.424 & 47.726 & 48.016 & 47.303 & 46.718 \\
\hline EN & 39.436 & 40.172 & 39.905 & 40.431 & 39.317 & 40.688 & 41.062 & 39.544 & 40,468 & 38.975 & 39.447 & 39.454 & 40.475 & 39.996 \\
\hline FS & 13.504 & 12.779 & 12.979 & 12.57 & 14.258 & 12 & 11.716 & 13.174 & 12.79 & 13.601 & 12.826 & 12.53 & 12.222 & 13.286 \\
\hline WEF & 92.763 & 92.63 & 92.62 & 92.789 & 92.892 & 92.754 & 93.189 & 92.596 & 92.922 & 92.248 & 92.72 & 92.606 & 92.939 & 92.871 \\
\hline JD & 7.237 & 7.37 & 7.38 & 7.211 & 7.108 & 7.246 & 6.811 & 7.404 & 7.078 & 7.752 & 7.28 & 7.394 & 7.061 & 7.129 \\
\hline $\mathrm{AE}$ & 0 & 0 & 0 & 0 & 0 & 0 & 0 & 0 & 0 & 0 & 0 & 0 & 0 & \\
\hline
\end{tabular}

Observaçőes de abreviaçס̄es como na tabela 15.0 


\begin{tabular}{|c|c|c|c|c|c|}
\hline Amostra & RP-198 & RP-198 & RP-198 & RP-198 & RP-198 \\
\hline Análises & 814 & 815 & 816 & 817 & 818 \\
\hline Locação & $\mathrm{C} 4 \mathrm{G} 2 \mathrm{~b}$ & C5G1n & C5G1b & C5G2n & $C 5 G 2 b$ \\
\hline Mineral & Px & Px & $P x$ & Px & Px \\
\hline $\mathrm{SiO}_{2}$ & 51.36 & 50.78 & 52.11 & 51.44 & 52.13 \\
\hline $\mathrm{TiO}_{2}$ & 1.08 & 1.38 & 0.97 & 0.89 & 0.81 \\
\hline $\mathrm{Al}_{2} \mathrm{O}_{3}$ & 2.61 & 3.25 & 2.53 & 2.56 & 2.17 \\
\hline $\mathrm{FeO}$ & 7.59 & 7.32 & 0.04 & 7.98 & 8.19 \\
\hline $\mathrm{Cr}_{2} \mathrm{O}_{3}$ & 0.02 & 0 & 0.04 & 0 & 0 \\
\hline $\mathrm{MnO}$ & 0.47 & 0.47 & 0.44 & 0.51 & 0.47 \\
\hline $\mathrm{NiO}$ & 0 & 0 & 0 & 0 & 0 \\
\hline $\mathrm{MgO}$ & 13.32 & 13.25 & 13.38 & 12.93 & 13.41 \\
\hline $\mathrm{CaO}$ & 22.05 & 22.2 & 22.43 & 22.21 & 22.54 \\
\hline $\mathrm{Na}_{2} \mathrm{O}$ & 1.12 & 1.09 & 1.02 & 1.12 & 1 \\
\hline $\mathrm{K}_{2} \mathrm{O}$ & 0 & 0.02 & 0.02 & 0 & 0 \\
\hline $\mathrm{ZnO}$ & 0 & 0 & 0 & 0 & 0 \\
\hline $\mathrm{ZrO}_{2}$ & 0.39 & 0.2 & 0.19 & 0.37 & 0.29 \\
\hline Total & 99.62 & 99.76 & 92.98 & 99.64 & 100.72 \\
\hline \multicolumn{6}{|c|}{ Fórmula estrutural caiculada na base de 6 átomos de oxigênio } \\
\hline TSi & 1.908 & 1.883 & 2.039 & 1.915 & 1.92 \\
\hline Tal & 0.092 & 0.117 & 0 & 0.085 & 0.08 \\
\hline $\mathrm{TFe}^{3+}$ & 0 & 0 & 0 & 0 & 0 \\
\hline M1AI & 0.022 & 0.025 & 0.117 & 0.027 & 0.014 \\
\hline M1Ti & 0.03 & 0.039 & 0.029 & 0.025 & 0.022 \\
\hline $\mathrm{MiFe}^{3+}$ & 0 & 0 & 0 & 0 & 0 \\
\hline $\mathrm{MAFe}^{2+}$ & 0.209 & 0.203 & 0.001 & 0.231 & 0.228 \\
\hline $\mathrm{M1Cr}$ & 0.001 & 0 & 0.001 & 0 & 0 \\
\hline M1Mg & 0.738 & 0.733 & 0.78 & 0.717 & 0.736 \\
\hline M1Ni & 0 & 0 & 0 & 0 & 0 \\
\hline M2Mg & 0 & 0 & 0 & 0 & 0 \\
\hline M2Fe2 & 0.027 & 0.024 & 0 & 0.017 & 0.025 \\
\hline M2Mn & 0.015 & 0.015 & 0.015 & 0.016 & 0.015 \\
\hline $\mathrm{M} 2 \mathrm{Ca}$ & 0.878 & 0.882 & 0.94 & 0.886 & 0.889 \\
\hline $\mathrm{M} 2 \mathrm{Na}$ & 0.081 & 0.078 & 0.077 & 0.081 & 0.071 \\
\hline M2K & 0 & 0.001 & 0.001 & 0 & 0 \\
\hline Sum_cat & 4 & 3.999 & 3.999 & 4 & 4 \\
\hline $\mathrm{Ca}$ & 47.036 & 47.516 & 54.145 & 47.424 & 46.995 \\
\hline Mg & 39.534 & 39.46 & 44.94 & 38.415 & 38.902 \\
\hline $\mathrm{Fe}^{2+}-\mathrm{Mn}$ & 13.43 & 13.024 & 0.915 & 14.161 & 14.103 \\
\hline Jd1 & 1.96 & 1.325 & 4.354 & 1.383 & 0.707 \\
\hline Ae1 & 3.016 & 2.805 & 0 & 2.8 & 2.956 \\
\hline CFTS1 & 0 & 0 & 0.069 & 0 & 0 \\
\hline CTTS1 & 1.562 & 2.004 & 0 & 1.289 & 1.151 \\
\hline CATS1 & 0 & 0 & 0 & 0 & 0 \\
\hline Wo1 & 43.869 & 43.915 & 52.158 & 44.546 & 44.476 \\
\hline En1 & 38.186 & 38.133 & 43.348 & 37.128 & 37.77 \\
\hline Fs1 & 12.206 & 11.818 & 0.073 & 12.854 & 12.94 \\
\hline Q & 1.851 & 1.842 & 1.722 & 1.851 & 1.878 \\
\hline$J$ & 0.161 & 0.157 & 0.455 & 0.162 & 0.143 \\
\hline Wo1 & 47.036 & 47.516 & 54.145 & 47.424 & 46.995 \\
\hline En1 & 39.534 & 39.46 & 44.94 & 38.415 & 38.902 \\
\hline Fs1 & 13.43 & 13.024 & 0.915 & 14.161 & 14.103 \\
\hline WEF & 92.041 & 92.213 & 91.817 & 92.034 & 92.983 \\
\hline Jd 1 & 7.959 & 7.787 & 8.183 & 7.966 & 7.017 \\
\hline Aef & 0 & 0 & 0 & 0 & 0 \\
\hline
\end{tabular}

Observações de abreviaçőes como na tabela 15.0 

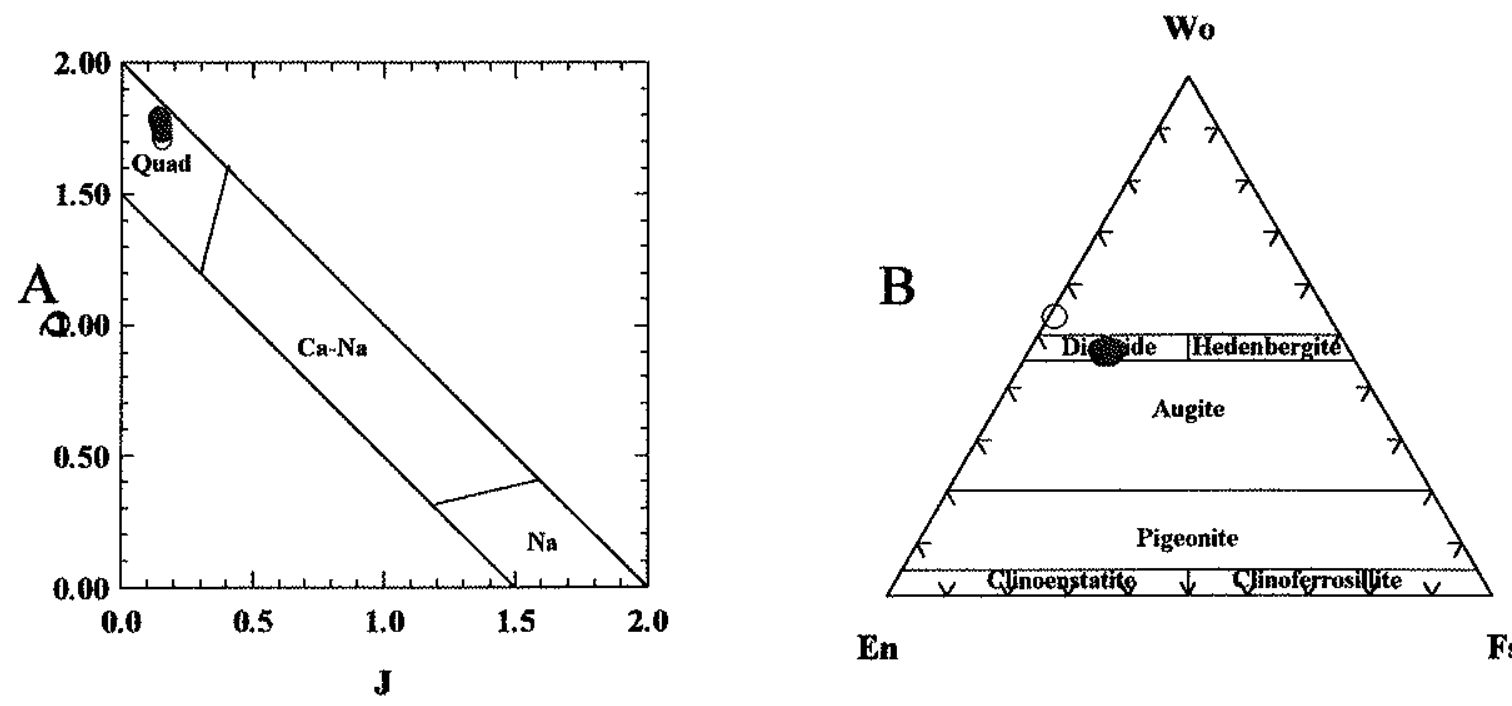

En

Fs

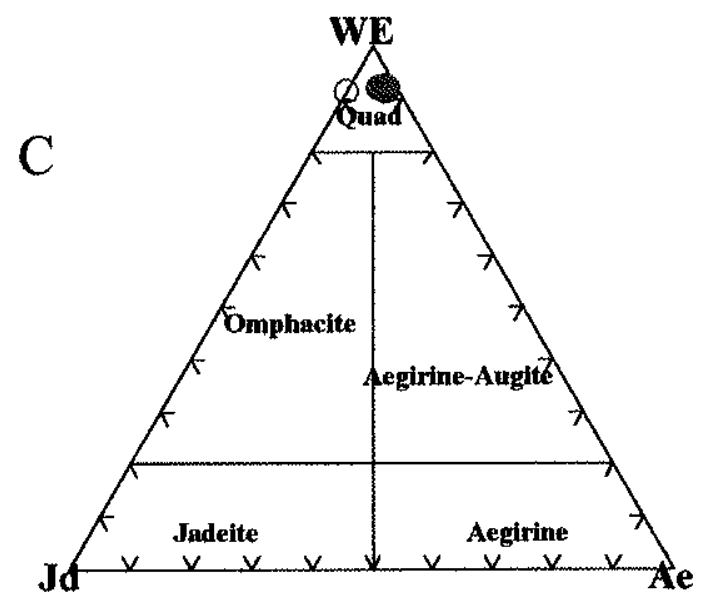

Figura 52 ( $A, B$ e C) - Composição dos piroxênios das rochas do corpo Cerrito nos diagramas do IMA (Morimoto. 1989). Símbolos como na figura 42. 

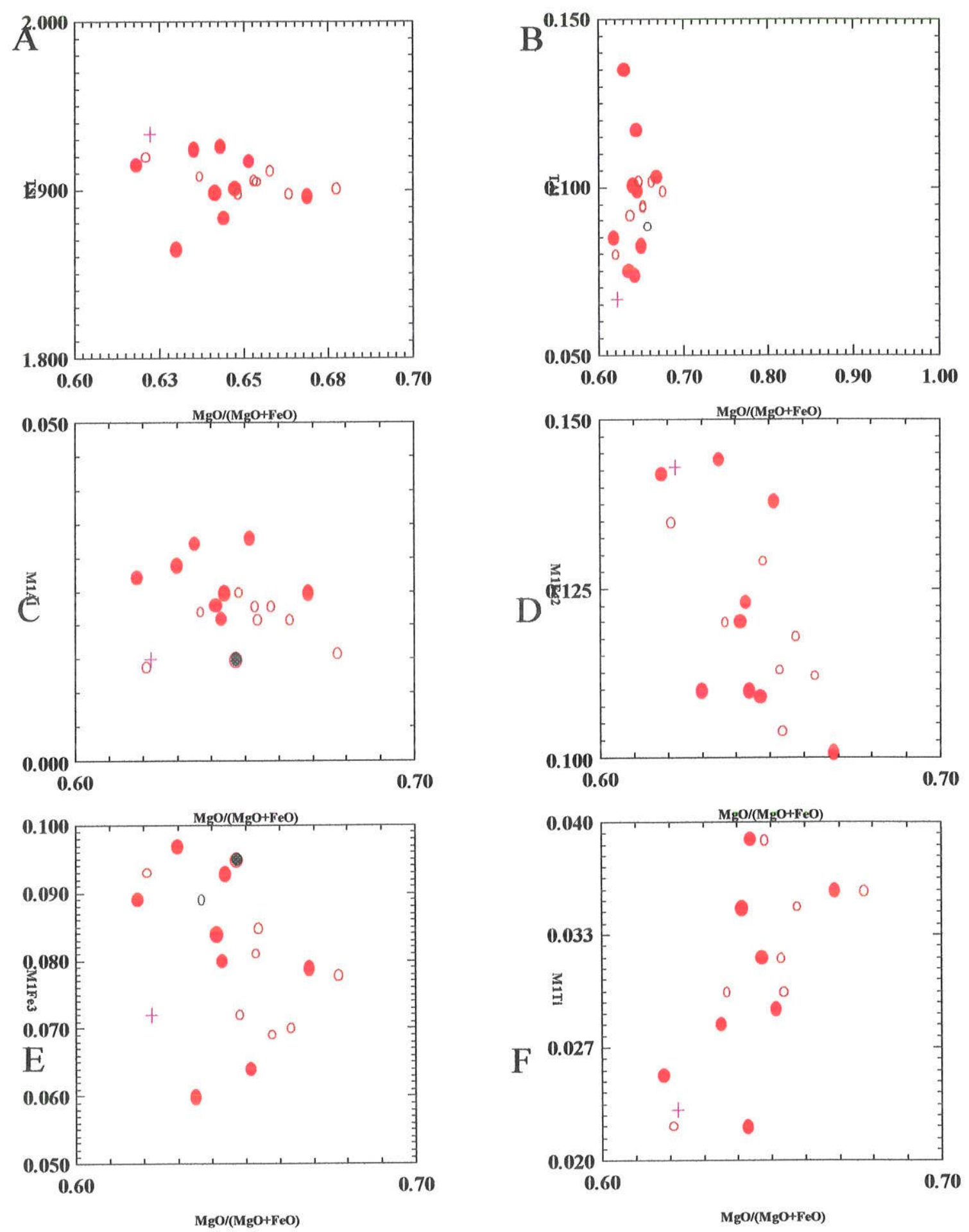

Figura 53 (A, B, C, D, E e F) - Diagramas de variação composicional dos piroxênios das rochas de Cerrito. Símbolos como na figura 42. 

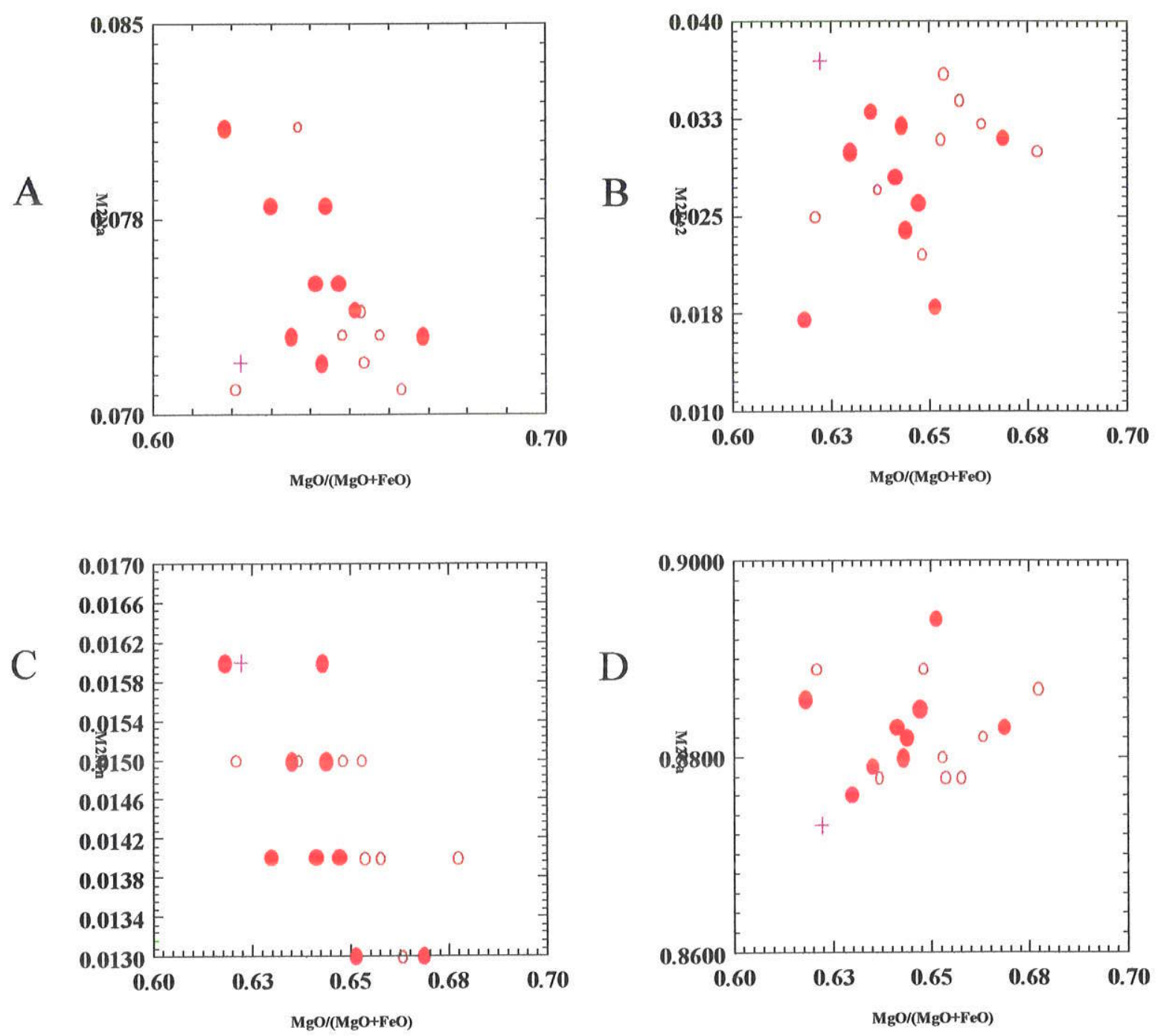

Figura 54 (A, B, C e D) - Diagramas de variação composicional dos piroxênios das rochas de Cerrito. Símbolos como na figura 42. 


\section{V.4.5 - Pão de Açúcar}

No Morro Pão de Açúcar os litotipos mais comuns portadores de microfenocristais de piroxênio são as rochas traquifonolíticas com textura porfirítica. Nesta ocorrência, as características ópticas dos piroxênios não diferem daquelas encontradas em outros corpos da Província Alcalina Alto Paraguai.

Os dados analíticos podem ser visualizados nas tabelas 15.19 a 15.20 , perfazendo uma população de 17 análises. Nelas, são ressaltadas principalmente os altos teores em $\mathrm{MgO}$ e $\mathrm{CaO}$, de respectivamente13,89 e 21,73\%. Já os valores médios de $\mathrm{Na}_{2} \mathrm{O}$ situam-se por volta de $1,6 \%$, exceto 3 análises onde os teores médios alcançam $10 \%$.

Os piroxênios de Pão de Açúcar locam-se principalmente no campo Quad do diagrama Q-J (Figura 55-A), com algumas poucas amostras situadas no campo dos piroxênios cálcico-sódicos e coincidindo com o campo da salita/ferrossalita no diagrama Wo-En-Fs (Figura 55-B). Em relação ao diagrama WEF-Jd-Ae (Figura 55C), os piroxênios locam-se nos campos Quad e dos egirina-augita.

Nos diagramas das figuras 56-A e 56-B, que relacionam as posições tetraédricas ocupadas ( $\mathrm{Si}$ e $\mathrm{Al}$ ) com $\mathrm{O}$ índice de diferenciação (mg\#), nota-se um grande intervalo com 1,9 a 2,0 a.f.u. (átomos por fórmula unitária) indicativo de que - Si não preenche todo o espaço tetraédrico, necessitando de Al o bastante para completar $\circ$ grupo $Z$. Já as posições octaédricas irregulares (M1) estão ocupadas por $\mathrm{Al}, \mathrm{Ti}, \mathrm{Fe}^{3+}$ e $\mathrm{Fe}^{2+}$ onde, à exceção do $\mathrm{Ti}$, todos os elementos evidenciam tendências de empobrecimento (Figuras 56-C, D, E e F) enquanto que nas posições octaédricas regulares ocorre empobrecimento em Na (Figura 57-A) e enriquecimento em $\mathrm{Fe}^{2+}$ e Ca (Figura 57-B e D) e comportamento indistinto em $\mathrm{Mn}$ (Figura 57-C). 
Tabela 15.19 - Composição química de piroxênios do Morro Pão de Açúcar (\% peso)

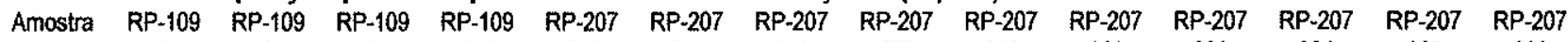
$\begin{array}{lllllllllllllll}\text { Análises } & 633 & 634 & 635 & 656 & 676 & 677 & 678 & 679 & 819 & 822 & 823 & 824 & 825 & 826\end{array}$ Locaçăo C2G1n C2G1b C2G2Fn C1G1m C5G3Fn C5G3Fb C5G4Fn C5G4Fb C1G1m C2G1Fn C2G1Fb C3G1n C3Gib C3G2n

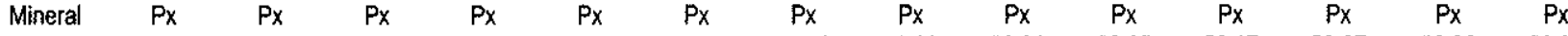

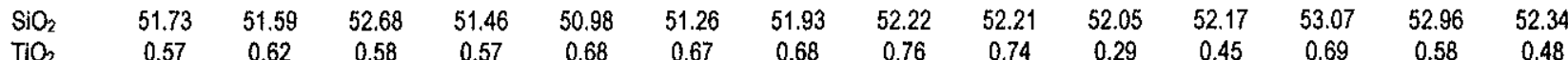

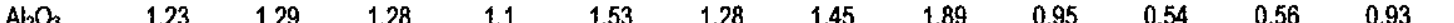

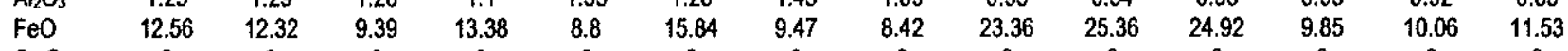

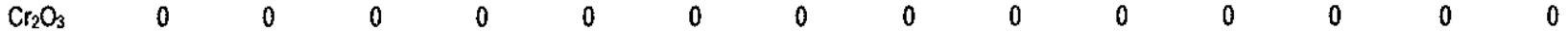

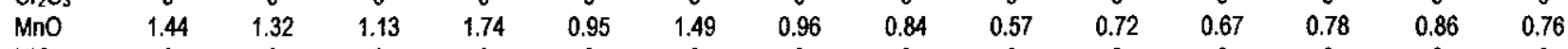

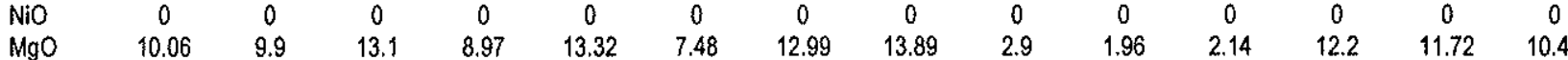

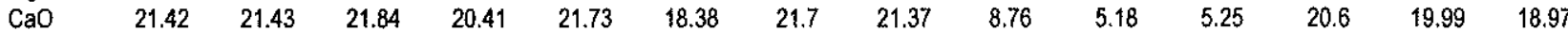
$\begin{array}{lllllllllllllll}\mathrm{Na}_{2} \mathrm{O} & 1.58 & 1.56 & 0.84 & 1.84 & 0.78 & 3.12 & 0.75 & 0.74 & 8.61 & 10.19 & 10.26 & 1.92 & 2.24 & 3.1\end{array}$

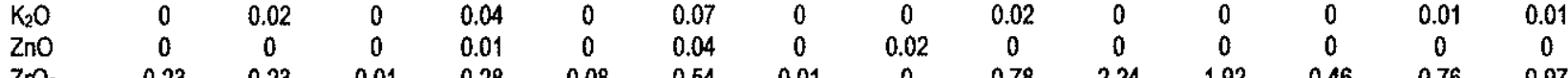

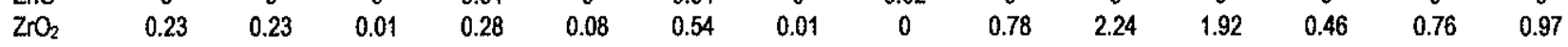

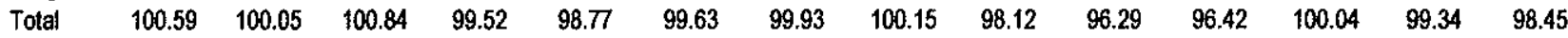

$\begin{array}{lllllllllllllll}\text { Fórmula estrutural calculada na base de } 6 & \text { átomos de oxigénio } & & & & & & & & & & & \\ \text { TSi } & 1.946 & 1.951 & 1.951 & 1.966 & 1.922 & 1.957 & 1.942 & 1.938 & 2.002 & 2.022 & 2.02 & 1.974 & 1.982 & 1.978\end{array}$

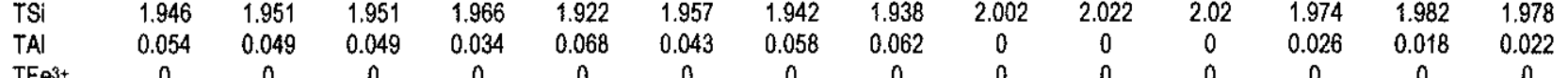

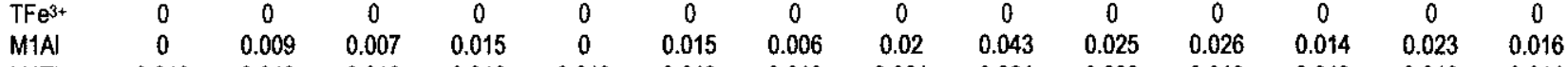

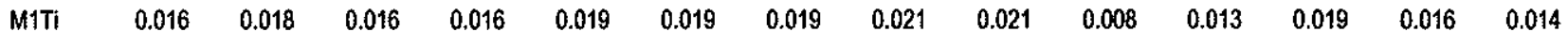

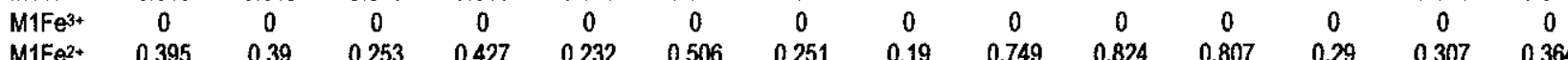

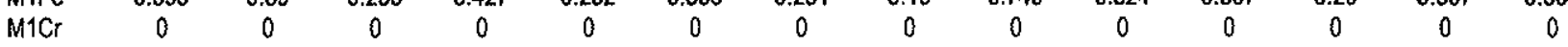

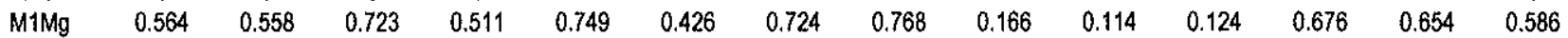

\begin{tabular}{|c|c|c|c|c|c|c|c|c|c|c|c|c|c|c|}
\hline $\mathrm{M} 1 \mathrm{Ni}$ & 0 & 0 & 0 & 0 & 0 & 0 & 0 & 0 & 0 & 0 & 0 & 0 & 0 & 0 \\
\hline M2Mg & 0 & 0 & 0 & 0 & 0 & 0 & 0 & 0 & 0 & 0 & 0 & 0 & 0 & \\
\hline M2Fe2 & 0 & 0 & 0.037 & 0 & 0.045 & 0 & 0.046 & 0.071 & 0 & 0 & 0 & 0.016 & 0.008 & \\
\hline M2Mn & 0.046 & 0.042 & 0.035 & 0.056 & 0.03 & 0.048 & 0.03 & 0.026 & 0.019 & 0.024 & 0.022 & 0.025 & 0.027 & \\
\hline $\mathrm{M} 2 \mathrm{Ca}$ & 0.863 & 0.868 & 0.867 & 0.835 & 0.878 & 0.752 & 0.87 & 0.85 & 0.36 & 0.216 & 0.218 & 0.821 & 0.802 & \\
\hline $\mathrm{M} 2 \mathrm{Na}$ & 0.115 & 0.114 & 0.06 & 0.136 & 0.057 & 0.231 & 0.054 & 0.053 & 0.64 & 0.768 & 0.77 & 0.138 & 0.163 & \\
\hline $\mathrm{M} 2 \mathrm{~K}$ & 0 & 0.001 & 0 & 0.002 & 0 & 0.003 & 0 & 0 & 0.001 & 0 & 0 & 0 & 0 & \\
\hline Sum_cat & 4 & 3.999 & 4 & 3.998 & 4 & 3.997 & 4 & 4 & 3.999 & 4 & 4 & 4 & 4 & \\
\hline $\mathrm{Ca}$ & 46.204 & 46.724 & 45.227 & 45.65 & 45.381 & 43.421 & 45.279 & 44.583 & 27.828 & 18.323 & 18.611 & 44.9 & 44.591 & \\
\hline $\mathrm{Mg}$ & 30.193 & 30.034 & 37.745 & 27.915 & 38.705 & 24.587 & 37.714 & 40.32 & 12.818 & 9.646 & 10.556 & 36.999 & 36.376 & \\
\hline $2^{2+}+M n$ & 23.603 & 23.242 & 17.028 & 26.435 & 15.913 & 31.991 & 17.007 & 15.097 & 59.354 & 72.031 & 70.833 & 18.102 & 19.033 & \\
\hline JD1 & 0.015 & 0.442 & 0.366 & 0.804 & 0 & 0.768 & 0.312 & 1.04 & 2.239 & 1.286 & 1.331 & 0.734 & 1.181 & \\
\hline E1 & 5.932 & 5.53 & 2.742 & 6.427 & 2.908 & 11.454 & 2.486 & 1.715 & 31.225 & 38.679 & 38.819 & 6.396 & 7.252 & \\
\hline CFTS1 & 0 & 0 & 0 & 0 & 0 & 0 & 0 & 0 & 0 & 0 & 0 & 0 & 0 & \\
\hline cITst & 0.832 & 0.913 & 0.832 & 0.857 & 0.983 & 1.003 & 0.984 & 1.098 & 0 & 0 & 0 & 0.994 & 0.845 & \\
\hline CATS1 & 0 & 0 & 0 & 0 & 0 & 0 & 0 & 0 & 0 & 0 & 0 & 0 & 0 & \\
\hline W01 & 43.718 & 44.044 & 43.815 & 42.837 & 43.78 & 38.202 & 43.737 & 42.866 & 18.784 & 11.226 & 11.352 & 41.273 & 40.615 & \\
\hline EN1 & 29.112 & 28.897 & 37.262 & 26.719 & 38.179 & 22.2 & 37.248 & 39.76 & 8.652 & & 6.438 & 34.829 & 33.822 & 30. \\
\hline FS1 & 20.39 & 20.174 & 14.983 & 22.358 & 14.15 & 26.373 & $\uparrow 5.233$ & 13.521 & 39.099 & 42.8 & 42.06 & 15.775 & 16.286 & \\
\hline$Q$ & 1.822 & 1.816 & 1.881 & 1.774 & 1.904 & 1.683 & 1.89 & 1.879 & 1.275 & 1.153 & 1.148 & 1.803 & 1.771 & .7 \\
\hline & 0.23 & 0.229 & 0.121 & 0.273 & 0.114 & 0.462 & 0.109 & 0.106 & 1.28 & 1.535 & 1.541 & 0.277 & 0.325 & 4 \\
\hline Wo & 46.204 & 46.724 & 45.227 & 45.65 & 45.381 & 43.421 & 45.279 & 44.583 & 27.828 & 18.323 & 18.611 & 44.9 & 44.591 & \\
\hline EN & 30.193 & 30.034 & 37.745 & 27.915 & 38.705 & 24.587 & 37.714 & 40.32 & 12.818 & 9.646 & 10.556 & 36.999 & 36.376 & \\
\hline FS & 23.603 & 23.242 & 17.028 & 26.435 & 15.913 & 31.991 & 17.007 & 15.097 & 59.354 & 72.031 & 70.833 & 18.102 & 19.033 & \\
\hline WEF & 89.019 & 89.038 & 94.077 & 87,035 & 94.432 & 78.94 & 94.639 & 94.708 & 50.252 & & 43.169 & 86.846 & 84,684 & \\
\hline & 10.981 & 10.962 & 5.923 & 12.965 & 0 & 21.06 & 5.361 & 5.292 & 49.748 & 56.609 & $56.83 \uparrow$ & 13.154 & 15.316 & \\
\hline
\end{tabular}

$\begin{array}{lcccccccccccccc}\mathrm{AE} & 10.981 & 10.962 & 5.923 & 12.965 & 0 & 21.06 & 5.361 & 5.292 & 49.748 & 56.609 & 56.831 & 13.154 & 15.316 & 20.673 \\ & 0 & 0 & 0 & 0 & 0.057 & 0 & 0 & 0 & 0 & 0 & 0 & 0 & 0 & 0\end{array}$

Observaçóes de abreviaçס̃es como na tabela 15.0 


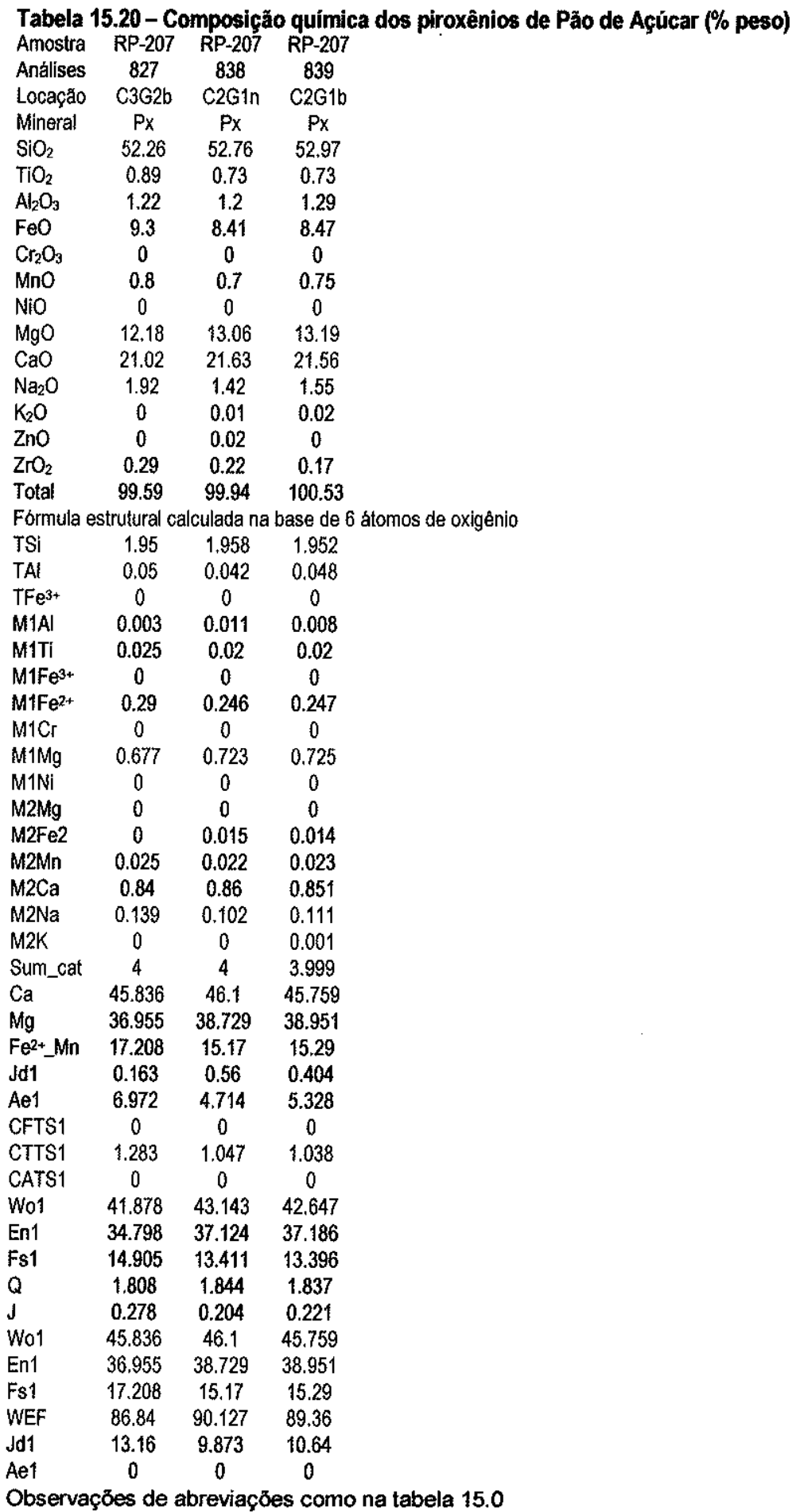



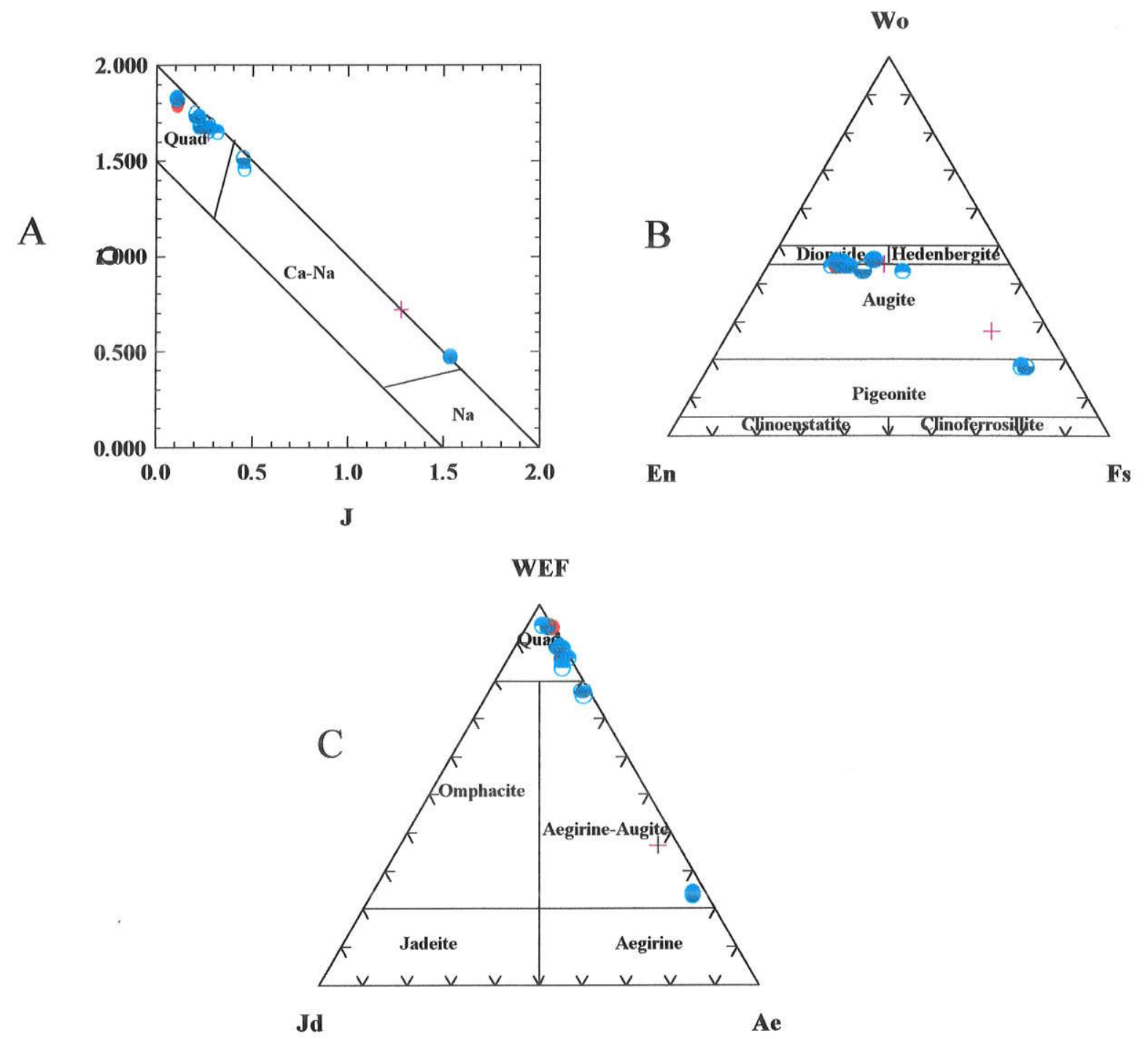

Figura 55 (A, B e C) -Composição dos piroxênios das rochas do Morro Pão de Açúcar, locados nos diagramas de classificação do IMA (Morimoto, 1989). Simbolos : núcleos de cristais provenientes de traquifonolitos (círculos com a metade inferior preenchida); bordas de cristais de traquifonolitos (circulos com a metade superior preenchidas); cristais da matriz da rocha (cruzes) e inclusões (xis). 

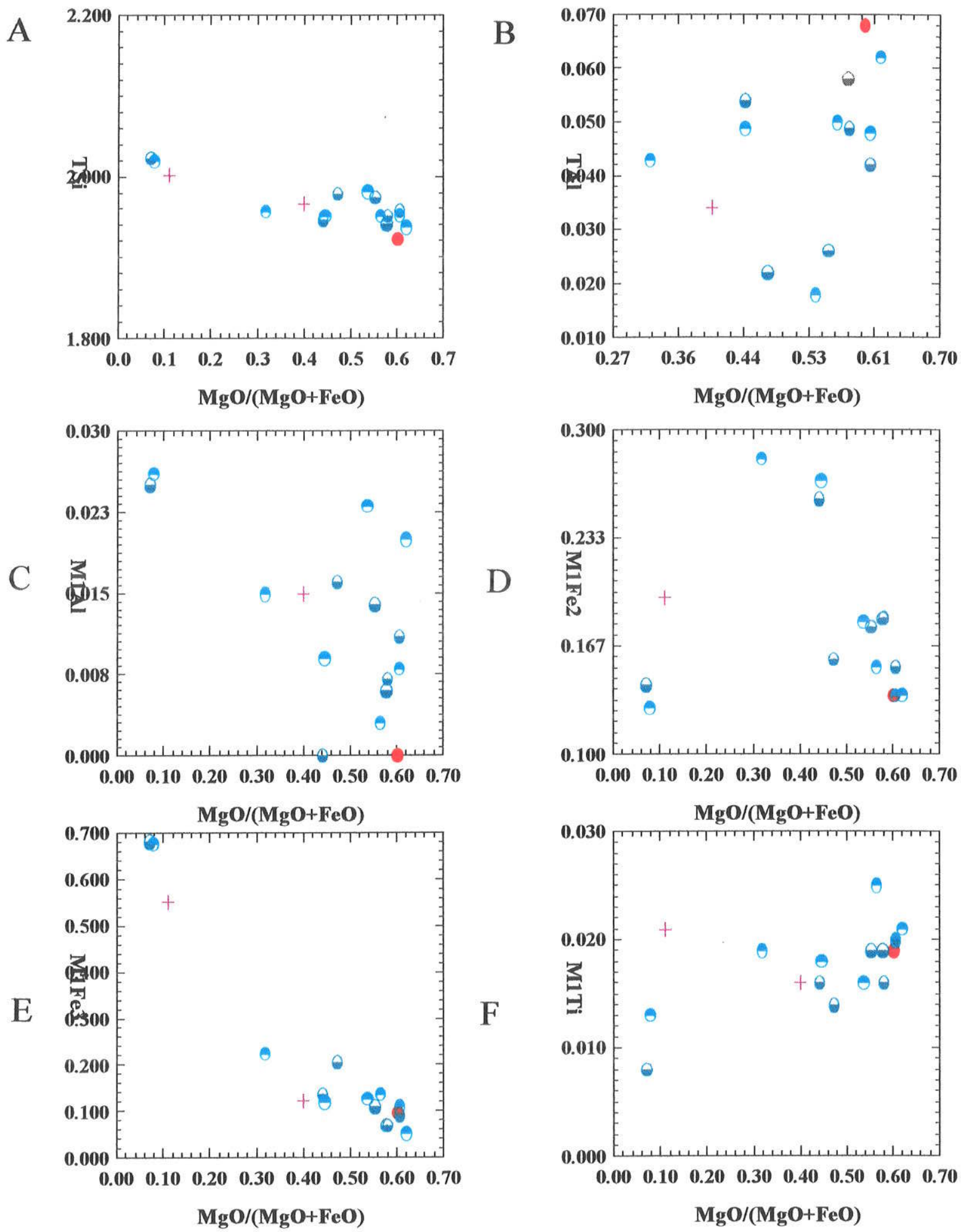

Figura 56 (A, B, C, D, E e F) - Diagramas de variação composicional de piroxênios das rochas do Morro Pão de Açúcar. Símbolos como na figura 55. 

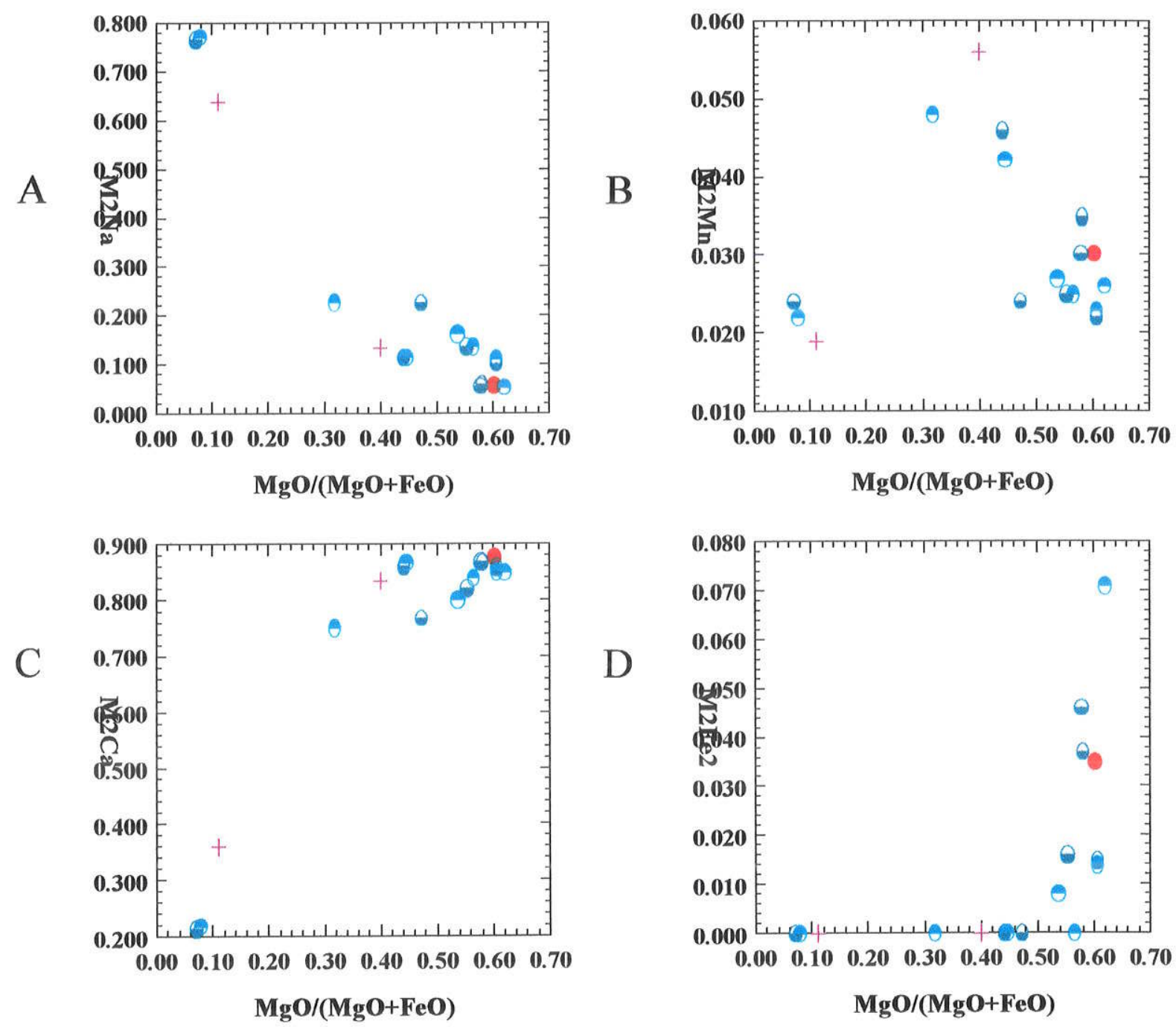

Figura 57 (A, B, C e D) Diagramas de variação composicional de piroxênios do Morro Pão de Açúcar. Simbolos como na figura 55. 
V.4.6 - São Pedro

Os litotipos do corpo alcalino denominado São Pedro possuidores de piroxênios são preferencialmente sienitos alcalinos.

$\mathrm{Na}$ tabela 15.21 podem ser observados os resultados analíticos dos piroxênios desse corpo, onde ficam evidenciados os teores elevados em $\mathrm{Al}_{2} \mathrm{O}_{3}$, geralmente superiores a $2 \%$. Apresentam ainda como características químicas, valores médios de $\mathrm{MgO}$ de $8,3 \%$ e de $\mathrm{CaO}$ em torno de $21,5 \%$.

Nas figuras 58-A e 58-C nas quais podem ser observados os diagramas Q-J e WEF-Jd-Ae, os piroxênios de São Pedro locam-se apenas no campo Quad (similarmente aos diagramas construídos para o corpo de Cerrito) enquanto que a composição apresentada no diagrama Wo-En-Fs (Figura 58-B) corresponde às salitas.

A exemplo de Pão de Açúcar, o sítio tetraédrico dos piroxênios de São Pedro não estão totalmente preenchidos, necessitando de $\mathrm{Al}^{\mathrm{lV}}$ para complementação das posições (Figuras 59-A e B). As posições octaédricas irregulares (M1) estão preenchidas por $\mathrm{Al}^{\mathrm{VI}}, \mathrm{Fe}^{2+}, \mathrm{Fe}^{3+}$ e $\mathrm{Ti}$ (Figuras 59-C, D, E e F) onde à excessão do último elemento $(\mathrm{Ti})$, todos os demais mostram correlação negativa. As posições (M2) acham-se ocupadas por Na e Mn mostrando correlação negativa (Figuras 60$\mathrm{A}$ e B) e Ca correlacionando-se positivamente (Figura 60-C) em relação ao indice de diferenciação (mg\#). 
Tabela 15.21- Composição quimica de piroxênios do Morro São Pedro ( $\%$ peso)

\begin{tabular}{|c|c|c|c|c|c|c|c|c|c|}
\hline Amostra & RP-255 & RP-255 & RP-255 & RP-255 & RP-256 & RP-256 & RP-256 & RP-256 & $\begin{array}{c}\text { RP-256 } \\
113\end{array}$ \\
\hline Análises & 1092 & 1097 & 1098 & 1101 & 1109 & 1110 & 1111 & 1112 & 1113 \\
\hline Locaçåo & $\mathrm{C} 2 \mathrm{G} 1 \mathrm{n}$ & $\mathrm{C} 2 \mathrm{G} 1 \mathrm{Fn}$ & $\mathrm{C} 2 \mathrm{G} 1 \mathrm{Fb}$ & C3G1n & C2GiFn & $\mathrm{C} 2 \mathrm{G} 1 \mathrm{Fb}$ & $\mathrm{C} 2 \mathrm{G} 2 \mathrm{Fbr}$ & C3G1Fn & C3G1Fb \\
\hline Mineral & $P x$ & Px & $P x$ & $P x$ & $P x$ & $P x$ & Px & $P x$ & $P x$ \\
\hline $\mathrm{SiO}_{2}$ & 51.2 & 51.2 & 51.08 & 50.99 & 52.43 & 50.89 & 51.79 & 51.86 & 51.68 \\
\hline $\mathrm{TiO}_{2}$ & 1.04 & 1.04 & 1.13 & 1 & 0.69 & 0.42 & 0.6 & 0.56 & 0.44 \\
\hline $\mathrm{Al}_{2} \mathrm{O}_{3}$ & 2.18 & 2.18 & 2.5 & 2.34 & $\{.1$ & 1.57 & 1.29 & 1.15 & 1.33 \\
\hline $\mathrm{FeO}$ & 9.6 & 9.6 & 9.47 & 10.81 & 8.5 & 14.41 & 9.92 & 11.06 & 12.29 \\
\hline $\mathrm{Cr}_{2} \mathrm{O}_{3}$ & 0 & 0 & 0 & 0 & 0 & 0 & 0 & 0 & 0 \\
\hline Mno & 0.67 & 0.67 & 0.64 & 0.75 & 0.74 & 1.27 & 0.87 & 0.93 & 1.13 \\
\hline $\mathrm{NiO}$ & 0 & 0 & 0 & 0 & 0 & 0 & 0 & 0 & 0 \\
\hline $\mathrm{MgO}$ & $1\} .46$ & 11.46 & 11.37 & 10.74 & 12.68 & 8.41 & $1\{.13$ & 10.35 & 9.65 \\
\hline $\mathrm{CaO}$ & 22.09 & 22.09 & 22.09 & 22.08 & 21.77 & 20.1 & 21.62 & 21.46 & 20.81 \\
\hline $\mathrm{Na}_{2} \mathrm{O}$ & 1.5 & 1.5 & 1.37 & 1.48 & 1.38 & 2.27 & 1.69 & 1.77 & 1.91 \\
\hline$K_{2}$ & 0.01 & 0.01 & 0 & 0 & 0 & 0.01 & 0.01 & 0 & 0 \\
\hline & 0 & 0 & 0 & 0 & 0 & 0 & 0 & 0 & 0 \\
\hline $\mathrm{ZrO}_{2}$ & 0.25 & 0.25 & 0.23 & 0.2 & 0.07 & 0.16 & 0.09 & 0.07 & 0.12 \\
\hline Total & 99.75 & 99.75 & 99.65 & 100.19 & 99.29 & 99.35 & 98.92 & 99.14 & 99.24 \\
\hline \multicolumn{10}{|c|}{ Fórmula estrutural calculada na base de 6 átomos de oxigênio } \\
\hline TSi & 1.917 & 1.917 & 1.917 & 1.911 & 1.962 & 1.945 & 1.957 & 1.966 & 1.965 \\
\hline TA & 0.083 & 0.083 & 0.083 & 0.089 & 0.038 & 0.055 & 0.043 & 0.034 & 0.035 \\
\hline & 0 & 0 & 0 & 0 & 0 & 0 & 0 & 0 & 0 \\
\hline M1Al & 0.013 & 0.013 & 0.027 & 0.015 & 0.011 & 0.015 & 0.015 & 0.017 & 0.025 \\
\hline & 0.029 & 0.029 & 0.032 & 0.028 & 0.019 & 0.012 & 0.017 & 0.016 & 0.013 \\
\hline & 0 & 0 & 0 & 0 & 0 & 0 & 0 & 0 & 0 \\
\hline $\mathrm{re}^{2+4}$ & 0.301 & 0.301 & 0.297 & 0.339 & 0.263 & 0.461 & 0.314 & 0.351 & 0.391 \\
\hline & 0 & 0 & 0 & 0 & 0 & 0 & 0 & 0 & 0 \\
\hline & 0.64 & 0.64 & 0.636 & 0.6 & 0.707 & 0.479 & 0.627 & 0.585 & 0.547 \\
\hline & 0 & 0 & 0 & 0 & 0 & 0 & 0 & 0 & 0 \\
\hline & 0 & 0 & 0 & c & 0 & ( & & 0 & 0 \\
\hline & 0 & 0 & 0 & 0 & 0.003 & 0 & 0 & 0 & 0 \\
\hline 12Mn & 0.021 & 0.021 & 0.02 & 0.024 & 0.023 & 0.041 & 0.028 & 0.03 & 0.036 \\
\hline & & & 0.888 & 887 & 0.873 & 0.82 & 875 & 0.872 & 0.848 \\
\hline & 0.109 & 0.109 & 0.1 & 0.108 & 0.1 & 0.168 & 0.124 & 0.13 & 0.141 \\
\hline & 0 & 0 & 0 & 0 & 0 & 0 & & 0 & 0 \\
\hline m_cat & 4 & 4 & 4 & 4 & 4 & 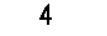 & 4 & 4 & 4 \\
\hline $\mathrm{Ca}$ & 47.961 & 47.961 & 48.223 & 47.944 & 46.684 & 45.627 & 47.478 & 47.447 & 46.531 \\
\hline M & 34.62 & & 34.536 & 32.448 & 37.834 & 26.562 & 34.008 & 34.84 & 30.022 \\
\hline $\mathrm{Fe}^{2+}+\mathrm{Mn}$ & 17.419 & 17.419 & 17.241 & 19.609 & 15.482 & 27.811 & 18.514 & 20.713 & 23.447 \\
\hline JD1 & 0.692 & 0.692 & 1.405 & 0.756 & 0.545 & 0.8 & 758 & 0.882 & 1.277 \\
\hline & 4.958 & 4.958 & 3.784 & 4.808 & 4.599 & 7.934 & 5.649 & 5.834 & 6.033 \\
\hline & 0 & 0 & 0 & 0 & 0 & 0 & 0 & 0 & 0 \\
\hline & 1.513 & 1.513 & 1.66 & 1.458 & 0.998 & 0.625 & 0.879 & 0.824 & 0.653 \\
\hline & 0 & 0 & 0 & 0 & 0 & 0 & 0 & 0 & 0 \\
\hline Wo & 44.264 & 44.264 & 4.571 & 44.408 & 43.847 & 41.987 & 4.238 & 4.168 & 43.355 \\
\hline EN1 & .044 & 33.044 & 33.109 & 31.042 & & 24.808 & 32.317 & 30.192 & 28.395 \\
\hline FS1 & 15.528 & 15.528 & & 17.528 & & 23.845 & 16.158 & 18.099 & 20.287 \\
\hline & & & & & 1.84 & & & 1.807 & 1.786 \\
\hline & 18 & & 0.199 & 0.215 & 0.2 & & 0.248 & 0.26 & 0.282 \\
\hline W & & & 48.223 & 47.944 & 46.684 & 45.627 & 47.478 & 47.447 & 46.531 \\
\hline EN & & 34.62 & 34.536 & 32.448 & 37.834 & 26.562 & 34.008 & 31.84 & 30,022 \\
\hline FS & 17.419 & 17.419 & 17.241 & 19.609 & 15.482 & 27.811 & 18.514 & 20.713 & 23.447 \\
\hline WEF & 89.455 & 89.455 & 90.232 & 89.58 & 90.325 & 84.281 & 88.158 & 87.593 & 86.612 \\
\hline & 10.545 & 10.545 & 9.768 & 10.42 & 9.675 & 15.749 & $\Uparrow 1.842$ & 12.407 & 13.388 \\
\hline 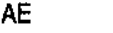 & 0 & 0 & 0 & 0 & 0 & 0 & 0 & 0 & 0 \\
\hline
\end{tabular}

Observaçס̃es de abreviaçð̌es como na tabela 15.0 

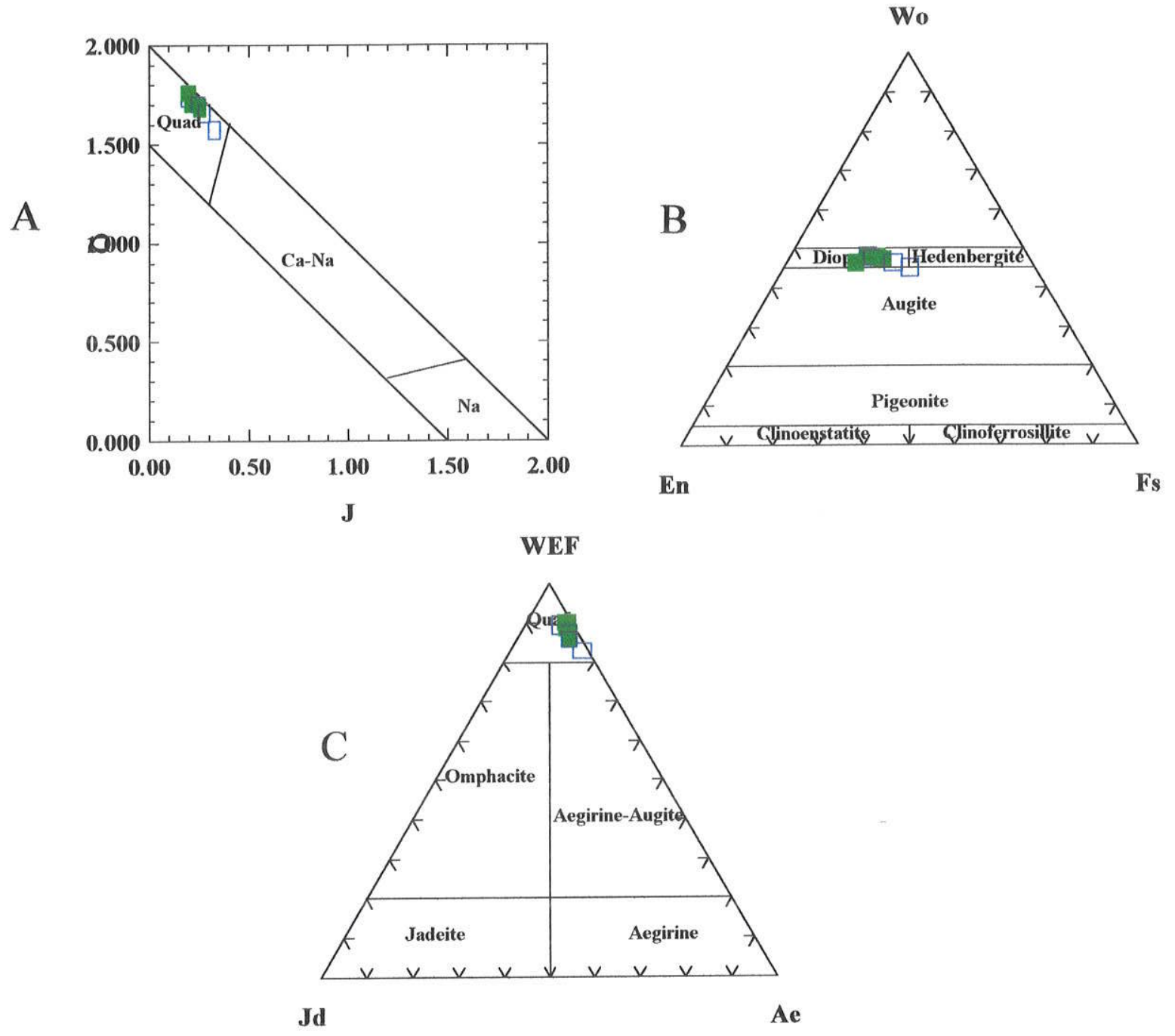

Figura 58 (A, B e C) Distribuição dos piroxênios das rochas do Morro São Pedro nos diagramas do IMA (Morimoto, 1989). Os litotipos representados são RP-255 (nefelina sienito) e RP-256 (fonolito peralcalino). Simbolos como na figura 49. 

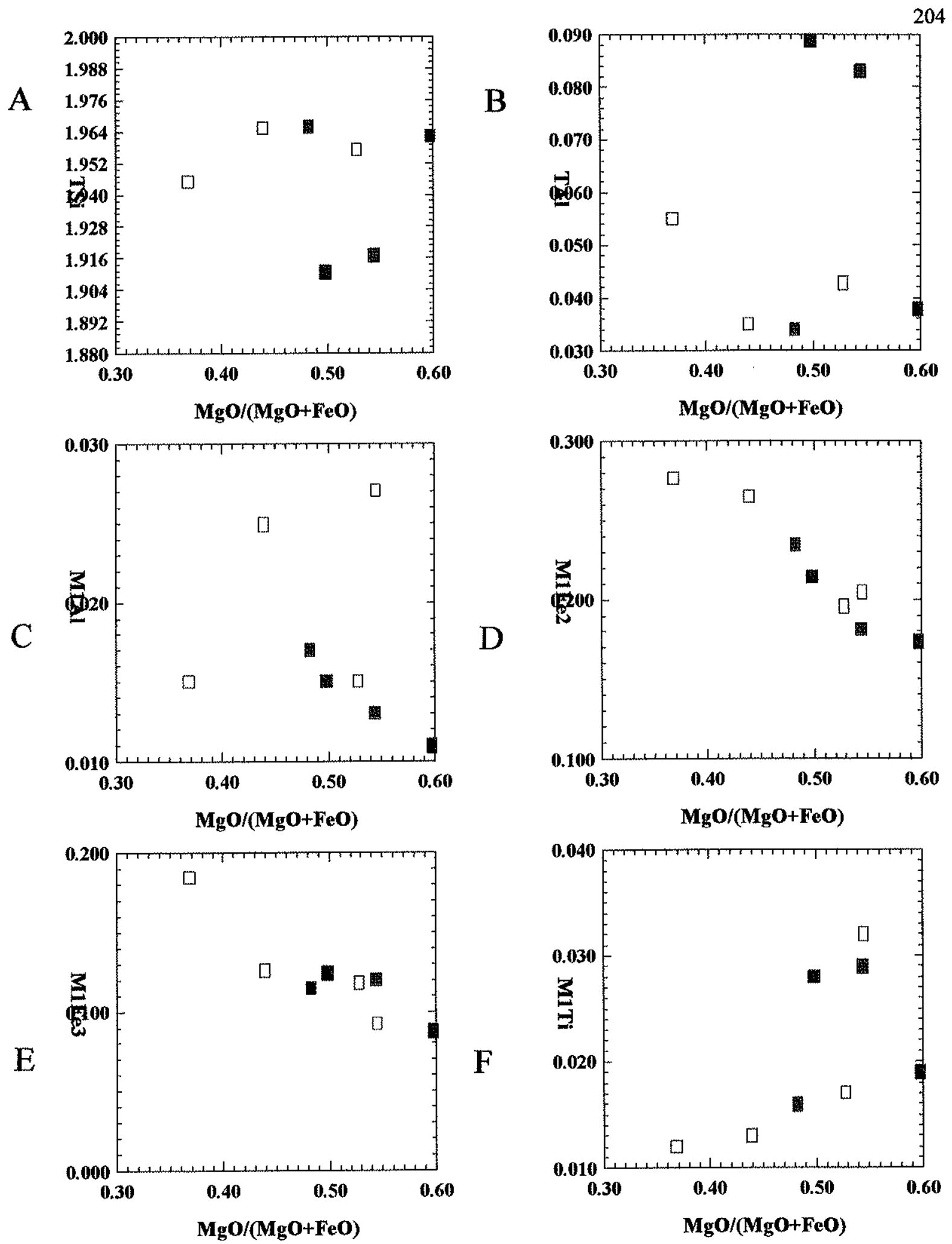

Figura 59 (A, B, C, D, E e F) - Diagramas de variação composicional dos piroxênios das rochas do Morro São Pedro. Símbolos como na figura 49. 

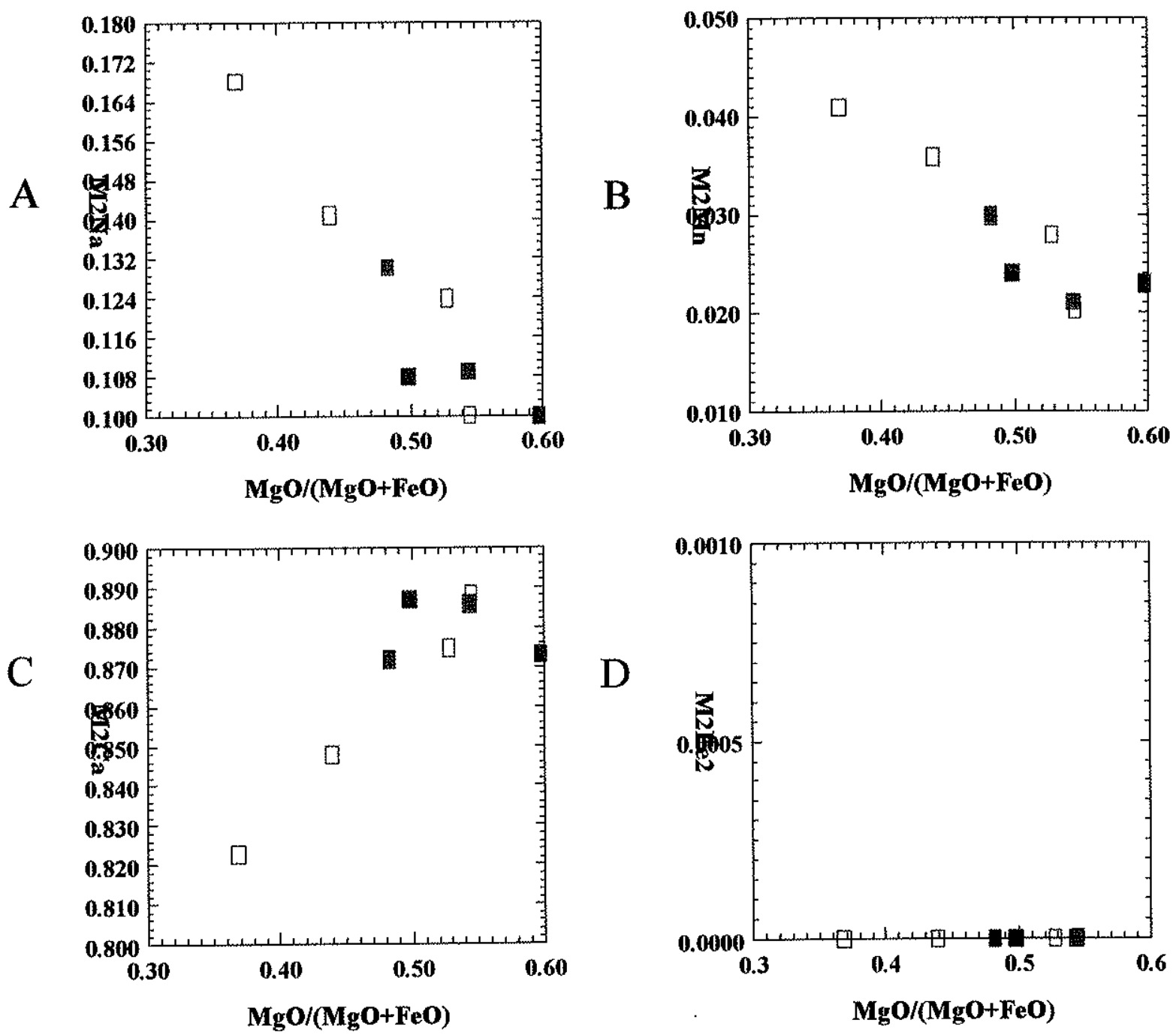

Figura 60 (A, B, C e D) - Diagramas de variação composicional de piroxênios do Morro São Pedro. Simbolos como na figura 49. 


\section{V.4.7 - Morro Distante}

No corpo alcalino denominado neste trabalho de Morro Distante, foram efetuadas 8 análises de piroxênios em uma amostra (RP-264) petrograficamente distinguida como fonolito peralcalino. Essas análises químicas são apresentadas na tabela 15.22 .

A exemplo dos piroxênios das rochas de São Pedro, os teores de alguns elementos são muito elevados tais como: $\mathrm{Al}_{2} \mathrm{O}_{3}$ podendo atingir $4,65 \%, \mathrm{MgO}$ até $17,62 \%$ e $\mathrm{CaO}$ até $22,03 \%$.

Nesse corpofoi efetuada a classificação dos piroxênios nos diagramas da IMA (Q-J e WEF-Jd-Ae) onde eles apresentam composição dentro do campo Quad (Figuras 61-A e C). Já no diagrama Wo-En-Fs (Figura 61-B), a quase totalidade das análises de piroxênios pertencentes à matriz plotam-se como salitas, enquanto que os minerais provenientes de fenocristais estão locados no campo das augitas.

Tentativamente foram elaborados os diagramas binários de correlação catiônica para os piroxênios das rochas de Morro Distante, porém, em razão do pequeno número de dados, o estudo dos sítios tetraédrico e octaédricos (regulares e irregulares) mostrou comportamento indistinto em quase todos os diagramas elaborados (Figuras 62-A, B, C, D, E e F e 63-A-B-C e D). 
Tabela 15.22 - Composiçăo quimica de piroxênios de Morro Distante (\% peso)

\begin{tabular}{|c|c|c|c|c|c|c|c|c|}
\hline Amostra & $\mathrm{RP}-264$ & RP-264 & RP-264 & RP-264 & RP-264 & RP-264 & $\mathrm{RP}-264$ & RP-264 \\
\hline Análises & 637 & 638 & 639 & 640 & 641 & 658 & 659 & 660 \\
\hline Locaçãá & C1G1m & $\mathrm{C} 1 \mathrm{G} 2 \mathrm{Fn}$ & $\mathrm{C} 1 \mathrm{G} 2 \mathrm{Fb}$ & C3G1n & C3G1b & $\mathrm{C} 2 \mathrm{G} 1 \mathrm{~m}$ & C3G1incl & $\mathrm{C} 5 \mathrm{G} 1 \mathrm{~m}$ \\
\hline Mineral & Px & Px & Px & Px & Px & Px & Px & Px \\
\hline $\mathrm{SiO}_{2}$ & 50.01 & 50.66 & 50.37 & 51.61 & 52.63 & 52.84 & 52.78 & 52.74 \\
\hline $\mathrm{TiO}_{2}$ & 1.01 & 0.75 & 1.09 & 0.13 & 0.18 & 0.22 & 0.34 & 0.29 \\
\hline $\mathrm{Al}_{2} \mathrm{O}_{3}$ & 4.56 & 4.06 & 4.65 & 3.35 & 2.61 & 1.03 & 0.87 & 0.65 \\
\hline $\mathrm{FeO}$ & 9.73 & 8.61 & 9.79 & 11.08 & 10.6 & 8.54 & 8.69 & 9.9 \\
\hline $\mathrm{Cr}_{2} \mathrm{O}_{3}$ & 0 & 0 & 0 & 0 & 0 & 0 & 0 & 0 \\
\hline $\mathrm{MnO}$ & 0.98 & 0.86 & 0.91 & 2.23 & 2.06 & 1.16 & 1.12 & 1.26 \\
\hline $\mathrm{NiO}$ & 0 & 0 & 0 & 0 & 0 & 0 & 0 & 0 \\
\hline $\mathrm{MgO}$ & 17.62 & 17.6 & 17.13 & 17.06 & 17.49 & 13.59 & 13.97 & 13.08 \\
\hline $\mathrm{CaO}$ & 10.76 & 10.63 & 11.03 & 9.78 & 10.05 & 22.11 & 22.03 & 21.57 \\
\hline $\mathrm{Na}_{2} \mathrm{O}$ & 2.09 & 1.49 & 2.08 & 1.7 & 1.44 & 0.58 & 0.58 & 0.56 \\
\hline $\mathrm{K}_{2} \mathrm{O}$ & 0.64 & 0.71 & 0.67 & 0.34 & 0.27 & 0 & 0.01 & 0 \\
\hline $\mathrm{ZnO}$ & 0 & 0 & 0 & 0 & 0 & 0.02 & 0 & 0.01 \\
\hline $\mathrm{ZrO}_{2}$ & 0.02 & 0.02 & 0.09 & 0.02 & 0.02 & 0.05 & 0 & 0 \\
\hline Total & 97.4 & 95.37 & 97.72 & 97.28 & 97.33 & 100.09 & 100.39 & 100.06 \\
\hline \multicolumn{9}{|c|}{ Formula estrutural calculada na base de 6 atomos de oxigénio } \\
\hline TSi & 1.856 & 1.923 & 1.868 & 1.939 & 1.978 & 1.968 & 1.958 & 1.976 \\
\hline Tal & 0.144 & 0.077 & 0.132 & 0.061 & 0.022 & 0.032 & 0.038 & 0.024 \\
\hline $\mathrm{TFe}^{3+}$ & 0 & 0 & 0 & 0 & 0 & 0 & 0 & 0 \\
\hline M1A| & 0.055 & 0.105 & 0.071 & 0.088 & 0.094 & 0.013 & 0 & 0.005 \\
\hline $\mathrm{M} 1 \mathrm{Ti}$ & 0.028 & 0.021 & 0.03 & 0.004 & 0.005 & 0.006 & 0.009 & 0.008 \\
\hline $\mathrm{M} 1 \mathrm{Fe}^{3+}$ & 0 & 0 & 0 & 0 & 0 & 0 & 0 & 0 \\
\hline $\mathrm{M1Fe}^{2+}$ & 0 & 0 & 0 & 0 & 0 & 0.227 & 0.218 & 0.257 \\
\hline $\mathrm{M} 1 \mathrm{Cr}$ & 0. & 0 & 0 & 0 & 0 & 0 & 0 & 0 \\
\hline M1Mg & 0.916 & 0.874 & 0.899 & 0.909 & 0.901 & 0.754 & 0.772 & 0.731 \\
\hline $\mathrm{M} 1 \mathrm{Ni}$ & 0 & 0 & 0 & 0 & 0 & 0 & 0 & 0 \\
\hline M2Mg & 0.059 & 0.122 & 0.048 & 0.047 & 0.079 & 0 & 0 & 0 \\
\hline $\mathrm{M} 2 \mathrm{Fe} 2$ & 0.302 & 0.273 & 0.304 & 0.348 & 0.333 & 0.039 & 0.051 & 0.053 \\
\hline $\mathrm{M} 2 \mathrm{Mn}$ & 0.031 & 0.028 & 0.029 & 0.071 & 0.066 & 0.037 & 0.035 & 0.04 \\
\hline $\mathrm{M} 2 \mathrm{Ca}$ & 0.428 & 0.432 & 0.438 & 0.394 & 0.405 & 0.882 & 0.875 & 0.866 \\
\hline $\mathrm{M} 2 \mathrm{Na}$ & 0.15 & 0.11 & 0.15 & 0.124 & 0.105 & 0.042 & 0.042 & 0.041 \\
\hline M2K & 0.03 & 0.034 & 0.032 & 0.016 & 0.013 & 0 & 0 & 0 \\
\hline Sum_cat & 3.97 & 3.966 & 3.968 & 3.984 & 3.987 & 4 & 4 & 4 \\
\hline $\mathrm{Ca}$ & 24.653 & 25.001 & 25.517 & 22.263 & 22.693 & 45.492 & 44.835 & 44.481 \\
\hline $\mathrm{Mg}$ & 56.171 & 57.594 & 55.14 & 54.036 & 54.948 & 38.906 & 39.559 & 37.53 \\
\hline $\mathrm{Fe}^{2+}{ }_{-2} \mathrm{Mn}$ & 19.176 & 17.405 & 19.343 & 23.701 & 22.359 & 15.602 & $\{5.606$ & 17.989 \\
\hline JD1 & 2.941 & 5.683 & 3.793 & 4.765 & 5.099 & 0.66 & 0 & 0.236 \\
\hline AE1 & 6.643 & 2.122 & 5.9 & 2.861 & 1.323 & 1.493 & 2.153 & 1.853 \\
\hline CFTS1 & 0 & 0 & 0 & 0 & 0 & 0 & 0 & 0 \\
\hline CTTS1 & 1.495 & 1.16 & 1.626 & 0.2 & 0.277 & 0.317 & 0.484 & 0.42 \\
\hline CATS1 & 0 & 0 & 0 & 0 & 0 & 0 & 0 & 0 \\
\hline WO1 & 24.198 & 22.264 & 21.808 & 21.225 & 21.769 & 45.051 & 44.19 & 44.045 \\
\hline EN1 & 51.705 & 53.962 & 50.638 & 52,001 & 53.383 & 38.8 & 39.418 & 37.517 \\
\hline FS1 & 16.017 & 14.809 & $\{6.235$ & 18.946 & 18.15 & 13.678 & 13.755 & 15.929 \\
\hline$Q$ & 1.705 & 1.702 & 1.689 & 1.698 & 1.718 & 1.903 & 1.917 & 1.907 \\
\hline J & 0.301 & 0.219 & 0.299 & 0.248 & 0.21 & 0.084 & 0.083 & 0.081 \\
\hline wo & 24.653 & 25.001 & 25.517 & 22.263 & 22.693 & 45.492 & 44,835 & 44.481 \\
\hline EN & 56.171 & 57.594 & 55.14 & 54.036 & 54.948 & 38.906 & 39.559 & 37.53 \\
\hline FS & 19.176 & 17.405 & 19.343 & 23.701 & 22.359 & 15.602 & 15.606 & 17.989 \\
\hline WEF & 85.228 & 88.744 & 85.167 & 87.714 & 89.471 & 95.859 & 95.903 & 95.988 \\
\hline JD & 14.772 & 11.256 & 14.833 & 12,286 & 10.529 & 4.141 & 0 & 4.012 \\
\hline$A E$ & 0 & 0 & 0 & 0 & 0 & 0 & 0.042 & 0 \\
\hline
\end{tabular}

Observações de abreviações como na tabela 15.0 

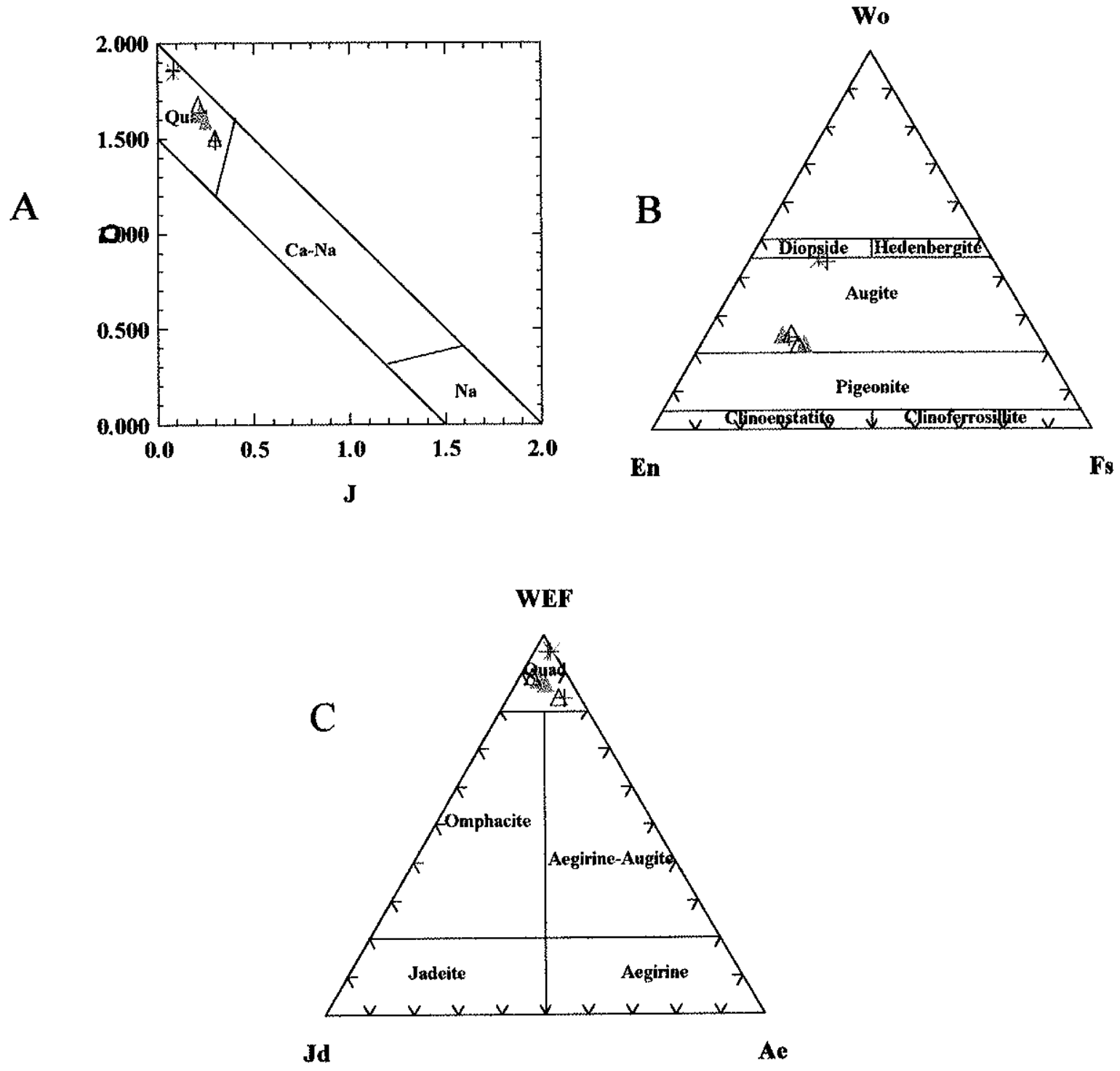

Figura 61 (A, B, C, ) - Composição dos piroxênios das rochas de Morro Distante nos diagramas de classificação do IMA (Morimoto, 1989). Símbolos como na figura 49. 
A
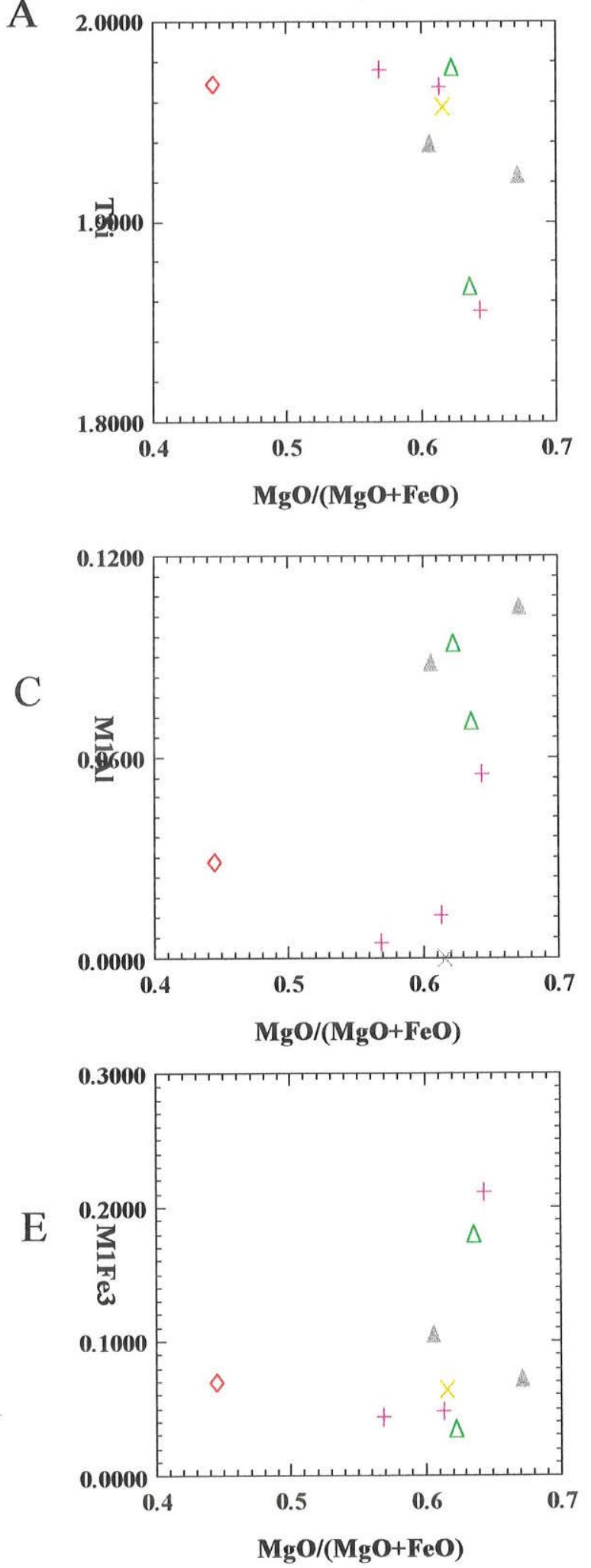

B

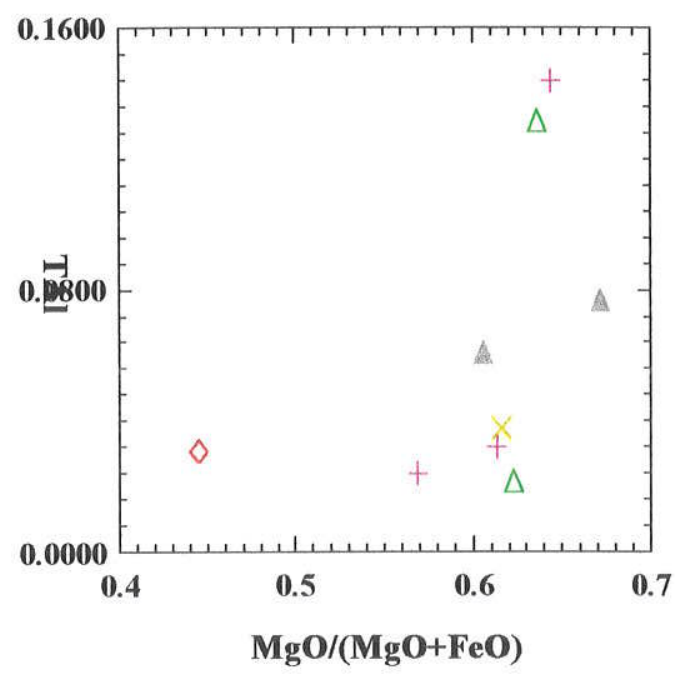

D
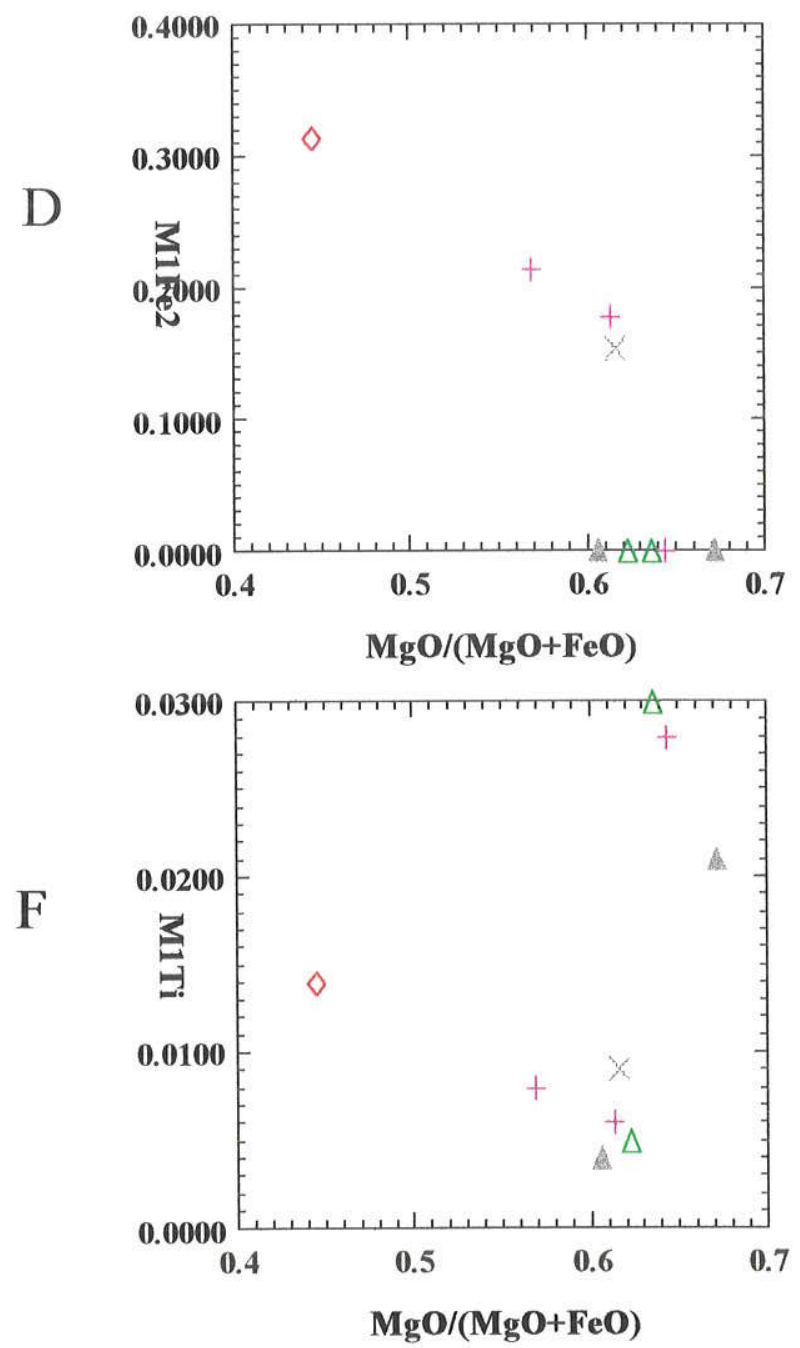

Figura 62 (A, B, C, D, E e F) - Diagramas de variação composicional dos piroxênios das rochas de Morro Distante. Simbolos como na figura 42. 

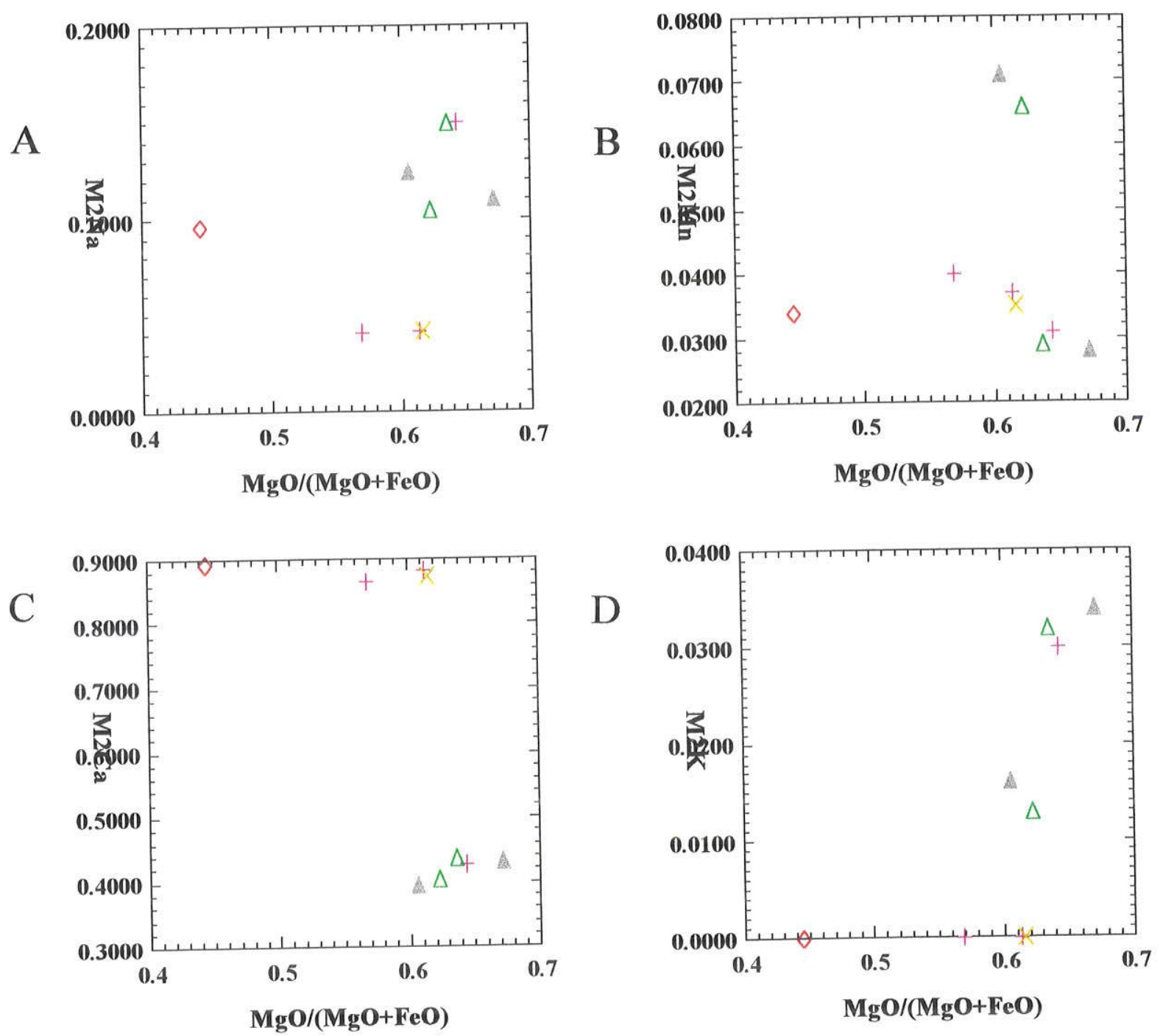

Figura 63 (A, B, C e D) - Diagramas de variação composicional dos piroxênios de Morro Distante. Símbolos como na figura 42 


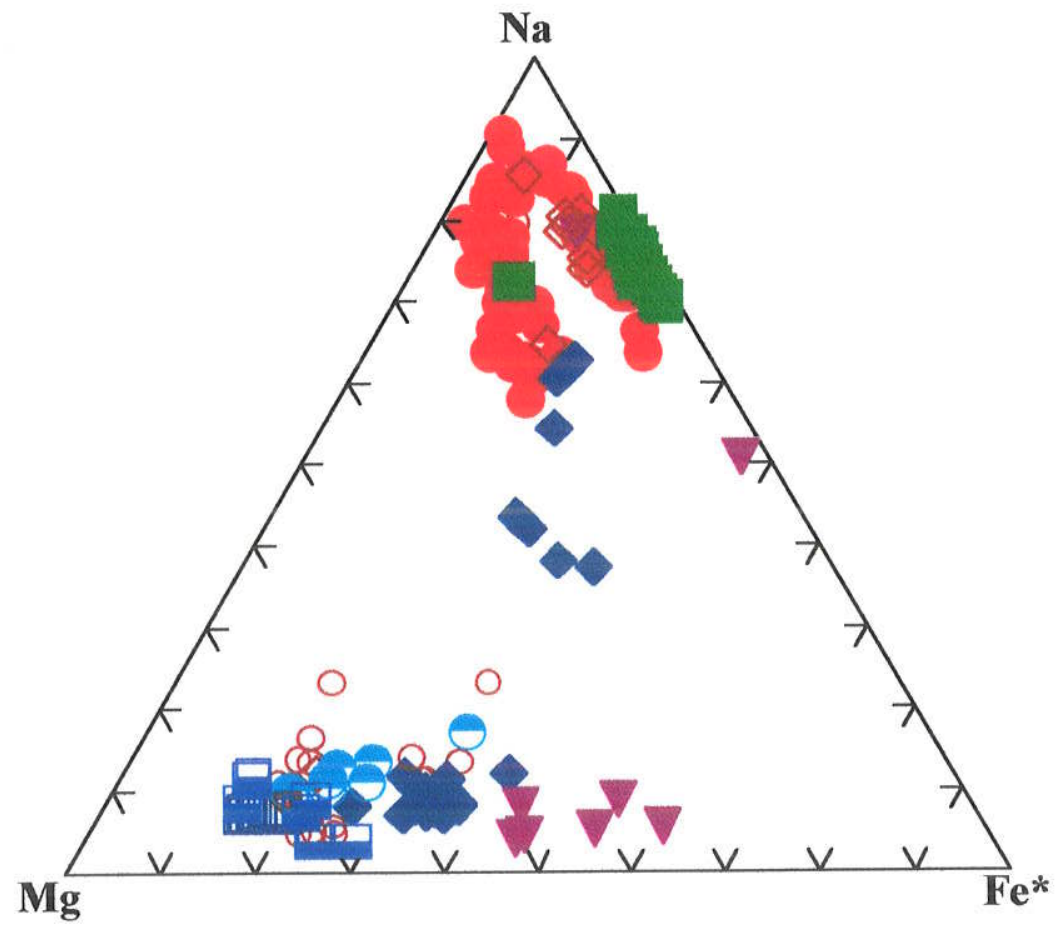

Figura 64 - Locação dos piroxênios das rochas da Província Alcalina Alto Paraguai no diagrama Na-Mg$\mathrm{Fe}^{*} . \mathrm{Fe}^{*}=\mathrm{Fe}^{2+}+\mathrm{Mn}+\left(\mathrm{Fe}^{3+}-\mathrm{Na}\right)$. Simbolos:Cerro Boggiani (círculos cheios); Cerro Siete Cabezas (losangos cheios); Satélite I (triângulos cheios); Satélite II (quadrados cheios); Pão de Açúcar (círculos vazios); Cerrito (quadrados vazios), llha Fecho dos Morros (losangos vazios); Cerro Pedreira (triângulos vazios); Morro de São Pedro (círculos com metade superior preenchidos) e Morro Distante (quadrados com metade inferior preenchida). 


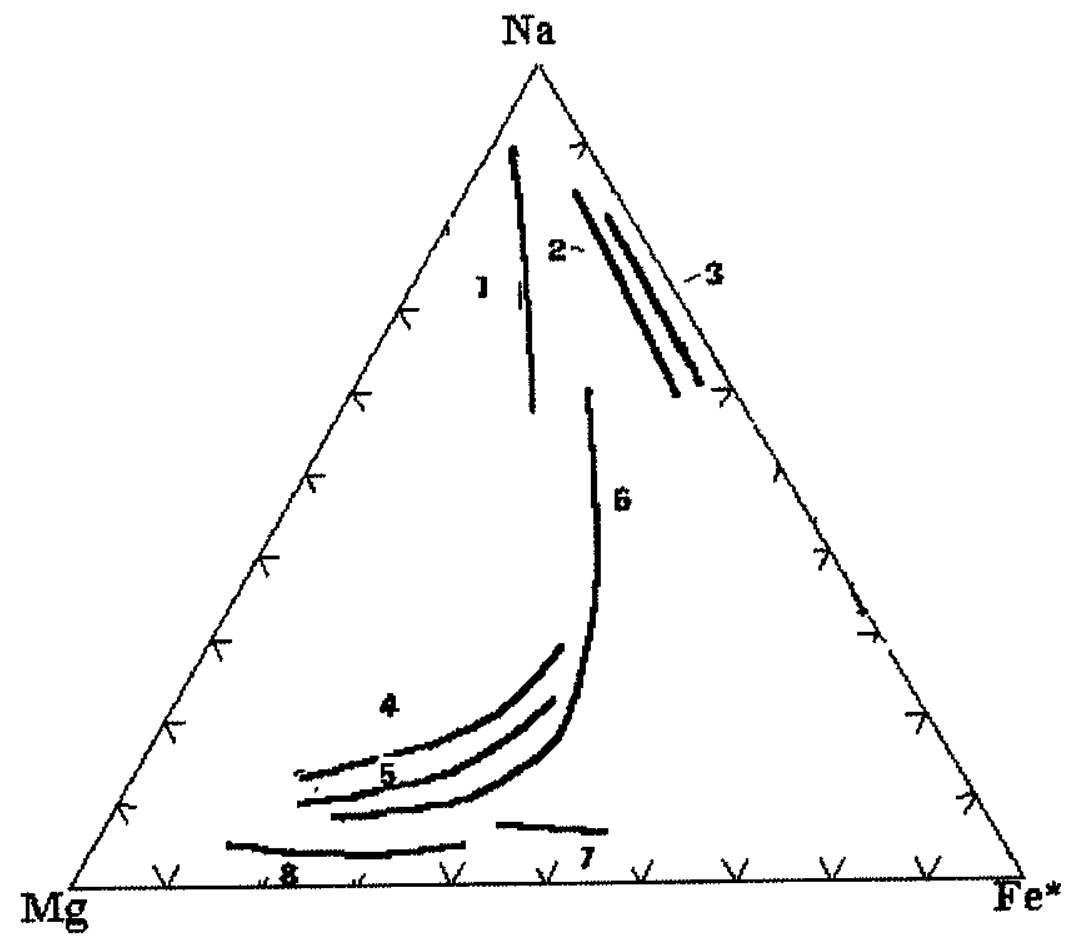

Figura 65 - Tendências composicionais para os piroxênios das rochas da Província Alcalina Alto Paraguai, estabelecidas com base nos dados plotados na figura 64. Símbolos: curvas 1 e 2 (Cerro Boggiani e Cerrito), 3 (Satélite II), 4 (Pão de Açúcar e Cerro Pedreira), 5 (São Pedro), 6 (Cerro Siete Cabezas), 7 (Satélite I) e 8 (Morro Distante). 


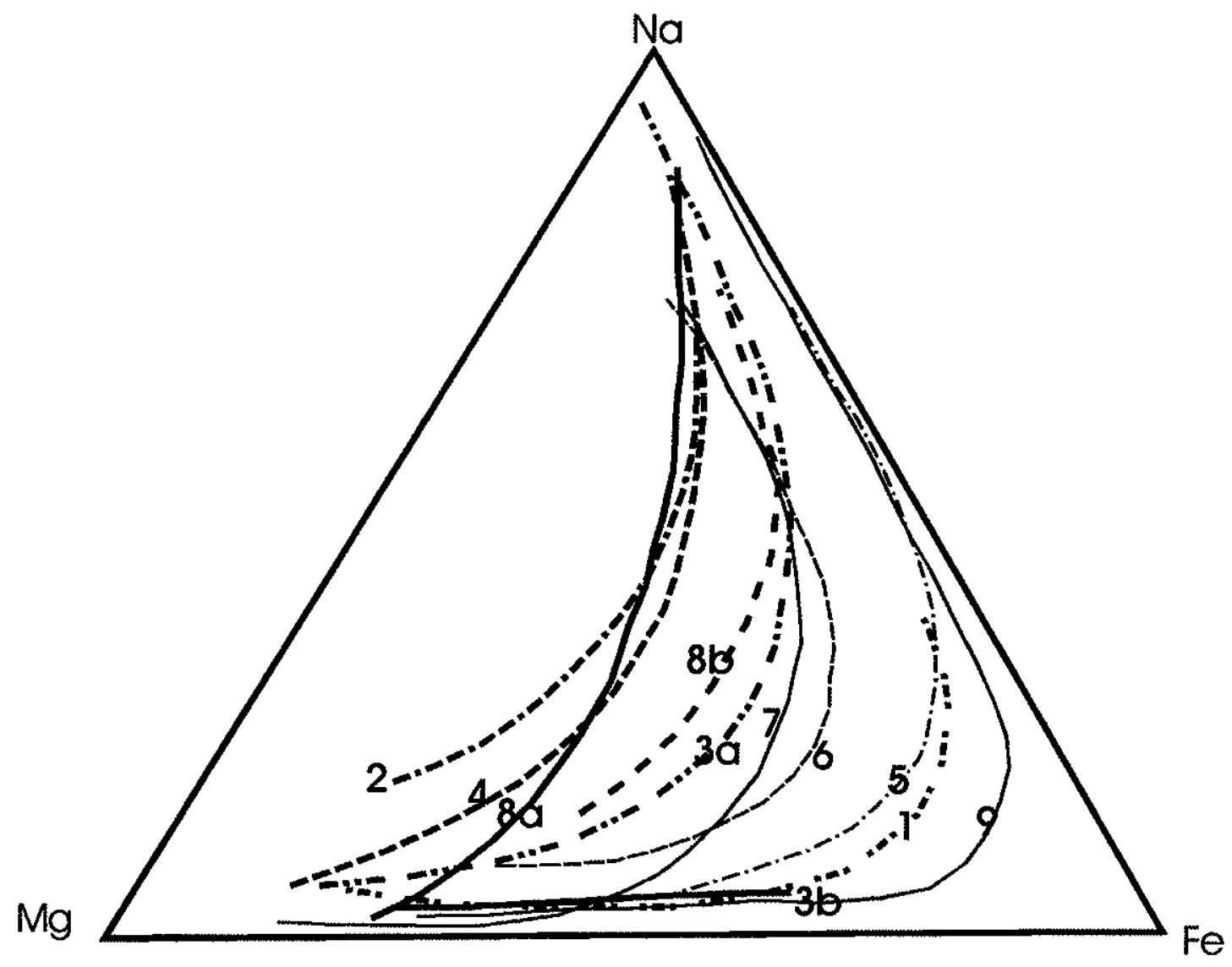

Figura 66 - Tendências de evolução composicional de piroxênios em alguns complexos alcalinos do Brasil. 1- Tunas (Gomes et al., 1987); 2- Itapirapuã (Gomes et al., 1970); 3-Rio de Janeiro: a) Tanguá - Rio Bonito - Itaúna - Morro de São João; b) Soarinho (Valença, 1980); 4- Banhadão (Ruberti, 1984); 5- Ilha de Vitoria (Motoki, 1986); 6- Piratini (Barbieri et al., 1987); 7 - Sapucaí, Paraguai Oriental (De Min, 1992); 8 a e 8b- diques e "Plugs" alcalinos da regiấo do Vale do Ribeira (Vasconcellos, 1995); 9-Complexo Ponta do Morro(Sousa, 1997). 
V.5 - Micas

Os minerais do grupo das micas apresentam, segundo Deer et al. (1963) uma variação considerável de suas propriedades químicas, podendo ser, no entanto, expressos pela seguinte fórmula estrutural geral:

$\mathrm{K}_{2}\left(\mathrm{Fe}^{2+}, \mathrm{Mg}\right)_{6-4}\left(\mathrm{Fe}^{3+}, \mathrm{Al}, \mathrm{Ti}\right)_{0-2}\left(\mathrm{Si}_{6-5} \mathrm{Al}_{2-3}\right) \mathrm{O}_{20-22}(\mathrm{OH}, \mathrm{F})_{4-2}$

Conforme esses autores, o termo "biotita" é restrito a uma mica octaédrica rica em ferro, e diferenciada da flogopita por apresentar a relação $\mathrm{Mg}: \mathrm{Fe}<2: 1$. Essa distinção entre biotitas e flogopitas foi proposta pela primeira vez por Heinrich et al. (1953, apud Sapountzis, 1976) e vem sendo adotada na literatura a partir de então, pela conveniência de subdividir um intervalo composicional muito extenso. Para se efetuar essa caracterização, toma-se como parâmetros a proporção catiônica Mg:Fe supra-citada, que estabelece o valor de 2 a.f.u. (átomos por fórmula unitária) como limite teórico entre as micas envolvidas: se maior que 2 a.f.u., o mineral chamar-se-á flogopita e para valores inferiores a 2 a.f.u. a classificação adotada é biotita. Ulbrich (1983), dentre outros autores, salienta que em função da complexidade cristaloquímica das micas, é praticamente impossivel obter-se uma relação $\mathrm{Fe}^{2+}: \mathrm{Fe}^{3+}$ satisfatória, enfatizando que nenhum método utilizado para a estimativa dessa relação é plenamente confiável. Optou-se portanto, neste trabalho, considerar o ferro desses minerais como $\mathrm{Fe}^{2+}$ total.

Excetuando-se as rochas de Porto Conceição, todas as outras dos corpos da Província Alcalina Alto Paraguai são portadoras de micas, no entanto, em quantidades subordinadas aos demais máficos. Ocorrem principalmente como microfenocristais e associadas aos máficos e opacos exibindo comumente com estes, intercrescimento simplectítico.

As análises químicas das micas das rochas da Província Alcalina Alto Paraguai são apresentadas nas tabelas 6.0 a 6.10 e sua fórmula estrutural calculada na base de 22 átomos de oxigênio pelo programa MINPET (Richard, 1995), seguindo as recomendações da IMA para análises por microssonda, que não fornecem a quantidade de $\mathrm{H}_{2} \mathrm{O}$ presente. 
Os teores de Si de algumas análises de biotitas de Cerro Boggiani, Satélite II, Iha Fecho dos Morros, Cerro Pedreira e Porto Conceição (tabelas 16.0, 16.1, 16.6, 16.7, 16.10 e Figuras 67-A e 67-B) excedem a 6,0 a.f.u. (átomos por fórmula unitária) . Nas demais análises, os valores de Si são inferiores a 6,0, implicando em teores de $\mathrm{Al}^{\mathrm{IV}}$ sempre inferiores a 2,0 a.f.u., necessários para o preenchimento do sítio tetraédrico (Figura 68-A).

O cátion Al ocupa, nas micas estudadas, tanto posições tetraédricas quanto posições octaédricas (Figura 68-A e B). O Al ${ }^{\mathrm{IV}}$ varia de 1,7 a 2,5 a.f.u. (Figuras $68-\mathrm{A}$ e B) e apresenta valores entre 0,18 e 0,88 na posição octaédrica (tabelas 16.0 a 16.10). Nesse sentido, Deer et al. (1992) destaca o dupla valência do Alumínio enfatizando que aquelas formadas à temperaturas mais elevadas tendem a possuir mais $\mathrm{Al}$ em coordenação tetraédrica, fato este que deve ter ocorrido nas biotitas das rochas da Província Alcalina do Alto Paraguai.

Nos diagramas binários multi-elementares em relação ao índice de diferenciação, verifica-se a inexistência de zonações químicas importantes, exceto nas micas das rochas no corpo de Cerrito onde se observa uma discreta perda de $\mathrm{TiO}_{2}$ do núcleo para as bordas (Figura 68-A).

No diagrama classificatório que tem como membros extremos: annita $\left[\mathrm{K}_{2} \mathrm{Fe}_{6} \mathrm{Si}_{6} \mathrm{Al}_{2} \mathrm{O}_{20}(\mathrm{OH})_{4}\right]$, siderofilita $\quad\left[\mathrm{K}_{2} \mathrm{Fe}_{5} \mathrm{Si}_{5} \mathrm{Al}_{4} \mathrm{O}_{20}(\mathrm{OH})_{4}\right], \quad$ flogopita $\left[\mathrm{K}_{2} \mathrm{Mg}_{6} \mathrm{Si}_{6} \mathrm{Al}_{2} \mathrm{O}_{20}(\mathrm{OH})_{4}\right]$ e eastonita $\left[\mathrm{K}_{2} \mathrm{Mg}_{5} \mathrm{Si}_{5} \mathrm{Al}_{4} \mathrm{O}_{20}(\mathrm{OH})_{4}\right]$, construído a partir do programa MINPET (Richard, 1995), com delimitação dos campos conforme Deer et al. (1992), a maioria das micas das rochas da Província Alcalina Alto Paraguai se classifica como biotitas o que é confirmado pela relação $\mathrm{Mg}: \mathrm{Fe}<2: 1$. Apenas as rochas de Cerrito, Cerro Siete Cabezas e Cerro Boggiani possuem flogopitas.

Os valores de Ti das micas nos corpos Satélite I e II, Pão de Açúcar, Cerrito, Cerro Pedreira e Porto Conceição (tabelas 16.1, 16.2, 16.4, 16.5, 16.7, 16.10 e Figura 68-A) são superiores a 0,5 a.f.u. caracterizando-as como Ti-biotitas (Rock, 1982). Nos demais corpos apresentam como característica geral os baixos valores de Ti (Figura 68-A). Nesse diagrama, observa-se um discreto enriquecimento em $\mathrm{TiO}_{2}$ das biotitas de rochas pertencentes à Cerrito, enquanto que as de Pão de Açúcar e Cerro 
Boggiani são mais enriquecidas em MnO do que a maioria das biotitas das rochas de outros corpos da Província Alto Paraguai.

O diagrama $\mathrm{Mg}-\left(\mathrm{Al} \mathrm{I}^{\mathrm{IV}}+\mathrm{Ti}\right)-\left(\mathrm{Fe}^{2+}+\mathrm{Mn}\right)$ da figura 69-A, apresenta tendência de enriquecimento em $\left(\mathrm{Fe}^{2+}+\mathrm{Mn}\right)$ nas rochas mais evoluídas da província (Satélite I e Satélite II), para uma razão $\mathrm{Mg} /\left(\mathrm{Al} \mathrm{I}^{\mathrm{V}}+\mathrm{Ti}\right)$ praticamente constante.

A exemplo de piroxênios e anfibólios, as biotitas apresentam tendências de evolução composicional com enriquecimento em $\mathrm{Fe}$, onde ocorre discreta perda de $\mathrm{Al}^{\mathrm{IV}}+\mathrm{Ti}, \mathrm{Al}_{2} \mathrm{O}_{3}$ e $\mathrm{K}$ (Figuras 69-A e 69-B). 
Tabela 16.0 - Composiçăo química de biotitas de Cerro Boggiani (\% peso)

\begin{tabular}{|c|c|c|c|c|c|c|c|c|c|c|c|c|c|c|c|c|c|}
\hline $\begin{array}{l}\text { Amostra } \\
\text { Analise }\end{array}$ & $\begin{array}{c}\text { RP-43 } \\
484\end{array}$ & $\begin{array}{c}\text { RP-43 } \\
485\end{array}$ & $\begin{array}{c}\text { RP-43 } \\
486\end{array}$ & $\begin{array}{c}R P-43 \\
487\end{array}$ & $\begin{array}{c}\text { RP-43 } \\
488\end{array}$ & $\begin{array}{c}\mathrm{RP}-43 \\
489\end{array}$ & $\begin{array}{c}\text { RP } 43 \\
490\end{array}$ & $\begin{array}{c}R P-43 \\
491\end{array}$ & $\begin{array}{c}\text { RP-43 } \\
492\end{array}$ & $\begin{array}{c}\text { RP-43 } \\
493\end{array}$ & $\begin{array}{c}\text { RP. } 43 \\
494\end{array}$ & $\begin{array}{c}\text { RP-43 } \\
495\end{array}$ & $\begin{array}{c}\text { RP-43 } \\
496\end{array}$ & $\begin{array}{c}\text { RP-43 } \\
497\end{array}$ & $\begin{array}{c}\text { RP-43 } \\
498\end{array}$ & $\begin{array}{c}\text { RP-43 } \\
499\end{array}$ & $\begin{array}{c}\text { RP-43 } \\
500\end{array}$ \\
\hline Locaçăa & C1G1Fn & C1G1Fb & $\mathrm{C} 1 \mathrm{G} 2 \mathrm{Fn}$ & $\mathrm{C} 1 \mathrm{G} 2 \mathrm{Fb}$ & C1G3Fn & C1G3Fb & C2G1m & $\mathrm{C} 2 \mathrm{G} 2 \mathrm{~m}$ & C5GiFn & C5G1Fb & C1G4m & C6GtFn & $\mathrm{C} 6 \mathrm{G} 1 \mathrm{Fb}$ & $\mathrm{C} 6 \mathrm{G} 2 \mathrm{~m}$ & C6G3m & C6GAFn & $\mathrm{C} 6 \mathrm{G} 4 \mathrm{Fb}$ \\
\hline Mineral & Bio & Bio & Bio & Bio & Bio & Bio & Bio & Bio & Bio & Bio & Bio & Bio & Bio & Bio & Bio & Bio & Bio \\
\hline $\mathrm{SiO}_{2}$ & 38.16 & 38.44 & 38.16 & 38.65 & 37.95 & 38.32 & 38.04 & 37.95 & 37.88 & 38.07 & 38.26 & 37.97 & 39.22 & 38.11 & 38.12 & 38.09 & 38.03 \\
\hline $\mathrm{TiO}_{2}$ & 2.18 & 2.44 & 2.64 & 2.83 & 2.57 & 2.34 & 2.67 & 2.52 & 2.84 & 2.47 & 2.51 & 2.56 & 2.82 & 2.52 & 2.53 & 2.73 & 2.58 \\
\hline $\mathrm{Al}_{2} \mathrm{O}_{3}$ & 11.23 & 11.31 & 11.07 & 11.19 & 10.72 & 10.81 & 11.58 & 11.12 & 11.12 & 10.77 & 10.95 & 11.02 & 10.84 & 10.93 & 10.97 & 10.89 & 10.9 \\
\hline $\mathrm{Cr}_{2} \mathrm{O}_{3}$ & 0.01 & 0 & 0 & 0.02 & 0.01 & 0.01 & 0.01 & 0.01 & 0 & 0.02 & 0.02 & 0 & 0.39 & 0 & 0 & 0.01 & 0 \\
\hline $\mathrm{FeO}$ & 21.31 & 20.92 & 21.32 & 20.07 & 21.72 & 21.4 & 21.83 & 22.24 & 21.71 & 21.08 & 21.63 & 21.54 & 21.2 & 21.23 & 21.6 & 21.66 & 21.84 \\
\hline $\mathrm{Fe}_{2} \mathrm{O}_{3}$ & 0 & & 0 & 0 & 0 & 0 & 0 & 0 & 0 & 0 & 0 & 0 & 0 & 0 & 0 & 0 & 0 \\
\hline Mno & 1.89 & 1.95 & 1.9 & 1.78 & 2.16 & 2.06 & 1.72 & 1.78 & 2.22 & 2.1 & 1.94 & 2.19 & 2.2 & 2.27 & 2.23 & 2.13 & 2.09 \\
\hline NiO & 0 & 0 & 0 & 0 & 0 & 0 & 0 & 0 & 0 & 0 & 0 & 0 & 0 & 0 & 0 & 0 & 0 \\
\hline $\mathrm{MgO}$ & 10.71 & 10.88 & 11.17 & 10.96 & 10.66 & 10.49 & 10.47 & 10.81 & 10.52 & 10.88 & 11.11 & 10.6 & 10.18 & 10.88 & 10.76 & 10.69 & 10.94 \\
\hline $\mathrm{CaO}$ & 0 & 0 & 0 & 0 & 0 & 0.01 & 0 & 0 & 0 & 0.01 & 0 & 0 & 0.1 & 0 & 0 & 0 & 0 \\
\hline $\mathrm{Na}_{2} \mathrm{O}$ & 0.31 & 0.4 & 0.32 & 0.65 & 0.29 & 0.29 & 0.29 & 0.24 & 0.26 & 0.3 & 0.38 & 0.27 & 1.31 & 0.37 & 0.28 & 0.29 & 0.29 \\
\hline $\mathrm{K}_{2} \mathrm{O}$ & 9.3 & 9.23 & 9.24 & 9.38 & 9.24 & 9.24 & 9.06 & 9.41 & 9.31 & 9.2 & 9.33 & 9.35 & 8.97 & 9.2 & 9.31 & 9.25 & 9.08 \\
\hline$F$ & 1.64 & 1.76 & 1.68 & 1.87 & 1.72 & 1.59 & 1.83 & 1.54 & 1.57 & 1.49 & 1.85 & 1.77 & 1.66 & 1.69 & 1.72 & 1.63 & 1.56 \\
\hline $\mathrm{Cl}$ & 0 & 0 & 0.01 & 0.09 & 0 & 0 & 0 & 0 & 0 & 0 & 0 & 0.02 & 0 & 0 & 0 & 0 & 0 \\
\hline $\mathrm{H}_{2} \mathrm{O}$ & 1.06 & 1.02 & 1.05 & 0.95 & 1.02 & 1.08 & 0.98 & 1. $\{2$ & 1.1 & 1.13 & 0.98 & 1 & 1.09 & 1.04 & 1.03 & 1.07 & 1.11 \\
\hline O_F_Cl & 0.69 & 0.74 & 0.71 & 0.81 & 0.72 & 0.67 & 0.77 & 0.65 & 0.66 & 0.63 & 0.78 & 0.75 & 0.7 & 0.71 & 0.72 & 0.69 & 0.66 \\
\hline Total & 98.49 & 99.09 & 99.27 & 99.25 & 98.78 & 98.31 & 99.25 & 99.39 & 99.19 & 98.15 & 99.74 & 99.04 & 100.68 & 98.95 & 99.27 & 99.13 & 99.08 \\
\hline \multicolumn{18}{|c|}{ Fómula estrutural calculada na base de 22 átomos de oxigenio } \\
\hline $\mathrm{Si}$ & 6.221 & 6.218 & 6.174 & 6.233 & 6.199 & 6.262 & 6.163 & 6.154 & 6.153 & 6.222 & 6.184 & 6.186 & 6.256 & 6.196 & 6.19 & 6.187 & 6.176 \\
\hline Allv & 1.779 & 1.782 & 1.826 & 1.767 & 1.801 & 1.738 & 1.837 & 1.846 & 1.847 & 1.778 & 1.816 & 1.814 & 1.744 & 1.804 & 1.81 & 1.813 & 1.824 \\
\hline ANI & 0.377 & 0.372 & 0.283 & 0.358 & 0.261 & 0.342 & 0.372 & 0.278 & 0.28 & 0.295 & 0.268 & 0.3 & 0.292 & 0.289 & 0.288 & 0.27 & 0.261 \\
\hline $\mathrm{TI}$ & 0.267 & 0.297 & 0.321 & 0.343 & 0.316 & 0.288 & 0.325 & 0.307 & 0.347 & 0.304 & 0.305 & 0.314 & 0.338 & 0.308 & 0.309 & 0.334 & 0.315 \\
\hline $\mathrm{Fe}^{\mathrm{a}+}$ & 0 & 0 & 0 & 0 & 0 & 0 & 0 & 0 & 0 & 0 & 0 & 0 & 0 & 0 & 0 & 0 & 0 \\
\hline $\mathrm{Fe}^{2+}$ & 2.905 & 2.83 & 2.885 & 2.707 & 2.967 & 2.924 & 2.958 & 3.016 & 2.949 & 2.881 & 2.924 & 2.935 & 2.828 & 2.887 & 2.933 & 2.942 & 2.966 \\
\hline $\mathrm{Cr}$ & 0.001 & 0 & 0 & 0.003 & 0.001 & 0.001 & 0.001 & 0.001 & 0 & 0.003 & 0.003 & 0 & 0.049 & 0 & 0 & 0.001 & 0 \\
\hline $\mathrm{Mn}$ & 0.261 & 0.267 & 0.26 & 0.243 & 0.299 & 0.285 & 0.236 & 0.245 & 0.305 & 0.291 & 0.266 & 0.302 & 0.297 & 0.313 & 0.307 & 0.293 & 0.287 \\
\hline $\mathrm{Mg}$ & 2.603 & 2.624 & 2.694 & 2.635 & 2.596 & 2.555 & 2.529 & 2.613 & 2.547 & 2.654 & 2.677 & 2.574 & 2.421 & 2.637 & 2.605 & 2.589 & 2.648 \\
\hline \multicolumn{18}{|l|}{$\mathrm{Ba}$} \\
\hline $\mathrm{Ca}$ & 0 & 0 & 0 & 0 & 0 & 0.002 & 0 & 0 & 0 & 0.002 & 0 & 0 & 0.017 & 0 & 0 & 0 & 0 \\
\hline $\mathrm{Na}$ & 0.098 & 0.125 & 0.1 & 0.203 & 0.092 & 0.092 & 0.091 & 0.075 & 0.082 & 0.095 & 0.119 & 0.085 & 0.405 & 0.117 & 0.088 & 0.091 & 0.091 \\
\hline $\mathrm{K}$ & 1.934 & 1.905 & 1.907 & 1.93 & 1.926 & 1.926 & 1.873 & 1.947 & 1.929 & 1.918 & 1.924 & 1.943 & 1.825 & 1.908 & 1.929 & 1.917 & 1.881 \\
\hline Cátions & 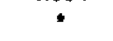 & $*$ & 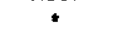 & $*$ & $x^{*}$ & * & " & $*$ & 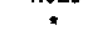 & $*$ & $*$ & $*$ & $\star$ & 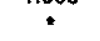 & 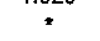 & 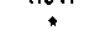 & 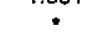 \\
\hline $\mathrm{CF}$ & 1.691 & 1.801 & 1.719 & 1.907 & 1.777 & 1.643 & 1.875 & 1.58 & 1.613 & 1.54 & 1.891 & 1.824 & 1.675 & 1.738 & 1.766 & 1.675 & 1.602 \\
\hline $\mathrm{CCl}$ & 0 & 0 & 0.005 & 0.049 & 0 & 0 & 0 & 0 & 0 & 0 & 0 & 0.011 & 0 & 0 & 0 & 0 & 0 \\
\hline $\mathrm{OH}$ & 1.155 & 1.1 & 1.138 & 1.022 & 1.111 & $1 .\{78$ & 1.062 & 1.21 & 1.194 & 1.23 & 1.054 & 1.083 & 1.163 & 1.131 & 1.117 & $\{.163$ & 1.199 \\
\hline 0 & 24 & 24 & 24 & 24 & 24 & 24 & 24 & 24 & 24 & 24 & 24 & 24 & 24 & 24 & 24 & 24 & 24 \\
\hline $\mathrm{Fe} \mathrm{FeMg}_{\mathrm{F}}$ & 0.53 & 0.52 & 0.52 & 0.51 & 0.53 & 0.53 & 0.54 & 0.54 & 0.54 & 0.52 & 0.52 & 0.53 & 0.54 & 0.52 & 0.53 & 0.53 & 0.53 \\
\hline $\mathrm{Mg}$ FeMg & 0.47 & 0.48 & 0.48 & 0.49 & 0.47 & 0.47 & 0.46 & 0.46 & 0.46 & 0.48 & 0.48 & 0.47 & 0.46 & 0.48 & 0.47 & 0.47 & 0.47 \\
\hline
\end{tabular}

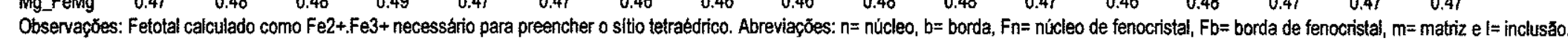


Tabela 16.1 - Composição química de biotitas do corpo Satélite Il (\% peso)

\begin{tabular}{|c|c|c|c|c|c|c|c|c|c|c|c|c|}
\hline Amostra & RP-44 & RP-44 & RP-44 & RP-44 & RP-50 & RP-50 & RP-50 & RP-50 & RP-50 & RP-50 & RP. 50 & RP.50 \\
\hline Analise & 149 & 150 & 151 & 152 & 139 & 142 & 143 & $\$ 44$ & 145 & 146 & 147 & 148 \\
\hline Locação & Cigin & Cigtb & C3Gin & C3G1b & Cigín & C1G2m & C1G2n & $\mathrm{C} 1 \mathrm{G} 2 \mathrm{Fb}$ & C1G3Fn & $\mathrm{C} 1 \mathrm{G} 3 \mathrm{Fb}$ & C3GIn & $\mathrm{C} 3 \mathrm{G} 1 \mathrm{~b}$ \\
\hline Mineral & Bio & Bio & Bio & Bio & Bio & Bio & Bio & Bio & Bio & Bio & Bio & Bio \\
\hline $\mathrm{SiO}_{2}$ & 35.94 & 37.211 & 34.268 & 35.931 & 37.85 & 38.569 & 35.446 & 35.152 & 34.949 & 35.011 & 36.916 & 38.075 \\
\hline $\mathrm{THO}_{2}$ & 3.876 & 3.688 & 3.318 & 4.305 & 2.587 & 2.344 & 5.387 & 3.583 & 3.682 & 4.466 & 2.848 & 2.589 \\
\hline $\mathrm{Al}_{2} \mathrm{O}_{3}$ & 12.744 & 13.764 & 11.148 & 12.853 & 10.633 & 10.837 & 12.662 & $\{2.656$ & 13.52 & 12.975 & 11.356 & 10.791 \\
\hline $\mathrm{Cr}_{2} \mathrm{O}_{3}$ & 0.001 & 0 & 0 & 0.004 & 0 & 0.025 & 0.013 & 0 & 0 & 0.001 & 0 & 0 \\
\hline $\mathrm{FeO}$ & 25.896 & 24.155 & 30.084 & 26.03 & 21.735 & 21.292 & 24.862 & 25.121 & 24.7 & 24.962 & 24.792 & 23.78 \\
\hline $\mathrm{Fe}_{2} \mathrm{O}_{3}$ & 0 & 0 & 0 & 0 & 0 & 0 & 0 & 0 & 0 & 0 & 0 & 0 \\
\hline MnO & 0.62 & 0.429 & 0.451 & 0.686 & 0.96 & 0.802 & 1.005 & 1.059 & 0.915 & 0.968 & 0.788 & 0.911 \\
\hline NiO & 0.006 & 0.006 & 0.013 & 0.018 & 0.015 & 0 & 0.012 & 0.01 & 0.001 & 0.007 & 0 & 0 \\
\hline $\mathrm{MgO}$ & 5.746 & 5.286 & 6.138 & 6.334 & 10.357 & 9.391 & 7.368 & 7.329 & 6.405 & 6.695 & 8.788 & 9.792 \\
\hline $\mathrm{CaO}$ & 0.042 & 0.079 & 0.064 & 0.024 & 0 & 0.53 & 0 & 0.261 & 0.893 & 0.04 & 0 & 0.013 \\
\hline $\mathrm{Na}_{2} \mathrm{O}$ & 0.193 & 0.163 & 0.196 & 0.198 & 0.354 & 0.176 & 0.426 & 0.274 & 0.195 & 0.23 & 0.227 & 0.237 \\
\hline $\mathrm{K}_{2} \mathrm{O}$ & 8.793 & 8.184 & 7.589 & 9.035 & 9.096 & 8.846 & 8.954 & 9.017 & 8.536 & 9.176 & 9.218 & 9.354 \\
\hline$F$ & 0.966 & 0.965 & 1.017 & 1.009 & 1.778 & 1.681 & 1.026 & 0.885 & 0.767 & 0.962 & 1.49 & 1.537 \\
\hline $\mathrm{Cl}$ & 0.185 & 0.191 & 0.149 & 0.186 & 0.109 & 0.088 & 0.061 & 0.133 & 0.109 & 0.101 & 0.118 & 0.123 \\
\hline $\mathrm{H}_{2} \mathrm{O}$ & 1.28 & 1.3 & 1.21 & 1.28 & 0.94 & 0.99 & 1.33 & 1.34 & 1.39 & 1.31 & 1.07 & 1.07 \\
\hline O_F_Cl & 0.45 & 0.45 & 0.46 & 0.47 & 0.77 & 0.73 & 0.45 & 0.4 & 0.35 & 0.43 & 0.65 & 0.67 \\
\hline Total & 96.738 & 95.871 & 96.105 & 98.363 & 97.484 & 96.301 & 99.002 & 97.22 & 96.412 & 97.334 & 98.261 & 98.942 \\
\hline \multicolumn{13}{|c|}{ Fómula estrutural calculada na base de 22 átomos de oxigenio } \\
\hline Si & 6.041 & 6.192 & 5.924 & 5.951 & 6.264 & 6.395 & 5.817 & 5.892 & 5.871 & 5.857 & 6.117 & 6.229 \\
\hline Allv & 1.959 & 1.808 & 2.076 & 2.049 & 1.736 & 1.605 & 2.183 & 2.108 & 2.129 & 2.143 & 1.883 & 1.771 \\
\hline AIVI & 0.564 & 0.889 & 0.194 & 0.458 & 0.336 & 0.511 & 0.264 & 0.39 & 0.546 & 0.413 & 0.333 & 0.308 \\
\hline $\mathrm{Ti}$ & 0.49 & 0.462 & 0.431 & 0.536 & 0.322 & 0.292 & 0.665 & 0.452 & 0.465 & 0.562 & 0.355 & 0.319 \\
\hline $\mathrm{Fe}^{3+}$ & 0 & 0 & 0 & 0 & 0 & 0 & 0 & 0 & 0 & 0 & 0 & 0 \\
\hline $\mathrm{Fe}^{2+}$ & 3.64 & 3.361 & 4.349 & 3.606 & 3.008 & 2.952 & 3.412 & 3.522 & 3.47 & 3.492 & 3.436 & 3.253 \\
\hline $\mathrm{Cr}$ & 0 & 0 & 0 & 0.001 & 0 & 0.003 & 0.002 & 0 & 0 & 0 & 0 & 0 \\
\hline $\mathrm{Mn}$ & 0.088 & 0.06 & 0.066 & 0.096 & 0.135 & 0.113 & 0.14 & 0.15 & 0.13 & 0.137 & 0.111 & 0.126 \\
\hline $\mathrm{Mg}$ & 1.44 & 1.311 & 1.582 & 1.564 & 2.555 & 2.321 & 1.802 & 1.831 & 1.604 & 1.67 & 2.171 & 2.388 \\
\hline \\
\hline $\mathrm{Ca}$ & 0.008 & 0.014 & 0.012 & 0.004 & 0 & 0.094 & 0 & 0.047 & 0.161 & 0.0 & 0 & 0.002 \\
\hline $\mathrm{Na}$ & 0.063 & 0.053 & 0.066 & 0.064 & 0.114 & 0.057 & 0.136 & 0.089 & 0.064 & 0.075 & 0.073 & 0.075 \\
\hline K & 1.885 & $\{.737$ & 1.674 & 1.909 & 1.92 & 1.871 & 1.874 & 1.928 & 1.829 & 1.958 & 1.949 & 1.952 \\
\hline Cátions & 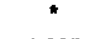 & ${ }^{*}$ & ${ }^{*}$ & 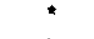 & 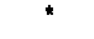 & & • & • & $*$ & $*$ & • & " \\
\hline CF & 1.027 & 1.016 & 1.112 & 1.057 & 1.861 & 1.763 & 1.065 & 0.938 & 0.815 & 1.018 & 1.562 & 1.59 \\
\hline $\mathrm{CCl}$ & 0.105 & 0.108 & 0.087 & 0.104 & 0.061 & 0.049 & 0.034 & 0.076 & 0.062 & 0.057 & 0.066 & 0.068 \\
\hline $\mathrm{OH}$ & 1.434 & 1.438 & 1.4 & 1.419 & 1.039 & 1.094 & 1.451 & 1.493 & 1.561 & 1.462 & 1.186 & 1.171 \\
\hline 0 & 24 & 24 & 24 & 24 & 24 & 24 & 24 & 24 & 24 & 24 & 24 & 24 \\
\hline $\mathrm{Fe}$ FeMg & 0.72 & 0.72 & 0.73 & 0.7 & 0.54 & 0.56 & 0.65 & 0.66 & 0.68 & 0.68 & 0.61 & 0.58 \\
\hline Mg_FeMg & 0.28 & 0.28 & 0.27 & 0.3 & 0.46 & 0.44 & 0.35 & 0.34 & 0.32 & 0.32 & 0.39 & 0.42 \\
\hline
\end{tabular}

Observaç̧̋es e abreviaç̧̋es como na tabela 6.0 
Tabela 16.2 - Composição quimica de biotitas do corpo Satélite I (\% peso)

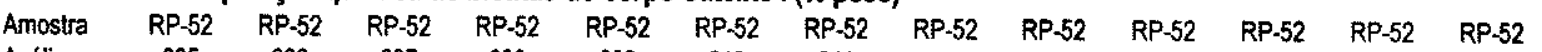

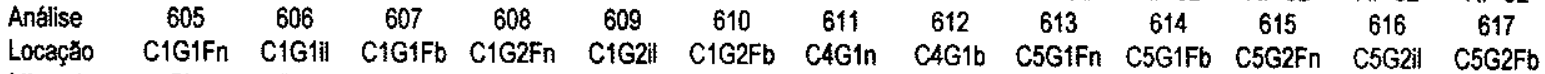

$\begin{array}{lllllllllll}\text { Mineral Bio Bio Bio Bio } & \text { Bio } & \text { Bio } & \text { Bio } & \text { Bio } & \text { Bio } & \text { Bio } & \text { Bio } & \text { Bio } & \text { Bio }\end{array}$

$\begin{array}{llllllllllllll}\mathrm{SiO}_{2} & 36.05 & 36.75 & 37.73 & 37.01 & 24.09 & 36.03 & 37.26 & 36.87 & 35.68 & 36.74 & 35.87 & 35.64 & 37.29\end{array}$

$\begin{array}{llllllllllllll}3.55 & 3.57 & 3.62 & 3.44 & 2.29 & 3.42 & 3.01 & 2.42 & 4.6 & 3.25 & 4.09 & 4.37 & 3.01\end{array}$

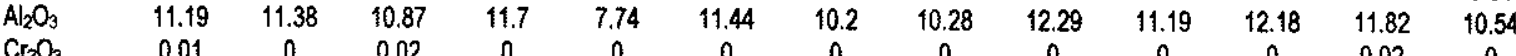

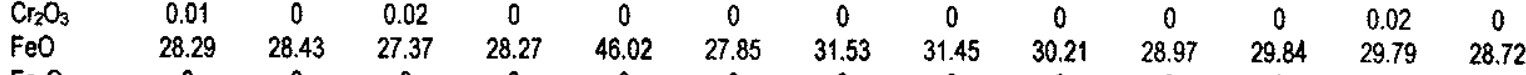

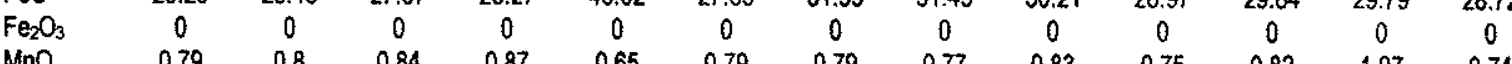

$\begin{array}{cccccccccccccc}\text { Mno } & 0.79 & 0.8 & 0.84 & 0.87 & 0.65 & 0.79 & 0.79 & 0.77 & 0.83 & 0.75 & 0.82 & 1.07 & 0.74 \\ \text { Nio } & 0 & 0 & 0 & 0 & 0 & 0 & 0 & 0 & 0 & 0 & 0 & 0 & 0\end{array}$

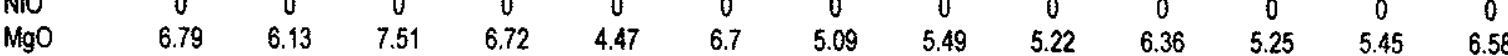

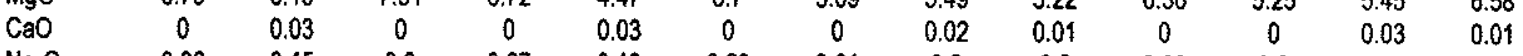

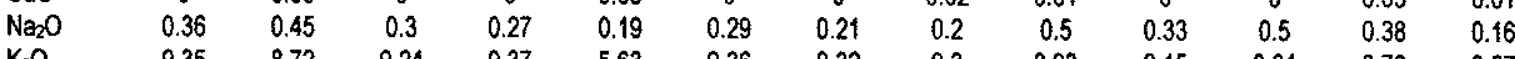

$\begin{array}{llllllllllllll}\mathrm{K}_{2} \mathrm{O} & 9.35 & 8.72 & 9.24 & 9.37 & 5.63 & 9.36 & 9.32 & 9.3 & 8.93 & 9.15 & 8.84 & 8.73 & 9.27 \\ \mathrm{~F} & 2.34 & 1.95 & 2.77 & 1.98 & 1.46 & 2.05 & 1.69 & 2.15 & 1.83 & 2.2 & 1.75 & 1.8 & 2.34\end{array}$

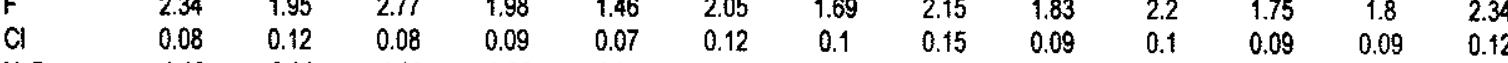

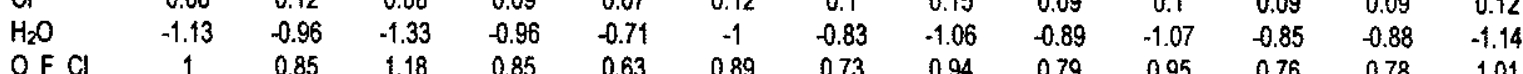

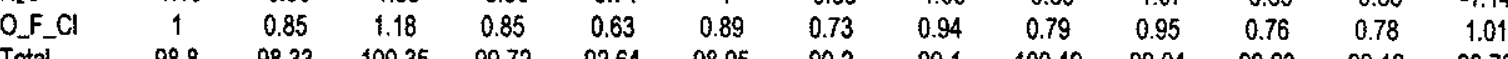

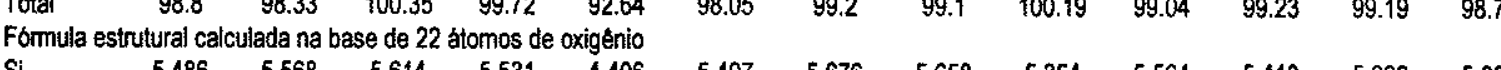

$\begin{array}{llllllllllllll}\mathrm{Si} & 5.486 & 5.568 & 5.614 & 5.531 & 4.406 & 5.497 & 5.676 & 5.658 & 5.354 & 5.564 & 5.418 & 5.396 & 5.663\end{array}$

$\begin{array}{lccccccccccccc}\text { AllV } & 2.005 & 2.03 & 1.905 & 2.059 & 1.667 & 2.056 & 1.83 & 1.858 & 2.172 & 1.996 & 2.167 & 2.108 & 1.885 \\ \text { AIV } & 0 & 0 & 0 & 0 & 0 & 0 & 0 & 0 & 0 & 0 & 0 & 0 & 0\end{array}$

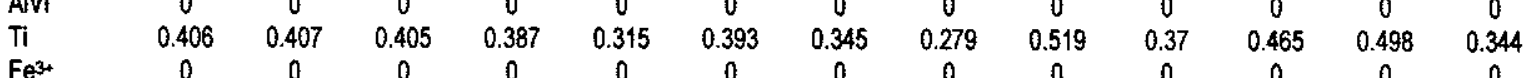

$\begin{array}{cccccccccccccc}\mathrm{Fe}^{3+} & 0 & 0 & 0 & 0 & 0 & 0 & 0 & 0 & 0 & 0 & 0 & 0 & 0 \\ \mathrm{Fe}^{2+} & 3.6 & 3.602 & 3.406 & 3.533 & 7.039 & 3.554 & 4.017 & 4.036 & 3.791 & 3.669 & 3.769 & 3.772 & 3.648\end{array}$

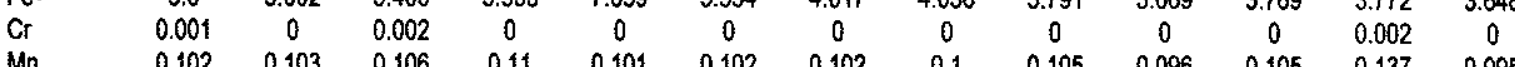

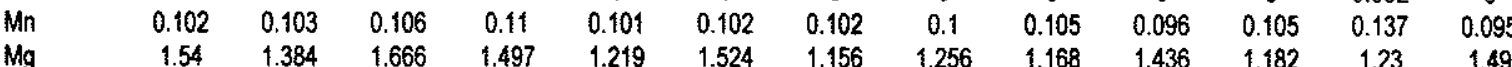

$\begin{array}{llllllllllllll}\mathrm{Mg} & 1.54 & 1.384 & 1.666 & 1.497 & 1.219 & 1.524 & 1.156 & 1.256 & 1.168 & 1.436 & 1.182 & 1.23 & 1.49 \\ \mathrm{Ba} & * & * & * & * & * & * & * & * & * & * & * & * & *\end{array}$

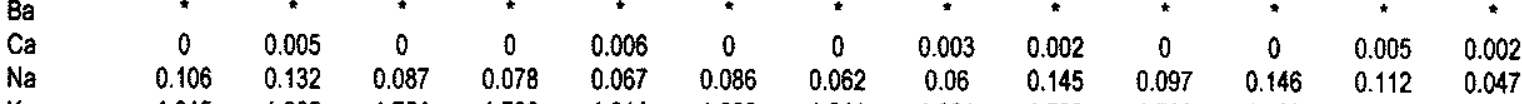

$\begin{array}{lccccccccccccc}\mathrm{K} & 1.815 & 1.685 & 1.754 & 1.786 & 1.314 & 1.822 & 1.811 & 1.821 & 1.709 & 1.768 & 1.703 & \$ .686 & 1.796\end{array}$

$\begin{array}{llllllllllllll}\text { CF } & 2.252 & 1.888 & 2.607 & 1.872 & 1.689 & 1.978 & 1.628 & 2.087 & 1.737 & 2.107 & 1.672 & \$ .724 & 2.248\end{array}$

$\begin{array}{llllllllllllll}\mathrm{CF} & 2.252 & 1.858 & 2.607 & 1.872 & 1.089 & 1.978 & 1.628 & 2.087 & 1.737 & 2.107 & 1.672 & 3.724 & 2.248 \\ \mathrm{CCl} & 0.041 & 0.062 & 0.04 & 0.046 & 0.043 & 0.062 & 0.052 & 0.078 & 0.046 & 0.051 & 0.046 & 0.046 & 0.062\end{array}$

$\begin{array}{llllllllllllll}\mathrm{OH} & 0 & 0 & 0 & 0 & 0 & 0 & 0 & 0 & 0 & 0 & 0 & 0 & 0\end{array}$

$\begin{array}{lccccccccccccc}0 & 22 & 22 & 22 & 22 & 22 & 22 & 22 & 22 & 22 & 22 & 22 & 22 & 22 \\ \text { Fe_FeMg } & 0.7 & 0.72 & 0.67 & 0.7 & 0.85 & 0.7 & 0.78 & 0.76 & 0.76 & 0.72 & 0.76 & 0.75 & 0.71 \\ \text { Mg_FeMg } & 0.3 & 0.28 & 0.33 & 0.3 & 0.15 & 0.3 & 0.22 & 0.24 & 0.24 & 0.28 & 0.24 & 0.25 & 0.29\end{array}$

Observaçðes e abreviaçðes como na tabela 6.0 
Tabela 16.3 - Composição química de biotitas de Cerro Siete Cabezas (\% peso)

\begin{tabular}{|c|c|c|c|c|c|c|c|c|c|c|}
\hline \multirow{2}{*}{\multicolumn{11}{|c|}{$\begin{array}{llllll}\text { Amostra } & \text { RP-74 } & \text { RP-74 } & \text { RP-74 } & \text { RP-74 } & \text { RP-74 }\end{array}$}} \\
\hline & & & & & & & & & & \\
\hline $\begin{array}{l}\text { Analise } \\
\text { Locacăo }\end{array}$ & $\begin{array}{c}990 \\
C 3 G 2 n\end{array}$ & 991 & 992 & 993 & 994 & 995 & 977 & 978 & 979 & 980 \\
\hline Mineral & $\begin{array}{c}\text { C3G2n } \\
\text { Bio }\end{array}$ & $\begin{array}{c}\text { C3G2b } \\
\text { Bio }\end{array}$ & $\begin{array}{c}\text { C4G1n } \\
\text { Bio }\end{array}$ & $\begin{array}{c}\text { C4G1b } \\
\text { Bio }\end{array}$ & $\begin{array}{c}\text { C4G2n } \\
\text { Bio }\end{array}$ & $\begin{array}{c}C 4 G_{2 b} \\
\mathrm{Bio}^{2}\end{array}$ & $\begin{array}{c}\text { CiGin } \\
\text { Bio }\end{array}$ & C1G1b & C3Gin & C3Gib \\
\hline $\mathrm{SiO}_{2}$ & 34.43 & 34.57 & 35.19 & 35.32 & 34.63 & 35.04 & 35.56 & $\begin{array}{l}810 \\
35.2\end{array}$ & $\begin{array}{c}\text { Bio } \\
34.77\end{array}$ & $\begin{array}{c}B i 0 \\
34.75\end{array}$ \\
\hline $\mathrm{TiO}_{2}$ & 3.44 & 3.38 & 3.37 & 3.13 & 3.46 & 3.42 & 3.37 & 3 & 2.74 & 2.57 \\
\hline $\mathrm{Al}_{2} \mathrm{O}_{3}$ & 11.69 & 11.37 & 10.91 & 14.06 & 11.76 & $\$ 1.79$ & 13.2 & 12.82 & 13.01 & 13.14 \\
\hline $\mathrm{Cr}_{2} \mathrm{O}_{3}$ & 0 & 0.02 & 0.02 & 0 & 0 & 0.01 & 0 & 0 & 0 & 0 \\
\hline $\mathrm{FeO}$ & 29.34 & 29.25 & 28.63 & 28.71 & 29.66 & 29.16 & 27.08 & 27.89 & 29.73 & 29.74 \\
\hline $\mathrm{Fe}_{2} \mathrm{O}_{3}$ & 0 & 0 & 0 & 0 & 0 & 0 & 0 & 0 & 0 & 0 \\
\hline MnO & 1.78 & 1.83 & 1.77 & 1.79 & 1.77 & 1.79 & 1.05 & 1.1 & 1.16 & 1.16 \\
\hline $\mathrm{NiO}$ & 0 & 0 & 0 & 0 & 0 & 0 & 0 & 0 & 0 & 0 \\
\hline $\mathrm{MgO}$ & 5.45 & 5.43 & 6.01 & 6.07 & 5.47 & 5.51 & 7.12 & 6.9 & 5.79 & 5.66 \\
\hline $\mathrm{CaO}$ & 0.05 & 0.07 & 0.02 & 0.03 & 0.06 & 0.03 & 0 & 0 & 0.02 & 0.07 \\
\hline $\mathrm{Na}_{2} \mathrm{O}$ & 0.29 & 0.28 & 0.27 & 0.34 & 0.29 & 0.22 & 0.35 & 0.27 & 0.27 & 0.31 \\
\hline $\mathrm{K}_{2} \mathrm{O}$ & 8.91 & 8.8 & 8.87 & 8.77 & 8.9 & 8.84 & 9.5 & 9.23 & 9.16 & 9.17 \\
\hline$F$ & 1.07 & 1 & 1.19 & 1.25 & 0.87 & 1.04 & १.14 & 1.1 & 0.94 & 0.86 \\
\hline $\mathrm{Cl}$ & 0.02 & 0.02 & 0 & 0.02 & 0.01 & 0 & 0.01 & 0.02 & 0 & 0.02 \\
\hline $\mathrm{H}_{2} \mathrm{O}$ & -0.51 & -0.48 & -0.56 & -0.6 & -0.42 & -0.49 & -0.54 & -0.53 & -0.45 & -0.41 \\
\hline $\mathrm{O}_{-} F_{-} \mathrm{Cl}$ & 0.46 & 0.43 & 0.5 & 0.53 & 0.37 & 0.44 & 0.48 & 0.47 & 0.4 & 0.37 \\
\hline Total & 96.47 & 96.02 & 96.25 & 96.49 & 96.88 & 96.85 & 98.38 & 97.53 & 97.59 & 97.45 \\
\hline \multicolumn{11}{|c|}{ Fómula estrutural calculada na base de 22 átomos de oxigênio } \\
\hline $\mathrm{Si}$ & 5.36 & 5.401 & 5.47 & 5.476 & 5.357 & 5.407 & 5.915 & 5.931 & 5.89 & 5.888 \\
\hline AllV & 2.143 & 2.092 & 1.997 & 2.02 & 2.143 & 2.143 & 2.085 & 2.069 & 2.11 & 2.112 \\
\hline AIVI & 0 & 0 & 0 & 0 & 0 & 0 & 0.501 & 0.475 & 0.486 & 0.51 \\
\hline$\pi$ & 0.403 & 0.397 & 0.394 & 0.365 & 0.403 & 0.397 & 0.422 & 0.38 & 0.349 & 0.328 \\
\hline $\mathrm{Fe}^{3+}$ & 0 & 0 & 0 & 0 & 0 & 0 & 0 & 0 & 0 & 0 \\
\hline $\mathrm{Fe}^{2+}$ & 3.82 & 3.822 & 3.722 & 3.723 & 3.837 & 3.763 & 3.767 & 3.93 & 4.212 & 4.214 \\
\hline $\mathrm{Cr}$ & 0 & 0.002 & 0.002 & 0 & 0 & 0.001 & 0 & 0 & 0 & 0 \\
\hline $\mathrm{Mn}$ & 0.235 & 0.242 & 0.233 & 0.235 & 0.232 & 0.234 & 0.148 & 0.157 & 0.166 & 0.166 \\
\hline $\mathrm{Mg}$ & 1.265 & 1.265 & 1.393 & 1.403 & 1.262 & 1.268 & 4.765 & 1.733 & 1.462 & 1.43 \\
\hline Ba & * & $\star$ & * & * & * & * & • & • & * & $\star$ \\
\hline $\mathrm{Ca}$ & 0.008 & 0.012 & 0.003 & 0.005 & 0.01 & 0.005 & 0 & 0 & 0.004 & 0.013 \\
\hline $\mathrm{Na}$ & 0.088 & 0.085 & 0.081 & 0.102 & 0.087 & 0.066 & 0.113 & 0.088 & 0.089 & 0.102 \\
\hline K & 1.77 & 1.754 & 1.759 & 1.735 & 1.757 & 1.74 & 2.016 & 1.984 & 1.98 & 1.982 \\
\hline Cátions & * & * & : & * & 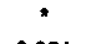 & * & * & • & * & * \\
\hline CF & 1.054 & 0.988 & 1.17 & 1.226 & 0.851 & 1.015 & 1.199 & 1.172 & 1.007 & 0.922 \\
\hline $\mathrm{CCl}$ & 0.011 & 0.011 & 0 & 0.011 & 0.005 & 0 & 0.006 & 0.011 & 0 & 0.011 \\
\hline $\mathrm{OH}$ & 0 & 0 & 0 & 0 & 0 & 0 & -0.6 & -0.596 & -0.509 & -0.464 \\
\hline 0 & 22 & 22 & 22 & 22 & 22 & 22 & 24 & 24 & 24 & 24 \\
\hline $\mathrm{Fe}$ FeMg & 0.75 & 0.75 & 0.73 & 0.73 & 0.75 & 0.75 & 0.68 & 0.69 & 0.74 & 0.75 \\
\hline Mg_FeMg & 0.25 & 0.25 & 0.27 & 0.27 & 0.25 & 0.25 & 0.32 & 0.31 & 0.26 & 0.25 \\
\hline
\end{tabular}


Tabela 16.4 - Composição química de biotittas do Morro Pão de Açúcar ( $\%$ peso)

\begin{tabular}{|c|c|c|c|c|c|c|c|c|c|c|c|c|c|c|c|}
\hline $\begin{array}{l}\text { Amostra } \\
\text { Análise }\end{array}$ & $\begin{array}{c}\text { RP-78 } \\
1000\end{array}$ & $\begin{array}{c}\text { RP-78 } \\
1001\end{array}$ & RP-109 & RP-109 & RP-207 & RP-207 & RP-207 & RP-207 & RP-207 & RP-207 & RP-207 & RP-207 & RP-207 & RP-207 & RP-207 \\
\hline $\begin{array}{l}\text { Análise } \\
\text { Locaçăo }\end{array}$ & $\begin{array}{c}1000 \\
\text { C3G2n }\end{array}$ & $\begin{array}{c}1001 \\
\text { C3G } 2 \mathrm{~b}\end{array}$ & 631 & 632 & 681 & 682 & 683 & 684 & 685 & 686 & 687 & 688 & 861 & 865 & 866 \\
\hline $\begin{array}{l}\text { Locaçao } \\
\text { Mineral }\end{array}$ & Bio & Bio & $\begin{array}{l}\text { C1G2n } \\
\text { Bio }\end{array}$ & $\begin{array}{c}\text { C1G2b } \\
\text { Bio }\end{array}$ & $\begin{array}{c}\text { C3G1Fn } \\
\text { Bio }\end{array}$ & $\begin{array}{c}\text { C3GiFb } \\
\text { Bio }\end{array}$ & $\begin{array}{c}\text { C3G2Fn } \\
\text { Bio }\end{array}$ & $\begin{array}{c}\text { C3G2Fb } \\
\text { Bio }\end{array}$ & $\begin{array}{c}\mathrm{C} 2 \mathrm{G} 2 \mathrm{Fn} \\
\mathrm{Bin}\end{array}$ & $\mathrm{C} 2 \mathrm{G} 2 \mathrm{Fb}$ & C2G3Fn & C2G3Fb & C1G1m & CAGIFn & $\begin{array}{c}\mathrm{C} 4 \mathrm{G} 1 F b \\
\mathrm{BiO}\end{array}$ \\
\hline $\mathrm{SiO}_{2}$ & 35.63 & 37.52 & 35.82 & 38.23 & 36.38 & 37.3 & 36.24 & 37.87 & 35.32 & 35.07 & 36.67 & $\begin{array}{l}810 \\
36.6\end{array}$ & $\begin{array}{c}B 10 \\
36.97\end{array}$ & $\begin{array}{c}810 \\
37.56\end{array}$ & $\begin{array}{c}B 10 \\
37.32\end{array}$ \\
\hline $\mathrm{TiO}_{2}$ & 6.21 & 3.49 & 5.69 & 4.21 & 6.63 & 3.47 & 6.04 & 3.74 & 6.93 & 5.19 & 7.01 & 5.88 & 0.1 & 3.3 & 3 \\
\hline $\mathrm{Al}_{2} \mathrm{O}_{3}$ & 12.35 & 13.56 & 13.47 & 11.99 & 13.36 & 12.02 & 13.43 & 12.04 & 12.82 & 12.31 & 13.11 & 13.22 & 9.6 & 10.51 & 10.58 \\
\hline $\mathrm{Cr}_{2} \mathrm{O}_{3}$ & 0 & 0 & 0 & 0 & 0.04 & 0.01 & 0.01 & 0.01 & 0 & 0.01 & 0 & 0 & 0 & 0 & 0.02 \\
\hline $\mathrm{FeO}$ & 15.21 & 15.77 & 21.14 & 19.51 & 19.59 & 20.58 & 20 & 19.94 & 19.24 & 20.7 & 19.65 & 20.01 & 25.49 & 25.08 & 26.07 \\
\hline $\mathrm{Fe}_{2} \mathrm{O}_{3}$ & 0 & 0 & 0 & 0 & 0 & 0 & 0 & 0 & 0 & 0 & 0 & 0 & 0 & 0 & 0 \\
\hline $\mathrm{MnO}$ & 0.79 & 0.6 & 1.22 & 1.19 & 1.13 & 1.26 & 1.21 & 1.26 & 1.11 & 1.19 & 1.16 & 1.22 & 2.52 & 1.41 & 1.25 \\
\hline $\mathrm{NiO}$ & 0 & 0 & 0 & 0 & 0 & 0 & 0 & 0 & 0 & 0 & 0 & 0 & 0 & 0 & 0 \\
\hline $\mathrm{MgO}$ & 15.34 & 15.22 & 9.38 & 11.85 & 10.25 & 11.08 & 9.98 & 11.82 & 10.21 & 10.44 & 10.11 & 10.35 & 9.89 & 8.13 & 8.1 \\
\hline $\mathrm{CaO}$ & 0 & 0 & 0 & 0.03 & 0.05 & 0.03 & 0.04 & 0 & 0 & 0.02 & 0 & 0.01 & 0.05 & 0.02 & 0.06 \\
\hline $\mathrm{Na}_{2} \mathrm{O}$ & 0.14 & 0.14 & 0.7 & 0.54 & 0.7 & 0.62 & 0.68 & 0.65 & 0.81 & 0.76 & 0.73 & 0.73 & 0.12 & 0.29 & 0.22 \\
\hline $\mathrm{K}_{2} \mathrm{O}$ & 9.32 & 9.88 & 8.64 & 9.34 & 8.92 & 8.89 & 8.69 & 9.09 & 8.96 & 8.89 & 8.97 & 8.99 & 9.24 & 9.55 & 9.34 \\
\hline$F$ & 2.07 & 1.99 & 0 & 0 & 4.79 & 2.12 & 2.28 & 2.59 & 1.94 & 2.15 & 1.66 & 1.81 & 1.31 & 0.99 & 0.82 \\
\hline $\mathrm{Cl}$ & 0.08 & 0.17 & 0 & 0 & 0 & 0.01 & 0 & 0.01 & 0.05 & 0.04 & 0.01 & 0.04 & 0 & 0.03 & 0.03 \\
\hline $\mathrm{H}_{2} \mathrm{O}$ & -1 & 0 & 0 & 0 & -0.85 & -1.01 & $-1,08$ & -1.23 & -0.93 & -1.03 & -0.79 & -0.87 & -0.62 & -0.48 & -0.4 \\
\hline $\mathrm{O}_{-} F_{-} \mathrm{Cl}$ & 0.89 & 0.88 & 0 & 0 & 0.75 & 0.89 & 0.96 & 1.09 & 0.83 & 0.91 & 0.7 & 0.77 & 0.55 & 0.42 & 0.35 \\
\hline Total & 97.14 & 98.34 & 96.03 & 96.89 & 98.84 & 97.39 & 98.6 & 99.02 & 97.39 & 96.77 & 99.08 & 98.86 & 95.29 & 96.87 & 96.81 \\
\hline \multicolumn{16}{|c|}{ Formula estrutural calculada na base de 22 átomos de oxigenio } \\
\hline $\mathrm{Si}$ & 5.168 & 5.357 & 5.766 & 6.043 & 5.867 & 6.18 & 5.929 & 6.206 & 5.828 & 5.905 & 5.884 & 5.921 & 6.381 & 6.271 & 6.233 \\
\hline AllV & 2.11 & 2.28 & 2.234 & 1.957 & 2.133 & 1.82 & 2.071 & 1.794 & 2.172 & 2.095 & 2.116 & 2.079 & 1.649 & 1.729 & 1.767 \\
\hline AIVI & 0 & 0 & 0.319 & 0.275 & 0.404 & 0.525 & 0.516 & 0.53 & 0.319 & 0.346 & 0.361 & 0.44 & 0.332 & 0.338 & 0.314 \\
\hline$\pi i$ & 0.678 & 0.375 & 0.689 & 0.501 & 0.804 & 0.432 & 0.743 & 0.461 & 0.86 & 0.657 & 0.846 & 0.716 & 0.013 & 0.414 & 0.377 \\
\hline $\mathrm{Fe}^{3+}$ & 0 & 0 & 0 & 0 & 0 & 0 & 0 & 0 & 0 & 0 & 0 & 0 & 0 & 0 & 0 \\
\hline $\mathrm{Fe}^{2+}$ & 1.845 & 1.883 & 2.846 & 2.579 & 2.642 & 2.852 & 2.736 & 2.733 & 2.655 & 2.915 & 2.637 & 2.707 & 3.679 & 3.502 & 3.641 \\
\hline $\mathrm{Cr}$ & 0 & 0 & 0 & 0 & 0.005 & 0.001 & 0.001 & 0.001 & 0 & 0.001 & 0 & 0 & 0 & 0 & 0.003 \\
\hline $\mathrm{Mn}$ & 0.097 & 0.073 & 0.166 & 0.159 & 0.154 & 0.177 & 0.168 & 0.175 & 0.155 & 0.17 & 0.158 & 0.167 & 0.368 & 0.199 & 0.177 \\
\hline Mg & 3.317 & 3.239 & 2.251 & 2.793 & 2.464 & 2.737 & 2.434 & 2.888 & 2.512 & 2.621 & 2.418 & 2.496 & 2.545 & 2.024 & 2.017 \\
\hline $\mathrm{Ba}$ & • & & * & * & * & * & • & $*$ & • & * & * & * & • & * & * \\
\hline $\mathrm{Ca}$ & 0 & 0 & 0 & 0.005 & 0.009 & 0.005 & 0.007 & 0 & 0 & 0.004 & 0 & 0.002 & 0.009 & 0.004 & 0.011 \\
\hline $\mathrm{Na}$ & 0.039 & 0.039 & 0.218 & 0.166 & 0.219 & 0.199 & 0.216 & 0.207 & 0.259 & 0.248 & 0.227 & 0.229 & 0.04 & 0.094 & 0.071 \\
\hline K & 1.725 & 1.799 & $\uparrow .768$ & $1.8 B 4$ & 1.835 & 1.879 & 1.814 & 1.9 & 1.886 & 1.91 & 1.836 & 1.855 & 2.035 & 2.034 & 1.99 \\
\hline Cátions & • & • & • & " & * & * & • & • & * & $\star$ & $\star$ & & $\star$ & * & * \\
\hline CF & 1.899 & 1.797 & 0 & 0 & 1.826 & 2.222 & 2.359 & 2.684 & 2.025 & 2.29 & 1.685 & 1.852 & 1.43 & 1.045 & 0.866 \\
\hline $\mathrm{CCl}$ & 0.039 & 0.082 & 0 & 0 & 0 & 0.006 & 0 & 0.006 & 0.028 & 0.023 & 0.005 & 0.022 & 0 & 0.017 & 0.017 \\
\hline $\mathrm{OH}$ & 0 & 0 & 0 & 0 & -0.915 & -1.117 & -1.18 & -1.346 & -1.025 & -1.158 & -0.846 & -0.94 & -0.714 & -0.535 & -0.446 \\
\hline 0 & 22 & 22 & 24 & 24 & 24 & 24 & 24 & 24 & 24 & 24 & 24 & 24 & 24 & 24 & 24 \\
\hline $\mathrm{Fe}$ _FeMg & 0.36 & 0.37 & 0.56 & 0.48 & 0.52 & 0.51 & 0.53 & 0.49 & 0.51 & 0.53 & 0.52 & 0.52 & 0.59 & 0.63 & 0.64 \\
\hline Mg_FeMg & 0.64 & 0.63 & 0.44 & 0.52 & 0.48 & 0.49 & 0.47 & 0.51 & 0.49 & 0.47 & 0.48 & 0.48 & 0.44 & 0.37 & 0.36 \\
\hline
\end{tabular}


Tabela 16.5 - Composição química de biotitas de Cerrito (\% peso)

\begin{tabular}{|c|c|c|c|c|c|c|c|c|c|c|c|c|c|}
\hline Amostra & RP-198 & RP-198 & RP-198 & RP-198 & RP-198 & RP-198 & RP-198 & RP-198 & RP-198 & RP-198 & RP-198 & RP-198 & RP-198 \\
\hline Analise & 797 & 803 & 812 & 851 & 852 & 853 & 854 & 855 & 856 & 857 & 858 & 859 & 860 \\
\hline Locação & CiGin & C2Gin & C4G1n & C1G2Fn & $\mathrm{C} 1 \mathrm{G} 2 \mathrm{Fb}$ & $\mathrm{C} 2 \mathrm{G} 1 \mathrm{Fn}$ & C2G1Fb & C3G1Fn & C3G1Fb & C4Gim & $C 4 G 2 n$ & C5G1Fn & $\mathrm{C} 5 \mathrm{G} 1 \mathrm{Fb}$ \\
\hline $\begin{array}{l}\text { Mineral } \\
\mathrm{SiO}_{3}\end{array}$ & $\begin{array}{c}\text { Bio } \\
33.24\end{array}$ & $\begin{array}{c}\text { Bio } \\
37.2\end{array}$ & $\begin{array}{c}\text { Bio } \\
37.46\end{array}$ & $\begin{array}{c}\text { Bio } \\
37.09\end{array}$ & $\begin{array}{c}\text { Bio } \\
37.45\end{array}$ & $\begin{array}{c}\text { Bio } \\
37.07\end{array}$ & $\begin{array}{c}\text { Bio } \\
3733\end{array}$ & $\begin{array}{c}\text { Bio } \\
37.38\end{array}$ & $\begin{array}{l}\text { Bio } \\
374\end{array}$ & $\begin{array}{c}\text { Bio } \\
3657\end{array}$ & $\begin{array}{c}\text { Bio } \\
2752\end{array}$ & Bio & Bio \\
\hline $\mathrm{TiO}_{2}$ & 0.49 & 7.62 & 8.62 & 7.81 & 7.51 & 7.88 & $\begin{array}{l}31.32 \\
7.58\end{array}$ & $\begin{array}{l}7.50 \\
7.61\end{array}$ & $\begin{array}{c}3 . .4 \\
6.9\end{array}$ & $\begin{array}{l}36.58 \\
5.56\end{array}$ & $\begin{array}{c}37.53 \\
8.14\end{array}$ & $\begin{array}{l}36.9 \\
7.94\end{array}$ & $\begin{array}{l}38.15 \\
7.16\end{array}$ \\
\hline $\mathrm{Al}_{2} \mathrm{O}_{3}$ & 14.43 & 14.09 & 13.82 & 13.82 & 13.98 & 13.88 & 14 & 13.87 & 13.68 & 13.44 & 13.89 & 13.67 & 14.5 \\
\hline $\mathrm{Cr}_{2} \mathrm{O}_{3}$ & 0 & 0 & 0 & 0.01 & 0.04 & 0 & 0.03 & 0.02 & 0.03 & 0.02 & 0 & 0.04 & 0 \\
\hline $\mathrm{FeO}$ & 32.12 & 13.47 & 13.66 & 13.67 & 13.79 & 15.91 & 15.11 & 11.64 & 11.54 & 13.14 & 12.76 & 12.46 & 11.35 \\
\hline $\mathrm{Fe}_{2} \mathrm{O}_{3}$ & 0 & 0 & 0 & 0 & 0 & 0 & 0 & 0 & 0 & 0 & 0 & 0 & 0 \\
\hline Mno & 0.55 & 0.25 & 0.211 & 0.28 & 0.25 & 0.34 & 0.31 & 0.22 & 0.21 & 0.25 & 0.25 & 0.22 & 0.2 \\
\hline NiO & 0 & 0 & 0 & 0 & 0 & 0 & 0 & 0 & 0 & 0 & 0 & 0 & 0 \\
\hline $\mathrm{MgO}$ & 5.71 & 13.89 & 13.88 & 13.32 & 13.31 & $\$ 1.9$ & 12.56 & 15.54 & 15.65 & 14.83 & 13.98 & 13.96 & 12.92 \\
\hline $\mathrm{CaO}$ & 0.61 & 0.01 & 0 & 0.05 & 0 & 0 & 0 & 0 & 0 & 0.04 & 0 & 0.01 & 0 \\
\hline $\mathrm{Na}_{2} \mathrm{O}$ & 0.24 & 0.44 & 0.5 & 0.43 & 0.35 & 0.37 & 0.42 & 0.36 & 0.33 & 0.33 & 0.55 & 0.43 & 0.53 \\
\hline $\mathrm{K}_{2} \mathrm{O}$ & 7.14 & 9.56 & 9.47 & 9.34 & 9.7 & 9.4 & 9.54 & 9.72 & 9.71 & 9.55 & 9.31 & 9.34 & 8.96 \\
\hline$F$ & 0 & 0 & 0 & 0.68 & 0.55 & 0.6 & 0.81 & 1.12 & 0.82 & 0.92 & 0.99 & 1.09 & 1.05 \\
\hline $\mathrm{Cl}$ & 0 & 0 & 0 & 0.04 & 0.02 & 0.04 & 0.04 & 0.02 & 0.05 & 0.06 & 0.05 & 0.03 & 0.06 \\
\hline $\mathrm{H}_{2} \mathrm{O}$ & 0 & 0 & 0 & -0.33 & -0.27 & -0.29 & -0.39 & -0.54 & -0.4 & -0.45 & -0.48 & -0.52 & -0.51 \\
\hline O_F_Cl & 0 & 0 & 0 & 0.3 & 0.24 & 0.26 & 0.35 & 0.48 & 0.36 & 0.4 & 0.43 & 0.47 & 0.46 \\
\hline Total & 94.53 & 96.53 & 97.62 & 96.54 & 96.95 & 97.39 & 97.72 & 97.5 & 96.32 & 94.71 & 97.45 & 96.09 & 94.88 \\
\hline \multicolumn{14}{|c|}{ Fómula estrutural calculada na base de 22 átomos de oxigenio } \\
\hline $\mathrm{Si}$ & 5.705 & 5.723 & 5.7 & 5.794 & 5.813 & 5.79 & 5.814 & 5.786 & 5.822 & 5.859 & 5.814 & 5.812 & 6.003 \\
\hline AllV & 2.295 & 2.277 & 2.3 & 2.206 & 2.187 & 2.21 & 2.186 & 2.214 & 2.178 & 2.141 & 2.186 & 2.188 & 1.997 \\
\hline AIVI & 0.622 & 0.276 & 0.177 & 0.336 & 0.368 & 0.343 & 0.382 & 0.314 & 0.33 & 0.395 & 0.348 & 0.348 & 0.69 \\
\hline $\mathrm{Ti}$ & 0.063 & 0.882 & 0.987 & 0.918 & 0.877 & 0.926 & 0.888 & 0.886 & 0.808 & 0.67 & 0.949 & 0.941 & 0.848 \\
\hline $\mathrm{Fe}^{3+}$ & 0 & 0 & 0 & 0 & 0 & 0 & 0 & 0 & 0 & 0 & 0 & 0 & 0 \\
\hline $\mathrm{Fe}^{2+}$ & 4.61 & 1.733 & 1.738 & 1.786 & 1.79 & 2.078 & 1.968 & 1.507 & 4.502 & 1.761 & 1.653 & 1.641 & 1.494 \\
\hline $\mathrm{Cr}$ & 0 & 0 & 0 & 0.001 & 0.005 & 0 & 0.004 & 0.002 & 0.004 & 0.003 & 0 & 0.005 & 0 \\
\hline $\mathrm{Mn}$ & 0.08 & 0.033 & 0.027 & 0.037 & 0.033 & 0.045 & 0.041 & 0.029 & 0.028 & 0.034 & 0.033 & 0.029 & 0.027 \\
\hline $\mathrm{Mg}$ & 1.461 & 3.186 & 3.149 & 3.102 & 3.08 & 2.771 & 2.917 & 3.586 & 3.632 & 3.542 & 3.229 & 3.278 & 3.031 \\
\hline $\mathrm{Ba}$ & * & $\cdot$ & * & $*$ & $*$ & 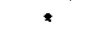 & $\bullet$ & • & " & * & 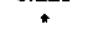 & * & * \\
\hline $\mathrm{Ca}$ & 0.112 & 0.002 & 0 & 0.008 & 0 & 0 & 0 & 0 & 0 & 0.007 & 0 & 0.002 & 0 \\
\hline $\mathrm{Na}$ & 0.08 & 0.131 & 0.148 & 0.13 & 0.105 & 0.112 & 0.127 & 0.108 & 0.1 & 0.103 & 0.165 & 0.131 & 0.162 \\
\hline K & 1.563 & 1.876 & 1.838 & 1.861 & 1.921 & 1.873 & 1.896 & 1.919 & 1.928 & 1.952 & 1.84 & 1.877 & 1.799 \\
\hline Cations & • & " & $*$ & 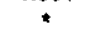 & 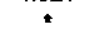 & 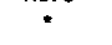 & 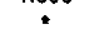 & * & $*$ & * & 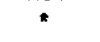 & 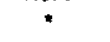 & * \\
\hline CF & 0 & 0 & 0 & 0.672 & 0.54 & 0.593 & 0.798 & 1.096 & 0.807 & 0.932 & 0.97 & 1.086 & 1.045 \\
\hline $\mathrm{CCl}$ & 0 & 0 & 0 & 0.021 & 0.011 & 0.021 & 0.021 & 0.01 & 0.026 & 0.033 & 0.026 & 0.016 & 0.032 \\
\hline $\mathrm{OH}$ & 0 & 0 & 0 & -0.344 & -0.28 & -0.302 & -0.406 & -0.558 & -0.416 & -0.481 & -0.496 & -0.547 & -0.536 \\
\hline 0 & 24 & 24 & 24 & 24 & 24 & 24 & 24 & 24 & 24 & 24 & 24 & 24 & 24 \\
\hline $\mathrm{Fe} \_\mathrm{FeMg}$ & 0.76 & 0.35 & 0.36 & 0.37 & 0.37 & 0.43 & 0.4 & 0.3 & 0.29 & 0.33 & 0.34 & 0.33 & 0.33 \\
\hline $\mathrm{Mg}$. FeMg & 0.24 & 0.65 & 0.64 & 0.63 & 0.63 & 0.57 & 0.6 & 0.7 & 0.71 & 0.67 & 0.66 & 0.67 & 0.67 \\
\hline
\end{tabular}




\begin{tabular}{|c|c|c|c|}
\hline Amostra & RP-201A & RP-201A & RP-201A \\
\hline Análise & 1078 & 1079 & 1080 \\
\hline Locaçäo & C1G2n & C4G1n & C5Gin \\
\hline Mineral & Bio & Bio & Bio \\
\hline $\mathrm{SiO}_{2}$ & 35.55 & 36.23 & 36.94 \\
\hline $\mathrm{TiO}_{2}$ & 3.38 & 1.39 & 3.17 \\
\hline $\mathrm{Al}_{2} \mathrm{O}_{3}$ & 10.67 & 10.73 & 10.56 \\
\hline $\mathrm{Cr}_{2} \mathrm{O}_{3}$ & 0.04 & 0.01 & 0 \\
\hline $\mathrm{FeO}$ & 29.08 & 28.92 & 25.76 \\
\hline $\mathrm{Fe}_{2} \mathrm{O}_{3}$ & 0 & 0 & 0 \\
\hline Mno & 0.78 & 1.14 & 0.7 \\
\hline NiO & 0 & 0 & 0 \\
\hline $\mathrm{MgO}$ & 5.81 & 7.65 & 8.8 \\
\hline $\mathrm{CaO}$ & 0.01 & 0.08 & 0.01 \\
\hline $\mathrm{Na}_{2} \mathrm{O}$ & 0.35 & 0.25 & 0.17 \\
\hline $\mathrm{K}_{2} \mathrm{O}$ & 9.01 & 9.27 & 9.42 \\
\hline$F$ & 0.55 & 0.58 & 0.68 \\
\hline $\mathrm{Cl}$ & 0.02 & 0 & 0 \\
\hline $\mathrm{H}_{2} \mathrm{O}$ & 0 & 0 & 0 \\
\hline O_F_Cl & 0.24 & 0.24 & 0.29 \\
\hline Total & 95.25 & 96.25 & 96.21 \\
\hline \multicolumn{4}{|c|}{ Formula estrutural calculada na base de 22 átomos de oxigênic } \\
\hline Si & 6.064 & 6.112 & 6.123 \\
\hline AllV & 1.936 & 1.888 & 1.877 \\
\hline AIVI & 0.207 & 0.244 & 0.184 \\
\hline$\pi$ & 0.434 & 0.176 & 0.395 \\
\hline $\mathrm{Fe}^{3+}$ & 0 & 0 & 0 \\
\hline $\mathrm{Fe}^{2+}$ & 4.148 & 4.08 & 3.571 \\
\hline $\mathrm{Cr}$ & 0.005 & 0.001 & 0 \\
\hline $\mathrm{Mn}$ & 0.113 & 0.163 & 0.098 \\
\hline $\mathrm{Mg}$ & 1.477 & 1.924 & 2.174 \\
\hline \multicolumn{4}{|l|}{$\mathrm{Ba}$} \\
\hline $\mathrm{Ca}$ & 0.002 & 0.014 & 0.002 \\
\hline $\mathrm{Na}$ & 0.116 & 0.082 & 0.055 \\
\hline$k$ & 1.961 & 1.995 & 1.992 \\
\hline Cátions & • & • & * \\
\hline $\mathrm{CF}$ & 0.593 & 0.619 & 0.713 \\
\hline $\mathrm{CCl}$ & 0.012 & 0 & 0 \\
\hline $\mathrm{OH}$ & 0 & 0 & 0 \\
\hline 0 & 24 & 24 & 24 \\
\hline $\mathrm{Fe}$ FeMgg & 0.74 & 0.68 & 0.62 \\
\hline Mg_FeMg & 0.26 & 0.32 & 0.38 \\
\hline \multicolumn{4}{|c|}{ Observaçð̄es e abreviaçðes como na tabela 6.0} \\
\hline
\end{tabular}




\begin{tabular}{|c|c|c|c|c|}
\hline Amostra & RP-205 & RP-205 & RP-205 & RP-205 \\
\hline Análise & 1061 & 1081 & 1082 & 1083 \\
\hline Locaçẵo & C4Gín & C1G1br & C2Gin & CAGIn \\
\hline Mineral & Bio & Bio & Bio & Bio \\
\hline $\mathrm{SiO}_{2}$ & 39.13 & 38.34 & 39.71 & 38.28 \\
\hline $\mathrm{TiO}_{2}$ & 9.33 & 1.88 & 7.51 & 8.89 \\
\hline $\mathrm{Al}_{2} \mathrm{O}_{3}$ & 2.3 & 11.18 & 2.14 & 3.02 \\
\hline $\mathrm{Cr}_{2} \mathrm{O}_{3}$ & 0 & 0 & 0 & 0.01 \\
\hline $\mathrm{FeO}$ & 35.48 & 21.87 & 35.12 & 34.87 \\
\hline $\mathrm{Fe}_{2} \mathrm{O}_{3}$ & 0 & 0 & 0 & 0 \\
\hline MnO & 1.44 & 0.52 & 1.56 & 1.51 \\
\hline $\mathrm{NiO}$ & 0 & 0 & 0 & 0 \\
\hline $\mathrm{MgO}$ & 3.91 & 12.22 & 3.9 & 3.64 \\
\hline $\mathrm{CaO}$ & 1.15 & 0.01 & 0.94 & 1.43 \\
\hline $\mathrm{Na}_{2} \mathrm{O}$ & 6.5 & 0.24 & 6.51 & 6.12 \\
\hline $\mathrm{K}_{2} \mathrm{O}$ & 0.01 & 9.47 & 0 & 0 \\
\hline$F$ & 0 & 0.99 & 0.06 & 0.11 \\
\hline $\mathrm{Cl}$ & 0 & 0.01 & 0 & 0 \\
\hline $\mathrm{H}_{2} \mathrm{O}$ & 0 & 0 & 0 & 0 \\
\hline O_F_Cl & 0 & 0.42 & 0.03 & 0.05 \\
\hline Total & 99.25 & 96.73 & 97.45 & 97.88 \\
\hline \multicolumn{5}{|c|}{ Fómula estrutural calculada na base de 22 átomos de oxigênio } \\
\hline $\mathrm{Si}$ & 6.4 & 6.188 & 6.603 & 6.352 \\
\hline AllV & 0.443 & 1.812 & 0.419 & 0.59 \\
\hline AIVI & 0 & 0.313 & 0 & 0 \\
\hline Ti & 1.148 & 0.228 & 0.939 & 1.11 \\
\hline $\mathrm{Fe}^{3+}$ & 0 & 0 & 0 & 0 \\
\hline $\mathrm{Fe}^{2+}$ & 4.853 & 2.952 & 4.884 & 4.839 \\
\hline $\mathrm{Cr}$ & 0 & 0 & 0 & 0.001 \\
\hline $\mathrm{Mn}$ & 0.199 & 0.071 & 0.22 & 0.212 \\
\hline $\mathrm{Mg}$ & 0.953 & 2.94 & 0.967 & 0.9 \\
\hline \multicolumn{5}{|l|}{$\mathrm{Ba}$} \\
\hline $\mathrm{Ca}$ & 0.202 & 0.002 & 0.167 & 0.254 \\
\hline $\mathrm{Na}$ & 2.061 & 0.075 & 2.099 & 1.969 \\
\hline K & 0.002 & 1.95 & 0 & 0 \\
\hline Cátions & $*$ & $*$ & • & * \\
\hline CF & 0 & 1.011 & 0.063 & 0.115 \\
\hline $\mathrm{CCl}$ & 0 & 0.005 & 0 & 0 \\
\hline $\mathrm{OH}$ & 0 & 0 & 0 & 0 \\
\hline 0 & 24 & 24 & 24 & 24 \\
\hline $\mathrm{Fe}_{-} \mathrm{FeMg}$ & 0.84 & 0.5 & 0.83 & 0.84 \\
\hline Mg_FeMg & 0.16 & 0.5 & 0.17 & 0.16 \\
\hline
\end{tabular}




\begin{tabular}{|c|c|c|c|c|}
\hline Amostra & RP-255 & RP-255 & RP.256 & RP-256 \\
\hline Análise & 1117 & 1118 & 1115 & 1116 \\
\hline Locaçăo & CAG2m & C2Gim & CiGin & C4G1m \\
\hline Mineral & Bio & Bio & Bio & $\mathrm{Bio}$ \\
\hline $\mathrm{SiO}_{2}$ & 36.86 & 36.59 & 37.94 & 36.55 \\
\hline $\mathrm{THO}_{2}$ & 4.03 & 4.49 & 2.19 & 2.51 \\
\hline $\mathrm{Al}_{2} \mathrm{O}_{3}$ & 13.21 & 13.47 & 12.71 & 12.49 \\
\hline $\mathrm{Cr}_{2} \mathrm{O}_{3}$ & 0 & 0.01 & 0 & 0 \\
\hline $\mathrm{FeO}$ & 20.08 & 20.91 & 18.51 & 20.15 \\
\hline $\mathrm{Fe}_{2} \mathrm{O}_{3}$ & 0 & 0 & 0 & 0 \\
\hline Mno & 0.64 & 0.7 & 1.19 & 1.82 \\
\hline NiO & 0 & 0 & 0 & 0 \\
\hline $\mathrm{MgO}$ & 12.15 & 10.8 & 12.5 & 11.1 \\
\hline $\mathrm{CaO}$ & 0.09 & 0.05 & 0.09 & 0 \\
\hline $\mathrm{Na}_{2} \mathrm{O}$ & 0.57 & 0.35 & 0.44 & 0.31 \\
\hline $\mathrm{K}_{2} \mathrm{O}$ & 9.05 & 8.99 & 9.47 & 8.4 \\
\hline$F$ & 0.76 & 0.52 & 1.63 & 0.92 \\
\hline $\mathrm{Cl}$ & 0 & 0.02 & 0.02 & 0 \\
\hline $\mathrm{H}_{2} \mathrm{O}$ & 0 & 0 & 0 & 0 \\
\hline O_F_Cl & 0.32 & 0.22 & 0.69 & 0.39 \\
\hline Total & 97.44 & 96.9 & 96.69 & 94.25 \\
\hline \multicolumn{5}{|c|}{ Fómula estrutural caiculada na base de 22 átomos de oxigênio } \\
\hline $\mathrm{Si}$ & 5.846 & 5.841 & 6.088 & 6.024 \\
\hline AllV & 2.154 & 2.159 & 1.912 & 1.976 \\
\hline AIVI & 0.313 & 0.373 & 0.49 & 0.448 \\
\hline $\mathrm{Ti}$ & 0.481 & 0.539 & 0.264 & 0.311 \\
\hline $\mathrm{Fe}^{3+}$ & 0 & 0 & 0 & 0 \\
\hline $\mathrm{Fe}^{2+}$ & 2.663 & 2.792 & 2.484 & 2.777 \\
\hline $\mathrm{Cr}$ & 0 & 0.001 & 0 & 0 \\
\hline $\mathrm{Mn}$ & 0.086 & 0.095 & 0.162 & 0.254 \\
\hline $\mathrm{Mg}$ & 2.873 & 2.57 & 2.99 & 2.727 \\
\hline \multicolumn{5}{|l|}{83} \\
\hline $\mathrm{Ca}$ & 0.015 & 0.009 & 0.015 & 0 \\
\hline $\mathrm{Na}$ & 0.175 & 0.108 & 0.137 & 0.099 \\
\hline K & 1.831 & 1.831 & 1.939 & 1.766 \\
\hline Cátions & * & * & $\bullet$ & * \\
\hline CF & 0.762 & 0.525 & 1.654 & 0.959 \\
\hline $\mathrm{CCl}$ & 0 & 0.011 & 0.011 & 0 \\
\hline $\mathrm{OH}$ & 0 & 0 & 0 & 0 \\
\hline 0 & 24 & 24 & 24 & 24 \\
\hline $\mathrm{Fe} F \mathrm{FeMg}$ & 0.48 & 0.52 & 0.45 & 0.5 \\
\hline $\mathrm{Mg} F \mathrm{FeMg}$ & 0.52 & 0.48 & 0.55 & 0.5 \\
\hline \multicolumn{5}{|c|}{ Observaç̧es e abreviaçסes como na tabela 6.0} \\
\hline
\end{tabular}


Tabela 16.9 - Composiçăo química de biotitas de Porto Conceiçāo (\% peso)

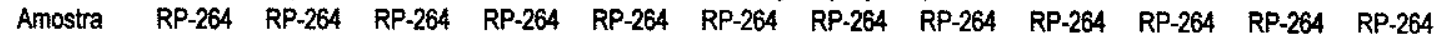

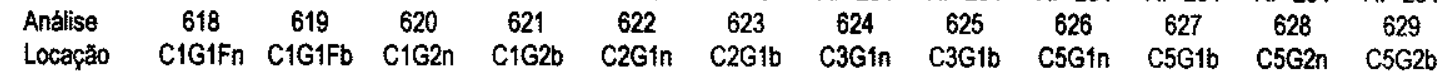

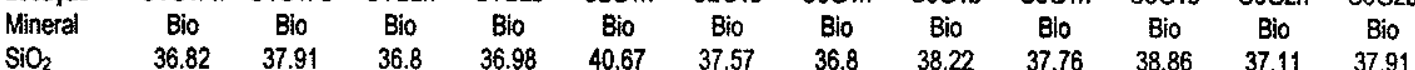
$\begin{array}{lllllllllllll}\mathrm{THO}_{2} & 5.03 & 4.38 & 5.74 & 6.09 & 2.75 & 4.02 & 4.73 & 3.91 & 4.24 & 4.01 & 4.81 & 4.1\end{array}$ $\begin{array}{lllllllllllll}\mathrm{Al}_{2} \mathrm{O}_{3} & 13.56 & 13.9 & 13.58 & 13.6 & 12.21 & 13.56 & 13.94 & 13.69 & 13.4 & 13.61 & 13.49 & 13.26\end{array}$ $\begin{array}{ccccccccccccc}\mathrm{Cr}_{2} \mathrm{O}_{3} & 0 & 0.03 & 0.04 & 0.05 & 0.05 & 0.01 & 0.01 & 0.01 & 0.03 & 0.02 & 0.02 & 0 \\ & 13.45 & 12.37 & 13.47 & 13.25 & 0.23 & 13.23 & 13.54 & 12.44 & 12.68 & 11.09 & 13.20 & 12.75\end{array}$

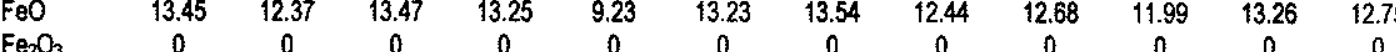

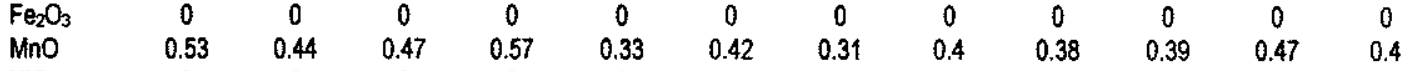

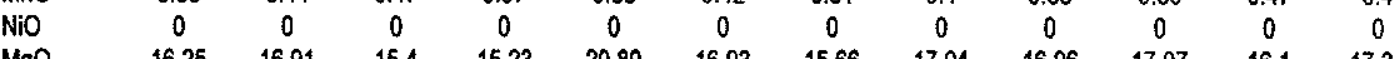

$\begin{array}{lcccccccccccc}\mathrm{MgO} & 16.25 & 16.91 & 15.4 & 15.23 & 20.89 & 16.93 & 15.66 & 17.04 & 16.96 & 17.07 & 16.1 & 17.34 \\ \mathrm{CaO} & 0.01 & 0 & 0.33 & 0.51 & 0.02 & 0 & 0 & 0.02 & 0 & 0 & 0 & 0.01\end{array}$

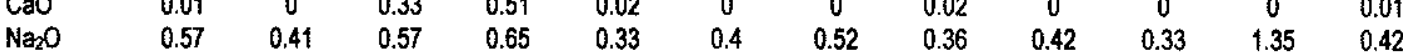

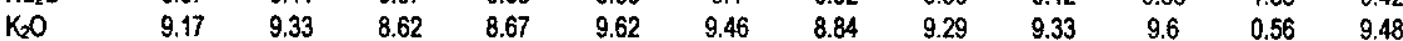

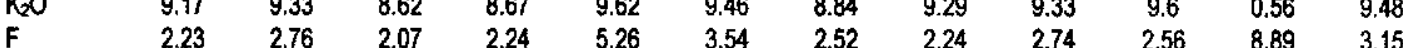

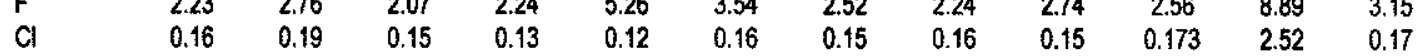

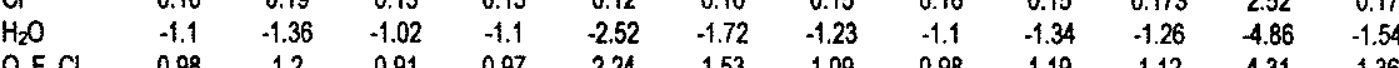
$\begin{array}{lcccccccccccc}0 . F_{C} \mathrm{Cl} & 0.98 & 1.2 & 0.91 & 0.97 & 2.24 & 1.53 & 1.09 & 0.98 & 1.19 & 1.12 & 4.31 & 1.36\end{array}$

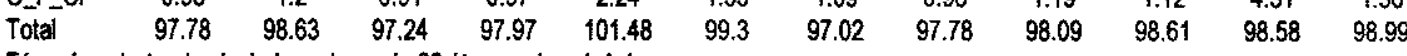
$\begin{array}{lllllllllllll}\mathrm{Si} & 5.887 & 6.023 & 5.881 & 5.885 & 6.481 & 6.063 & 5.946 & 6.05 & 6.043 & 6.127 & 6.76 & 6.071\end{array}$

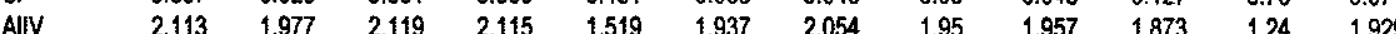

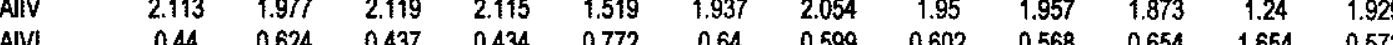
$\begin{array}{lllllllllllll}\text { AIV } & 0.44 & 0.624 & 0.437 & 0.434 & 0.772 & 0.64 & 0.599 & 0.602 & 0.568 & 0.654 & 1.654 & 0.572 \\ \text { Ti } & 0.605 & 0.523 & 0.69 & 0.729 & 0.33 & 0.488 & 0.575 & 0.466 & 0.51 & 0.476 & 0.659 & 0.494\end{array}$

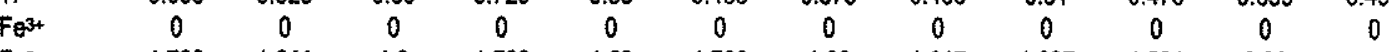
$\begin{array}{lcccccccccccc}\mathrm{Fe}^{2+} & 1.798 & 1.644 & 1.8 & 1.763 & 1.23 & 1.786 & 1.83 & 1.647 & 1.697 & 1.581 & 2.02 & 1.708 \\ \mathrm{Cr} & 0 & 0.004 & 0.005 & 0.006 & 0.006 & 0.001 & 0.001 & 0.001 & 0.004 & 0.002 & 0.003 & 0\end{array}$ \begin{tabular}{ccccccccccccc}
$\mathrm{Cr}$ & 0 & 0.004 & 0.005 & 0.006 & 0.006 & 0.001 & 0.001 & 0.001 & 0.004 & 0.002 & 0.003 & 0 \\
\hline & 0.072 & 0.059 & 0.064 & 0.077 & 0.045 & 0.057 & 0.042 & 0.054 & 0.052 & 0.052 & 0.073 & 0.054
\end{tabular} $\begin{array}{lllllllllllll}\mathrm{Mn} & 0.072 & 0.059 & 0.064 & 0.077 & 0.045 & 0.057 & 0.042 & 0.054 & 0.052 & 0.052 & 0.073 & 0.054\end{array}$

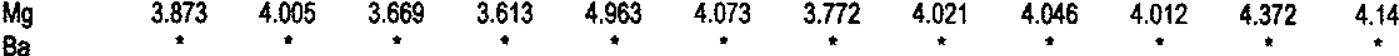

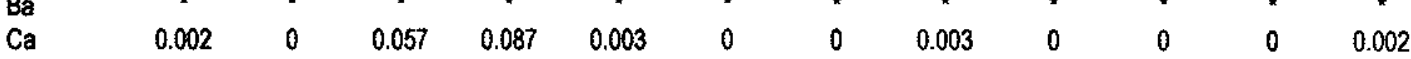

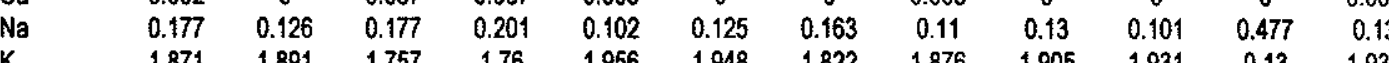
$\begin{array}{lllllllllllll}K & 1.871 & 1.891 & 1.757 & 1.76 & 1.956 & 1.948 & 1.822 & 1.876 & 1.905 & 1.931 & 0.13 & 1.937\end{array}$ $\begin{array}{lcccccccccccc}\text { Cátions } & * & * & * & * & * & * & * & * & * & * & * & * \\ \text { CF } & 2.255 & 2.774 & 2.092 & 2.255 & 5.301 & 3.613 & 2.575 & 2.242 & 2.773 & 2.553 & 10.242 & 3.191\end{array}$ $\begin{array}{llllllllllllll}\mathrm{CCl} & 0.087 & 0.102 & 0.081 & 0.07 & 0.065 & 0.088 & 0.082 & 0.086 & 0.081 & 0.092 & 1.557 & 0.092\end{array}$ $\begin{array}{lllllllllllll}\mathrm{OH} & -1.174 & -1.443 & -1.088 & -1.169 & -2.681 & -1.853 & -1.327 & -1.162 & -1.432 & -1.326 & -5.91 & -1.647\end{array}$

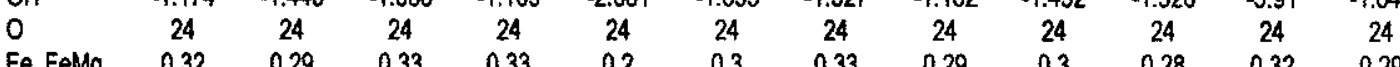
$\begin{array}{lllllllllllll}\text { Fe_FeMg } & 0.32 & 0.29 & 0.33 & 0.33 & 0.2 & 0.3 & 0.33 & 0.29 & 0.3 & 0.28 & 0.32 & 0.29 \\ \text { Mg_FeMg } & 0.68 & 0.71 & 0.67 & 0.67 & 0.8 & 0.7 & 0.67 & 0.71 & 0.7 & 0.72 & 0.68 & 0.71\end{array}$ Observaçoses e abreviaç̧es como na tabela 6.0 

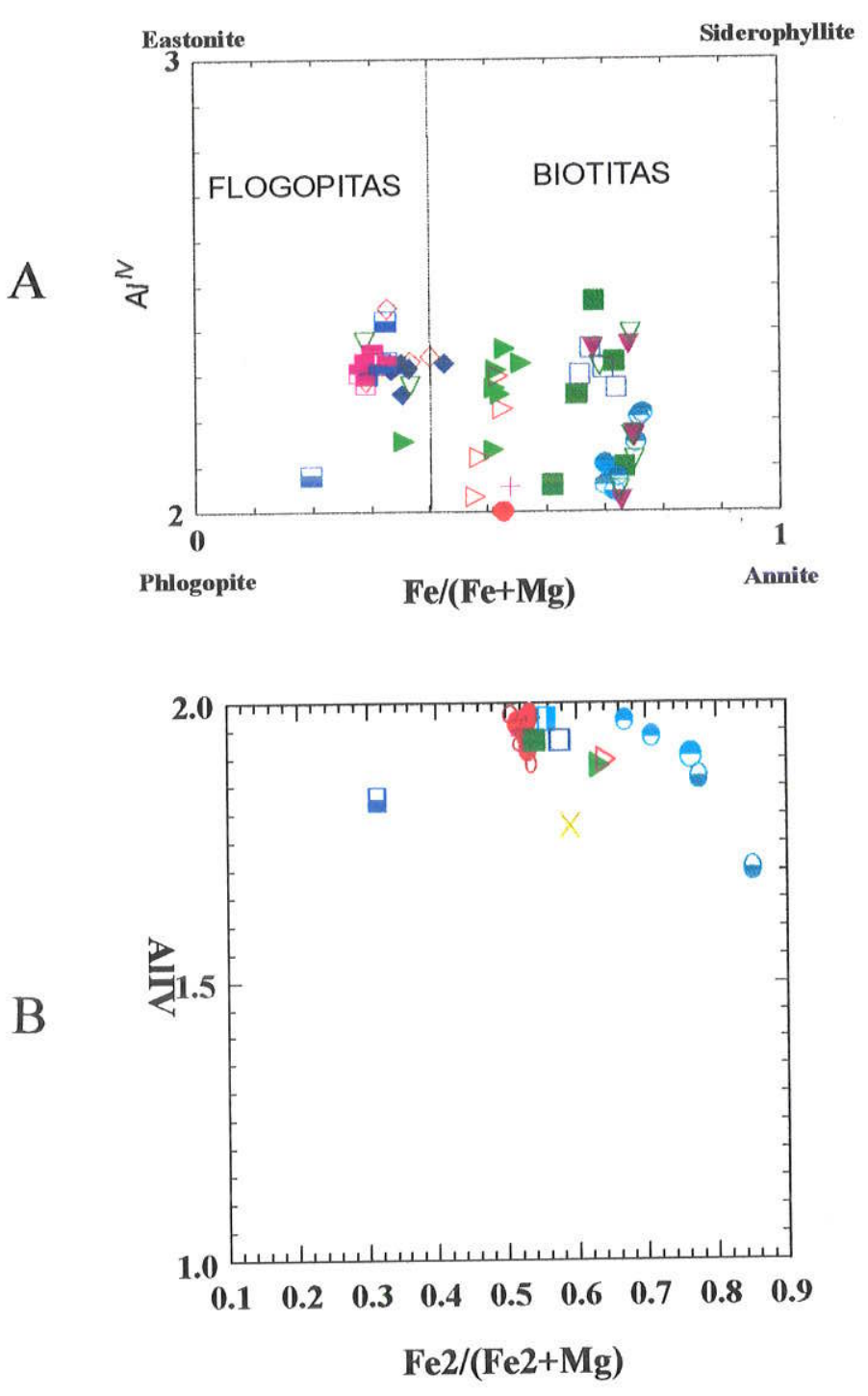

Figura 67 (A e B) - Classificação das micas das rochas da Província Alcalina Alto Paraguai nos diagramas $\mathrm{Al}^{\mathrm{IV}}$ versus $\mathrm{Fe} /(\mathrm{Fe}+\mathrm{Mg})$ e $\mathrm{Al}^{\mathrm{IV}}$ contra $\mathrm{Fe}^{2+} /\left(\mathrm{Fe}^{2+}+\mathrm{Mg}\right)$.

Simbolos: losangos= Cerrito: cheios (núcleos), vazios (bordas); triângulo com a ponta voltada para a direita = Pão de Açúcar: cheios (núcleos), vazios (bordas); triângulo com a ponta voltada para baixo= Cerro Siete Cabezas: cheios (núcleos), vazios (bordas); Cerro Boggiani= círculos: cheios (núcleos), vazios (bordas); círculos com metade preenchida= Satélite I: inferior (núcleos), superior (bordas); quadrados= Satélite II: cheios (núcleos), vazios (bordas); quadrados com metade preenchida= Morro Distante: inferior (núcleos), superior (bordas), xis= matriz (Pão de Açúcar) e cruzes $=$ matriz (Cerro Boggiani). 

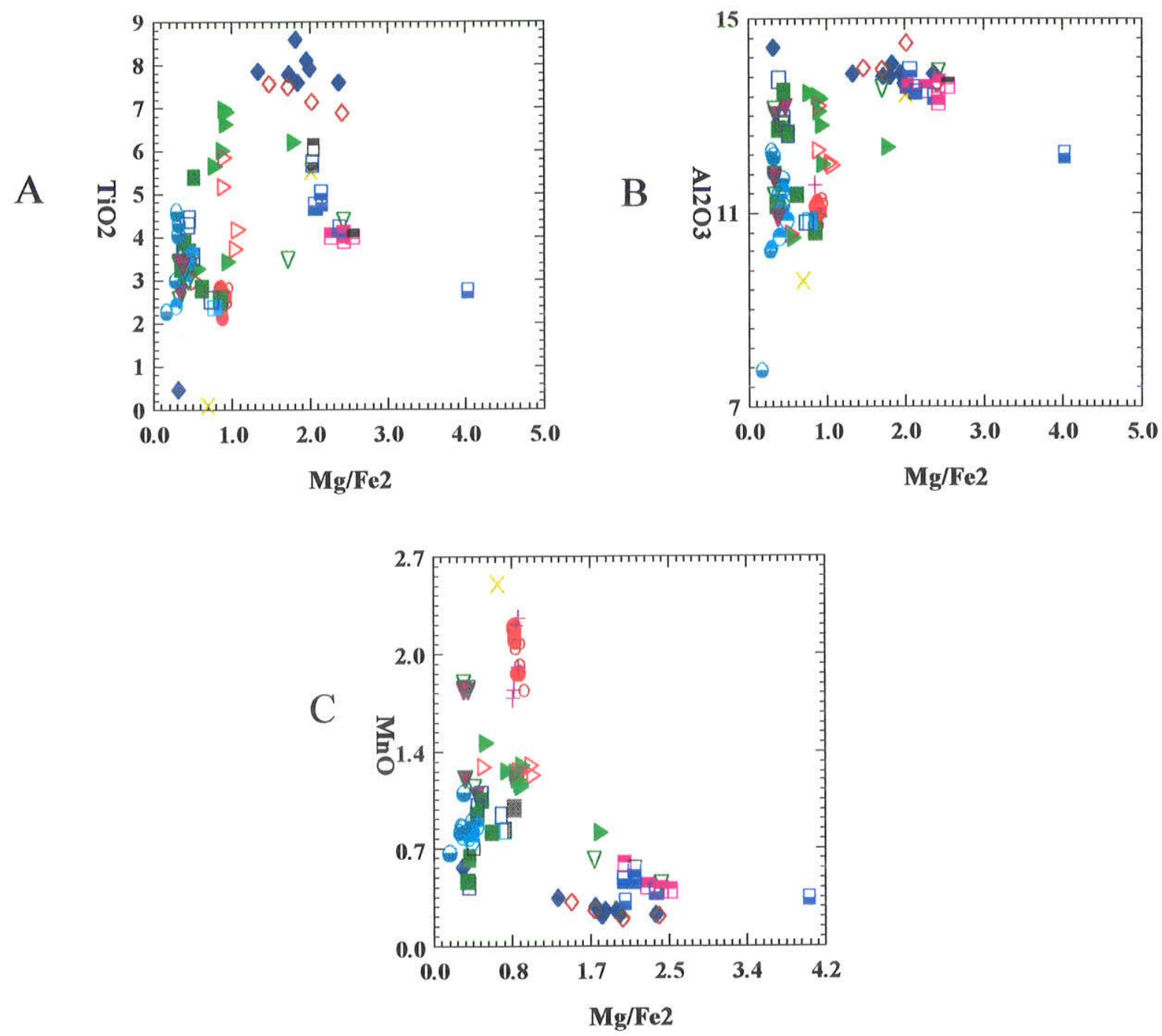

Figura 68 (A, B e C) - Variações composicionais nos teores de $\mathrm{TiO}_{2}, \mathrm{Al}_{2} \mathrm{O}_{3}$ e $\mathrm{MnO}$ versus $\mathrm{Mg} / \mathrm{Fe}^{2}$ de biotitas das rochas da Província Alcalina Alto Paraguai. Símbolos como na figura 67. 

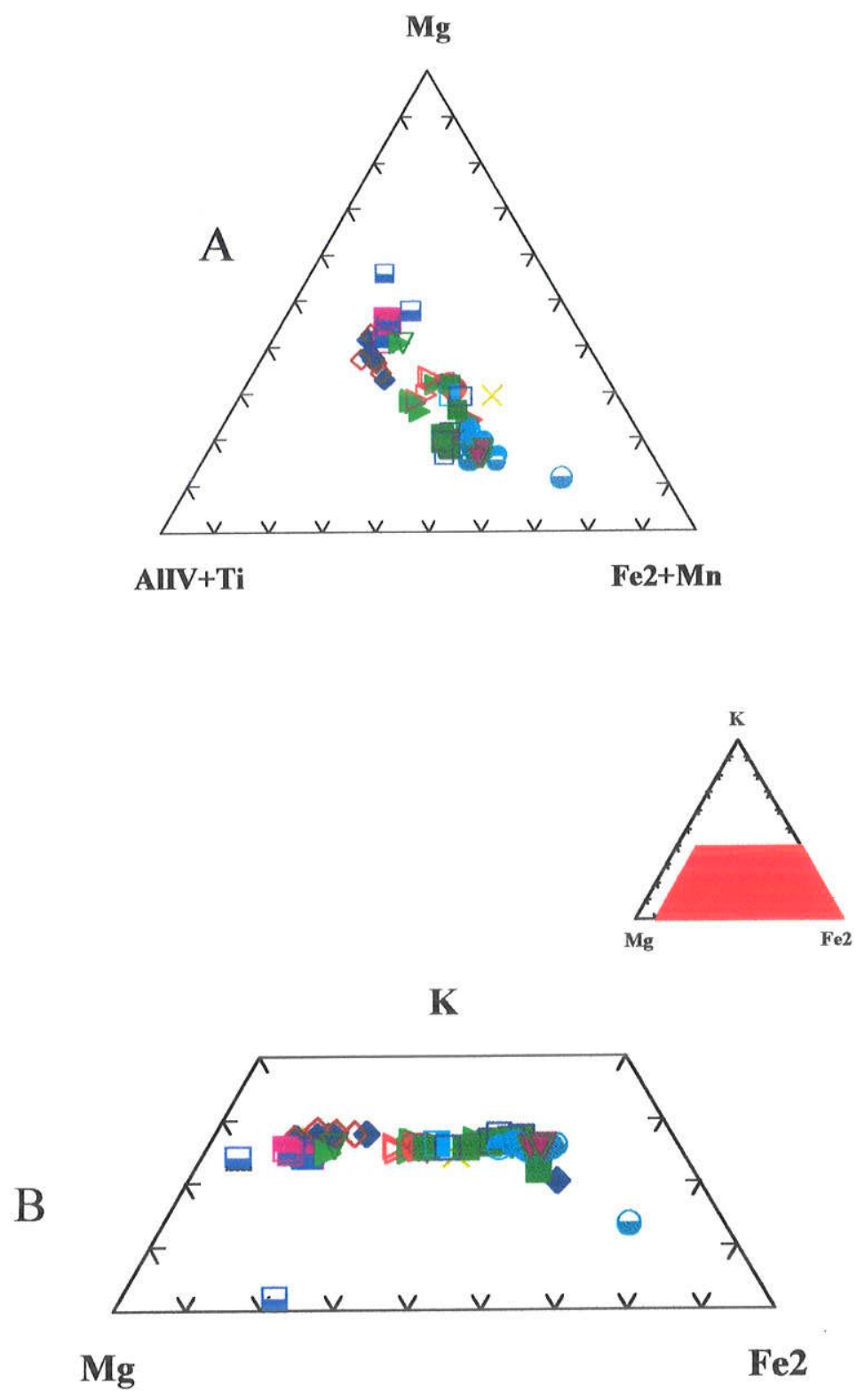

Figura 69 ( $A$ e B) - Distribuição das biotitas das rochas da Província Alcalina Alto Paraguai nos diagramas $\mathrm{Mg}$ - $\left(\mathrm{Al}^{\mathrm{IV}}+\mathrm{Ti}\right)-\left(\mathrm{Fe}^{2}+\mathrm{Mn}\right)$ e $\mathrm{K}-\mathrm{Mg}-\mathrm{Fe}^{2}$. Símbolos como na figura 67 . 
V.6 - Espinélios e Ilmenitas

Os espinélios são encontrados nas rochas de praticamente todos os corpos da Província Alcalina Alto Paraguai, com exceção do de Cerro Boggiani. Ocorrem freqüentemente como fenocristais, microfenocristais e raramente como componentes da matriz, não sendo constatado zoneamentos composicionais nos cristais analisados.

Conforme Deer et al (1963), a fórmula estrutural dos espinélios é $\mathrm{R}^{2+}\left(\mathrm{R}^{3+}\right)_{2} \mathrm{O}_{4}$ formando inúmeras séries de soluções sólidas, raramente ocorrendo os membros finais na natureza. Formam comumente três séries minerais, de conformidade com os íns trivalentes presentes: série do espinélio $\left(R=\left.A\right|^{3+}\right)$, série da magnetita $\left(\mathrm{R}=\mathrm{Fe}^{3+}\right)$ e série da cromita $\left(\mathrm{R}=\mathrm{Cr}^{3+}\right)$, onde as diferenças composicionais entre os membros das séries são definidas pelo cátion $\mathrm{R}^{2+}$, que comumente pode ser: $\mathrm{Mg}$, $\mathrm{Fe}^{2+}, \mathrm{Zn}, \mathrm{Mn}, \mathrm{Ni}, \mathrm{Co}$, Ge ou Cu (Deer et al. 1963; Haggerty, 1976).

Cristalograficamente, os espinélios apresentam-se com estrutura normal ou invertida. $\mathrm{Na}$ estrutura normal, $\mathrm{R}^{2+}$ e $\mathrm{R}^{3+}$ são exclusivamente de coordenação tetraédrica e octaédrica, respectivamente, incluindo espécies como a hercinita $\left(\mathrm{Fe}^{2+} \mathrm{Al}_{2} \mathrm{O}_{4}\right)$, a cromita $\left(\mathrm{Fe}^{2+} \mathrm{Cr}_{2} \mathrm{O}_{4}\right)$, a magnesiocromita $\left(\mathrm{MgCr}_{2} \mathrm{O}_{4}\right)$ e o espinélio $\left(\mathrm{MgAl}_{2} \mathrm{O}_{4}\right)$, que podem ser representados na base do prisma multicomponente dos espinélios. Na estrutura invertida (série da magnetita) as posições $R^{2+}$ e $R^{3+}$ estão preenchidas tanto com íons de coordenação tetraédrica como íons em coordenação octaédrica, tendo os seus membros listados como se segue: magnetita $\left(\mathrm{Fe}^{2+} \mathrm{Fe}^{3+}{ }_{2} \mathrm{O}_{4}\right)$, ulvöespinélio $\left(\mathrm{Fe}^{2+}{ }_{2} \mathrm{OTiO}_{4}\right)$, maghemita $\left(\mathrm{Fe}^{3+}{ }_{2} \mathrm{O}_{3-\gamma}\right)$, magnesioferrita $\left(\mathrm{MgFe}^{3+}{ }_{2} \mathrm{O}_{4}\right)$, franklinita $\left(\mathrm{ZnFe}^{3+}{ }_{2} \mathrm{O}_{4}\right)$, jacobsita $\left(\mathrm{MnFe}^{3+}{ }_{2} \mathrm{O}_{4}\right)$ e trevorita $\left(\mathrm{NiFe}^{3+}{ }_{2} \mathrm{O}_{4}\right)$, Deer et al. (1963) e Haggerty ( 1976 e 1991).

Em termos composicionais, pode-se dividir os espinélios em dois grandes grupos: os espinélios de $\mathrm{Fe}$ e $\mathrm{Ti}$ (sistema magnetita-ulvöespinélio) e os cromoespinélios do multisistema cromita-hercinita-ulvöespinélio-picrocromitaespinélio-magnesioferrita. 
A fórmula estrutural dos espinélios das rochas da Província Alcalina Alto Paraguai foi calculada na base de 32 átomos de oxigênio e os recálculos de $\mathrm{Fe}^{3+}$ feitos segundo o método de Finger (1972). Suas composições químicas estão apresentadas nas tabelas 17.0 a 17.5 .

As magnetitas das rochas analisadas apresentam elevado enriquecimento em $\mathrm{ZnO}(0,13$ a 0,42\%) e $\mathrm{MnO}(0,46$ a 3,26\%) em relação aos dados de literatura, destacando-se no corpo liha Fecho dos Morros, magnetitas com valores de $\mathrm{MnO}$ situados entre 1,51 e $5,13 \%$.

Nas magnetitas de Cerrito, apenas uma amostra (RP-88) apresenta valores de $\mathrm{TiO}_{2}$ superior a $10 \%$, teores variáveis de $\mathrm{Al}_{2} \mathrm{O}_{3}(0,15$ a 2,8\%), concentrações que permitem classifica-las como magnetitas titaniferas. Ressalta-se também uma análise cujo teor de $\mathrm{MgO}$ ultrapassa 1\%, caracterizando-a segundo nomenclatura proposta por Mitchell \& Bergman (1991) e Mitchell (1995), como magnetita titanifera magnesiana.

Segundo Deer et al (1966) a ilmenita é melhor representada como um titanato de ferro ferroso $\left(\mathrm{Fe}^{2+} \mathrm{Ti}^{4+} \mathrm{O}_{3}\right)$ do que como um óxido duplo de ferro férrico e titânio $\left(\mathrm{Fe}^{3+} \mathrm{Ti}^{3+} \mathrm{O}_{3}\right.$ ), sendo que a sua estrutura guarda semelhança com a da hematita, ressalvando apenas uma distorção nas camadas de oxigênio.

O grupo da ilmenita é composto pelos seguintes minerais: ilmenita $\left(\mathrm{FeTiO}_{3}\right)$, hematita $\left(\mathrm{Fe}_{2} \mathrm{O}_{3}\right)$, geikielita $\left(\mathrm{MgTiO}_{3}\right)$, pirofanita $\left(\mathrm{MnTiO}_{3}\right)$ e eskolaíta $\left(\mathrm{Cr}_{2} \mathrm{O}_{3}\right)$, sendo que ocorre duas séries de solução sólida: uma entre a ilmenita-geikielita e outra entre a ilmenita-hematita. Seus principais produtos de alteração formam-se por estádios sucessivos representados por manchas de alteração, óxidos de titânio e ferro amorfo e leucoxênio. A arizonita é um produto de alteração que inclui minerais como: hematita, pseudobrookita, rutilo e anatásio.

As composições químicas das ilmenitas da Província Alcalina Alto Paraguai e suas fórmulas estruturais normalizadas para 6 oxigênios podem ser visualizadas nas tabelas 18.0 a 18.1 .

Espinélios ocorrem principalmente nos sienitos alcalinos de Satélite I e Satélite II, nefelina sienitos de Cerro Siete Cabezas, quartzo sienitos e 
traquifonolitos de Pão de Açúcar, sienitos nefelínicos de Cerrito e da llha Fecho dos Morros e fonolitos de São Pedro.

A figura 70 mostra o sistema $\mathrm{FeO}-\mathrm{Fe}_{2} \mathrm{O}_{3}-\mathrm{TiO}_{2}$ (Buddington \& Lindsley, 1964), adaptado por Haggerty (1976) no qual estão representadas as composições das principais fases dos espinélios de $\mathrm{Fe}$ e $\mathrm{Ti}$ e ilmenitas dos diversos corpos estudados. As composições das fases representativas dos espinélios de $\mathrm{Fe}$ e $\mathrm{Ti}$ distribuem-se ao longo da linha $\mathrm{Fe}_{3} \mathrm{O}_{4}-\mathrm{Fe}_{2} \mathrm{TiO}_{4}$, série da magnetita-ulvöespinélio, indicando para esses minerais, temperaturas de cristalização por volta de $600^{\circ} \mathrm{C}$, com baixa fugacidade de oxigênio enquanto que as ilmenitas se concentram junto ao lado $\mathrm{FeTiO}_{3}$ da série ilmenita-hematita, com temperaturas de cristalização em torno de $800^{\circ} \mathrm{C}$ e fugacidade de oxigênio maiores em relação aos espinélios. 
Tabela 17.0 - Composição quimica de magnetitas das rochas de Satélite I e II (\% peso)

\begin{tabular}{|c|c|c|c|c|c|c|c|c|c|c|c|c|c|c|c|c|c|c|c|c|}
\hline mostra & $R P-44$ & RP-44 & RP-44 & RP-45 & RP-45 & RP-45 & RP-45 & RP-45 & RP.50 & RP-50 & RP-50 & RP-51 & RP-5i & RP-51 & RP-51 & RP-51 & RP-52 & RP-52 & RP-52 & RP-52 \\
\hline Análise & 1151 & 1152 & 1153 & 1154 & 1155 & 1156 & 1157 & 1158 & 1159 & $1\{60$ & 1162 & $\$ 141$ & 1142 & 1143 & 1144 & 1145 & $1\} 63$ & 1165 & 1166 & 1167 \\
\hline Locação & C3G1n & C4Gim & C4G2m & C1G1n & $\mathrm{C} 2 \mathrm{G} 1 \mathrm{n}$ & C3G1n & C4Gin & C5Gin & C1G1n & C2Gin & C5GIn & C1G1n & C2Gin & C3G1n & C4Gin & C6G1n & C1G1n & C4G1n & C6G1n & C6G1n \\
\hline $\mathrm{SiO}_{2}$ & 0.15 & 0.12 & 0.24 & 0.39 & 0.28 & 0.11 & 1.23 & 0.59 & 0.12 & 0.07 & 0.1 & 0.08 & 0.19 & 0.22 & 0.47 & 0.19 & 0.1 & 0.14 & 0.47 & 0.15 \\
\hline $\mathrm{TiO}_{2}$ & 2.12 & 8.97 & 5.84 & 4.6 & 4.95 & 4.71 & 3.51 & 4.61 & 6.81 & 2.77 & 1.33 & 11.55 & 11.82 & 7.78 & 15.7 & 7.68 & 10.58 & 5.56 & 6.45 & 9.6 \\
\hline $\mathrm{Al}_{2} \mathrm{O}_{3}$ & 0.11 & 0.27 & 0.2 & 0.1 & 0.04 & 0.01 & 0.1 & 0.1 & 0.1 & 0.34 & 0.05 & 0.12 & 0.04 & 0.27 & 0.06 & 0.03 & 0.06 & 0.17 & 0.13 & 0.11 \\
\hline $\mathrm{Cr}_{2} \mathrm{O}_{3}$ & 0 & 0 & 0.01 & 0.02 & 0 & 0 & 0.03 & 0.03 & 0.01 & 0.01 & 0 & 0 & 0.04 & 0 & 0.04 & 0.01 & 0 & 0 & 0.01 & 0.02 \\
\hline $\mathrm{FeO}$ & 31.38 & 37.4 & 34.06 & 31.89 & 32.23 & 32.56 & 33.96 & 33.98 & 33.82 & 32.74 & 30.68 & 38.05 & 38.43 & 33.51 & 42.63 & 35.73 & 39.1 & 35.57 & 35.28 & 38.48 \\
\hline $\mathrm{Fe}_{2} \mathrm{O}_{3}$ & 60.79 & 49.19 & 52.38 & 54.99 & 55.79 & 59.09 & 58.88 & 51.8 & 52.49 & 64.86 & 62.55 & 43.86 & 41.73 & 47.48 & 32.15 & 50.68 & 47.59 & 57.07 & 51.69 & 49.19 \\
\hline no & 0.15 & 1.21 & 0.58 & 1.72 & 2.26 & 2.59 & 1.64 & 0.91 & 2.3 & 0.38 & 0.19 & 2.49 & 1.89 & 2.32 & 1.13 & 1.24 & 1.49 & 0.58 & 0.73 & 1.13 \\
\hline $\mathrm{MgO}$ & 0 & 0 & 0.03 & 0 & 0 & 0 & 0.01 & 0.02 & 0.02 & 0.01 & 0.02 & 0.03 & 0 & 0.02 & 0.02 & 0.02 & 0 & 0 & 0.03 & 0.01 \\
\hline $\mathrm{CaO}$ & 0.02 & 0 & 0 & 0 & 0.01 & 0.04 & 0.09 & 0.26 & 0 & 0.06 & 0.02 & 0.03 & 0.11 & 0.05 & 0.07 & 0.07 & 0.03 & 0.16 & 0.02 & 0 \\
\hline $\mathrm{ZnO}$ & 0.1 & 0.12 & 0.11 & 0.38 & 0.24 & 0.15 & 0.15 & 0.04 & 0.1 & 0.13 & 0.01 & 0.19 & 0.05 & 0.25 & 0.1 & 0.08 & 0.14 & 0 & 0.08 & 0.07 \\
\hline $\mathrm{Nb}_{2} \mathrm{O}_{5}$ & 0.06 & 0.05 & 0.03 & 0.05 & 0 & 0.01 & 0.04 & 2.47 & 0 & 0.01 & 0.03 & 0 & 0.05 & 0.02 & 0.2 & 0.11 & 0.04 & 0.01 & 0.01 & 0.09 \\
\hline Total & 94.88 & 97.33 & 93.48 & 94.14 & 95.8 & 99.27 & 99.64 & 94.81 & 95.77 & 98.38 & 94.98 & 96.4 & 94.35 & 91.92 & 92.57 & 95.84 & 99.13 & 99.26 & 94.9 & 98.85 \\
\hline $\mathrm{FeOl}$ & 86.09 & 81,67 & 81.2 & 81.38 & 82.44 & 85.74 & 86.95 & 80.6 & 81.06 & 88.41 & 86.97 & 77.52 & 75.99 & 76.24 & 71.56 & 81.34 & 81.93 & 86.93 & 81.8 & 82.75 \\
\hline $\mathrm{Si}$ & 0.171 & 0.143 & 0.299 & 0.455 & 0.314 & 0.113 & 1.277 & 0.709 & 0.139 & 0.074 & 0.112 & 0.099 & 0.253 & 0.282 & 0.726 & 0.229 & 0.118 & 0.153 & 0.577 & 0.176 \\
\hline Al & 0.148 & 0.38 & 0.294 & 0.137 & 0.053 & 0.012 & 0.122 & 0.142 & 0.137 & 0.425 & 0.066 & 0.175 & 0.063 & 0.408 & 0.109 & 0.043 & 0.083 & 0.219 & 0.188 & 0.152 \\
\hline Ti & 1.818 & 8.064 & 5.479 & 4.037 & 4.181 & 3.649 & 2.741 & 4.169 & 5.941 & 2.211 & 1.123 & 10.782 & 11.831 & 7.500 & 18.245 & 6.975 & 9.384 & 4.584 & 5.952 & 8.461 \\
\hline $\mathrm{Cr}$ & 0 & 0 & 0.01 & 0.018 & 0 & 0 & 0.025 & 0.028 & 0.009 & 0.008 & 0 & 0 & 0.042 & 0 & 0.049 & 0.01 & 0 & 0 & 0.01 & 0.019 \\
\hline $\mathrm{Fe}^{2}$ & 0 & 0 & 0 & 0 & 0 & 0 & 0 & 0 & 0 & 0 & 0 & 0 & 0 & 0 & 0 & 0 & 0 & 0 & 0 & 0 \\
\hline $\mathrm{Fe}^{3}$ & 52.108 & 44.194 & 49.114 & 48.228 & 47.091 & 45.750 & 45.960 & 46.813 & 45.769 & 49.340 & 52.806 & 40.919 & 41.746 & 45.745 & 37.339 & 46.002 & 42.186 & 47.027 & 47.669 & 43.329 \\
\hline $\mathrm{Mn}$ & 0.145 & 1.225 & 0.613 & 1.700 & 2.149 & 2.259 & $\{.442$ & 0.927 & 2.260 & 0.341 & 0.181 & 2.617 & 2.130 & 2.518 & 1.479 & 1.268 & 1.488 & 0.538 & 0.759 & 1.121 \\
\hline $\mathrm{Mg}$ & 0 & 0 & 0.056 & 0 & 0 & 0 & 0.015 & 0.036 & 0.035 & 0.016 & 0.033 & 0.056 & 0 & 0.038 & 0.046 & 0.036 & 0 & 0 & 0.055 & 0.017 \\
\hline $\mathrm{Ca}$ & 0.024 & 0 & 0 & 0 & 0.012 & 0.044 & 0.1 & 0.335 & 0 & 0.068 & 0.024 & 0.04 & 0.157 & 0.069 & 0.116 & 0.091 & 0.038 & 0.188 & 0.026 & 0 \\
\hline $\mathrm{Zn}$ & 0.084 & 0.106 & 0.101 & 0.327 & 0.199 & 0.114 & 0.115 & 0.036 & 0.086 & 0.102 & 0.008 & 0.174 & 0.049 & 0.237 & 0.114 & 0.071 & 0.122 & 0 & 0.072 & 0.061 \\
\hline $\mathrm{Nb}$ & 0.031 & 0.027 & 0.017 & 0.026 & 0 & 0.005 & 0.019 & 1.342 & 0 & 0.005 & 0.015 & 0 & 0.03 & 0.012 & 0.14 & 0.06 & 0.021 & 0.005 & 0.006 & 0.048 \\
\hline Cátions & 54.529 & 54.139 & 55.983 & 54.928 & 53.999 & 51.946 & 51.816 & 54.537 & 54.376 & 52.590 & 54.368 & 54.862 & 56.301 & 56.809 & 58.363 & 54.785 & 53.440 & 52.714 & 55.314 & 53.384 \\
\hline $\mathrm{Fe}^{3}$-TRIVAL & 0.997 & 0.991 & 0.994 & 0.997 & 0.999 & 1.000 & 0.997 & 0.996 & 0.997 & 0.991 & 0.999 & 0.996 & 0.997 & 0.991 & 0.996 & 0.999 & 0.998 & 0.995 & 0.996 & 0.996 \\
\hline Al_TRIVAL & 0.003 & 0.009 & 0.006 & 0.003 & 0.001 & 0 & 0.003 & 0.003 & 0.003 & 0.009 & 0.001 & 0.004 & 0.002 & 0.009 & 0.003 & 0.001 & 0.002 & 0.005 & 0.004 & 0.003 \\
\hline Cr_TRIVAL & 0 & 0 & 0 & 0 & 0 & 0 & 0.001 & 0.001 & 0 & 0 & 0 & 0 & 0.001 & 0 & 0.001 & 0 & 0 & 0 & 0 & 0 \\
\hline XFe & 0 & 0 & 0 & 0 & 0 & 0 & 0 & 0 & 0 & 0 & 0 & 0 & 0 & & 0 & 0 & 0 & 0 & 0 & 0 \\
\hline XMg & 0 & 0 & 1.000 & 0 & 0 & 0 & 1.000 & 1.000 & 1.000 & 1.000 & 1.000 & 1.000 & 0 & 1.000 & 1.000 & 1.000 & 0 & 0 & 1.000 & 1.000 \\
\hline $\mathrm{PMSiO}_{2}$ & 0.002 & 0.002 & 0.004 & 0.006 & 0.005 & 0.002 & 0.02 & 0.01 & 0.002 & 0.001 & 0.002 & 0.001 & 0.003 & 0.004 & 0.008 & 0.003 & 0.002 & 0.002 & 0.008 & 0.002 \\
\hline $\mathrm{PMTIO}_{2}$ & 0.027 & 0.112 & 0.073 & 0.058 & 0.062 & 0.059 & 0.044 & 0.058 & 0.085 & 0.035 & 0.017 & 0.145 & 0.148 & 0.097 & 0.196 & 0.096 & 0.132 & 0.07 & 0.081 & 0.12 \\
\hline $\mathrm{PMAl}_{2} \mathrm{O}_{3}$ & 0.001 & 0.003 & 0.002 & 0.001 & 0 & 0 & 0.001 & 0.001 & 0.001 & 0.003 & 0 & 0.001 & 0 & 0.003 & 0.001 & 0 & 0.001 & 0.002 & 0.001 & 0.001 \\
\hline PMFeOI & 1.198 & 1.137 & 1.130 & 1.133 & 1.147 & 1.193 & 1.210 & 1.122 & 1.128 & 1.230 & 1.210 & 1.079 & 1.058 & 1.061 & 0.996 & 1.132 & 1.140 & 1.210 & 1.338 & 1.152 \\
\hline PMFeO & 0.437 & 0.521 & 0.474 & 0.444 & 0.449 & 0.453 & 0.473 & 0.473 & 0.471 & 0.456 & 0.427 & 0.53 & 0.535 & 0.466 & 0.593 & 0.497 & 0.544 & 0.495 & 0.491 & 0.536 \\
\hline $\mathrm{PMFe}_{2} \mathrm{O}_{3}$ & 0.381 & 0.308 & 0.328 & 0.344 & 0.349 & 0.37 & 0.369 & 0.324 & 0.329 & 0.387 & 0.392 & 0.275 & 0.261 & 0.297 & 0.201 & 0.317 & 0.298 & 0.357 & 0.324 & 0.308 \\
\hline PMMnO & 0.002 & 0.017 & 0.008 & 0.024 & 0.032 & 0.037 & 0.023 & 0.013 & 0.032 & 0.005 & 0.003 & 0.035 & 0.027 & 0.033 & 0.016 & 0.017 & 0.021 & 0.008 & 0.01 & 0.016 \\
\hline PMMgO & 0 & 0 & 0.001 & 0 & 0 & 0 & 0 & 0 & 0 & 0 & 0 & 0.001 & 0 & 0 & 0 & 0 & 0 & 0 & 0.001 & 0 \\
\hline PMZno & 0.001 & 0.001 & 0.001 & 0.005 & 0.003 & 0.002 & 0.002 & 0 & 0.001 & 0.002 & 0 & 0.002 & 0.001 & 0.003 & 0.001 & 0.001 & 0.002 & 0 & 0.001 & 0.001 \\
\hline SUM1 & 1.142 & 0.924 & 0.984 & 1.033 & 1.048 & $\$ .110$ & 1.106 & 0.973 & 0.986 & 1.162 & 1.175 & 0.824 & 0.784 & 0.892 & 0.604 & 0.952 & 0.894 & 1.072 & 0.971 & 0.924 \\
\hline
\end{tabular}




\begin{tabular}{|c|c|c|c|c|c|c|}
\hline Amostra & RP-74 & RP-74 & $R P-230$ & RP-230 & RP-230 & RP-230 \\
\hline Analise & 1126 & 1129 & & 1122 & 1220 & 1221 \\
\hline Locação & C1G1n & CiGím & C4Gin & C5Gin & C2Gin & C3G1n \\
\hline $\mathrm{SiO}_{2}$ & $7.7 \hat{3}$ & 0.08 & 0.56 & 0.09 & 0.04 & 0.01 \\
\hline $\mathrm{THO}_{2}$ & 0.01 & 5.49 & 5.17 & 7.45 & 6.72 & 7.46 \\
\hline $\mathrm{Al}_{2} \mathrm{O}_{3}$ & 1.58 & 0.05 & 0.57 & 0.14 & 0.23 & 0.35 \\
\hline $\mathrm{Cr}_{2} \mathrm{O}_{3}$ & 0.05 & 0.06 & 0.02 & 0.01 & 0.04 & 0.02 \\
\hline $\mathrm{FeO}$ & 33.98 & 32.7 & 34.28 & 36.21 & 34.39 & 35.16 \\
\hline $\mathrm{Fe}_{2} \mathrm{O}_{3}$ & 36.68 & 53.77 & 55.58 & 53.93 & 53.98 & 53.45 \\
\hline $\mathrm{MnO}$ & 0.41 & 1.48 & 1.52 & 1.26 & 1.87 & 2.11 \\
\hline $\mathrm{MgO}$ & 0.48 & 0.02 & 0.08 & 0.13 & 0.08 & 0.06 \\
\hline $\mathrm{CaO}$ & 0.74 & 0.01 & 0.01 & 0 & 0.02 & 0.03 \\
\hline $\mathrm{ZnO}$ & 0.01 & 0 & 0.15 & 0.05 & 0.27 & 0.26 \\
\hline $\mathrm{Nb}_{2} \mathrm{O}_{5}$ & 0.02 & 0 & 0.04 & 0.01 & 0.06 & 0 \\
\hline Total & 81.67 & 93.65 & 97.98 & 99.28 & 97.7 & 98.91 \\
\hline $\mathrm{FeOl}$ & 66.99 & 81.09 & 84.3 & 84.75 & 82.97 & 83.27 \\
\hline Si & 12.218 & 0.097 & 0.611 & 0.099 & 0.044 & 0.011 \\
\hline A & 2.949 & 0.071 & 0.732 & 0.182 & 0.301 & 0.448 \\
\hline $\mathrm{Ti}$ & 0.012 & 4.983 & 4.240 & 6.177 & 5.612 & 6.104 \\
\hline $\mathrm{Cr}$ & 0.063 & 0.057 & 0.017 & 0.009 & 0.035 & 0.017 \\
\hline $\mathrm{Fe}^{2}$ & 0 & 0 & 0 & 0 & 0 & 0 \\
\hline $\mathrm{Fe}^{3}$ & 43.696 & 48.774 & 45.551 & 44.689 & 45.053 & 43.712 \\
\hline $\mathrm{Mn}$ & 0.55 & 1.513 & 1.404 & 1.176 & 1.759 & 1.944 \\
\hline $\mathrm{Mg}$ & 1.134 & 0.036 & 0.13 & 0.214 & 0.132 & 0.097 \\
\hline $\mathrm{Ca}$ & 1.256 & 0.013 & 0.012 & 0 & 0.024 & 0.035 \\
\hline $\mathrm{Zn}$ & 0.012 & 0 & 0.121 & 0.041 & 0.221 & 0.209 \\
\hline $\mathrm{Nb}$ & 0.014 & 0 & 0.02 & 0.005 & 0.03 & 0 \\
\hline Cations & 61.904 & 55.544 & 52.838 & 52.592 & 53.211 & 52.577 \\
\hline $\mathrm{Fe}^{3}$ _TRIVAL & 0.936 & 0.997 & 0.984 & 0.996 & 0.993 & 0.989 \\
\hline Al_TRIVAL & 0.063 & 0.001 & 0.016 & 0.004 & 0.007 & 0.01 \\
\hline Cr_TRIVAL & 0.001 & 0.001 & 0 & 0 & 0.001 & 0 \\
\hline$X F e$ & 0 & 0 & 0 & 0 & 0 & 0 \\
\hline $\mathrm{XMg}$ & 1.000 & 1.000 & 1.000 & 1.000 & 1.000 & 1.000 \\
\hline $\mathrm{PMSiO}_{2}$ & 0.128 & 0.001 & 0.009 & 0.001 & 0.001 & 0 \\
\hline $\mathrm{PMTiO}_{2}$ & 0 & 0.069 & 0.065 & 0.093 & 0.084 & 0.093 \\
\hline $\mathrm{PMA}_{2} \mathrm{O}_{3}$ & 0.015 & 0 & 0.006 & 0.001 & 0.002 & 0.003 \\
\hline PMFeOI & 0.932 & $\$ .129$ & 1.173 & $\$ .180$ & 1.155 & 1.159 \\
\hline PMFeO & 0.473 & 0.455 & 0.477 & 0.504 & 0.479 & 0.489 \\
\hline $\mathrm{PMFe}_{2} \mathrm{O}_{3}$ & 0.23 & 0.337 & 0.348 & 0.338 & 0.338 & 0.335 \\
\hline PMMnO & 0.006 & 0.021 & 0.021 & 0.018 & 0.026 & 0.03 \\
\hline PMMgO & 0.012 & 0 & 0.002 & 0.003 & 0.002 & 0.001 \\
\hline PMZnO & 0 & 0 & 0.002 & 0.001 & 0.003 & 0.003 \\
\hline SUM1 & 0.689 & 1.010 & 1.044 & 1.013 & 1.014 & 1.004 \\
\hline
\end{tabular}


Tabela 17.2 - Composição química das magnetitas de Pazo de Açúcar (\% peso)

\begin{tabular}{|c|c|c|c|c|c|c|c|c|c|c|}
\hline Amostra & RP-78 & RP-78 & RP-78 & RP-109 & RP-109 & RP-109 & RP-207 & RP-207 & RP-207 & RP-207 \\
\hline Análise & 1128 & 1130 & 1134 & 1123 & 1124 & 1125 & 1216 & 1217 & $\{218$ & 1219 \\
\hline _ocação & Cigim & C2Gin & C5Gin & cigin & C4G1n & C5G1n & Cigin & $\mathrm{C} 2 \mathrm{G} 1 \mathrm{n}$ & CAGtn & C5Gin \\
\hline $\mathrm{SiO}_{2}$ & 0.06 & 0.07 & 0.46 & 0.06 & 0.08 & 0.03 & 0.05 & 0.05 & 0.07 & 0.08 \\
\hline $\mathrm{TiO}_{2}$ & 3.28 & 0.51 & 0.41 & 15.46 & 14.72 & 14.95 & 12.45 & $\{5.12$ & 14.32 & 12.97 \\
\hline $\mathrm{Al}_{2} \mathrm{O}_{3}$ & 0.06 & 0.01 & $0.5 \xi$ & 0.29 & 0.13 & 0.16 & 0.2 & 0.28 & 0.39 & 0.37 \\
\hline $\mathrm{C}_{2} \mathrm{O}_{3}$ & 0 & 0.01 & 0.04 & 0 & 0.02 & 0.02 & 0.04 & 0 & 0.03 & 0 \\
\hline $\mathrm{FeO}$ & 33.15 & 30.79 & 29.79 & 40.28 & 39.84 & 39.74 & 37.35 & 40.46 & 39.82 & 38.94 \\
\hline $\mathrm{Fe}_{2} \mathrm{O}_{3}$ & 61.91 & 66.33 & 61.75 & 36.89 & 38.65 & 37.53 & 42.8 & 38.27 & 39.93 & 42.75 \\
\hline $\mathrm{MnO}$ & 0.81 & 0.09 & 0.12 & 3.91 & 3.89 & 3.86 & 4.53 & 4.05 & 3.54 & 3.55 \\
\hline $\mathrm{VigO}$ & 0.02 & 0 & 0.02 & 0.08 & 0.02 & 0.01 & 0 & 0.04 & 0.28 & 0.11 \\
\hline $\mathrm{CaO}$ & 0.01 & 0.02 & 0.04 & 0.01 & 0.04 & 0.03 & 0.02 & 0.02 & 0 & 0.01 \\
\hline $\mathrm{ZnO}$ & 0.04 & 0 & 0.05 & 0.3 & 0.28 & 0.25 & 0.04 & 0.2 & 0.23 & 0.27 \\
\hline $\mathrm{Nb}_{2} \mathrm{O}_{5}$ & 0.05 & 0.05 & 0.05 & 0.08 & 0.06 & & 0 & 0.02 & 0.02 & 0.02 \\
\hline Total & 99.39 & 97.88 & 93.24 & 97.36 & 97.73 & & 97.48 & 98.51 & 98.63 & 99.07 \\
\hline $\mathrm{FeOl}$ & 88.87 & 90.49 & 85.36 & 73. & 74.62 & & 75.87 & 74.9 & 75.76 & 77.41 \\
\hline $\mathrm{Si}$ & 0.063 & 0.073 & 0.526 & 0.075 & 0.099 & 0.038 & 0.059 & 0.061 & 0.083 & 0.093 \\
\hline Al & 0.074 & 0.012 & 0.687 & 0.427 & 0.189 & 0.239 & 0.277 & 0.402 & 0.546 & 0.505 \\
\hline $\mathrm{Ti}$ & 2.576 & 0.399 & 0.353 & 14,556 & $\{3.645$ & 14.281 & 11.028 & 13.859 & 12.807 & 11.313 \\
\hline $\mathrm{Cr}$ & 0 & 0.008 & 0.036 & 0 & 0.019 & 0.02 & 0.037 & 0 & 0.028 & 0 \\
\hline $\mathrm{Fe}^{2}$ & 0 & 0 & 0 & & & & 0 & 0 & 0 & 0 \\
\hline $\mathrm{Fe}^{3}$ & 48.601 & 51.924 & 53.131 & 34.712 & 35.805 & 35.830 & 37.891 & 35.057 & 35.691 & 37.265 \\
\hline $\mathrm{Mn}$ & 0.716 & 0.079 & 0.116 & & 4.060 & & 4.519 & 4.180 & 3.565 & 3.487 \\
\hline $\mathrm{Mg}$ & 0.031 & 0 & 0.034 & 0.14 & 0.037 & 0.01 & 0 & 0.07 & 0.496 & 0.19 \\
\hline $\mathrm{Ca}$ & 0.011 & 0.022 & 0.049 & 0.013 & 0.053 & 0.041 & 0.025 & 0.026 & 0 & 0.012 \\
\hline $\mathrm{Zn}$ & 0.031 & 0 & 0.042 & $0.27 \pi$ & 0.255 & 0.272 & 0.035 & 0.18 & 0.202 & 0.231 \\
\hline $\mathrm{Nb}$ & 0.024 & 0.024 & 0.0 & 0.0 & 0.033 & & 0 & & & 0.01 \\
\hline Cations & 52.127 & 52.541 & 55.000 & 54.399 & 54.195 & 54.8 & 53.871 & 53.849 & 53.429 & 53.106 \\
\hline $\mathrm{Fe}^{3}$-TRIVAL & 0.998 & 1.000 & 0.987 & 0.9 & 0.994 & 0.993 & 0.992 & 0.989 & 0.984 & 0.987 \\
\hline Al_TRIVAL & 0.002 & 0 & & 0.012 & 0.005 & & 0.007 & 0.011 & 0.015 & 0.013 \\
\hline $\mathrm{Cr}_{-}$TRI & 0 & 0 & & 0 & 0.001 & & 0.001 & 0 & 0.001 & 0 \\
\hline $\mathrm{XFe}$ & 0 & 0 & 0 & 0 & 0 & 0 & 0 & 0 & 0 & 0 \\
\hline$X M g$ & 1.000 & 0 & 1.000 & 1.000 & 1.000 & 1.000 & 0 & 1.000 & 1.000 & 1.000 \\
\hline $\mathrm{PMSiO}_{2}$ & 0.001 & 0.001 & 0.008 & 0.0 & 0.001 & 0 & 0.001 & 0.001 & 0.001 & 0.001 \\
\hline $\mathrm{PMTIO}_{2}$ & 0.041 & 0.006 & 0.005 & 0.1 & 0.184 & 0.187 & 0.156 & 0.18 & 0.179 & 0.162 \\
\hline $\mathrm{PMAl}_{2} \mathrm{O}_{3}$ & 0.001 & 0 & 0.005 & 0.0 & 0.001 & 0.002 & 0.002 & 0.003 & 0.004 & 0.004 \\
\hline PMFeOI & 1.237 & 1.259 & 1.188 & 1.0 & 1.039 & 1.023 & 1.056 & 1.042 & 1.054 & 1.077 \\
\hline PMFeO & 0.461 & 0.429 & & & 0.554 & 0.553 & 0.52 & 0.56 & 0.554 & 0.542 \\
\hline $\mathrm{PMFe}_{2} \mathrm{O}_{3}$ & 0.388 & 0.415 & 0.387 & & 0.242 & & 0.268 & & & 0.268 \\
\hline PMMnO & 0.011 & 0.001 & 0.002 & 0.05 & 0.055 & 0.054 & 0.064 & 0.057 & 0.05 & 0.05 \\
\hline PMMgO & 0 & 0 & 0 & & 0 & 0 & 0 & & 0.007 & 0.003 \\
\hline PMZno & 0 & 0 & 0.001 & 0.0 & 0.003 & 0.004 & 0 & 0.002 & 0.003 & 0.003 \\
\hline SUMi & 1.163 & 1.246 & 1.160 & 0.693 & 0.726 & 0.705 & 0.804 & 0.719 & 0.75 & 0.803 \\
\hline
\end{tabular}


Tabela 17.3 - Composição quimica de magnetitas das rochas de Cerrito (\% peso)

\begin{tabular}{|c|c|c|c|c|c|c|c|c|c|c|}
\hline $\begin{array}{l}\text { Amostra } \\
\text { Análise }\end{array}$ & $\begin{array}{c}\text { RP-88 } \\
1135\end{array}$ & $\begin{array}{c}\text { RP-88 } \\
3136\end{array}$ & $\begin{array}{c}\text { RP-88 } \\
1137\end{array}$ & $\begin{array}{c}\text { RP-88 } \\
1138\end{array}$ & $\begin{array}{c}\text { RP-88 } \\
1139\end{array}$ & $\begin{array}{c}\text { RP-88 } \\
1140\end{array}$ & RP-198 & RP-198 & RP-198 & $\begin{array}{c}\text { RP-198 } \\
1215\end{array}$ \\
\hline Locação & Cigín & C2G1n & C3G1n & C4G1n & C4G2n & $\mathrm{C} 4 \mathrm{G} 2 \mathrm{~b}$ & C3G1b & C3G1n & C4G1n & C5G1n \\
\hline $\mathrm{SiO}_{2}$ & 0.05 & 0.1 & 3.79 & 0.06 & 0.13 & 0.02 & 0.14 & 0.02 & 0.06 & 0.03 \\
\hline $\mathrm{TiO}_{2}$ & 9.64 & 9.35 & 6.58 & 10.78 & 6.08 & 8.87 & 4.99 & 7.64 & 5.3 & 4.68 \\
\hline $\mathrm{Al}_{2} \mathrm{O}_{3}$ & 0.13 & 0.24 & 1.36 & 0.23 & 0.87 & 0.15 & 5.24 & 2.8 & 2.75 & 1.93 \\
\hline $\mathrm{Cr}_{2} \mathrm{O}_{3}$ & 0 & 0.01 & 0.01 & 0 & 0 & 0 & 0.03 & 0 & 0.02 & 0 \\
\hline $\mathrm{FeO}$ & 36.06 & 36.39 & 39.86 & 36.79 & 34.14 & 35.62 & 33.85 & 36.17 & 35.07 & 33.7 \\
\hline $\mathrm{Fe}_{2} \mathrm{O}_{3}$ & 48.76 & 49.4 & 45.35 & 46.21 & 54.09 & 50.47 & 53.55 & 50.78 & 54.3 & 56.21 \\
\hline $\mathrm{MnO}$ & 3.26 & 2.86 & 1.98 & 3.37 & 1.94 & 2.83 & 0.49 & 0.94 & 0.54 & 0.46 \\
\hline $\mathrm{MgO}$ & 0 & 0 & 0.04 & 0.02 & 0.01 & 0.01 & 1.26 & 0.78 & 0.11 & 0.47 \\
\hline $\mathrm{CaO}$ & 0.03 & 0.04 & 0.05 & 0 & 0.04 & 0 & 0.05 & 0.02 & 0.03 & 0.02 \\
\hline Zno & 0.18 & 0.23 & 0.21 & 0.23 & 0.08 & 0.22 & 0.42 & 0.13 & 0.19 & 0.15 \\
\hline $\mathrm{Nb}_{2} \mathrm{O}_{5}$ & 0.06 & 0.02 & 0 & 0.01 & 0.01 & 0 & 0.01 & 0 & 0.01 & 0 \\
\hline Total & 98.17 & 98.61 & 99.23 & 97.7 & 97.39 & 98.19 & 100.03 & 99.28 & 98.38 & 97.65 \\
\hline $\mathrm{FeOl}$ & 79.94 & 80.85 & 80.67 & 78.38 & 82.82 & 81.04 & 82.04 & 81.87 & 83.94 & 84.29 \\
\hline $\mathrm{Si}$ & 0.057 & 0.113 & 4.270 & 0.07 & 0.144 & 0.022 & 0.131 & 0.021 & 0.064 & 0.032 \\
\hline Al & 0.173 & 0.278 & 1.804 & 0.314 & 1.131 & 0.198 & 5.764 & 3.441 & 3.452 & 2.416 \\
\hline $\mathrm{Ti}$ & 8.206 & 7.915 & 5.576 & 9.406 & 5.049 & 7.483 & 3.506 & 5.997 & 4.250 & 3.742 \\
\hline $\mathrm{Cr}$ & 0 & 0.009 & 0.009 & 0 & 0 & 0 & 0.022 & 0 & 0.017 & 0 \\
\hline $\mathrm{Fe}^{2}$ & 0 & 0 & 0 & 0 & 0 & 0 & 0 & 0 & 0 & 0 \\
\hline $\mathrm{Fe}^{3}$ & 41.483 & 41.795 & 38.408 & 40.298 & 44.894 & 42.555 & 37.604 & 39.837 & 43.515 & 44.917 \\
\hline $\mathrm{Mn}$ & 3.125 & 2.726 & 1.889 & 3.311 & 1.814 & 2.689 & 0.388 & 0.831 & 0.488 & 0.414 \\
\hline $\mathrm{Mg}$ & 0 & 0 & 0.067 & 0.035 & 0.016 & 0.017 & 1.755 & 1.213 & 0.175 & 0.745 \\
\hline $\mathrm{Ca}$ & 0.036 & 0.048 & 0.06 & 0 & 0.047 & 0 & 0.05 & 0.022 & 0.034 & 0.023 \\
\hline $\mathrm{Zn}$ & 0.15 & 0.191 & 0.175 & 0.197 & 0.065 & 0.182 & 0.29 & 0.1 & 0.15 & 0.118 \\
\hline $\mathrm{Nb}$ & 0.031 & 0.01 & 0 & 0.005 & 0.005 & 0 & 0.004 & 0 & 0.005 & 0 \\
\hline Cations & 53.261 & 53.085 & 52.258 & 53.636 & 53.165 & 53.146 & 49.514 & 51.462 & 52.150 & 52.407 \\
\hline Fe'_tRIVAL & 0.996 & 0.993 & 0.955 & 0.992 & 0.975 & 0.995 & 0.867 & 0.92 & 0.926 & 0.949 \\
\hline Al_TRIVAL & 0.004 & 0.007 & 0.045 & 0.008 & 0.025 & 0.005 & 0.133 & 0.08 & 0.073 & 0.051 \\
\hline $\mathrm{Cr}_{\text {. TRIVAL }}$ & 0 & 0 & 0 & 0 & 0 & 0 & 0.001 & 0 & 0 & 0 \\
\hline $\mathrm{XFe}$ & 0 & 0 & 0 & 0 & 0 & 0 & 0 & 0 & 0 & 0 \\
\hline $\mathrm{XMg}$ & 0 & 0 & 1.000 & 1.000 & 1.000 & 1.000 & 1.000 & 1.000 & 1.000 & 1.000 \\
\hline $\mathrm{PMSiO}_{2}$ & 0.001 & 0.002 & 0.063 & 0.001 & 0.002 & 0 & 0.002 & 0 & 0.001 & 0 \\
\hline $\mathrm{PMTIO}_{2}$ & 0.121 & 0.117 & 0.082 & 0.135 & 0.076 & 0.111 & 0.062 & 0.096 & 0.066 & 0.059 \\
\hline $\mathrm{PMAl}_{2} \mathrm{O}_{3}$ & 0.001 & 0.002 & 0.013 & 0.002 & 0.009 & 0.001 & 0.051 & 0.027 & 0.027 & 0.019 \\
\hline PMFeOI & 1.113 & 1.125 & 1.123 & 1.091 & 1.153 & 1.128 & $\{.142$ & 1.139 & 1.168 & 1.173 \\
\hline PMFeO & 0.502 & 0.506 & 0.555 & 0.512 & 0.475 & 0.496 & 0.471 & 0.503 & 0.488 & 0.469 \\
\hline $\mathrm{PMFe}_{2} \mathrm{O}_{3}$ & 0.305 & 0.309 & 0.284 & 0.289 & 0.339 & 0.316 & 0.335 & 0.318 & 0.34 & 0.352 \\
\hline PMMnO & 0.046 & 0.04 & 0.028 & 0.048 & 0.027 & 0.04 & 0.007 & 0.013 & 0.008 & 0.006 \\
\hline PMMgO & 0 & 0 & 0.001 & 0 & 0 & 0 & 0.031 & 0.019 & 0.003 & 0.012 \\
\hline PMZnO & 0.002 & 0.003 & 0.003 & 0.003 & 0.001 & 0.003 & 0.005 & 0.002 & 0.002 & 0.002 \\
\hline SUM1 & 0.916 & 0.928 & 0.852 & 0.868 & 1.016 & 0.948 & 1.006 & 0.954 & 1.020 & 1.056 \\
\hline
\end{tabular}


Tabela 17.4 - Composição química de magnetitas das rochas da llha Fecho dos Morros (\% peso)

Amostra $\quad$ RP-91 RP-91 RP-201A RP-201A RP-201A RP-201A RP-201A RP-205 RP-205 RP-205

$\begin{array}{lllllllllll}\text { Analise } & 1154 & 1156 & 1200 & 1201 & 1202 & 1203 & 1204 & 1206 & 1207 & 1208\end{array}$

Locação C1G1n C3Gin C3Gín C3G1b C4Gin C4G1b C5G1n C2Gin C3Gín CAGín

$\begin{array}{lllllllllll}\mathrm{SiO}_{2} & 0.02 & 0.13 & 0.03 & 0.06 & 0.04 & 0.05 & 0.12 & 0.35 & 0.21 & 0.88\end{array}$

$\begin{array}{lcccccccccc}\mathrm{TiO}_{2} & 18.01 & 10.62 & 13.44 & 7.56 & 14.11 & 14.86 & 11.46 & 3.54 & 4.82 & 1.27 \\ \mathrm{Al}_{2} \mathrm{O}_{3} & 0.16 & 0.11 & 0.27 & 0.27 & 0.46 & 0.48 & 0.32 & 0.08 & 0.08 & 0.12\end{array}$

$\begin{array}{ccccccccccc}\mathrm{Cr}_{2} \mathrm{O}_{3} & 0 & 0.09 & 0.01 & 0 & 0.01 & 0 & 0 & 0.03 & 0.01 & 0\end{array}$

$\begin{array}{lllllllllll}\mathrm{FeO} & 43.8 & 34.63 & 40.21 & 36.52 & 38.66 & 39.86 & 37.1 & 32.54 & 33.82 & 30.86\end{array}$

$\begin{array}{lllllllllll}\mathrm{Fe}_{2} \mathrm{O}_{3} & 32.63 & 43.49 & 41.47 & 53.39 & 39.82 & 39.02 & 44.5 & 56.69 & 55.31 & 59.46\end{array}$

$\begin{array}{lllllllllll}\mathrm{MnO} & 2.99 & 4.01 & 2.7 & 1.51 & 5.13 & 4.73 & 3.82 & 0.16 & 0.1 & 0.26\end{array}$

$\begin{array}{lllllllllll}\mathrm{MgO} & 0.06 & 0.05 & 0 & 0.01 & 0 & 0.01 & 0.03 & 0 & 0 & 0.06\end{array}$

$\begin{array}{lllllllllll}\mathrm{CaO} & 0.05 & 0.04 & 0.03 & 0.01 & 0.01 & 0.02 & 0.02 & 0.02 & 0.04 & 0.03 \\ \mathrm{ZnO} & 0.33 & 0.04 & 0.05 & 0.02 & 0.03 & 0.05 & 0.01 & 0.08 & 0.06 & 0.07\end{array}$

$\begin{array}{lllllllllll}\text { ZnO } & 0.33 & 0.24 & 0.05 & 0.02 & 0.03 & 0.05 & 0.01 & 0.08 & 0.06 & 0.07\end{array}$

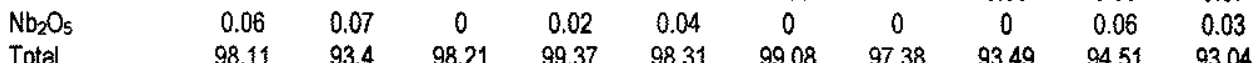

$\begin{array}{lllllllllll}\mathrm{FeOI} & 73.17 & 73.77 & 77.53 & 84.57 & 74.5 & 74.98 & 77.15 & 83.56 & 83.6 & 84.37\end{array}$

$\begin{array}{lllllllllll}\mathrm{Si} & 0.003 & 0.027 & 0.005 & 0.012 & 0.007 & 0.009 & 0.023 & 0.077 & 0.045 & 0.205 \\ \mathrm{Al} & 0.031 & 0.027 & 0.057 & 0.062 & 0.01 & 0.02 & 0.073 & 0.021 & 0.02 & 0.033\end{array}$

$\begin{array}{lllllllllll}\text { Al } & 0.031 & 0.027 & 0.057 & 0.062 & 0.101 & 0.102 & 0.073 & 0.021 & 0.02 & 0.033\end{array}$

$\begin{array}{lllllllllll}\mathrm{Ti} & 2.219 & 1.655 & 1.804 & 1.117 & 1.969 & 2.012 & 1.667 & 0.587 & 0.769 & 0.222 \\ \mathrm{Cr} & 0 & 0.002 & 0.001 & 0 & 0.001 & 0 & 0 & 0.005 & 0.002 & 0\end{array}$

$\begin{array}{lcccccccccc}\mathrm{Cr} & 0 & 0.002 & 0.001 & 0 & 0.001 & 0 & 0 & 0.005 & 0.002 & 0 \\ \mathrm{Fe}^{2} & 5.999 & 6.001 & 6.000 & 6.001 & 6.000 & 6.000 & 5.999 & 5.999 & 6.001 & 6.000\end{array}$

$\begin{array}{lllllllllll}\mathrm{Fe}^{2} & 5.999 & 6.001 & 6.000 & 6.001 & 6.000 & 6.000 & 5.999 & 5.999 & 6.001 & 6.000 \\ \mathrm{Fe}^{3} & 4.018 & 6.774 & 5.563 & 7.886 & 5.555 & 5.280 & 6.469 & 9.395 & 8.822 & 10.393\end{array}$

$\begin{array}{lllllllllll}\mathrm{Mn} & 0.415 & 0.704 & 0.408 & 0.251 & 0.806 & 0.721 & 0.626 & 0.03 & 0.018 & 0.051\end{array}$

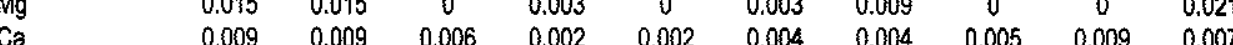

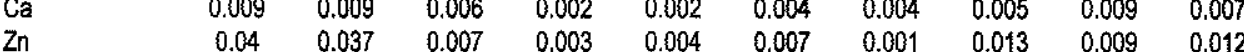

$\begin{array}{lccccccccccc}\mathrm{Zn} & 0.04 & 0.037 & 0.007 & 0.003 & 0.004 & 0.007 & 0.001 & 0.013 & 0.009 & 0.012 \\ \mathrm{Nb} & 0.004 & 0.007 & 0 & 0.002 & 0.003 & 0 & 0 & 0 & 0.006 & 0.003\end{array}$

$\begin{array}{lllllllllll}\text { Cátions } & 12.753 & 15.258 & 13.85\} & 15.339 & 14.448 & 14.438 & 14.871 & 16.132 & \$ 5.701 & 16.947\end{array}$

$\begin{array}{llllllllllll}\text { Fe } 3 \text { _TRIVAL } & 0.992 & 0.996 & 0.99 & 0.992 & 0.982 & 0.981 & 0.989 & 0.997 & 0.998 & 0.997\end{array}$

$\begin{array}{lllllllllll}\text { AL_TIVAL } & 0.008 & 0.004 & 0.01 & 0.008 & 0.018 & 0.019 & 0.011 & 0.002 & 0.002 & 0.003\end{array}$

$\begin{array}{llllllllll}0.998 & 0.998 & 1.000 & 1.000 & 1.000 & 1.000 & 0.999 & 1.000 & 1.000 & 0.097\end{array}$

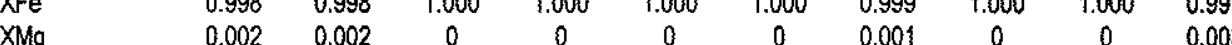

$\begin{array}{lcccccccccc}\mathrm{XMg} & 0.002 & 0.002 & 0 & 0 & 0 & 0 & 0.003 & 0 & 0 & 0.003 \\ \mathrm{PMSSO}_{2} & 0 & 0.002 & 0 & 0.001 & 0.001 & 0.001 & 0.002 & 0.006 & 0.003 & 0.015\end{array}$

$\begin{array}{lcccccccccc}\mathrm{PMSiO}_{2} & 0 & 0.002 & 0 & 0.001 & 0.001 & 0.001 & 0.002 & 0.006 & 0.003 & 0.015 \\ \mathrm{PMTiO}_{2} & 0.225 & 0.133 & 0.168 & 0.095 & 0.177 & 0.186 & 0.143 & 0.044 & 0.06 & 0.016\end{array}$

$\begin{array}{lllllllllll}\mathrm{PMA}_{2} \mathrm{O}_{3} & 0.002 & 0.001 & 0.003 & 0.003 & 0.005 & 0.005 & 0.003 & 0.001 & 0.001 & 0.001\end{array}$

$\begin{array}{lllllllllll}\text { PMFeOI } & 1.018 & 1.027 & 1.079 & 1.177 & 1.037 & 1.044 & 1.074 & 1.163 & 1.164 & 1.174\end{array}$

$\begin{array}{lllllllllll}\mathrm{PMFEO} & 0.61 & 0.482 & 0.56 & 0.508 & 0.538 & 0.555 & 0.516 & 0.453 & 0.471 & 0.43\end{array}$

$\begin{array}{lllllllllll}\mathrm{PMFe}_{2} \mathrm{O}_{3} & 0.204 & 0.272 & 0.26 & 0.334 & 0.249 & 0.244 & 0.279 & 0.355 & 0.346 & 0.372\end{array}$

$\begin{array}{lllllllllll}\mathrm{PMMnO} & 0.042 & 0.057 & 0.038 & 0.021 & 0.072 & 0.067 & 0.054 & 0.002 & 0.001 & 0.004\end{array}$

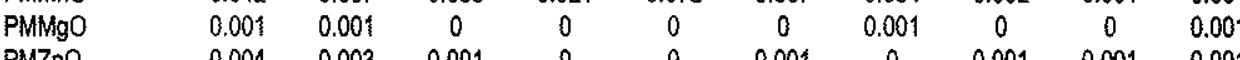

$\begin{array}{llllccccccc}\text { PMZnO } & 0.004 & 0.003 & 0.001 & 0 & 0 & 0.001 & 0 & 0.001 & 0.001 & 0.001 \\ \text { SUM1 } & 0.613 & 0.817 & 0.779 & 1.003 & 0.748 & 0.733 & 0.836 & 1.065 & 1.039 & 1.117\end{array}$ 
Tabela 17.5 - Composição química de magnefitas das rochas de Săo Pedro (\% peso)

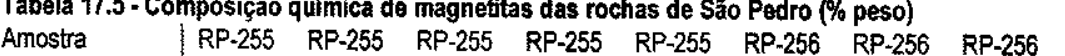

Locaçäo

$\mathrm{TiO}_{2}$

$\mathrm{Al}_{2} \mathrm{O}_{3}$

$\mathrm{Cr}_{2} \mathrm{O}_{3}$

$\mathrm{FeO}$

$\mathrm{Fe}_{2} \mathrm{O}_{3}$

$\mathrm{MnO}$

$\mathrm{MgO}$

$\mathrm{CaO}$

$\mathrm{Nb}_{2} \mathrm{O}_{5}$

$\mathrm{Si}$

$\mathrm{Ti}$

$\mathrm{Fe}^{2}$

$\mathrm{Fe}^{3}$

Mn

$\mathrm{Mg}$

$\mathrm{Ca}$

$\mathrm{Nb}$

Cátions

$\mathrm{Fe}^{3}$ _TRIVAL

Al TRIVAL

Cr_TRIVAL

$X \mathrm{Fe}$

$\mathrm{XMg}$

$\mathrm{PMSiO}_{2}$

$\mathrm{PMTiO}_{2}$

$\mathrm{PMAl}_{2} \mathrm{O}_{3}$

PMFeOI

$\mathrm{PMFeO}$

$\mathrm{PMFe}_{2} \mathrm{O}_{3}$

PMMnO

$\mathrm{PMMOO}$

SUM1

\begin{tabular}{|c|c|c|c|c|c|c|c|}
\hline$R P-255$ & RP-255 & RP-255 & RP-255 & RP-255 & $\mathrm{RP}-256$ & RP-256 & RP-256 \\
\hline 1100 & 1149 & 1150 & 1151 & 1152 & 1145 & $\{146$ & 1147 \\
\hline $\mathrm{C} 2 \mathrm{G} 2 \mathrm{n}$ & C4Gin & $\mathrm{C} 3 \mathrm{G} 1 \mathrm{n}$ & C2Gin & Cigin & $\mathrm{C} 2 \mathrm{G} 1 \mathrm{n}$ & C3G1b & C1Gin \\
\hline 0.02 & 0.02 & 0.09 & 0.03 & 0.03 & 0.02 & 0.05 & 0 \\
\hline 11.6 & 13.01 & 12.94 & 16.16 & 11.72 & 4.91 & 5.93 & 4.66 \\
\hline 1.03 & 0.94 & 1.13 & 0.62 & 0.79 & 0.54 & 0.58 & 0.55 \\
\hline 0 & 0 & 0 & 0 & 0 & 0.01 & 0 & 0 \\
\hline 39.75 & 40.15 & 39.54 & 42.06 & 38.49 & 32.54 & 33.3 & 34.75 \\
\hline 44.66 & 41.36 & 40.51 & 34.5 & 42.37 & 58.24 & 55.63 & 57.23 \\
\hline 1.86 & 2.13 & 2.18 & 2.73 & 2.04 & 2.49 & 2.58 & 2.33 \\
\hline 0.02 & 0.04 & 0.23 & 0.02 & 0.03 & 0.05 & 0.04 & 0 \\
\hline 0.02 & 0.03 & 0.05 & 0.04 & 0.06 & 0 & 0.13 & 0.01 \\
\hline 0 & 0.29 & 0.27 & 0.19 & 0.2 & 0.23 & 0.29 & 0.34 \\
\hline 0 & 0.01 & 0.04 & 0 & 0.04 & 0 & 0.05 & 0 \\
\hline 98.96 & 97.98 & 96.98 & 96.35 & 95.77 & 99.03 & 98.58 & 96.87 \\
\hline 79.94 & 77.37 & 76 & 73.11 & 76.62 & 84.96 & 83.37 & 83.26 \\
\hline 0.004 & 0.004 & 0.016 & 0.005 & 0.006 & 0.004 & 0.011 & 0 \\
\hline 0.219 & 0.198 & 0.241 & 0.125 & 0.173 & 0.14 & 0.147 & 0.146 \\
\hline 1.575 & 1.749 & 1.766 & 2.073 & 1.643 & 0.814 & 0.961 & 0.792 \\
\hline 0 & 0 & 0 & 0 & 0 & 0.002 & 0 & 0 \\
\hline 6.001 & 6.000 & 5.999 & 6.000 & 6.000 & 6.001 & 6.000 & 6.001 \\
\hline 6.060 & 5.556 & 5.525 & 4.424 & 5.937 & 9.654 & 9.009 & 9.723 \\
\hline 0.284 & 0.322 & 0.335 & 0.394 & 0.322 & 0.465 & 0.471 & 0.446 \\
\hline 0.005 & 0.011 & 0.062 & 0.005 & 0.008 & 0.016 & 0.013 & 0 \\
\hline 0.004 & 0.006 & 0.01 & 0.007 & 0.012 & 0 & 0.03 & 0.002 \\
\hline 0 & 0.038 & 0.036 & 0.024 & 0.028 & 0.037 & 0.046 & 0.057 \\
\hline 0 & 0.001 & 0.003 & 0 & 0.003 & 0 & 0.005 & 0 \\
\hline 14.152 & 13.885 & 13.993 & 13.057 & 14.132 & $\{7.133$ & $\{6.693$ & 17.167 \\
\hline 0.965 & 0.966 & 0.958 & 0.973 & 0.972 & 0.986 & 0.984 & 0.985 \\
\hline 0.035 & 0.034 & 0.042 & 0.027 & 0.028 & 0.014 & 0.016 & 0.015 \\
\hline 0 & 0 & 0 & 0 & 0 & 0 & 0 & 0 \\
\hline 0.999 & 0.998 & 0.99 & 0.999 & 0.999 & 0.997 & 0.998 & 1.000 \\
\hline 0.00$\}$ & 0.002 & 0.01 & 0.001 & 0.001 & 0.003 & 0.002 & 0 \\
\hline 0 & 0 & 0.001 & 0 & 0 & 0 & 0.001 & 0 \\
\hline 0.145 & 0.163 & 0.162 & 0.202 & 0.147 & 0.061 & 0.074 & 0.058 \\
\hline 0.01 & 0.009 & 0.011 & 0.006 & 0.008 & 0.005 & 0.006 & 0.005 \\
\hline 1.113 & 1.077 & 1.058 & 1.018 & $\{.066$ & 1.182 & 1.160 & 1.159 \\
\hline 0.553 & 0.559 & 0.55 & 0.585 & 0.536 & 0.453 & 0.463 & 0.442 \\
\hline 0.28 & 0.259 & 0.254 & $0.2 \uparrow 6$ & 0.265 & 0.365 & 0.348 & 0.358 \\
\hline 0.026 & 0.03 & 0.031 & 0.038 & 0.029 & 0.035 & 0.036 & 0.033 \\
\hline 0 & 0.001 & 0.006 & 0 & 0.001 & 0.001 & 0.001 & 0 \\
\hline 0 & 0.004 & 0.003 & 0.002 & 0.002 & 0.003 & 0.004 & 0.004 \\
\hline 0.839 & 0.777 & 0.761 & 0.648 & 0.796 & 1.094 & 1.045 & 1.075 \\
\hline
\end{tabular}

Morro Conceição (5peso)

RP-259 RP-259 RP-259

$\begin{array}{lll}1357 & 1158 & 1159\end{array}$

0.11 c1G2il c1G21

$\begin{array}{lll}11.06 & 18.67 & 12.95\end{array}$

$\begin{array}{lll}0.56 & 0.35 & 0.25\end{array}$

$\begin{array}{ccc}0.56 & 0.35 & 0.25 \\ 0 & 0 & 0 \\ 39.29 & 45.92 & 41.43\end{array}$

$\begin{array}{lll}39.29 & 45.92 & 41.43 \\ 45.09 & 30.98 & 42.69\end{array}$

$\begin{array}{lll}1.18 & 1.78 & 1.2\end{array}$

$\begin{array}{lll}0 & 0 & 0.01\end{array}$

$\begin{array}{lll}0.02 & 0 & 0\end{array}$

$\begin{array}{lll}0.23 & 0.22 & 0.14\end{array}$

$\begin{array}{lll}0.05 & 0.14 & 0\end{array}$

$\begin{array}{lll}97.59 & 98.1 & 98.74\end{array}$

$\begin{array}{lll}79.87 & 73.8 & 79.85\end{array}$

$\begin{array}{lll}0.02 & 0.006 & 0.012\end{array}$

$\begin{array}{lll}0.519 & 2.194 & 1.687\end{array}$

0000

$\begin{array}{lll}6.000 & 6.000 & 6.001\end{array}$

$\begin{array}{lll}6.189 & 3.639 & 5.558\end{array}$

$\begin{array}{lll}0.182 & 0.236 & 0.176\end{array}$

$\begin{array}{ccc}0 & 0 & 0.003\end{array}$

$\begin{array}{ccc}0.004 & 0 & 0 \\ 0.031 & 0.025 & 0.018\end{array}$

$\begin{array}{lll}0.004 & 0.01 & 0\end{array}$

$\begin{array}{lll}14.069 & 12.174 & 13.505\end{array}$

$\begin{array}{lll}0.981 & 0.983 & 0.991\end{array}$

$\begin{array}{lll}0.019 & 0.017 & 0.009\end{array}$

$\begin{array}{ccc}0 & 0 & 0\end{array}$

$\begin{array}{lll}1.000 & 1.000 & 1.000\end{array}$

$\begin{array}{ccc}0 & 0 & 0 \\ 0.002 & 0.001 & 0.001\end{array}$

$\begin{array}{lll}0.138 & 0.234 & 0.162\end{array}$

$0.005 \quad 0.003 \quad 0.002$

$\begin{array}{lll}1.112 & 1.027 & 1.002\end{array}$

$\begin{array}{lll}0.547 & 0.030 & 0.577\end{array}$

$\begin{array}{lll}0.282 & 0.194 & 0.267\end{array}$

$\begin{array}{lll}0.017 & 0.025 & 0.017\end{array}$

$\begin{array}{ccc}0 & 0 & 0\end{array}$

$\begin{array}{lll}0.847 & 0.582 & 0.802\end{array}$
Morro Distante (\% peso)

RP-264 RP-264 RP-264

$\begin{array}{lll}1209 & 1210 \quad 1211\end{array}$

C1G1n C1G1b C2Gin

$\begin{array}{lll}0.05 & 0.02 & 0.13 \\ 0.51 & 0.72 & 0.27\end{array}$

$\begin{array}{lll}0.51 & 0.72 & 0.27 \\ 0.44 & 0.45 & 0.29\end{array}$

$\begin{array}{lll}0 & 0.01 & 0.01\end{array}$

$\begin{array}{lll}30.98 & 30.82 & 30.58\end{array}$

$\begin{array}{lll}66.59 & 65.58 & 66.01\end{array}$

$\begin{array}{lll}0.12 & 0.06 & 0.1 \\ 0.06 & 0.08 & 0\end{array}$

$\begin{array}{lll}0.01 & 0.06 & 0.06\end{array}$

$\begin{array}{lll}0.12 & 0.05 & 0\end{array}$

$\begin{array}{lll}0.04 & 0.04 & 0.05\end{array}$

$\begin{array}{lll}98.92 & 97.89 & 97.5\end{array}$

$\begin{array}{lll}90.91 & 89.84 & 89.99\end{array}$

$\begin{array}{lll}0.012 & 0.005 & 0.031\end{array}$

$\begin{array}{lll}0.12 & 0.123 & 0.08\end{array}$

$\begin{array}{lll}0.089 & 0.126 & 0.048\end{array}$

$\begin{array}{ccc}0 & 0.002 & 0.002\end{array}$

$\begin{array}{lll}6.000 & 5.999 & 6.000\end{array}$

$\begin{array}{lll}0.024 & 0.012 & 0.02\end{array}$

$\begin{array}{lll}0.021 & 0.028 & 0\end{array}$

$\begin{array}{lll}0.002 & 0.015 & 0.015\end{array}$

$0.004 \quad 0.004 \quad 0.005$

$\begin{array}{lll}17.886 & 17.798 & 17.844\end{array}$

$\begin{array}{lll}0.99 & 0.989 & 0.993\end{array}$

$\begin{array}{lll}0.01 & 0.011 & 0.007\end{array}$

$\begin{array}{ccc}0 & 0 & 0 \\ 0.997 & 0.995 & 1.000\end{array}$

$\begin{array}{lll}0.003 & 0.005 & 0\end{array}$

$\begin{array}{lll}0.001 & 0 & 0.002\end{array}$

$\begin{array}{lll}0.006 & 0.009 & 0.003\end{array}$

$\begin{array}{lll}0.004 & 0.004 & 0.003\end{array}$

$\begin{array}{lll}1.265 & 1.250 & 1.252\end{array}$

$\begin{array}{lll}0.431 & 0.429 & 0.426\end{array}$

$\begin{array}{lll}0.417 & 0.411 & 0.413\end{array}$

$\begin{array}{lll}0.002 & 0.001 & 0.001\end{array}$

$\begin{array}{lll}0.001 & 0.002 & 0\end{array}$

$\begin{array}{lll}0.001 & 0.001 & 0 \\ 1.251 & 1232 & 1.240\end{array}$ 
Tabela 18.0 - Composição química de ilmenitas das rochas da Província Alcalina Alto Paraguai (\% peso)

\begin{tabular}{|c|c|c|c|c|c|c|c|c|c|c|c|c|c|c|c|}
\hline Amostra & RP-32 & RP-32 & RP-44 & $R P-44$ & RP-44 & RP-50 & RP-52 & RP-58 & RP-58 & RP.74 & RP-78 & RP-78 & RP-78 & RP-91 & RP-91 \\
\hline Análise & 1168 & 1169 & 1148 & 1149 & 1150 & 1161 & 1164 & 1146 & 1147 & 1127 & 1131 & 1132 & $\$ 133$ & 1155 & 1456 \\
\hline Locação & $\mathrm{C} 3 \mathrm{GH}$ & C3G1 & C1G1 & $\mathrm{C}_{1 \mathrm{G} 2}$ & $\mathrm{C} 2 \mathrm{G1}$ & C3G1 & $\mathrm{C} 2 \mathrm{G} 1$ & C1G1 & C2G1 & C3G1 & C3G1 & C3G1 & CAGI & C3G & C3G2 \\
\hline $\mathrm{SiO}_{2}$ & 0.04 & 0.05 & 0.12 & 0.02 & 0.17 & 0 & 0.03 & 0.23 & 0.53 & 0.04 & 0.04 & 0.02 & 0 & 0.03 & 0.13 \\
\hline $\mathrm{TiO}_{2}$ & 51.91 & 52.19 & 54.62 & 49.32 & 8.29 & 50.92 & 48.74 & 52.83 & 90.05 & 50.21 & 93.65 & 49.9 & 49.81 & 51.31 & 10.62 \\
\hline $\mathrm{Al}_{2} \mathrm{O}_{3}$ & 0 & 0 & 0 & 0.01 & 0.21 & 0.01 & 0.02 & 0.04 & 0.1 & 0.02 & 0.1 & 0 & 0.02 & 0.03 & 0.11 \\
\hline $\mathrm{Cr}_{2} \mathrm{O}_{3}$ & 0.08 & 0 & 0.03 & 0.02 & 0.01 & 0 & 0 & 0 & 0.01 & 0.03 & 0 & 0 & 0.01 & 0 & 0.01 \\
\hline $\mathrm{FeO}$ & 31.542 & 26.225 & 47.852 & 29.459 & 6.826 & 36.212 & 38.943 & 46.774 & 82. 196 & 35.135 & 84.927 & 29.890 & 27.734 & 38.009 & 5.532 \\
\hline $\mathrm{Fe}_{2} \mathrm{O}_{3}$ & 0.342 & -0.061 & -13.711 & 4.785 & 82.366 & 2.351 & 2,428 & -9.684 & -87.575 & 2.581 & -90.961 & 2.231 & 3.059 & 2.110 & 75.744 \\
\hline $\mathrm{MnO}$ & 15.02 & 20.51 & 1.33 & $\{3.87$ & 0.86 & 9.36 & 5.56 & 0.96 & 0.12 & 8.91 & 0.06 & 14.74 & 16.8 & 7.77 & 4.01 \\
\hline $\mathrm{MgO}$ & 0.02 & 0.02 & 0.04 & 0.03 & 0.01 & 0.06 & 0.02 & 0.01 & 0.01 & 0.01 & 0 & 0.03 & 0.01 & 0.12 & 0.05 \\
\hline $\mathrm{CaO}$ & 0.02 & 0.02 & 0 & 0 & 0.01 & 0.01 & 0.01 & 0.06 & 0.08 & 0.03 & 0.04 & 0.03 & 0.02 & 0.03 & 0.04 \\
\hline $\mathrm{ZnO}$ & 0 & 0.09 & 0.04 & 0.86 & 0.11 & 0.17 & 0.15 & 0 & 0.02 & 0 & 0.04 & 0.11 & 0.21 & 0.27 & 0.24 \\
\hline $\mathrm{Nb}_{2} \mathrm{O}_{5}$ & 0.26 & 0.26 & 0.86 & 0.8 & 0.02 & 0.56 & 1.8 & 0.32 & 2.32 & 0.2 & 2.15 & 0.74 & 0.34 & 0.14 & 0.07 \\
\hline Total & 99.23 & 99.22 & 91.18 & 99.17 & 98.88 & 99.65 & 97.7 & 94.54 & 87.86 & 98.17 & 90.05 & 97.69 & 98.04 & 99.82 & 96.56 \\
\hline $\mathrm{FeOl}$ & 31.85 & 26.17 & 35.5 & 33.77 & 81.03 & 38.33 & 41.13 & 38.05 & 3.3 & 37.46 & 2.98 & 31.9 & 30.49 & 39.91 & 73.77 \\
\hline \multicolumn{16}{|c|}{ Formula estrutural calculada na base de 6 atornos de oxigénio } \\
\hline $\mathrm{Si}$ & 0.009 & 0.014 & 0.018 & 0.005 & 0.179 & 0 & 0.006 & 0.035 & 0.046 & 0.008 & 0.003 & 0.005 & 0 & 0.006 & 0.169 \\
\hline $\mathrm{Ti}$ & 8.880 & 10.742 & 6.159 & 9.035 & 6.559 & 7.588 & 6.754 & 6.095 & 5.912 & 7.712 & 5.951 & 9.009 & 9.692 & 7.284 & 10.367 \\
\hline Al & 0 & 0 & 0 & 0.003 & 0.26 & 0.002 & 0.004 & 0.007 & 0.01 & 0.005 & 0.01 & 0 & 0.006 & 0.007 & 0.168 \\
\hline $\mathrm{Cr}$ & 0.014 & 0 & 0.004 & 0.004 & 0.008 & 0 & 0 & 0 & 0.001 & 0.005 & 0 & 0 & 0.002 & 0 & 0.01 \\
\hline $\mathrm{Fe}^{2}$ & 5.999 & 6.001 & 5.999 & 6.000 & 6.005 & 6.000 & 5.999 & 6.000 & 6.000 & 6.000 & 6.000 & 6.000 & 6.000 & 5.999 & 6.004 \\
\hline $\mathrm{Fe}^{3}$ & 0.058 & -0.013 & -1.545 & 0.876 & 65.129 & 0.35 & 0.336 & -1.117 & -5.746 & 0.396 & -5.776 & 0.403 & 0.595 & 0.299 & 73.900 \\
\hline Mn & 2.893 & 4.754 & 0.169 & 2.861 & 0.766 & 1.571 & 0.868 & 0.125 & 0.009 & 1.714 & 0.004 & 2.997 & 3.681 & 1.242 & 4.408 \\
\hline $\mathrm{Mg}$ & 0.007 & 0.008 & 0.009 & 0.011 & 0.016 & 0.018 & 0.005 & 0.002 & 0.001 & 0.003 & 0 & 0.011 & 0.004 & 0.034 & 0.097 \\
\hline $\mathrm{Ca}$ & 0.005 & 0.006 & 0 & 0 & 0.011 & 0.002 & 0.002 & 0.01 & 0.007 & 0.007 & 0.004 & 0.008 & 0.006 & 0.006 & 0.056 \\
\hline $2 n$ & 0 & 0.002 & 0.004 & 0.155 & 0.085 & 0.025 & 0.02 & 0 & 0.001 & 0 & 0.002 & 0.019 & 0.04 & 0.038 & 0.23 \\
\hline $\mathrm{Nb}$ & 0.027 & 0.032 & 0.058 & 0.088 & 0.01 & 0.05 & 0.15 & 0.022 & 0.092 & 0.018 & 0.082 & 0.08 & 0.04 & 0.012 & 0.041 \\
\hline Cátions & 17.892 & 21.546 & 10.875 & 19.038 & 79.028 & 15.606 & 14.144 & 11.179 & 6.333 & 15.868 & 6.280 & 18.532 & 20.066 & 14.927 & 95.450 \\
\hline $\mathrm{PMSiO}_{2}$ & 0.001 & 0.001 & 0.002 & 0 & 0.003 & 0 & 0 & 0.004 & 0.009 & 0.001 & 0.001 & 0 & 0 & 0 & 0.002 \\
\hline $\mathrm{PMTIO}_{2}$ & 0.65 & 0.653 & 0.684 & 0.617 & 0.104 & 0.637 & 0.61 & 0.661 & 1.127 & 0.628 & 1.172 & 0.625 & 0.623 & 0.642 & 0.133 \\
\hline $\mathrm{PMAl}_{2} \mathrm{O}_{3}$ & 0 & 0 & 0 & 0 & 0.002 & 0 & 0 & 0 & 0.001 & 0 & 0.001 & 0 & 0 & 0 & 0.001 \\
\hline $\mathrm{PMCF}_{2} \mathrm{O}_{3}$ & 0.001 & 0 & 0 & 0 & 0 & 0 & 0 & 0 & 0 & 0 & 0 & 0 & 0 & 0 & 0 \\
\hline PMFeO & 0.439 & 0.365 & 0.666 & 0.41 & 0.095 & 0.504 & 0.542 & 0.651 & 1.144 & 0.489 & 1.182 & 0.416 & 0.386 & 0.529 & 0.077 \\
\hline $\mathrm{PMFe}_{2} \mathrm{O}_{3}$ & 0.002 & 0 & -0.086 & 0.03 & 0.516 & 0.015 & 0.015 & -0.061 & -0.548 & 0.016 & -0.57 & 0.014 & 0.019 & 0.013 & 0.474 \\
\hline PMMnO & 0.212 & 0.289 & 0.019 & 0.196 & 0.012 & 0.132 & 0.078 & 0.014 & 0.002 & 0.14 & 0.001 & 0.208 & 0.237 & 0.11 & 0.057 \\
\hline PMMgO & 0 & 0 & 0.001 & 0.001 & 0 & 0.001 & 0 & 0 & 0 & 0 & 0 & 0.001 & 0 & 0.003 & 0.001 \\
\hline SUMMOL & 0.654 & 0.654 & 0.6 & 0.647 & 0.625 & 0.652 & 0.625 & 0.604 & 0.589 & 0.645 & 0.604 & 0.639 & 0.642 & 0.655 & 0.61 \\
\hline Riio & 99.541 & 100.000 & $\{14.333$ & 95.363 & 17.120 & 97.699 & 97.600 & 110.099 & 192.869 & 97.519 & 194.205 & 97.809 & 97.040 & 98.015 & 22.131 \\
\hline $\mathrm{RHil}_{2} \mathrm{O}_{3}$ & 0.459 & 0 & -14.333 & 4.637 & 82.880 & 2.301 & 2.400 & -10.099 & -92.869 & 2.481 & -94.205 & 2.191 & 2.960 & 1.985 & 77.869 \\
\hline
\end{tabular}

Obs: Amostra RP-32 fonolito peralcalino (Cerro Boggiani), RP-44 e 50 sienitos alcalinos (Satélite Il), RP-52 e 58 sienitos alcalinos (Satélite I), RP-74 nefelina sienitos de Cerro

Siete Cabezas, RP-78 quartzo sienito de Pão de Açúcar e RP-91 sienito nefelínico da llha Fecho dos Morros. 
Tabela 18.1 - Composição química de ilmenitas das rochas da Provincia Alcalina Alto Paraguai (\% peso)

\begin{tabular}{|c|c|c|c|c|c|c|}
\hline Amnstra & RP_198 & POP14 & 0000 & D & 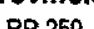 & 00967 \\
\hline Análise & $\{212$ & 1199 & 1205 & $\begin{array}{c}K r-\angle 08 \\
1160\end{array}$ & 1161 & 1162 \\
\hline Locaçäo & $\mathrm{C} 2 \mathrm{G} 1$ & C1G1 & C1G1 & $\mathrm{C} 2 \mathrm{GS}$ & $\mathrm{C} 3 \mathrm{GI}$ & C1G1 \\
\hline $\mathrm{SiO}_{2}$ & 0.01 & 0.04 & 0.15 & 0.05 & 0.1 & 0.01 \\
\hline $\mathrm{TiO}_{2}$ & 50.62 & 50.56 & 47.48 & 48.33 & 44.38 & 36.11 \\
\hline $\mathrm{Al}_{2} \mathrm{O}_{3}$ & 0.02 & 0.02 & 1.9 & 0.02 & 0.83 & 0.07 \\
\hline $\mathrm{Cr}_{2} \mathrm{O}_{3}$ & 0.02 & 0.02 & 0 & 0 & 0 & 0.01 \\
\hline $\mathrm{FeO}$ & 40.452 & 37.721 & 35.278 & 39.086 & 35.207 & 23.711 \\
\hline $\mathrm{Fe}_{2} \mathrm{O}_{3}$ & 3.206 & 1.564 & 3.632 & 5.266 & 12.635 & 30.979 \\
\hline Mno & 4.82 & 7.75 & 7.47 & 4.4 & 4.77 & 8.56 \\
\hline $\mathrm{MgO}$ & 0.11 & 0.02 & 0 & 0 & 0 & 0.04 \\
\hline $\mathrm{CaO}$ & 0.04 & 0.03 & 0.07 & 0.01 & 0.07 & 0.01 \\
\hline $\mathrm{ZnO}$ & 0 & 0.03 & 0.23 & 0.01 & 0.29 & 0.18 \\
\hline $\mathrm{Nb}_{2} \mathrm{O}_{5}$ & 0.17 & 0.55 & 1.1 & 0.92 & 0.05 & 0 \\
\hline Total & 99.47 & 98.31 & 97.31 & 98.09 & 98.33 & 99.68 \\
\hline $\mathrm{FeOl}$ & 43.34 & 39.13 & 38.55 & 43.83 & 46.59 & 54.62 \\
\hline \multicolumn{7}{|c|}{ Fórmula estrutural calculada na base de $\tilde{c}$ átomos de oxigénio } \\
\hline $\mathrm{Si}$ & 0.002 & 0.008 & 0.031 & 0.009 & 0.02 & 0.003 \\
\hline $\mathrm{Ti}$ & 6.753 & 7.234 & 7.264 & 6.672 & 6.802 & 8.217 \\
\hline Al & 0.004 & 0.004 & 0.455 & 0.004 & 0.199 & 0.025 \\
\hline $\mathrm{Cr}$ & 0.003 & 0.003 & 0 & 0 & 0 & 0.002 \\
\hline $\mathrm{Fe}^{2}$ & 6.000 & 6.001 & 6.001 & 5.999 & 6.000 & 5.999 \\
\hline $\mathrm{Fe}^{3}$ & 0.427 & 0.224 & 0.555 & 0.727 & 1.935 & 7.046 \\
\hline $\mathrm{Mn}$ & 0.724 & 1.249 & 1.287 & 0.684 & 0.823 & 2.194 \\
\hline $\mathrm{Mg}$ & 0.029 & 0.006 & 0 & 0 & 0 & 0.018 \\
\hline $\mathrm{Ca}$ & 0.008 & 0.006 & 0.015 & 0.002 & 0.015 & 0.003 \\
\hline $\mathrm{Zn}$ & 0 & 0.004 & 0.035 & 0.001 & 0.044 & 0.04 \\
\hline $\mathrm{Nb}$ & 0.014 & 0.047 & 0.101 & 0.076 & 0.005 & 0 \\
\hline Cátions & 13.964 & $\$ 4.786$ & 15.744 & 14.174 & 15.843 & 23.547 \\
\hline $\mathrm{PMSiO}_{2}$ & 0 & 0.001 & 0.002 & 0.001 & 0.002 & 0 \\
\hline $\mathrm{PMTIO}_{2}$ & 0.634 & 0.633 & 0.594 & 0.605 & 0.555 & 0.452 \\
\hline $\mathrm{PMAl}_{2} \mathrm{O}_{3}$ & 0 & 0 & 0.019 & 0 & 0.008 & 0.001 \\
\hline $\mathrm{PMCr}_{2} \mathrm{O}_{3}$ & 0 & 0 & 0 & 0 & 0 & 0 \\
\hline PMFeO & 0.563 & 0.525 & 0.491 & 0.544 & 0.49 & 0.33 \\
\hline $\mathrm{PMFe}_{2} \mathrm{O}_{3}$ & 0.02 & 0.01 & 0.023 & 0.033 & 0.079 & 0.194 \\
\hline PMMnO & 0.068 & 0.109 & 0.105 & 0.062 & 0.067 & 0.121 \\
\hline PMMgO & 0.003 & 0 & 0 & 0 & 0 & 0.001 \\
\hline SUMMOL & 0.654 & 0.644 & 0.638 & 0.639 & 0.644 & 0.647 \\
\hline Rilo & 96.942 & 98.447 & 93.417 & 94.836 & 86.491 & 69.861 \\
\hline $\mathrm{Rili}_{2} \mathrm{O}_{3}$ & 3.058 & 1.553 & 6.583 & 5.164 & 13.509 & 30.139 \\
\hline
\end{tabular}

Obs: RP-198 sienito nefelínico de Cerrito, RP-201-A sienito nefelinico da liha Fecho dos Morros, RP-205 quartzo sienito de Cerro Pedreira, RP-259 sienito alcalino de Morro

Conceição e RP-267 nefelina sientito de Porto Conceição. 


\section{$\mathrm{TiO}_{2}$}

(Rutilo, anatásio, brookita)

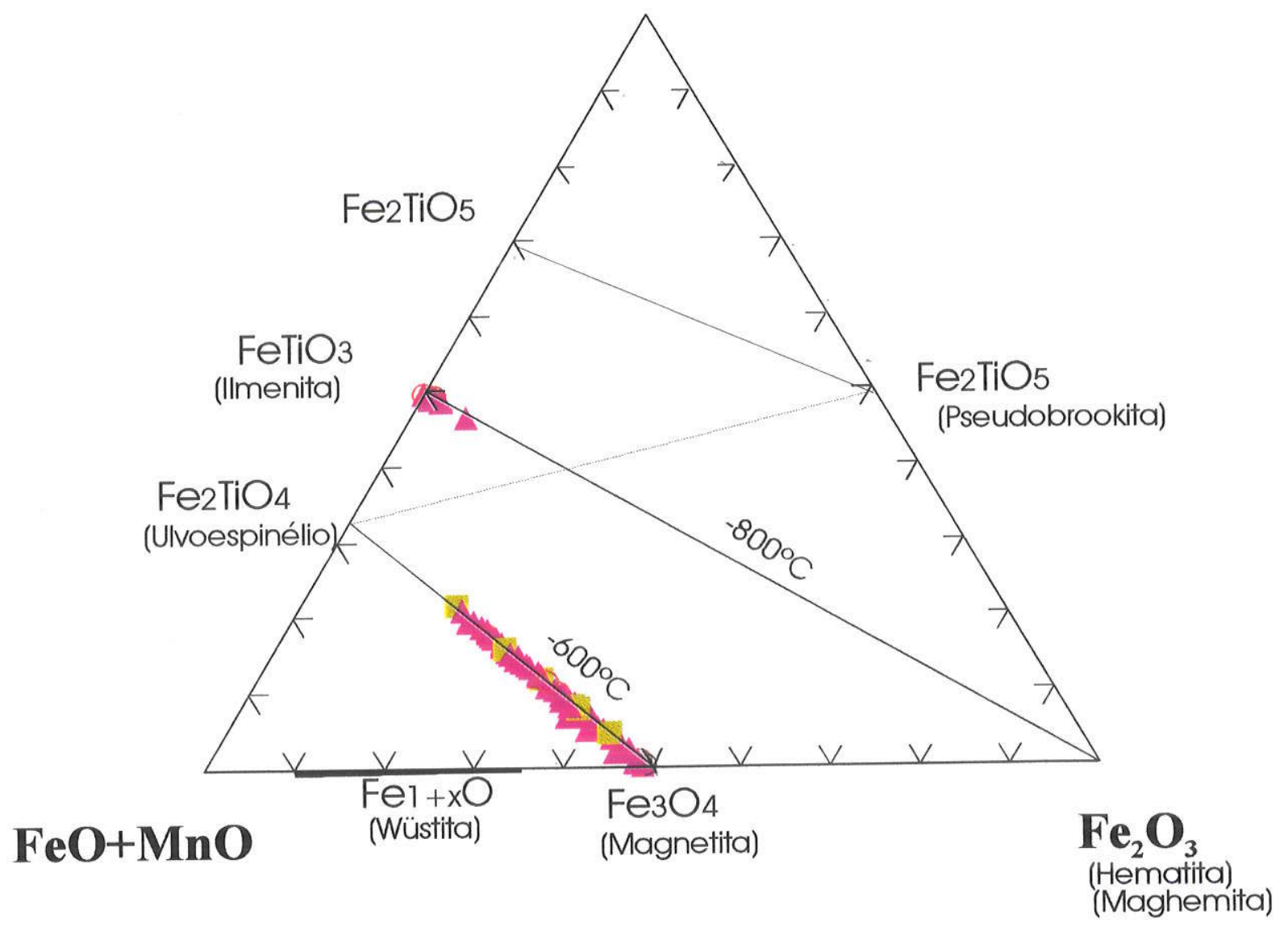

Figura 70 - Distribuição das ilmenitas e magnetitas das rochas da Província Alcalina Alto Paraguai no diagrama $\mathrm{FeO}-\mathrm{TiO}_{2}-\mathrm{Fe}_{2} \mathrm{O} 3$ de Buddington \& Lindsley (1964), modificado por Haggerty (1976). Símbolos: núcleo de grãos (triângulo); borda de grão (círculo); grão da matriz (quadrados) 


\section{CAPITULO 06 - CONSIDERAÇÕES PETROLÓGICAS E FINAIS}

Os corpos alcalinos estudados são constituídos por associaçס̋es típicamente insaturadas nas intrusōes de Cerro Boggiani, Cerrito e llha Fecho dos Morros, correspondendo principalmente a nefelina sienitos, e mais raramente a manifestações fonolíticas. Rochas insaturadas associadas a litotipos saturados a supersaturados foram encontrados nos corpos de Satélite I, Satélite II, Pão de Açúcar, Cerro Pedreira, São Pedro, Porto Conceição, Morro Conceição e Morro Distante, tendo como principais representantes os sienitos alcalinos e subordinadamente traquitos, quartzo sienitos e esporadicamente álcali-feldspato granitos.

Complexos alcalinos compostos por rochas insaturadas em sílica, intrinsecamente associadas à litotipos contendo quartzo modal, distribuem-se nos mais diferentes lugares do mundo (Lovozero, llimaussaq, Velasco, Tunas, Ilha de Vitória dentre outros), podendo caracterizar uma transposição da barreira termal do plano AbOr do Sistema Petrogenético Residual (Bowen, 1937).

A hipótese de Fases Intrusivas Separadas, onde a colocação magmática se faz por pulsos sucessivos, nos quais a temperatura é progressivamente mais elevada gerando líquidos cada vez menos fracionados originados de uma mesma fonte magmática, é a mais aceita pela maioria dos petrólogos ocidentais em detrimento das preconizadas para a transição de nefelina sienitos até quartzo sienitos e sienogranitos, se deve à cristalização fracionada (Taylor, 1980; Brooks \& Gill, 1982). Autores como Landoll et al. (1989) preferem um modelo de evolução onde os processos de cristalização fracionada e contaminação crustal se combinam para formar rochas insaturadas associadas a litologias saturadas em sílica.

A grande similaridade nas composições químicas e mineralógicas dos maciços com ocorrência conjunta de rochas insaturadas em sílica e supersaturadas, derivadas de um mesmo magma parental, sugere que o processo que leva à formação de nefelina sienitos associados a rochas com quartzo livre modal, indica que ambas constituem típicos produtos de diferenciação magmática. Nesse sentido, Kogarko (1979) defendem que a evolução das composições quimicas de Lovozero e Khibina se deu a partir de um magma parental de natureza alcali-basáltico, salientando que os magmas supersaturados em álcalis, relativamente ao alumínio podem ser explicados pela 
separação do alumínio com plagioclásio (efeito plagioclásio) e com piroxênio (molécula Tschermak), formando solução sólida no sistema diopsídio-egirina-augita.

O sistema petrogenético residual, tal como estabelecido por Bowen (1937), ratificado nos trabalhos experimentais de Fudali (1963), Bailey \& Schairer (1966), Hamilton \& Mackenzie (1965) e Henderson et al. (1989), dentre outros, pode ser aplicado às condições de cristalização das rochas sieníticas da Província Alcalina Alto Paraguai, partindo-se da premissa de um magma parental muito diferenciado, cuja composiçăo inicial é assumida para os nefelina sienitos como $\mathrm{Ne}_{37} \mathrm{Ks}_{19} \mathrm{Q}_{44}$, valores de proporção moleculares médios para os litotipos menos evoluídos da série moderadamente insaturada a saturada (Velázquez, 1996). A retirada de fases félsicas e máficas do magma em cristalização tais como: feldspato potássico, nefelina, piroxênios, anfibólios, e de minerais óxidos como espinélios e ilmenitas, induziria o líquido residual a assumir uma composição peralcalina, permitindo então a cristalização de feldspato potássico e quartzo acima do plano Ab-Or, sendo que todo $\circ \mathrm{K}_{2} \mathrm{O}$ do sistema seria utilizado no ortoclásio.

A semelhança mineralógica entre os litotipos estudados sugere que as rochas sieníticas e suas equivalentes extrusivas/sub-intrusivas são consangüineas. No entanto, - comportamento químico de alguns sienitos e fonolitos de Cerrito, Pão de Açúcar, Satélite II, Cerro Pedreira, São Pedro, Morro Conceição e Morro Distante (Velázquez, 1996 e Matos et al., 2000), evidencia uma provável contaminação crustal com enriquecimento em $\mathrm{SiO}_{2}$ e pela diminuição relativa de $\mathrm{Zr}, \mathrm{MnO}, \mathrm{Na}_{2} \mathrm{O}$ e $\mathrm{K}_{2} \mathrm{O}$, propiciando um caráter peraluminoso observado nesses litotipos, similarmente ao Complexo Alcalino Ponta do Morro (Sousa, 1997). Esses dados são amplamente consubstanciados pelos dados isotópicos determinados por Velázquez et al. (1993) e Velázquez (1996).

A adição de material crustal ao sistema, modificaria a composição do líquido, enriquecendo-o em sílica, e o levando para uma cristalização no plano mínimo granítico. Em contrapartida, o liquido residual não contaminado do magma parental, revela uma composição cuja tendência de evolução aponta para o plano mínimo fonolítico. Este sistema foi denominado por Bowen (1937) de "Sistema Petrogenético Residual", mostrado esquematicamente na figura 71. 


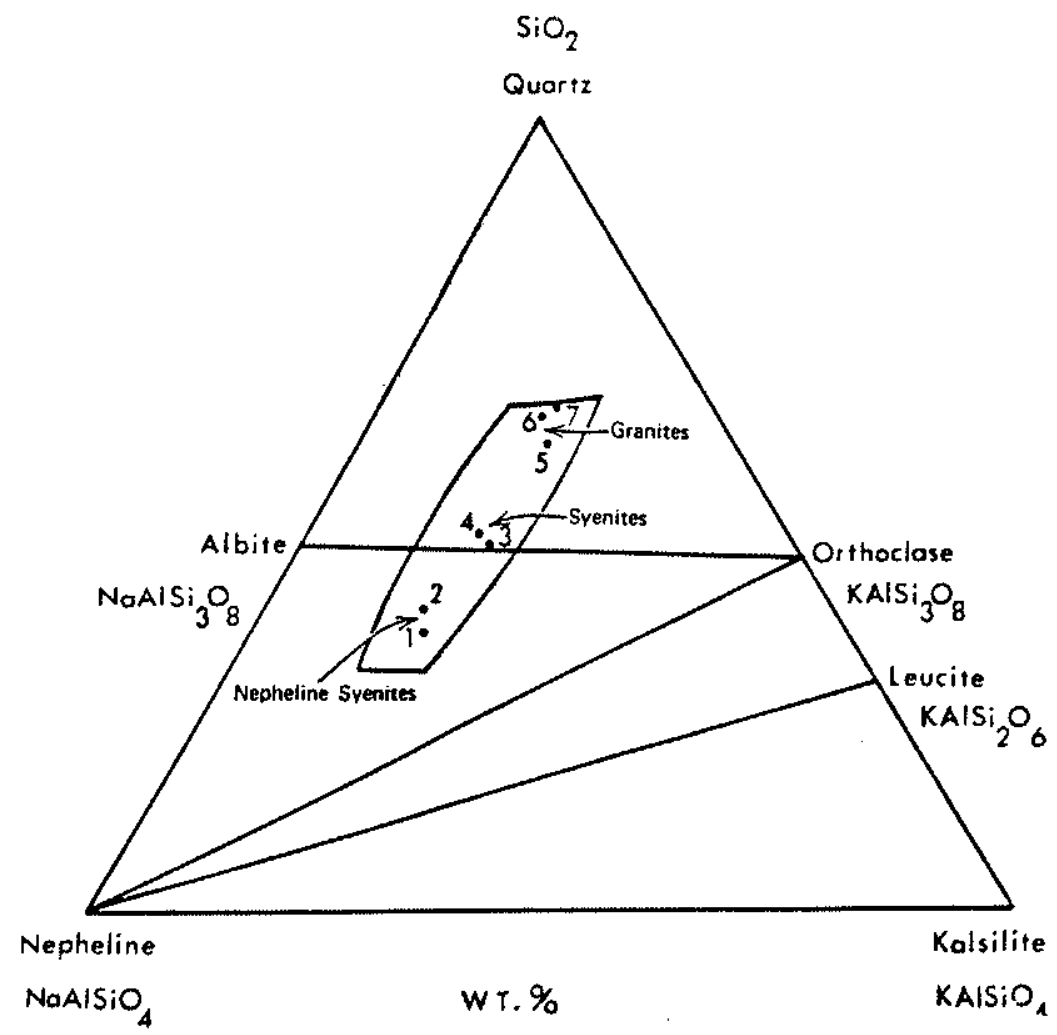

Figura 71 - Representação esquemática de rochas félsicas no Sistema Nefelina-KalsilitaSílica (Sistema Petrogenético Residual), segundo Bowen (1937). As rochas que se plotam no vale termal do diagrama separando os campos dos granitos (riolitos), sienitos (traquitos) e nefelina sienitos (fonolitos). 1- tinguaítos (fonolito com textura tinguaítica), 2- fonolitos, 3alcali-sienitos, 4- alcali-traquitos, 5-pantteleritos (riolito peralcalino), 6- granitos, 7-riolitos 
As rochas alcalinas ocorrem espacial e temporalmente associadas a processos de rifteamentos intracontinentais, soerguimentos verticais e esforços extensionais. A ocorrência dos corpos intrusivos da Província Alcalina Alto Paraguai parece ter sido controlada também por esses processos, já que os corpos se distribuem ao longo do rio Paraguai que possui uma direção geral norte-sul.

A partir de dados químicos encontrados na literatura (Velázquez, 1996; Gomes et al., 1997 e Matos et al., 2000), foram aqui construídos alguns diagramas de química de rocha, para elementos maiores, confirmando o caráter peralcalino da maioria dos corpos da Província Alcalina Alto Paraguai. Subordinadamente, podem ser observadas ocorrências metaluminosas tais como alguns fonolitos de Cerrito, sienitos alcalinos de Cerro Pedreira e quartzo sienito de Pão de Açucar (Figura 72-A e B). Os diagramas fundamentados em elementos mais compativeis tais como $\mathrm{Nb}$ e $\mathrm{Y}$, revelaram resultados indicando uma origem intra-placa para o magmatismo da Província Alcalina Alto Paraguai (Figuras $72-C$ e D).

Alguns corpos estudados, especialmente os maciços Pão de Açúcar e Cerro Siete Cabezas parecem indicar em imagens orbitais e de aeronave, colocação em forma de complexos anelares, como admitido em Velázquez (1996) e Gomes et al. (1997). Essa feição está diretamente associada às manifestações vulcânicas que formam em um estágio inicial de sua evolução, estruturas em caldeira.

Segundo Bonin (1982), ocorre uma estruturação diversificada nesses complexos anelares que é, quase sempre, marcada por uma zonalidade horizontal e vertical, distribuída em estágios específicos. Bonin (1982) descreve ainda como "estágio superficial" um conjunto de processos que envolve arqueamentos crustais devido à sobrepressão da câmara magmática adjacente, ocasionando fraturamento radial os que serve como conduto do vulcanismo pré-caldeira. $O$ estágio evolui para 0 extravasamento de produtos vulcânicos tais como piroclastitos e ignimbritos, seguindose então, processos de degaseificação do magma e conseqüente formação de "sills" e domos de borda.

Esse modelo pode ser aplicado de forma coerente ao magmatismo alcalino Alto Paraguai, em função dos vários corpos satélites alcalinos que circundam as intrusões de Cerro Siete Cabezas, Pão de Açúcar e Cerro Boggiani, descritos neste trabalho. 

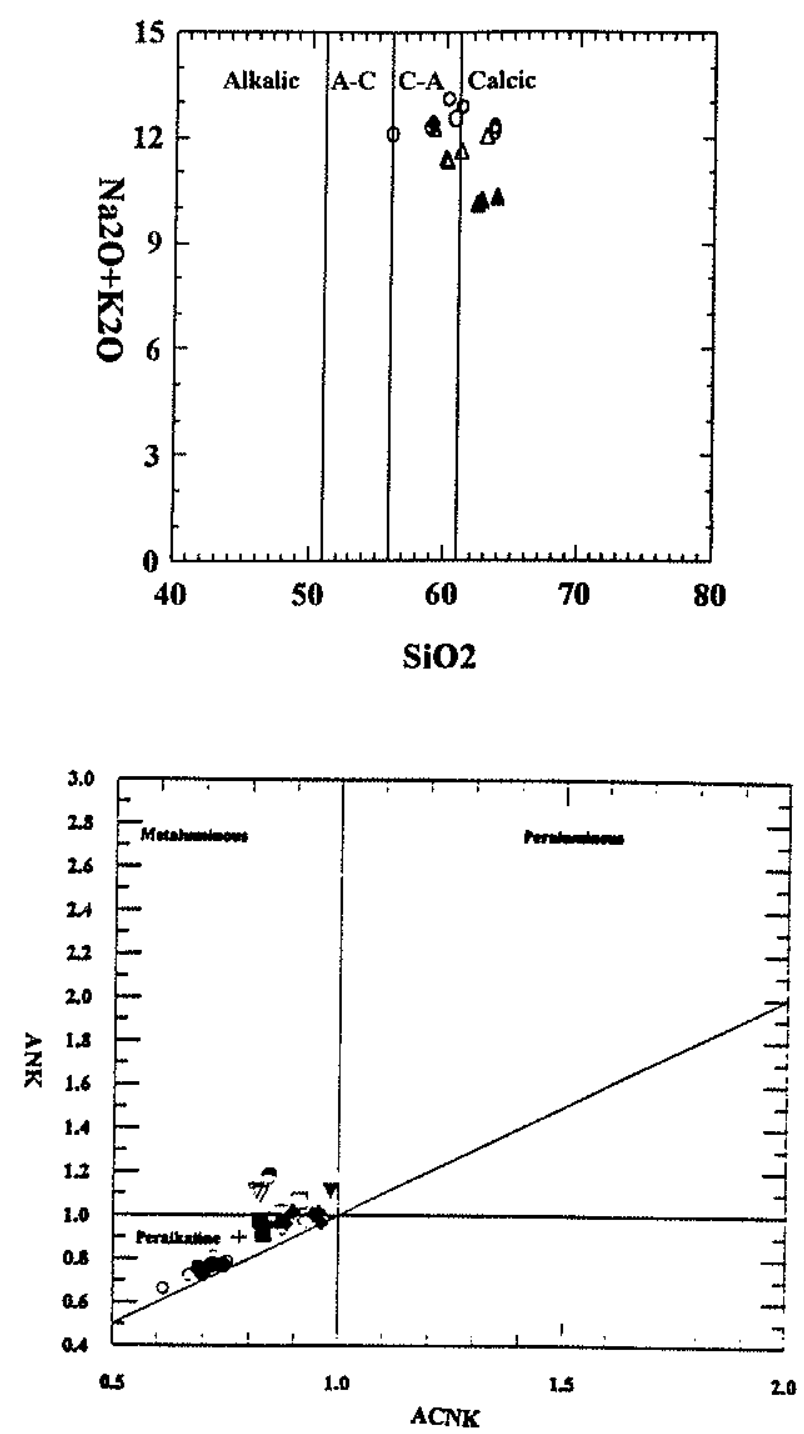
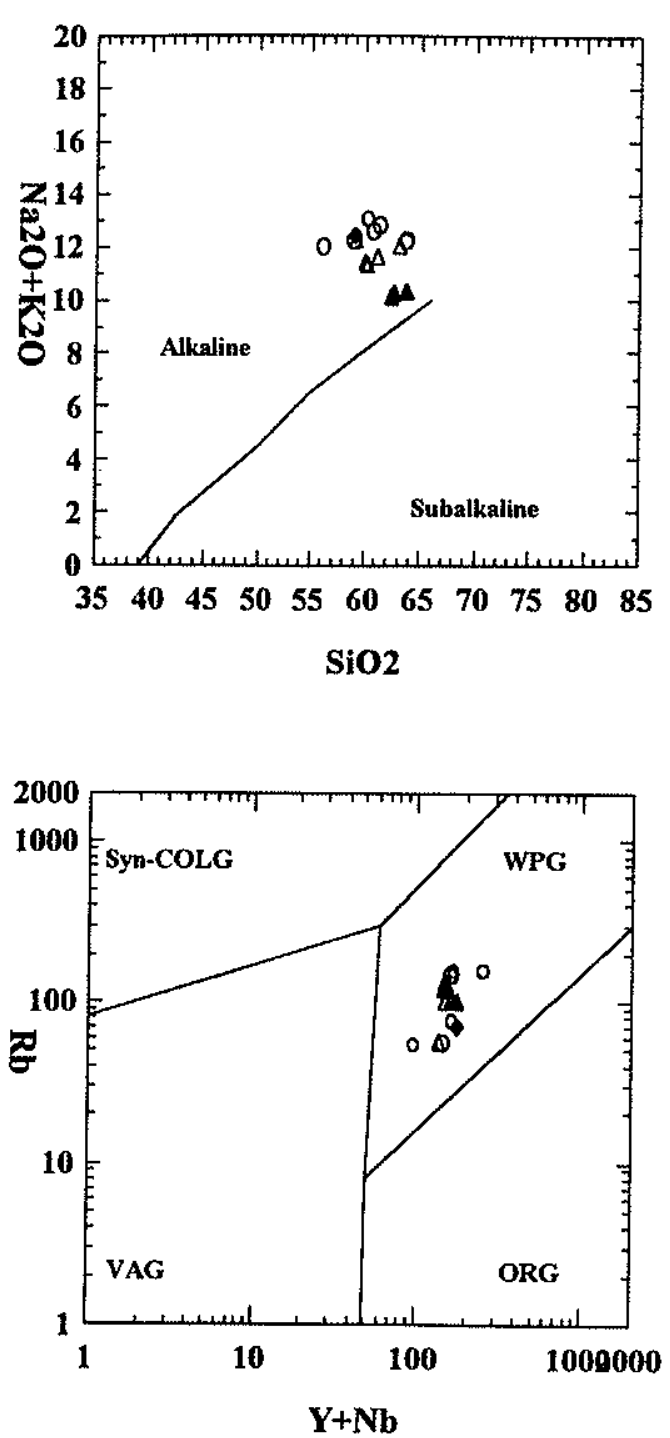

Figura $72(\mathrm{~A})$ - Diagrama $\mathrm{Na}_{2} \mathrm{O}+\mathrm{K}_{2} \mathrm{O}$ versus $\mathrm{SiO}_{2}$ de Irvine \& Baragar (1971) aplicado à rochas da Povíncia Alcalina Alto Paraguai: (B) diagrama $\mathrm{Na}_{2} \mathrm{O}+\mathrm{K}_{2} \mathrm{O}$ versus SiO2 separa 0 campo das rochas alcalinas das sub-alcalinas: (C) Diagrama ANK versus ACNK, define os campos de composição preferenciais para as rochas da Província Alto Paraguai: e (D) diagrama de variação $\mathrm{Rb}$ versus $\mathrm{Y}+\mathrm{Nb}$ (Pearce et al. 1984), para a discriminação tectônica de rochas graniticas (s.l.). Abreviaçōes:

ORG $=$ cadeias oceânicas, $V A G=$ arcos vulcânicos, SynCOLG $=$ Sin-Colisionais, $W P G=$ magmatismo intra-placa. 
Entretanto, o único corpo a apresentar litotipos de aspecto ignimbritico é o Pão de Açúcar, que apesar de não configurar, na atualidade, a dimensão que Bonin (1982) estima para o empilhamento piroclástico, aproximadamente $600 \mathrm{~m}$, pode ter sido lixiviada pelos sucessivos ciclos erosivos pós-cretácicos descritos em Almeida (1943, 1949, 1959, 1964a e 1964b), Alvarenga et al. (1982) e Franco \& Pinheiro (1982).

Como neste trabalho não foram efetuados estudos geocronológicos e a literatura apresenta vários compêndios que demonstram uma concentração de idades radiométricas no intervalo 250-240Ma. (Amaral et al.,1966; Comte \& Hasui, 1971; Velázquez et al., 1993 e Velázquez, 1996), acredita-se que sejam estas as idades de colocação/resfriamento dos corpos da Província Alcalina Alto Paraguai.

Nas rochas estudadas, os minerais félsicos mais importantes do ponto de vista quantitativo são os feldspatos alcalinos, seguidos por nefelina e subordinadamente plagioclásios, sendo que estes últimos são encontrados apenas nas intrusões de Morro Conceição e Morro Distante, enquanto que o quartzo ocorre esporadicamente em assembléias saturadas como as do Morro Pão de Açúcar e Morro Conceição. Os minerais máficos ocorrem na seguinte ordem de importância: piroxênios sódicocálcicos, piroxênios sódicos, anfibólios cálcico-sódicos, anfibólios sódicos e biotitas. Foram encontradas também texturas de reequilíbrio sólido-líquido, transformações mineralógicas sugestivas de processos pós-magmáticos, tais como: sericitização de feldspatos, saussuritização de plagioclásios, uralitização de piroxênios e substituição de nefelina por cancrinita e subordinadamente por carbonàtos.

Os feldspatóides dos sienitos e extrusivas associadas estão representados pela nefelina e subordinadamente pela sodalita. Esses minerais estão ausentes, como esperado, apenas nas rochas supersaturadas em sílica tais como aquelas que ocorrem nos corpos de: Satélite I, Satélite II, Cerro Pedreira, Morro Conceição e Morro Distante. O estudo microquímico dos componentes moleculares $\mathrm{Ne}-\mathrm{Ks}-\mathrm{Qz}$ das nefelinas dos corpos da Província Alcalina Alto Paraguai não revela tendências de enriquecimento em Qz como parecem indicar as intrusões de Banhadão (Ruberti, 1984), diques e "plugs" alcalinos do Vale do Ribeira (Vasconcellos, 1995) e liha Monte de Trigo (Enrich \& Ruberti, 2000). A partir do diagrama de Hamilton \& Mackenzie (1965), conclui-se que as nefelinas da Província Alto Paraguai foram formadas em um intervalo de temperatura 
que tem como limites inferior e superior $500^{\circ} \mathrm{C}$ e $<1068^{\circ} \mathrm{C}$, respectivamente. As nefelinas das rochas da liha Fecho dos Morros são as representativas de temperaturas de cristalização mais elevadas, correspondendo a um enriquecimento em "excesso de sílica", relativamente àquelas que ocorrem em Cerrito. Em contrapartida, as nefelinas dos fonolitos de Cerro Boggiani são as que correspondem a temperaturas de cristalização mais baixas.

Os piroxênios ocorrem em praticamente todos os litotipos estudados, exceto nos quartzo sienitos de Pão de Açúcar, nefelina sienitos de Cerrito e Porto Conceição e sienitos alcalinos de Morro Conceição. De uma maneira geral, os piroxênios encontrados na Província Alto Paraguai, independentemente do tipo petrográfico, coincidem com os domínios do Quad e cálcico-sódicos do diagrama Q-J. Os do campo do Quad classificam-se como salitas e ferrossalitas, enquanto que os cálcico-sódicos correspondem às egirina-augitas do diagrama WEF-Jd-Ae. Os piroxênios dos corpos de Cerrito e São Pedro possuem piroxênios que se plotam somente no campo Quad, classificados como salitas no diagrama Wo-En-Fs, consubstanciando os estudos petrográficos. A tendência química dos piroxênios da Província Alto Paraguai é, de uma maneira geral, de empobrecimento em $\mathrm{Mg}$ e enriquecimento em Fe e $\mathrm{Na}$, similarmente ao Complexo de Banhadão (Ruberti, 1984). Os piroxênios de Cerro Siete Cabezas, Morro Pão de Açúcar e Morro São Pedro também mostram essa característica evolutiva; enquanto que, os de Cerro Boggiani e Satélite II apresentam acentudo enriquecimento em $\mathrm{Na}$ e perda de $\mathrm{Fe}$, para teores de $\mathrm{Mg}$ constantes, coincidindo com as curvas evolutivas de Tanguá-RJ (Valença, 1980), liha de Vitória (Motoki, 1986) e Complexo Ponta do Morro (Sousa, 1997).

Nas rochas da Província Alto Paraguai, predominam anfibólios cálcico-sódicos, correspondendo principalmente à ferro edenita e edenita rica em sílica, ferro eckermanita, ferro- pargasita hornblenda, ferro richterita e ferro glaucofânio. A tendência química é de enriquecimento em Fe para uma razão $\mathrm{Ca} / \mathrm{Mg}$ constante. São observadas ainda, "trends" com aumento de $\mathrm{Na}$ em anfibólios de rochas mais diferenciadas, para valores de $\mathrm{K}$ praticamente constantes, similarmente a outros corpos alcalinos descritos em Neumann (1976b), Giret et al. (1980). Conceição et al. (1991) e 
Sousa (1997). São observados nos anfibólios da Província Alto Paraguai, esquemas típicos de substituição de $\mathrm{Ca}+\mathrm{Al}^{\mathrm{lV}}$ por $\mathrm{Si}+\mathrm{Na}$.

Excetuando-se as rochas de Porto Conceição, todas as outras dos corpos da Província Alcalina Alto Paraguai são portadoras de micas, no entanto, em quantidades subordinadas aos demais máficos. De acordo com a relação $\mathrm{Mg:F}<2: 1$, que serve de parâmetro para a sua classificação (Sapountzis, 1976), as micas estudadas são biotitas. Nas rochas de Cerrito, Cerro Siete Cabezas e Cerro Boggiani ocorrem apenas micas classificadas como flogopitas. A exemplo de piroxênios e anfibólios, as biotitas estudadas apresentam tendências de evolução composicional caracterizadas por enriquecimento em $\mathrm{Fe}$, com discreta perda de $\left(\mathrm{Al}^{\mathrm{N}}+\mathrm{Ti}\right), \mathrm{Al}_{2} \mathrm{O}_{3} \in \mathrm{K}$.

Os espinélios e ilmenitas ocorrem em todas as rochas dos corpos da Provincia Alcalina Alto Paraguai, com exceção daquelas de Cerro Boggiani. Esses minerais apresentam geralmente valores elevados de $\mathrm{TiO}_{2}$, teores variáveis de $\mathrm{Al}_{2} \mathrm{O}_{3}$ e elevados em $\mathrm{ZnO}$ e MnO. Os minerais óxidos das rochas de liha Fecho dos Morros chega a possuir valores anômalamente altos de $\mathrm{MnO}$. Os espinélios e ilmenitas dos corpos estudados possuem composições representativas dos espinélios de $\mathrm{Fe} \mathrm{e} \mathrm{Ti,}$ distribuindo-se ao longo da linha $\mathrm{Fe}_{3} \mathrm{O}_{4}-\mathrm{Fe}_{2} \mathrm{TiO}_{4}$, série da magnetita-ulvöespinélio, indicando para esses minerais, temperaturas de cristalização em torno de $600^{\circ} \mathrm{C}$, correspondendo a uma baixa fugacidade de oxigênio, enquanto que as ilmenitas concentram-se junto ao lado de $\mathrm{FeTiO}_{3}$ da série ilmenita-hematita, indicando temperaturas de cristalização de aproximadamente $800^{\circ} \mathrm{C}$ e fugacidade de oxigênio maiores do que as prevalecentes durante a cristalização dos espinélios. 


\section{CAPÍTULO 7- REFERÊNCIAS BIBLIOGRÁFICAS}

ALMEIDA, F.F.M. (1943) Geomorfologia da Região de Corumbá. Bol. Assoc. GeoGraf. Bras. São Paulo 3(3):8-18

ALMEIDA, F.F.M. de; (1945) Geologia do sudoeste mato-grossense. Bol. Div. Geol. e Min. Rio de Janeiro 116: 1-118.

ALMEIDA, F.F.M. de; (1949) Relevo de "cuestas" na bacia sedimentar do rio Paraná. Boletim Paulista de Geografia. São Paulo. 3:21-33

ALMEIDA, F.F.M. de; (1959) Traços gerais da geomorfologia do Centro Oeste brasileiro. In: ALMEIDA, F.F.M. de \& LIMA, M.A. de; Planalto CentroOcidental e Pantanal matogrossense. Guia de Excursaão $n^{\circ} 1,18^{\circ}$ CONGRESSO BRASILEIRO DE GEOGRAFIA, CNG, Rio de Janeiro p.7-65.

ALMEIDA, F.F.M. de; (1964a) Geologia do centro-oeste matogrossense. Bol. DGM, DNPM 215: 1-137.

ALMEIDA, F.F.M. de; (1964b) Glaciação eo-Cambriana em Mato Grosso. Notas preliminares e Estudos.DGM-DNPM. 117: 1-11.

ALMEIDA, F.F.M. de; (1965) Geologia da Serra da Bodoquena (Mato Grosso). Rio de Janeiro, DGM/DNPM Boletim 219, 96p.

ALMEIDA, F.F.M. de (1967) Origem e evolução da Plataforma Brasileira. Boletim da Divisão de Geologia e Mineralogia. Rio de Janeiro. (241): 1-36.

ALMEIDA, F.F.M. de; (1969) Diferenciação Tectônica da Plataforma Brasileira In: CONGRESSO BRASILEIRO DE GEOLOGIA 23, Salvador. Anais...SBG p.2946

ALMEIDA, F.F.M de; (1971) Condicionamento tectônico do magmatismo alcalino mesozóico do sul do Brasil e do Paraguai oriental. An. Acad Bras. Ciênc. 43: 835-836.

ALMEIDA, F.F.M. (1983) Relações tectônicas das rochas mesozóicas da região meridional da Plataforma Sul-Americana. Rev. Bras. Geoc. 13: 139-158. 
ALVARENGA, S.M.; BRASIL, A.E. \& Del'ARCO, D.M. (1982) Geomorfologia. In: Projeto Radambrasil, Folha SF-21 Campo Grande. Rio de Janeiro. Levantamento de Recursos Naturais, V. 28, p.125-184. AMARAL, G.; CORDANI, U.G.; KAWASHITA, K. \& REYNOLDS, J. H. (1966) Potassium-argon dates of basaltic from southern Brazil. Geochim. Cosmochim. Acta, 30(2):159-189.

AMARAL, G. (1984) Províncias Tapajós e Rio Branco. In: ALMEIDA, F.F.M. de \& HHASUI, Y; (Eds.), O pré-Cambriano do Brasil . Ed. Edgard Blücher Ltda. 6-33. ARAÚJO, H.J.T. de; NETO, A. dos S.; TRINDADE, C.A.H.; ARRUDA PINTO, J.C. de; MONTALVÃO, R.M.G. de; DOURADO, T.D. de C.; PALMEIRA, R.C. de B. \& TASSINARI, C.C.G. (1982) Folha SF-21 Campo Grande. Geologia. Projeto RADAMBRASIL Levantamento de Recursos Naturais. Rio de Janeiro. V. 28 , p.23-124.

BAILEY, D.K. \& SCHAIRER, J.F. (1966) The system $\mathrm{Na}_{2} \mathrm{O}-\mathrm{Al}_{2} \mathrm{O}_{3}-\mathrm{Fe}_{2} \mathrm{O}_{3}-\mathrm{SiO}_{2}$ at 1 atmosphere and petrogenesis of alkaline rocks. J. Petol., 7: 114-170.

BARBIERI, M.; BECCALUVA, L.; BROTZU, P.; CONTE, A.; GARBARINO, C.; GOMES, C. B.; LOSS, E. L.; MACCIOTA, G.; MORBIDELLI, L.; SCHEIBE, L.F.; TAMURA, R.M. \& TRAVERSA, A. (1987) Petrological and geochemical studies of alkaline rocks from continental Brazil.1. The phonolite suite from Piratini. RS Geochim. Brasil., 1:109-138

BARD, J.P. (1980) Microtextures of igneous and metamorphic rocks. Transl. by Marianne Mareschal, Ed. by S.W. Morel. D. Reidel Publ. Co. Dordrecht, 264p.

BONIN, B. (1982) Les granites des complexes annulaires. BRGM, Orleans, Manuels et Méthodes $n^{\circ} 4,183 p$.

BOWEN, N.L. (1937) Recent high temperature research on silicates and its significance in igneous geology. Am. J. Sci. 33:1-21.

BROOKS, C.K. \& GILL, R.C.O. (1982) Compositional variation in the pyroxenes and amphiboles of the Kangerdlugssuaq intrusion, East Greenland: further evidence for the crustal contamination of the syenite magma. Mineralogical Magazine 45: $1-9$. 
BUDDINGTON, A.F. \& LINDSLEY, D.H. (1964) Iron-Titanium oxide minerals and synthetic equivalents. J. Petrol. 5(2): 310-357.

CHAYES, F. (1949) A simple counter for thin sections analysis. Am. Min. 134:1-11. COMTE, D. \& HASUI, Y (1971) Geocronology of eastern Paraguay by potassiumargon method. Rev. Bras. Geoc.,9:59-88.

CONCEIÇÃO, H.; SABATÉ, P. \& BONIN, B. (1991) The ltiúba alkaline syenite massif, Bahia State (Brazil): mineralogical, geochemical and petrological constraintsrelation to the genesis of rapakivi magmatism. Prec. Research, 51:283-314.

CORREA, J.A.; CORREIA FILHO, F. das C.L.; SCISLEWSKI, G.; NETO, C.; CAVALON, L.A.; CERQUEIRA, N.L. de S. \& NOGUEIRA, V.L. (1976) Geologia das Regiões centro-oeste de Mato Grosso do Sul. Projeto Bodoquena, CPRMIRelatório Final (Inédito) Goiânia.

CORREIA, E.A. \& BASTOS, M.L.L. (1993) Magmatismo kimberlitico e lamproítico no Brasil e seu contrôle estrutural. Anais Simp. Bras. Geol. Diamante Cuiabá, V.1 p. 32-41.

COUTINHO, J.M.V.; HACHIRO, J.; COIMBRA, A.M. \& SANTOS. P.R. (1991) Ash fallderived vitroclastic tuffaceous sediments in the Permian of the Parana Basin and its provenance. In: H.H.G. ULBRICH \& A.C. ROCHA CAMPOS. Eds. Seventh Intern. Gondwana Symposium. São Paulo. Brazil.

DALLA SALDA, I. H. \& DALZIEL, I.W.D. (1993) O supercontinente Neoproterozóico e as interações Gondwana-Laurentia durante o Paleozóico Inferior-Médio. Trad. Benjamim B. Brito Neves. Rev. Bras. Geoc. 23(3) 183-186.

DALLA SALDA, I.H.; DALZIEL, I.W.D.; CINGOLANI,C. \& VARELA, R.(1992a) Did the Taconic Appalachian continue into southern South América? Geology. 20:1059 1062.

DALLA SALDA, I. H.; CINGOLANI, C. \& VARELA, R. (1992b) Early Paleozoic orogenic belt of the Andes in southwestern South America: results of LaurentiaGondwana collision? Geology 20: 617-620.

DALZIEL, I.W.D.; DALLA SALDA, L. \& GAHAGAN, L. (1993) Laurentia-Gondwana interation and the origin of the Appalachian-pre-Andean mountain system. Geol. Soc. Amer. Bull. 
DEER, W.A.; HOWIE, R.A. \& ZUSSMAN, J. (1963) Rock Forming Minerals. Vol. I (Ortho and Ring Silicates), Vol.III (Sheet Silicates) and Vol. IV (Framework Silicates), Longman Group Ltd. London.

DEER, W.A.; HOWIE, R.A. \& ZUSSMAN, J. (1963) An introduction to the rock forming minerals. Longman. London, 528p.

DEER, W.A.; HOWIE, R.A. \& ZUSSMAN, J. (1992) An introduction to the rock forming minerals. Longman Group Ltd. London, 538p.

DE LA ROCHE, H.C. (1986) Classification et nomenclature des roches ignées: unessai restauration de la convergence entre systématique, quantitative, typologie de usage et modélisation génétique. Bull. Soc. Géol. France. 2: 313-337.

DE MIN, A. (1992) II magmatismo mesozoico k-alcalino del Paraguai orientale:aspetti petrogenetici ed implicazioni geodinamiche. Tesi di Dottorato. Universita degli Studi di Trieste. Itália. 242p.

DERBY, O.A.A. (1895) Notas sobre a geologia e paleontologia de Matto Grosso. Archivos do Museu Nacional, Rio de Janeiro, 9: 59-88.

DORR II, J.van N. (1945) Manganese and iron deposits of Morro do Urucum, Mato Grosso, Brazil. Geol. Surv. Bull, Washington 946-A: 1-47.

ECKEL, E.B. (1959) Geology and mineral resources of Paraguay: a reconnaissance. Geol. Surv. Prof. Paper 34: 110p.

ENRICH, G.E. \& RUBERTI, E. (2000) Mineral chemstry of alkaline rocks from Monte de Trigo Island, Southeast Coast of Brazil. $31^{\circ}$ IGC - Rio de Janeiro, Brazil CDRoom, Abstracts.

EVANS, J.W. (1894) The Geology of Mato Grosso. Quart. J. Geol. Soc. London, 50: 85-104.

FINGER, L.W. (1972) The uncertainty of the calculated ferric iron content of a microprobe analysis. Camegie Inst. Wash. Year Book 71:600-603.

FRANCO, M.S.M. \& PINHEIRO, R. (1982) Geomorfologia. In:BRASIL. Ministério das Minas e Energia. SG. Projeto RADAMBRASIL. Folha SE-21 Corumbá e parte da Folha SE-20. Rio de Janeiro, (Levantamento de Recursos Naturais) V.27 
FUDALI, R.F. (1963) Experimental studies bearing on the origin of pseudoleucite and associated of alkaline rock systems. Geol. Soc. Am. Bull., 74:1001-1026.

FULFARO, V.J. (1996) Geology of Eastern Paraguay in: P. COMIN-CHIARAMONTI \& C. B. GOMES (Eds) Alkaline Magmatism in Central-Eastern Paraguay. Rela tionships with coeval magmatism in Brazil. São Paulo. Edusp-Fapesp.; Brazil, 17-30.

GARDA, G.M. (1995) Os diques básicos e ultrabásicos da região costeira entre as cidades de São Sebastião e Ubatuba, Estado de São Paulo.IG_USP, Tese de Doutoramento, São Paulo 156p. Inédito.

GIRET, A.; BONIN, B. \& LEGER, J.M. (1980) Amphibole compositional trends in over saturated and undersaturated alkaline plutonic ring-complexes. Can. Mineral. 18:481-495.

GIRET, A. \& LAMEYRE, J. (1985) Inverted alkaline-tholeitic sequences related to lithospheric thickness in the evolution of continental rifts and oceanic islands. In: BLACK, R \& BOWEN, P., Alkaline ring complexes in Africa. J. African Earth Sci. 3 (1-2):261-266.

GOMES, C.B.; MORO, S.L.; DUTRA, C.V. (1970) Pyroxenes from the alkaline rocks of Itapirapuã, São Paulo, Brazil. Am. Miner. 55: 224-230.

GOMES, C. B.; COMIN-CHIARAMONTI, P.; VELAZQUEZ, V. F. \& ORUÉ, D. (1996) Alkaline magmatism in Paraguay: a review. In: COMIN-CHIARAMONTI, P. \& GOMES, C. B. (Eds) Alkaline Magmatism in Central-Eastern Paraguay: relationships with coeval magmatism in Brazil. São Paulo, Edusp-Fapesp, 31-56.

GOMES, C.B.; VELAZQUEZ, V.F. \& COMIN-CHIARAMONTI, P. (1997) Aspectos Geoquímicos da Província Alcalina Alto Paraguai (Mato Grosso do Sul, Brasil). Actas X Semana de Geoquímica/IV Congr. Geoquim. dos países de Língua Portuguesa. Braga. Portugal. p.55. 
GUIMARÃES, D. (1958) Rochas alcalinas da região do Fecho dos Morros no sul de Mato Grosso e Republica do Paraguai: estudo petrográfico dos sienitos da região do Fecho dos Morros. An. Acad. Bras. Ciênc. Rio de Janeiro, 30(2):171-3 GUIMARÃES, D. \& DUTRA, C.V. (1962) Distribuição de alguns constituintes menores nas rochas alcalinas do Brasil. Bol. SBG. 11(01) 5-26.

HAGGERTY, S.E. (1976) Opaque mineral oxides in terrestrial igneous rocks. In: D. RUMBLE (Ed). Oxide minerals Mineral. Soc. Am. Short Course Notes, 3: 101300.

HAGGERTY, S.E. (1991) Oxide mineralogy of the upper mantle. In: LINDSLEY (Ed) Oxide Minerals: Petrologic and magnetic significance. Mineral. Soc. America. Reviews in Mineralogy 25: 129-218.

HAMILTON, D.L. (1961) Nepheline as crystallization temperature indicators. J. Geol., 69:321-329.

HAMILTON, D.L. \& MACKENZIE, W.S. (1960) Nepheline solid solution in the system $\mathrm{NaAISiO}_{4}-\mathrm{KAISiO}_{4}-\mathrm{SiO}_{2}$. J. Petrol., 1:56-72.

HAMILTON, D.L. \& MACKENZIE, W.S. (1965) Phase-equilibrium studies in the System $\mathrm{NaAlSiO}_{4}$ (nepheline) - $\mathrm{KalSiO}_{4}$ (kalsilite) $-\mathrm{SiO}_{2}-\mathrm{H}_{2} \mathrm{O}$. Mineralogical Magazine 34: 214-231.

HENDERSON, C.M.B.; PENDLEBURY, K. \& FOLAND, K. (1989) Mineralogy and petrology of Red Hill Alkaline Igneous Complex. New Hampshire, U.S.A. Journal of Petrology 30(3):627-666.

HUTHINSON, D.S. (1980) Reconnaissence exploration in the Apa High. DRM-MPOC T.A.C. Report Intern. Asunción, 13p.

HYNDMAN, D.W. (1972) Petrology of Igneous and Metamorphic Rocks. McGraw Hill Book Co. New York. 533p.

IRVINE, T. N. \& BARAGER, W. R. A., 1971. A Guide to the Chemical Classification of the Common Volcanic Rocks. Can. J. Earth Sci., 8: 523-548.

KOGARKO, L.N. (1979) Role of volatiles. In: H. SÖRENSEN (Ed.), The Alkaline Rocks. J. Wiley \& Sons. P.474-487.

LANDOLL, J.D.; FOLAND, K.A. \& HENDERSON, C.M.B. (1989) Formation of cogenetic quartz and nepheline syenites due to crustal interation: evidence from Marangdzi Complex, Zimbabue. Geol. Soc. Amer. Abstr. Prog., 21:A 189. 
LEAKE, B.E. (1978) Nomenclature of amphiboles. Can. Mineral. 16:501-520.

LEAKE, B.E.; WOOLEY, A.R.; ARPS, C.E.S.; BIRCH, W.D.; GILBERT, M.C.; GRICE, J.D.; HAWTHORNE, F.C.; KATO, A.; KISCH, H.J.; KRIVOVICHEV, V.G.; LINTHOUT, K.; LAIRD,J.; MANDARINO, J.; MARESCH, W.V.; NICKEL, E.H.; ROCK, N.M.S.; SHUMACHER, J.C.; SMITH, D.C., STEPHENSON. N.C.N.; UNGARETTI, L.; WHITTAKER, E.J.W. \& YOUZHI. G. (1997) Nomenclature of Amphiboles. Report of subcommitee on amphiboles of the International Mineralogical Association Commission on new minerals and Mineral names. Europ. J Mineral, 9: 623-651.

LE MAITRE, R.W.; (ed.) (1989) A classification of the igneous rocks and glossary of terms. Recommendations of the International Union of Geol. Sci. Subcommission on the Systematics of Igneous Rocks. Oxford, U.K. Blackwell Sci. Publ., 193p.

LISBOA, M.A.R. (1909) Oeste de São Paulo, Sul de Matto Grosso, geologia industria mineral, clima, vegetação, solo agrícola, industria pastoril. Rio de Janeiro, Typ. do Journal do Comércio, 172p.

LIVIERES, R.A. \& QUADE, H. (1987) Distribución regional y asentamiento tectónico de los complejos alcalinos del Paraguay. Zbl. Geol. Pälont. Teil I (7/8): 791-805.

MACKENZIE, W.S.; DONALDSON, C.H. \& GUILFORD, C.; (1982) Atlas of igneous rocks and their textures. London, Longman., 148p.

MATOS, J.B.; GOMES, C.B.; RUBERTI, E. \& VELÁZQUEZ, V.F. (2000) Petrography and geochemistry of alkaline plugs from São Pedro, Porto Conceição, Morro Conceição and Morro Distante, SW of Mato Grosso do Sul State, Brazil. $31^{\circ}$ IGC, Rio de Janeiro, Brazil. CD-Room, Abstracts.

MILANI, E.J. (1997) Evolução tectono-estratigráfica da Bacia do Paraná e seu relacionamento com a geodinâmica fanerozóica do Gondwana sul-ocidental. IG-UFRS - Tese de Doutoramento 255p. Inédito.

MILANI, E.J. \& RAMOS, V.A. (1998) Orogenias paleozóicas no domínio sul-ocidental do Gondwana e os ciclos de subsidência da Bacia do Paraná. Rev. Bras. Geoc. 28(4):473-484. 
MITCHELL, R. (1972) Composition of nepheline, pyroxene and biotite in ijolite from the Seabrook Lake Complex. Ontário. Canada. N. Jb. Miner. 9:415-422.

MITCHELL, R.N. (1995) Kimberlites, orangeites and related rocks. Plenum Press. New York, 410p.

MITCHELL, R.N. \& BERGMAN, S.C. (1991) Petrology of lamproites. Plenum Press. New York, 447p.

MORAES, L.J. (1958) Rochas alcalinas da região do Fecho dos Morros, no sul de Mato Grosso e República do Paraguai. I- Distribuição geográfica das montanhas sieníticas do Fecho dos Morros. Anais da Acad. Bras. Ciênc. Rio de Janeiro, 30(2): 165-170.

MORIMOTO, N. (1989) Nomenclature of Pyroxenes. Mineral J. 14 (5): 198-221.

MOTOKI, A. (1986) Geologia e petrologia do maciço alcalino da liha de Vitória, SP.

Tese de Doutoramento IG-USP, 245p. Inédito.

NEUMANN, E.R. (1976) Compositional relations among pyroxenes, amphiboles and Other mafic phases in the Oslo region plutonic rocks. Lithos, 9:85-109.

NOGUEIRA, V.L.; OLIVEIRA, C.C.; FIGUEIREDO, J.A.; CORREIA FILHO, F. das

C.L.; SCILEWSKI, N..G.; SOUZA, M.R.; MORAES FILHO, J.C.R.; LEITE, E.A.; SOUZA, N.B.; SOUZA, J.O.; CERQUEIRA, N.L.S.; VANDERLEI, A.A.; TAKASHI, A.T.; ABREU FILHO, W.; ROSITO, J.; OLIVATTI, O.; HAUSEN, J.E.P.; GONÇALVES, G.N.D.; RAMALHO, R. \& PEREIRA, L.C.B. (1978) Projeto Bonito-Aquidauana. Relatório Final, Goiânia, DNPM/CPRM, $14 \mathrm{~V}$. (Relatório do Arquivo Técnico da DGM, 2744).

OLIVATTI, O \& CORREIA FILHO, F. das C.L. (1981) Problemas estratigráficos do Pré-Cambriano no Mato Grosso do Sul. In: Simp. Geol. do Centro-Oeste, 1, Goiânia, 1981, Anais. SBG. p.212-224.

OLIVEIRA, E.P. de; (1915) Geologia: reconhecimento geológico do noroeste de Mato Grosso, Expedição Scientífica Roosevelt-Rondon. Rio de Janeiro, 82p Brasil. Commissão de Linhas Telegráphicas e Estratégicas de Matto Grosso ao Amazônas, Anexo 1, publ. 50.

OLIVEIRA, A.I. de \& LEONARDOS, O.H. (1943) Geologia do Brasil. $2^{\text {a }}$ Ed. Rev. Atual. Rio de Janeiro, Serviço de Informação Agrícola, 813p. (Sér. Did. 2). 
PANKHURST, R.J. (1999) Geochronology in southern South América and western Antartica: achievements and prospects. Actas / South American Symposium on Isotope Geology. Buenos Aires V.1. p.548-551.

PEARCE, J.A. ; HARRIS, N.B.W. \& TINDLE, A.G. (1984) Trace element discrimination diagrams for the tectonic interpretation of granitic rocks. J. Petrol. 25: 956-983.

RAMOS, V. A. (1988) Late Proterozoic-Early Paleozoic of South America:a collisional history. Episodes 11:168-175.

RAMOS, V.A.; JORDAN, T.; ALLMENDINGER, R.; MPODOZIS, C.; KAY, S.; CORTÉS, J. \& PALMA, M. (1986) Paleozoic terranes of the central Argentine-Chilean Andes. Tectonics, 5:855-880.

RAPELA, C. W; COIRA, B.; TOSELLI, A. \& SAAVEDRA, J. (1992) El magmatismo del Paleozóico Inferior en el sudoeste del Gondwana. In: GUTIERREZ MARCO, J.; SAAVEDRA, J. \& RABANO, J. eds. Paleozóico Inferior de Ibero América. Extremadura. Universidad de Extremadura. P.21-68.

RAPELA, C.W. \& KAY, S.M. (1988) Late Paleozoic to Recent Magmatic Evolution of Northern Patagonia. Episodes. 11 (3) 175-182.

RICHARD, L.R. (1995) MINPET: The ultimate mineralogical and petrological data processing system for windows. Québec, Canada, 263p.

ROBINSON, P.; SPEAR, F.S.; SCHUMACHER, J.C.; LAIRD, J.; KLEIN, C.; EVANS, B.W. \& DOOLAN, B.L. (1981) Phase relations of metamorphic amphiboles: Natural occurrence and theory. Mineral. Soc. Amer., Reviews in Mineralogy, 9B:1-228.

ROCK, N.M.S. (1982) Chemical mineralogy of the Monchique Alkaline Complex, southern Portugal. Contrib. Mineral. Petrol. 81: 64-78.

RUBERTI, E. (1984) Petrologia do Maciço Alcalino do Banhadão, PR. IG-USP, Tese de Doutoramento. São Paulo, 248p. Inédito.

SANTOS, J.O.S. \& LOGUÉRCIO, S.O.C. (1984) A parte meridional do Cráton Amazónico (Escudo Brasil Central) e as Bacias do Alto Tapajós e Parecis-Alto Xingú. Geologia do Brasil. DNPM. Brasilia. p.93-127.

SAPOUNTZIS, E.S. (1976) Biotites from the Sithonia Igneous Complex (North Greece). N. Jb. Miner. Abh., 126 (3): 327-341. 
SILVA, E.L.; da; (1998) Geologia da Região da Serra da Alegria, Extremo sul do Cráton Amazônico, Município de Porto Murtinho-MS. Dissertação de Mestrado IG-USP. São Paulo. 147p. (inédito).

SÖRENSEN, H. (1979) The alkaline rocks. London, Wiley \& Sons, 622p.

SORENSEN,H. (1986) The alkaline rocks: a review. Fortschr. Miner. 64: 63-86.

SOUSA, M.Z.A. (1997) Petrologia e geoquímica do complexo alcalino Ponta do Morro-MT. IG-USP, Tese de Doutoramento, São Paulo, 168p. Inédito.

STRECKEISEN, A.; (1976) To each plutonic rocks its proper name. Earth Sci. Rev. 12: 1-33.

SYKES, L.R. (1978) Intraplate seismicity, reactivation of preexisting zones of weakness, alkaline magmatism, and other tectonism post-dating continental fragmentation. Rev. Geophys. Space. Phys., 16:621-688.

TAYLOR, H.P.Jr. (1980) The effects of the assimilation of country rocks by magma on ${ }^{18} \mathrm{O} /{ }^{16} \mathrm{O}$ and ${ }^{87} \mathrm{Sr} /{ }^{86} \mathrm{Sr}$ systematics in igneous rocks. Earth Plan. Sci. Lett. 47:243-254.

TROGER, W.E. (1979) Optical determination of rock forming minerals Part I, (Determinative Tables) English edition of the fourth German edition Stuttgart E. Schweizerbart.

TURNER, F.J. \& VERHOOGEN, J. (1960) Igneous and Metamorphic Petrology. Mc Graw Hill Book Co., New York. 694p.

ULBRICH, H.H.G.J. (1984) A petrologia, a estrutura e o quimismo de nefelina sienitos do Maciço Alcalino de Poços de Caldas, MG-SP. Tese de Livre Docência. IG_USP. Inédito

ULBRICH, M.N.C. (1983) Aspectos mineralógicos e petrológicos de nefelina sienitos do maciço de Poços de Caldas, MG-SP. IG-USP, Tese de Doutoramento, São Paulo, 369p. Inédito.

UNTERNEHR, P.; CURIE, D.; OLIVET, J.L.; GOSLIN, J. \& BEUZART, P. (1988) South Atlantic fits and intraplate boundaries in Afica and South America. Tectonophysics. 155: 169-179. 
VALENÇA, J.G. (1980) Geology, petrography and petrogenesis of some alkaline Igneous complex of Rio de Janeiro State, Brazil. PhD Thesis, University of Western Ontario, Canada, 248p. Inédito.

VASCONCELLOS, E.M.G. (1995) Petrologia e geoquímica de diques e "plugs" alcalinos da região do Vale do Ribeira, divisa dos estados do Paraná e São Paulo. IG-USP, Tese de Doutoramento, São Paulo, 151p. Inédito.

VELÁZQUEZ, V.F. (1996) Província Alcalina Alto Paraguai: Características Petrográficas, Geoquímicas e Geocronológicas. IG-USP, Tese de Doutoramento. São Paulo. 101p. (inédito).

VELAZQUEZ, V.F.; GOMES, C. B.; COMIN-CHIARAMONTI, P.; TASSINARI, C.C.G \& TEIXEIRA, W. (1993) Geocronologia da Província Alcalina Alto Paraguai (Área Puerto Guarani-Porto Murtinho):Consideraçōes preliminares. IV Congr. Bras. Geoq. Brasilia DF Resumos Expandidos, p.245.

VELAZQUEZ, V.F.; GOMES, C. B.; ORUÉ, D. \& COMIN-CHIARAMONTI, P. (1996) Magmatismo Alcalino do Paraguai: uma revisão e atualização das Províncias. Bol. IG-USP, Sér. Cient., 27: 61-79.

VELAZZUEZ, V.F.; RICCOMINI, C.; GOMES, C. B.; FIGUEIREDO, L. \& FIGUEIREDO, C. (1998) Relações tectônicas do magmatismo alcalino do Paraguai Oriental. Rev. IG-USP. São Paulo. (no prelo).

VEEVERS, J.J. (1994) Pangea: Evolution of a supercontinent and its consequences For Earth's paleoclimate and sedimentary environments. In: G.D.KLEIN ed.; Pangea: Paleoclimate, Tectonics and Sedimentation During Accretion, Zenith and Breakup of a Supercontinent. Boulder. Colorado. Geol. Soc. Am. Special Paper 288.

VEEVERS, J.J.; CONAGHAN, P.J. \& SHAW, S.E. (1994) Turning point in Pangean environmental history at the Permian/Triassic (P/Tr) Boundary. In: G.D. KLEIN ed.; Pangea: Paleoclimate, Tectonics and Sedimentation During Accretion, Zenith and Breakup of a Supercontinent: Boulder. Colorado. Geol. Soc. Am. Special Paper 288. 
WIENS, F. (1986) Zur lithostratigraphischen, petrographischen und strukturelen entwicklung des Rio Apa-Hochlandes, nordost Paraguay. Ph.D. Thesis. Clausthal Universität (Inst. der Techinischen). 280p.

WILKINSON, J.F.G. \& HENSEL, H.D. (1994) Nepheline and analcimes in some alkaline igneous rocks. Contr. Miner. Petrol. 118(1): 79-91.

WILLIAMS, H,; TURNER, F.J. \& GILBERT, C.M. (1954 ) Petrography: un introduction to the study of Rocks in thin sections $W$. L. Freeman. San Francisco. 434p.

ZALAN, P.V.; WOLFF, S.; CONCEIÇÃO, J.C.J.; ASTOLFI, M.A.M.; VIEIRA, I.S.; APPI, V.T.; ZANOTTO, O.A. \& MARQUES, A. (1987) Tectonic and Sedimentation of the Paraná Basin. Atas do III Simp. Sul-Brasileiro Geol. Curitiba V.1: 441-477.

ZALAN, P.V.; WOLFF, S.; ASTOLFI, M.A.M.; VIEIRA, I.S.; CONCEIÇÃO, J.C.J.; APPI, V.T.; NETO, E.V.S.; CERQUEIRA, J.R.; MARQUES, A. (1990) The Paraná Basin, Brazil. In: M.W. LEIGHTON; D.R. COLATA; D.F. OLTZ; J.J. EIDEL (Eds) Interior Intracratonic basins. Tulsa. Amer. Assoc. Petrol. Geol. Mem. 51:681-708. 